\title{
Chemical carcinogens and chronic inflammation
}

Citation for published version (APA):

Shi, Q. (2017). Chemical carcinogens and chronic inflammation: partners in crime. [Doctoral Thesis, Maastricht University]. Gildeprint Drukkerijen. https://doi.org/10.26481/dis.20171218qs

Document status and date:

Published: 01/01/2017

DOI:

10.26481/dis.20171218qs

Document Version:

Publisher's PDF, also known as Version of record

\section{Please check the document version of this publication:}

- A submitted manuscript is the version of the article upon submission and before peer-review. There can be important differences between the submitted version and the official published version of record.

People interested in the research are advised to contact the author for the final version of the publication, or visit the DOI to the publisher's website.

- The final author version and the galley proof are versions of the publication after peer review.

- The final published version features the final layout of the paper including the volume, issue and page numbers.

Link to publication

\footnotetext{
General rights rights.

- You may freely distribute the URL identifying the publication in the public portal. please follow below link for the End User Agreement:

www.umlib.nl/taverne-license

Take down policy

If you believe that this document breaches copyright please contact us at:

repository@maastrichtuniversity.nl

providing details and we will investigate your claim.
}

Copyright and moral rights for the publications made accessible in the public portal are retained by the authors and/or other copyright owners and it is a condition of accessing publications that users recognise and abide by the legal requirements associated with these

- Users may download and print one copy of any publication from the public portal for the purpose of private study or research.

- You may not further distribute the material or use it for any profit-making activity or commercial gain

If the publication is distributed under the terms of Article $25 \mathrm{fa}$ of the Dutch Copyright Act, indicated by the "Taverne" license above, 
Chemical carcinogens and chronic inflammation:

\section{Partners in Crime}


(C)Quan Shi, Maastricht 2017

ISBN: 9789462338487

Cover design: $\quad$ Quan Shi

Layout: $\quad$ Quan Shi

Printed by: $\quad$ Gildeprint-Enschede

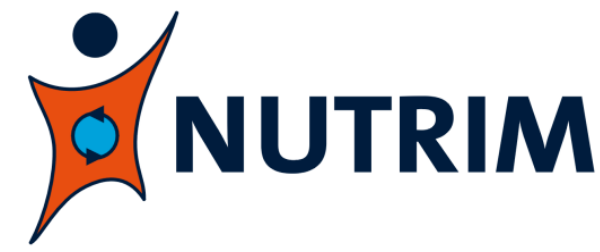

The research presented in this thesis was performed at NUTRIM School of Nutrition and Translational Research in Metabolism of Maastricht University. 


\title{
Chemical carcinogens and chronic inflammation:
}

\section{Partners in Crime}

\author{
Dissertation \\ To obtain the degree of Doctor \\ at the Maastricht University on the authority of the Rector Magnificus \\ Prof. Dr. Rianne M. Letschert \\ in accordance with the decision of the board of Deans \\ to be defended in public \\ on Monday 18 ${ }^{\text {th }}$ December 2017 \\ at 10.00 hours \\ by
}

Quan Shi 


\section{Promotor}

Prof. dr. F. J. van Schooten

\section{Co-promotor}

Dr. R. W. Godschalk

\section{Beoordelingscommissie}

Prof. dr. A-M. C. Dingemans (voorzitter)

Prof. dr. A. Bast

Prof. dr. ir. I. M. C. M. Rietjens (Wageningen Universiteit)

Dr. R. Schins (IUF-Leibniz Research Institute for Environmental Medicine, Düsseldorf, Germany)

Prof. dr. M. A. G. G. Vooijs 


\section{Contents}

$\begin{array}{lll}\text { Chapter } 1 & \text { General Introduction } & 7\end{array}$

Chapter 2 Inflammation associated extracellular $\beta$-glucuronidase alters 29

cellular responses to the chemical carcinogen benzo[a]pyrene

Chapter 3 Acidic cellular microenvironment modifies carcinogen induced

DNA damage and repair

Chapter 4 Effect of interleukin (IL)-8 on benzo[a]pyrene metabolism and

DNA damage in human lung epithelial cells

Chapter 5 Pulmonary Inflammation Impacts on CYP1A1-Mediated

Respiratory Tract DNA Damage Induced by the Carcinogenic Air

Pollutant Benzo[a]pyrene

Chapter 6 Altered gene expression profiles in the lungs of

benzo[a]pyrene-exposed mice in the presence of

lipopolysaccharide-induced pulmonary inflammation

Chapter 7 Inflammation and the chemical carcinogens benzo[a]pyrene:

partners in crime

Chapter 8 Summary and general discussion

Hoofdstuk 8 Samenvatting en algemene discussie

Appendix I Valorization Addendum

Appendix II Acknowledgements

Appendix III Curriculum Vitae

Appendix IV List of Publications 

Chapter 1

General Introduction 



\section{Chemical Carcinogens}

Cancer is one of the leading causes of death worldwide, and was responsible for 8.2 million deaths in 2012 [1] and numbers are still increasing. There are over 100 different types of cancer and the most common types are lung, liver, colorectal, stomach and female breast cancer [2]. Nowadays, we know that the factors that lead to an increased risk for developing cancer are either the inherited genetic background or other established risk factors, such as age, lifestyle (diet, alcohol consumption and tobacco use), naturally occurring exposures (e.g. ultraviolet light and infectious agents), medical treatments (e.g. radiation and immune suppression drugs), chronic inflammation, obesity, hormones and carcinogen exposure [3]. Of these risk factors, exposure to carcinogens is one of the most common reasons for increased cancer risk, but it also is an avoidable risk factor for human cancers. Back in the 1700s, a link between cancer and chemical exposure was firstly established by the English physician Sir Percival Pott as he observed a large number of scrotal cancer cases in chimney sweeps, who were exposed to soot and tar [4]. Later in 1761, John Hill also reported an association between the inhalation of nasal snuff and nasal cancer [5]. After that, more and more epidemiological observations indicated that contact with or intake of certain substances could induce cancer development and scientists defined chemicals that are known or suspected to cause cancer as carcinogens and the process of carcinogen induced cancer development was called chemically induced carcinogenesis [6]. Since then, many chemicals have been identified as carcinogens by epidemiologic observations and animal experiments [7].

A common feature of genotoxic carcinogens is that their ultimate carcinogenic forms are electrophilic reactants, which are able to covalently bind to DNA to form so called DNA-adducts. These DNA adducts can give rise to a variety of mutations in cellular DNA if they are not repaired before DNA replication. Many carcinogens are not electrophilic reactants by themselves, but they arise through metabolism of the parent compound in the human body after absorption [8]. Up till now, 971 suspected agents were evaluated by the International Agency for Research on Cancer (IARC) and almost half of them are classified as human carcinogens [9]. Among these carcinogens, the group of polycyclic aromatic hydrocarbons (PAHs) represents the most environmentally abundant and best studied carcinogens [10]. PAHs, which consist of only carbon and hydrogen arranged in two or more fused benzene rings, are a large class of chemical compounds formed during the incomplete combustion or pyrolysis of organic material [11]. Despite the enormous amount of studies performed on human exposure to PAHs, they still receive a lot of attention in the scientific literature of recent years, not only because of their relatively high concentrations in urban centers, but also because some PAHs are known to be highly carcinogenic or mutagenic [12]. One of the best studied members of the group of PAHs is benzo[a]pyrene (B[a]P), which is therefore considered as a model carcinogen [11].

$\mathrm{B}[\mathrm{a}] \mathrm{P}$ is universally present in the environment and therefore it is inevitable for humans to be exposed to $\mathrm{B}[\mathrm{a}] \mathrm{P}[12]$. $\mathrm{B}[\mathrm{a}] \mathrm{P}$ is listed as a group 2A carcinogen (a known animal carcinogen and probable human carcinogen) by the IARC, and all exposure routes should therefore be carefully controlled to obtain as low as possible levels [13]. The fate of $\mathrm{B}[\mathrm{a}] \mathrm{P}$ is determined by its physico-chemical properties and it is known that $\mathrm{B}[\mathrm{a}] \mathrm{P}$ is highly persistent in the environment because it is a non-polar and hydrophobic compound. Because of this presence in the environment and its persistence, it is routinely analyzed in environmental media, such as air, water, soils and sediments as a measure of pollution [11, 12]. Moreover, $\mathrm{B}[\mathrm{a}] \mathrm{P}$ is also found in some foods, 
pharmaceutical skin products containing coal tar, as well as tobacco smoke (range from 22.9 to $26.3 \mathrm{ng} /$ cigarette) $[13,14]$. Although a large amount of studies (both in vivo and in vitro) have confirmed the health consequences of $\mathrm{B}[\mathrm{a}] \mathrm{P}$ exposure, variation exists in exposed humans in their chance of actually developing $\mathrm{B}[\mathrm{a}] \mathrm{P}$ induced cancers. For instance, not all smokers will develop lung cancer and not all people that use $\mathrm{B}[\mathrm{a}] \mathrm{P}$ containing ointments will develop skin cancer $[15,16]$. Initially, scientific research focused on genetic variation and life style to explain these differences, but so far the findings indicate that additional factors ultimately determine an individuals' susceptibility. These other factors may include the presence of chronic inflammation, which contributes to the development of cancer already by itself. Many people that are exposed to $\mathrm{B}[\mathrm{a}] \mathrm{P}$ additionally develop an inflammatory response, because of the nature of the mixtures in which $\mathrm{B}[\mathrm{a}] \mathrm{P}$ is present. For instance, cigarette smoke, diesel exhaust or cooking fumes all contain $\mathrm{B}[\mathrm{a}] \mathrm{P}$, but also particles that induce an inflammatory response in the lung. So far, the combined exposure to $\mathrm{B}[\mathrm{a}] \mathrm{P}$ and inflammation is not taken into consideration. Therefore, the objective of the research described in this $\mathrm{PhD}$ thesis is investigating the role and the effect of different inflammatory mediators, which are known to be released during chronic inflammation, on $\mathrm{B}[\mathrm{a}] \mathrm{P}$ induced genetic DNA damage.

\section{Human exposure to $B[a] P$}

$\mathrm{B}[\mathrm{a}] \mathrm{P}$ consists of five fused benzene rings and acts as an indicator species for PAH contamination [10]. The mutagenic and carcinogenic properties of $\mathrm{B}[\mathrm{a}] \mathrm{P}$ can be explained by the bay-region in the molecular structure (Fig 1). Not only because the bay region could generate reactive diol-epoxides during $\mathrm{B}[\mathrm{a}] \mathrm{P}$ metabolism that easily form covalent bounds with DNA (so-called DNA adducts), but also because bay regional structures more potently bind to the aryl hydrocarbon receptor (AhR) which activates the transcription of genes of the cytochrome P450 (CYP1) family. Cytochrome P450's are essential for $\mathrm{B}[\mathrm{a}] \mathrm{P}$ activation into reactive metabolites (see section 3: Metabolism and biotransformation of $\mathrm{B}[\mathrm{a}] \mathrm{P})[17,18]$.

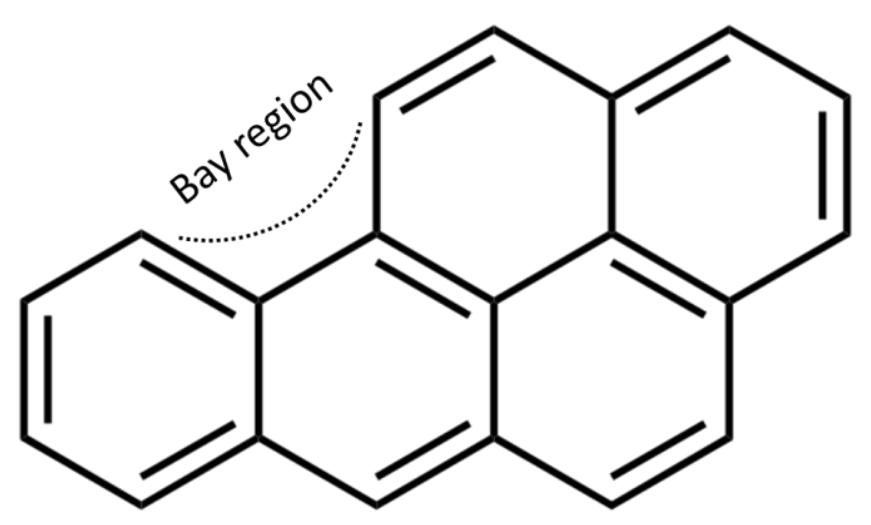

Figure 1. Structure of $\mathrm{B}[\mathrm{a}] \mathrm{P}$ with its so-called bay-region.

$\mathrm{B}[\mathrm{a}] \mathrm{P}$ is primarily formed as a results of incomplete combustion [11]. Therefore, $\mathrm{B}[\mathrm{a}] \mathrm{P}$ is a ubiquitous environmental chemical which is naturally produced via the eruption of volcanoes, forest fires and burning plants, wood and coal [11]. As a result, it can be found in the air, soil and all kinds of waters (e.g. surface water, groundwater, wastewater and sewage sludge). B[a]P is also found in for instance diesel exhaust, 
wood-burning fireplaces and stoves, and it is present in tobacco smoke [19]. There are three pathways in which humans can be exposed to B[a]P including breathing $(0.9 \%)$, dermal contact (0.1\%), and ingestion (99\%) [20].

For occupational inhalation, the exposure to $\mathrm{B}[\mathrm{a}] \mathrm{P}$ depends on the concentration of $\mathrm{B}[\mathrm{a}] \mathrm{P}$ in the air, with high levels in various working places including coking plants, coal-tar production, asphalt production plants and production of asphalt roads, and local trash burning sites [21]. Additional daily inhalatory exposure may come from cigarette smoking (active and passive), wood smoke and vehicle exhaust [21]. The concentration of $\mathrm{B}[\mathrm{a}] \mathrm{P}$ in outdoor air varies between places and regions (Table 1). For example a range of non-detectable levels to $37.01 \mathrm{ng} / \mathrm{m}^{3}$ of $\mathrm{B}[\mathrm{a}] \mathrm{P}$ was detected in industrial, urban and traffic areas of Taiwan, Italy, India, Malaysia, Hong Kong and Belgium, respectively. The indoor source of B[a]P predominantly comes from indoor emission of cooking and gas home appliances [22]. The release of $\mathrm{B}[\mathrm{a}] \mathrm{P}$ in the air of domestic kitchens was found to be $0.0044-0.016 \mu \mathrm{g} /$ day, while it increased to $0.32-0.94 \mu \mathrm{g} /$ day in commercial kitchens [12], with different types of cooking fuels producing different concentrations of $\mathrm{B}[\mathrm{a}] \mathrm{P}$. For example, using kerosene as fuel will generate $\mathrm{B}[\mathrm{a}] \mathrm{P}$ between 0.2 to 17.6 $\mathrm{ng} / \mathrm{m}^{3}$ and cooking fuels like coal, wood and cattle dung produce even higher concentrations of $33-186 \mathrm{ng} / \mathrm{m}^{3} \mathrm{~B}$ [a]P [23]. Inhalatory exposure to $\mathrm{B}[\mathrm{a}] \mathrm{P}$ is of special importance because $\mathrm{B}[\mathrm{a}] \mathrm{P}$ is specifically considered to be a lung carcinogen, and therefore lowering air concentrations should be a first attempt to reduce risks. In addition, the U.S. Environmental Protection Agency (EPA) calculated a lifetime lung cancer risk of $6.4 \times 10^{-4}$ linearly associated with occupational exposure to $1 \mu \mathrm{g} / \mathrm{m}^{3}$ of $\mathrm{B}$ [a]P for 25 years [24]. However, this calculated inhalation risk should only be used with exposures below $0.3 \mathrm{mg} / \mathrm{m}^{3}$, and the overall cancer risk $>10 \%$ if the exposure is above $0.3 \mathrm{mg} / \mathrm{m}^{3}$ [25]. Therefore, as the inevitable exposure to $\mathrm{B}[\mathrm{a}] \mathrm{P}$, the European directive 2004/107/EC stated that the estimated acceptable risk level for $\mathrm{B}[\mathrm{a}] \mathrm{P}$ in ambient air is $0.12 \mathrm{ng} / \mathrm{m}^{3}$ [26].

Table 1: Concentrations of $B[a] P$ in air at various sites and subsequent estimated inhalatory intake of $B[a] P$.

\begin{tabular}{|l|l|l|l|}
\hline Location & \multicolumn{1}{|c|}{$\begin{array}{c}\mathrm{B}[\mathrm{a}] \mathrm{P} \text { concentration } \\
\left(\mathrm{ng} / \mathrm{m}^{3}\right)\end{array}$} & $\begin{array}{l}\text { Estimated intake of B[a]P in } \\
\text { ng/day* }\end{array}$ & $\begin{array}{l}\text { Reference } \\
\text { s }\end{array}$ \\
\hline Traffic, Tainan, Taiwan & 37.0 & 222 & {$[27]$} \\
\hline Urban, Tainan, Taiwan & 10.5 & 63 & {$[27]$} \\
\hline Industrial, Tainan, Taiwan & 2.39 & 14 & {$[27]$} \\
\hline Traffic, Naples, Italy & 2.97 & 18 & {$[28]$} \\
\hline Urban, Naples, Italy & 0.9 & 5 & {$[28]$} \\
\hline Industrial, Naples, Italy & 2.75 & 17 & {$[28]$} \\
\hline Urban, Mumbai, India & 1.8 & 11 & {$[23]$} \\
\hline Industrial, Mumbai, India & 2.1 & 13 & {$[23]$} \\
\hline $\begin{array}{l}\text { Urban, Kuala Lumpur, } \\
\text { Malaysia }\end{array}$ & $\mathrm{ND}$ & $<1$ & {$[29]$} \\
\hline Traffic, Hong Kong, China & 2.13 & 13 & {$[30]$} \\
\hline Industrial, Hong Kong, China & 1.3 & 9 & {$[30]$} \\
\hline Urban, Flanders, Belgium & 0.82 & 5 & {$[31]$} \\
\hline Industrial, Flanders, Belgium & 0.76 & 5 & {$[31]$} \\
\hline Occupational setting & Up to $100 \mathrm{ng} / \mathrm{m3}$ & 600 & {$[30]$} \\
\hline Cigarette smoke & $20 \mathrm{ng}$ per cigarette & 200 & {$[32]$} \\
\hline Average Netherlands & 0.6 & 4 & {$[33]$} \\
\hline Indoor air with open fire site & 70 & 420 & {$[34]$} \\
\hline
\end{tabular}

ND: not detected, *Intake calculated on basis of on basis of inhaling $12 \mathrm{~m}^{3}$ per day, or 20 cigarettes per day and a PAH deposition rate of $50 \%$. 
$\mathrm{B}[\mathrm{a}] \mathrm{P}$ has also been detected in water (surface water, groundwater and porewater) [35]. According to the World Health Organization, concentrations of $0.7 \mu \mathrm{g} / \mathrm{L}$ of B[a]P in daily drinking water corresponds to an excess lifetime cancer risk of 5-10 cancer cases in a million exposed persons [36]. Even in Western societies, B[a]P in drinking water is 1.72 $\mu \mathrm{g} / \mathrm{L}$ as observed in four major cities of the USA [12]. The major source for $\mathrm{B}[\mathrm{a}] \mathrm{P}$ contamination in water is via atmospheric fallout, urban run-off, municipal effluents, industrial effluents and oil spillage or leakage [12]. The presence of $\mathrm{B}[\mathrm{a}] \mathrm{P}$ in drinking water may be due to the use of contaminated surface water or groundwater as raw sources of water production, or the use of coal tar coated pipes in public water supply systems [12]. Governments aim to reduce the $\mathrm{B}[\mathrm{a}] \mathrm{P}$ level to zero $\mu \mathrm{g} / \mathrm{L}$ in drinking water, however, it is technically not feasible due to the detection limit of methodologies . Hence, a maximum acceptable concentration (MAC) for B[a]P in drinking water $(0.01 \mu \mathrm{g} / \mathrm{L}$ ) is set in the U.S and Canada [36]. It has to be mentioned that $\mathrm{B}[\mathrm{a}] \mathrm{P}$ has the potential to additionally cause developmental effects and reproductive effects after long-term exposures at levels above the MAC [37].

With regard to quantities, food is the main source of $\mathrm{B}[\mathrm{a}] \mathrm{P}$ intake for humans in non-occupational settings, such as eating grilled or charred meats, contaminated seafood, cereals, flour, bread and vegetables [38]. Due to the physicochemical properties of $\mathrm{B}[\mathrm{a}] \mathrm{P}$ (i.e. its lipophilicity), it can accumulate in many food products, but it can also be formed as a result of the preparation of the food $[39,40]$. The estimates of B[a]P intake from food varies widely, ranging from nanograms to micrograms per person per day and the average level of B[a]P found in daily food intake was $2.6 \mathrm{ng} / \mathrm{g}$ based on 200 food items in United States [41]. In the Netherlands, dietary intake of B[a]P was systematically measured between 1984 and 1986, and was found to be approximately $100 \mathrm{ng} \mathrm{B}[\mathrm{a}] \mathrm{P}$ per day and the intake of total $\mathrm{PAH}$ was estimated to by $6 \mu \mathrm{g} /$ day. Although there are no human data available for oral consumption of $\mathrm{B}[\mathrm{a}] \mathrm{P}$ and subsequent cancer risk, mice carcinogenicity studies provide clear evidence that dietary intake of $\mathrm{B}[\mathrm{a}] \mathrm{P}$ is dose-dependently related to increased incidences of forestomach squamous cell papillomas and carcinomas, alveolar and bronchiolar adenomas and carcinomas [42]. The European Commission Regulation No 1881/2006 sets maximum levels in muscle meat of smoked fish, smoked fishery products, smoked meat and smoked meat products at $5 \mu \mathrm{g} / \mathrm{kg}$ or at $2 \mu \mathrm{g} / \mathrm{kg}$ for vegetable and animal oils and fats, muscle meat of fish, other than smoked fish intended to be used for direct human consumption, or use as an ingredient in food $[43,44]$.

Last but not least, dermal contact is also a possible route when $\mathrm{B}[\mathrm{a}] \mathrm{P}$ is released into air, water, soil or any polluted site, because $\mathrm{B}[\mathrm{a}] \mathrm{P}$ is easily absorbed via the skin. However, this route of exposure seems to be less important for the general population. The most frequent reported cases of dermal exposure includes contact with materials containing soot, tar, crude petroleum in occupational settings, or using pharmaceutical skin products containing coal tar, such as coal tar based shampoos and ointments $[45,46]$. $\mathrm{B}[\mathrm{a}] \mathrm{P}$ was found to induce skin tumors (mainly papilloma and squamous cell carcinomas) in different strains of mice following repeated dermal administrations for prolonged periods of time [47]. Based on the carcinogenicity studies with mice, an estimated skin cancer risk of one case in 100,000 was calculated and extrapolated to humans for life-time daily dermal exposure to $0.003 \mathrm{ng} / \mathrm{cm}^{3} \mathrm{~B}$ [a]P [48].

From an epidemiological point of view, increased risks of $\mathrm{B}[\mathrm{a}] \mathrm{P}$ induced cancers haves been reported predominantly in occupational settings with heavy exposures to $\mathrm{B}[\mathrm{a}] \mathrm{P}$, primarily through inhalation and via skin contact [12], but it is generally accepted that exposure of the general population also increases the risk of various types of cancer. 


\section{Metabolism and biotransformation of $B[a] P$}

$\mathrm{B}[\mathrm{a}] \mathrm{P}$ itself is not dangerous, and it actually needs biotransformation to obtain its mutagenic and carcinogenic properties. The metabolism of $\mathrm{B}[\mathrm{a}] \mathrm{P}$ can occur in all tissue types, but the highest metabolic capacity is found in the liver and the tissues at the portal of entry, such as lung (after inhalation), skin (after dermal contact) and gastrointestinal (GI) tract (after ingestion) [5]. The complexity of $\mathrm{B}$ [a]P metabolism is demonstrated by numerous in vitro and in vivo studies, that have been performed since the discovery of $\mathrm{B}[\mathrm{a}] \mathrm{P}$ in the previous century, but the best described pathway is the metabolic activation to $\mathrm{B}[\mathrm{a}] \mathrm{P}-7,8-$ diol, 9,10-epoxide (BPDE) by cytochrome P450 and epoxide hydrolase. Within this pathway, the metabolic enzymes have isoenzymes which have varying metabolic specificities, many of the critical enzymes are inducible by a variety of agents including B[a]P itself, and many of the enzymes are species, strain and organ specific [11]. Altogether, this complexity will contribute to the formation of different stereoisomers of $\mathrm{B}[\mathrm{a}] \mathrm{P}$ metabolites which eventually generate various mutagenic effects. Overall, the purpose of metabolism of $\mathrm{B}[\mathrm{a}] \mathrm{P}$ is to transform the lipophilic parent compound into a more water soluble derivative, that is more readily excreted in feces and urine. A simplified illustration of $\mathrm{B}[\mathrm{a}] \mathrm{P}$ metabolism and biotransformation is shown in Figure 2, and this metabolic pathway is discussed below in more detail.

Due to its lipophilic characteristics, $\mathrm{B}[\mathrm{a}] \mathrm{P}$ can easily cross the cell membrane and it can subsequently bind to the protein complex that contains the aryl hydrocarbon receptor (AhR), Hsp90, XAP2 and p23 [49]. After this binding, the AhR translocates to the nucleus where it dimerizes with the aryl hydrocarbon receptor nuclear translocator (Arnt) protein, and the AhR/Arnt complex can subsequently activate the xenobiotic responsive element (XRE) sequences that are located in the promoter region of target genes, including NAD(P)H dependent cytochrome P450 isoforms 1A1 (CYP1A1), 1A2 and 1B1 [50]. $\mathrm{B}[\mathrm{a}] \mathrm{P}$ is mainly oxidized by $\mathrm{NAD}(\mathrm{P}) \mathrm{H}$ dependent mixed-function oxidases (i.e. CYP1A1 and CYP1B1) ) which form arena oxides (e.g. B[a]P-7,8-epoxide and $\mathrm{B}[\mathrm{a}] \mathrm{P}-9,10$-epoxide). Also myeloperoxidase (MPO), an enzyme released during inflammation is thought to be able to metabolize $\mathrm{B}[\mathrm{a}] \mathrm{P}$ [51]. In another metabolic pathway $\mathrm{B}[\mathrm{a}] \mathrm{P}$ is catalyzed by other peroxidase and prostaglandin $\mathrm{H}$ synthase leads to the formation of $\mathrm{B}[\mathrm{a}] \mathrm{P}$-radical cations which can form depurating DNA adducts $[13,52]$. The radical cations of $\mathrm{B}[\mathrm{a}] \mathrm{P}$ is formed via one-electron oxidation and creates a radical specifically localized on carbon 6 of $\mathrm{B}[\mathrm{a}] \mathrm{P}$, because of its ionization potential and geometric configuration [13].

After the formation of the $\mathrm{B}[\mathrm{a}] \mathrm{P}$-epoxides, the epoxide group can be hydrolyzed by epoxide hydrolase $(\mathrm{EH})$ to form dihydrodiols leading to B[a]P-7,8-diol or B[a]P-9,10-diol [53]. These dihydrodiols are further oxidized to the mutagenic and carcinogenic $\mathrm{B}$ [a]P-7,8-dihydrodiol-9,10-epoxide (BPDE) by another the metabolic step that is catalyzed by CYP1A1/ CYP1B1 and the ultimate metabolite $(+)$-anti-BPDE possesses the highest tumor-inducing activity [54, 55]. In addition, dihydrodiols and the radical cations can be converted into reactive and redox-active $o$-quinones by dihydrodiol dehydrogenases, such as aldo-keto reductase (AKR) [56]. This one-electron oxidation process not only generate $\mathrm{B}[\mathrm{a}] \mathrm{P}$-quinones, but also leads to the formation of reactive oxygen species (ROS), which could cause further DNA damage and it increases lipid peroxidation via redox cycling [56].

The reactive metabolites generated during this so-called phase I metabolism are subject to the phase II detoxification system which plays a critical role in protecting cellular 
macromolecules (i.e. DNA and protein) from binding with reactive $\mathrm{B}[\mathrm{a}] \mathrm{P}$ derived metabolites [11]. There are three major phase II detoxification enzymes families that are involved in the metabolism of $\mathrm{B}[\mathrm{a}] \mathrm{P}$, including glutathione S-transferase (GSTs), UDP-glucuronosyltransferase (UGTs) and sulfotransferase (SULTs), and each of them act on the oxidized metabolites from phase I metabolism and form conjugates with glutathione, glucuronide and sulphate, respectively [57]. For example, B[a]P-epoxide, $\mathrm{B}[\mathrm{a}] \mathrm{P}$-diol epoxides, $\mathrm{B}[\mathrm{a}] \mathrm{P}$ quinones and hydroperoxides are detoxified through GSTs (e.g. GSTM1 and GSTT1) by glutathione (GSH) conjugation [58], where B[a]P-derived phenols and diols predominantly form conjugates by glucuronidation or sulfation [11]. However, not all detoxified $\mathrm{B}[\mathrm{a}] \mathrm{P}$ metabolites are harmless. For example, the $\mathrm{B}[\mathrm{a}] \mathrm{P}-7,8,9,10$-tetrahydro-7-ol-sulfate is able to form potentially damaging DNA adducts, and $\mathrm{B}[\mathrm{a}] \mathrm{P}-3-\mathrm{yl}$-hydrogen sulfate is very lipid soluble that could accumulate in the body $[59,60]$.

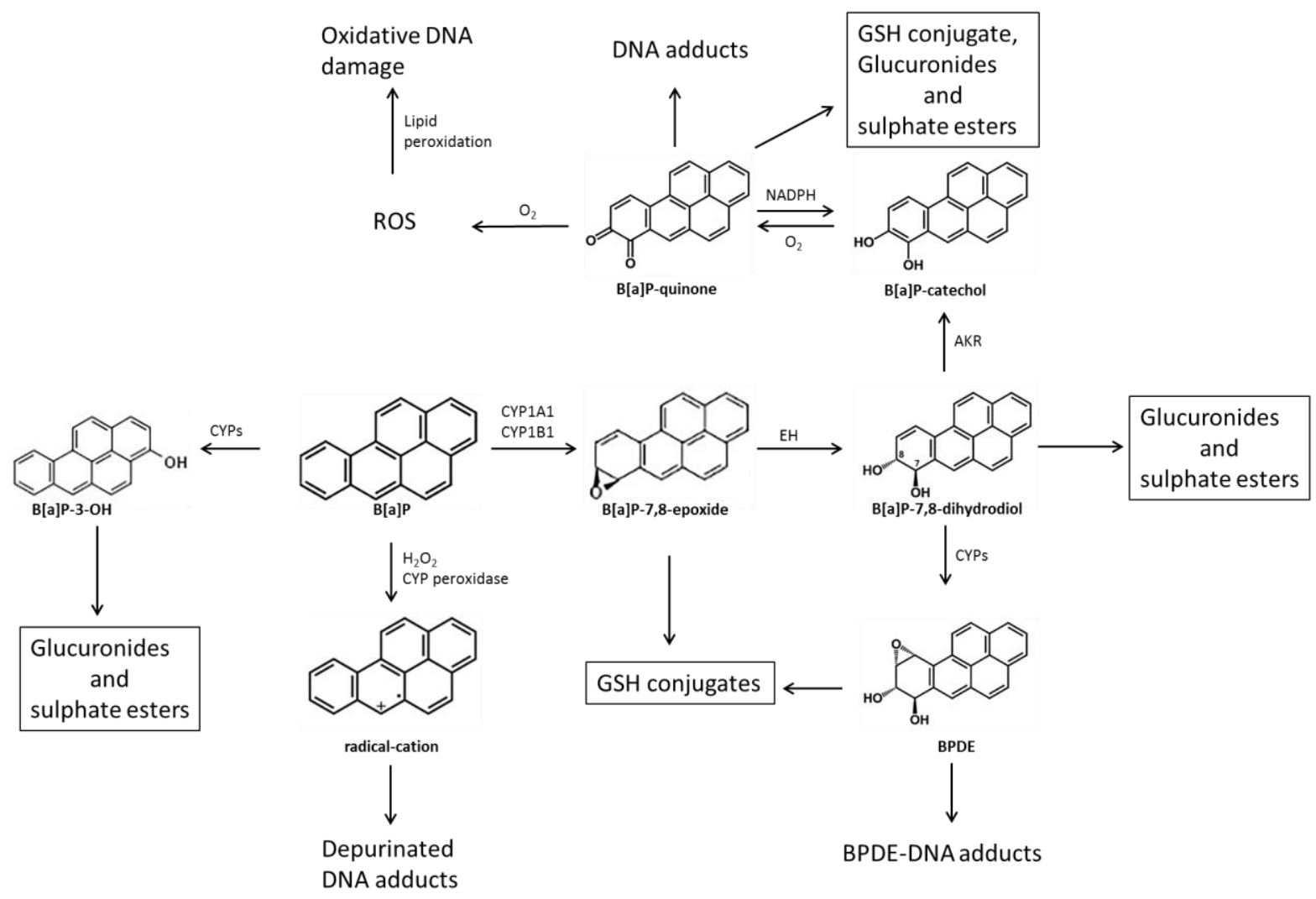

Figure 2. Schematic overview of the phase I and II metabolism of B[a]P leading to both active and inactive metabolites. Abbreviations: Cytochromes P450 (CYPs), Epoxide hydrolase (EH), Aldo-keto reductase (AKR), Benzo[a]pyrene-7,8-dihydrodiol-9,10-epoxide (BPDE), Reactive oxygen species (ROS).

\section{4. $B[a] P$ induced DNA damage and repair}

There are three classes of biologically reactive $\mathrm{B}[\mathrm{a}] \mathrm{P}$ metabolites (i.e. radical cations, BPDE and $o$-quinones), which could covalently bind to DNA by themselves to form DNA adducts, but the quinone metabolites can also undergo redox cycling, leading to excessive production of ROS. ROS are known to damage DNA directly or indirectly after inducing for instance reactive lipid peroxidation products. The $\mathrm{B}[\mathrm{a}] \mathrm{P}$ cation radical forms an unstable DNA adducts at guanine (at the C8 carbon and N7 nitrogen) and adenine ( at the N7 nitrogen), and can therefore lead to depurination, which generates apurinic sites $[13,61]$. The best described metabolite, BPDE, however, forms stable 14 
products with DNA, known as BPDE-DNA adducts. Due to multiple stereochemical forms of B[a]P-7,8-diol, four isoforms of BPDE (i.e. ( \pm )-anti/syn-BPDE) can be produced and $(+)$-anti-BPDE is the most predominant and the most potent tumor initiator $[11,54]$. BPDE can covalently bind to the purines deoxyguanosine and deoxyadenosine, preferentially to the $\mathrm{N} 2$ position of guanine to form an $\mathrm{N}^{2}$-deoxyguanosine adduct (BPDE- $\mathrm{N}^{2}-\mathrm{dG}$ ) [13]. This DNA adduct can lead to errors during replication causing for instance $\mathrm{G} \rightarrow \mathrm{T}$ and $\mathrm{G} \rightarrow \mathrm{A}$ mutations in the $K$-Ras gene at codon $12, \mathrm{G} \rightarrow \mathrm{T}$ mutations in codon 13 and $\mathrm{A} \rightarrow \mathrm{T}$ mutations in codon 61 of the Ha-Ras gene, and $\mathrm{G} \rightarrow \mathrm{T}$ mutations in the Tp53 tumor-suppressor gene [62-64]. Quinones of B[a]P can also react with DNA and form stable as well as depurinating DNA adducts, but it mainly causes DNA damage via repetitive redox cycling and generation of large amounts of ROS $[56,65]$. It has been reported in a yeast reporter-assay that the $\mathrm{B}[\mathrm{a}] \mathrm{P}$ quinone induced $\mathrm{G} \rightarrow \mathrm{T}$ transversions in the Tp53 tumor-suppressor gene, increased the number of strand-breaks and the formation of 8-oxo-deoxyguanosine [66].

Since the various forms of DNA damage that is induced by $\mathrm{B}[\mathrm{a}] \mathrm{P}$ is a threat to genomic integrity and cell survival, several protective mechanisms have evolved, including cell cycle arrest, apoptosis and DNA repair. DNA repair processes remove DNA lesions and it is a complex process in which multiple proteins work in a coordinated and regulated way [67].

There are six major DNA repair pathways which are the double-strand breaks repair (i.e. homologous recombination (HR) and non-homologous end joining (NHEJ), and single strand repair (i.e. direct reversal repair), mismatch repair (MMR), base excision repair and nucleotide excision repair (NER) [68]. Each of these DNA repair pathways respond to some type of damage, for instance, HR and NHEJ respond to double-strand breaks and DNA cross-links, direct reversal corrects several types of alkylated bases, MMR corrects mismatched base pairs and small insertion loops, BER repairs damage to single bases that usually do not block transcription and replication, and NER repairs bulky helix-distorting lesions [69]. DNA repair should clear the template strands from damage to increase the reliability of replication, but DNA repair does not necessarily occur before replication of the damaged site. Fortunately, cells can bypass the damaged site and allow DNA synthesis via DNA damage tolerance mechanisms [70]. In addition, when the level of DNA damage is exceeding the capacity of DNA repair or DNA damage tolerance mechanisms, cells might undergo apoptosis (programmed cell death) in order to prevent accumulation of mutated cells [70].

The major type of DNA adducts produced after B[a]P exposure is bulky DNA adducts for which NER is the major repair mechanism [71]. NER is a complex process involving a series of proteins, such as damaged DNA binding protein (DDB), xerodermatic pigmentosum complementation groups (e.g. XPE, XPC, XPA, XPB (ERCC3), XPG (ERCC5), XPD (ERCC2) and XPF (ERCC4)), cockayne syndrome complementation group (e.g. CSA (ERCC8) and CSB (ERCC6)), transcription factor $11 \mathrm{H}$ (TFIIH), excision repair cross-complementing rodent repair deficiency complementation group 1 (ERCC1), replication protein A (RPA), proliferating cell nuclear antigen (PCNA), replication factor $\mathrm{C}(\mathrm{RCF})$, and DNA polymerase $\delta$ (POL $\delta)[69,72]$. In general, NER can be divided in three steps (Fig 3): 1) recognition of DNA damage and the subsequent formation of a pre-incision complex; 2) single strand incisions and excision of the lesion containing DNA fragment; 3) DNA repair synthesis/ligation. In detail, there are two NER sub-pathway which are the global genome repair (GGR) that acts on DNA lesions in non-transcribed regions; and the transcription coupled repair (TCR) that specifically repairs actively transcribed strands [73, 74]. For the GGR pathway, the damage in 
transcriptionally inactive regions is detected by DDB1 and DDB2 (XPE), and form a heterodimer complex which promotes damage recognition [75]. After the DDB complex dissociated from the lesion via protein ubiquitination, the lesion transfers to XPC which initiates NER [76]. Then, XPC-RAD23B directly binds to the lesion, attract other XP factors to the damaged site, causing local DNA unwinding [69]. For TCR pathway, the damage is recognized through the blockage of the RNA polymerase I and II during transcription. Then, additional proteins including CSA and CSB bind to the DNA, eliminate stalled transcription complexes from the damaged sites, and leave the active gene accessible for repair [77]. After damage recognition of both pathways, XPA bind to the damaged DNA strand and RPA envelops the undamaged strand. Then, DNA is unwounded by XPB and XPD which act as part of transcription factor TFIIH. Next, the DNA around the damaged site releases a damage-containing oligomer of 24-32 bases long by incisions that are produced by the XPG and the XPF heterodimer. Finally, DNA polymerases $\delta$ or $\varepsilon$ fill the gap and ligase seals the newly synthesized DNA strand to the parental strand [78]. The rate limiting steps in NER are damage recognition and incision, as ATP is required for the cleavage and opening of the damaged DNA strand [79]. Although DNA repair mechanisms could correct DNA damage induced by reactive $\mathrm{B}[\mathrm{a}] \mathrm{P}$ metabolites, part of the $\mathrm{B}[\mathrm{a}] \mathrm{P}$ induced damage may escape from repair before the DNA is replicated [80]. In that case, the damaged site may lead to miscoding during the replication by DNA polymerases, inducing predominantly transversions of $\mathrm{G} \rightarrow \mathrm{T}$ or $\mathrm{G} \rightarrow \mathrm{A}$ [81]. What is more, when the mutation occurs in a critical region of important genes, such as the Tp53 tumor suppressor gene or K-ras proto-oncogene, B[a]P induced damage may initiate carcinogenesis [82].

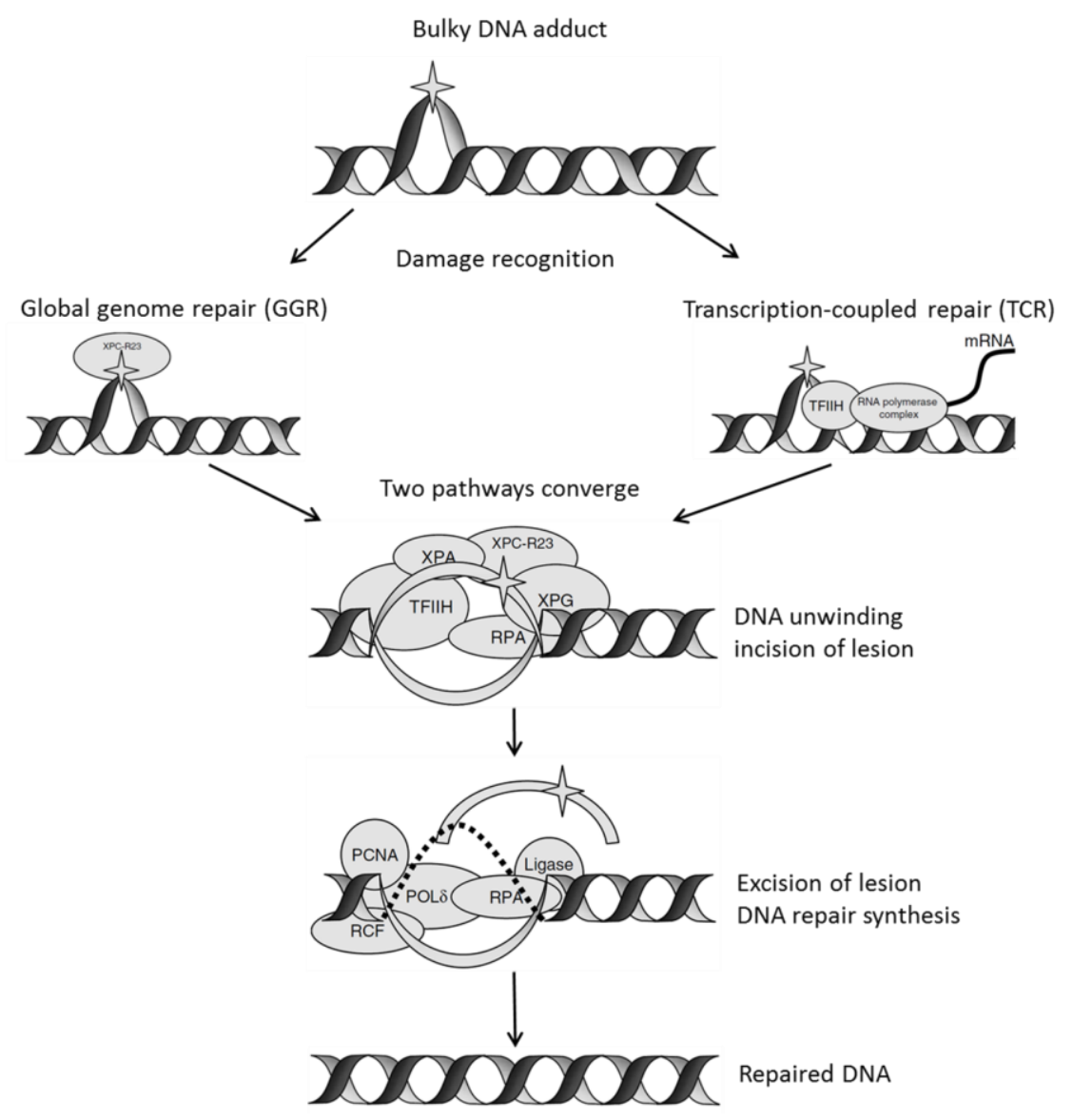

Figure 3. Overview of the nucleotide excision pathway adapted from Tyson and Mathers [69]. 


\section{Genotoxicity and carcinogenicity of $B[a] P$}

\subsection{Genotoxicity in vitro and in vivo}

In vitro studies provide overwhelming evidence for the genotoxicity and mutagenicity of $\mathrm{B}[\mathrm{a}] \mathrm{P}$. The formation of $\mathrm{B}[\mathrm{a}] \mathrm{P}$ related DNA adducts was observed in cultures from human and laboratory animal derived cells of the respiratory tract, skin, liver and other tissues as well as peripheral blood lymphocytes [11]. In addition, the reactive $\mathrm{B}[\mathrm{a}] \mathrm{P}$ metabolites (including BPDE) showed strongly enhanced mutagenicity in the Salmonella typhimurium mutation assay using strains TA97, TA98and TA100 as well as in human B-lymphoblastoid cells (MCL-5) [83, 84]. Moreover, the mutational spectra induced in a yeast reporter assay showed that BPDE predominantly caused $\mathrm{G} \rightarrow \mathrm{T}$ transversions in the Tp53 gene and this closely matched those seen in DNA from human lung tumors [66]. Furthermore, $\mathrm{B}[\mathrm{a}] \mathrm{P}$ also significantly increased the number of DNA strand breaks in CHO 3-6 cell line [85]. In agreement with these in vitro experiments, numerous in vivo studies demonstrated genotoxicity after exposure to $\mathrm{B}[\mathrm{a}] \mathrm{P}$. The formation of DNA adducts in vivo has been reported for $\mathrm{B}[\mathrm{a}] \mathrm{P}$ upon ingestion, dermal contact, inhalation or other administration methods (e.g. intratracheal, intraperitoneal, intrafetal injection etc.) mostly in rat, mouse or hamster [13]. For example, exposure to $\mathrm{B}[\mathrm{a}] \mathrm{P}$ in male rodents , lead to detectable levels of various types of $\mathrm{B}[\mathrm{a}] \mathrm{P}-\mathrm{DNA}$ adducts in liver, lung, testis, stomach and skin using ${ }^{32} \mathrm{P}-$ postlabeling [86-88]. DNA adduct levels are also related to mutation induction in animal models [89]. Many more in vivo and in vitro studies can be found in the scientific literature that support the notion that $\mathrm{B}[\mathrm{a}] \mathrm{P}$ and its metabolites are genotoxic as well as mutagenic.

\subsection{Carcinogenicity}

Experimental animal studies support the association between $\mathrm{B}[\mathrm{a}] \mathrm{P}$ exposure and the subsequent development of cancer in for instance lung, trachea, larynx, forestomach, liver, lymphoid tissue, skin and mammary glands [11, 47]. In most cases, cancer was found at the site of entry of $\mathrm{B}[\mathrm{a}] \mathrm{P}$; thus, dermal exposure to $\mathrm{B}[\mathrm{a}] \mathrm{P}$ induced skin cancers, oral exposure lead to the formation of stomach cancer and inhalatory exposure to the formation of tumors in the upper and lower respiratory tract. The role of DNA adduct formation in the induction of tumors is undisputed, because DNA adduct levels were better predictors of carcinogenicity than the level of exposure only [90].

For human epidemiological data, there is no direct evidence for the carcinogenicity of $\mathrm{B}[\mathrm{a}] \mathrm{P}$ alone because humans are mostly exposed to complex mixtures of compounds. However, the initial connection between $\mathrm{B}[\mathrm{a}] \mathrm{P}$ exposure and its ability to induce human cancers was made based on the analysis of tumor incidences with the corresponding $\mathrm{B}[\mathrm{a}] \mathrm{P}$ exposures via life style and/ or occupation [11]. For instance, lung cancer risk increased with increasing cumulative exposure to cigarette smoke, which contains $\mathrm{B}[\mathrm{a}] \mathrm{P}$ [91]. In addition, bladder cancer incidence was related to $\mathrm{B}[\mathrm{a}] \mathrm{P}$ exposure in aluminum smelter workers (exposure to $\mathrm{B}[\mathrm{a}] \mathrm{P}>80 \mu \mathrm{g} / \mathrm{m}^{3}$ in air), but no relationship was found in asphalt workers with a much lower cumulative exposure to B[a]P of up to $\sim 2 \mu \mathrm{g} / \mathrm{m}^{3}[92$, 93]. This might be due to the difference in exposure dose, where aluminum smelter workers were 40 times higher exposed than asphalt workers, and $\mathrm{B}[\mathrm{a}] \mathrm{P}$ could be efficiently detoxified at low doses.

Several prospective studies in humans indicate that DNA adduct levels could be predictive for cancer incidences later in life [94]. In these studies, DNA adduct levels were determined in white blood cells of exposed healthy individuals. Those subjects that 
developed cancer after years of follow-up, had higher adduct levels in their blood years before the actual detection of lung cancer. Interestingly, the association was evident only in current smokers and was absent in former smokers.

Additional molecular evidence for a role of $\mathrm{B}[\mathrm{a}] \mathrm{P}$ in human induced cancers was provided by Denissenko et al. [95], who mapped the distribution of benzo[a]pyrene diol epoxide (BPDE) DNA adducts at nucleotide level along the exons of the TP53 gene in BPDE-treated cells, and they found selective DNA adduct formation at guanine positions in codons 157, 248, and 273, which are known mutational hotspots in human lung cancers. Later on, it was also reported that these typical mutations in TP53 could be explained not only by the site specific formation of DNA damage, but also by the lower levels of DNA repair of bulky lesions at these specific mutational hotspots [96].

\section{Susceptibility for B[a]P induced carcinogenesis}

Interestingly, not every smoker will develop lung cancer, despite the fact that they are exposed to $\mathrm{B}[\mathrm{a}] \mathrm{P}$ (and many other DNA damaging compounds), and DNA adducts will undoubtedly be formed in their tissues [97]. To explain these differences in susceptibility, genetic variation has been widely studied. In general, it was found that subjects that carried low activity variants (single-nucleotide polymorphisms (SNPs)) in genes that encode functional proteins that protect cells against $\mathrm{B}$ [a]P induced damage indeed have more DNA damage [39]. These polymorphisms include phase I and II enzymes in the xenobiotic metabolism pathway, and DNA repair enzymes $[98,99]$. Other studies focused on life-style as determinant for increased susceptibility and increased formation of DNA adducts, by for instance studying the intake of fruits and vegetables [100], but both genetic variation, life style or both combined cannot fully explain the variation in vulnerability that is observed in the population [101]. Therefore, additional sources of variation need to be found to better understand $\mathrm{B}[\mathrm{a}] \mathrm{P}$ induced carcinogenesis, and to improve disease prevention. One such source of variation, which is specifically studied in this thesis, is the concurrent presence of inflammation.

\section{Chronic Inflammation and cancer}

Inflammation has been recognized as a "hallmark" of cancer [102]. Inflammation is a natural host defense system against insults or variety of injuries induced by bacteria, viruses, chemicals and heat induced damage [103]. In general, when inflammation is initiated a multifactorial network of chemical signals (such as cytokines, chemokines and other inflammatory mediators) are released and these mediators activate and attract inflammatory cells, including neutrophils, monocytes and eosinophils from the venous system to the sites of damage [102]. As a result, a microenvironment is constructed which favors the removal of the insults and it promotes wound healing [104]. Once the insult is cleared, the inflammatory response should weaken, but in some cases inflammation may persist and chronic inflammation develops [105]. The link between chronic inflammation and increased risk of developing cancer is supported by an enormous amount of epidemiological studies, which suggest that more than $15 \%$ of the worldwide cancer incidence may be associated with chronic inflammation, and use non-steroidal anti-inflammatory drugs (NSAIDs) may thus reduce the risk of cancer development [106]. For example, patients with inflammatory bowel disease (chronic ulcerative colitis or Crohn's disease) have a 5 to 7 -fold increased risk for developing colorectal carcinoma, or the risk of lung cancer in smokers with chronic obstructive 
pulmonary disease (COPD) is increased up to 10 -fold in comparison to smokers without COPD [105].

The underlying mechanisms of cancer induced by chronic inflammation is widely investigated, and include increased production of reactive nitrogen and oxygen species (RNS/ROS) leading to oxidative DNA damage and reduced DNA repair, which causes mutations in essential anti-tumor genes such as the tumor suppressor gene TP53. These typical mutations in TP53 have frequently been found in patients with chronic inflammatory diseases [105]. In addition, chronic inflammation destroys the balance between anti- and pro-inflammatory cytokines and therefore excessive amounts of pro-inflammatory cytokines are produced which may result in excessive DNA replication and proliferation of cells that lost normal growth control [105]. The major inflammatory mediators that are involved in this process are nuclear factor- $\kappa \mathrm{B}(\mathrm{NF}-\kappa \mathrm{B})$, signal transducer and activator of transcription 3 (STAT3), and hypoxia-inducible factor $1 \alpha$ (HIF $1 \alpha)$, and their downstream targets (inflammatory cytokines, chemokines and enzymes) including interleukin-6 (IL-6), interleukin-8 (IL-8), tumor necrosis factor- $\alpha$ (TNF- $\alpha$ ) and cyclo-oxygenase-2 (COX-2) [107]. During chronic inflammation, these inflammatory pathways are continuously being activated and inflammatory mediators are generated. All of this results in the formation of a positive loop where excessive amounts of inflammatory mediators further assist tumor development at different stages (e.g. initiation, promotion and expansion) [108]. Regarding tumor initiation, inflammatory mediators and chemical carcinogens can both initiate the process of carcinogenesis, but the question remains how they can act synergistically if both are simultaneously present.

\section{The potential impact of inflammation on $\mathrm{B}[\mathrm{a}] \mathrm{P}$ induced carcinogenesis}

Nowadays, it is recognized that part of the population is more susceptible to $\mathrm{B}[\mathrm{a}] \mathrm{P}$ induced carcinogenesis not only because of genetic variation and life style, but also because of the health status of the subject (i.e. presence of inflammation). For example, in a study of hepatocellular carcinoma (HCC) patients, the highest B[a]P-DNA adduct levels were present in those patients with inflammation by a chronic hepatitis B virus (HBV) infection [109]. In the last two decades, several inflammatory mediators and enzymes have been reported to promote $\mathrm{B}[\mathrm{a}] \mathrm{P}$ induced DNA damage by interfering with $\mathrm{B}[\mathrm{a}] \mathrm{P}$ phase I and II metabolism, DNA repair and the functioning of tumor suppressor genes. For instance, myeloperoxidase (MPO) could increase the metabolic activation of $\mathrm{B}[\mathrm{a}] \mathrm{P}$ as well as catalyze the formation of hypochlorous acid ( $\mathrm{HOCl}$ ) which appeared to be a potent inhibitor of the NER pathway [110]. IL- 6 and TNF- $\alpha$ enhanced genotoxic effects of $\mathrm{B}[\mathrm{a}] \mathrm{P}$ and subsequent formation of TP53 mutations via upregulation of CYP1B1 expression [111, 112]. In addition, the inflammatory pathway (i.e. NF- $\kappa B$ ) could cross-talk with other pathways that are important for the action of chemical carcinogens, such as AhR, p53 and HIF1 $\alpha$. The cross-talk between AhR and NF- $\mathrm{BB}$ has recently been reported in various in vitro and in vivo studies $[113,114]$. These studies showed that there is an mutual interaction of AhR and NF- $\kappa B$ signaling, where AhR promoted NF- $\mathrm{B}$ activity and its downstream effect, and NF- $\kappa \mathrm{B}$ increased AhR-mediated CYP1A1 expression which could increase metabolic activation of $\mathrm{B}[\mathrm{a}] \mathrm{P}[113,115]$. Furthermore, stimulation of NF- $\kappa \mathrm{B}$ has been shown to promote resistance to programmed cell death, and both p53 and NF- $\kappa$ B inhibited each other's ability to stimulate gene expression of target genes [116]. As a result, more $\mathrm{B}[\mathrm{a}] \mathrm{P}$ induced DNA damage and $\mathrm{B}[\mathrm{a}] \mathrm{P}$ induced mutations could be observed under inflammatory conditions. Moreover, the micro-environment that is generated by inflammation may also enhance DNA adduct 
formation by $\mathrm{B}[\mathrm{a}] \mathrm{P}$. It was previously shown that there is an extensive degree of cross-talk occurring between $\mathrm{AhR}$ and $\operatorname{HIF}[117,118]$. As a result, the activating metabolic enzymes (CYP1A1 and CYP1B1), the pre-cursor metabolite of the reactive metabolite BPDE (B[a]P-7,8-dihydrodiol) and B[a]P-DNA adducts were increased under hypoxic conditions [119]. This could partly be due to hypoxia diminishing $\mathrm{B}[\mathrm{a}] \mathrm{P}$ glucuronidation, which is an important $\mathrm{B}[\mathrm{a}] \mathrm{P}$ detoxification process [119].

On the other hand, not only inflammation could enhance the genotoxic effect of $\mathrm{B}[\mathrm{a}] \mathrm{P}$, but also $\mathrm{B}[\mathrm{a}] \mathrm{P}$ could stimulate inflammatory responses in vitro and in vivo [120-123]. Il-8 is an inflammatory biomarker and $\mathrm{B}[\mathrm{a}] \mathrm{P}$ was found to upregulate IL-8 mRNA expression and IL-8 secretion in primary human macrophages in a dose-dependent manner [123]. Interestingly, the ultimate reactive metabolite of $\mathrm{B}$ [a]P (i.e. BPDE) demonstrated similar effects, suggesting that its binding to macro-molecules could form the inflammatory trigger [122].

In vivo, administration of $\mathrm{B}[\mathrm{a}] \mathrm{P}$ to rats significantly increased the expression of pro-inflammatory biomarkers [120], including increased level of neutrophil elastase activity and nitric oxide generation and significantly increased level of free thiols and hydrogen peroxide [121].

\section{Objectives and outline of the thesis}

Humans are inevitably exposed to genotoxic agents via their environment or diet which contributes to cancer development. One host factor that could make individuals more susceptible for such exposures is the presence of inflammation. On basis of the observations in a vast number of epidemiological studies, the causal relationship between inflammations in combination with chemical carcinogens in cancer development is widely accepted. However, the molecular and cellular mechanisms mediating this relationship remain unresolved. Therefore, the main objective of the present thesis was to investigate the underlying mechanisms of how inflammatory factors can alter $\mathrm{B}[\mathrm{a}] \mathrm{P}$ metabolism and $\mathrm{B}[\mathrm{a}] \mathrm{P}$ induced DNA damage in such a way that it increases cancer risk.

In chapter 2 , the effect of $\beta$-glucuronidase on $\mathrm{B}[\mathrm{a}] \mathrm{P}$ metabolism and $\mathrm{B}[\mathrm{a}] \mathrm{P}$ induced DNA damage in carcinoma human epithelial lung (A549) and liver hepatocellular carcinoma (HepG2) cells in vitro is studied. $\beta$-Glucuronidase is released from neutrophils during inflammation, and currently little is known about the role of $\beta$-glucuronidase in $\mathrm{B}[\mathrm{a}] \mathrm{P}$ metabolism, because in theory $\beta$-glucuronidase could hydrolyze glucuronide conjugates of $\mathrm{B}[\mathrm{a}] \mathrm{P}$. Glucuronidation is one of the important phase II metabolic processes of $\mathrm{B}[\mathrm{a}] \mathrm{P}$ and the presence of $\beta$-glucuronidase might thus increase concentrations of active $B[a] P$ metabolites.

Considering the inflammation induced microenvironment, an acidic $\mathrm{pH}$ is often observed at the site of inflammation. The acidic microenvironment has been reported to contribute to cytokine production and action during inflammation [124]. The metabolism of $\mathrm{B}[\mathrm{a}] \mathrm{P}$ is depending on enzymes, each with their own $\mathrm{pH}$ optimum. However, how acidic $\mathrm{pH}$ may influence $\mathrm{B}[\mathrm{a}] \mathrm{P}$ metabolism and subsequent formation of DNA damage has not been investigated yet. Therefore, in Chapter 3, five different acidic pH's (i.e. extracellular $\mathrm{pH}\left(\mathrm{pH}_{\mathrm{e}}\right)$ of 7.8, 7.0, 6.5, 6.0 and 5.5) were applied to human pulmonary epithelial cells (A549 and BEAS-2B) with nontoxic doses of B[a]P. We examined the effect of these various $\mathrm{pH}$ on intra- and extra-cellular $\mathrm{pH}$ changes at different time points (i.e. 6, 24 and 48 hours), gene expression and enzyme activity of essential B[a]P metabolic enzymes CYP1A1 and CYP1B1, the formation of important 
$\mathrm{B}[\mathrm{a}] \mathrm{P}$ metabolites (i.e. $\mathrm{B}[\mathrm{a}] \mathrm{P}-78$-dihydrodiols), $\mathrm{B}[\mathrm{a}] \mathrm{P}-\mathrm{DNA}$ adduct level and DNA repair capacity (i.e. NER).

In Chapter 4, we study the effect of IL-8 on B[a]P metabolism and elucidate the potential underlying mechanism in BEAS-2B cells. IL-8, also known as neutrophil chemotactic factor, induces a series of physiological responses that is required for migration and phagocytosis. Previous in vitro studies focused on the role of IL-6 on B[a]P induced genotoxicity, but whether IL-8 could promote $\mathrm{B}[\mathrm{a}] \mathrm{P}$ induced genotoxicity has not been studied yet.

For most of the studies which investigate how inflammation promote $\mathrm{B}[\mathrm{a}] \mathrm{P}$ induced genotoxic effect, in vivo data on $\mathrm{B}[\mathrm{a}] \mathrm{P}$ metabolism and genotoxicity can overcome the concerns raised about the relevance of in vitro data. Chapter 5 therefore investigates the influence of inflammation (induced by LPS) on B[a]P metabolism (e.g. CYP1A1 gene expression and enzyme activity) and $\mathrm{B}[\mathrm{a}] \mathrm{P}-\mathrm{DNA}$ adduct formation in mouse lung and liver after a single dose $(0.5 \mathrm{mg} /$ mouse $)$ administration of $\mathrm{B}[\mathrm{a}] \mathrm{P}$. In order to get further insight into how LPS induced inflammation affects $\mathrm{B}[\mathrm{a}] \mathrm{P}$ induced genotoxicity and to understand the mode of action, an RNA microarray analysis was applied to mouse lungs as described in chapter 6. A link between phenotype (chapter 5) and expression data (chapter 6) could be established.

As a general overview, the scientific literature on inflammation and chemical carcinogen induced genotoxicity and carcinogenicity is reviewed in Chapter 7.

Finally, Chapter 8 presents the overall summary and discussion of the main findings of this thesis, as well as suggestions for future work. 


\section{References}

[1] B. Stewart, C.P. Wild, World cancer report 2014, (2014).

[2] J. Ferlay, I. Soerjomataram, R. Dikshit, S. Eser, C. Mathers, M. Rebelo, D.M. Parkin, D. Forman, F. Bray, Cancer incidence and mortality worldwide: sources, methods and major patterns in GLOBOCAN 2012, Int J Cancer, 136 (2015) E359-386.

[3] E. Silverberg, J.A. Lubera, A review of American Cancer Society estimates of cancer cases and deaths, CA: a cancer journal for clinicians, 33 (1983) 2-8.

[4] A. Dayan, Principles of toxicology: environmental and industrial applications, 2nd edition, Occupational and Environmental Medicine, 58 (2001) 545-545.

[5] S. Sreedharan, M.C. Hegde, R. Pai, S. Rhodrigues, R. Kumar, A. Rasheed, Snuff-induced malignancy of the nasal vestibule: a case report, Am J Otolaryngol, 28 (2007) 353-356.

[6] W.C. Hueper, Carcinogens in the human environment, Arch Pathol, 71 (1961) 237-267 contd.

[7] L.A. Loeb, C.C. Harris, Advances in Chemical Carcinogenesis: A Historical Review and Prospective, Cancer research, 68 (2008) 6863-6872.

[8] E.C. Miller, J.A. Miller, Mechanisms of chemical carcinogenesis, Cancer, 47 (1981) 1055-1064.

[9] N. Pearce, A. Blair, P. Vineis, W. Ahrens, A. Andersen, J.M. Anto, B.K. Armstrong, A.A. Baccarelli, F.A. Beland, A. Berrington, P.A. Bertazzi, L.S. Birnbaum, R.C. Brownson, J.R. Bucher, K.P. Cantor, E. Cardis, J.W. Cherrie, D.C. Christiani, P. Cocco, D. Coggon, P. Comba, P.A. Demers, J.M. Dement, J. Douwes, E.A. Eisen, L.S. Engel, R.A. Fenske, L.E. Fleming, T. Fletcher, E. Fontham, F. Forastiere, R. Frentzel-Beyme, L. Fritschi, M. Gerin, M. Goldberg, P. Grandjean, T.K. Grimsrud, P. Gustavsson, A. Haines, P. Hartge, J. Hansen, M. Hauptmann, D. Heederik, K. Hemminki, D. Hemon, I. Hertz-Picciotto, J.A. Hoppin, J. Huff, B. Jarvholm, D. Kang, M.R. Karagas, K. Kjaerheim, H. Kjuus, M. Kogevinas, D. Kriebel, P. Kristensen, H. Kromhout, F. Laden, P. Lebailly, G. LeMasters, J.H. Lubin, C.F. Lynch, E. Lynge, A. t Mannetje, A.J. McMichael, J.R. McLaughlin, L. Marrett, M. Martuzzi, J.A. Merchant, E. Merler, F. Merletti, A. Miller, F.E. Mirer, R. Monson, K.C. Nordby, A.F. Olshan, M.E. Parent, F.P. Perera, M.J. Perry, A.C. Pesatori, R. Pirastu, M. Porta, E. Pukkala, C. Rice, D.B. Richardson, L. Ritter, B. Ritz, C.M. Ronckers, L. Rushton, J.A. Rusiecki, I. Rusyn, J.M. Samet, D.P. Sandler, S. de Sanjose, E. Schernhammer, A.S. Costantini, N. Seixas, C. Shy, J. Siemiatycki, D.T. Silverman, L. Simonato, A.H. Smith, M.T. Smith, J.J. Spinelli, M.R. Spitz, L. Stallones, L.T. Stayner, K. Steenland, M. Stenzel, B.W. Stewart, P.A. Stewart, E. Symanski, B. Terracini, P.E. Tolbert, H. Vainio, J. Vena, R. Vermeulen, C.G. Victora, E.M. Ward, C.R. Weinberg, D. Weisenburger, C. Wesseling, E. Weiderpass, S.H. Zahm, IARC monographs: 40 years of evaluating carcinogenic hazards to humans, Environ Health Perspect, 123 (2015) 507-514.

[10] H.I. Abdel-Shafy, M.S.M. Mansour, A review on polycyclic aromatic hydrocarbons: Source, environmental impact, effect on human health and remediation, Egyptian Journal of Petroleum, 25 (2016) 107-123.

[11] U.S.E.P. Agency, IRIS Toxicological Review of Benzo[a]pyrene (Final Report). U.S. EPA, EPA, Washington, DC, 2017.

[12] K. Srogi, Monitoring of environmental exposure to polycyclic aromatic hydrocarbons: a review, Environmental Chemistry Letters, 5 (2007) 169-195.

[13] Chemical agents and related occupations, IARC Monogr Eval Carcinog Risks Hum, 100 (2012) 9-562.

[14] J. Zuo, D.S. Brewer, V.M. Arlt, C.S. Cooper, D.H. Phillips, Benzo pyrene-induced DNA adducts and gene expression profiles in target and non-target organs for carcinogenesis in mice, BMC Genomics, 15 (2014) 880.

[15] C.S. Dela Cruz, L.T. Tanoue, R.A. Matthay, Lung Cancer: Epidemiology, Etiology, and Prevention, Clinics in chest medicine, 32 (2011) 10.1016/j.ccm.2011.1009.1001.

[16] G. Fabbrocini, M. Triassi, M.C. Mauriello, G. Torre, M.C. Annunziata, V.D. Vita, F. Pastore, V. D’Arco, G. Monfrecola, Epidemiology of Skin Cancer: Role of Some Environmental Factors, Cancers, 2 (2010) 1980-1989.

[17] S. Potratz, H. Jungnickel, S. Grabiger, P. Tarnow, W. Otto, E. Fritsche, M. von Bergen, A. Luch, Differential cellular metabolite alterations in HaCaT cells caused by exposure to the aryl hydrocarbon receptor-binding polycyclic aromatic hydrocarbons chrysene, benzo[a]pyrene and dibenzo[a,l]pyrene, Toxicology Reports, 3 (2016) 763-773.

[18] J.S. Kerley-Hamilton, H.W. Trask, C.J.A. Ridley, E. DuFour, C. Lesseur, C.S. Ringelberg, K.L. Moodie, S.L. Shipman, M. Korc, J. Gui, N.W. Shworak, C.R. Tomlinson, Inherent and Benzo[a]pyrene-Induced Differential Aryl Hydrocarbon Receptor Signaling Greatly Affects Life Span, Atherosclerosis, Cardiac Gene Expression, and Body and Heart Growth in Mice, Toxicological Sciences, 126 (2012) 391-404.

[19] Some non-heterocyclic polycyclic aromatic hydrocarbons and some related exposures, IARC Monogr Eval Carcinog Risks Hum, 92 (2010) 1-853.

[20] 0. World Health, Guidelines for drinking water quality, Geneva, 1984, pp. 183-189.

[21] K. Ravindra, A.K. Mittal, R. Van Grieken, Health risk assessment of urban suspended particulate matter with special reference to polycyclic aromatic hydrocarbons: a review, Reviews on environmental health, 16 (2001) 169-189.

[22] Y. Liu, L. Zhu, X. Shen, Polycyclic aromatic hydrocarbons (PAHs) in indoor and outdoor air of Hangzhou, China, Environ Sci Technol, 35 (2001) 840-844.

[23] P. Kulkarni, C. Venkataraman, Atmospheric polycyclic aromatic hydrocarbons in Mumbai, India, Atmospheric Environment, 34 (2000) 2785-2790.

[24] T. Petry, P. Schmid, C. Schlatter, The use of toxic equivalency factors in assessing occupational and environmental health risk associated with exposure to airborne mixtures of polycyclic aromatic hydrocarbons (PAHs), Chemosphere, 32 (1996) 639-648. 
[25] E.P. Agency, Toxicological Review of Benzo[a]pyrene (EPA publication No. CASRN 50-32-8), U. S. Environmental Protection Agency2017.

[26] C.B.B. Guerreiro, J. Horalek, F. de Leeuw, F. Couvidat, Benzo(a)pyrene in Europe: Ambient air concentrations, population exposure and health effects, Environ Pollut, 214 (2016) 657-667.

[27] H.L. Sheu, W.J. Lee, S.J. Lin, G.C. Fang, H.C. Chang, W.C. You, Particle-bound PAH content in ambient air, Environ Pollut, 96 (1997) 369-382.

[28] A.M. Caricchia, S. Chiavarini, M. Pezza, Polycyclic aromatic hydrocarbons in the urban atmospheric particulate matter in the city of Naples (Italy), Atmospheric Environment, 33 (1999) 3731-3738.

[29] N.Y.M.J. Omar, M.R.B. Abas, K.A. Ketuly, N.M. Tahir, Concentrations of PAHs in atmospheric particles (PM-10) and roadside soil particles collected in Kuala Lumpur, Malaysia, Atmospheric Environment, 36 (2002) 247-254.

[30] H. Guo, S.C. Lee, K.F. Ho, X.M. Wang, S.C. Zou, Particle-associated polycyclic aromatic hydrocarbons in urban air of Hong Kong, Atmospheric Environment, 37 (2003) 5307-5317.

[31] E. Roekens, J. Dumollin, C. Matheeussen, PM10 dust and chemical characterisation of aerosols in Flanders, Belgium, WIT Transactions on Ecology and the Environment, 42 (2000).

[32] M.J. Kaiserman, W.S. Rickert, Carcinogens in tobacco smoke: benzo[a]pyrene from Canadian cigarettes and cigarette tobacco, American Journal of Public Health, 82 (1992) 1023-1026.

[33] C.B.B. Guerreiro, J. Horálek, F. de Leeuw, F. Couvidat, Benzo(a)pyrene in Europe: Ambient air concentrations, population exposure and health effects, Environ Pollut, 214 (2016) 657-667.

[34] O. World Health, Indoor air quality: Organic pollutants, Environmental Technology Letters, 10 (1989) 855-858.

[35] C. Anyakora, A. Ogbeche, P. Palmer, H. Coker, Determination of polynuclear aromatic hydrocarbons in marine samples of Siokolo Fishing Settlement, J Chromatogr A, 1073 (2005) 323-330.

[36] W.H. Organization, Guidelines for drinking-water quality, World Health Organization2004.

[37] U. Epa, National Primary Drinking Water Regulations: Benzo(a)pyrene, Federal Register, (1995).

[38] N. Grova, G. Rychen, F. Monteau, B. Le Bizec, C. Feidt, Effect of oral exposure to polycyclic aromatic hydrocarbons on goat's milk contamination, Agronomy for sustainable development, 26 (2006) 195.

[39] P. Vineis, Individual susceptibility to carcinogens, Oncogene, 23 (0000) 6477-6483.

[40] E.S. Fischer, K. Böhm, J.R. Lydeard, H. Yang, M.B. Stadler, S. Cavadini, J. Nagel, F. Serluca, V. Acker, G.M. Lingaraju, R.B. Tichkule, M. Schebesta, W.C. Forrester, M. Schirle, U. Hassiepen, J. Ottl, M. Hild, R.E.J. Beckwith, J.W. Harper, J.L. Jenkins, N.H. Thomä, Structure of the DDB1-CRBN E3 ubiquitin ligase in complex with thalidomide, Nature, 512 (2014) 49-53.

[41] N. Kazerouni, R. Sinha, C.H. Hsu, A. Greenberg, N. Rothman, Analysis of 200 food items for benzo[a]pyrene and estimation of its intake in an epidemiologic study, Food Chem Toxicol, 39 (2001) 423-436.

[42] F. Joint, W.E.C.o.F. Additives, W.H. Organization, Safety evaluation of certain contaminants in food, (2006).

[43] E.D.-A. SVĚTLÍKOVÁ, Occurence of benzo [a] pyrene in some foods of animal origin in the Slovak Republic, Journal of Food and Nutrition Research, 46 (2007) 181-185.

[44] C. Directorate, S. Opinions, Polycyclic Aromatic Hydrocarbons-Occurrence in foods, dietary exposure and health effects, (2002).

[45] Cal/Epa, Public health goals for chemicals in drinking water. Benzo(a)pyrene, 2010.

[46] Iarc, Some non-heterocyclic polycyclic aromatic hydrocarbons and some related exposures, Lyon, France, 2010, pp. 1-853.

[47] I.W.G.o.t.E.o.C.R.t. Humans, Some non-heterocyclic polycyclic aromatic hydrocarbons and some related exposures, IARC Monogr Eval Carcinog Risks Hum, 92 (2010) 1-853.

[48] A. Knafla, S. Petrovic, M. Richardson, J. Campbell, C. Rowat, Development and application of a skin cancer slope factor for exposures to benzo[a]pyrene in Soil, Regulatory Toxicology and Pharmacology, 59 (2011) 101-110.

[49] S. Shi, D.Y. Yoon, K.C. Hodge-Bell, I.G. Bebenek, M.J. Whitekus, R. Zhang, A.J. Cochran, S. Huerta-Yepez, S.H. Yim, F.J. Gonzalez, A.K. Jaiswal, O. Hankinson, The aryl hydrocarbon receptor nuclear translocator (Arnt) is required for tumor initiation by benzo[a]pyrene, Carcinogenesis, 30 (2009) 1957-1961.

[50] K. Shiizaki, M. Kawanishi, T. Yagi, Modulation of benzo [a] pyrene-DNA adduct formation by CYP1 inducer and inhibitor, Genes and Environment, 39 (2017) 14.

[51] M. Rojas, R. Godschalk, K. Alexandrov, I. Cascorbi, E. Kriek, J. Ostertag, F.J. Van Schooten, H. Bartsch, Myeloperoxidase--463A variant reduces benzo[a]pyrene diol epoxide DNA adducts in skin of coal tar treated patients, Carcinogenesis, 22 (2001) 1015-1018.

[52] T. Parman, P.G. Wells, Embryonic prostaglandin H synthase-2 (PHS-2) expression and benzo[a]pyrene teratogenicity in PHS-2 knockout mice, Faseb J, 16 (2002) 1001-1009.

[53] D.M. Johnson, T.C. Bruice, Nucleophilic catalysis of the aromatization of an arene oxide. Reaction of trimethylamine with 4-carb-o-tert-butoxybenzene oxide, Journal of the American Chemical Society, 97 (1975) 6901-6903.

[54] H.V. Gelboin, Benzo[alpha]pyrene metabolism, activation and carcinogenesis: role and regulation of mixed-function oxidases and related enzymes, Physiol Rev, 60 (1980) 1107-1166.

[55] K. Straif, R. Baan, Y. Grosse, B. Secretan, F. El Ghissassi, V. Cogliano, Carcinogenicity of polycyclic aromatic hydrocarbons, Lancet Oncology, 6 (2005) 931.

[56] T.M. Penning, M.E. Burczynski, C.F. Hung, K.D. McCoull, N.T. Palackal, L.S. Tsuruda, Dihydrodiol dehydrogenases and polycyclic aromatic hydrocarbon activation: generation of reactive and redox active o-quinones, Chem Res Toxicol, 12 (1999) 1-18. 
[57] J.E. Kucab, H. van Steeg, M. Luijten, H.H. Schmeiser, P.A. White, D.H. Phillips, V.M. Arlt, TP53 mutations induced by BPDE in Xpa-WT and Xpa-Null human TP53 knock-in (Hupki) mouse embryo fibroblasts, Mutat Res, 773 (2015) 48-62.

[58] J.D. Hayes, J.U. Flanagan, I.R. Jowsey, Glutathione transferases, Annu. Rev. Pharmacol. Toxicol., 45 (2005) 51-88. [59] Y.J. Surh, S.R. Tannenbaum, Sulfotransferase-mediated activation of 7,8,9,10-tetrahydro-7-ol, 7,8-dihydrodiol, and 7,8,9,10-tetraol derivatives of benzo[a]pyrene, Chem Res Toxicol, 8 (1995) 693-698.

[60] G.M. Cohen, S.M. Haws, B.P. Moore, J.W. Bridges, Benzo(a)pyren-3-yl hydrogen sulphate, a major ethyl acetate-extractable metabolite of benzo(a)pyrene in human, hamster and rat lung cultures, Biochem Pharmacol, 25 (1976) 2561-2570.

[61] D. Sagher, B. Strauss, Abasic sites from cytosine as termination signals for DNA synthesis, Nucleic acids research, 13 (1985) 4285-4298.

[62] M.J. Mass, A.J. Jeffers, J.A. Ross, G. Nelson, A.J. Galati, G.D. Stoner, S. Nesnow, Ki-ras oncogene mutations in tumors and DNA adducts formed by benz[j]aceanthrylene and benzo[a]pyrene in the lungs of strain A/J mice, Mol Carcinog, 8 (1993) 186-192.

[63] D. Chakravarti, D. Venugopal, P.C. Mailander, J.L. Meza, S. Higginbotham, E.L. Cavalieri, E.G. Rogan, The role of polycyclic aromatic hydrocarbon-DNA adducts in inducing mutations in mouse skin, Mutat Res, 649 (2008) 161-178.

[64] B. Ruggeri, M. DiRado, S.Y. Zhang, B. Bauer, T. Goodrow, A.J. Klein-Szanto, Benzo[a]pyrene-induced murine skin tumors exhibit frequent and characteristic G to T mutations in the p53 gene, Proc Natl Acad Sci U S A, 90 (1993) 1013-1017.

[65] N. Balu, W.T. Padgett, G.B. Nelson, G.R. Lambert, J.A. Ross, S. Nesnow, Benzo[a]pyrene-7,8-quinone-3'-mononucleotide adduct standards for 32P postlabeling analyses: detection of benzo[a]pyrene-7,8-quinone-calf thymus DNA adducts, Anal Biochem, 355 (2006) 213-223.

[66] Y.-M. Shen, A.B. Troxel, S. Vedantam, T.M. Penning, J. Field, Comparison of p53 Mutations Induced by PAH o-Quinones with Those Caused by anti-Benzo[a]pyrene Diol Epoxide In Vitro: Role of Reactive Oxygen and Biological Selection, Chem Res Toxicol, 19 (2006) 1441-1450.

[67] M. Christmann, C. Boisseau, R. Kitzinger, C. Berac, S. Allmann, T. Sommer, D. Aasland, B. Kaina, M.T. Tomicic, Adaptive upregulation of DNA repair genes following benzo(a)pyrene diol epoxide protects against cell death at the expense of mutations, Nucleic Acids Research, 44 (2016) 10727-10743.

[68] T. Helleday, E. Petermann, C. Lundin, B. Hodgson, R.A. Sharma, DNA repair pathways as targets for cancer therapy, Nat Rev Cancer, 8 (2008) 193-204.

[69] J. Tyson, J.C. Mathers, Dietary and genetic modulation of DNA repair in healthy human adults, Proc Nutr Soc, 66 (2007) 42-51.

[70] E.C. Friedberg, DNA damage and repair, Nature, 421 (2003) 436-440.

[71] R. Hakem, DNA-damage repair; the good, the bad, and the ugly, EMBO J, 27 (2008) 589-605.

[72] J.T. Reardon, T. Bessho, H.C. Kung, P.H. Bolton, A. Sancar, In vitro repair of oxidative DNA damage by human nucleotide excision repair system: Possible explanation for neurodegeneration in Xeroderma pigmentosum patients, Proceedings of the National Academy of Sciences of the United States of America, 94 (1997) 9463-9468.

[73] L.C. Gillet, O.D. Scharer, Molecular mechanisms of mammalian global genome nucleotide excision repair, Chem Rev, 106 (2006) 253-276.

[74] S.C. Shuck, E.A. Short, J.J. Turchi, Eukaryotic nucleotide excision repair: from understanding mechanisms to influencing biology, Cell Res, 18 (2008) 64-72.

[75] S. Keeney, H. Wein, S. Linn, Biochemical heterogeneity in xeroderma pigmentosum complementation group E, Mutat Res, 273 (1992) 49-56.

[76] K. Sugasawa, Y. Okuda, M. Saijo, R. Nishi, N. Matsuda, G. Chu, T. Mori, S. Iwai, K. Tanaka, K. Tanaka, F. Hanaoka, UV-induced ubiquitylation of XPC protein mediated by UV-DDB-ubiquitin ligase complex, Cell, 121 (2005) 387-400.

[77] A. van Hoffen, A.S. Balajee, A.A. van Zeeland, L.H. Mullenders, Nucleotide excision repair and its interplay with transcription, Toxicology, 193 (2003) 79-90.

[78] K.Y. Lee, K. Myung, PCNA modifications for regulation of post-replication repair pathways, Mol Cells, 26 (2008) $5-11$.

[79] W.K. Hansen, M.R. Kelley, Review of mammalian DNA repair and translational implications, J Pharmacol Exp Ther, 295 (2000) 1-9.

[80] M. Suh, F. Ariese, G.J. Small, R. Jankowiak, A. Hewer, D.H. Phillips, Formation and persistence of benzo[a]pyrene-DNA adducts in mouse epidermis in vivo: importance of adduct conformation, Carcinogenesis, 16 (1995) 2561-2569.

[81] H. Dong, R.R. Bonala, N. Suzuki, F. Johnson, A.P. Grollman, S. Shibutani, Mutagenic potential of benzo[a]pyrene-derived DNA adducts positioned in codon 273 of the human P53 gene, Biochemistry, 43 (2004) $15922-15928$.

[82] M.S. Greenblatt, W.P. Bennett, M. Hollstein, C.C. Harris, Mutations in the p53 tumor suppressor gene: clues to cancer etiology and molecular pathogenesis, Cancer Res, 54 (1994) 4855-4878.

[83] J.L. Green, Y.H. Pan, G.A. Reed, Mutagenicity of benzo[a]pyrene bay-region sulfonates, Carcinogenesis, 12 (1991) 1359-1362.

[84] W.F. Busby, Jr., H. Smith, C.L. Crespi, B.W. Penman, Mutagenicity of benzo[a]pyrene and dibenzopyrenes in the Salmonella typhimurium TM677 and the MCL-5 human cell forward mutation assays, Mutat Res, 342 (1995) 9-16. 
[85] E.W. Tung, N.A. Philbrook, C.L. Belanger, S. Ansari, L.M. Winn, Benzo[a]pyrene increases DNA double strand break repair in vitro and in vivo: a possible mechanism for benzo[a]pyrene-induced toxicity, Mutat Res Genet Toxicol Environ Mutagen, 760 (2014) 64-69.

[86] V.M. Arlt, A.M. Krais, R.W. Godschalk, Y. Riffo-Vasquez, I. Mrizova, C.A. Roufosse, C. Corbin, Q. Shi, E. Frei, M. Stiborova, F.J. van Schooten, D.H. Phillips, D. Spina, Pulmonary Inflammation Impacts on CYP1A1-Mediated Respiratory Tract DNA Damage Induced by the Carcinogenic Air Pollutant Benzo[a]pyrene, Toxicol Sci, 146 (2015) 213-225.

[87] R.W. Godschalk, E.J. Moonen, P.A. Schilderman, W.M. Broekmans, J.C. Kleinjans, F.J. Van Schooten, Exposure-route-dependent DNA adduct formation by polycyclic aromatic hydrocarbons, Carcinogenesis, 21 (2000) 87-92.

[88] N. Verhofstad, C.T. van Oostrom, J. van Benthem, F.J. van Schooten, H. van Steeg, R.W. Godschalk, DNA adduct kinetics in reproductive tissues of DNA repair proficient and deficient male mice after oral exposure to benzo(a)pyrene, Environ Mol Mutagen, 51 (2010) 123-129.

[89] A. De Vries, M. Dolle, J. Broekhof, J. Muller, E.D. Kroese, C.F. Van Kreijl, P. Capel, J. Vijg, H. Van Steeg, Induction of DNA adducts and mutations in spleen, liver and lung of XPA-deficient/lacZ transgenic mice after oral treatment with benzo [a] pyrene: correlation with tumour development, Carcinogenesis, 18 (1997) 2327-2332.

[90] J.A. Ross, G.B. Nelson, K.H. Wilson, J.R. Rabinowitz, A. Galati, G.D. Stoner, S. Nesnow, M.J. Mass, Adenomas induced by polycyclic aromatic hydrocarbons in strain A/J mouse lung correlate with time-integrated DNA adduct levels, Cancer research, 55 (1995) 1039-1044.

[91] B.G. Armstrong, G. Gibbs, Exposure-response relationship between lung cancer and polycyclic aromatic hydrocarbons (PAHs), Occupational and Environmental Medicine, 66 (2009) 740-746.

[92] G.W. Gibbs, B. Armstrong, M. Sevigny, Mortality and cancer experience of Quebec aluminum reduction plant workers. Part 2: mortality of three cohorts hired on or before january 1, 1951, J Occup Environ Med, 49 (2007) 1105-1123.

[93] I. Burstyn, H. Kromhout, C. Johansen, S. Langard, T. Kauppinen, J. Shaham, G. Ferro, P. Boffetta, Bladder cancer incidence and exposure to polycyclic aromatic hydrocarbons among asphalt pavers, Occupational and Environmental Medicine, 64 (2007) 520-526.

[94] F. Veglia, S. Loft, G. Matullo, M. Peluso, A. Munnia, F. Perera, D.H. Phillips, D. Tang, H. Autrup, O. Raaschou-Nielsen, A. Tjonneland, P. Vineis, DNA adducts and cancer risk in prospective studies: a pooled analysis and a meta-analysis, Carcinogenesis, 29 (2008) 932-936.

[95] M.F. Denissenko, A. Pao, M. Tang, G.P. Pfeifer, Preferential formation of benzo[a]pyrene adducts at lung cancer mutational hotspots in P53, Science, 274 (1996) 430-432.

[96] M.F. Denissenko, A. Pao, G.P. Pfeifer, M. Tang, Slow repair of bulky DNA adducts along the nontranscribed strand of the human p53 gene may explain the strand bias of transversion mutations in cancers, Oncogene, 16 (1998) 1241-1247.

[97] R. Godschalk, J. Nair, F.J. van Schooten, A. Risch, P. Drings, K. Kayser, H. Dienemann, H. Bartsch, Comparison of multiple DNA adduct types in tumor adjacent human lung tissue: effect of cigarette smoking, Carcinogenesis, 23 (2002) 2081-2086.

[98] H.B. Ketelslegers, R.W. Gottschalk, R.W. Godschalk, A.M. Knaapen, F.J. van Schooten, R.F. Vlietinck, J.C. Kleinjans, J.H. van Delft, Interindividual variations in DNA adduct levels assessed by analysis of multiple genetic polymorphisms in smokers, Cancer Epidemiol Biomarkers Prev, 15 (2006) 624-629.

[99] G. Matullo, M. Peluso, S. Polidoro, S. Guarrera, A. Munnia, V. Krogh, G. Masala, F. Berrino, S. Panico, R. Tumino, P. Vineis, D. Palli, Combination of DNA repair gene single nucleotide polymorphisms and increased levels of DNA adducts in a population-based study, Cancer Epidemiol Biomarkers Prev, 12 (2003) 674-677.

[100] D. Palli, G. Masala, P. Vineis, S. Garte, C. Saieva, V. Krogh, S. Panico, R. Tumino, A. Munnia, E. Riboli, M. Peluso, Biomarkers of dietary intake of micronutrients modulate DNA adduct levels in healthy adults, Carcinogenesis, 24 (2003) 739-746.

[101] D. Palli, G. Masala, M. Peluso, L. Gaspari, V. Krogh, A. Munnia, S. Panico, C. Saieva, R. Tumino, P. Vineis, S. Garte, The effects of diet on DNA bulky adduct levels are strongly modified by GSTM1 genotype: a study on 634 subjects, Carcinogenesis, 25 (2004) 577-584.

[102] L.M. Coussens, Z. Werb, Inflammation and cancer, Nature, 420 (2002) 860-867.

[103] A. Cekici, A. Kantarci, H. Hasturk, T.E. Van Dyke, Inflammatory and immune pathways in the pathogenesis of periodontal disease, Periodontology 2000, 64 (2014) 57-80.

[104] D.R. Blake, R. Allen, Inflammation: Basic Principles and Clinical Correlates, Annals of the Rheumatic Diseases, 47 (1988) 792-792.

[105] L.M. Coussens, Z. Werb, Inflammation and cancer, Nature, 420 (2002) 860-867.

[106] H. Kuper, H.O. Adami, D. Trichopoulos, Infections as a major preventable cause of human cancer, J Intern Med, 248 (2000) 171-183.

[107] S.M. Crusz, F.R. Balkwill, Inflammation and cancer: advances and new agents, Nat Rev Clin Oncol, 12 (2015) 584-596.

[108] S. Rakoff-Nahoum, Why Cancer and Inflammation?, The Yale Journal of Biology and Medicine, 79 (2006) 123-130.

[109] S.Y. Chen, L.Y. Wang, R.M. Lunn, W.Y. Tsai, P.H. Lee, C.S. Lee, H. Ahsan, Y.J. Zhang, C.J. Chen, R.M. Santella, Polycyclic aromatic hydrocarbon-DNA adducts in liver tissues of hepatocellular carcinoma patients and controls, Int J Cancer, 99 (2002) 14-21. 


\section{Chapter 1}

[110] N. Gungor, R.W. Godschalk, D.M. Pachen, F.J. Van Schooten, A.M. Knaapen, Activated neutrophils inhibit nucleotide excision repair in human pulmonary epithelial cells: role of myeloperoxidase, Faseb J, 21 (2007) 2359-2367.

[111] L. Umannova, M. Machala, J. Topinka, Z. Novakova, A. Milcova, A. Kozubik, J. Vondracek, Tumor necrosis factor-alpha potentiates genotoxic effects of benzo[a]pyrene in rat liver epithelial cells through upregulation of cytochrome P450 1B1 expression, Mutation research, 640 (2008) 162-169.

[112] S.A.A. Patel, N.J. Gooderham, Interleukin-6 promotes dietary carcinogen-induced DNA damage in colorectal cancer cells, Toxicology Research, 4 (2015) 858-866.

[113] C.F. Vogel, E.M. Khan, P.S. Leung, M.E. Gershwin, W.L. Chang, D. Wu, T. Haarmann-Stemmann, A. Hoffmann, M.S. Denison, Cross-talk between aryl hydrocarbon receptor and the inflammatory response: a role for nuclear factor-kappaB, J Biol Chem, 289 (2014) 1866-1875.

[114] C.F. Vogel, F. Matsumura, A new cross-talk between the aryl hydrocarbon receptor and RelB, a member of the NF-kappaB family, Biochemical pharmacology, 77 (2009) 734-745.

[115] J. Øvrevik, M. Låg, V. Lecureur, D. Gilot, D. Lagadic-Gossmann, M. Refsnes, P.E. Schwarze, T. Skuland, R. Becher, J.A. Holme, AhR and Arnt differentially regulate NF- $\mathrm{KB}$ signaling and chemokine responses in human bronchial epithelial cells, Cell Communication and Signaling, 12 (2014) 48.

[116] G.A. Webster, N.D. Perkins, Transcriptional cross talk between NF-kappaB and p53, Molecular and cellular biology, 19 (1999) 3485-3495.

[117] M. Nie, A.L. Blankenship, J.P. Giesy, Interactions between aryl hydrocarbon receptor (AhR) and hypoxia signaling pathways, Environmental toxicology and pharmacology, 10 (2001) 17-27.

[118] N. Zhang, M.K. Walker, Crosstalk Between the Aryl Hydrocarbon Receptor and Hypoxia on the Constitutive Expression of Cytochrome P4501A1 mRNA, Cardiovascular toxicology, 7 (2007) 282-290.

[119] M.A. Schults, K. Sanen, R.W. Godschalk, J. Theys, F.J. van Schooten, R.K. Chiu, Hypoxia diminishes the detoxification of the environmental mutagen benzo[a]pyrene, Mutagenesis, 29 (2014) 481-487.

[120] A.E. Archibong, A. Ramesh, M.S. Niaz, D.-S. Son, D. Alcendor, Benzo(a)pyrene-induced Inflammatory Cytokine Production Contributes to Suppressed E2 Synthesis and Secretion at Proestrus, Biology of Reproduction, 85 (2011) 290.

[121] W. Qamar, A.Q. Khan, R. Khan, A. Lateef, M. Tahir, M.U. Rehman, F. Ali, S. Sultana, Benzo(a)pyrene-induced pulmonary inflammation, edema, surfactant dysfunction, and injuries in rats: alleviation by farnesol, Exp Lung Res, 38 (2012) 19-27.

[122] K. Dreij, K. Rhrissorrakrai, K.C. Gunsalus, N.E. Geacintov, D.A. Scicchitano, Benzo[a]pyrene diol epoxide stimulates an inflammatory response in normal human lung fibroblasts through a p53 and JNK mediated pathway, Carcinogenesis, 31 (2010) 1149-1157.

[123] N. Podechard, V. Lecureur, E. Le Ferrec, I. Guenon, L. Sparfel, D. Gilot, J.R. Gordon, V. Lagente, O. Fardel, Interleukin-8 induction by the environmental contaminant benzo(a)pyrene is aryl hydrocarbon receptor-dependent and leads to lung inflammation, Toxicol Lett, 177 (2008) 130-137.

[124] A. Bellocq, S. Suberville, C. Philippe, F. Bertrand, J. Perez, B. Fouqueray, G. Cherqui, L. Baud, Low environmental $\mathrm{pH}$ is responsible for the induction of nitric-oxide synthase in macrophages. Evidence for involvement of nuclear factor-kappaB activation, J Biol Chem, 273 (1998) 5086-5092. 




\section{Chapter 2}

\section{Inflammation associated extracellular}

\section{$\beta$-glucuronidase alters cellular responses to}

\section{the chemical carcinogen benzo[a]pyrene}

Shi Q, Haenen GR, Maas L, Arlt VM, Spina D, Vasquez YR, Moonen E, Veith C, Van Schooten FJ, Godschalk RW.

Arch Toxicol. 2016 Sep;90(9):2261-73. doi: 10.1007/s00204-015-1593-7. 


\begin{abstract}
Neutrophils infiltrate tissues during inflammation and when activated, they release $\beta$-glucuronidase. Since inflammation is associated with carcinogenesis, we investigated how extracellular $\beta$-glucuronidase changed the in vitro cellular response to the chemical carcinogen benzo(a)pyrene (B[a]P). For this we exposed human liver (HepG2) and lung (A549) cells to $\mathrm{B}[\mathrm{a}] \mathrm{P}$ in the presence or absence of $\beta$-glucuronidase. $\beta$-Glucuronidase reduced $\mathrm{B}[\mathrm{a}] \mathrm{P}$-induced expression of $C Y P 1 A 1$ and $C Y P 1 B 1$ at 6 hours after exposure, which did not depend on $\beta$-glucuronidase activity, because the inhibitor D-saccharic acid 1,4-lactone monohydrate did not antagonize the effect of $\beta$-glucuronidase. On the other hand, the inhibitory effect of $\beta$-glucuronidase on CYP expression was dependent on signaling via the insulin like growth factor receptor (IGF2R, a known receptor for $\beta$-glucuronidase), because co-incubation with the IGF2R inhibitor mannose-6-phosphate (M6P) completely abolished the effect of $\beta$-glucuronidase. Extracellular $\beta$-glucuronidase also reduced the formation of several $\mathrm{B}[\mathrm{a}] \mathrm{P}$ metabolites and $\mathrm{B}[\mathrm{a}] \mathrm{P}$-DNA adducts. Interestingly, at 24 hours of exposure, $\beta$-glucuronidase significantly enhanced $C Y P$ expression, probably because $\beta$-glucuronidase de-glucuronidated $\mathrm{B}[\mathrm{a}] \mathrm{P}$ metabolites, which continued to trigger the aryl hydrocarbon receptor (Ah-receptor) and induced expression of CYP1A1 (in both cell lines) and CYP1B1 (in A549 only). Consequently, significantly higher concentrations of $\mathrm{B}[\mathrm{a}] \mathrm{P}$ metabolites and DNA adducts were found in $\beta$-glucuronidase-treated cells at $24 \mathrm{hrs}$. DNA adduct levels peaked at 48 hours in cells that were exposed to $\mathrm{B}[\mathrm{a}] \mathrm{P}$ and treated with $\beta$-glucuronidase. Overall, these data show that $\beta$-glucuronidase alters the cellular response to $\mathrm{B}[\mathrm{a}] \mathrm{P}$ and ultimately enhances $\mathrm{B}[\mathrm{a}] \mathrm{P}$-induced DNA adduct levels.
\end{abstract}

Key words: Benzo[a]pyrene, Inflammation, $\beta$-glucuronidase, Cytochrome P450 1A1, carcinogen metabolism, IGF2R, DNA adducts 


\section{Introduction}

Chronic inflammation is causally associated with cancer development and therefore, inflammation was considered as the seventh hallmark feature of cancer $[1,2]$. This is illustrated for instance by the relatively high incidence of lung cancer in chronic obstructive pulmonary disease (COPD) patients [3]. Recent studies have pointed out that polymorphonuclear neutrophils (PMN), which are recruited at the site of inflammation play an important role in the initiation and progression of cancer [4, 5]. Inhalation of complex air pollutants like tobacco smoke and/or fine particles may result in pulmonary inflammation, which generates reactive oxygen/nitrogen species (ROS/RNS) that can damage lung tissue [6]. At the same time it has been shown that under inflammatory conditions, PMN enhance the mutagenic potential of chemical carcinogens $[7,8]$. This is partly explained by the action of the PMN-derived enzyme myeloperoxidase (MP0), that can metabolically activate carcinogens and inhibit DNA repair, leading to higher levels of carcinogen-DNA adducts [9-11]. However, there is still little data available on other factors that are released by the relatively high number of PMN during chronic inflammation, including $\beta$-glucuronidase, and how these influence the cellular response to chemical carcinogens [12].

Inhalatory exposure to air pollutants like particles often results in a combination of an inflammatory response in the presence of genotoxic agents, like polycyclic aromatic hydrocarbons (PAHs) [13]. PAHs, including benzo[a]pyrene (B[a]P) have gained much attention, because they are abundantly present in the environment [14] and they have serious adverse genotoxic effects. $\mathrm{B}[\mathrm{a}] \mathrm{P}$ becomes mutagenic and carcinogenic after bioactivation by enzymes, including cytochrome P450 (CYP) and epoxide hydrolase (EH) [15]. It is converted into various metabolites, including oxides, phenols, diols, diol-epoxides, quinones, and radical cations [16]. The best studied metabolite is $\mathrm{B}$ [a]P-diol epoxide (BPDE) (Figure 1). The first steps is the conversion of $\mathrm{B}[\mathrm{a}] \mathrm{P}$ by the microsomal NADPH-dependent cytochrome P450 isoforms 1A1 (CYP1A1) and 1B1 (CYP1B1) to yield the B[a]P-7,8-oxide, B[a]P-9,10-oxide or 3-hydroxy-B[a]P (3-OH-B[a]P) $[17,18]$. Subsequently, both $\mathrm{B}[\mathrm{a}] \mathrm{P}-7,8$-oxide and $\mathrm{B}[\mathrm{a}] \mathrm{P}-9,10$-oxide can be hydrated by microsomal EH to yield the corresponding $\mathrm{B}[\mathrm{a}] \mathrm{P}-7,8-$ trans-dihydrodiols (B[a]P-7,8-diol) and $\mathrm{B}[\mathrm{a}] \mathrm{P}-9,10$-trans-dihydrodiols $\quad(\mathrm{B}[\mathrm{a}] \mathrm{P}-9,10-d i o l) . \mathrm{B}[\mathrm{a}] \mathrm{P}-7,8-d i o l$ is further metabolized to the ultimate carcinogen benzo[a]pyrene-7,8-diol-9,10-epoxide (BPDE), which is known as a reactive derivative of $\mathrm{B}[\mathrm{a}] \mathrm{P}$ that can covalently bind to DNA to form adducts preferentially at guanine residues (e.g. 10-(deoxyguanosin- $N^{2}$-yI)-7,8,9-trihydroxy-7,8,9,10-tetrahydro benzo[a]pyrene; $\mathrm{dG}-N^{2}$-BPDE) [18-20]. It is generally accepted that the formation of such DNA adducts leads to mutations relevant for carcinogenesis [21]. In addition, the reactive metabolites can be conjugated by an important phase II detoxification enzyme UDP-glucuronosyltransferases (UGTs) that leads to glucuronides which are not mutagenic or carcinogenic $[22,23]$. Indeed, UGT1A6 was found to glucuronate a range of $\mathrm{B}[\mathrm{a}] \mathrm{P}$ metabolites including $3-\mathrm{OH}-\mathrm{B}[\mathrm{a}] \mathrm{P}, \mathrm{B}[\mathrm{a}] \mathrm{P}-9,10-$ diol and the pro-carcinogen B[a]P-7,8-diol [24-26].

In order to elucidate the role of $\beta$-glucuronidase in inflammatory disease and its effect on chemically-induced cancer, it is crucial to understand how $\beta$-glucuronidase changes the cellular response toward $\mathrm{B}[\mathrm{a}] \mathrm{P}$. In a recent study, it was found that lipopolysaccharide (LPS) treatment increased $\mathrm{B}[\mathrm{a}] \mathrm{P}$-induced DNA adduct levels in lung and liver tissues of $\mathrm{B}[\mathrm{a}] \mathrm{P}$ inhalatory exposed mice [27]. To explain this result we hypothesise that the LPS induced an inflammatory response resulting in the release of 
$\beta$-glucuronidase that hydrolysed glucuronidated $\mathrm{B}[\mathrm{a}] \mathrm{P}$ metabolites and thus reverse the protective effect of glucuronidation, and subsequently enhanced the binding of $\mathrm{B}[\mathrm{a}] \mathrm{P}$ metabolites to DNA. To test our hypothesis, we studied the impact of extracellular $\beta$-glucuronidase on the formation of $\mathrm{B}[\mathrm{a}] \mathrm{P}$ metabolites $(3-\mathrm{OH}-\mathrm{B}[\mathrm{a}] \mathrm{P}, \mathrm{B}[\mathrm{a}] \mathrm{P}-9,10$-diol and $\mathrm{B}[\mathrm{a}] \mathrm{P}-7,8-d i o l)$, gene expression of some enzymes pivotal in $\mathrm{B}[\mathrm{a}] \mathrm{P}$ metabolism (including CYP1A1, CYP1B1 and UGT1A6) and DNA adduct formation in human liver cell line (HepG2) and human lung cell line (A549).

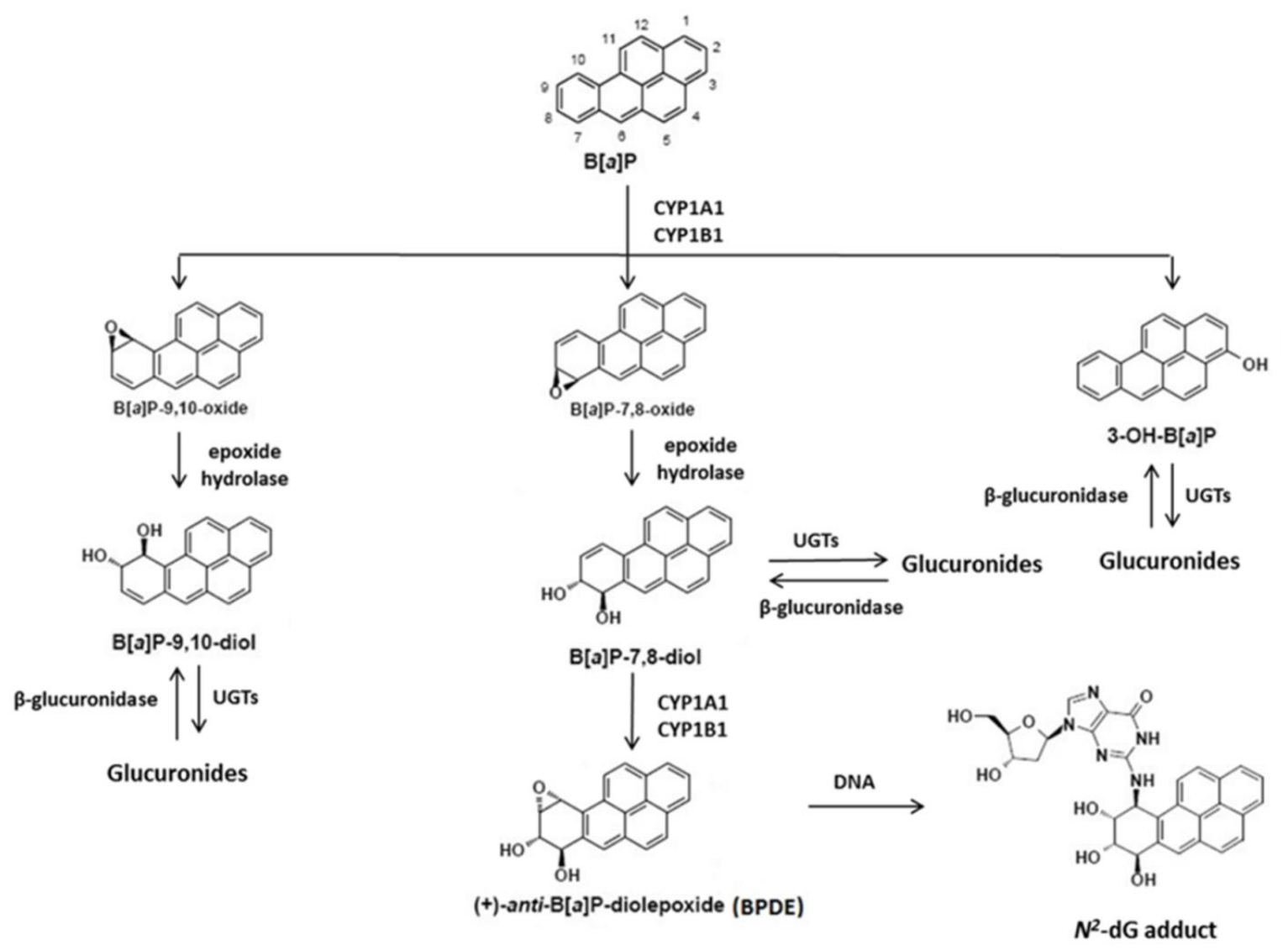

Figure 1. Critical steps of $\mathrm{B}[\mathrm{a}] \mathrm{P}$ activation and UDP-glucuronosyltransferases (UGTs) detoxification. B[a]P is metabolized to hydroxylated $\mathrm{B}[\mathrm{a}] \mathrm{P}$ including $\mathrm{B}[\mathrm{a}] \mathrm{P}-7,8-d i o l$ and these $\mathrm{B}[\mathrm{a}] \mathrm{P}$ metabolites are further detoxified by UGTs. $\beta$-glucuronidases are able to hydrolyze glucuronidated $\mathrm{B}[\mathrm{a}] \mathrm{P}$ metabolites and therefore increase the amount of $\mathrm{B}[\mathrm{a}] \mathrm{P}-7,8-d i o l$, consequently leading to more BPDE and DNA adducts formation.

\section{Materials and Methods}

\section{Mouse lung and liver tissues}

All procedures performed in the study involving animal experiments were conducted at King's College London under license in accordance with the institutional ethics committee on the protocols approved by the Home Office under 'The Animals (Scientific Procedures) Act (1986)'. Mice were divided into four groups ( $\mathrm{n}=3$ in each group): A) control group; mice were nasally instilled with saline. After 24 hours, mice were intratracheally instilled with tricaprylin. B) the lipopolysaccharide (LPS) treatment group; each mouse was nasally instilled with $20 \mu \mathrm{g}$ LPS (dissolved in saline). After 24 hours, mice were intratracheally instilled with tricaprylin. C) the B[a]P-treated group; mice were nasally instilled with saline and intratracheally instilled with $0.5 \mathrm{mg} \mathrm{B}[\mathrm{a}] \mathrm{P}$ 
(dissolved in $25 \mu$ l tricaprylin) after 24 hours. D) the B[a]P- and LPS-treated group; each mouse was nasally instilled with $20 \mu \mathrm{g}$ of LPS. After 24 hours, mice were intratracheally instilled with $0.5 \mathrm{mg} \mathrm{B}[\mathrm{a}] \mathrm{P}$. All mice were sacrificed at 48 hours after the intratracheal exposure. The collection of bronchoalveolar lavage fluid (BAL fluid) and the isolation of cytosolic fractions from lung and liver was performed as described in Arlt et al. (2015).

\section{Cell lines and cell treatment}

Human liver hepatocellular carcinoma HepG2 cells and human epithelial lung adenoma carcinoma A549 cells were obtained from the American Tissue Culture Collection. HepG2 cells were cultured in Minimum Essential Medium (MEM) plus glutamax containing $10 \%$ (v/v) foetal calf serum (FCS, Gibco invitrogen, Breda, The Netherlands), $1 \%$ (v/v) Sodium Pyruvate, 1\% (v/v) penicillin/streptomycin (Sigma, Zwijndrecht, The Netherlands) and 1\% (v/v) non-essential amino acids (Sigma). A549 cells were cultured in RPMI (Sigma) supplemented with 5\% (v/v) FCS and 1\% (v/v) penicillin/streptomycin. All cells were cultured under humidified atmosphere containing $5 \% \mathrm{CO}_{2}$ at $37^{\circ} \mathrm{C}$. Cell passages between 20 and 29 were used for experiments. All chemicals were purchased from Sigma-Aldrich unless stated otherwise.

Cells with $80 \%$ confluency were exposed to $1 \mu \mathrm{M} \mathrm{B}[\mathrm{a}] \mathrm{P}$ in the presence or absence of $\beta$-glucuronidase $(4 \mathrm{U} / \mathrm{ml}$ ) for 6,24 or 48 hours. $\mathrm{B}[\mathrm{a}] \mathrm{P}$ was dissolved in dimethylsulfoxide (DMSO) and added to the medium with a final DMSO concentration of $0.5 \%(\mathrm{v} / \mathrm{v})$. $\beta$-glucuronidase was dissolved in $0.1 \mathrm{M}$ sodium-acetate buffer ( $\mathrm{pH}$ 5.5). Mannose-6-phosphate (M6P) was dissolved in $0.1 \mathrm{M}$ sodium-acetate buffer ( $\mathrm{pH} 5.5)$ and the final concentration in cell culture is $100 \mu \mathrm{M}$. D-saccharic acid 1,4-lactone monohydrate was dissolved in $0.1 \mathrm{M}$ sodium-acetate buffer $(\mathrm{pH} 5.5)$ the final concentration in cell culture is $100 \mu \mathrm{M}$. Before incubation, all cell media were adjusted to pH 5.5 by using $1 \mathrm{M} \mathrm{HCl}$ in order to mimic the micro-environment of inflammation. After incubation, the medium and cells were stored at $-20^{\circ} \mathrm{C}$ until further analysis. Experiments were performed at least with three replicates in three independent cultures.

\section{Measurement of $\beta$-glucuronidase activity}

$\beta$-Glucuronidase (Helix pomatia type $\mathrm{H} 5, \geq 400,000$ Units/g solid) activity was determined by fluometrically monitoring the hydrolysis of 4-methylumbelliferyl- $\beta$-d-glucuronide (4MUgIA) according to the method described by Bartholome et al [28] with some modifications. Briefly, the reaction mixture in a total volume of $140 \mu \mathrm{l}$ contained $0.1 \mathrm{M}$ sodium-acetate buffer ( $\mathrm{pH} 5.5$ ), $2 \mathrm{mM}$ 4MUgIA and sample containing $\beta$-glucuronidase. The reaction was initiated by mixing 4MUgIA and the sample. The hydrolysis of 4MUgIA was measured in a thermostated plate reader (Spectra max m2, MDS, CA) at $37^{\circ} \mathrm{C}$ and $320 / 460 \mathrm{~nm}$ excitation/ emission wavelengths. A standard curve of $\beta$-glucuronidase $(0.4-400$ Units $/ \mathrm{ml}(\mathrm{U} / \mathrm{ml}))$ was generated to quantitate formation of fluorescence in the presence of 4MUgIA. D-saccharic acid 1,4-lactone monohydrate, a $\beta$-glucuronidase inhibitor, was used to inhibit $\beta$-glucuronidase activity.

For testing the interaction between $\mathrm{B}[\mathrm{a}] \mathrm{P}$ and $\beta$-glucuronidase, we used similar condition as mentioned above. A total volume of $140 \mu \mathrm{l}$ contained $0.1 \mathrm{M}$ sodium-acetate buffer (pH 5.5), different concentration of 4MUgIA (e.g. 500, 250, 100, 50, 10 and $1 \mu \mathrm{M}$ ) and $4 \mathrm{U} / \mathrm{ml} \beta$-glucuronidase with additional $1 \mu \mathrm{l}$ of $200 \mu \mathrm{M}$ B[a]P or $1 \mu \mathrm{l}$ DMSO. The measurement of fluorescence was performed for 10 hours at $37^{\circ} \mathrm{C}$. 


\section{HPLC fluorescence analysis of B[a]P and B[a]P metabolites}

$\mathrm{B}[\mathrm{a}] \mathrm{P}$ and its metabolites were extracted from $5 \mathrm{ml}$ cell medium by mixing with $1 \mathrm{ml}$ ethylacetate for $20 \mathrm{mins}$ and followed by centrifugation (10 $\mathrm{min}, 980 \mathrm{~g})$. The top layer was transferred to a new tube. This procedure was repeated twice. The top layers were evaporated under nitrogen and the residue was redissolved in $0.5 \mathrm{ml}$ methanol (Biosolve Chemicals, Valkenswaard, The Netherlands). Samples were subsequently analyzed by HPLC-FD using a Gynkotek P580A HPLC system (Separations Analytical Instruments, Hendrik-Ido-Ambacht, The Netherlands) consisting of a Spark SP830 autosampler (Spark Holland, Emmen, The Netherlands) and a Perkin Elmer LS-30 programmable fluorescence detector (Perkin Elmer, Foster City, CA, USA) operated at excitation/emission wavelengths $257 />350 \mathrm{~nm}$. The samples were injected onto a Hypersil $5 \mu \mathrm{m}$ ODS HPLC column (250 $\mathrm{mm} \times 3 \mathrm{~mm}$ ) (Supelco 54933, Bellefonte, PA, USA) with a flow rate of $0.5 \mathrm{ml} / \mathrm{min}$. Separation was performed using a mixture of two mobile phases: A (100\% methanol) and B (40\% methanol in water) in the following multi-step gradient conditions: 0-5 min, 30/70 (A/B, v/v); 5-30 min, gradient from 30/70 (A/B, v/v) to $90 / 10(\mathrm{~A} / \mathrm{B}, \mathrm{v} / \mathrm{v}) ; 30-35 \mathrm{~min}, 90 / 10(\mathrm{~A} / \mathrm{B}, \mathrm{v} / \mathrm{v})$; 35-37 min, gradient from $90 / 10(\mathrm{~A} / \mathrm{B}$, $\mathrm{v} / \mathrm{v})$ to $30 / 70(\mathrm{~A} / \mathrm{B}, \mathrm{v} / \mathrm{v}) ; 37-40 \mathrm{~min}, 30 / 70(\mathrm{~A} / \mathrm{B}, \mathrm{v} / \mathrm{v})$. For quantitation of the specific metabolites, a standard mix which contained $50 \mathrm{ng} / \mathrm{ml} \mathrm{B}$ [a]P-9,10-diol $50 \mathrm{ng} / \mathrm{ml}$ $\mathrm{B}[\mathrm{a}] \mathrm{P}-7,8-d i o l$ and $50 \mathrm{ng} / \mathrm{ml}$ 3-OH-B[a]P (Midwest Research Institute, Kansas City, MO, USA) were injected and the area of each metabolite peak in the chromatogram was determined.

\section{Quantitative real-time PCR}

Gene expression levels were measured by quantitative real-time reverse transcriptase-PCR (RT-qPCR) using a MyiQ Single Colour real-time PCR detection system (BioRad, Veenendaal, The Netherlands). Total RNA was isolated and purified by using the RNeasy® Mini Kit (Qiagen Westburg, Leusden, the Netherlands) in combination with DNase treatment (Qiagen). cDNA was generated from 500 ng total RNA by using the iScript $^{\mathrm{TM}}$ cDNA synthesis kit protocol (BioRad). Primers were purchased from Operon (Leiden, The Netherlands) for the following genes: $\beta$-actin, CYP1A1, CYP1B1 and UGT1A6 (see [29]). The reaction contained SYBR ${ }^{\odot}$ Green Supermix (BIO-RAD), $5 \mu$ l (40 times diluted) cDNA and $0.3 \mu \mathrm{M}$ primers in a total volume of $25 \mu \mathrm{l}$. PCR was conducted under the following condition: denaturation at $95^{\circ} \mathrm{C}$ for $3 \mathrm{~min}$, followed by 40 cycles of $95^{\circ} \mathrm{C}$ for $10 \mathrm{sec}$ and $55^{\circ} \mathrm{C}$ for $45 \mathrm{sec}$. All PCR reactions included a cDNA dilution curve to assess PCR efficiency and all reactions were followed by a melt curve $\left(55-95^{\circ} \mathrm{C}\right)$. Data were analyzed by using MyiQ Software system (BioRad) and the amount of target cDNA in each sample was determined by a fractional PCR threshold cycle number (Ct-value) and compared to the corresponding Ct-value for the housekeeping gene $\beta$-actin. The relative gene expression level for each gene was calculated by using the $2^{-\Delta \Delta \mathrm{Ct}}$ method [30].

\section{${ }^{32} P$-postlabelling of $B[a] P-D N A$ adducts}

DNA harvested from cells was isolated using a phenol-chloroform-isoamylalcohol extraction procedure as described by Schults et al. [31]. Briefly, after incubation, cells were resuspended in $450 \mu \mathrm{l}$ lysis buffer [10 mM Tris, $10 \mathrm{mM}$ TEMPO, $1 \mathrm{mM}$ EDTA and 1\% $(\mathrm{w} / \mathrm{v})$ sodium dodecyl sulfate (SDS); $\mathrm{pH}$ 8] and incubated with proteinase $\mathrm{K}(10 \mu \mathrm{g} / \mathrm{ml})$ at $37^{\circ} \mathrm{C}$ overnight. The mixture was extracted with 1 volume Tris-saturated phenol, 1 volume Tris-saturated phenol-chloroform-isoamyl alcohol (25:24:1 by volume) and 1 
volume chloroform-isamyl alcohol $(24: 1, \mathrm{v} / \mathrm{v})$. The DNA was precipitated with $1 / 30$ volume $3 \mathrm{M} \mathrm{NaAc}$ pH 5.2 and 2 volumes of cold 100\% ethanol. Precipitated DNA was washed with $70 \%$ ethanol and dried under nitrogen. The DNA was dissolved in $2 \mathrm{mM}$ Tris (pH 8.0) with final concentration $0.5 \mu \mathrm{g} / \mu \mathrm{l}$.

DNA digestion and ${ }^{32} \mathrm{P}$-postlabelling were performed as described by Van Schooten et al [32]. In short, DNA samples $(10 \mu \mathrm{g})$ were digested with micrococcal nuclease (Sigma) $(0.25 \mathrm{U} / \mu \mathrm{l})$ and spleen phosphodiesterase (Sigma) $(2 \mu \mathrm{g} / \mu \mathrm{l})$ for 4 hours at $37^{\circ} \mathrm{C}$ in a total volume of $9.5 \mu \mathrm{l}$. For DNA adduct enrichment, samples were treated with nuclease P1 (Sigma) $(2.5 \mu \mathrm{g} / \mu \mathrm{l})$ at $37^{\circ} \mathrm{C}$ for $30 \mathrm{~min}$. The nuclease P1 reaction was terminated by addition of $1 \mu \mathrm{l} 1 \mathrm{M}$ Tris ( $\mathrm{pH}$ 9.6). DNA adducts were subsequently labelled with [ $\left.\gamma^{-32} \mathrm{P}\right] \mathrm{ATP}(50 \mu \mathrm{Ci} /$ sample; Perkin Elmer, Indianapolis) using T4-polynucleotide kinase $(10 \mathrm{U} / \mu \mathrm{l})$ for $30 \mathrm{~min}$ at $37^{\circ} \mathrm{C}$. The ${ }^{32} \mathrm{P}$-labelled adducts were separated on PEI-cellulose sheets (Machery Nagel, Düren, Germany) by multi-directional thin-layer chromatography (TLC).

The TLC sheets were scanned using Phosphor-Imaging technology (Fujifilm FLA-3000) and DNA adducts levels were calculated from two B[a]PDE-DNA standards with known adducts levels ( 1 adduct $/ 10^{6}$ and 1 adduct $/ 10^{7}$ nucleotides). The major B[a]P-DNA adduct that was used for quantitation purposes in both HepG2 and A549 cells migrated to the same position as the major adduct of the BPDE-DNA adduct standard. In addition, the $\mathrm{B}[\mathrm{a}] \mathrm{PDE}-\mathrm{DNA}$ adduct levels were corrected for the amount of DNA in the sample which was assessed by HPLC-UV analysis.

\section{Statistical analysis}

Data were expressed as mean \pm standard error of the mean (SEM). Statistical analysis was performed using Graphpad Prism 6. To examine differences between the different treatments at each time point, a two-way analysis of variance test (ANOVA) with Bonferroni post hoc multiple comparison was used. Differences were considered to be statistically significant if the p-value was less than $0.05(\mathrm{P}<0.05)$.

\section{Results}

\section{Activity of $\beta$-glucuronidase in lung and liver tissues of mice}

Intranasal exposure of the mice to LPS resulted in an approximately 2-fold induction of $\beta$-glucuronidase activity in lung tissue compared to control (Table 1). Similarly, when LPS treatment was combined with $\mathrm{B}[\mathrm{a}] \mathrm{P}$ treatment, a significant 1.5 -fold higher activity of $\beta$-glucuronidase was observed compared with the $\mathrm{B}[\mathrm{a}] \mathrm{P}$-treated group without LPS. In addition, bronchoalveolar lavage fluid (BAL fluid) was collected and the $\beta$-glucuronidase activity in BAL fluid was lower than in the tissues, but LPS treatment did result in a significant increase of $\beta$-glucuronidase when compared to animals that were not treated with LPS (i.e. irrespective of $\mathrm{B}[\mathrm{a}] \mathrm{P}$ exposure). On the other hand, in liver tissue a 1.2-fold lower activity of $\beta$-glucuronidase was observed in LPS-treated animals when compared to control and $\mathrm{B}[\mathrm{a}] \mathrm{P}$ treated mice, respectively. These changes in $\beta$-glucuronidase activity after LPS treatment were in the range of 2 to $30 \mathrm{U} / \mathrm{ml}$ $\beta$-glucuronidase, and therefore $4 \mathrm{U} / \mathrm{ml}$ was used as biologically relevant dose in the subsequent cell culture experiments (see Table 1). 
Table 1: Activity of $\beta$-glucuronidase in mouse liver, lung tissues and BAL fluids.

\begin{tabular}{lllll}
\hline & $\begin{array}{l}\text { Control } \\
(\mathrm{U} / \mathrm{ml})\end{array}$ & $\begin{array}{l}\text { LPS } \\
(\mathrm{U} / \mathrm{ml})\end{array}$ & $\begin{array}{l}\mathrm{B}[\mathrm{a}] \mathrm{P} \\
(\mathrm{U} / \mathrm{ml})\end{array}$ & $\begin{array}{l}\text { B[a]P\&LPS } \\
(\mathrm{U} / \mathrm{ml})\end{array}$ \\
\cline { 2 - 5 } Liver cytosol & $27.1 \pm 1.5$ & $23.3 \pm 0.4^{*}$ & $27.6 \pm 0.9$ & $22.5 \pm 1.0^{* *}$ \\
Lung cytosol & $7.6 \pm 0.8$ & $15.4 \pm 1.3^{*}$ & $7.4 \pm 0.8$ & $11.1 \pm 1.3^{* *}$ \\
BAL fluids & $2 \pm 0.2$ & $2.2 \pm 0.1^{\#}$ & $2.0 \pm 0.1$ & $2.2 \pm 0.1^{\#}$ \\
\hline
\end{tabular}

${ }^{*}$ significantly different from control animals $(\mathrm{p}<0.05)$

${ }^{* *}$ significantly different from B[a]P-treated animals $(\mathrm{p}<0.05)$

${ }^{*} \mathrm{p}<0.05$ if both LPS-treated groups were combined when compared to non-LPS-treated animals.

\section{Phenotypes after B[a]P exposure with or without $\beta$-glucuronidase}

\section{Expression of CYP1A1 and CYP1B1}

Exposure to $\mathrm{B}[\mathrm{a}] \mathrm{P}$ significantly induced the expression of $C Y P 1 A 1$ and $C Y P 1 B 1$ (Fig 2a and Fig 3a). In A549 cells, the expression of these genes at 6 hours after exposure was increased 56-fold and 5-fold, respectively. Surprisingly, co-incubation with $\beta$-glucuronidase inhibited the induction of expression with approximately $50 \%-90 \%$. Expression of CYP1A1 and CYP1B1 in cells that were treated with $\beta$-glucuronidase without additional exposure to $\mathrm{B}[\mathrm{a}] \mathrm{P}$ was also reduced when compared to the expression observed in control cells, but this difference did not reach statistical significance. At 24 hours, the expression of $C Y P 1 A 1$ and $C Y P 1 B 1$ was induced by B[a]P to 39-fold and 3-fold, respectively. Surprisingly, the induction of both genes was now strongly increased by the presence of $\beta$-glucuronidase (191-fold and 6-fold, respectively). At $\mathrm{t}=48$ hours, the induction of $C Y P 1 A 1$ and CYP1B1 in cells that were co-exposed to $\beta$-glucuronidase remained higher than in cells that were only exposed to $\mathrm{B}[\mathrm{a}] \mathrm{P}$. The same pattern of changes in gene expression of CYP1A1 and CYP1B1 by $\beta$-glucuronidase was observed in the absence of $\mathrm{B}[\mathrm{a}] \mathrm{P}$, although less pronounced. Moreover, changes in gene expression of $C Y P 1 A 1$ and $C Y P 1 B 1$ were essentially similar in HepG 2 cells (Fig $\mathbf{2} \mathbf{b}$ and Fig $\mathbf{3 b}$ ), but the fold changes that were reached were lower than in A549 cells.

(a)

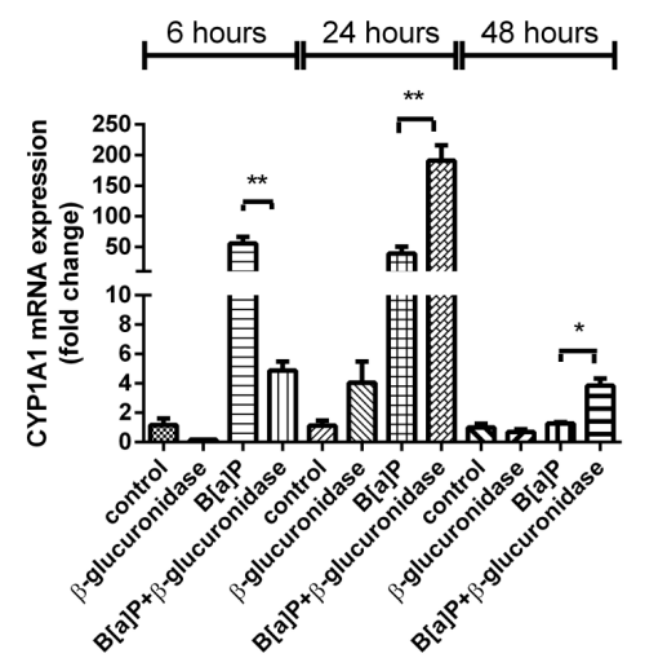

(b)
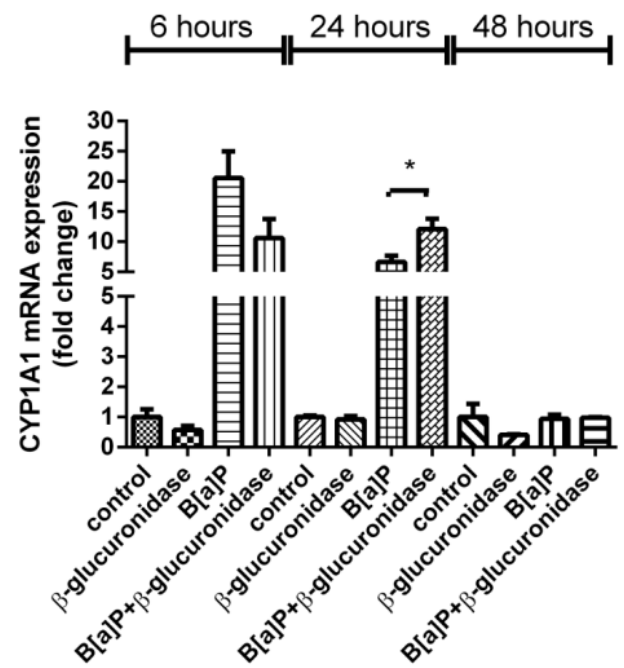

Figure 2. RT-qPCR analysis of gene expression CYP1A1 in both A549 (a) and HepG2 (b) cells after exposure to $\beta$-glucuronidase and/or B[a]P. Cells were exposed to $1 \mu \mathrm{M} \mathrm{B}[\mathrm{a}] \mathrm{P}$ with or without $4 \mathrm{U} / \mathrm{ml}$ $\beta$-glucuronidase and harvested after the times indicated. Cells exposed to DMSO and sodium acetate buffer were used as a vehicle control. All values are given as the means \pm SEM ( $\mathrm{n}=4$ per data point). $\left({ }^{*} \mathrm{p}<0.05 ;{ }^{* *} \mathrm{p}<0.01 ;{ }^{* * *} \mathrm{p}<0.001\right)$ 
(a)
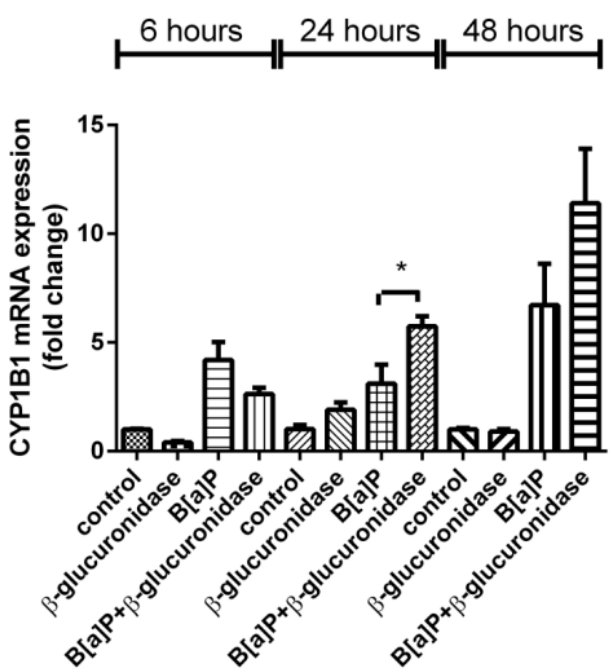

(b)
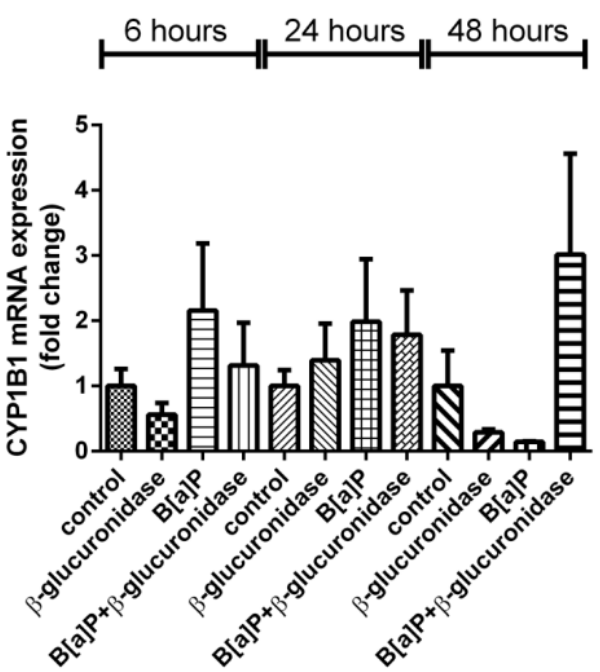

Figure 3. RT-qPCR analysis of gene expression CYP1B in both A549 (a) and HepG2 cells (b) after exposure to $\beta$-glucuronidase and/or $\mathrm{B}[\mathrm{a}] \mathrm{P}$. Cells were exposed to $1 \mu \mathrm{M} \mathrm{B}[\mathrm{a}] \mathrm{P}$ with or without $4 \mathrm{U} / \mathrm{ml}$ $\beta$-glucuronidase and harvested after the times indicated. Cells exposed to DMSO and sodium acetate buffer were used as a vehicle control. All values are given as the means \pm SEM ( $n=4$ per data point). $\left({ }^{*} \mathrm{p}<0.05 ;{ }^{* *} \mathrm{p}<0.01 ;{ }^{* * *} \mathrm{p}<0.001\right)$

\section{Expression of UGT1A6}

As shown in Fig 4b, in HepG2 cells the expression of UGT1A6 was 3-fold and 11-fold induced by $\mathrm{B}[\mathrm{a}] \mathrm{P}$ when compared to unexposed cells at 6 and 24 hours after exposure, respectively. Addition of $\beta$-glucuronidase inhibited UGT1A6 expression after 6 hours when compared to cells treated with $\mathrm{B}[\mathrm{a}] \mathrm{P}$ alone. However, a significant increase in UGT1A6 expression was observed 24 hours after exposure (61-fold and 6-fold compared to unexposed cells and only B[a]P-treated cells, respectively). At 48 hours, the expression of UGT1A6 remained enhanced by $\mathrm{B}[\mathrm{a}] \mathrm{P}$ and $\mathrm{B}[\mathrm{a}] \mathrm{P}$ with additional $\beta$-glucuronidase, but the induction levels were three times lower (9-fold and 28-fold, respectively). In addition, a similar pattern of changes in gene expression of UGT1A6 were shown by $\beta$-glucuronidase in the absence of $\mathrm{B}[\mathrm{a}] \mathrm{P}$.

On the other hand, in A549 cells, there was no significant induction or inhibition of UGT1A6 expression by $\mathrm{B}[\mathrm{a}] \mathrm{P}$ nor by $\beta$-glucuronidase, but at $\mathrm{t}=48$ hours, all treatments induced the expression of UGT1A6 compared to unexposed cells (see Fig 4a). 
(a)

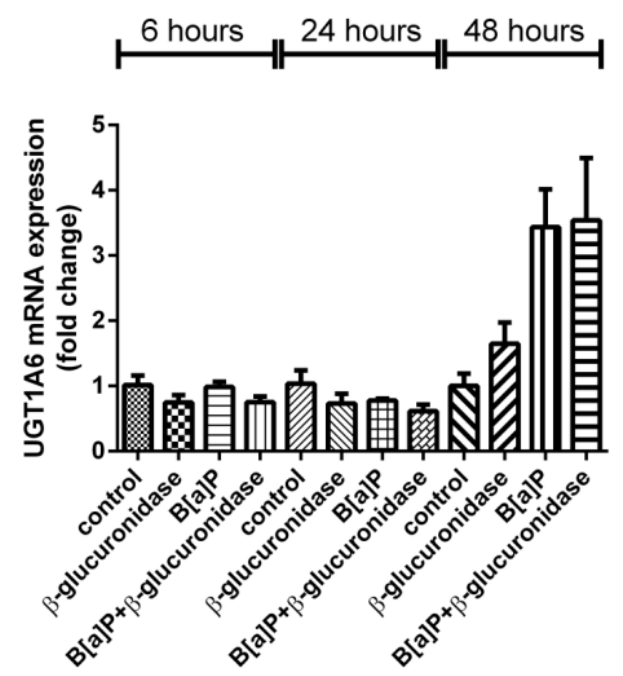

(b)

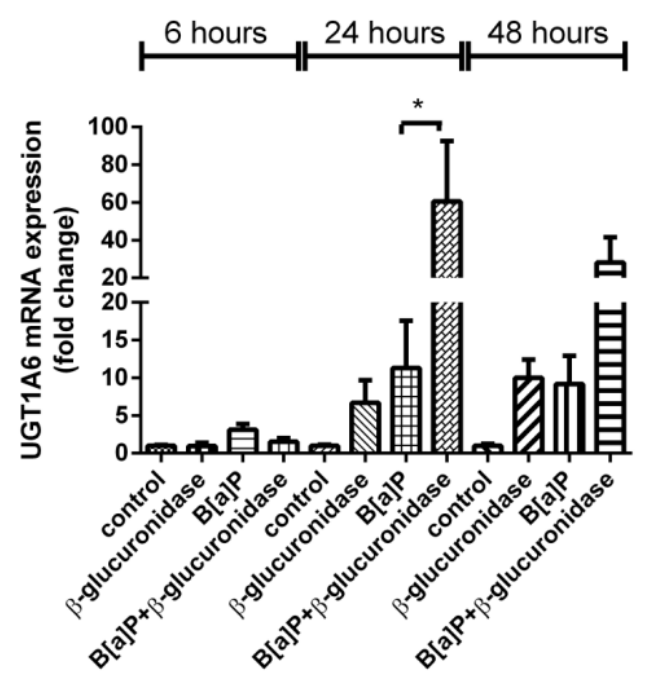

Figure 4. RT-qPCR analysis of gene expression UGT1A6 in A549 (a) and HepG2 (b) cells after exposure to $\beta$-glucuronidase and/or B[a]P. Cells were exposed to $1 \mu \mathrm{M} \mathrm{B}[\mathrm{a}] \mathrm{P}$ with or without $4 \mathrm{U} / \mathrm{ml} \beta$-glucuronidase and harvested after the times indicated. Cells exposed to DMSO and sodium acetate buffer were used as a vehicle control. All values are given as the means \pm SEM $\left(n=4\right.$ per data point). $\quad\left({ }^{*} \mathrm{p}<0.05 ;{ }^{* *} \mathrm{p}<0.01\right.$; $* * * \mathrm{p}<0.001$ )

\section{$B[a] P$ and its metabolites}

Extracellular $\mathrm{B}[\mathrm{a}] \mathrm{P}$ metabolite $(\mathrm{B}[\mathrm{a}] \mathrm{P}-7,8-$ diol and $\mathrm{B}[\mathrm{a}] \mathrm{P}-9,10-$ diol) concentrations of A549 cells that were exposed to $1 \mu \mathrm{M} \mathrm{B}$ [a]P with $\beta$-glucuronidase $(10 \mu \mathrm{g} / \mathrm{ml})$ for 6 hours significantly decreased, when compared to A549 cells that were exposed to B[a]P only (Fig 5, right column). However, when cells were exposed for 24 hours, the concentrations of extracellular $\mathrm{B}[\mathrm{a}] \mathrm{P}$ metabolites in the medium of $\beta$-glucuronidase-treated cells significantly increased and were higher than in A549 cells that were exposed to $\mathrm{B}[\mathrm{a}] \mathrm{P}$ alone. At 48 hours, the extracellular $\mathrm{B}[\mathrm{a}] \mathrm{P}$ metabolite levels were below the detection limit in both treatments (presence or absence of $\beta$-glucuronidase).

The results were essentially similar for HepG2 cells (Fig 5, left column). However, the initial difference at $\mathrm{t}=6$ hours was more pronounced, and statistically significant for $\mathrm{B}[\mathrm{a}] \mathrm{P}-7,8-d i o l$ and B[a]P-9,10-diol.

Moreover, the concentration of unmetabolized $\mathrm{B}[\mathrm{a}] \mathrm{P}$ in the medium showed similar time-dependent patterns in both cell lines (Fig $5 \mathrm{~g}$ and $\mathrm{h}$ ). The concentration of unmetabolized $\mathrm{B}[\mathrm{a}] \mathrm{P}$ gradually declined with time. However, after 24 hours of exposure, the concentration of the parent compound in A549 cells was about 3 -fold higher $(\mathrm{P}<0.05)$ in the samples that included $\beta$-glucuronidase than in cells without $\beta$-glucuronidase. For HepG2 cells, the concentration of $\mathrm{B}[\mathrm{a}] \mathrm{P}$ in the presence of $\beta$-glucuronidase was approximately 2 -fold higher than in samples that were treated with $\mathrm{B}[\mathrm{a}] \mathrm{P}$ alone. For both cell lines, $\mathrm{B}[\mathrm{a}] \mathrm{P}$ was almost fully metabolized 48 hours after exposure. 
(a)

HepG2

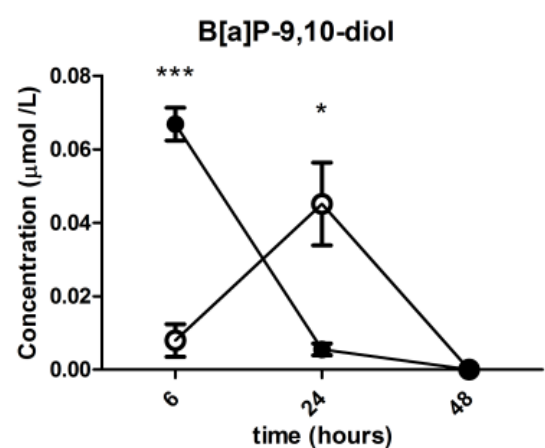

(c)

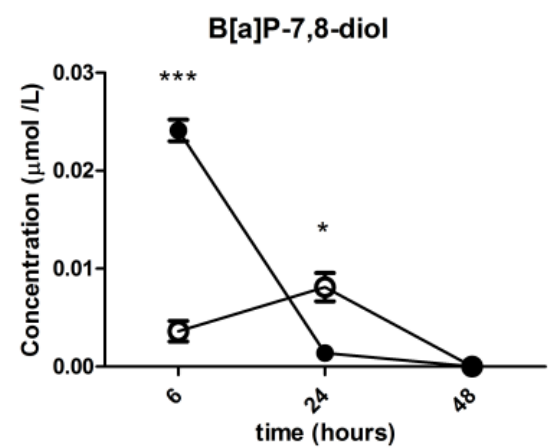

(e)

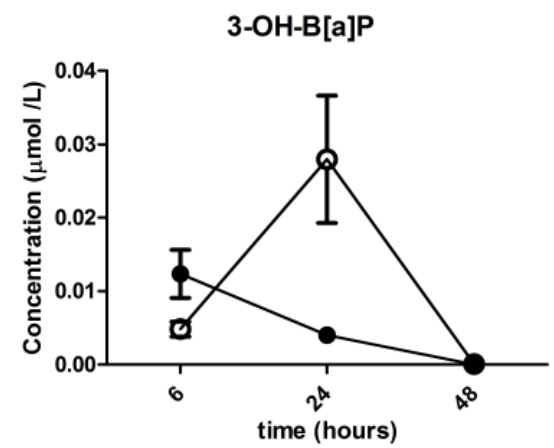

(g)

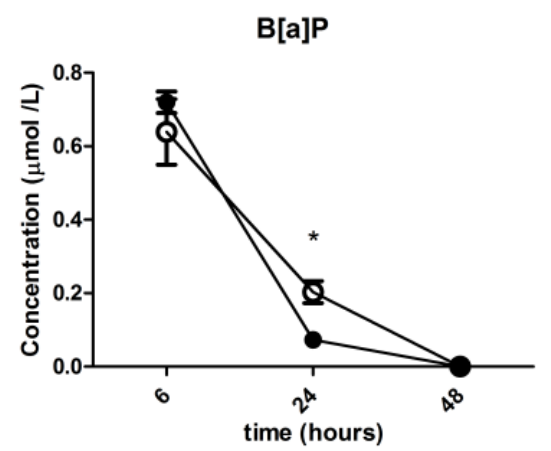

(b)

A549

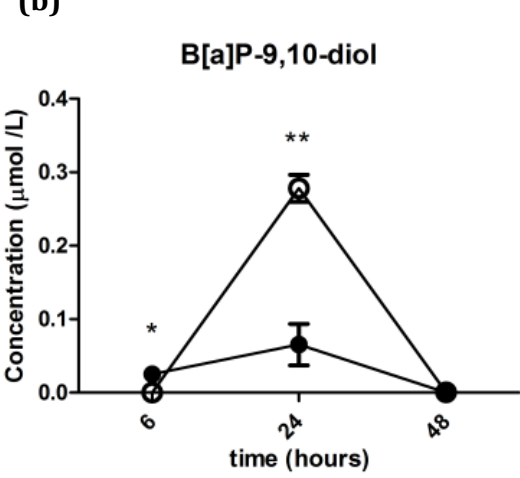

(d)

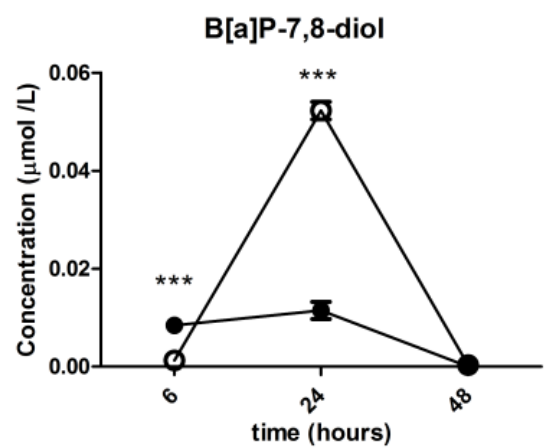

(f)

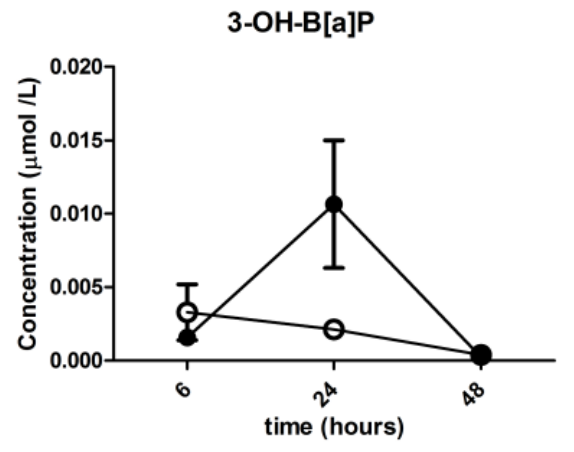

(h)

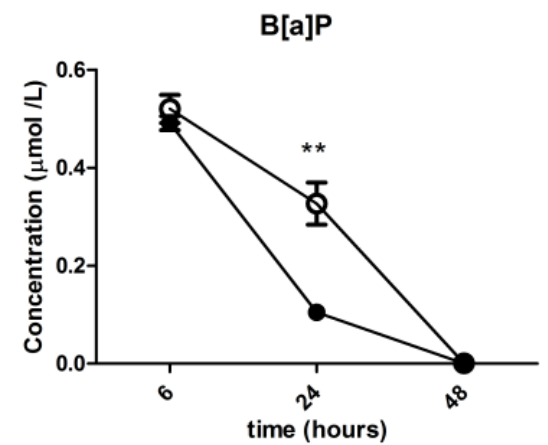

Figure 5. HPLC fluorescence analysis of $\mathrm{B}[\mathrm{a}] \mathrm{P}-7,8-$ diol, $\mathrm{B}[\mathrm{a}] \mathrm{P}-9,10-$ diol, $\quad 3-0 \mathrm{H}-\mathrm{B}[\mathrm{a}] \mathrm{P}$ and $\mathrm{B}[\mathrm{a}] \mathrm{P}$ in HepG2 cells (left column) and A549 cells (right column) after exposure to $\beta$-glucuronidase and/ or $\mathrm{B}[\mathrm{a}] \mathrm{P}$. Cells were exposed to $1 \mu \mathrm{M}$ $\mathrm{B}[\mathrm{a}] \mathrm{P}$ with or without $4 \mathrm{U} / \mathrm{ml}$ $\beta$-glucuronidase and cell medium was harvested after the time indicated. Cells exposed to DMSO and sodium acetate buffer were used as a vehicle control. All values are given as the means \pm SEM $(\mathrm{n}=3$ per data point). Filled circle without $\beta$-glucuronidase, open circle with $\beta$-glucuronidase

\section{B[a]P-DNA adducts level}

$\mathrm{B}[\mathrm{a}] \mathrm{P}$ exposure resulted in a time-dependent increase of $\mathrm{B}[\mathrm{a}] \mathrm{P}-\mathrm{DNA}$ adduct levels in both cell lines (Fig 6). However, the presence of $\beta$-glucuronidase altered the kinetics in which DNA adducts were formed: in A549 cells, at $t=6$ and $t=24$ hours, DNA adduct levels were initially lower in cells that were treated with $\mathrm{B}[\mathrm{a}] \mathrm{P}$ and $\beta$-glucuronidase. 
However, a strong increase in DNA adduct levels from 5 adducts per $10^{7}$ nucleotides at $\mathrm{t}=24$ hours to 65 adducts per $10^{7}$ nucleotides at 48 hours $(\mathrm{P}<0.0001)$, was found in $\beta$-glucuronidase-treated A549. This was not the case in the samples with B[a]P only. Consequently, at $\mathrm{t}=48$ hours, $\mathrm{B}[\mathrm{a}] \mathrm{P}$-DNA adduct levels were 1.4-fold higher in cells that were treated with $\beta$-glucuronidase compared to treatment with $\mathrm{B}[\mathrm{a}] \mathrm{P}$ only. In HepG2 cells, the presence of $\beta$-glucuronidase resulted in 1.5-fold, 2 -fold and 1.6-fold higher levels of $\mathrm{B}[\mathrm{a}] \mathrm{P}$-DNA adducts at 6,24 and 48 hours, respectively, compared to the samples that were treated with $\mathrm{B}[\mathrm{a}] \mathrm{P}$ only ( $\mathrm{P}<0.05$ at 48 hours).

(a)

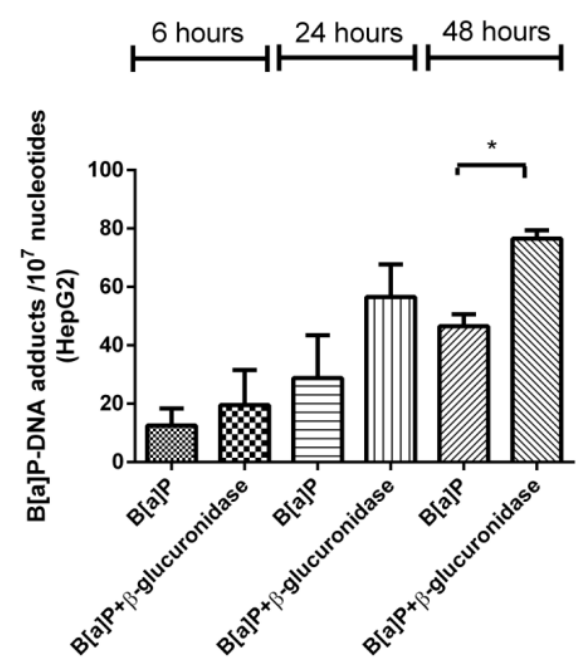

(b)

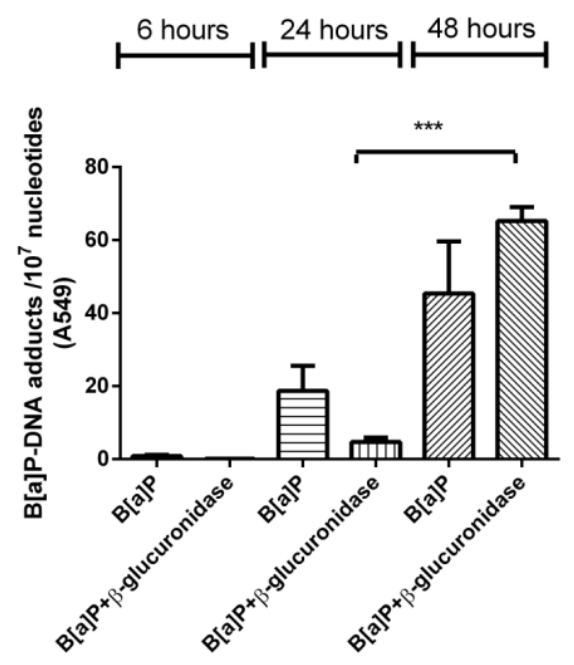

(c)

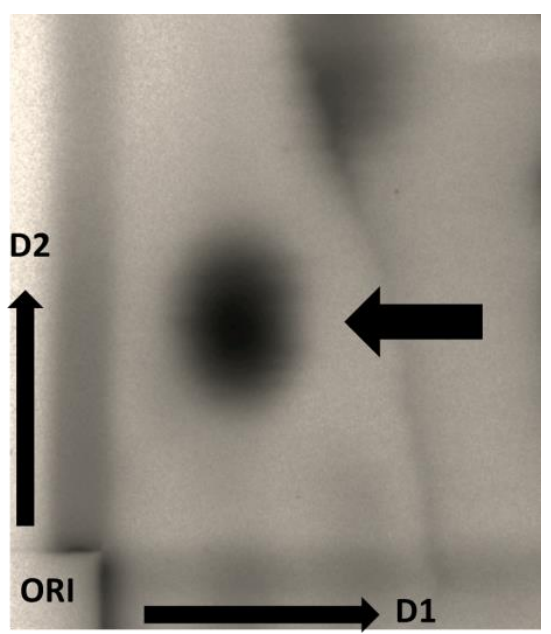

(d)

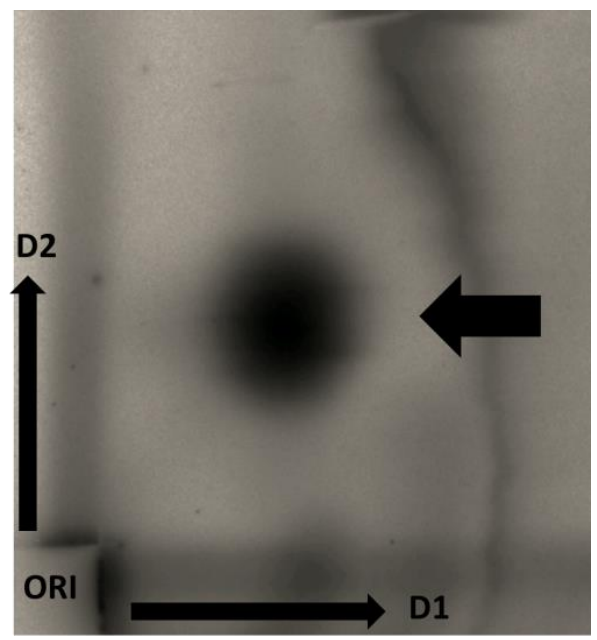

Figure 6. 32P-postlabelling analysis of DNA adducts level in HepG2 cells and A549 cells after exposure to $\mathrm{B}[\mathrm{a}] \mathrm{P}$ with or without $\beta$-glucuronidase. (a) HepG2 cells were exposed to $1 \mu \mathrm{M} \mathrm{B}[\mathrm{a}] \mathrm{P}$ with or without 10 $\mu \mathrm{g} / \mathrm{ml} \beta$-glucuronidase and harvest after the times indicated. (b) A549 cells were exposed to $1 \mu \mathrm{M} \mathrm{B}[\mathrm{a}] \mathrm{P}$ with or without $4 \mathrm{U} / \mathrm{ml} \beta$-glucuronidase and harvest after the times indicated. Data are expressed as number of B[a]P-DNA adducts per 107 nucleotides $(n=5$ for HepG 2 cells and $n=4$ for A549 cells, mean \pm SEM). $\left({ }^{*} \mathrm{p}<0.05\right.$; $\left.{ }^{* * *} \mathrm{p}<0.001\right)$. Representative chromatograms obtained by 32P-postlabeling in HepG2 cells (c) and A549 cells (d). The adduct spot (arrow) that migrated during 2D-TLC to the same position as the major DNA adduct in a BPDE-DNA adduct standard was quantitated in all samples. Before phophorimaging of the TLC plates the origin located at the bottom left-hand corner was excised. 


\section{Potential mechanisms}

\section{Can $\beta$-glucuronidase interact with $B[a] P$ to prevent $B[a] P$ from entering the cells?}

Since $\mathrm{B}[\mathrm{a}] \mathrm{P}$ metabolism seems to be delayed, we studied whether $\mathrm{B}[\mathrm{a}] \mathrm{P}$ could temporarily bind to $\beta$-glucuronidase, which could prevent $\mathrm{B}[\mathrm{a}] \mathrm{P}$ from entering the cell. We assumed that binding of $\mathrm{B}[\mathrm{a}] \mathrm{P}$ to $\beta$-glucuronidase would interfere with $\beta$-glucuronidase activity. Therefore, we assessed the $\beta$-glucuronidase hydrolysis of 4MUgIA in the presence B[a]P (Fig 7). $10 \mu \mathrm{g} / \mathrm{ml}$ of $\beta$-glucuronidase and $1 \mu \mathrm{M} \mathrm{B}$ [a]P were mixed with different concentration of substrate (4MUgIA) at $37^{\circ} \mathrm{C}$ for 10 hours. The addition of $\mathrm{B}[\mathrm{a}] \mathrm{P}$ lowered the changes in fluorescence units per hours compared to control. With increasing concentrations of 4MUgIA, the difference of the ?fluorescence/hour between these two groups became larger. This difference was significant at $100 \mu \mathrm{M}(p<0.01), 250 \mu \mathrm{M}(p<0.05)$ and $500 \mu \mathrm{M}(p<0.001)$ of 4MUgIA. The largest difference was observed at the highest concentration of 4MUgIA and was approximately 18\% lower than control. In addition, we performed Michaelis-Menten equation to determine the $V_{\max }$ and $K_{m}$ for both reactions. Although the $K_{m}$ in both reactions is same $(0.07 \pm 0.01 \mu \mathrm{M}$ and $0.07 \pm 0.01 \mu \mathrm{M}$ for control and $\mathrm{B}[\mathrm{a}] \mathrm{P}$ treated, respectively), the $\mathrm{V}_{\max }$ in control is significantly larger than in the $\mathrm{B}[\mathrm{a}] \mathrm{P}$ treated sample $(\mathrm{p}<0.05)$. Therefore, we concluded that there is a noncompetitive inhibition reaction.

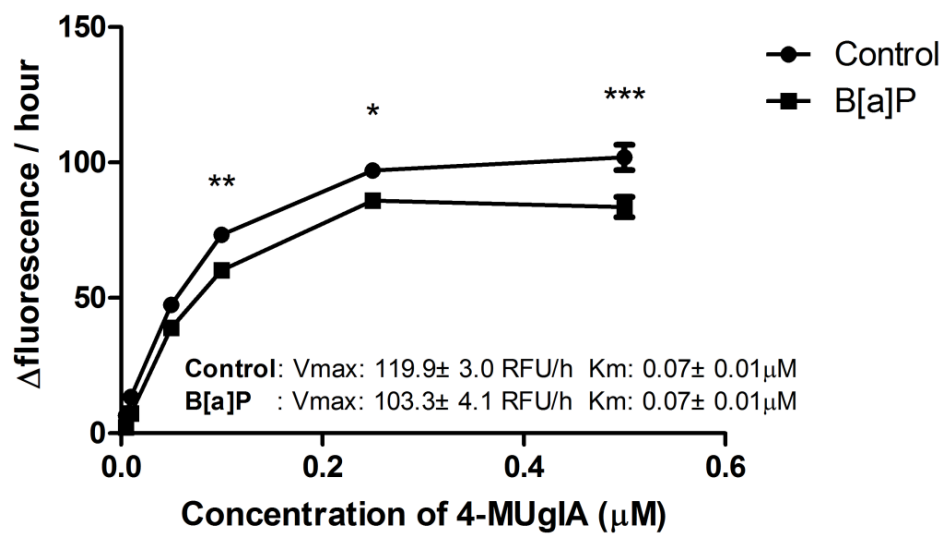

Figure 7. The 4MUgIA assay was applied to assess the possibility of $\mathrm{B}[\mathrm{a}] \mathrm{P}$ to bind to $\beta$-glucuronidase. A total volume of $140 \mu$ l contained $0.1 \mathrm{M}$ sodium-acetate buffer ( $\mathrm{pH} 5.5$ ), different concentration of 4MUgIA (e.g. 500, 250, 100, 50, 10 and $1 \mu \mathrm{M}$ ) and $4 \mathrm{U} / \mathrm{ml} \beta$-glucuronidase with $1 \mu \mathrm{l}$ of $200 \mu \mathrm{M} \mathrm{B}$ [a]P or $1 \mu \mathrm{l}$ DMSO. The measurement of fluorescence (Relative Fluorescence Unit (RFU)) was performed for 10 hours at $37^{\circ} \mathrm{C}$. $\mathrm{B}[\mathrm{a}] \mathrm{P}$ treated samples were compared with control at each concentration, respectively. $\left({ }^{*} \mathrm{p}<0.05\right.$; ${ }^{* *} \mathrm{p}<0.01$; $* * * \mathrm{p}<0.001)$

\section{Is the inhibitory effect of $\beta$-glucuronidase on CYP1A1 expression dependent on its activity?}

In order to gain further insight into the role of $\beta$-glucuronidase activity in influencing CYP1A1 expression, an $\beta$-glucuronidase inhibitor (D-saccharic acid 1,4-lactone monohydrate) was added to the $\mathrm{B}[\mathrm{a}] \mathrm{P}$ and $\beta$-glucuronidase incubations in A549 cells (Fig 8). A concentration of $100 \mu \mathrm{M}$ fully inhibited $\beta$-glucuronidase activity (Fig 8a). As shown in Fig $\mathbf{8 b}$, the presence of this inhibitor in incubations with $\mathrm{B}[\mathrm{a}] \mathrm{P}$ and $\beta$-glucuronidase did not change the inhibitory effect of $\beta$-glucuronidase on CYP1A1 expression $(0.13 \pm 0.03$ and $0.08 \pm 0.01$ in the absence or presence of inhibitor, respectively) at $\mathrm{t}=6 \mathrm{~h}$. On the contrary, at $\mathrm{t}=24 \mathrm{~h}$, the presence of this inhibitor 
significantly lowered $C Y P 1 A 1$ expression when compared to cells that were exposed to $\mathrm{B}[\mathrm{a}] \mathrm{P}$ and $\beta$-glucuronidase without inhibitor $(p<0.01)$.

(a)

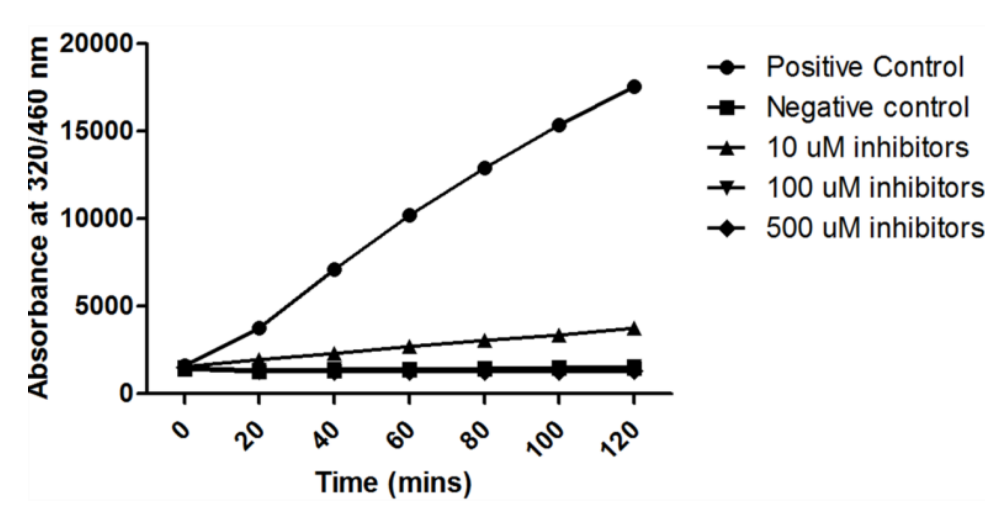

(b)

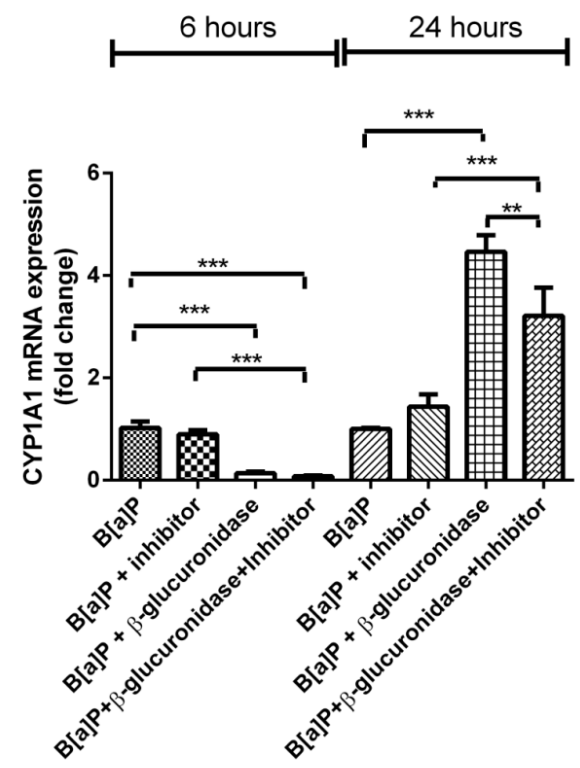

Figure 8. (a) 4MUgIA assay was applied to assess the inhibition of $\beta$-glucuronidase by D-saccharic acid 1,4-lactone monohydrate. A total volume of $140 \mu$ l contained $0.1 \mathrm{M}$ sodium-acetate buffer (pH 5.5), $2 \mathrm{mM}$ 4MUgIA, $4 \mathrm{U} / \mathrm{ml} \beta$-glucuronidase and different concentration of D-saccharic acid 1,4-lactone monohydrate $(10 \mu \mathrm{M}, 100 \mu \mathrm{M}$ and $500 \mu \mathrm{M}) .100 \mu \mathrm{M}$ of D-saccharic acid 1,4-lactone monohydrate was used in the following incubation. (b) A549 cells were exposed to $1 \mu \mathrm{M} \mathrm{B}[\mathrm{a}] \mathrm{P}$ with or without $\beta$-glucuronidase, D-saccharic acid 1,4-lactone monohydrate for 6 and 24 hours. Cells exposed to $1 \mu \mathrm{M} \mathrm{B}$ [a]P and sodium acetate buffer was used as a control. All values are given as the means \pm SEM ( $\mathrm{n}=4$ per data point). $\left({ }^{*} \mathrm{p}<0.05 ; * \mathrm{p}<0.01 ; * * \mathrm{p}<0.001\right)$

\section{Involvement of the Insulin-like growth factor 2/ mannose-6-phosphate pathway}

Extracellular enzymes like $\beta$-glucuronidase are known to bind to the Mannose-6-phosphate (M6P) receptor [33], which is also known as IGF2 receptor. The IGF2 receptor can be inhibited by high concentrations of M6P [34]. $\beta$-glucuronidase inhibited the induction of CYP1A1 expression by B[a]P at 6 hours of incubation to approximately 10\% (Fig 9), whereas in the presence of M6P, $\beta$-glucuronidase was unable to inhibit CYP1A1 expression at 6 hours. As shown previously, $\beta$-glucuronidase significantly induced CYP1A1 expression at 24 hours when coincubated with $\mathrm{B}[\mathrm{a}] \mathrm{P}$ $(p<0.01)$. CYP1A1 expression was still enhanced with additional M6P at 24 hours, but the changes in expression were less pronounced. 


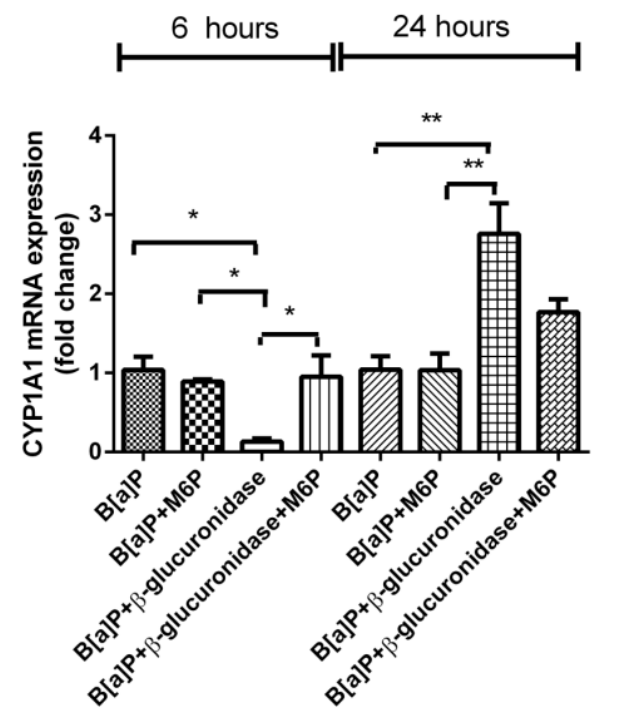

Figure 9. RT-qPCR analysis of gene expression CYP1A1 in A549 cells after exposure to $\beta$-glucuronidase and $\mathrm{B}[\mathrm{a}] \mathrm{P}$ with the IGF2R inhibitor M6P. Cells were exposed to $1 \mu \mathrm{M}$ B[a]P with or without $4 \mathrm{U} / \mathrm{ml} \beta$-glucuronidase and with or without $100 \mu \mathrm{M}$ M6P. Cells were harvested after the times indicated. Cells exposed to $\mathrm{B}[\mathrm{a}] \mathrm{P}$ and sodium acetate buffer were used as vehicle control. All values are given as the means \pm SEM $(n=4$ per data point). $\left({ }^{*} \mathrm{p}<0.05 ;{ }^{* *} \mathrm{p}<0.01 ;{ }^{* * *} \mathrm{p}<0.001\right)$

\section{Discussion}

It remains to be established how the cellular response to $\mathrm{B}[\mathrm{a}] \mathrm{P}$ is affected by the presence of extracellular $\beta$-glucuronidase, which is released during inflammation. In this study, we demonstrated that $\beta$-glucuronidase initially ( 6 hours after exposure) inhibited gene expression of enzymes that are pivotal in $\mathrm{B}[\mathrm{a}] \mathrm{P}$ metabolism, including CYP1A1, CYP1B1 and UGT1A6. As a result, subsequent formation of $\mathrm{B}[\mathrm{a}] \mathrm{P}$ metabolites and the formation of $\mathrm{B}[\mathrm{a}] \mathrm{P}-\mathrm{DNA}$ adducts was delayed in the presence of $\beta$-glucuronidase. However, at 24 hours of exposure, CYP expression was significantly enhanced in $\beta$-glucuronidase-treated cells, probably because more $\mathrm{B}[\mathrm{a}] \mathrm{P}$ remained unmetabolized and $\beta$-glucuronidase converted $\mathrm{B}[\mathrm{a}] \mathrm{P}$ derived glucuronide metabolites into active $\mathrm{B}[\mathrm{a}] \mathrm{P}$ metabolites. The higher concentration of active $\mathrm{B}[\mathrm{a}] \mathrm{P}$ metabolites continued to trigger the Ah-receptor for gene expression of CYP1A1 (in both cell lines) and CYP1B1 (in A549 only). Consequently, the formation of active B[a]P metabolites and DNA adducts at $t=24$ hours was further increased in $\beta$-glucuronidase-treated cells. Because of this delayed metabolism of $\mathrm{B}[\mathrm{a}] \mathrm{P}, \mathrm{DNA}$ adduct levels could accumulate in cells that were treated with $\beta$-glucuronidase and peaked at 48 hours after the initial exposure.

$A$ recent study observed that increased $\mathrm{B}[\mathrm{a}] \mathrm{P}-\mathrm{DNA}$ adduct levels in mice that were exposed to B[a]P and intranasally instilled with LPS (Arlt et al., 2015). As LPS can induce an inflammatory response and stimulate the release of $\beta$-glucuronidase from neutrophils $[12,35]$, we determined the $\beta$-glucuronidase activity in lung and liver tissues from these mice (Table 1 ). Indeed, $\beta$-glucuronidase activity was significantly enhanced in lung and BAL-fluid of all LPS-treated animals when compared to the control group. On the other hand, we found that the $\beta$-glucuronidase activity was significantly decreased in liver tissue 3 days after being intranasally instilled with LPS. LPS treatment results in the recruitment of neutrophils from the liver to the lung, which could explain the lower $\beta$-glucuronidase activity in the liver after LPS treatment [36]. The significant increase of $\beta$-glucuronidase activity in the lung samples by LPS treatment was approximately $4 \mathrm{U} / \mathrm{ml}$, which we also subsequently used in our in vitro experiments.

$\mathrm{B}[\mathrm{a}] \mathrm{P}$ is known to bind to the AhR which stimulates its own metabolism by inducing the expression of CYP1A1 and CYP1B1 [37]. CYP1A1 and CYP1B1 play an important role in both $\mathrm{B}[\mathrm{a}] \mathrm{P}$ activation and detoxification [38], and $\mathrm{B}[\mathrm{a}] \mathrm{P}$ metabolites are further detoxified by glucuronidation. $\beta$-glucuronidase will hydrolyse glucuronidated $\mathrm{B}[\mathrm{a}] \mathrm{P}$ 
metabolites and therefore increase the concentration of active $\mathrm{B}[\mathrm{a}] \mathrm{P}$ metabolites [22]. Higher concentrations of these B[a]P metabolites (e.g. B[a]P-7,8-diol and B[a]P-9,10-diol) enhance the expression of $C Y P 1 A 1$ and $C Y P 1 B 1[39,40]$. Therefore, we expected that addition of $\beta$-glucuronidase would increase $C Y P 1 A 1$ and $C Y P 1 B 1$ expression. However, we found that $\beta$-glucuronidase inhibited $C Y P$ expression shortly after $\mathrm{B}[\mathrm{a}] \mathrm{P}$ exposure (i.e. 6 hours) in both A549 and HepG2 cells. This initial inhibition of gene expression by $\beta$-glucuronidase was independent of $\beta$-glucuronidase activity, because the $\beta$-glucuronidase inhibitor D-saccharic acid 1,4-lactone monohydrate did not change the results. Several studies report the binding of $\beta$-glucuronidase to insulin like growth factor 2 receptors (IGF2R), which are located in the cell membrane [41-43]. Moreover, IGF2 induced AhR in MCF-7 cells [44]. Therefore, we studied the involvement of IGF2R signaling by adding its inhibitor mannose-6-phosphate (M6P) and we found that the inhibitory effect of $\beta$-glucuronidase on CYP-expression was also blocked. Therefore, we suggest a connection between IGF2R as receptor of extracellular $\beta$-glucuronidase and intracellular AhR-signaling after B[a]P exposure.

In addition, UGT1A6 can be induced by AhR ligands in order to detoxify reactive $\mathrm{B}[\mathrm{a}] \mathrm{P}$ derivatives [24]. UGT1A6 is an important enzyme for the detoxification of $\mathrm{B}[\mathrm{a}] \mathrm{P}$ metabolites and is predominantly located in human liver nuclear membranes $[25,45]$. This could explain the different kinetics of expression of UGT1A6 between the two cell lines in this study. Hence, our mRNA expression data of UGT1A6 exhibited a similar pattern as CYP1A1 in HepG2 cells, but not in A549 cells. It is known that lung cells have a lower expression of UGT's than liver cells [46], and therefore it was expected that the effects of $\beta$-glucuronidase on the metabolism of $\mathrm{B}[\mathrm{a}] \mathrm{P}$ would be more pronounced in the liver-derived HepG2 cells than in the lung-derived A549 cells. Indeed, B[a]P-DNA adducts were already higher in $\beta$-glucuronidase-treated HepG2 cells at $t=24$ hours, whereas in A549 cells an additional 24 hours was needed for further accumulation of DNA adducts. At the $24 \mathrm{~h}$ timepoint, the effects of $\beta$-glucuronidase on CYP expression were at least partly dependent on $\beta$-glucuronidase activity. Thus, we suggest that de-glucuronidated metabolites of $\mathrm{B}[\mathrm{a}] \mathrm{P}$ in combination with the higher concentrations of unmetabolized $\mathrm{B}[\mathrm{a}] \mathrm{P}$, continued to trigger the Ah-receptor and the subsequent expression of $C Y P 1 A 1$ and $C Y P 1 B 1$. Therefore, our results indicate that there are two possible underlying mechanisms resulting in altered $\mathrm{B}[\mathrm{a}] \mathrm{P}$ metabolism and subsequent DNA adduct formation; 1 . changes in gene-expression by IGF2 signalling and 2 . de-glucuronidation of glucuronidated metabolites.

Moreover, we studied whether $\mathrm{B}[\mathrm{a}] \mathrm{P}$ could temporarily bind to $\beta$-glucuronidase which would postpone $\mathrm{B}[\mathrm{a}] \mathrm{P}$ from entering the cell. Indeed, the presence of $\mathrm{B}[\mathrm{a}] \mathrm{P}$ decreased the capacity of $\beta$-glucuronidase to deconjugate 4MUgIA, suggesting an interaction between $\beta$-glucuronidase and $\mathrm{B}[\mathrm{a}] \mathrm{P}$. However, this effect is unlikely to explain the present data, because the changes in $\beta$-glucuronidase activity by $\mathrm{B}[\mathrm{a}] \mathrm{P}$ are relatively small $(<20 \%)$ and in our experiments $\mathrm{B}[\mathrm{a}] \mathrm{P}$ is added in excess. However, this interaction may become more relevant at sites of inflammation and low $\mathrm{B}[\mathrm{a}] \mathrm{P}$ exposure.

Since CYP1A1 is considered to be the major enzyme for the activation and detoxification of $\mathrm{B}[\mathrm{a}] \mathrm{P}[20]$, our measured $\mathrm{B}[\mathrm{a}] \mathrm{P}$ metabolites, including $\mathrm{B}[\mathrm{a}] \mathrm{P}-7,8$-diol paralleled the pattern of CYP1A1 expression in both cell lines (HepG2 and A549). In addition, it is known that inhibition of CYP1A1 decreased B[a]P-DNA adduct formation in vitro [47], but not in vivo [48]. However, we showed that with additional $\beta$-glucuronidase, the metabolism of $\mathrm{B}[\mathrm{a}] \mathrm{P}$ is delayed, which prolonged the effective exposure of cells to unmetabolized $\mathrm{B}[\mathrm{a}] \mathrm{P}$, ultimately producing more toxic metabolites instead of excretable derivatives of $\mathrm{B}[\mathrm{a}] \mathrm{P}$. A study using Cyp1a1(-/-) mice revealed that slower metabolic 
clearance of $\mathrm{B}[\mathrm{a}] \mathrm{P}$ may indeed lead to greater formation of $\mathrm{B}[\mathrm{a}] \mathrm{P}$-mediated $\mathrm{DNA}$ adducts [49].

In summary, in this study we showed that $\beta$-glucuronidase alters the cellular response towards $\mathrm{B}[\mathrm{a}] \mathrm{P}$ by changing gene expression of $C Y P 1 A 1$ in both lung and liver derived cells, ultimately causing higher DNA adduct levels. Moreover, we identified that $\beta$-glucuronidase may bind to IGF2R, thereby delaying $\mathrm{B}[\mathrm{a}] \mathrm{P}$ metabolism. This study exemplifies the complexity of the effect of inflammation on $\mathrm{B}[\mathrm{a}] \mathrm{P}$-induced carcinogenesis, which deserves further attention. 


\section{References}

[1] E. Shacter, S.A. Weitzman, Chronic inflammation and cancer, Oncology (Williston Park), 16 (2002) 217-226, 229; discussion 230-212.

[2] F. Colotta, P. Allavena, A. Sica, C. Garlanda, A. Mantovani, Cancer-related inflammation, the seventh hallmark of cancer: links to genetic instability, Carcinogenesis, 30 (2009) 1073-1081.

[3] R.P. Young, R.J. Hopkins, T. Christmas, P.N. Black, P. Metcalf, G.D. Gamble, COPD prevalence is increased in lung cancer, independent of age, sex and smoking history, Eur Respir J, 34 (2009) 380-386.

[4] Z.G. Fridlender, S.M. Albelda, Tumor-associated neutrophils: friend or foe?, Carcinogenesis, (2012).

[5] A.M. Knaapen, N. Gungor, R.P. Schins, P.J. Borm, F.J. Van Schooten, Neutrophils and respiratory tract DNA damage and mutagenesis: a review, Mutagenesis, 21 (2006) 225-236.

[6] D. van Berlo, A. Wessels, A.W. Boots, V. Wilhelmi, A.M. Scherbart, K. Gerloff, F.J. van Schooten, C. Albrecht, R.P. Schins, Neutrophil-derived ROS contribute to oxidative DNA damage induction by quartz particles, Free radical biology \& medicine, 49 (2010) 1685-1693.

[7] P.J. Borm, A.M. Knaapen, R.P. Schins, R.W. Godschalk, F.J. Schooten, Neutrophils amplify the formation of DNA adducts by benzo[a]pyrene in lung target cells, Environmental health perspectives, 105 Suppl 5 (1997) 1089-1093.

[8] F.J. Van Schooten, A.W. Boots, A.M. Knaapen, R.W. Godschalk, L.M. Maas, P.J. Borm, M. Drent, J.A. Jacobs, Myeloperoxidase (MPO) -463G->A reduces MPO activity and DNA adduct levels in bronchoalveolar lavages of smokers, Cancer epidemiology, biomarkers \& prevention : a publication of the American Association for Cancer Research, cosponsored by the American Society of Preventive Oncology, 13 (2004) 828-833.

[9] N. Gungor, J.L. Pennings, A.M. Knaapen, R.K. Chiu, M. Peluso, R.W. Godschalk, F.J. Van Schooten, Transcriptional profiling of the acute pulmonary inflammatory response induced by LPS: role of neutrophils, Respir Res, 11 (2010) 24.

[10] N. Gungor, A.M. Knaapen, A. Munnia, M. Peluso, G.R. Haenen, R.K. Chiu, R.W. Godschalk, F.J. van Schooten, Genotoxic effects of neutrophils and hypochlorous acid, Mutagenesis, 25 (2010) 149-154.

[11] N. Gungor, A. Haegens, A.M. Knaapen, R.W. Godschalk, R.K. Chiu, E.F. Wouters, F.J. van Schooten, Lung inflammation is associated with reduced pulmonary nucleotide excision repair in vivo, Mutagenesis, 25 (2010) 77-82.

[12] A. Basinska, B. Florianczyk, Beta-glucuronidase in physiology and disease, Ann Univ Mariae Curie Sklodowska Med, 58 (2003) 386-389.

[13] D. Hoffmann, I. Hoffmann, The changing cigarette, 1950-1995, J Toxicol Environ Health, 50 (1997) 307-364.

[14] H. Uppstad, S. Ovrebo, A. Haugen, S. Mollerup, Importance of CYP1A1 and CYP1B1 in bioactivation of benzo[a]pyrene in human lung cell lines, Toxicol Lett, 192 (2010) 221-228.

[15] M. Stiborova, M. Moserova, V. Cerna, R. Indra, M. Dracinsky, M. Sulc, C.J. Henderson, C.R. Wolf, H.H. Schmeiser, D.H. Phillips, E. Frei, V.M. Arlt, Cytochrome b5 and epoxide hydrolase contribute to benzo[a]pyrene-DNA adduct formation catalyzed by cytochrome P450 1A1 under low NADPH:P450 oxidoreductase conditions, Toxicology, 318 (2014) 1-12.

[16] T. Shimada, F.P. Guengerich, Inhibition of human cytochrome P450 1A1-, 1A2-, and 1B1-mediated activation of procarcinogens to genotoxic metabolites by polycyclic aromatic hydrocarbons, Chem Res Toxicol, 19 (2006) 288-294.

[17] A.M. Krais, E.N. Speksnijder, J.P. Melis, R. Indra, M. Moserova, R.W. Godschalk, F.J. van Schooten, A. Seidel, K. Kopka, H.H. Schmeiser, M. Stiborova, D.H. Phillips, M. Luijten, V.M. Arlt, The impact of p53 on DNA damage and metabolic activation of the environmental carcinogen benzo[a]pyrene: effects in Trp53(+/+), Trp53(+/-) and Trp53(-/-) mice, Arch Toxicol, (2015).

[18] L.E. Wohak, A.M. Krais, J.E. Kucab, J. Stertmann, S. Ovrebo, A. Seidel, D.H. Phillips, V.M. Arlt, Carcinogenic polycyclic aromatic hydrocarbons induce CYP1A1 in human cells via a p53-dependent mechanism, Arch Toxicol, (2014).

[19] J.H. Kim, K.H. Stansbury, N.J. Walker, M.A. Trush, P.T. Strickland, T.R. Sutter, Metabolism of benzo[a]pyrene and benzo[a]pyrene-7,8-diol by human cytochrome P450 1B1, Carcinogenesis, 19 (1998) 1847-1853.

[20] V.M. Arlt, M. Stiborova, C.J. Henderson, M. Thiemann, E. Frei, D. Aimova, R. Singh, G. Gamboa da Costa, O.J. Schmitz, P.B. Farmer, C.R. Wolf, D.H. Phillips, Metabolic activation of benzo[a]pyrene in vitro by hepatic cytochrome P450 contrasts with detoxification in vivo: experiments with hepatic cytochrome P450 reductase null mice, Carcinogenesis, 29 (2008) 656-665.

[21] J.E. Kucab, H. van Steeg, M. Luijten, H.H. Schmeiser, P.A. White, D.H. Phillips, V.M. Arlt, TP53 mutations induced by BPDE in Xpa-WT and Xpa-Null human TP53 knock-in (Hupki) mouse embryo fibroblasts, Mutat Res, 773 (2015) 48-62.

[22] K. Shimoi, T. Nakayama, Glucuronidase deconjugation in inflammation, Methods Enzymol, 400 (2005) 263-272.

[23] K. Shimoi, N. Saka, R. Nozawa, M. Sato, I. Amano, T. Nakayama, N. Kinae, Deglucuronidation of a flavonoid, luteolin monoglucuronide, during inflammation, Drug Metab Dispos, 29 (2001) 1521-1524.

[24] C.J. Jin, J.O. Miners, B. Burchell, P.I. Mackenzie, The glucuronidation of hydroxylated metabolites of benzo[a]pyrene and 2-acetylaminofluorene by cDNA-expressed human UDP-glucuronosyltransferases, Carcinogenesis, 14 (1993) 2637-2639.

[25] Z. Zheng, J.L. Fang, P. Lazarus, Glucuronidation: an important mechanism for detoxification of benzo[a]pyrene metabolites in aerodigestive tract tissues, Drug Metab Dispos, 30 (2002) 397-403.

[26] N. Trushin, S. Alam, K. El-Bayoumy, J. Krzeminski, S.G. Amin, J. Gullett, C. Meyers, B. Prokopczyk, Comparative metabolism of benzo[a]pyrene by human keratinocytes infected with high-risk human papillomavirus types 16 and 18 as episomal or integrated genomes, J Carcinog, 11 (2012) 1.

[27] V.M. Arlt, A.M. Krais, R.W. Godschalk, Y. Riffo-Vasquez, I. Mrizova, C.A. Roufosse, C. Corbin, Q. Shi, E. Frei, M. Stiborova, F.J. van Schooten, D.H. Phillips, D. Spina, Pulmonary Inflammation Impacts on CYP1A1-Mediated 
Respiratory Tract DNA Damage Induced by the Carcinogenic Air Pollutant Benzo[a]pyrene, Toxicological sciences : an official journal of the Society of Toxicology, (2015).

[28] R. Bartholome, G. Haenen, C.H. Hollman, A. Bast, P.C. Dagnelie, D. Roos, J. Keijer, P.A. Kroon, P.W. Needs, I.C. Arts, Deconjugation kinetics of glucuronidated phase II flavonoid metabolites by beta-glucuronidase from neutrophils, Drug Metab Pharmacokinet, 25 (2010) 379-387.

[29] M.A. Schults, K. Sanen, R.W. Godschalk, J. Theys, F.J. van Schooten, R.K. Chiu, Hypoxia diminishes the detoxification of the environmental mutagen benzo[a]pyrene, Mutagenesis, 29 (2014) 481-487.

[30] K.J. Livak, T.D. Schmittgen, Analysis of relative gene expression data using real-time quantitative PCR and the 2(-Delta Delta C(T)) Method, Methods, 25 (2001) 402-408.

[31] M.A. Schults, Y. Oligschlaeger, R.W. Godschalk, F.J. Van Schooten, R.K. Chiu, Loss of VHL in RCC Reduces Repair and Alters Cellular Response to Benzo[a]pyrene, Front Oncol, 3 (2013) 270.

[32] F.J. Van Schooten, R.W. Godschalk, A. Breedijk, L.M. Maas, E. Kriek, H. Sakai, G. Wigbout, P. Baas, L. Van't Veer, N. Van Zandwijk, 32P-postlabelling of aromatic DNA adducts in white blood cells and alveolar macrophages of smokers: saturation at high exposures, Mutat Res, 378 (1997) 65-75.

[33] A. Gonzalez-Noriega, C. Michalak, J.R. Cruz-Perez, F. Masso, Mannose 6-phosphate-independent endocytosis of beta-glucuronidase by human fibroblasts. I. Evidence for the existence of a membrane-binding activity, Biochim Biophys Acta, 1538 (2001) 141-151.

[34] H.M. El-Shewy, L.M. Luttrell, Insulin-like growth factor-2/mannose-6 phosphate receptors, Vitam Horm, 80 (2009) 667-697.

[35] A. Ngkelo, K. Meja, M. Yeadon, I. Adcock, P.A. Kirkham, LPS induced inflammatory responses in human peripheral blood mononuclear cells is mediated through NOX4 and Gialpha dependent PI-3kinase signalling, J Inflamm (Lond), 9 (2012) 1.

[36] J. Reutershan, A. Basit, E.V. Galkina, K. Ley, Sequential recruitment of neutrophils into lung and bronchoalveolar lavage fluid in LPS-induced acute lung injury, Am J Physiol Lung Cell Mol Physiol, 289 (2005) L807-815.

[37] D.C. Spink, B.H. Katz, M.M. Hussain, B.C. Spink, S.J. Wu, N. Liu, R. Pause, L.S. Kaminsky, Induction of CYP1A1 and CYP1B1 in T-47D human breast cancer cells by benzo[a]pyrene is diminished by arsenite, Drug Metab Dispos, 30 (2002) 262-269.

[38] M. Moserova, V. Kotrbova, D. Aimova, M. Sulc, E. Frei, M. Stiborova, Analysis of benzo[a]pyrene metabolites formed by rat hepatic microsomes using high pressure liquid chromatography: optimization of the method, Interdiscip Toxicol, 2 (2009) 239-244.

[39] T. Almahmeed, J.O. Boyle, E.G. Cohen, J.F. Carew, B. Du, N.K. Altorki, L. Kopelovich, J.-L. Fang, P. Lazarus, K. Subbaramaiah, A.J. Dannenberg, Benzo[a]pyrene phenols are more potent inducers of CYP1A1, CYP1B1 and COX-2 than benzo[a]pyrene glucuronides in cell lines derived from the human aerodigestive tract, Carcinogenesis, 25 (2004) 793-799.

[40] D.C. Spink, S.J. Wu, B.C. Spink, M.M. Hussain, D.D. Vakharia, B.T. Pentecost, L.S. Kaminsky, Induction of CYP1A1 and CYP1B1 by benzo(k)fluoranthene and benzo(a)pyrene in T-47D human breast cancer cells: roles of PAH interactions and PAH metabolites, Toxicol Appl Pharmacol, 226 (2008) 213-224.

[41] A. Gonzalez-Noriega, C. Michalak, Mannose 6-phosphate-independent endocytosis of beta-glucuronidase. II. Purification of a cation-dependent receptor from bovine liver, Biochim Biophys Acta, 1538 (2001) 152-161.

[42] C. Vogler, B. Levy, J.H. Grubb, N. Galvin, Y. Tan, E. Kakkis, N. Pavloff, W.S. Sly, Overcoming the blood-brain barrier with high-dose enzyme replacement therapy in murine mucopolysaccharidosis VII, Proc Natl Acad Sci U S A, 102 (2005) 14777-14782.

[43] A. Urayama, J.H. Grubb, W.S. Sly, W.A. Banks, Developmentally regulated mannose 6-phosphate receptor-mediated transport of a lysosomal enzyme across the blood-brain barrier, Proc Natl Acad Sci U S A, 101 (2004) 12658-12663.

[44] J.K. Tomblin, T.B. Salisbury, Insulin like growth factor 2 regulation of aryl hydrocarbon receptor in MCF-7 breast cancer cells, Biochem Biophys Res Commun, 443 (2014) 1092-1096.

[45] A. Radominska-Pandya, I.D. Pokrovskaya, J. Xu, J.M. Little, A.R. Jude, R.C. Kurten, P.J. Czernik, Nuclear UDP-glucuronosyltransferases: identification of UGT2B7 and UGT1A6 in human liver nuclear membranes, Arch Biochem Biophys, 399 (2002) 37-48

[46] S. Ohno, S. Nakajin, Determination of mRNA expression of human UDP-glucuronosyltransferases and application for localization in various human tissues by real-time reverse transcriptase-polymerase chain reaction, Drug Metab Dispos, 37 (2009) 32-40.

[47] K. Endo, S. Uno, T. Seki, T. Ariga, Y. Kusumi, M. Mitsumata, S. Yamada, M. Makishima, Inhibition of aryl hydrocarbon receptor transactivation and DNA adduct formation by CYP1 isoform-selective metabolic deactivation of benzo[a]pyrene, Toxicol Appl Pharmacol, 230 (2008) 135-143.

[48] Q. Ma, A.Y. Lu, CYP1A induction and human risk assessment: an evolving tale of in vitro and in vivo studies, Drug Metab Dispos, 35 (2007) 1009-1016.

[49] S. Uno, T.P. Dalton, H.G. Shertzer, M.B. Genter, D. Warshawsky, G. Talaska, D.W. Nebert, Benzo[a]pyrene-induced toxicity: paradoxical protection in Cyp1a1(-/-) knockout mice having increased hepatic BaP-DNA adduct levels, Biochem Biophys Res Commun, 289 (2001) 1049-1056. 



\section{Chapter 3}

\section{Acidic cellular microenvironment modifies carcinogen induced DNA damage and repair}

Shi Q, Maas L, Veith C, Van Schooten FJ, Godschalk RW.

Arch Toxicol. 2017 Jun;91(6):2425-2441. doi: 10.1007/s00204-016-1907-4. 


\begin{abstract}
Chronic inflammation creates an acidic microenvironment, which plays an important role in cancer development. To investigate how low $\mathrm{pH}$ changes the cellular response to the carcinogen benzo[a]pyrene $(\mathrm{B}[\mathrm{a}] \mathrm{P})$, we incubated human pulmonary epithelial cells (A549 and BEAS-2B) with non-toxic doses of $\mathrm{B}$ [a] $\mathrm{P}$ using culturing media of various $\mathrm{pH}$ 's (extracellular $\mathrm{pH}\left(\mathrm{pH}_{\mathrm{e}}\right)$ of 7.8, 7.0, 6.5, 6.0 and 5.5) for 6, 24 and 48 hours. In most incubations $\left(\mathrm{pH}_{\mathrm{e}}\right.$ 7.0-6.5) the $\mathrm{pH}$ in the medium returned back to the physiological $\mathrm{pH}$ 7.8 after 48 hours, but at the lowest $\mathrm{pH}\left(\mathrm{pH}_{\mathrm{e}}<6.0\right)$, this recovery was incomplete. Similar changes were observed for the intracellular $\mathrm{pH}\left(\mathrm{pH}_{\mathrm{i}}\right)$. We observed that acidic conditions delayed $\mathrm{B}[\mathrm{a}] \mathrm{P}$ metabolism and at $\mathrm{t}=48 \mathrm{~h}$, the concentration of unmetabolised extracellular $\mathrm{B}[\mathrm{a}] \mathrm{P}$ and $\mathrm{B}[\mathrm{a}] \mathrm{P}-7,8-$ diol was significantly higher in acidic samples than under normal physiological conditions $\left(\mathrm{pH}_{\mathrm{e}} \mathrm{7.8}\right)$ for both cell lines. Cytochrome $\mathrm{P} 450$ (CYP1A1/CYP1B1) expression and its activity (ethoxyresorufin-0-deethylase activity) were repressed at low $\mathrm{pH}_{\mathrm{e}}$ after 6 and $24 \mathrm{hrs}$, but were significantly higher at $\mathrm{t}=48 \mathrm{~h}$. In addition, a DNA repair assay showed that the incision activity was $\sim 80 \%$ inhibited for 6 hours at low $\mathrm{pH}_{\mathrm{e}}$ and concomitant exposure to $\mathrm{B}[\mathrm{a}] \mathrm{P}$. However at $\mathrm{t}=48 \mathrm{~h}$, the incision activity recovered to more than $100 \%$ of the initial activity observed at neutral $\mathrm{pH}_{\mathrm{e}}$. After 48 hours, higher B[a]P-DNA adduct levels and $\gamma$-H2AX foci were observed at low $\mathrm{pH}$ samples than at $\mathrm{pH}_{\mathrm{e}}$ 7.8. In conclusion, acidic $\mathrm{pH}$ delayed the metabolism of $\mathrm{B}[\mathrm{a}] \mathrm{P}$ and inhibited DNA repair, ultimately leading to increased $\mathrm{B}[\mathrm{a}] \mathrm{P}$ induced DNA damage.
\end{abstract}

Keywords: acidic pH, benzo[a]pyrene, Cytochrome P450 (CYP1A1), DNA damage, NER 


\section{Introduction}

Acidic microenvironments have been found in tumors and in chronically inflamed tissues $[1,2]$. During tumorigenesis, the main cause for the acidic microenvironment is anaerobic glycolysis, which produces acidic metabolites (e.g. lactic acid) [1]. Under chronic inflammatory conditions, the local extracellular $\mathrm{pH}$ can decrease to $\mathrm{pH} 5.5$ or even lower, through release of acidic compounds by inflammatory cells, including hypochloric acid ( $\mathrm{HOCl}$ ) and by subsequent damaging of surrounding tissues. [3, 4]. Endogenous airway acidification is related to inflammation in for instance chronic obstructive pulmonary disease (COPD) patients, whose exhaled breath condensate $\mathrm{pH}$ is related to disease severity [5]. Many cancers are preceded and accompanied by inflammatory surroundings explaining partly the association between COPD and lung cancer [6,7]. Inflammation may thus be a factor involved in initiation as well as progression of tumorigenesis [8]. Although the mechanism behind the development of both chronic inflammation and cancer is different, a common characteristic is an acidic microenvironment. At present there are few studies and thus little knowledge about the underlying mechanism of how a low $\mathrm{pH}$ can modulate DNA damage formation and subsequent tumorigenesis. Nonetheless, there are some studies that suggest that acidic $\mathrm{pH}$ can also change the response of cells to exogenous genotoxins, such as polycyclic aromatic hydrocarbons (PAH). For instance, acidic conditions promoted carcinogenesis in the hamster cheek pouch after exposure to the tumor initiator 9,10-dimethyl-1,2-benzanthracene (DMBA) [9]. In addition, a combination of hypoxia and low $\mathrm{pH}$ diminished DNA repair and increased mutagenesis in mammalian cells [10]. Interestingly, a dose dependent inhibition of nucleotide excision repair (NER) was also reported after exposure of cells to $\mathrm{HOCl}$, which is expected to lower the extracellular $\mathrm{pH}$ [11].

Inhibition of NER capacity would result in accumulation of DNA damage after exposure to DNA damaging compounds such as PAH. One environmentally abundant $\mathrm{PAH}$ is benzo[a]pyrene $(\mathrm{B}[\mathrm{a}] \mathrm{P})$ and human exposure to $\mathrm{B}[\mathrm{a}] \mathrm{P}$ is inevitable, since $\mathrm{B}[\mathrm{a}] \mathrm{P}$ is present in cigarette smoke, diesel exhaust, furnace burning of coal or oil and in food [12-14]. When $\mathrm{B}[\mathrm{a}] \mathrm{P}$ enters the cell, it binds to the aryl hydrocarbon receptor (AhR) and this leads to the up-regulation of cytochrome P450 isoforms CYP1A1 [15]. By inducing the expression of $C Y P 1 A 1, \mathrm{~B}[\mathrm{a}] \mathrm{P}$ induces its own metabolism [16]. Eventually, $\mathrm{B}$ [a]P may be activated to the ultimate carcinogen $\mathrm{B}[\mathrm{a}] \mathrm{P}$-diol epoxide (BPDE) which can covalently bind to DNA to form pro-mutagenic DNA adducts [17] (Fig 1). Interestingly, the majority of in vitro studies on $\mathrm{B}[\mathrm{a}] \mathrm{P}$ induced genotoxicity were conducted at neutral physiological $\mathrm{pH}$ (7.4-7.8). However, human exposure to $\mathrm{B}[\mathrm{a}] \mathrm{P}$ via cigarette smoke and air pollution is often characterized by inducing inflammation. Therefore, the combined effects of carcinogenic exposures with inflammation are worth studying.

An acidic $\mathrm{pH}$ changes multiple characteristics of cells and the influence on the molecular events induced by B[a]P exposure are still unclear. In the current study, we focus on lung cells because the lung is probably one of the most vulnerable organs for exposure to both inflammation and B[a]P. Therefore, we incubated human adenocarcinoma cells (A549) and human bronchial epithelial cells (BEAS-2B) under different extracellular $\mathrm{pH}$ conditions with $\mathrm{B}[\mathrm{a}] \mathrm{P}$ and we investigated whether acidic $\mathrm{pH}$ can alter metabolic enzyme activity, $\mathrm{B}[\mathrm{a}] \mathrm{P}$ metabolite formation, DNA repair and ultimately $\mathrm{B}[\mathrm{a}] \mathrm{P}$ induced DNA damage. 


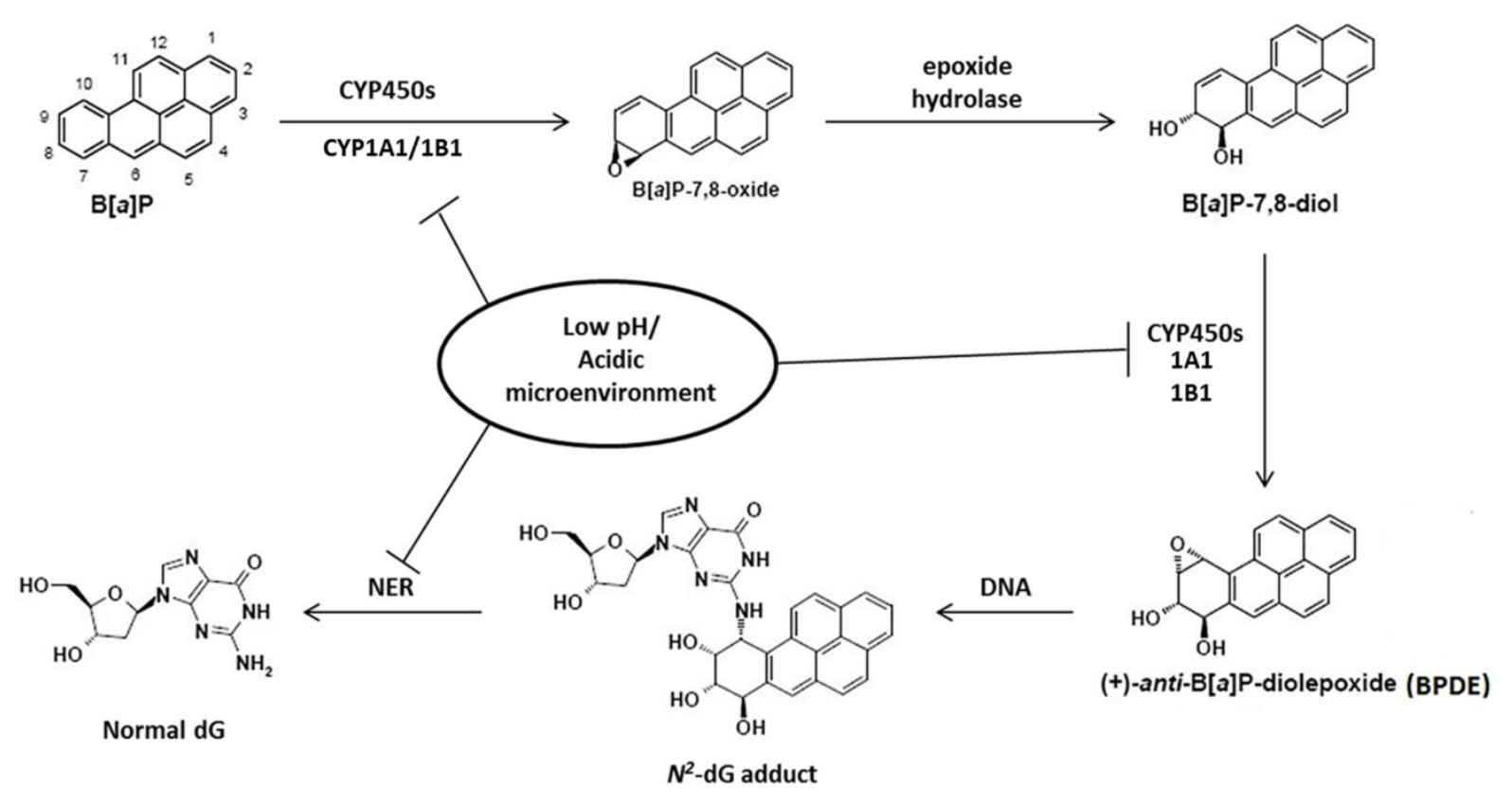

Figure 1. General $\mathrm{B}[\mathrm{a}] \mathrm{P}$ metabolism pathway and the role of low $\mathrm{pH} /$ acidic microenvironment. This figure is adapted from Shi et al. [18] with some modifications.

\section{Materials and Methods}

\section{Cell culture and treatment}

A549 cells (human epithelial lung carcinoma cells) and BEAS-2B cells (human bronchial epithelium cells) were purchased from the American Tissues Culture Collection (ATCC, Rockville, MD, USA) and were authenticated by ATCC using short tandem repeat profiling (www.atcc.org/STR\%20Database.aspx). A549 cells were cultured in RPMI 1640 Medium (Sigma-Aldrich) supplemented with 5\% heat inactivated fetal calf serum (FCS, Gibco Invitrogen, Breda, The Netherlands) and 1\% penicillin/streptomycin (Sigma) in T75 flasks. BEAS-2B cells were cultured in Dulbecco's Modified Eagle Medium/F-12 Nutrient Mixture (Ham) (DEME/F-12, Gibco, Carlsbad, CA, USA) supplemented with 10\% heat inactivated fetal bovine serum (FBS, Gibco) and 1\% penicillin/streptomycin (Sigma) in T75 flasks. All cells were cultured under a humidified atmosphere containing $5 \% \mathrm{CO}_{2}$ at $37{ }^{\circ} \mathrm{C}$ and passages between 15 and 30 were used. Cells were routinely screened for mycoplasma contamination by a Mycoplasma Detection Kit (InvivoGen, The Netherlands). Different $\mathrm{pH}$ in media ( $\mathrm{pH}$ 5.5, 6, 6.5, 7 and 7.8) were achieved by adding 1 $\mathrm{N} \mathrm{HCl}$ to the medium. All chemicals were purchased from Sigma-Aldrich unless stated otherwise. All cells were cultured with different $\mathrm{pH}$ media and $1 \mu \mathrm{M} \mathrm{B}[\mathrm{a}] \mathrm{P}$, which was dissolved in DMSO (final concentration did not exceed 0.5\%). After 6, 24 and 48 hours treatment, the medium were harvested and cells were collected as pellets, and all materials were stored at $-20^{\circ} \mathrm{C}$ until further analysis.

\section{Measurement of cell cytotoxicity and viability}

Cytotoxicity of different $\mathrm{pH}$ media and $\mathrm{B}[\mathrm{a}] \mathrm{P}$ were evaluated by using the 3-(4,5-dimethylthiazol-2-yl)-2,5-diphenyl-tetrazolium bromide (MTT) colorimetric assay described by Mosmann [19]. Briefly, cells were plated into 96-well plates (Costar, Cambridge, MA) at $1 \times 10^{4}$ cells $/ 100 \mu \mathrm{l}$ medium and cultured for 2 days. At confluence, cells were exposed to different $\mathrm{pH}$ media ( $\mathrm{pH} 5.5,6,6.5,7$ and 7.8 ) and $1 \mu \mathrm{M} \mathrm{B}$ [a]P for 6 , 
24 and 48 hours. After incubation, all cells were washed with $100 \mu \mathrm{l} 37^{\circ} \mathrm{C}$ Hank's balanced salts (HBSS) and MTT $(0.5 \mathrm{mg} / \mathrm{ml})$, which was dissolved in phosphate buffered saline (PBS), was added. Cells were incubated in the dark at $37{ }^{\circ} \mathrm{C}$ for 1 hour. Then, solutions were removed and formazan crystals were dissolved in $200 \mu$ DMSO for 30 min at room temperature. Finally, absorption was measured by using a microplate reader at $540 \mathrm{~nm}$ (Biorad, Veenendaal, The Netherlands) and the cell viability was expressed as percentage of control (i.e. 'physiological' pH 7.8).

Since acidic pH might influence the results of the MTT assay [20], we additionally performed a Trypan blue exclusion test as an additional cell viability indicator. Briefly, cells were cultured in 24-well plates (Costar, Cambridge, MA) at $1 \times 10^{5}$ cells $/ 500 \mu \mathrm{l}$ medium and cultured for 2 days. As described above, cells were treated with different $\mathrm{pH}$ media and $1 \mu \mathrm{M} \mathrm{B}$ [a]P for 6, 24 and 48 hours when the cells in each well reached to $90 \%$ confluence. After harvesting the cells, cells were re-suspended in $1 \mathrm{ml}$ warm HBSS. A total volume of $1 \mathrm{ml}$ contained $0.5 \mathrm{ml}$ of $0.4 \%$ trypan blue solution with additional 0.3 $\mathrm{ml}$ of HBSS and $0.2 \mathrm{ml}$ of the cell suspension. The cell viability was presented as percentage of the ratio of total cells (stained and unstained) divided by total viable cells (unstained) $\times 100$.

\section{Cell proliferation}

Cells were cultured in 6-well plates (Costar, Cambridge, MA) at $1.2 \times 10^{6}$ cells $/ 3 \mathrm{ml}$ in different $\mathrm{pH}$ media (pH 5.5, 6, 6.5, 7 and 7.8) for 2 days. After trypsinization, cells were collected and re-suspended in $1 \mathrm{ml}$ warm HBSS. Ten $\mu \mathrm{l}$ of cell suspension was transferred to a hemacytometer to microscopically count the cells. Each well was counted twice.

\section{Extracellular and Intracellular $p H$ measurement}

Extracellular $\mathrm{pH}(\mathrm{pHe})$ in media was measured with a pH meter (HI 2210, HANNA, Australia). The medium (with and without cells) at each time point was collected and the $\mathrm{pH}$ was measured immediately in an aliquot of $4 \mathrm{ml}$. For intracellular $\mathrm{pH}\left(\mathrm{pH}_{\mathrm{i}}\right)$ measurement, $1 \times 10^{4}$ cells $/ 200 \mu \mathrm{l}$ medium were incubated in 96-well plates. When the cells reached $70-80 \%$ confluency, the attached cells were loaded with the $\mathrm{pH}_{\mathrm{i}}$-sensitive fluorescent dye 2',7'-bis(2-carboxyethyl)-5,6- carboxyfluorescein acetoxymethyl ester (BCECF-AM) by incubation with $5 \mu \mathrm{M}$ of the cell-permeant dye BCECF-AM for $30 \mathrm{~min}$. The loaded cells were washed two times to minimize extracellular BCECF. After that, cells were cultured with different pH media (pH 7.8, 7.0, 6.5, 6.0 and 5.5) for 6, 24 and 48 hours. Fluorescence was measured using a spectrofluorometer (Spectra max m2, MDS, CA) at $37^{\circ} \mathrm{C}$ and with excitation wavelength pairs of 505/439 $\mathrm{nm}$ and an emission wavelength of $535 \mathrm{~nm}$ for $10 \mathrm{~min}$. The ratio of fluorescence of BCECF at 505-439 $\mathrm{nm}$ is considered as the function of $\mathrm{pH}_{\mathrm{i}}[21]$.

The $\mathrm{pH}$ calibration curve was obtained as described by Lo et al. [22], by incubation of BCECF-loaded cells with additional depolarizing buffer containing the proton ionophore nigericin $(10 \mu \mathrm{M})$ for $10 \mathrm{~min}$; under this condition the $\mathrm{pH}_{\mathrm{i}}$ is equal to the $\mathrm{pH}$ of the medium. The $\mathrm{pH}$ medium was made from $50 \mathrm{mM}$ Tris- $\mathrm{HCl}$ buffer and titrated from 7.8 to 5.5 by additions of $1 \mathrm{M} \mathrm{HCl}$, respectively. The final added volume of acid solution is less than $2 \%$ of total volume and this amount was unlikely to create an osmotic effect. The $\mathrm{pH}$ calibration curve was constructed from four independent sets of data. The ratio of the fluorescence at the dual excitation wavelengths (505 and $439 \mathrm{~nm}$ ) were converted into $\mathrm{pH}_{\mathrm{i}}$. 


\section{HPLC fluorescence analysis of B [a]P metabolites}

$\mathrm{B}[\mathrm{a}] \mathrm{P}$ and its metabolites were extracted and identified as described by Schults et al. [23]. Briefly, $5 \mathrm{ml}$ of cell medium was mixed by $1 \mathrm{ml}$ of ethyl acetate for $20 \mathrm{~min}$, followed by centrifugation (10 $\mathrm{min}, 980 \mathrm{~g}$ ). The top layer was transferred to a new tube and evaporated under nitrogen. Finally, the evaporated residue was redissolved in $0.5 \mathrm{ml}$ methanol and analyzed by HPLC-FD using a Gynkotek P580A HPLC system (Separations Analytical Instruments, Hendrik-Ido-Ambacht, The Netherlands) consisting of a Spark SP830 autosampler (Spark Holland, Emmen, The Netherlands) with a Perkin Elmer LS-30 programmable fluorescence detector (Perkin Elmer, Foster City, CA, USA) operated at excitation/emission wavelengths 257/350 nm. A standard mix that contained $50 \mathrm{ng} / \mathrm{ml}$ of B[a]P-9,10-diol, B[a]P-7,8-diol and 3-OH-B[a]P (Midwest Research Institute, Kansas City, MO, USA) were injected for quantitation purposes.

\section{Real-time Quantitative PCR}

For investigating $C Y P 1 A 1$ and $C Y P 1 B 1$ gene expression, cell pellets were collected after 6, 24 and 48 hours incubation. Total RNA was isolated and purified by using the RNeasy® Mini Kit (Qiagen Westburg, Leusden, The Netherlands) in combination with DNase treatment (Qiagen). cDNA was prepared by using the iScript ${ }^{\mathrm{TM}}$ cDNA Synthesis kit (BioRad, CA, USA), strating with 500 ng of RNA. cDNA was 10x diluted in water before use in the RT-PCR reaction. The reaction was conducted using a Biorad MyiQ iCycler Single Color RT-PCR detection system using iQ ${ }^{\mathrm{TM}}$ SYBR $®$ Green Supermix (BioRad), $5 \mu \mathrm{l}$ diluted cDNA and $0.3 \mu \mathrm{M} \beta$-actin, GAPDH, CYP1A1 or CYP1B1 primers (for specific sequence see $[23,24]$ ) in a total volume of $25 \mu$ l. The PCR reactions were started by denaturation at $95^{\circ} \mathrm{C}$ for $3 \mathrm{~min}$, followed by 40 cycles of $95^{\circ} \mathrm{C}$ for $10 \mathrm{sec}$ and $55^{\circ} \mathrm{C}$ for 45 sec. The PCR efficiency of all primer sets were assessed by the use of cDNA dilution curves and melt curves $\left(55-95^{\circ} \mathrm{C}\right)$. Data were analyzed by using MyiQ Software system (BioRad) and were expressed as relative gene expression (fold change) using the $2^{-\Delta \Delta \mathrm{Ct}}$ method [25]. The Ct-value of the house-keeping gene $\beta$-actin and GAPDH were calculated for all samples and used as reference Ct-value. Since the expression Ct-value of $\beta$-actin is more close to our target genes, the final results are displayed as compared to house-keeping gene $\beta$-actin.

\section{Measurement of EROD activity}

Ethoxyresorufine- $O$-deethylase (EROD) assay was used to assess the CYP1A1 activity in cells as described by Burke and Mayer [26] with modifications. Briefly, BEAS-2B and A549 cells were cultured in 96-well plate and treated with different $\mathrm{pH}$ and $1 \mu \mathrm{M} \mathrm{B}[\mathrm{a}] \mathrm{P}$ for 6, 24 and 48 hours. After that, all cells were incubated with reaction mixtures which contained in the final volume $(100 \mu \mathrm{l})$ : Tris-HCl buffer ( $\mathrm{pH} 7.4), 0.5 \mathrm{mM}$ nicotinamide adenine dinucleotide phosphate (NADPH), $1.0 \mathrm{mg} / \mathrm{ml}$ Bovine Serum Albumin (BSA) and $5 \mu \mathrm{M}$ 7-ethoxyresorufin (dissolved in DMSO). The reaction was initiated by adding NADPH. The formation of fluorescent resorufin was measured in a thermostated plate reader (Spectra max $\mathrm{m} 2$, MIDS, CA) at $37^{\circ} \mathrm{C}$ and 535/590 $\mathrm{nm}$ excitation/emission wavelengths for $10 \mathrm{~min}$. The results were calculated based on the resorufin standard curve and presented as $\mathrm{RFU} / \mathrm{min}$. 


\section{Measurement of DNA incision activity}

A modified comet assay was performed to assess the DNA repair activity as described by Langie et al. and Azqueta et al. [27-29]. This method specifically measures the DNA damage recognition and DNA incision step of nucleotide excision repair. A549 cell suspensions were diluted $1: 4$ in $0.5 \%$ low melting point agarose and added to microscopic slides which were pre-coated with a layer of $1.5 \%$ normal melting point agarose and put at $4^{\circ} \mathrm{C}$ for $45 \mathrm{~min}$. Subsequently these cells were lysed overnight in cold $\left(4^{\circ} \mathrm{C}\right)$ lysis buffer $(2.5 \mathrm{M} \mathrm{NaCl}, 0.1 \mathrm{M}$ EDTA, $10 \mathrm{mM}$ Tris, $0.25 \mathrm{M} \mathrm{NaOH}, \mathrm{pH} 10,1 \%$ Triton X-100 and 10\% DMSO). After that, the cells were washed with cold phosphate buffered saline (PBS) and exposed to either $1 \mu \mathrm{M}$ BPDE ( $\mathrm{NCl}$ Chemical Carcinogen Reference Standard Repository, Mid-west Research Institute, Kansas City, MO, USA) or DMSO for 30 min on ice.

Cell extracts were prepared from the cultured A549 and BEAS-2B cells with B[a]P and different $\mathrm{pH}$ media after 6, 24 and 48 hours, and the method as developed by Langie et al. [27] was used. Briefly, cells were trypsinized and diluted to a final concentration of $5 \times 10^{6}$ cells $/ \mathrm{ml}$ HBSS. Then, the cell suspensions were centrifuged at $14,000 \mathrm{rpm}(20,800$ g) for $5 \mathrm{~min}$ and the pellets were immediately resuspended in $50 \mu \mathrm{l}$ buffer A ( $45 \mathrm{mM}$ HEPES, $0.4 \mathrm{M} \mathrm{KCl}, 1 \mathrm{mM}$ EDTA, $0.1 \mathrm{mM}$ dithiothreitol, $10 \%$ glycerol, and adjusted to $\mathrm{pH}$ 7.8 using $\mathrm{KOH}$ ) per $5 \times 10^{6}$ cells. All aliquots were snap frozen in liquid nitrogen and $15 \mu \mathrm{l}$ of buffer B (1\% Triton X-100 in buffer A) was added to each $50 \mu \mathrm{l}$ aliquot. Then all the aliquots were centrifuged at $11,000 \mathrm{rpm}$ at $4^{\circ} \mathrm{C}$ for $5 \mathrm{~min}$ and the supernatant was used as protein extract. The protein concentration in the supernatant was determined by the BIO-RAD DC Protein Assay Kit (BIO-RAD, Veenendaal, The Netherlands) using bovine serum albumin (BSA) as external standard. Finally, $1 \mathrm{mg} / \mathrm{ml}$ of protein extracts were used for repair assay and stored at $-80^{\circ} \mathrm{C}$.

To assess the in vitro repair capacity, $50 \mu \mathrm{l}$ of protein extracts were added onto either DMSO exposed or BPDE exposed gel-embedded nucleoids and incubated for $20 \mathrm{~min}$ at $37^{\circ} \mathrm{C}$. Subsequently, the slides were further processed according to the conventional comet assay as described by Collins [30]. The slides were stained with ethidium bromide $(10 \mu \mathrm{g} / \mathrm{ml})$ for $10 \mathrm{~min}$ and the comets were visualized using a Zeiss Axioskop fluorescence microscope. All the samples were tested in two independent incubations within each single experiment in at least 2 independent experiments. For each slide, 50 cells were analyzed randomly using the Comet assay III software program (Perceptive Instruments, Haverhill, UK). The DNA incision activity of the cell extracts were calculated by the tail moment (median of the value) in the BPDE modified nucleoids versus the DMSO treated nucleoids. The final DNA incision activity was obtained according to the calculation made by Langie et al. [27].

\section{${ }^{32} P$-postlabelling of $B[a] P-D N A$ adducts}

After cells were collected, DNA was isolated from cells using a phenol-chloroform-isoamylalcohol extraction procedure as described earlier by Schults et al. [31]. The DNA adduct level were determined according to the nuclease P1 enrichment technique as described by Reddy and Randerath [32] with some modifications described by Godschalk et al. [33]. Two BPDE-DNA standards with known adduct levels ( 1 adduct/106 and 1 adduct/107 normal nucleotides) were used in all experiments and analyzed in parallel for quantification purposes. The quantification was conducted by using Phosphor-Imaging technology (Fujifilm FLA-3000, Rotterdam, The Netherlands). 


\section{Histone protein H2AX phosphorylation assay ( $\gamma H 2 A X)$}

DNA double-stranded breaks (DSBs) and blocked replication forks lead to the phosphorylation of histone protein H2AX on serine 139 [34]. We performed a $\gamma \mathrm{H} 2 \mathrm{AX}$ staining to investigate the DNA damage by the procedure as previously described by Mariotti et al. [35] with some modifications. Briefly, after treatment with various $\mathrm{pH}$ and $\mathrm{B}[\mathrm{a}] \mathrm{P}$ at different timepoints, A549 cells were fixed in 2\% formaldehyde for $20 \mathrm{~min}$ at room temperature. After fixation cells were permeabilized with $0.5 \%$ Triton X-100:PBS for 20 min at $4{ }^{\circ} \mathrm{C}$ and then blocked with $2 \%$ BSA and $0.5 \%$ Tween-20 in PBS. Cells were then stained with anti- $\gamma \mathrm{H} 2 \mathrm{AX}$ antibody (Upstate via Merck Millipore) overnight at $4^{\circ} \mathrm{C}$ and the use anti-mouse Alexa fluor 488 secondary antibody (Life Technologies) for 1 hour at $37^{\circ} \mathrm{C}$. Coverslips were mounted with VESTASHIELD® Mounting Medium containing DAPI, to counterstain cellular nuclei. $\gamma \mathrm{H} 2 \mathrm{AX}$ stained cells were scored manually by a digital fluorescent microscope with $100 \mathrm{X}$ objective and the average number of positive cells was calculated from a minimum of 100 cells per dose/time point. Experimental data present the average of 4 independent experiments.

\section{Statistical analysis}

Data are expressed as the mean \pm standard error of the mean (SEM). GraphPad Prism 6 was used for statistical analysis. To assess the statistical significances between each incubation, a one-way analysis of variance test (ANOVA) with Bonferroni post-hoc multiple comparison correction was used. To compare 2 groups, Student's test was performed. Differences were considered to be statistically significant when $p<0.05$. Correlations between the different variables were investigated using nonparametric spearrmen bivariate correlation analysis in the SPSS (v. 20.0) software package.

\section{Results}

\section{Cell viability and cell proliferation rate}

The results of the MTT assay were presented as a percentage of the results obtained for 'physiological' pH (i.e. pH of unmodified culture medium; pH 7.8). For A549 cells, MTT results demonstrated that although there is some toxicity at $\mathrm{pH}<7$ at various time points, these differences were not statistically significant when compared to their respective controls (Table 1). Furthermore, the results of the trypan blue exclusion assay for A549 cells indicated that the cell viability was above $93 \%$ at all time-points.

MTT results were different for BEAS-2B cells (Table 1), essentially showing that BEAS-2B were more sensitive for low $\mathrm{pH}$ conditions: At $\mathrm{t}=6 \mathrm{~h}$, the viability significantly dropped at lower $\mathrm{pH}$ with approximately $20 \%$ at $\mathrm{pH} 7$, to $45 \%$ at $\mathrm{pH} 5.5$. The viability further declined in a $\mathrm{pH}$ dependent manner after 24 hours incubation. However, at $\mathrm{t}=48$ $\mathrm{h}$, the viability for each condition improved by ca. $10 \%-15 \%$, except for $\mathrm{pH} 5.5$. The results obtained by the trypan blue assay demonstrated a similar pattern as obtained with the MTT assay. At $\mathrm{t}=6 \mathrm{~h}$, the cell viability was above $94 \%$ for all conditions, but after 24 hours incubation, exposure to $\mathrm{pH}<6.5$ resulted in significantly decreased cell viability. At $\mathrm{pH} \geq 6,5$, all samples showed a viability above $92 \%$. Again, at $\mathrm{t}=48 \mathrm{~h}$, cell viability slightly recovered to $65 \%$ for $\mathrm{pH} 6$, but further decreased to $44 \%$ for $\mathrm{pH} 5.5$. Therefore, for BEAS-2B, only $\mathrm{pH} \geq 6.5$ were used for all subsequent experiments. $\mathrm{pH}$ did not influenced the cell proliferation rate. 
Table 1: Cell viability test based on MTT assay and Trypan blue after incubated A549 cells and BEAS-2B cells for 6, 24 and 48 hours under combination of both $1 \mu \mathrm{M} \mathrm{B}[\mathrm{a}] \mathrm{P}$ with different $\mathrm{pH}(\mathrm{pH} 7.8,7,6.5,6$ and 5.5) mediums. Results of MTT are expressed as percentage of pH 7.8. Results of trypan blue are presented as survival rate (total live cells/total cells). All the value is presented as mean $\% \pm \mathrm{SEM}, \mathrm{n}=6$.

\begin{tabular}{|c|c|c|c|c|c|c|}
\hline Methods & Time (h) & pH 7.8 & pH 7 & pH 6.5 & pH 6 & pH 5.5 \\
\hline & & \multicolumn{5}{|c|}{ A549 cells } \\
\hline & 6 & $100 \pm 1.2$ & $92.1 \pm 5.7$ & $91.0 \pm 3.9$ & $93.4 \pm 4.8$ & $95.6 \pm 5.2$ \\
\hline \multirow[t]{8}{*}{ MTT assay } & 24 & $100 \pm 5.3$ & $90.7 \pm 8.9$ & $95.5 \pm 4.6$ & $88.3 \pm 3.6$ & $87.7 \pm 5.4$ \\
\hline & 48 & $100 \pm 5.1$ & $83.5 \pm 8.2$ & $98.9 \pm 1.2$ & $95.5 \pm 3.8$ & $95.1 \pm 3.3$ \\
\hline & & \multicolumn{5}{|c|}{ BEAS-2B cells } \\
\hline & 6 & $100 \pm 8.6$ & $80.4 \pm 7.8^{* *}$ & $79.3 \pm 5.5^{* *}$ & $66.9 \pm 3.2^{* * *}$ & $55.5 \pm 3.8^{* * *}$ \\
\hline & 24 & $100 \pm 17.2$ & $56.6 \pm 14.1^{* * *}$ & $53.3 \pm 6.5^{* * *}$ & $40.8 \pm 9.2^{* * *}$ & $31.5 \pm 5.9^{* * *}$ \\
\hline & 48 & $100 \pm 6.2$ & $71.3 \pm 1.9^{* * *}$ & $63.5 \pm 6.8^{* * *}$ & $55.1 \pm 7.1^{* * *}$ & $4.5 \pm 0.3^{* * *}$ \\
\hline & & \multicolumn{5}{|c|}{ A549 cells } \\
\hline & 6 & $98.0 \pm 1.2$ & $95.6 \pm 3.0$ & $95.1 \pm 1.4$ & $96.5 \pm 0.8$ & $93.7 \pm 2.8$ \\
\hline \multirow[t]{6}{*}{ Trypan blue } & 24 & $98.3 \pm 1.2$ & $97.7 \pm 0.1$ & $97.9 \pm 1.5$ & $95.5 \pm 3.9$ & $94.1 \pm 1.0$ \\
\hline & 48 & $98.9 \pm 0.7$ & $97.7 \pm 1.9$ & $96.2 \pm 2.8$ & $94.4 \pm 3.8$ & $98.4 \pm 1.3$ \\
\hline & & \multicolumn{5}{|c|}{ BEAS-2B cells } \\
\hline & 6 & $95 \pm 0.1$ & $97 \pm 0.1$ & $98 \pm 0.1$ & $96 \pm 0.1$ & $94.3 \pm 1.2$ \\
\hline & 24 & $96 \pm 2$ & $96.3 \pm 1.5$ & $92.3 \pm 1.5^{*}$ & $59.7 \pm 1.2^{* * *}$ & $54.7 \pm 3.2^{* * *}$ \\
\hline & 48 & $96.3 \pm 0.6$ & $94.7 \pm 1.2$ & $93.3 \pm 1.5^{*}$ & $65.3 \pm 0.6^{* * *}$ & $34 \pm 3^{* * *}$ \\
\hline
\end{tabular}

\section{Intracellular and extracellular pH measurement}

The normal $\mathrm{pH}$ range for $\mathrm{A} 549$ cell culture medium is between 7.4-8.0 and for BEAS-2B between 7.2-7.8. After lowering the extracellular $\mathrm{pH}(\mathrm{pHe})$, the $\mathrm{pHe}$ at least partially recovered after 6 hours incubation in all A549 cell samples (Fig 2A). The samples of pHe 7 and pHe 6.5 were raised again to a normal pH range (pH 7.8 and $\mathrm{pH} 7.6$ respectively) after 6 hours incubation and samples maintained this pHe after 48 hours. However, for the relatively low pHe samples (pHe 6 and pHe 5.5), the pHe was not fully restored to normal $\mathrm{pH}$. After 6 hours incubation; the pHe for the samples that had an initial pHe of 6 and 5.5, increased to $\mathrm{pH} 7.0$ and $\mathrm{pH}$ 6.5, respectively. pHe of these samples only slightly further restored after 48 hours incubation to $\mathrm{pH} 7.2$ and $\mathrm{pH}$ 6.6, respectively. Similar to A549 cells, the extracellular pH in all BEAS-2B cells sample were raised after 6 hours incubation (Fig 2B). The samples with pHe 7.8 remained their extracellular $\mathrm{pH}$ and the extracellular pH of samples with an initial pHe 7 and pHe 6.5 increased to $\mathrm{pH} 7.2$ and $\mathrm{pH}$ 6.9 , respectively. At $\mathrm{t}=24 \mathrm{~h}$, the extracellular $\mathrm{pH}$ of $\mathrm{pHe} 6.5$ partially restored to $\mathrm{pH} 7$. After 48 hours incubations, all samples' $\mathrm{pH}$ reached $\mathrm{pH}$ 7.1-7.2. Furthermore, in order to confirm that the restored $\mathrm{pH}$ is an effect of the presence of cells, two $\mathrm{pH}$ media (RPMI $\mathrm{pH}$ 7.8 and $\mathrm{pH}$ 5.5; DMEM pH 7.8 and $\mathrm{pH}$ 6.5) without cells were cultured under the same conditions. Fig $2 \mathrm{~A}$ and $2 \mathrm{~B}$ show that the $\mathrm{pH}$ of the medium is not able to restore without the presence of cells.

The intracellular $\mathrm{pH}(\mathrm{pHi})$ of A549 cells changed in time in accordance with their extracellular $\mathrm{pH}$, (Fig 2C) and consequently, pHe and pHi correlated very well $(\mathrm{R} 2=0.87$, 
$\mathrm{p}<0.0001$, Fig 2E). With increasing incubation time, the pHi restored to the 'physiological' $\mathrm{pH}$ range ( $\mathrm{pH}$ 7.4-8.0), but only in those samples in which the initial pHe at $\mathrm{t}=0$ was above 6.5. For instance the pHi of the samples with an initial pHe of 6.5 , increased to pHi 7.4 and pHi 7.6 at respectively $\mathrm{t}=6$ and 24 hours. However, at low initial pH (pHe 6 and 5.5), the pHi remained lower than in untreated cells with $\mathrm{pHi} 7.3$ and $\mathrm{pHi} 7.0$, respectively. At $t=48 \mathrm{~h}$, the recovery of $\mathrm{pHi}$ of the lowest pHe sample ( $\mathrm{pH} 5.5$ ) only reached to $\mathrm{pHi}$ 7.0.

For BEAS-2B cells the results were essentially similar; the pHi changes in time generally in line with the respective pHe with a good correlation between both parameters (Fig 2D and $2 \mathrm{~F}, \mathrm{R} 2=0.59, \mathrm{p}<0.05)$. After 6 hours incubations, all samples's pHi restored to $\mathrm{pH}$ above 7 ( $\mathrm{pH} 7.3$ for pHe 7.8, pH 7 for both pHe 7 and pHe 6.5, respectively). At $\mathrm{t}=24$ and 48 hours, the pHi in all samples were within the BEAS-2B "physiological" pH range (7.2-7.8).

(A)

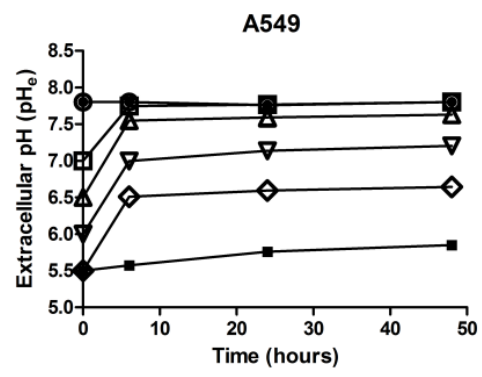

(C)

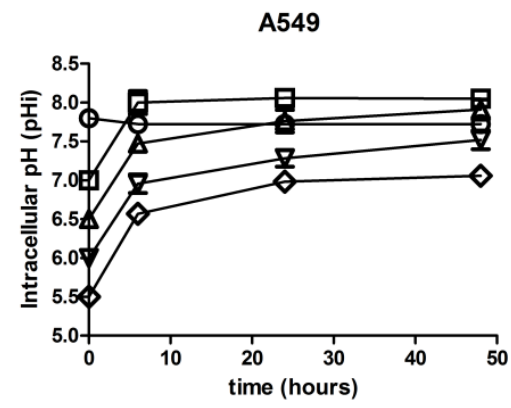

(E)

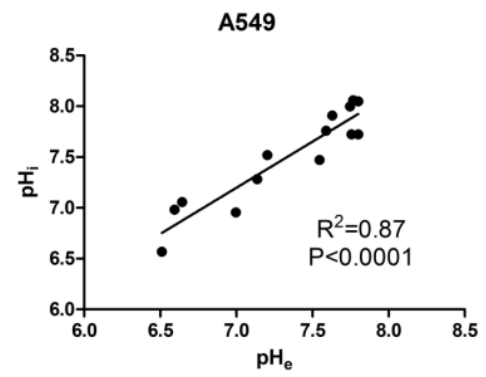

(B)

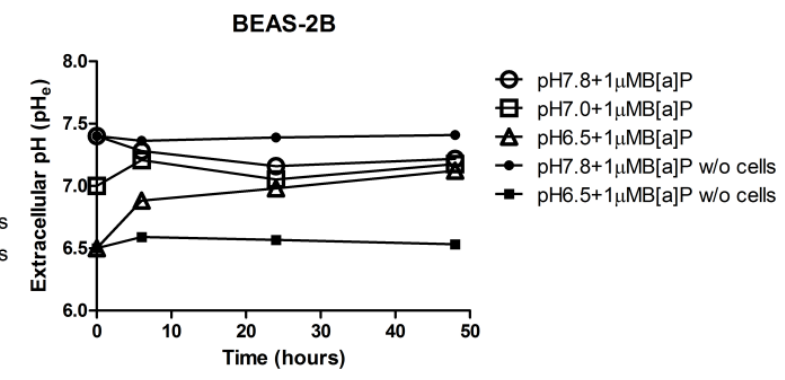

(D)
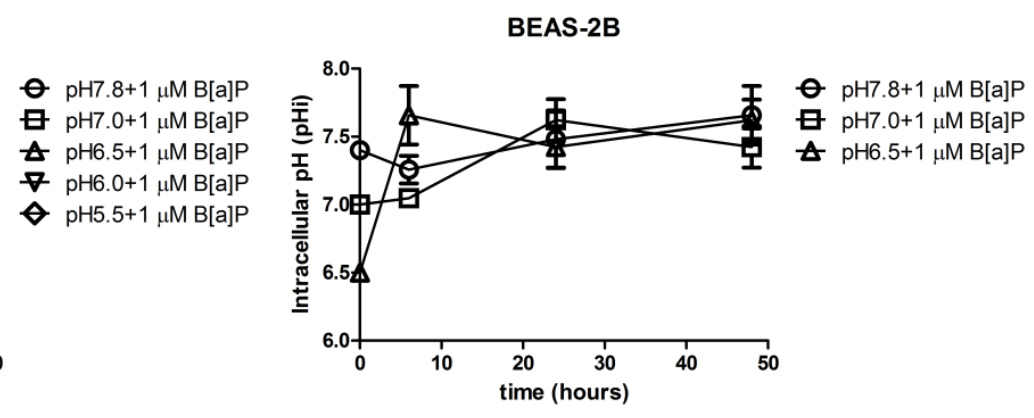

(F)

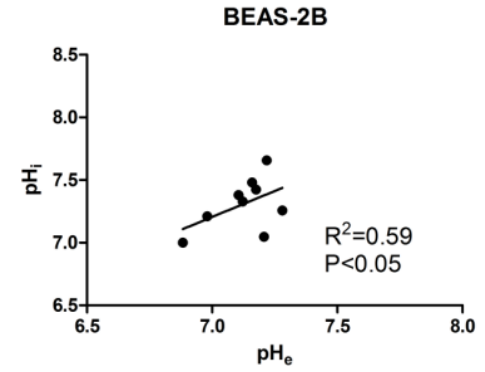

Figure 2. Measurements of $\mathrm{pH}_{\mathrm{e}}$ and $\mathrm{pH}_{\mathrm{i}}$ (mean $\pm \mathrm{SEM}, \mathrm{n}=4$ for $\mathrm{pH}_{\mathrm{e}}$ and $\mathrm{n}=8$ for $\mathrm{pH}_{\mathrm{i}}$ ). (a) and (b) Changes in extracellular $\mathrm{pH}_{\mathrm{e}}$ in $\mathrm{A} 549$ and BEAS-2B cell culture medium (with and without cells) after 6, 24 and 48 hours (w/o= without), respectively; (c) and (d) Changes in intracellular $\mathrm{pH}_{\mathrm{i}}$ in $\mathrm{A} 549$ and $\mathrm{BEAS}-2 \mathrm{~B}$ cells after 6, 24 and 48 hours, respectively; (e) and (f) correlation between $\mathrm{pH}_{\mathrm{e}}$ and $\mathrm{pH}_{\mathrm{i}} \mathrm{in} \mathrm{A} 549$ and $\mathrm{BEAS}-2 \mathrm{~B}$ cells, respectively. 


\section{$B[a] P$ and $B[a] P$ metabolites}

Three important extracellular $\mathrm{B}[\mathrm{a}] \mathrm{P}$ metabolites, $\mathrm{B}[\mathrm{a}] \mathrm{P}-9,10$-dihydrodiol (B[a]P-9,10-diol), B[a]P-7,8-dihydrodiol $\quad$ (B[a]P-7,8-diol) and 3-hydroxy-B[a]P $(\mathrm{B}[\mathrm{a}] \mathrm{P}-3-\mathrm{OH})$, and unmetabolized $\mathrm{B}[\mathrm{a}] \mathrm{P}$ were measured in order to determine how changes in $\mathrm{pH}$ affect the metabolism of $\mathrm{B}[\mathrm{a}] \mathrm{P}$ (Fig 3, for detail metabolites data see Supplement Table 1). In A549 cell with decreased $\mathrm{pH}_{\mathrm{e}}$, the extracellular B[a]P-7,8-diol levels after 6 hours of incubation were significantly lower compared to the normal $\mathrm{pH}$ (pH 7.8) with decreases of $~ 34 \%(\mathrm{pH} \mathrm{7,} \mathrm{p<0.001),} \mathrm{31 \%} \mathrm{(pH} \mathrm{6.5,} \mathrm{p<0.01),} \mathrm{69 \%} \mathrm{(pH} \mathrm{6,}$ $\mathrm{p}<0.001$ ) and $\sim 97 \%$ (pH 5.5, p<0.001), respectively. After 24 hours, the concentration of $\mathrm{B}[\mathrm{a}] \mathrm{P}-7,8$-diol was still lower in those samples whose $\mathrm{pH}$ was decreased, except at the lowest $\mathrm{pH}_{\mathrm{e}}\left(\mathrm{pH}\right.$ 5.5). At $\mathrm{t}=48 \mathrm{~h}$, the $\mathrm{B}[\mathrm{a}] \mathrm{P}-7,8$-diol levels in samples with an initial $\mathrm{pH}_{\mathrm{e}} 5.5$ kept increasing to $101 \mathrm{nM}$, which was 1000 -fold higher than its concentration at $\mathrm{pH} 7.8$. On the other hand, the $\mathrm{B}[\mathrm{a}] \mathrm{P}-7,8-$ diol levels in the other samples declined over time to 1.4-0.1 nM after 48 hours incubation; the concentration at $\mathrm{t}=48$ hours is $\mathrm{pH}$ dependent. Extracellular concentrations of $\mathrm{B}[\mathrm{a}] \mathrm{P}-9,10-$ diol and $\mathrm{B}[\mathrm{a}] \mathrm{P}-3-\mathrm{OH}$ (Fig $\mathbf{3 A}$ and $\mathbf{3 E}$ ) displayed a similar pattern as the concentration of $\mathrm{B}[\mathrm{a}] \mathrm{P}-7,8-$ diol. The extracellular metabolite concentrations were lower at $\mathrm{pH}_{\mathrm{e}} 5.5$ at $\mathrm{t}=6 \mathrm{~h}$. However, at $\mathrm{t}=48 \mathrm{~h}$, the concentration of $\mathrm{B}[\mathrm{a}] \mathrm{P}-9,10$-diol and $\mathrm{B}[\mathrm{a}] \mathrm{P}-3-\mathrm{OH}$ at $\mathrm{pH}_{\mathrm{e}} 5.5$ were 336 -fold and 9-fold higher than the concentrations observed at $\mathrm{pH}_{\mathrm{e}} 7.8$, respectively.

The extracellular metabolites level (B[a]P-9,10-diol, B[a]P-7,8-diol and B[a]P-3-OH) in BEAS-2B cells displayed a similar patterns as in A549 cells but the effects were already seen at a non-cytotoxic extracellular $\mathrm{pH}$ of 6.5 (Fig 3). After 6 hours incubation, the concentration of $\mathrm{B}[\mathrm{a}] \mathrm{P}-7,8-$ diol in $\mathrm{pH} 7(\mathrm{p}<0.05)$ and $\mathrm{pH} 6.5(\mathrm{p}<0.001)$ were significantly lower than at $\mathrm{pH}_{\mathrm{e}} 7.8$, respectively. At $\mathrm{t}=24 \mathrm{~h}$, the level of $\mathrm{B}[\mathrm{a}] \mathrm{P}-7,8$-diol in $\mathrm{pH}_{\mathrm{e}} 7.8$ decreased about $69 \%$ when compared to its level at $\mathrm{t}=6$, whereas the concentration of $\mathrm{B}[\mathrm{a}] \mathrm{P}-7,8$-diol in the samples with $\mathrm{pH}_{\mathrm{e}} 7$ and $\mathrm{pH}_{\mathrm{e}} 6.5$, increased approximately 1.7-fold and 3.4-fold, respectively. At $\mathrm{t}=48 \mathrm{~h}$, the $\mathrm{B}[\mathrm{a}] \mathrm{P}-7,8$-diol levels at $\mathrm{pH} 7 \quad(\mathrm{p}<0.001)$ decreased to $22.7 \mathrm{nM}$, but was still significantly higher than at $\mathrm{pH}_{\mathrm{e}}$ 7.8. The $\mathrm{B}[\mathrm{a}] \mathrm{P}-7,8-$ diol concentration at $\mathrm{pH}_{\mathrm{e}} 6.5$, kept increasing in time to $111 \mathrm{nM}$ and was ultimately 48-fold higher than at $\mathrm{pH}_{\mathrm{e}}$ 7.8. Extracellular $\mathrm{B}[\mathrm{a}] \mathrm{P}-9,10-$ diol and $\mathrm{B}[\mathrm{a}] \mathrm{P}-3-\mathrm{OH}$ (Fig 3B and 3F) levels were initially significantly lower at $\mathrm{pH}_{\mathrm{e}} 6.5$ compared to $\mathrm{pH}_{\mathrm{e}} 7.8$ at $\mathrm{t}=6 \mathrm{~h}, \approx 54 \%(\mathrm{p}<0.001)$ and $\approx 65 \%(\mathrm{p}<0.001)$, respectively. However, at $\mathrm{t}=24 \mathrm{~h}$, concentrations of both metabolites further increased at $\mathrm{pH}_{\mathrm{e}} 6.5$ but decreased in $\mathrm{pH}_{\mathrm{e}}$ 7.8. Consequently, at $\mathrm{t}=48 \mathrm{~h}$, both metabolites were 3.1-fold and 2.8-fold higher at $\mathrm{pH}_{\mathrm{e}} 6.5$ than at $\mathrm{pH}_{\mathrm{e}} 7.8$, respectively.

The extracellular kinetics of unmetabolized $\mathrm{B}[\mathrm{a}] \mathrm{P}$ is indicative for the rate of metabolism of $\mathrm{B}[\mathrm{a}] \mathrm{P}$ under each $\mathrm{pH}$ condition (Fig 3G and 3H). In A549 cells, the level of metabolized $\mathrm{B}[\mathrm{a}] \mathrm{P}$ in time was reduced with decreasing $\mathrm{pH}_{\mathrm{e}}$, eventually reaching a $>50$ fold difference when $\mathrm{pH}_{\mathrm{e}} 5.5$ was compared with $\mathrm{pH}_{\mathrm{e}} 7.8(\mathrm{p}<0.001)$. The concentration of unmetabolized $\mathrm{B}[\mathrm{a}] \mathrm{P}$ was $\mathrm{pH}$ dependent $\left(\mathrm{R}^{2}=0.71, \mathrm{p}=0.074\right)$. In BEAS-2B cells, the level of extracellular unmetabolized B[a]P showed a similar pattern as for A549 cells; the concentration of unmetabolized $\mathrm{B}[\mathrm{a}] \mathrm{P}$ was significantly higher at low $\mathrm{pH}$ than at neutral $\mathrm{pH}$ in a $\mathrm{pH}$ dependent manner $\left(\mathrm{R}^{2}=0.68, \mathrm{p}=0.0009\right)$. 
(A)

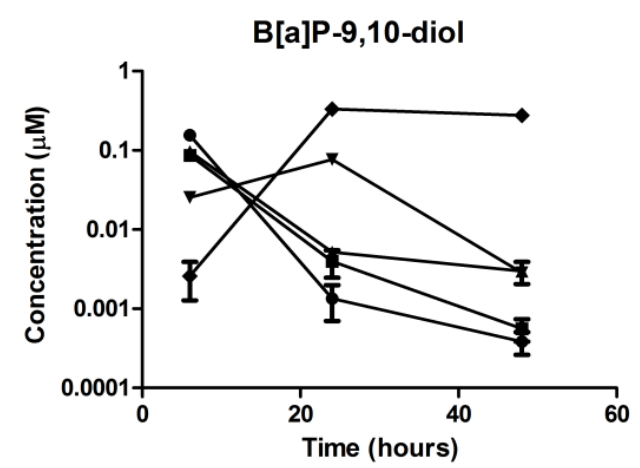

(C)

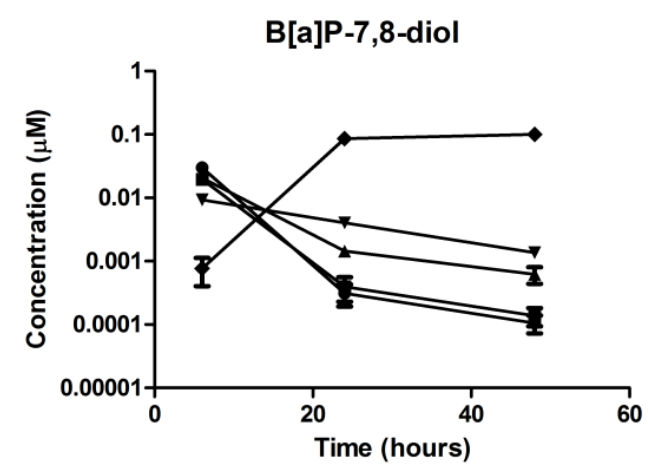

(E)

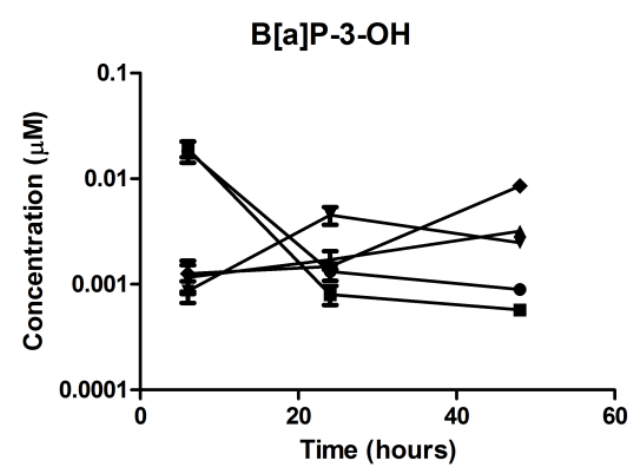

(G)

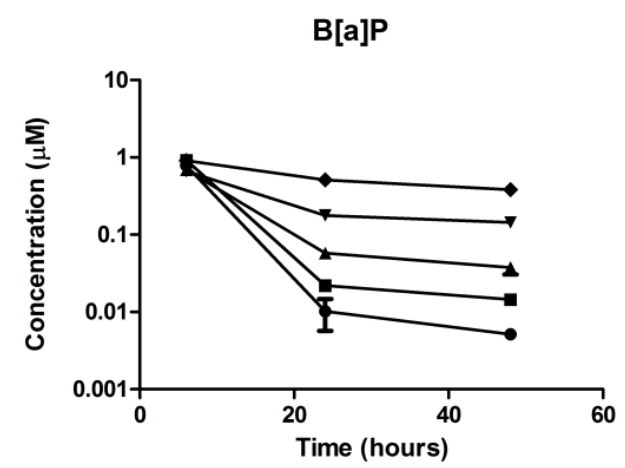

(B)
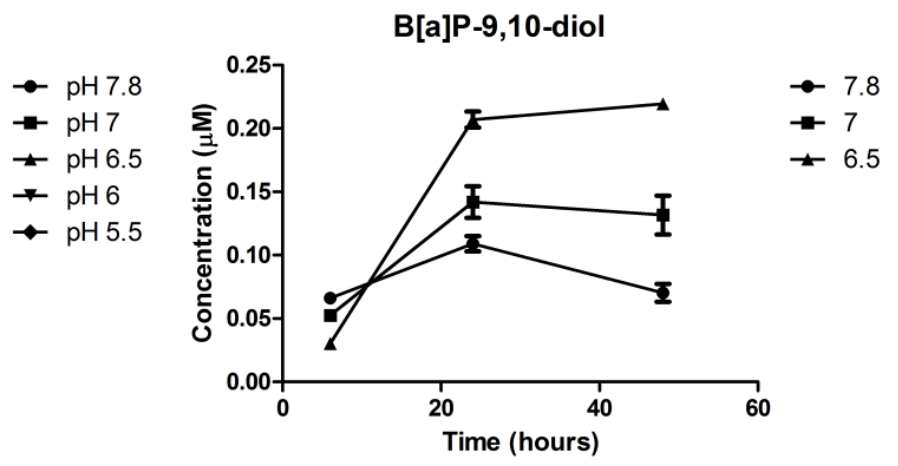

(D)
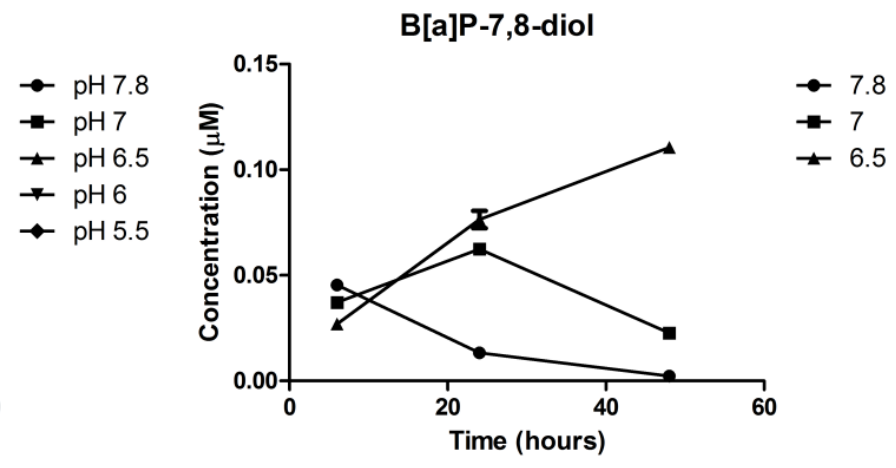

(F)
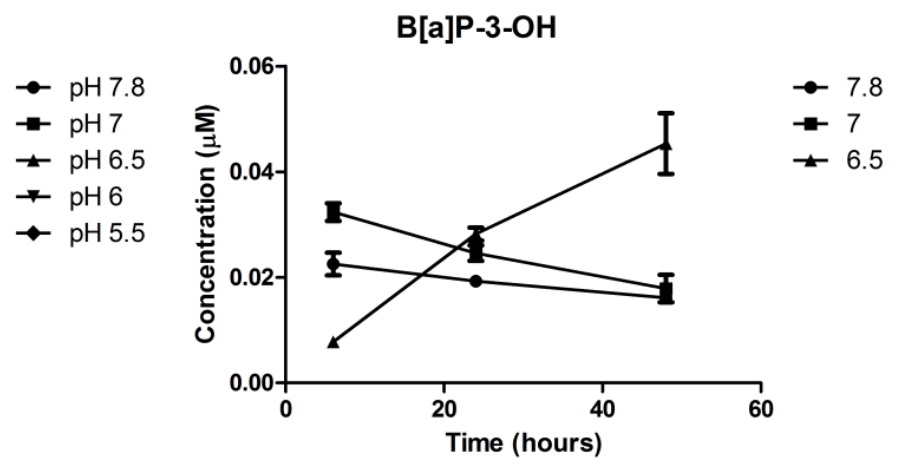

(H)
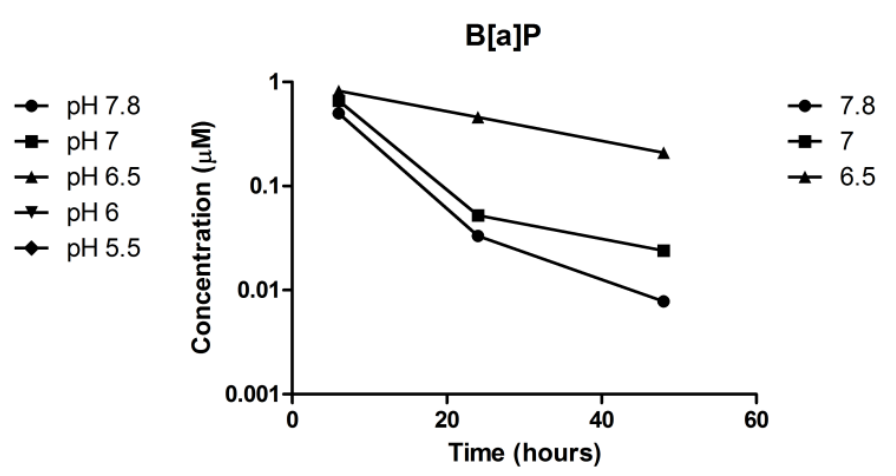

Figure 3. A549 and BEAS-2B cells were treated with $1 \mu \mathrm{M} \mathrm{B}[\mathrm{a}] \mathrm{P}$ and incubated at the indicated $\mathrm{pH}_{\mathrm{e}}$ for 6 , 24 and 48 hours. The left column represents data from A549 cells and the right column from BEAS-2B cells. The extracellular concentrations of B[a]P-9,10-diol ((a) and (b)); B[a]P-7,8-diol ((c) and (d)); $\mathrm{B}[\mathrm{a}] \mathrm{P}-3-\mathrm{OH}(\mathbf{( e )}$ and (f)); and $\mathrm{B}[\mathrm{a}] \mathrm{P}(\mathbf{( g )}$ and (h)) were measured at the indicated time points. Data are presented as mean \pm SEM, $n=4$ independent experiment. The results of statistical analysis are included in supplemental Table 1.

60 


\section{CYP1A1 and CYP1B1 gene expression and EROD activity}

To determine whether the activity of the main cytochrome P450 enzyme that is involved in $\mathrm{B}[\mathrm{a}] \mathrm{P}$ metabolism was altered by decreased $\mathrm{pH}$ in cells, we assessed the mRNA expression of $C Y P 1 A 1$ and $C Y P 1 B 1$ and EROD activity as a indicator of CYP1A1 activity for both A549 (Fig 4A, 4C and 4E) and BEAS-2B (Fig 4B, 4D and 4F) cells. In A549 cells (Fig 4A), CYP1A1 expression decreased to 48\% (pH 7, p=0.0002), 34\% (pH 6.5, $\mathrm{p}=0.0002$ ), 33\% (pH 6, p=0.0001) and 20\% (pH 5.5, p<0.0001) compared to $\mathrm{pH} 7.8$ when exposed to $\mathrm{B}[\mathrm{a}] \mathrm{P}$ for 6 hours, respectively. However, the $\mathrm{pH}$ dependent trend converted after 24 hours in such a way that $C Y P 1 A 1$ expression was now up-regulated as the initial $\mathrm{pH}$ decreased. When compared to $\mathrm{pH} 7.8$ with $\mathrm{B}[\mathrm{a}] \mathrm{P}$ at $\mathrm{t}=24 \mathrm{~h}$, the $C Y P 1 A 1$ expression at pH 7, pH 6.5, pH 6 and pH 5.5 were 1.3-fold, 1.3-fold, 1.3-fold and 5-fold $(\mathrm{p}=0.0025)$ increased, respectively. This trend remained after 48 hours incubation and the lowest $\mathrm{pH}(\mathrm{pH}$ 5.5) showed a significant induction of CYP1A1 (12.9-fold, $\mathrm{p}<0.001$ ) compared to $\mathrm{pH} 7.8$ with B[a]P. For the mRNA expression of CYP1A1 in BEAS-2B cells, a similar pattern as described for A549 cells was observed but less pronounced (Fig 4B). At $\mathrm{t}=48 \mathrm{~h} \mathrm{pH}_{\mathrm{e}}=6.5$, the $C Y P 1 A 1$ expression was decreased in A549 cells but kept increasing in BEAS-2B cells.

Figures 4c and 4d indicate the changes of CYP1B1 gene expression after incubation with $\mathrm{B}[\mathrm{a}] \mathrm{P}$ under various pH conditions for 6, 24 and 48 hours in both A549 and BEAS-2B cells, respectively. The CYP1B1 mRNA expression changes in A549 cells were similar to the changes seen for $C Y P 1 A 1$ gene expression. At $\mathrm{t}=6 \mathrm{~h}$, an 19 -fold increasing of $C Y P 1 B 1$ mRNA expression was observed after treatment with $1 \mu \mathrm{M} \mathrm{B}[\mathrm{a}] \mathrm{P}$ at $\mathrm{pH}$ 7.8. Meanwhile, a significantly pH-dependent decrease of CYP1B1 gene expression was found when compared to $\mathrm{pH} 7.8$, and the CYP1B1 mRNA level at the lowest $\mathrm{pH}_{\mathrm{e}}\left(\mathrm{pH}_{\mathrm{e}} 5.5\right)$ was $42 \%$ of pH 7.8 (Fig 4C). After 24 hours incubation, the CYP1B1 mRNA level decreased at neutral $\mathrm{pH}$. Although the CYP1B1 mRNA expression also decreased for the rest of $\mathrm{pH}$ samples (except pH 5.5), the trend was a pH-dependent increase when compared to $\mathrm{pH} 7.8$. The CYP1B1 mRNA level in samples with initial $\mathrm{pH}_{\mathrm{e}} 5.5$ was about 8-fold higher than at $\mathrm{pH}$ 7.8 at $\mathrm{t}=24 \mathrm{~h}$. Additionally, at $\mathrm{t}=48 \mathrm{~h}$, the $C Y P 1 B 1$ mRNA levels were back to basal level in most samples, except for samples with pH 5.5, in which the expression remained 8.7-fold increased compared at $\mathrm{pH}$ 7.8. For BEAS-2B cell, the expression of $C Y P 1 B 1$ showed a slightly different trend when compared to $C Y P 1 A 1$ gene expression at $\mathrm{t}=6 \mathrm{~h}$. The $C Y P 1 B 1$ gene expression at pH 7 and pH 6.5 demonstrated 1.7-fold and 1.8-fold higher levels than at $\mathrm{pH} 7.8$, respectively (Fig 4D). At $\mathrm{t}=24 \mathrm{~h}$ and $\mathrm{t}=48 \mathrm{~h}$, the CYP1B1 mRNA levels at both $\mathrm{pH} 7$ and $\mathrm{pH} 6.5$ remained significantly higher than at $\mathrm{pH} 7.8$, eventually, $\mathrm{pH} 6.5$ displayed 3.3-fold higher CYP1B1 gene expression after 48 hours incubation when compared to samples that were incubated at $\mathrm{pH}$ 7.8.

The EROD activity as an indicator of CYP1A1 activity was measured under different $\mathrm{pH}$ conditions for 6, 24 and 48 hours for both A549 and BEAS-2B cells (Fig 4E and 4F). The results of the EROD activity paralleled the results of $C Y P 1 A 1$ expression for both cell lines. In A549 cells at $\mathrm{t}=6 \mathrm{~h}$, the low $\mathrm{pH}$ treatment resulted in significantly lower EROD activity (pH 6.5, p<0.05; $\mathrm{pH} 6, \mathrm{p}<0.001$ and $\mathrm{pH}$ 5.5, $\mathrm{p}<0.001$, respectively) when compared to $\mathrm{pH} 7.8$, but at $\mathrm{t}=24$ hours, the EROD activity in low $\mathrm{pH}$ and $\mathrm{B}$ [a] $\mathrm{P}$ treated samples showed significantly higher activity ( $\mathrm{pH} 6, \mathrm{p}<0.001$ and $\mathrm{pH} 5.5, \mathrm{p}<0.001$ ) when compared to $\mathrm{pH}$ 7.8. After 48 hours incubation, although the EROD activity was decreased in all samples, the activity in the low $\mathrm{pH}_{\mathrm{e}}$ treated samples remained higher than at pH 7.8 (see Fig. 4c, pH 6, p<0.01 and pH 5.5, p<0.001). The EROD activity in 
BEAS-2B cells displayed similar trends and corresponded to the CYP1A1 gene expression.

(A)

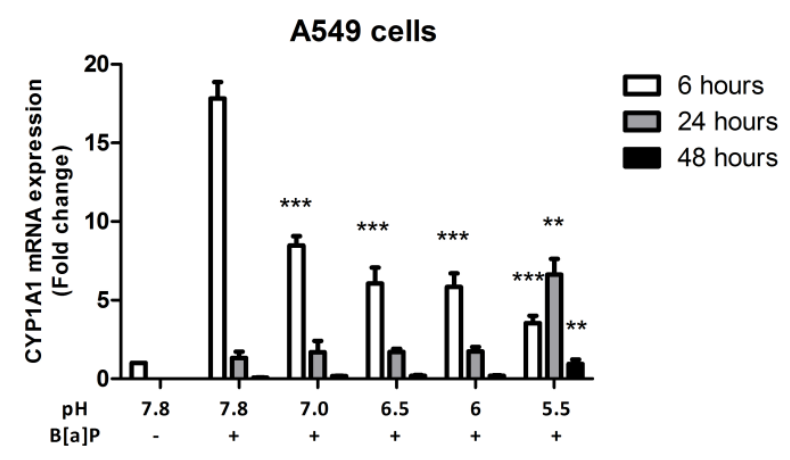

(C)

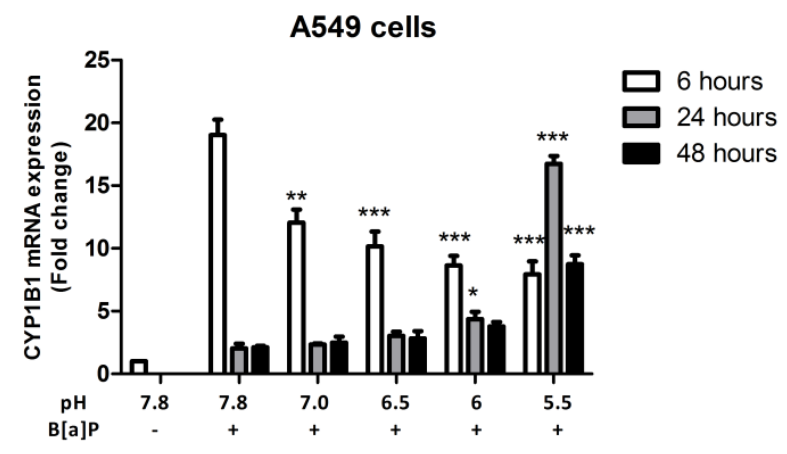

(E)

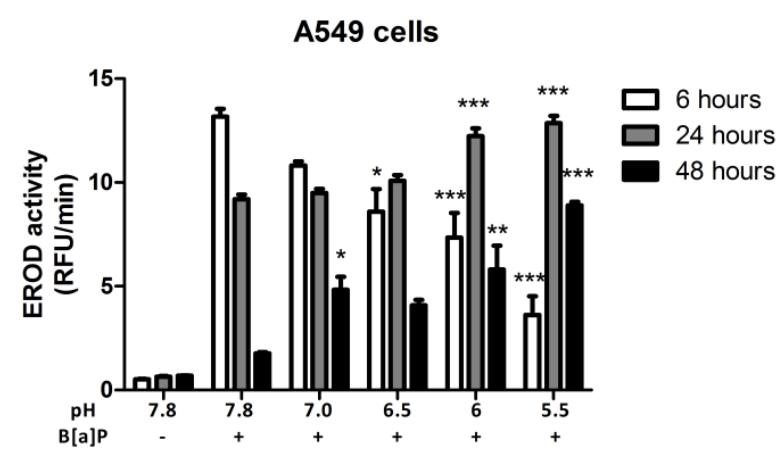

(B)

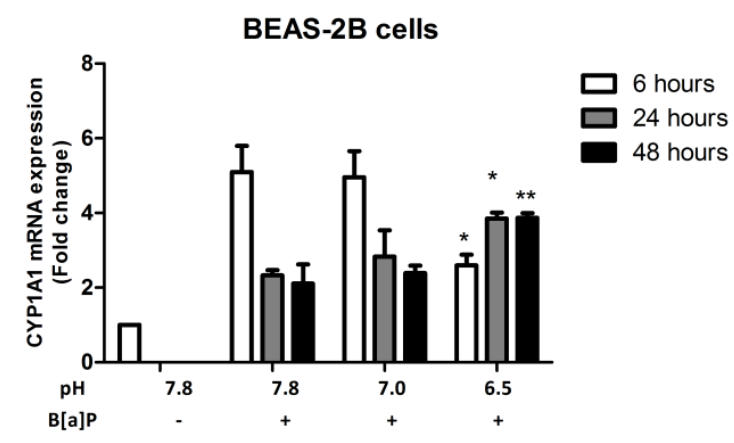

(D)

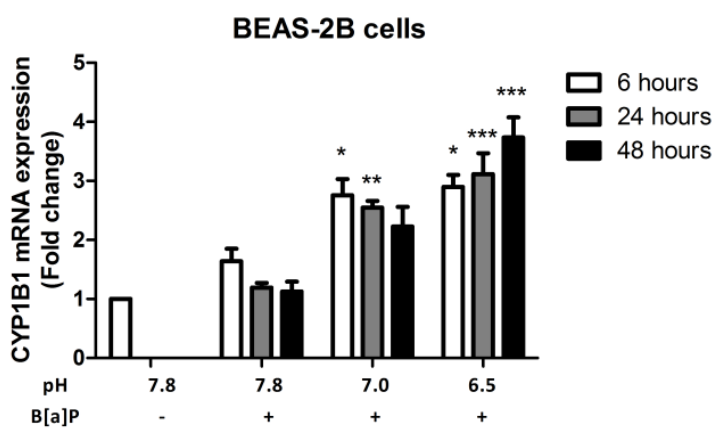

(F)

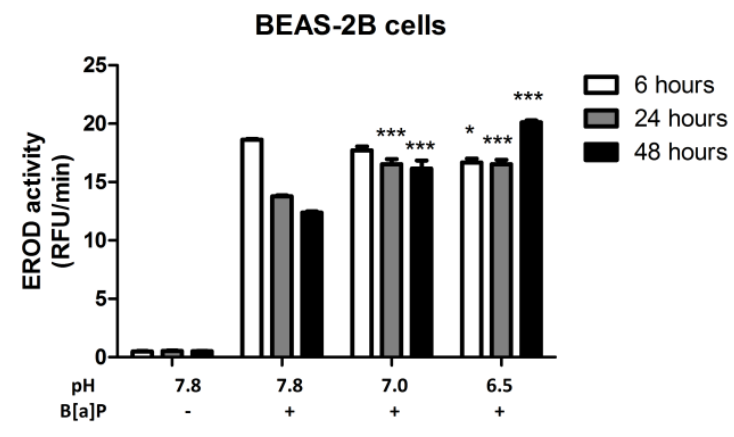

Figure 4. A549 and BEAS-2B cells were treated with $1 \mu \mathrm{M} \mathrm{B}[\mathrm{a}] \mathrm{P}$ and incubated at the indicated $\mathrm{pH}_{\mathrm{e}}$ for 6 , 24 and 48 hours. CYP1A1 mRNA expression level was assessed in A549 cells (a) and BEAS-2B cells (b) by qRT-PCR. CYP1B1 mRNA expression level was assessed in A549 cells (c) and BEAS-2B cells (d) by qRT-PCR. All data were normalized with the house keeping gene ( $\beta$-actin) and compared to controls (A549 cells and BEAS-2B cells incubated with DMSO for 6 hours) and expressed as mean \pm SEM, $n=4$; CYP450s activity (CYP1A1 activity) was measured by an EROD assay in A549 cells (e) and BEAS-2B cells (f). Data are presented as relative fluorescence units $/ \mathrm{min}(\mathrm{RFU} / \mathrm{min})$ and expressed as mean $\pm \mathrm{SEM}, \mathrm{n}=5$. Statistical comparison was performed between each $\mathrm{pH}$ conditions $(\mathrm{pH} 7,6.56$ and 5.5) with $\mathrm{pH} 7.8$ at each time point. ${ }^{*} \mathrm{p}<0.05,{ }^{* *} \mathrm{p}<0.01$ and $^{* * *} \mathrm{p}<0.001$.

\section{pH dependency of DNA incision activity}

DNA adduct levels are the net effect of DNA adduct formation and removal by DNA repair. Therefore, the impact of acidic $\mathrm{pH}$ on DNA incision activity in both cell lines (A549 and BEAS-2B) was assessed (Fig 5). In A549 cells, at $\mathrm{t}=6 \mathrm{~h}$, a markedly reduced 
DNA incision activity was observed at lowered $\mathrm{pH}_{\mathrm{e}}$; approximately $25 \%(\mathrm{pH} 6.5$, $\mathrm{p}<0.001), 11 \%(\mathrm{pH} \mathrm{6}, \mathrm{p}<0.001)$ and 20\% (pH 5.5, p<0.001) of DNA incision activity remained when compared to $\mathrm{pH} 7.8$. After 24 hours incubation, the DNA incision activity in the majority of samples (except $\mathrm{pH} 7$ ) partly recovered, but at low $\mathrm{pH}_{\mathrm{e}}$ the DNA incision activity remained lower than at $\mathrm{pH} 7.8$ (pH 6, p<0.001 and $\mathrm{pH} \mathrm{5.5,p<0.01).}$ Interestingly, at $\mathrm{t}=48 \mathrm{~h}$, the DNA incision activity fully recovered to more than $100 \%$ compared to pH 7.8 for all the samples, including pH 7 (121\%, p<0.01), pH 6.5 (115\%, $\mathrm{p}=0.065)$, $\mathrm{pH} 6$ (135\%, p<0.001) and pH 5.5 (110\%, p=0.062). For BEAS-2B cells, although there were only three $\mathrm{pH}$ condition ( $\mathrm{pH} 7.8, \mathrm{pH} 7$ and $\mathrm{pH} 6.5)$ tested, a similar trend as for A549 cells was observed (Fig 5B). At $\mathrm{t}=6$, when compared to $\mathrm{pH} 7.8$, a strong decreased DNA incision activity was found at $\mathrm{pH} 7$ (decrease of $45 \%, \mathrm{p}=0.14$ ) and pH 6.5 (decrease of 77\%, p<0.05). After 24 hours incubation, for both $\mathrm{pH} 7$ and $\mathrm{pH} 6.5$, the DNA incision activity was slightly raised but remained lower than at pH 7.8 (but not statistically significant). At $\mathrm{t}=48 \mathrm{~h}$, for both $\mathrm{pH} 7$ and $\mathrm{pH} 6.5$, the DNA incision activity was significantly increased to 1.6 -fold $(\mathrm{p}<0.05)$ and 2.8-fold $(\mathrm{p}<0.01)$ higher than at $\mathrm{pH}$ 7.8, respectively.

(A)

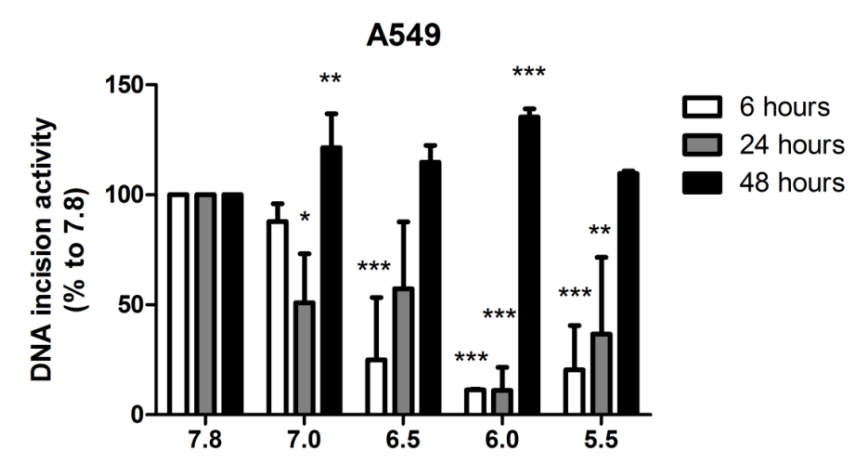

(B)

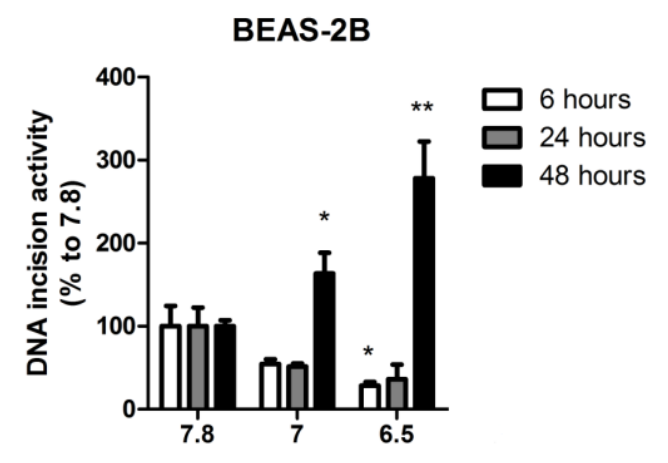

Figure 5. DNA incision activity measured by a modified Comet assay. Nuclei were treated with BPDE and cell extracts were prepared from cells incubated at different $\mathrm{pH}$ and $\mathrm{B}[\mathrm{a}] \mathrm{P}$ for variable times. These extracts were then used to treat the BPDE-damaged nuclei for 20 mins. The DNA incision activity of the extract was determined by the comet assay. DNA incision activity was calculated as percentage of the values observed in $\mathrm{pH} 7.8$ samples $(\mathrm{pH}$ 7.8 with $\mathrm{B}[\mathrm{a}] \mathrm{P}$ at 6,24 and 48 hours) (mean \pm SEM, $n=4$ ). All raw data (Tail Moment and Tail Intensity) for both cell lines will be presented in Supplemental Table 2; (a) A549 cells; (b) BEAS-2B cells; Statistical comparison was performed between each $\mathrm{pH}$ conditions with pH 7.8 with BaP only at each time point. ${ }^{*} \mathrm{p}<0.05,{ }^{* *} \mathrm{p}<0.01$ and ${ }^{* * *} \mathrm{p}<0.001$.

\section{$p H$ dependent levels of $B[a] P-D N A$ adducts}

As shown in Fig 6A, incubation of A549 cells with different $\mathrm{pH}_{\mathrm{e}}$ in combination with $\mathrm{B}[\mathrm{a}] \mathrm{P}$ initially resulted in significantly lower DNA adduct levels as the $\mathrm{pH}_{\mathrm{e}}$ decreased $(\mathrm{pH}$ $6, \mathrm{p}<0.05$ and $\mathrm{pH} 5.5, \mathrm{p}<0.001$ ). After 24 hours of incubation, the B[a]P-DNA adduct levels were increased for all samples, but DNA adduct levels increased predominantly in the samples that were treated at $\mathrm{pH} 6(\mathrm{p}<0.05)$. At $\mathrm{t}=48 \mathrm{~h}$, the DNA adduct levels decreased in all samples, except at pH 5.5. After 48 hours at pH 5.5, DNA adduct levels were 138 adducts per $10^{7}$ nucleotides which is 5.5 -fold higher than the adduct levels observed for samples that were incubated at $\mathrm{pH}_{\mathrm{e}} 7.8(\mathrm{p}<0.001)$. 
A pH dependency of $\mathrm{B}[\mathrm{a}] \mathrm{P}$-induced DNA adduct levels was also found for BEAS-2B cells (Fig 6B). At $\mathrm{t}=6 \mathrm{~h}, 24$ adducts per $10^{7}$ nucleotides were reached at $\mathrm{pH} 7.8$. Samples with initial pHe 7 and pHe 6.5 contained 28\% and 76\% (p<0.01) lower DNA adduct levels than at pHe 7.8, respectively. However, after 24 hours of incubation, the B[a]P-DNA adduct levels increased for all samples and the DNA adduct level at $\mathrm{pH} 7$ was 74 adducts per $10^{7}$ nucleotides which was 2 -fold $(\mathrm{p}<0.05)$ higher than at $\mathrm{pHe} 7.8$. At $\mathrm{t}=48 \mathrm{~h}$, the DNA adduct levels decreased at $\mathrm{pH} 7.8$ and $\mathrm{pH}$ 7, but not for $\mathrm{pH}$ 6.5. Eventually, the DNA adduct levels for $\mathrm{pH} 7$ and $\mathrm{pH} 6.5$ were 1.5 -fold $(\mathrm{p}<0.05)$ and 1.9 -fold higher $(\mathrm{p}<0.05)$ than in samples in which the initial pHe was 7.8 after 48 hours incubation, respectively.

\section{Histone protein $H 2 A X$ phosphorylation $(\gamma H 2 A X)$}

To determine the overall DNA damage after exposure of A549 and BEAS-2B cell at different $\mathrm{pH}$ 's in combination with $\mathrm{B}[\mathrm{a}] \mathrm{P}$, we measured the phosphorylation of histone protein H2AX under each condition (Fig 6). At pH 7.8, exposure of both cell lines (A549 and BEAS-2B cells) to B[a]P significantly induced DNA damage after 6, 24 and 48 hours. In A549 cells (Fig 6C), when comparing to B[a]P exposed samples at $\mathrm{pH} 7.8$, there was no significant difference at $\mathrm{t}=6 \mathrm{~h}$ for samples that were incubated at lower $\mathrm{pH}$. However, at $\mathrm{t}=24 \mathrm{~h}$, the DNA damage was enhanced for all lowered $\mathrm{pH}$ conditions; $\mathrm{pH} 6(\mathrm{p}<0.001)$ and $\mathrm{pH} 5.5(\mathrm{p}<0.05)$ showed a 1.9- and 1.5-fold higher percentage of $\gamma \mathrm{H} 2 \mathrm{AX}$ stained cells than at $\mathrm{pH} 7.8$, respectively. At $\mathrm{t}=48 \mathrm{~h}$, the DNA damage level decreased in all samples, except for samples with $\mathrm{pH}$ 5.5. Moreover, DNA damage at $\mathrm{pH} 6(\mathrm{p}<0.01,3$-fold) and $\mathrm{pH}$ 5.5 ( $\mathrm{p}<0.001,4.9$-fold) were still significantly higher after 48 hours of incubation when compared to levels of $\gamma \mathrm{H} 2 \mathrm{AX}$ staining at $\mathrm{pH} 7.8$.

Interestingly, again similar results were also found for BEAS-2B cells (Fig 6D). After 6 and 24 hours incubations, the DNA damage increased in all samples and there was no significant difference between any $\mathrm{pH}$ condition and $\mathrm{pH}$ 7.8. However, at $\mathrm{t}=48 \mathrm{~h}$, the number of positive cells at $\mathrm{pH} 7.8$ and $\mathrm{pH} 7$ decreased, whereas, the positive cells increased at $\mathrm{pH} 6.5$ to a 3.2 -fold $(\mathrm{p}<0.01)$ higher level when compared to samples that were incubated at $\mathrm{pH} 7.8$. 
(A)

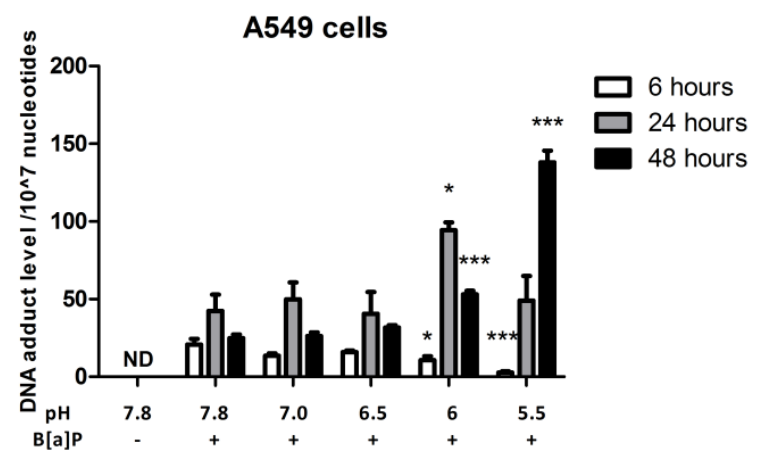

(C)

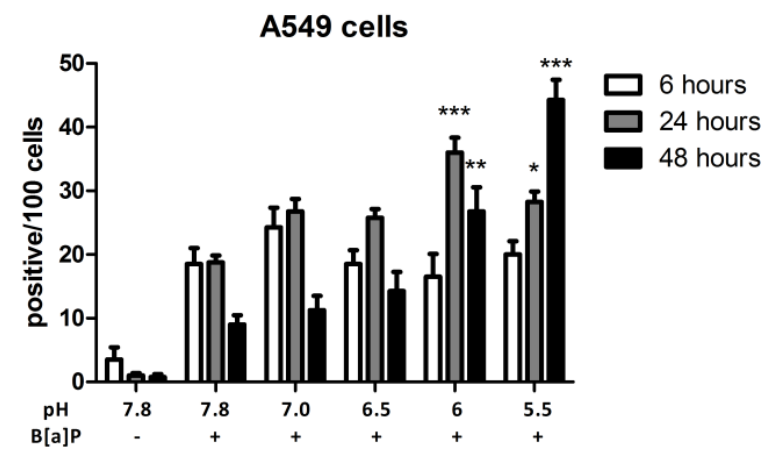

(B)

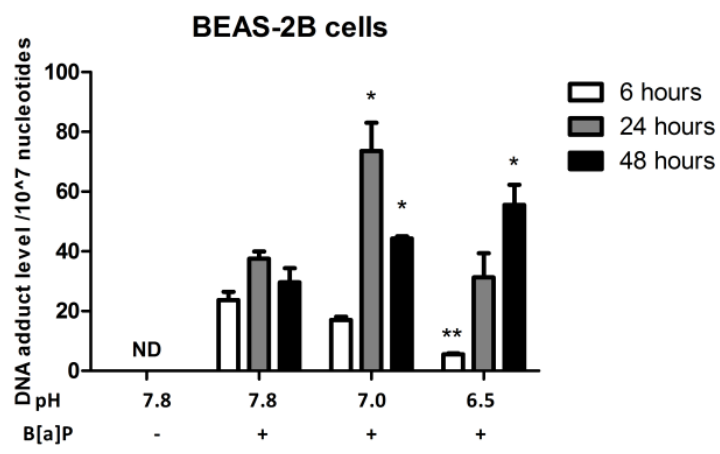

(D)

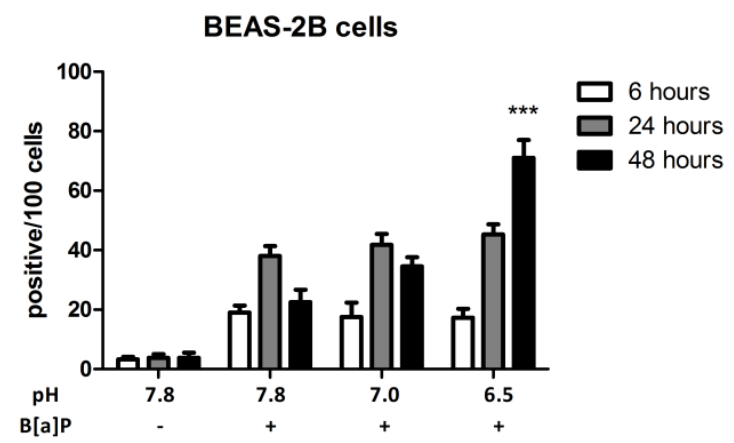

(E)

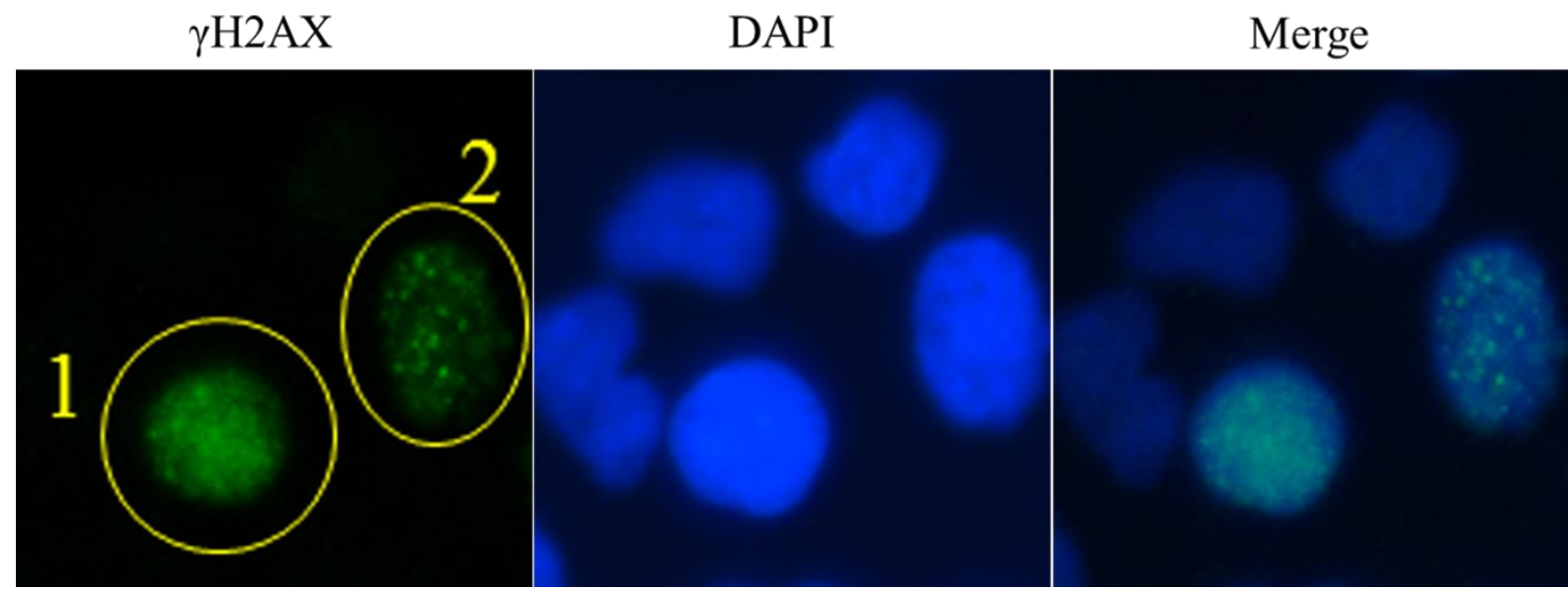

Figure 6. A549 and BEAS-2B cells were treated with $1 \mu \mathrm{M} \mathrm{B}[\mathrm{a}] \mathrm{P}$ and incubated the indicated $\mathrm{pH}_{\mathrm{e}}$ for 6 , 24 and 48 hours. (a) DNA adduct levels in A549 cells. (b) DNA adduct levels in BEAS-2B cells. DNA was isolated and analyzed by ${ }^{32} \mathrm{P}$-postlabeling. Data is presented as mean DNA adduct level per $10^{7}$ nucleotides \pm SEM (n=4). ND: Not Detected; (c) DNA damage in A549 cells measured by $\gamma \mathrm{H} 2 \mathrm{AX}$ staining. (d) DNA damage in BEAS-2B cells measured by $\gamma \mathrm{H} 2 \mathrm{AX}$ staining. Data are expressed as positive cells per 100 cells (mean \pm SEM, $n=4)$; (e) Example of positive cells under 100X objective using a digital fluorescent microscope (including $\gamma \mathrm{H} 2 \mathrm{AX}$ staining, DAPI and merge). Yellow circle of 1 and 2 represents cells that were counted as positive ; Statistical comparison was performed between each $\mathrm{pH}$ conditions with $\mathrm{pH} 7.8$ with $\mathrm{B}[\mathrm{a}] \mathrm{P}$ at each time point. ${ }^{*} \mathrm{p}<0.05,{ }^{* *} \mathrm{p}<0.01$ and ${ }^{* * *} \mathrm{p}<0.001$.

Correlation between each variable (B[a]P,7-8-diol, CYP1A1/CYP1B1 mRNA expression, EROD activity, DNA incision activity and DNA adduct)

After measuring different types of variables related to $\mathrm{B}[\mathrm{a}] \mathrm{P}$ related metabolism or $\mathrm{B}[\mathrm{a}] \mathrm{P}$ induced DNA damage, correlations between the variables were assessed for both cell 
lines. Most parameters related to $\mathrm{B}[\mathrm{a}] \mathrm{P}$ metabolism correlated with each other in both cell lines, because they are involved in the same pathway. For instance, in A549 cells (Supplemental Table 3), the extracellular concentration of B[a]P-7,8-diol correlated significantly with CYP1A1 mRNA expression $(\mathrm{r}=0.704, \mathrm{p}<0.01)$, CYP1B1 mRNA expression ( $\mathrm{r}=0.914, \mathrm{p}<0.001)$, EROD activity $(\mathrm{r}=0.607, \mathrm{p}<0.05)$ and $\mathrm{B}[\mathrm{a}] \mathrm{P}$-induced DNA adduct level $(\mathrm{r}=0.555, \mathrm{p}<0.05)$. None of variable showed a good correlation with DNA incision activity. In addition, only $\mathrm{B}[\mathrm{a}] \mathrm{P}-7,8-$ diol, the precursor of $\mathrm{BPDE}$, demonstrated good correlation with BPDE-DNA adduct level.

In BEAS-2B cells (Supplemental Table 4), the extracellular concentration of $\mathrm{B}$ [a]P-7,8-diol showed significant correlations with CYP1A1 mRNA expression ( $\mathrm{r}=0.750$, $\mathrm{p}<0.01), C Y P 1 B 1$ mRNA expression ( $\mathrm{r}=0.800, \mathrm{p}<0.01)$, EROD activity $(\mathrm{r}=0.733, \mathrm{p}<0.05)$ and $\mathrm{B}[\mathrm{a}] \mathrm{P}$-induced DNA adduct level $(\mathrm{r}=0.717, \mathrm{p}<0.05)$. Similar to A549 cells, none of variables gave significant correlations with DNA incision activity and only B[a]P-7,8-diol displayed a significant correlation with DNA adduct level.

\section{Discussion}

A low extracellular $\mathrm{pH}$ can occur for instance in tumors [36], but also at sites of inflammation [2] and an acidic micro-environment may drive the initiation and progression phase of the carcinogenic process.. We found in the present study that a change in extracellular $\mathrm{pH}\left(\mathrm{pH}_{\mathrm{e}}\right)$ leads to a corresponding change in intracellular $\mathrm{pH}$ $\left(\mathrm{pH}_{\mathrm{i}}\right)$, which affect xenobiotic activation and deactivation processes. Cells try to restore the normal situation by increasing the $\mathrm{pH}$ via H+ ATPases and H+-pumps [37] and indeed we found that 48 hours after starting acidic in vitro incubations, most of the samples' $\mathrm{pH}\left(\mathrm{pH}_{\mathrm{e}}\right.$ as well as $\left.\mathrm{pH}_{\mathrm{i}}\right)$ were back at normal levels ( $\mathrm{pH}$ 7.8). Interestingly, we noticed that $\mathrm{pH}_{\mathrm{i}}$ was always slightly higher than $\mathrm{pH}_{\mathrm{e}}$ and this phenomenon was also observed by McBrian et al. [25] and Justus et al. [38]. For samples that were exposed to relatively low $\mathrm{pH}$ ( $\mathrm{pH} 6$ and $\mathrm{pH} 5.5$ ), the $\mathrm{pH}_{\mathrm{e}}$ and $\mathrm{pH}_{\mathrm{i}}$ did not fully recover and maximally reached to $\mathrm{pH} 7.2$ and $\mathrm{pH} 6.5$ after 48 hours incubation, respectively.

It has been reported that acidic $\mathrm{pH}$ reduces cell density and cell viability, which may be cell type dependent. For example, incubation of neurons and glial cells under pH 5.0 for $1 \mathrm{~h}$ decreased the number of viable cells to <50\% [39], and mouse epithelial cells demonstrated a significantly decreased cell viability in an acidic dose-dependent manner after $1 \mathrm{~h}$ incubation [40] and also Chinese hamster ovary (CHO) cells exposed to low $\mathrm{pH}$ showed cytotoxicity in a time- and $\mathrm{pH}$-dependent manner [41]. In our study, an acidic $\mathrm{pH}$ of $<6.5$ similarly led to decreased viability in human bronchial epithelial cells (BEAS-2B) (Table 1). However, most tumor cell types seem to be able to resist acidic environments quite well. In a previous study, we showed that a human liver hepatocellular carcinoma cell line (HepG2) could survive more than 48 hours at pH 5.5 [18]. Moreover, there was no noticeable drop in cell viability by low pH in cancer type cells as LlA2 ascites cells (at pH 6.4-7.2) or MCF-7 cells [42]. In the our study, we additionally cultured A549 cells (human lung carcinoma cell) under various $\mathrm{pH}$ 's and the cell viability was always above $80 \%$ even after 48 hours incubation at $\mathrm{pH} 5.5$, indicating a relative resistance to acidic conditions. BEAS-2B cell were more sensitive for acidic conditions and pH's above 6.5 had to be used for culturing BEAS-2B cells to avoid cytotoxicity. We initially used the MTT test to check for cell viability, which actually measures the activity of mitochondrial succinate dehydrogenase, and the activity of that enzyme may be $\mathrm{pH}$ dependent [20]. Thus, trypan blue exclusion was used as an alternative method and the results showed that $>90 \%$ of A549 cells were viable after incubation at various pH for up to 48 hours. In 
addition, an acidic microenvironment is associated with promotion of cell growth [1]. In our study, we indeed observed a growth promoting effect on A549 cells of low pH (i.e. $\mathrm{pH} 6$ and $\mathrm{pH} 5.5$ ) but the difference in the number of cells at the end of the incubation was not statistically significant.

Pulmonary inflammation is often induced by inhalation of particles, from smoking or other environmental sources and can locally reduce the $\mathrm{pH}$ in inflamed tissue. Vice versa, lowering extracellular $\mathrm{pH}$ can increase the inflammatory response and can induce hypoxia, which results in the formation of reactive oxygen species (ROS) and subsequent DNA damage $[41,43]$. However, inflammation induced by exposures is often in combination with ubiquitous environmental contaminants such as polycyclic aromatic hydrocarbons (PAH). We previously showed that the presence of inflammation may change the way in which cells metabolize the model PAH, benzo[a]pyrene (B[a]P)[31, 44]. Therefore, we investigated whether a low $\mathrm{pH}$ affected $\mathrm{B}[\mathrm{a}] \mathrm{P}$ metabolism, DNA adduct formation and removal, and DNA damage. We investigated the expression and activity of $C Y P 1 A 1$ and $C Y P 1 B 1$, which is important for $\mathrm{B}[\mathrm{a}] \mathrm{P}$ metabolism. We found a lower initial expression of both CYP1A1 and CYP1B1 and EROD activity at acidic pH conditions ( $\mathrm{pH}$ 5.5-6), than at normal $\mathrm{pH}$ ( $\mathrm{pH}$ 6.5-7.8). However, while the $\mathrm{pH}$ restored, both CYP1 expression and its activity significantly increased for up to 48 hours at conditions of lowered $\mathrm{pH}$. On the other hand, at neutral $\mathrm{pH}$ both expression and EROD activity of CYP decreased. As a result, the metabolism of $\mathrm{B}[\mathrm{a}] \mathrm{P}$ was initially high at neutral $\mathrm{pH}$ and was inhibited at low $\mathrm{pH}$. Inhibition of $\mathrm{B}[\mathrm{a}] \mathrm{P}$ metabolism resulted in accumulation of unmetabolized $\mathrm{B}[\mathrm{a}] \mathrm{P}$ which keeps triggering the aryl hydrocarbon receptor $(\mathrm{AhR})$ that upregulates various $\mathrm{B}[\mathrm{a}] \mathrm{P}$ metabolizing enzymes [23], which all have their own optimal $\mathrm{pH}$ range. For example, the phase I enzyme cytochrome $\mathrm{P} 450$ works at pH 5.9-8.5 and its optimal pH is between 7.4 and 7.8 [45, 46]. Moreover, also UDP-glucuronosyltransferase (UGTs) isozymes, which are important phase II enzymes for detoxification of $\mathrm{B}[\mathrm{a}] \mathrm{P}$ metabolites, exhibit a broad $\mathrm{pH}$ range from 5.5 to 8.5 in which they can function [47]. The UGTs superfamily is large, and therefore, UGT's are active over a very wide $\mathrm{pH}$ range and each UGT has its own optimal $\mathrm{pH}$ [48]. Since $\mathrm{B}[\mathrm{a}] \mathrm{P}$ metabolizing enzymes have different relative activities at different $\mathrm{pH}$, it can be expected that $\mathrm{B}[\mathrm{a}] \mathrm{P}$ metabolism is significantly affected by $\mathrm{pH}$. Indeed, at $\mathrm{t}=48 \mathrm{~h}, \mathrm{~B}[\mathrm{a}] \mathrm{P}$ and its metabolites were close to non-detectable in samples that were incubated at a neutral $\mathrm{pH}$ range (pH 6.5-7.8) in A549 cells and at $\mathrm{pH} 7.8$ in BEAS-2B cells, whereas, B[a]P and its metabolites remained high in low $\mathrm{pH}$ samples with a notable increase of $\mathrm{B}[\mathrm{a}] \mathrm{P}-7,8-\mathrm{diol}$, which is the precursor of the pro-mutagenic BPDE. Therefore, it seems that low $\mathrm{pH}$ results in delayed $\mathrm{B}[\mathrm{a}] \mathrm{P}$ metabolism which we previously observed under hypoxic conditions [31] and in the presence of beta-glucuronidase [18].

Most of the DNA damage and BPDE-DNA adducts will be removed by neucleotide excision repair (NER) in which DNA incision is a rate limiting step [49]. Therefore, in the present study we also investigated whether acidic $\mathrm{pH}$ inhibits DNA incision activity. After incubation of A549 and BEAS-2B cells at acidic $\mathrm{pH}$, the DNA incision activity was inhibited by approximately $70 \%-90 \%$, but repair activity recovered when pH restored to close to neutral levels. We previously reported that hypochlorous acid ( $\mathrm{HOCl}$ ) dose dependently inhibited DNA incision activity $[11,21]$. We attributed this decrease in DNA incision activity to the release of inflammation related MPO (myeloperoxidase), because the in vitro inhibition of MPO restored DNA incision activity. In later in vivo experiments, the effect appeared not to be MPO dependent, because inhibition of MPO release or knock out of MPO could not restore DNA incision activity during inflammation in vivo 
[50]. Therefore, we now suggest that the effect on DNA incision activity was not specifically related to $\mathrm{HOCl}$, but can better be explained by an acidic $\mathrm{pH}$.

The altered metabolism of $\mathrm{B}[\mathrm{a}] \mathrm{P}$ ultimately resulted in higher levels of DNA damage under conditions of low $\mathrm{pH}$ for both cell lines. DNA damage is a continuous process/combinational effect of accumulation of damage (activation) and elimination by DNA repair (detoxification) [51]. At $\mathrm{t}=6$, the $\mathrm{B}$ [a] $\mathrm{P}$ induced DNA damage is significantly lower at low $\mathrm{pH}$ when compared to neutral $\mathrm{pH}(\mathrm{pH} 7.8)$. This is due to reduced metabolism of $\mathrm{B}[\mathrm{a}] \mathrm{P}$ under acidic condition leads to lower amount of $\mathrm{B}[\mathrm{a}] \mathrm{P}-7,8-d i o l$ formation and subsequently low BPDE lesions were observed at low $\mathrm{pH}$ samples at $6 \mathrm{~h}$. Although the DNA repair was significantly inhibited by acidic $\mathrm{pH}$ at $6 \mathrm{~h}$, the effect of DNA repair in DNA adduct removal is less strong at low $\mathrm{pH}$ samples than at $\mathrm{pH}$ 7.8. After 24 hours incubation, the DNA adducts were increased for all samples since the intracellular $\mathrm{pH}$ and metabolism were restored. However, the metabolism in the lowest $\mathrm{pH}$ samples (e.g. pH 5.5 for A549 cells and pH 6.5 for BEAS-2B cells) stayed low. Meanwhile, the DNA incision activity also remained low for low $\mathrm{pH}$ samples. Therefore, the highest DNA adduct level was reached by the sample which is not under extreme acidic conditions (e.g. $\mathrm{pH} 6$ for A549 cells and $\mathrm{pH} 7$ for BEAS-2B cells). At $\mathrm{t}=48 \mathrm{~h}$, the intracellular $\mathrm{pH}$ completely restored for all samples as well as the metabolism and DNA repair. Hence, we observed a decrease in BPDE related lesions for all samples at 48h (except for pH 5.5 for A549 cells and $\mathrm{pH} 6.5$ for BEAS-2B cells).

Correlation analysis confirmed the interrelationship between the various metabolic parameters. For examples, CYP1B1 was reported to be involved in the metabolic activation of $\mathrm{B}[\mathrm{a}] \mathrm{P}[52,53]$. Therefore, we observed that the extracellular $\mathrm{B}[\mathrm{a}] \mathrm{P}-7,8-$ diol concentration showed a good correlation with CYP1B1 mRNA gene expression. Furthermore, CYP1A1 mRNA gene expression gave a better correlation with EROD activity than CYP1B1 for both cell line [54]. Moreover, we also observed that only the $\mathrm{B}[\mathrm{a}] \mathrm{P}-7,8-$ diol concentrations demonstrated a good correlation with DNA adducts level in both cell line. This is due to the fact that DNA adducts measured in the current study were most probably related to BPDE and B[a]P-7,8-diol is the precursor to the BPDE [55, 56].

Because of this interrelation of many of the parameters that we assessed, investigating the role of acidic $\mathrm{pH}$ in $\mathrm{B}[\mathrm{a}] \mathrm{P}$ metabolism is not straightforward and therefore our study has some limitations. Firstly, lowering extracellular $\mathrm{pH}$ will affect not only the intra- and extracellular pH balance, but also all kind of cellular enzyme activities and downstream pathways. For instance, acidic $\mathrm{pH}$ can activate inflammation related pathway, including activator protein 1 (AP-1), MAPK and nuclear factor kappa-light-chain-enhancer of activated $B$ cells (NF- $\kappa B$ ) pathways which result in an induction of a series of genes, such as tumor necrosis factor $\alpha$ (TNF- $\alpha$ ), extracellular signal-regulated kinases (ERK1/2), isoform of nitric oxide synthase (iNOS), and p38 [1, 43, 57]. In addition, the induction of TNF- $\alpha$ further increases genotoxic effect of $\mathrm{B}[\mathrm{a}] \mathrm{P}$ via for instance upregulation of $\mathrm{p} 38$ and CYP1B1 [58, 59]. Besides these, acidic pH also cause hypoxia like reactions, oxidative stress and ROS formation which makes the results of current study more complicated to explain from a mechanistic point of view $[1,43,60,61]$. For example, we observed a pH-dependent DNA incision activity in the present study, however, it might be the combined result of ROS inhibiting DNA repair via targeting at the thiol-groups of DNA repair enzymes [62, 63], or because of changes in GSH levels [64] or even a direct effect of $\mathrm{pH}$ on DNA damage incision activity. Therefore, the conclusions drawn in this study need further mechanistic investigations. Secondly, some studies pointed out that the metabolic pathways may differ between normal cells and cancerous cells $[65,66]$. 
Under certain conditions of stress (including hypoxia or low $\mathrm{pH}$ ), tumors may change their gene expression and adapt, whereas most normal cells may undergo apoptosis [67-69]. Therefore, in the current study, we included both a normal cell line (BEAS-2B cells) and a carcinoma cell line (A549) and similar effects of low pH combined with $\mathrm{B}[\mathrm{a}] \mathrm{P}$ exposure on CYP1A1 mRNA expression, EROD activity and B[a]P metabolism were observed, although at a different $\mathrm{pH}$. BEAS-2B had a delay in their $\mathrm{B}[\mathrm{a}] \mathrm{P}$ metabolism already at $\mathrm{pH}$ 7.0, whereas the same effect was only observed in A549 cells at it's most extreme $\mathrm{pH}$ condition ( $\mathrm{pH} 5.5$ ) after 48 hours of incubation. Therefore, the delay in $\mathrm{B}[\mathrm{a}] \mathrm{P}$ metabolism by low pH seems stronger in normal cells than in cancer cells.

Our present results indicated that exposure of A549 and BEAS-2B cells to B[a]P at acidic pH results in lower CYP1A1/CYP1B1 expression, EROD activity and DNA repair. This leads to inefficient $\mathrm{B}[\mathrm{a}] \mathrm{P}$ metabolism and subsequent accumulation of active $\mathrm{B}[\mathrm{a}] \mathrm{P}$ metabolites, $\mathrm{B}[\mathrm{a}] \mathrm{P}$ related DNA adducts and overall DNA damage as assessed by $\mathrm{B}[\mathrm{a}] \mathrm{P}$ related DNA adducts and $\gamma \mathrm{H} 2 \mathrm{AX}$. At later time points, the $\mathrm{pH}_{\mathrm{i}}$ and $\mathrm{pH}_{\mathrm{e}}$ gradually restored towards pH 7.8, which increased enzyme activities and the cells started to metabolize $\mathrm{B}[\mathrm{a}] \mathrm{P}$. Meanwhile, the unmetabolized $\mathrm{B}[\mathrm{a}] \mathrm{P}$ continuously triggers CYP1A1 expression/activity possibly via an interaction with AhR. Moreover, DNA incision activity was not completely recovered in acidic samples after 24 hours. In conclusion, our data demonstrate that acidic $\mathrm{pH}$ delayed metabolism of $\mathrm{B}[\mathrm{a}] \mathrm{P}$ and DNA repair activity. Consequently, higher DNA damage and DNA adduct formation was observed. Although we did not include all the enzymes which are involved in the metabolism of $\mathrm{B}[\mathrm{a}] \mathrm{P}$, we showed a general molecular mechanism of how acidic $\mathrm{pH}$ influences the cellular response to the carcinogen $\mathrm{B}[\mathrm{a}] \mathrm{P}$. 


\section{References}

[1] Y. Kato, S. Ozawa, C. Miyamoto, Y. Maehata, A. Suzuki, T. Maeda, Y. Baba, Acidic extracellular microenvironment and cancer, Cancer Cell Int, 13 (2013) 89.

[2] A. Lardner, The effects of extracellular pH on immune function, J Leukoc Biol, 69 (2001) 522-530.

[3] B. Mollon, V. da Silva, J.W. Busse, T.A. Einhorn, M. Bhandari, Electrical stimulation for long-bone fracture-healing: a meta-analysis of randomized controlled trials, The Journal of bone and joint surgery. American volume, 90 (2008) 2322-2330.

[4] W.F. Ganong, Review of Medical Physiology, Lange Medical Publications, Los Altos, CA, 1985.

[5] A.I. Papaioannou, S. Loukides, M. Minas, K. Kontogianni, P. Bakakos, K.I. Gourgoulianis, M. Alchanatis, S. Papiris, K. Kostikas, Exhaled breath condensate pH as a biomarker of COPD severity in ex-smokers, Respir Res, 12 (2011) 67.

[6] S. Bozinovski, R. Vlahos, D. Anthony, J. McQualter, G. Anderson, L. Irving, D. Steinfort, COPD and squamous cell lung cancer: aberrant inflammation and immunity is the common link, Br J Pharmacol, (2015).

[7] A.M. Knaapen, N. Gungor, R.P. Schins, P.J. Borm, F.J. Van Schooten, Neutrophils and respiratory tract DNA damage and mutagenesis: a review, Mutagenesis, 21 (2006) 225-236

[8] D. Hanahan, Robert A. Weinberg, Hallmarks of Cancer: The Next Generation, Cell, 144 (2011) 646-674.

[9] J. Adams, P. Heintz, N. Gross, P. Andersen, E. Everts, M. Wax, J. Cohen, Acid/pepsin promotion of carcinogenesis in the hamster cheek pouch, Archives of otolaryngology--head \& neck surgery, 126 (2000) 405-409.

[10] J. Yuan, L. Narayanan, S. Rockwell, P.M. Glazer, Diminished DNA repair and elevated mutagenesis in mammalian cells exposed to hypoxia and low pH, Cancer Res, 60 (2000) 4372-4376.

[11] N. Gungor, R.W. Godschalk, D.M. Pachen, F.J. Van Schooten, A.M. Knaapen, Activated neutrophils inhibit nucleotide excision repair in human pulmonary epithelial cells: role of myeloperoxidase, FASEB journal : official publication of the Federation of American Societies for Experimental Biology, 21 (2007) 2359-2367.

[12] N. Kazerouni, R. Sinha, C.-H. Hsu, A. Greenberg, N. Rothman, Analysis of 200 food items for benzo[a]pyrene and estimation of its intake in an epidemiologic study, Food and Chemical Toxicology, 39 (2001) 423-436.

[13] P.J. Tancell, M.M. Rhead, C.J. Trier, M.A. Bell, D.E. Fussey, The sources of benzo[a]pyrene in diesel exhaust emissions, Science of The Total Environment, 162 (1995) 179-186.

[14] R. Godschalk, J. Nair, F.J. van Schooten, A. Risch, P. Drings, K. Kayser, H. Dienemann, H. Bartsch, Comparison of multiple DNA adduct types in tumor adjacent human lung tissue: effect of cigarette smoking, Carcinogenesis, 23 (2002) 2081-2086.

[15] D.C. Spink, B.H. Katz, M.M. Hussain, B.C. Spink, S.J. Wu, N. Liu, R. Pause, L.S. Kaminsky, Induction of CYP1A1 and CYP1B1 in T-47D human breast cancer cells by benzo[a]pyrene is diminished by arsenite, Drug metabolism and disposition: the biological fate of chemicals, 30 (2002) 262-269.

[16] W.M. Baird, L.A. Hooven, B. Mahadevan, Carcinogenic polycyclic aromatic hydrocarbon-DNA adducts and mechanism of action, Environmental and molecular mutagenesis, 45 (2005) 106-114.

[17] H.V. Gelboin, Benzo[alpha]pyrene metabolism, activation and carcinogenesis: role and regulation of mixed-function oxidases and related enzymes, 1980.

[18] Q. Shi, G.R. Haenen, L. Maas, V.M. Arlt, D. Spina, Y.R. Vasquez, E. Moonen, C. Veith, F.J. Van Schooten, R.W. Godschalk, Inflammation-associated extracellular beta-glucuronidase alters cellular responses to the chemical carcinogen benzo[a]pyrene, Arch Toxicol, (2015).

[19] T. Mosmann, Rapid colorimetric assay for cellular growth and survival: application to proliferation and cytotoxicity assays, J Immunol Methods, 65 (1983) 55-63.

[20] J.A. Plumb, R. Milroy, S.B. Kaye, Effects of the pH dependence of 3-(4,5-dimethylthiazol-2-yl)-2,5-diphenyl-tetrazolium bromide-formazan absorption on chemosensitivity determined by a novel tetrazolium-based assay, Cancer Res, 49 (1989) 4435-4440.

[21] M. Whiteman, D.C. Hooper, G.S. Scott, H. Koprowski, B. Halliwell, Inhibition of hypochlorous acid-induced cellular toxicity by nitrite, Proc Natl Acad Sci U S A, 99 (2002) 12061-12066.

[22] C. Lo, J. Ferrier, H.C. Tenenbaum, C.A. McCulloch, Regulation of cell volume and intracellular pH in hyposmotically swollen rat osteosarcoma cells, Biochemistry and cell biology = Biochimie et biologie cellulaire, 73 (1995) 535-544.

[23] M.A. Schults, Y. Oligschlaeger, R.W. Godschalk, F.J. Van Schooten, R.K. Chiu, Loss of VHL in RCC Reduces Repair and Alters Cellular Response to Benzo[a]pyrene, Frontiers in oncology, 3 (2013) 270.

[24] M.A. Schults, L. Timmermans, R.W. Godschalk, J. Theys, B.G. Wouters, F.J. van Schooten, R.K. Chiu, Diminished carcinogen detoxification is a novel mechanism for hypoxia-inducible factor 1-mediated genetic instability, J Biol Chem, 285 (2010) 14558-14564.

[25] M.A. McBrian, I.S. Behbahan, R. Ferrari, T. Su, T.W. Huang, K. Li, C.S. Hong, H.R. Christofk, M. Vogelauer, D.B. Seligson, S.K. Kurdistani, Histone acetylation regulates intracellular pH, Molecular cell, 49 (2013) 310-321.

[26] M.D. Burke, R.T. Mayer, Ethoxyresorufin: direct fluorimetric assay of a microsomal O-dealkylation which is preferentially inducible by 3-methylcholanthrene, Drug Metab Dispos, 2 (1974) 583-588.

[27] S.A. Langie, A.M. Knaapen, K.J. Brauers, D. van Berlo, F.J. van Schooten, R.W. Godschalk, Development and validation of a modified comet assay to phenotypically assess nucleotide excision repair, Mutagenesis, 21 (2006) 153-158.

[28] A. Azqueta, J. Slyskova, S.A.S. Langie, I. O’Neill Gaivão, A. Collins, Comet assay to measure DNA repair: approach and applications, Frontiers in Genetics, 5 (2014) 288.

[29] A. Azqueta, A.R. Collins, The essential comet assay: a comprehensive guide to measuring DNA damage and repair, Arch Toxicol, 87 (2013) 949-968. 
[30] A.R. Collins, The comet assay for DNA damage and repair: principles, applications, and limitations, Mol Biotechnol, 26 (2004) 249-261.

[31] M.A. Schults, K. Sanen, R.W. Godschalk, J. Theys, F.J. van Schooten, R.K. Chiu, Hypoxia diminishes the detoxification of the environmental mutagen benzo[a]pyrene, Mutagenesis, 29 (2014) 481-487.

[32] M.V. Reddy, K. Randerath, 32P-postlabeling assay for carcinogen-DNA adducts: nuclease P1-mediated enhancement of its sensitivity and applications, Environ Health Perspect, 76 (1987) 41-47.

[33] R.W. Godschalk, L.M. Maas, N. Van Zandwijk, L.J. van 't Veer, A. Breedijk, P.J. Borm, J. Verhaert, J.C. Kleinjans, F.J. van Schooten, Differences in aromatic-DNA adduct levels between alveolar macrophages and subpopulations of white blood cells from smokers, Carcinogenesis, 19 (1998) 819-825.

[34] A. Muslimovic, I.H. Ismail, Y. Gao, O. Hammarsten, An optimized method for measurement of gamma-H2AX in blood mononuclear and cultured cells, Nat. Protocols, 3 (2008) 1187-1193.

[35] L.G. Mariotti, G. Pirovano, K.I. Savage, M. Ghita, A. Ottolenghi, K.M. Prise, G. Schettino, Use of the gamma-H2AX assay to investigate DNA repair dynamics following multiple radiation exposures, PLoS One, 8 (2013) e79541.

[36] P. Vaupel, F. Kallinowski, P. Okunieff, Blood flow, oxygen and nutrient supply, and metabolic microenvironment of human tumors: a review, Cancer Res, 49 (1989) 6449-6465.

[37] J. van Adelsberg, Q. Al-Awqati, Regulation of cell pH by Ca+2-mediated exocytotic insertion of H+-ATPases, The Journal of cell biology, 102 (1986) 1638-1645.

[38] C.R. Justus, L. Dong, L.V. Yang, Acidic tumor microenvironment and pH-sensing G protein-coupled receptors, Frontiers in physiology, 4 (2013) 354.

[39] M. Nedergaard, S.A. Goldman, S. Desai, W.A. Pulsinelli, Acid-induced death in neurons and glia, J Neurosci, 11 (1991) 2489-2497.

[40] B.B. Block, E. Kuo, H.G. Zalzal, H. Escobar, M. Rose, D. Preciado, In vitro effects of acid and pepsin on mouse middle ear epithelial cell viability and MUC5B gene expression, Archives of otolaryngology--head \& neck surgery, 136 (2010) 37-42.

[41] D. Rotin, B. Robinson, I.F. Tannock, Influence of hypoxia and an acidic environment on the metabolism and viability of cultured cells: potential implications for cell death in tumors, Cancer Res, 46 (1986) 2821-2826.

[42] E.S. Lee, K. Na, Y.H. Bae, Polymeric micelle for tumor pH and folate-mediated targeting, Journal of Controlled Release, 91 (2003) 103-113.

[43] A. Riemann, B. Schneider, A. Ihling, M. Nowak, C. Sauvant, O. Thews, M. Gekle, Acidic Environment Leads to ROS-Induced MAPK Signaling in Cancer Cells, PLoS One, 6 (2011) e22445.

[44] P.J. Borm, A.M. Knaapen, R.P. Schins, R.W. Godschalk, F.J. Schooten, Neutrophils amplify the formation of DNA adducts by benzo[a]pyrene in lung target cells, Environ Health Perspect, 105 Suppl 5 (1997) 1089-1093.

[45] A. Sen, E. Arinc, Purification and characterization of cytochrome P450 reductase from liver microsomes of feral leaping mullet (Liza saliens), Journal of biochemical and molecular toxicology, 12 (1998) 103-113.

[46] I. Axarli, A. Prigipaki, N.E. Labrou, Cytochrome P450 102A2 catalyzes efficient oxidation of sodium dodecyl sulphate: A molecular tool for remediation, Enzyme research, 2010 (2010).

[47] N.K. Basu, M. Ciotti, M.S. Hwang, L. Kole, P.S. Mitra, J.W. Cho, I.S. Owens, Differential and special properties of the major human UGT1-encoded gastrointestinal UDP-glucuronosyltransferases enhance potential to control chemical uptake, J Biol Chem, 279 (2004) 1429-1441.

[48] T. Luque, K. Okano, D.R. O'Reilly, Characterization of a novel silkworm (Bombyx mori) phenol UDP-glucosyltransferase, Eur J Biochem, 269 (2002) 819-825.

[49] T. Lindahl, R.D. Wood, Quality control by DNA repair, Science, 286 (1999) 1897-1905.

[50] N. Gungor, A. Haegens, A.M. Knaapen, R.W. Godschalk, R.K. Chiu, E.F. Wouters, F.J. van Schooten, Lung inflammation is associated with reduced pulmonary nucleotide excision repair in vivo, Mutagenesis, 25 (2010) 77-82.

[51] I. Manière, T. Godard, D.R. Doerge, M.I. Churchwell, M. Guffroy, M. Laurentie, J.-M. Poul, DNA damage and DNA adduct formation in rat tissues following oral administration of acrylamide, Mutation Research/Genetic Toxicology and Environmental Mutagenesis, 580 (2005) 119-129.

[52] L. Smerdova, J. Neca, J. Svobodova, J. Topinka, J. Schmuczerova, A. Kozubik, M. Machala, J. Vondracek, Inflammatory mediators accelerate metabolism of benzo[a]pyrene in rat alveolar type II cells: the role of enhanced cytochrome P450 1B1 expression, Toxicology, 314 (2013) 30-38.

[53] M.A. Schults, R.K. Chiu, P.W. Nagle, L.C. Wilms, J.C. Kleinjans, F.J. van Schooten, R.W. Godschalk, Genetic polymorphisms in catalase and CYP1B1 determine DNA adduct formation by benzo(a)pyrene ex vivo, Mutagenesis, 28 (2013) 181-185.

[54] M.B. van Duursen, J.T. Sanderson, M. van den Berg, Cytochrome P450 1A1 and 1B1 in human blood lymphocytes are not suitable as biomarkers of exposure to dioxin-like compounds: polymorphisms and interindividual variation in expression and inducibility, Toxicol Sci, 85 (2005) 703-712.

[55] J.L. Fang, F.A. Beland, D.R. Doerge, D. Wiener, C. Guillemette, M.M. Marques, P. Lazarus, Characterization of benzo(a)pyrene-trans-7,8-dihydrodiol glucuronidation by human tissue microsomes and overexpressed UDP-glucuronosyltransferase enzymes, Cancer Res, 62 (2002) 1978-1986.

[56] M. Moserová, V. Kotrbová, D. Aimová, M. Šulc, E. Frei, M. Stiborová, Analysis of benzo[a]pyrene metabolites formed by rat hepatic microsomes using high pressure liquid chromatography: optimization of the method, Interdisciplinary Toxicology, 2 (2009) 239-244.

[57] A. Bellocq, S. Suberville, C. Philippe, F. Bertrand, J. Perez, B. Fouqueray, G. Cherqui, L. Baud, Low environmental pH is responsible for the induction of nitric-oxide synthase in macrophages. Evidence for involvement of nuclear factor-kappaB activation, J Biol Chem, 273 (1998) 5086-5092. 


\section{Chapter 3}

[58] L. Umannova, M. Machala, J. Topinka, J. Schmuczerova, P. Krcmar, J. Neca, K. Sujanova, A. Kozubik, J. Vondracek, Benzo[a]pyrene and tumor necrosis factor-alpha coordinately increase genotoxic damage and the production of proinflammatory mediators in alveolar epithelial type II cells, Toxicol Lett, 206 (2011) 121-129.

[59] L. Umannova, M. Machala, J. Topinka, Z. Novakova, A. Milcova, A. Kozubik, J. Vondracek, Tumor necrosis factor-alpha potentiates genotoxic effects of benzo[a]pyrene in rat liver epithelial cells through upregulation of cytochrome P450 1B1 expression, Mutat Res, 640 (2008) 162-169.

[60] J. Chiche, M.C. Brahimi-Horn, J. Pouyssegur, Tumour hypoxia induces a metabolic shift causing acidosis: a common feature in cancer, J Cell Mol Med, 14 (2010) 771-794.

[61] L.M. Maurer, E. Yohannes, S.S. Bondurant, M. Radmacher, J.L. Slonczewski, pH regulates genes for flagellar motility, catabolism, and oxidative stress in Escherichia coli K-12, J Bacteriol, 187 (2005) 304-319.

[62] G. Bertin, D. Averbeck, Cadmium: cellular effects, modifications of biomolecules, modulation of DNA repair and genotoxic consequences (a review), Biochimie, 88 (2006) 1549-1559.

[63] J.E. Klaunig, L.M. Kamendulis, B.A. Hocevar, Oxidative stress and oxidative damage in carcinogenesis, Toxicol Pathol, 38 (2010) 96-109.

[64] S.A. Langie, A.M. Knaapen, J.M. Houben, F.C. van Kempen, J.P. de Hoon, R.W. Gottschalk, R.W. Godschalk, F.J. van Schooten, The role of glutathione in the regulation of nucleotide excision repair during oxidative stress, Toxicol Lett, 168 (2007) 302-309.

[65] D. Hockenbery, M. Tom, C. Abikoff, D. Margineantu, The Warburg Effect and Beyond: Metabolic Dependencies for Cancer Cells, in: D.E. Johnson (Ed.) Cell Death Signaling in Cancer Biology and Treatment, Springer New York2013, pp. 35-51.

[66] N.D. Amoedo, J.P. Valencia, M.F. Rodrigues, A. Galina, F.D. Rumjanek, How does the metabolism of tumour cells differ from that of normal cells, Biosci Rep, 33 (2013).

[67] R.P. Hill, K. De Jaeger, A. Jang, R. Cairns, pH, hypoxia and metastasis, Novartis Found Symp, 240 (2001) 154-165; discussion 165-158.

[68] C. Brooks, P. Ketsawatsomkron, Y. Sui, J. Wang, C.Y. Wang, F.S. Yu, Z. Dong, Acidic pH inhibits ATP depletion-induced tubular cell apoptosis by blocking caspase- 9 activation in apoptosome, Am J Physiol Renal Physiol, 289 (2005) F410-419.

[69] H.J. Park, J.C. Lyons, T. Ohtsubo, C.W. Song, Acidic environment causes apoptosis by increasing caspase activity, Br J Cancer, 80 (1999) 1892-1897. 
Supplemental Table 1: Concentration (nM) of B[a]P-9,10-diol, B[a]P-7,8-diol, B[a]P-3-0H and B[a]P at 6, 24 and 48 hours. Statistical comparison was performed between each $\mathrm{pH}$ condition (pH 7, 6.5, 6 and 5.5) with pH 7.8 at each time point.

\begin{tabular}{|c|c|c|c|c|c|c|c|}
\hline $\begin{array}{l}\text { Cell } \\
\text { type }\end{array}$ & $\begin{array}{l}\text { Metabolites or } \\
\text { unmetabolised } \\
\mathrm{B}[\mathrm{a}] \mathrm{P}\end{array}$ & $\begin{array}{l}\text { Time } \\
\text { (h) }\end{array}$ & pH 7.8 & $\mathrm{pH} 7$ & pH 6.5 & pH 6 & pH 5.5 \\
\hline \multirow[t]{12}{*}{ A549 } & \multirow[t]{3}{*}{$\mathrm{B}[\mathrm{a}] \mathrm{P}-9,10$-diol } & 6 & $155 \pm 4.3$ & $87 \pm 12^{* * *}$ & $96 \pm 3.9^{* * *}$ & $26 \pm 0.7^{* * *}$ & $2.6 \pm 1.3^{* * *}$ \\
\hline & & 24 & $1.3 \pm 0.6$ & $3.9 \pm 1.5$ & $5.2 \pm 0.2$ & $77 \pm 6.8^{* * *}$ & $332 \pm 25.3^{* * *}$ \\
\hline & & 48 & $0.8 \pm 0.1$ & $0.6 \pm 0.2$ & $2.9 \pm 0.9$ & $2.8 \pm 0.4$ & $269 \pm 2.5^{* * *}$ \\
\hline & \multirow[t]{3}{*}{$\mathrm{B}[\mathrm{a}] \mathrm{P}-7,8$-diol } & 6 & $30 \pm 1.2$ & $19.7 \pm 2.0^{* * *}$ & $20.6 \pm 0.5^{* *}$ & $9.3 \pm 0.9^{* * *}$ & $0.8 \pm 0.4^{* * *}$ \\
\hline & & 24 & $0.3 \pm 0.1$ & $0.4 \pm 0.2$ & $1.5 \pm 0.02$ & $4.0 \pm 0.3$ & $86.6 \pm 6.2^{* * *}$ \\
\hline & & 48 & $0.1 \pm 0.01$ & $0.1 \pm 0.04$ & $0.6 \pm 0.2$ & $1.4 \pm 0.1$ & $101 \pm 8.3^{* * *}$ \\
\hline & \multirow[t]{3}{*}{$\mathrm{B}[\mathrm{a}] \mathrm{P}-3-\mathrm{OH}$} & 6 & $18.3 \pm 4.1$ & $19.3 \pm 3.3$ & $1.2 \pm 0.4^{* * *}$ & $0.9 \pm 0.2^{* * *}$ & $1.3 \pm 0.4^{* * *}$ \\
\hline & & 24 & $1.3 \pm 0.2$ & $0.8 \pm 0.2$ & $1.7 \pm 0.3$ & $4.5 \pm 0.9$ & $1.5 \pm 0.1$ \\
\hline & & 48 & $0.9 \pm 0.1$ & $0.6 \pm 0.03$ & $3.2 \pm 0.07$ & $2.5 \pm 0.02$ & $8.5 \pm 0.2^{* * *}$ \\
\hline & \multirow[t]{3}{*}{$\mathrm{B}[\mathrm{a}] \mathrm{P}$} & 6 & $787 \pm 47$ & $922 \pm 88$ & $688 \pm 31$ & $661 \pm 65$ & $905 \pm 141$ \\
\hline & & 24 & $10.2 \pm 4.6$ & $22 \pm 2.4$ & $57.6 \pm 13$ & $177 \pm 24^{* * *}$ & $509 \pm 20^{* * *}$ \\
\hline & & 48 & $5.2 \pm 0.1$ & $14.5 \pm 1.8$ & $37.7 \pm 7.1^{*}$ & $143 \pm 6.5^{* * *}$ & $383 \pm 14^{* * *}$ \\
\hline \multirow[t]{12}{*}{ BEAS-2B } & \multirow[t]{3}{*}{$\mathrm{B}[\mathrm{a}] \mathrm{P}-9,10$-diol } & 6 & $66.2 \pm 4.3$ & $52.5 \pm 2.7$ & $30.3 \pm 2.9^{* * *}$ & & \\
\hline & & 24 & $109 \pm 6$ & $142 \pm 12$ & $207 \pm 6^{* * *}$ & & \\
\hline & & 48 & $70 \pm 7$ & $131.7 \pm 15.3^{* *}$ & $220 \pm 4^{* * *}$ & & \\
\hline & \multirow[t]{3}{*}{$\mathrm{B}[\mathrm{a}] \mathrm{P}-7,8$-diol } & 6 & $45.5 \pm 2.7$ & $37.1 \pm 0.4^{*}$ & $27 \pm 1.7^{* * *}$ & & \\
\hline & & 24 & $13.3 \pm 0.4$ & $62.4 \pm 2^{* * *}$ & $76.4 \pm 4.2^{* * *}$ & & \\
\hline & & 48 & $2.3 \pm 0.2$ & $22.7 \pm 0.1^{* * *}$ & $111 \pm 1.7^{* * *}$ & & \\
\hline & \multirow[t]{3}{*}{$\mathrm{B}[\mathrm{a}] \mathrm{P}-3-\mathrm{OH}$} & 6 & $22.5 \pm 2.1$ & $32.4 \pm 1.7^{* *}$ & $7.8 \pm 0.8^{* * *}$ & & \\
\hline & & 24 & $19.3 \pm 0.9$ & $24.6 \pm 1.5^{*}$ & $28.2 \pm 1.2^{* *}$ & & \\
\hline & & 48 & $16.1 \pm 0.6$ & $17.9 \pm 2.6$ & $45.3 \pm 5.8^{* * *}$ & & \\
\hline & \multirow[t]{3}{*}{$\mathrm{B}[\mathrm{a}] \mathrm{P}$} & 6 & $500 \pm 22$ & $663 \pm 10^{* * *}$ & $823 \pm 18^{* * *}$ & & \\
\hline & & 24 & $33.2 \pm 0.5$ & $52.4 \pm 2$ & $458 \pm 19^{* * *}$ & & \\
\hline & & 48 & $7.8 \pm 0.5$ & $24 \pm 2.5$ & $209 \pm 12^{* * *}$ & & \\
\hline
\end{tabular}


Chapter 3

Supplemental Table 2: Raw data of DNA incision activity based on tail moment (TM) and tail intensity (TI) for both A549 and BEAS-2B cell lines. Median of the raw data were extracted and incision activity was calculated according to the formula in Langie et al. (2006). Data shown are the mean \pm SEM of 4 independent samples $(n=4)$.

\begin{tabular}{llllllll}
\hline Cell & TM or TI & $\begin{array}{l}\text { Time } \\
(\mathrm{h})\end{array}$ & 7.8 & 7.0 & 6.5 & 6.0 & 5.5 \\
\hline A549 & Tail & 6 & $2.06 \pm 0.2$ & $1.80 \pm 0.05$ & $0.47 \pm 0.37$ & $0.23 \pm 0.02$ & $0.39 \pm 0.25$ \\
& Moment & 24 & $3.39 \pm 0.93$ & $1.58 \pm 0.06$ & $1.74 \pm 0.19$ & $0.31 \pm 0.14$ & $1.01 \pm 0.49$ \\
& & 48 & $0.96 \pm 0.09$ & $1.18 \pm 0.22$ & $1.11 \pm 0.16$ & $1.30 \pm 0.10$ & $1.05 \pm 0.11$ \\
\cline { 2 - 7 } & Tail & 6 & $6.62 \pm 1.48$ & $5.37 \pm 1.32$ & $3.06 \pm 0.49$ & $3.17 \pm 2.30$ & $2.87 \pm 1.06$ \\
& Intensity & 24 & $9.36 \pm 0.25$ & $5.88 \pm 1.48$ & $5.59 \pm 1.78$ & $3.50 \pm 0.11$ & $4.19 \pm 0.18$ \\
& & 48 & $3.23 \pm 0.41$ & $4.56 \pm 0.20$ & $4.73 \pm 0.30$ & $5.90 \pm 0.29$ & $7.84 \pm 0.63$ \\
\hline BEAS-2B & Tail & 6 & $2.47 \pm 1.05$ & $1.34 \pm 0.25$ & $0.71 \pm 0.19$ & & \\
& Moment & 24 & $3.78 \pm 1.47$ & $1.95 \pm 0.24$ & $1.37 \pm 1.17$ & & \\
& & 48 & $1.88 \pm 0.24$ & $3.07 \pm 0.81$ & $5.22 \pm 1.44$ & & \\
& Tail & 6 & $15.39 \pm 6.52$ & $12.45 \pm 3.61$ & $5.84 \pm 3.23$ & & \\
& Intensity & 24 & $21.13 \pm 3.93$ & $15.45 \pm 1.50$ & $8.29 \pm 5.60$ & & \\
& & 48 & $10.79 \pm 1.68$ & $15.16 \pm 7.77$ & $23.10 \pm 3.43$ & & \\
& & & & & &
\end{tabular}


Supplemental Table 3: Nonparametric Spearmen's rho correlation analysis of different variables (B[a]P-7,8-diol, CYP1A1 mRNA expression, CYP1B1 mRNA expression, EROD activity, DNA incision activity and DNA adducts) derived from experiments with $\mathbf{A 5 4 9}$ cells.

\begin{tabular}{|c|c|c|c|c|c|c|c|c|}
\hline $\begin{array}{l}\text { Cell } \\
\text { type }\end{array}$ & & & $\mathrm{B}[\mathrm{a}] \mathrm{P}-7,8$-diol & $\begin{array}{l}\text { CYP1A1 } \\
\text { mRNA } \\
\text { expression }\end{array}$ & $\begin{array}{l}\text { CYP1B1 } \\
\text { mRNA } \\
\text { expression }\end{array}$ & $\begin{array}{l}\text { EROD } \\
\text { activity }\end{array}$ & $\begin{array}{l}\text { DNA } \\
\text { incision } \\
\text { activity }\end{array}$ & $\begin{array}{l}\text { DNA } \\
\text { adducts }\end{array}$ \\
\hline \multirow[t]{12}{*}{ A549 } & $\mathrm{B}[\mathrm{a}] \mathrm{P}-7,8-$ diol & $\begin{array}{l}\text { Correlation } \\
\text { Coefficient }\end{array}$ & & $.704^{* *}$ & $.914^{* * *}$ & $.607^{*}$ & -.121 & $.555^{*}$ \\
\hline & & $\begin{array}{l}\text { Sig. } \\
\text { (2-tailed) }\end{array}$ & & .003 & .0001 & .016 & .666 & .032 \\
\hline & $\begin{array}{l}\text { CYP1A1 mRNA } \\
\text { expression }\end{array}$ & $\begin{array}{l}\text { Correlation } \\
\text { Coefficient }\end{array}$ & $.704^{* *}$ & & $.807^{* * *}$ & $.679^{* *}$ & .0001 & -.400 \\
\hline & & $\begin{array}{l}\text { Sig. } \\
\text { (2-tailed) }\end{array}$ & .003 & & .0001 & .005 & 1.000 & .140 \\
\hline & $\begin{array}{l}\text { CYP1B1 mRNA } \\
\text { expression }\end{array}$ & $\begin{array}{l}\text { Correlation } \\
\text { Coefficient }\end{array}$ & $.914^{* * *}$ & $.807^{* * *}$ & & $.514^{*}$ & -.154 & -.239 \\
\hline & & $\begin{array}{l}\text { Sig. } \\
\text { (2-tailed) }\end{array}$ & .0001 & .0001 & & .050 & .585 & .390 \\
\hline & EROD activity & $\begin{array}{l}\text { Correlation } \\
\text { Coefficient }\end{array}$ & $.607^{*}$ & $.679^{* *}$ & $.514^{*}$ & & .371 & .289 \\
\hline & & $\begin{array}{l}\text { Sig. } \\
\text { (2-tailed) }\end{array}$ & .016 & .005 & .050 & & .173 & .296 \\
\hline & $\begin{array}{l}\text { DNA incision } \\
\text { activity }\end{array}$ & $\begin{array}{l}\text { Correlation } \\
\text { Coefficient }\end{array}$ & -.121 & .0001 & -.154 & .371 & & .164 \\
\hline & & $\begin{array}{l}\text { Sig. } \\
\text { (2-tailed) }\end{array}$ & .666 & 1.000 & .585 & .173 & & .558 \\
\hline & DNA adducts & $\begin{array}{l}\text { Correlation } \\
\text { Coefficient }\end{array}$ & $.555^{*}$ & -.400 & -.239 & .289 & .164 & \\
\hline & & $\begin{array}{l}\text { Sig. } \\
\text { (2-tailed) }\end{array}$ & .032 & .140 & .390 & .296 & .558 & \\
\hline
\end{tabular}

$* * *$. Correlation is significant at the 0.001 level (2-tailed).

**. Correlation is significant at the 0.01 level (2-tailed).

*. Correlation is significant at the 0.05 level (2-tailed). 


\section{Chapter 3}

Supplemental Table 4: Nonparametric Spearmen's rho correlation analysis of different variables (B[a]P-7,8-diol, CYP1A1 mRNA expression, CYP1B1 mRNA expression, EROD activity, DNA incision activity and DNA adducts) derived from experiments with BEAS-2B cells.

\begin{tabular}{|c|c|c|c|c|c|c|c|c|}
\hline $\begin{array}{l}\text { Cell } \\
\text { type }\end{array}$ & & & $\mathrm{B}[\mathrm{a}] \mathrm{P}-7,8$-diol & $\begin{array}{l}\text { CYP1A1 } \\
\text { mRNA } \\
\text { expression }\end{array}$ & $\begin{array}{l}\text { CYP1B1 } \\
\text { mRNA } \\
\text { expression }\end{array}$ & $\begin{array}{l}\text { EROD } \\
\text { activity }\end{array}$ & $\begin{array}{l}\text { DNA } \\
\text { incision } \\
\text { activity }\end{array}$ & $\begin{array}{l}\text { DNA } \\
\text { adducts }\end{array}$ \\
\hline \multirow[t]{12}{*}{$\begin{array}{l}\text { BEAS- } \\
2 \mathrm{~B}\end{array}$} & $\mathrm{~B}[\mathrm{a}] \mathrm{P}-7,8$-diol & $\begin{array}{l}\text { Correlation } \\
\text { Coefficient }\end{array}$ & & $.750^{*}$ & $.800^{* *}$ & $.733^{*}$ & .100 & $.717^{*}$ \\
\hline & & Sig. (2-tailed) & & .020 & .010 & .025 & .798 & .030 \\
\hline & $\begin{array}{l}\text { CYP1A1 mRNA } \\
\text { expression }\end{array}$ & $\begin{array}{l}\text { Correlation } \\
\text { Coefficient }\end{array}$ & $.750^{*}$ & & .517 & $.883^{* *}$ & -.067 & -.167 \\
\hline & & Sig. (2-tailed) & .020 & & .154 & .002 & .865 & .668 \\
\hline & $\begin{array}{l}\text { CYP1B1 mRNA } \\
\text { expression }\end{array}$ & $\begin{array}{l}\text { Correlation } \\
\text { Coefficient }\end{array}$ & $.800^{* *}$ & .517 & & .633 & -.167 & .067 \\
\hline & & Sig. (2-tailed) & .010 & .154 & & .067 & .688 & .865 \\
\hline & EROD activity & $\begin{array}{l}\text { Correlation } \\
\text { Coefficient }\end{array}$ & $.733^{*}$ & $.883^{* *}$ & $.633^{*}$ & & .033 & -.117 \\
\hline & & Sig. (2-tailed) & .025 & .002 & .067 & & .932 & .765 \\
\hline & $\begin{array}{l}\text { DNA incision } \\
\text { activity }\end{array}$ & $\begin{array}{l}\text { Correlation } \\
\text { Coefficient }\end{array}$ & .100 & -.067 & -.167 & .033 & & .317 \\
\hline & & Sig. (2-tailed) & .798 & .865 & .668 & .932 & & .406 \\
\hline & DNA adducts & $\begin{array}{l}\text { Correlation } \\
\text { Coefficient }\end{array}$ & $.717^{*}$ & -.167 & .067 & -.117 & .317 & \\
\hline & & Sig. (2-tailed) & .030 & .668 & .865 & .765 & .406 & \\
\hline
\end{tabular}

***. Correlation is significant at the 0.001 level (2-tailed)

**. Correlation is significant at the 0.01 level (2-tailed).

*. Correlation is significant at the 0.05 level (2-tailed). 




\section{Chapter 4}

\section{Effect of interleukin (IL)-8 on benzo[a]pyrene metabolism and DNA damage in human lung epithelial cells}

Shi Q, Boots AW, Maas L, Veith C, van Kuijk K, Haenen GR, Godschalk RW, Van Schooten FJ.

Toxicology. 2017 Apr 15;381:64-74. doi: 10.1016/j.tox.2017.02.013. 


\begin{abstract}
It has been well established that inflammation and concurrent mutagenic exposures drive the carcinogenic process in a synergistic way. To elucidate the role of the inflammatory cytokine IL-8 in this process, we studied its effect on the activation and deactivation of the chemical mutagen benzo[a]pyrene $\mathrm{B}[\mathrm{a}] \mathrm{P}$ in the immortalized pulmonary BEAS-2B cell line. After 24 hours incubation with $\mathrm{B}[\mathrm{a}] \mathrm{P}$ in the presence or absence of IL-8, the B[a]P induced cytochrome P450 1A1 and 1B1 (CYP1A1 and CYP1B1) gene expression and CYP1A1 enzyme activity was significantly higher in the presence of the cytokine. Consistent with these findings, we observed higher concentration of the metabolite B[a]P-7,8-diol under concurrent IL-8 treatment conditions. Interestingly, we also found higher concentrations of unmetabolized $\mathrm{B}[\mathrm{a}] \mathrm{P}$. To explain this, we examined the downstream effects of IL-8 on NADPH oxidases (NOXes). IL-8 lowered the intracellular NADPH level, but this effect could not explain the changes in $\mathrm{B}[\mathrm{a}] \mathrm{P}$ metabolism. IL-8 also significantly depleted intracellular glutathione (GSH), which also resulted in enhanced levels of unmetabolized $\mathrm{B}[\mathrm{a}] \mathrm{P}$, but increased concentrations of the metabolite $\mathrm{B}[\mathrm{a}] \mathrm{P}-7,8-d i o l$. No differences in $\mathrm{B}[\mathrm{a}] \mathrm{P}-\mathrm{DNA}$ adducts level were found between $\mathrm{B}[\mathrm{a}] \mathrm{P}$ and $\mathrm{B}[\mathrm{a}] \mathrm{P}$ combined with IL-8, and this might be due to a 3 -fold increase in nucleotide excision repair (NER) after IL-8 treatment. These findings suggest that IL-8 increased the formation of $\mathrm{B}[\mathrm{a}] \mathrm{P}-7,8$-diol despite an overall delayed $\mathrm{B}[\mathrm{a}] \mathrm{P}$ metabolism via depletion of GSH, but DNA damage levels were unaffected due to an increase in NER capacity.
\end{abstract}

Key words: Benzo[a]pyrene (B[a]P), Interleukin (IL)-8, NADPH-dependent cytochrome P450s 1A1/1B1 (CYP1A1/CYP1B1), NADPH oxidase pathway (NOX), Glutathione (GSH), DNA adducts. 


\section{Introduction}

The human lung offers an enormous surface area for exposure to contaminants in air, making this organ particularly vulnerable to a variety of toxic agents including cigarette smoke, automobile exhaust, microorganisms and a wide range of other pollutants [1]. The inhalation of such toxic agents can induce lung injury by the generation of reactive oxygen/nitrogen species (ROS/RNS), which results in the production of pro-inflammatory cytokines and chemokines [2]. Subsequently, inflammation is triggered and polymorphonuclear leukocytes (PMNs) are recruited to the site of damage to eliminate the pathogenic insult and to restore damaged tissue back to its normal physiological functions [1]. However, if such an inflammatory condition persists, chronic inflammation develops, which is a causative factor in lung cancer etiology [3]. For example, chronic obstructive pulmonary disease (COPD) patients showed increased number of neutrophils and macrophages in their sputum and bronchoalveolar lavage fluid and this results in the release of proteolytic enzymes and the generation of oxidants which cause tissue damage as well as cytokine and chemokine release [4]. Moreover, large amounts of neutrophils and macrophages in the airways can contribute to alterations of the lung microenvironment, which subsequently increases the risk for developing primary lung cancer [5-7].

IL-8, also known as CXCL8, is a pro-inflammatory chemokine, released during inflammation that plays a crucial role in chemoattracting neutrophils $[8,9]$. The promoter region of the $I L-8$ gene contains binding sites for the redox-sensitive transcription factors nuclear factor-kappa $\mathrm{B}(\mathrm{NF}-\kappa \mathrm{B})$ and activator protein-1 (AP-1) [10]. For example, stimulation of the bronchial epithelial cell line BEAS-2B with lipopolysaccharide (LPS) elevated IL-8 levels in the supernatant that were even further enhanced when the LPS-triggerd cells were co-incubated with PMNs [11]. In addition, upon secretion of IL-8, large amounts of PMN will be attracted to the site of injury/infection. In order to eliminate invading microorganisms, IL-8 induces a respiratory burst and generates ROS, which is initiated by activation of nicotinamide adenine dinucleotide phosphate (NADPH) oxidases (Noxes) [12-15].

Moreover, humans are inevitably exposed to benzo[a]pyrene $(\mathrm{B}[\mathrm{a}] \mathrm{P})$ via cigarette smoke, diesel exhaust emissions and environmental pollutants. $\mathrm{B}[\mathrm{a}] \mathrm{P}$ is the best studied polycyclic aromatic hydrocarbon (PAH) which plays a major role in lung cancer development [16-19]. B[a]P itself is not a direct genotoxin, but gains its carcinogenic and mutagenic effects after metabolic activation [20]. The most important route of $\mathrm{B}[\mathrm{a}] \mathrm{P}$ metabolic activation is via monooxygenation, catalyzed by the microsomal NADPH-dependent cytochrome P450 isoforms 1A1/1B1 (CYP1A1/CYP1B1), followed by hydration by microsomal epoxide hydrolase [21]. Phase I activation of $\mathrm{B}[\mathrm{a}] \mathrm{P}$ results in the generation of an intermediate of ( \pm )-trans-7,8-dihydroxy-7,8-dihydrobenzo[a]pyrene $(\mathrm{B}[\mathrm{a}] \mathrm{P}-7,8-d i o l)$, that is mostly detoxified via conjugation with glutathione (GSH) by specific glutathione- $S$-transferases (GSTs) in phase II reactions [22, 23]. If not conjugated, $\mathrm{B}[\mathrm{a}] \mathrm{P}-7,8-d i o l$ is further metabolized by CYPs and yields a highly reactive $\mathrm{B}[\mathrm{a}] \mathrm{P}-7,8$-dihydrodiol-9,10-epoxide (BPDE) which can covalently bind to DNA. BPDE-DNA adducts may cause mutations and then initiate carcinogenesis $[20,24]$. Apart from the mutagenicity of B[a]P and BPDE, both of them have been found to induce an inflammatory response and elicit the production of inflammatory mediators including IL-8 [25-27]. Although the metabolism of $\mathrm{B}[\mathrm{a}] \mathrm{P}$ can be affected by the presence of inflammation by a variety of cytokines, chemokines and enzymes that are released at the inflamed site [21,28-37], there is still 
little knowledge about the way IL-8 can affect $\mathrm{B}[\mathrm{a}] \mathrm{P}$ induced genotoxicity. Here, we describe the effect of IL-8 on B[a]P metabolism in human bronchial epithelial cells (BEAS-2B) and describe a possible underlying mechanism.

\section{Materials and Methods}

\section{Chemicals}

All chemicals were purchased from Sigma-Aldrich Chemie B.V. (Zwijndrecht, The Netherlands) unless stated otherwise.

\section{Cell culture}

BEAS-2B cells (SV40-immortalized normal bronchial epithelium cells) from the American Tissue Culture Collection (ATCC, Manassas, USA), were cultured in Dulbecco's Modified Eagle's Medium (DMEM/F-12; Gibco, Bleiswijk, The Netherlands) supplemented with $1 \%$ penicillin/streptomycin, $15 \mu \mathrm{g} / \mathrm{ml}$ bovine pituitary extract, 0.5 $\mathrm{ng} / \mathrm{ml}$ bovine serum albumin (Invitrogen, Breda,The Netherlands), $10 \mathrm{ng} / \mathrm{ml}$ epidermal growth factor (Merck Millipore, Darmstadt, Germany), $10 \mathrm{ng} / \mathrm{ml}$ cholera-toxin (list Biological Laboratories, Inc., Campbell, California), $5 \mu \mathrm{g} / \mathrm{ml}$ insulin, $5 \mu \mathrm{g} / \mathrm{ml}$ transferrin and $0.1 \mu \mathrm{M}$ dexamethasone (Sigma-Aldrich, St. Louis, MO, USA) and maintained in a 5\% $\mathrm{CO}_{2}$ environment at $37^{\circ} \mathrm{C}$. Cell passages between 10 and 20 were used for experiments and cells were routinely screened for mycoplasma contamination by a Mycoplasma Detection Kit (InvivoGen, The Netherlands).

\section{Cell treatments}

To investigate the effect of IL-8 on $\mathrm{B}[\mathrm{a}] \mathrm{P}$ metabolism, $\mathrm{B}[\mathrm{a}] \mathrm{P}(1 \mu \mathrm{M})$ in the present or absence of IL-8 (10 ng/ml) was used for exposure of BEAS-2B cells ( $80 \%$ confluency) for 6, 24 and 48 hours. Previous studies have revealed that simulating these lung cells with LPS or particles resulted in supernatant IL-8 levels ranging from $1 \mathrm{ng} / \mathrm{ml}$ to $100 \mathrm{ng} / \mathrm{ml}$ $[11,38]$. To mimic such a pro-inflammatory condition, $10 \mathrm{ng} / \mathrm{ml} \mathrm{IL-8}$ was added to BEAS-2B cells and coincubated with $1 \mu \mathrm{M} \quad \mathrm{B}[\mathrm{a}] \mathrm{P} . \mathrm{B}[\mathrm{a}] \mathrm{P}$ was dissolved in dimethylsulphoxide (DMSO) and added into the medium with a final DMSO concentration of $0.5 \%(\mathrm{v} / \mathrm{v})$. IL-8 was dissolved in phosphate-buffered saline (PBS, pH 7.4). To study the possible influence of GSH and ROS on the interaction studied, pre-treatments with a glutathione synthesis inhibitor (buthionine sulphoximine, BSO) and a general NOXs pathway inhibitor (diphenyleneiodonium chloride, DPI)) were included. To deplete intracellular GSH levels, BEAS-2B cells were preincubated with a non-toxic dose of $400 \mu \mathrm{M}$ BSO for 24 hours, following by washing the cells with cell media and then 24 hours treatment with $1 \mu \mathrm{M}$ B[a]P. For DPI treatments, cells were directly coincubated with different concentrations of this inhibitor $(100,10,1,0.1$, and $0.01 \mu \mathrm{M}$ ). In concordance with literature, DPI doses above $1 \mu \mathrm{M}$ were toxic to the cells [39-41]. Consequently, 0.1 and $1 \mu \mathrm{M}$ DPI were used in the current study to inhibit NOXes activity. All cell media and pellets were collected and stored at $-20{ }^{\circ} \mathrm{C}$ for further analysis upon these incubations. Experiments were performed at least in duplicate in two independent cultures $(n=4)$. 


\section{Detection of cellular viability}

The 3-(4,5-dimethylthiazol-2-yl)-2,5-diphenyl-tetrazolium bromide (MTT) assay was used to assess cell cytotoxicity and cell viability. As previous described by Shi et al., [42], BEAS-2B cells were cultured in 96-well plates (Costar, Cambridge, MA) at $1 \times 10^{4}$ cells/100 $\mu \mathrm{l}$ medium and exposed to $\mathrm{B}[\mathrm{a}] \mathrm{P}, \mathrm{IL}-8$, DPI or a combination of these three triggers. After all treatments, wells were washed with warm $\left(37^{\circ} \mathrm{C}\right)$ Hank's Balanced Salt Solution (HBSS) and incubated with MTT $(0.5 \mathrm{mg} / \mathrm{ml})$ at $37^{\circ} \mathrm{C}$ in the dark for 1 hour. Then, wells were emptied and cells were incubated with $200 \mu \mathrm{l}$ DMSO for 30 mins at room temperature. Finally, absorption was measured by using a microplate reader at $540 \mathrm{~nm}$ (Biorad, Veenendaal, The Netherlands) and the cell viability was expressed as percentage of DMSO control.

\section{Measurement of IL-8 protein levels}

In order to determine the IL-8 protein levels in cell medium after 6, 24 and 48 hours incubation, an enzyme-linked immunosorbent assay (ELISA) (cat. no. M950050192; CLB/Sanquin, The Netherlands) was carried out according to the manufacturer's instructions.

\section{NADPH quantification}

To assess the concentration of intracellular NADPH, a NADPH quantification kit was applied (cat. no. MAK038; Sigma-Aldrich). After incubating BEAS-2B cells with different treatments for 6, 24 and 48 hours, cells were washed with cold PBS, trypsinized and harvested as pellets by centrifuging at $1200 \mathrm{RPM}$ at $4{ }^{\circ} \mathrm{C}$ for 5 mins. Next, cells were extracted by adding $800 \mu \mathrm{l}$ NADPH extraction buffer vortexing for $10 \mathrm{sec}$ and centrifuging at 14,000 RPM for 5 mins. In order to purify the NADPH present in the obtained supernatants, all samples were filtered through a $10 \mathrm{kD}$ spin column before performing the assay. Samples were further preceded according to the manufacturer's instructions and measured at $450 \mathrm{~nm}$. Finally, results were normalized to total cellular protein determined by BCA protein assay kit (cat no. 23225; ThermoFisher SCIENTIFIC).

\section{GSH and GSSG level measurement}

In order to assess the level of total intracellular GSH and GSSG, cells were harvested and the analysis was performed according to Sthijns et al. [43]. After cells were washed with Dulbecco's Phosphate Buffered Saline (DPBS; Gibco, Bleisijk, The Netherlands) and harvested as pellet, $500 \mu \mathrm{l} 0.1 \mathrm{M}$ potassium phosphate buffer ( $\mathrm{pH}$ 7.5), which contained $5 \mathrm{mM}$ EDTA disodium salt and $0.1 \%$ Triton X-100, was added to lyse the cells. Cells were incubated on ice for $30 \mathrm{mins}$ and centrifuged for $10 \mathrm{mins}$ at $14,000 \mathrm{rpm}$ at $4^{\circ} \mathrm{C}$. Next, 300 $\mu \mathrm{l}$ supernatant was mixed $1: 1$ with $6 \%$ sulfosalicylic acid and diluted 1:5 in $0.1 \mathrm{M}$ potassium phosphate buffer. Eventually, GSH level was determined based on an enzymatic recycling method [44].

\section{Measurement of CYP1A1 activity}

Ethoxyresorufine-0-deethylase (EROD) assay was used to assess CYP1A1 activity which was performed according to the protocol of Burke and Mayer with some modifications [45]. Briefly, after harvesting the cells, cell pellets were incubated with $100 \mu$ EROD reaction mixtures at $37^{\circ} \mathrm{C}$ for 20 mins. The reaction mixtures contained Tris- $\mathrm{HCl}$ buffer (pH 7.4), with/without $0.5 \mathrm{mM}$ nicotinamide adenine dinucleotide phosphate (NADPH), 
$1.0 \mathrm{mg} / \mathrm{ml}$ Bovine Serum Albumin (BSA) and $5 \mu \mathrm{M}$ 7-ethoxyresorufin (dissolved in DMSO). The reaction was terminated by adding $2 \mathrm{M}$ glycine. The formation of fluorescent resorufin was measured in a thermostated plate reader (Spectra max m2, MIDS, CA) at $37^{\circ} \mathrm{C}$ and $535 / 590 \mathrm{~nm}$ excitation/emission wavelengths. The results were presented as relative fluorescence units per minute (RFU/min).

\section{Measurement of extracellular B $[a] P$ and $B[a] P$ metabolites}

In order to determine the extracellular levels of $\mathrm{B}[\mathrm{a}] \mathrm{P}$ and its metabolites, cell media were collected and analyzed by fluorescence HPLC. As previously described [29], $5 \mathrm{ml}$ cell medium was mixed and vortexed with $1 \mathrm{ml}$ ethyl acetate for 20 mins, followed by centrifugation (10 mins, $2000 \mathrm{rpm}$ ). The ethyl acetate fraction (top layer) was collected and the extraction step was repeated twice. The ethyl acetate fractions were combined, evaporated under nitrogen, and residues were resuspended in $0.3 \mathrm{ml}$ methanol (Biosolve Chemicals, Valkenswaard, The Netherlands). A $100 \mu \mathrm{l}$ volume of each sample was injected into a Hypersil $5 \mu \mathrm{m}$ ODS HPLC column (250x3mm i.d.) (Supelco 54933, Bellefonte, PA, USA) at a flow rate of $1 \mathrm{ml} / \mathrm{min}$. Samples were subsequently analyzed by HPLC-FD using a Gynkotek P580A HPLC system (Separations Analytical Instruments, Hendrik-Ido-Ambacht, The Netherlands) consisting of a Spark SP830 autosampler (Spark Holland, Emmen, The Netherlands) and a Perkin Elmer LS-30 programmable fluorescence detector (Perkin Elmer, Foster City, CA, USA) operated at excitation/emission wavelengths $257 / 350 \mathrm{~nm}$. For quantification purposes, a standard mix consisting of $50 \mathrm{ng} / \mathrm{ml} \mathrm{B}$ [a]P-9,10-diol, B[a]P-7,8-diol and 3-OH-B[a]P (Midwest Research Institute, Kansas City, MO, USA) was injected and the area of each metabolite peak in the chromatogram was determined.

\section{Quantitative Real-Time PCR}

To assess gene expression, total RNA was isolated and purified by using RNeasy ${ }^{\circledR}$ Mini Kit (Qiagen Westburg, Leusden, The Netherlands) in combination with DNase treatment (Qiagen). The quantity of each sample's RNA was quantified by spectrophotometric Nanodrop 1000 (Thermo Scientific, Waltham, MA, USA). cDNA was synthesized from 500 ng total RNA by using the iScript $^{\text {tm }}$ cDNA synthesis kit (Biorad, Veenendaal, The Netherlands). cDNA was diluted 10x in RNase free water after which real-time PCR was performed on the MyiQ Single Color RT-PCR detection system (Biorad) using Supermix SYBR ${ }^{\circledR}$ Green (Quantace, London, UK), $5 \mu$ l diluted cDNA and $0.3 \mu \mathrm{M}$ primers (Table 1) in a total volume of $25 \mu$ l. The PCR reactions were initiated by denaturation at $95{ }^{\circ} \mathrm{C}$ for 3 min, followed by 40 cycles of $95^{\circ} \mathrm{C}$ for $10 \mathrm{sec}$ and $55^{\circ} \mathrm{C}$ for $45 \mathrm{sec}$. The PCR efficiency of all primer sets was assessed by the use of cDNA dilution curves and melt curves $\left(55-95^{\circ} \mathrm{C}\right)$. Data were analyzed using MyiQ Software system (BioRad) and expressed as relative gene expression (fold change) using the $2^{-\Delta \Delta C t}$ method [46]. The stably expressed genes $\beta$-actin and GAPDH were included as reference.

Table 1: Primer sequences for real time RT-PCR

\begin{tabular}{lll}
\hline Gene & Forward primer $\left(5^{\prime}-3^{\prime}\right)$ & Reverse primer $\left(5^{\prime}-3^{\prime}\right)$ \\
\hline$\beta$-actin & CCTGGCACCCAGCACAAT & GCCGATCCACACGGAGTACT \\
GAPDH & GCACCACCAACTGCTTAGCA & TGGCAGTGATGGCATGGA \\
CYP1A1 & TCCTGGAGACCTTCCGACACT & CTTTCAAACTTGTGTCTCTTGTTCTG \\
CYP1B1 & AGTGCAGGCAGAATTGGATCA & GCGCATGGCTTCATAAAGGA \\
\hline
\end{tabular}




\section{P-postlabeling of $B[a] P-D N A$ adducts}

To determine $\mathrm{B}[\mathrm{a}] \mathrm{P}$ induced $\mathrm{DNA}$-adduct formation, ${ }^{32} \mathrm{P}$-postlabeling was performed using the nuclease P1 enrichment technique as described by Reddy and Randerath [47] with modifications [48]. After incubation, cells were harvested and resuspended in 450 $\mu \mathrm{l}$ SET/SDS (100 mM NaCl, $20 \mathrm{mM}$ EDTA, $50 \mathrm{mM}$ Tris, 0.5\% SDS) and incubated with proteinase $\mathrm{K} \quad(10 \mu \mathrm{g} / \mathrm{ml})$ at $37{ }^{\circ} \mathrm{C}$ overnight. After addition of $500 \mu \mathrm{l}$ phenol/chloroform/isoamyl alcohol (25:24:1), samples were rotated for 5 mins and centrifuged for 5 mins at $14000 \mathrm{rpm}$. $500 \mu \mathrm{l}$ chloroform/isoamyl alcohol (24:1) was added to the upper aqueous phase,. After mixing for 5 mins and centrifugation for 5 mins at $14000 \mathrm{rpm}, 1 / 30$ volume $3 \mathrm{M} \mathrm{NaAc}$ pH 5.2 was added to the upper phase. Samples were mixed and vortexed for a few seconds and 2 volumes of cold $100 \%$ ethanol were added. Precipitated DNA was washed with 70\% ethanol, dried under gas nitrogen, and resuspended in $50 \mu \mathrm{l}$ Mili-Q $\mathrm{H}_{2} \mathrm{O}$. The quantity of DNA was assessed by spectrophotometry in a Nanodrop 1000. $10 \mu \mathrm{g}$ of DNA was digested with micrococcal nuclease $(0.25 \mathrm{U} / \mu \mathrm{l})$ and spleen phosphodiesterase $(2 \mu \mathrm{g} / \mu \mathrm{l})$ for 4 hours at $37^{\circ} \mathrm{C}$ in a total volume of $9.5 \mu$. Then, samples were further enriched by adding nuclease P1 $(2.5$ $\mu \mathrm{g} / \mu \mathrm{l})$ at $37^{\circ} \mathrm{C}$ for $30 \mathrm{~min}$ and nuclease $\mathrm{P} 1$ reaction was terminated by addition of $1 \mu \mathrm{l} 1$ $\mathrm{M}$ Tris ( $\mathrm{pH}$ 9.6). DNA adducts were subsequently labelled with [ $\left.\mathrm{\gamma}^{-32} \mathrm{P}\right] A T P$ (50 $\mu \mathrm{Ci} /$ sample; PerkinElmer, Indianapolis) using T4-polynucleotide kinase $(10 \mathrm{U} / \mu \mathrm{l})$ for 30 min at $37{ }^{\circ} \mathrm{C}$. The ${ }^{32} \mathrm{P}$-labelled adducts were separated on PEI-cellulose sheets (Machery Nagel, Düren, Germany) by multidirectional thin-layer chromatography (TLC). The adducts spots in DNA from $\mathrm{B}[\mathrm{a}] \mathrm{P}$ treated samples chromatographed at the same position as the major adduct of the BPDE-DNA adduct standard, and were quantified using Phosphor-Imaging technology (Fujifilm FLA-3000, Rotterdam, The Netherlands) and DNA adducts levels were calculated from two B[a]PDE-DNA standards with known adducts levels ( 1 adduct $/ 10^{6}$ and 1 adduct $/ 10^{7}$ nucleotides).

\section{Measurement of Nucleotide Excision Repair (NER) capacity}

In order to phenotypically assess the NER capacity of BEAS-2B cells after each treatment, a modified comet assay was performed based on Langie et al. [49]. Briefly, untreated human lung carcinoma (A549) cells were used as substrate nucleoids and embedded in low melting point agarose gel. Subsequently, these cells were lysed overnight in cold $\left(4^{\circ} \mathrm{C}\right)$ lysis buffer and then exposed to either BPDE $(1 \mu \mathrm{M})$ or DMSO $(0.5 \%)$ for 30 mins on ice. Protein concentrations in cell extracts of BEAS-2B cells were determined by the BIO-AD DC Protein Assay Kit (BIO-RAD, Veenendaal, The Netherlands) and all samples were diluted to a concentration of $1 \mathrm{mg} / \mathrm{ml}$. The assessment of NER capacity was initiated by incubating the diluted cell extract with BPDE- and DMSO-exposed gel-embedded nucleoids for 20 mins at $37^{\circ} \mathrm{C}$. Subsequently, samples were treated with alkaline and electrophoresis for 20 mins. The comets were visualized using a Zeiss Axloskop fluorescence microscope with the amount of DNA strand breakage (tail moment) being indicative for the NER capacity of the cell extracts. The final incision activity was calculated according to Langie et al. [49].

\section{Statistical analysis}

All data are shown as mean \pm SEM. Statistical comparisons of the results were made using GraphPad Prism 5.0 (GraphPad Software, San Diego, CA, USA). To compare 2 groups, Student's test was performed. To compare multiple groups with the same 
control group, one-way analysis of variance (ANOVA) test with Bonferroni post hoc multiple comparison was used. Differences were considered to be statistically significant if $p<0.05$.

\section{Results}

\section{Cell viability}

Both IL-8 $(10 \mathrm{ng} / \mathrm{ml})$ and $\mathrm{B}[\mathrm{a}] \mathrm{P}(1 \mu \mathrm{M})$, as well as their combination, did not induce significant cytotoxicity in BEAS-2B cells after 6, 24 and 48 hours (Supplement Fig 1). However, incubating the cells with 10 or $100 \mu \mathrm{M}$ DPI results in a significantly decreased viability below $50 \%$ at all time points. Although 0.1 and $1 \mu \mathrm{M}$ of DPI also showed an initially significantly reduced viability to approximately $65 \%$ at $24 \mathrm{~h}$, the viability in both treatments increased to $>80 \%$ after 48 hours incubation and no significant difference was observed when compared with controls. In considering the effect and toxicity of the DPI treatment, only 0.1 and $1 \mu \mathrm{M}$ of DPI were applied in later experiments.

\section{$B[a] P$ induced IL-8 production in BEAS-2B cells}

Exposure of BEAS-2B cells to $1 \mu \mathrm{M}$ B[a]P significantly enhanced IL-8 concentrations compared to those measured in control supernatants at each time point $(6,24$ and 48 hours) (Fig 1A). This increase was time-dependent with the maximum IL-8 level (1.2 $\mathrm{ng} / \mathrm{ml}$ ) being reached at 48 hours. However, previous studies have shown that the concentration of IL-8 was much higher (between $10 \mathrm{ng} / \mathrm{ml}$ to $40 \mathrm{ng} / \mathrm{ml}$ ) when BEAS-2B cells were exposed to LPS [11]. Therefore, in order to investigate the effect of more relevant concentrations of IL-8 on B[a]P metabolism, an additional $10 \mathrm{ng} / \mathrm{ml}$ IL-8 was added to the cells and incubation was continued for 6, 24 and 48 hours. No significant differences in IL8 concentrations were observed between samples treated with IL-8 only or in combination with B[a]P (Fig 1B). Although we added $10 \mathrm{ng} / \mathrm{ml} \mathrm{IL-8,} \mathrm{the} \mathrm{level} \mathrm{of}$ IL-8 dropped to $\sim 3.5 \mathrm{ng} / \mathrm{ml}$ after 6 hours incubation followed by a slight, but not statistically significant, increase with incubation time. In other words, the endogenous production of IL-8 by BEAS-2B did not interfere with the addition of $10 \mathrm{ng} / \mathrm{ml}$ IL-8. Additionally, IL-8 concentrations decreased within 6 hours after addition to the cells (i.e., $10 \mathrm{ng} / \mathrm{ml}$ is added, but only $\sim 3.5 \mathrm{ng} / \mathrm{ml}$ can be detected after 6 hours), but after that the levels of IL-8 are stable.

A

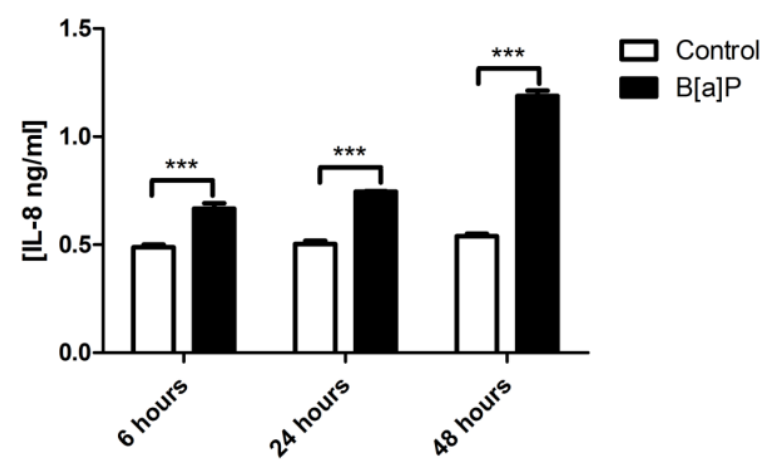

B

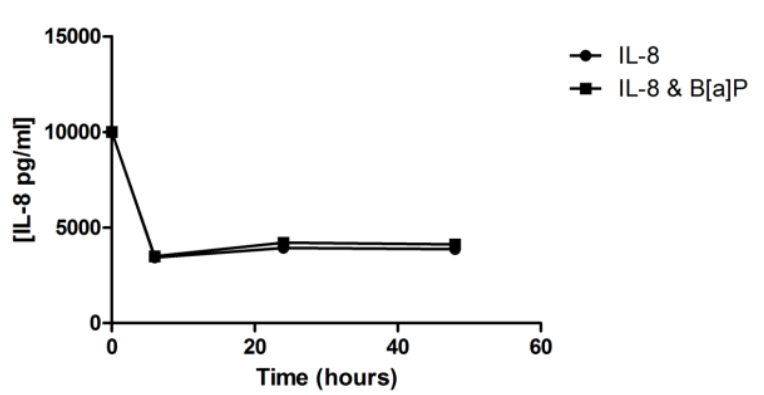

Figure 1. The effect of different treatments on IL-8 release after 6,24 and 48 hours incubation in BEAS-2B cells. A, Cells were stimulated with $1 \mu \mathrm{M} \mathrm{B}$ [a]P for 6,24 and 48 hours. The vehiculum DMSO were served as vehicle control; B, Cells with stimulated with $10 \mathrm{ng} / \mathrm{ml} \mathrm{IL-8}$ or $1 \mu \mathrm{M} \mathrm{B}$ [a]P with additional $10 \mathrm{ng} / \mathrm{ml}$ IL-8 for 6, 24 and 48 hours. Data were obtained from at least two independent experiments. (Data presented as mean \pm SEM, $n=4) .{ }^{*} p<0.05,{ }^{* *} p<0.01$ and ${ }^{* * *} \mathrm{p}<0.001$. 


\section{IL-8 alters $B[a] P$ induced $C Y P 1 A 1$ and CYP1B1 mRNA expression and EROD activity}

B[a]P significantly elevated $C Y P 1 A 1$ and $C Y P 1 B 1$ mRNA levels (Fig 2A and 2B). For CYP1A1 gene expression, $\mathrm{B}[\mathrm{a}] \mathrm{P}$ caused a time-dependent increase in mRNA levels which reached its maximum (approximately 23 fold increase) at $\mathrm{t}=48 \mathrm{~h}$. With additional IL-8, the $\mathrm{B}[\mathrm{a}] \mathrm{P}$ induced CYP1A1 gene expression was 1.9-fold higher after 24 hours of incubation (Fig 2B) when compared to B[a]P exposure without addition of IL-8 $(\mathrm{p}<0.05)$. At $\mathrm{t}=48$ hours, this induction of CYP1A1 expression by IL-8 was still 1.7 -fold higher but did no longer reach statistical significance $(\mathrm{p}=0.078)$. For $C Y P 1 B 1, \mathrm{~B}[\mathrm{a}] \mathrm{P}$ initially induced gene expression, followed by a significant time-dependent decrease from 9.8-fold at 6 hours to to 5.3 -fold at 48 hours. After addition of IL-8 in combination with $\mathrm{B}[\mathrm{a}] \mathrm{P}$, CYP1B1 mRNA levels were 2.6-fold $(\mathrm{p}<0.01)$ and 1.6-fold $(\mathrm{p}<0.05)$ higher than when compared to $\mathrm{B}[\mathrm{a}] \mathrm{P}$ treatment only at respectively $\mathrm{t}=24 \mathrm{~h}$ and $48 \mathrm{~h}$.

To analyze the effect of IL-8 on B[a]P induced CYP1A1/1B1 activity, EROD activity was measured (Fig 2C). B[a]P exposure significantly enhanced EROD activity from 16.8 $\mathrm{RFU} / \mathrm{min}(\mathrm{t}=6 \mathrm{~h})$ to $52 \mathrm{RFU} / \mathrm{min}(\mathrm{t}=24 \mathrm{~h})$, followed by a decrease to $22.2 \mathrm{RFU} / \mathrm{min}$ at 48 hours incubation. Similar to $C Y P 1 A 1 / 1 B 1$ gene expression, there was no significant difference between $\mathrm{B}[\mathrm{a}] \mathrm{P}$ only and $\mathrm{B}[\mathrm{a}] \mathrm{P}$ with IL-8 treatment at $\mathrm{t}=6 \mathrm{~h}$. However, IL-8 significantly enhanced $\mathrm{B}[\mathrm{a}] \mathrm{P}$ induced EROD activity after 24 and 48 hours incubation and the EROD activities were 1.2-fold $(\mathrm{p}<0.05)$ and 1.5-fold $(\mathrm{p}<0.05)$ higher with addition of IL-8 when compared to $\mathrm{B}[\mathrm{a}] \mathrm{P}$ alone.

A

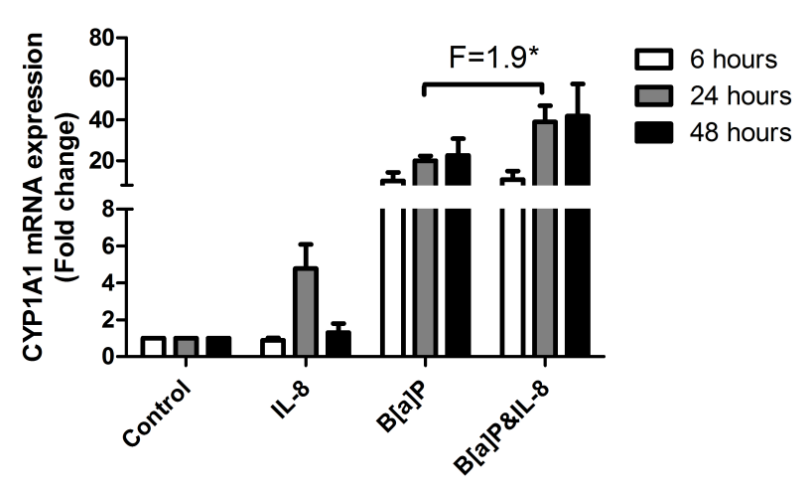

C

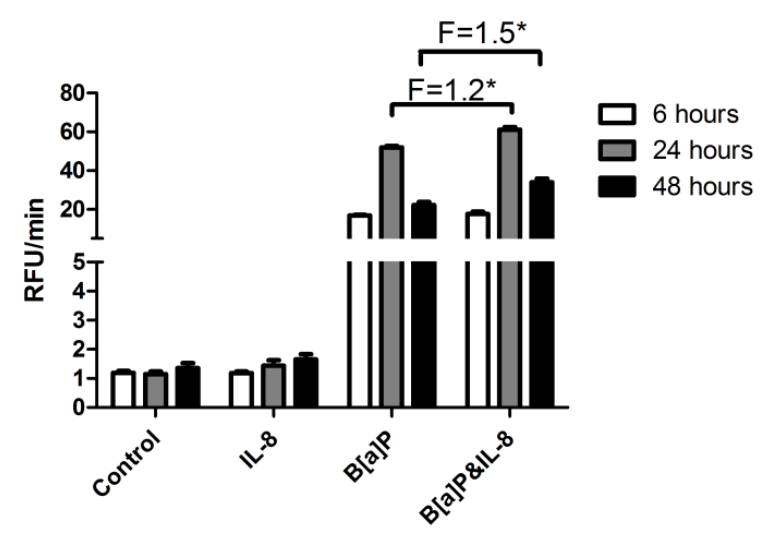

B

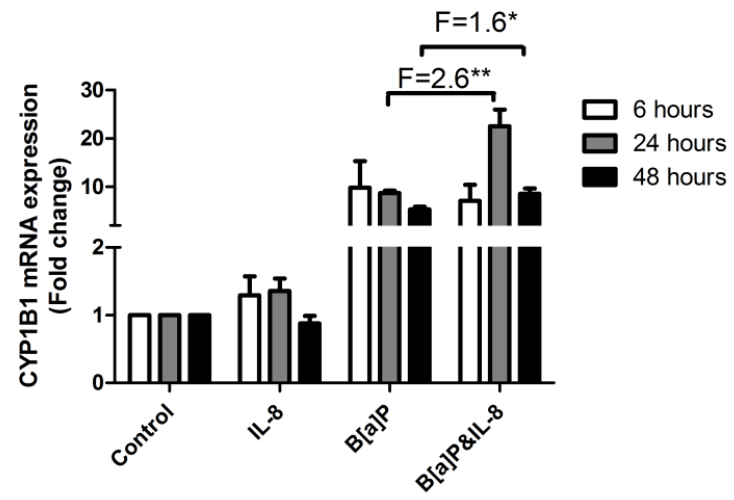

Figure 2. $C Y P 1 A 1$ and $C Y P 1 B 1$ gene expression and it's activity in BEAS-2B cell treated with 10 ng/ml IL-8, $1 \mu \mathrm{M}$ B[a]P B[a]P, $1 \mu \mathrm{M}$ B[a]P B[a]P + $10 \mathrm{ng} / \mathrm{ml} \mathrm{IL-8,} \mathrm{or} \mathrm{vehicle} \mathrm{control} \mathrm{DMSO} \mathrm{for} \mathrm{6,} 24$ and 48 hours. A, Expression of CYP1A1 was assessed by qRT-PCR. B, Expression of $C Y P 1 B 1$ was assessed by qRT-PCR. C, CYPs enzyme activity as measured by EROD activity. All data are given as the means \pm SEM ( $n=4$ per group) . For statistical analysis, the relative mRNA expression data were presented as fold change to control. The enzyme activity data were expressed as relative fluorescence unit per min (RFU/min). Values significantly different from each other are indicated by asterisks. ${ }^{*} \mathrm{p}<0.05$, ${ }^{* *} \mathrm{p}<0.01$ and ${ }^{* * *} \mathrm{p}<0.001$. 


\section{Effect of IL-8 on $B[a] P$ metabolism and its related metabolites}

To determine whether IL-8 interfered with the metabolism of $\mathrm{B}[\mathrm{a}] \mathrm{P}$, the level of three important extracellular $\mathrm{B}[\mathrm{a}] \mathrm{P}$ metabolites, $\mathrm{B}[\mathrm{a}] \mathrm{P}-9,10$-dihydrodiol $(\mathrm{B}[\mathrm{a}] \mathrm{P}-9,10$-diol), $\mathrm{B}[\mathrm{a}] \mathrm{P}-7,8-d i h y d r o d i o l ~(\mathrm{~B}[\mathrm{a}] \mathrm{P}-7,8-d i o l), 3-h y d r o x y-\mathrm{B}[\mathrm{a}] \mathrm{P}(\mathrm{B}[\mathrm{a}] \mathrm{P}-3-\mathrm{OH})$, and $\mathrm{B}[\mathrm{a}] \mathrm{P}$ itself were measured (Fig 3). The extracellular $\mathrm{B}[\mathrm{a}] \mathrm{P}-9,10-$ diol and $\mathrm{B}[\mathrm{a}] \mathrm{P}-3-\mathrm{OH}$ concentrations did not significantly differ between cells treated with $\mathrm{B}[\mathrm{a}] \mathrm{P}$ or $\mathrm{B}[\mathrm{a}] \mathrm{P}$ combined with IL-8 at any time point, except for B[a]P-9,10-diol which was significantly enhanced by IL-8 at $\mathrm{t}=48 \mathrm{~h}$ (Fig 3A and 3C). At $\mathrm{t}=6 \mathrm{~h}$, the extracellular B[a]P-7,8-diol showed no difference between both conditions. However, the presence of IL-8 significantly increased the extracellular B[a]P-7,8-diol levels at 24 and 48 hours incubations, which were 1.7-fold $(\mathrm{p}<0.001)$ and 2.2 -fold $(\mathrm{p}<0.01)$ higher than in samples that were treated with $\mathrm{B}[\mathrm{a}] \mathrm{P}$ alone, respectively (Fig 3B).

Interestingly, concentrations of unmetabolized extracellular $\mathrm{B}[\mathrm{a}] \mathrm{P}$ were higher at all timepoints when compared to samples that were not treated with IL-8, indicating that the overall rate of $\mathrm{B}[\mathrm{a}] \mathrm{P}$ metabolism seems to be decreased upon addition of IL-8 ( Fig 3D). After 6 hours incubation, the level of extracellular $\mathrm{B}[\mathrm{a}] \mathrm{P}$ decreased to $676 \pm 17 \mathrm{nM}$, whereas $\mathrm{B}[\mathrm{a}] \mathrm{P}$ concentrations in samples that were additionally treated with IL-8 decreased to $803 \pm 21 \mathrm{nM}$, which is 1.2 -fold $(\mathrm{p}<0.05)$ higher than $\mathrm{B}[\mathrm{a}] \mathrm{P}$ treated sample. At $\mathrm{t}=24 \mathrm{~h}$, the remaining extracellular $\mathrm{B}[\mathrm{a}] \mathrm{P}$ level decreased to $32 \pm 2 \mathrm{nM}$ in $\mathrm{B}[\mathrm{a}] \mathrm{P}$ treated sample, which was 5 -fold $(\mathrm{p}<0.001)$ lower than $\mathrm{B}[\mathrm{a}] \mathrm{P}$ concentrations in samples that were additionally treated with IL-8. Eventually, at $\mathrm{t}=48$ hours, the unmetabolized $\mathrm{B}[\mathrm{a}] \mathrm{P}$ concentration in $\mathrm{B}[\mathrm{a}] \mathrm{P}$ treated samples was down to $8 \pm 1 \mathrm{nM}$ and this is 2.4 -fold $(\mathrm{p}<0.01)$ lower than $\mathrm{B}[\mathrm{a}] \mathrm{P}$ concentrations in samples that were additionally treated with IL-8.

A

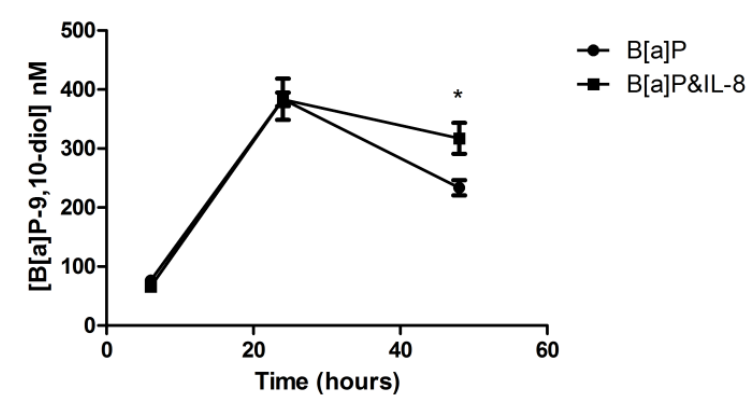

C

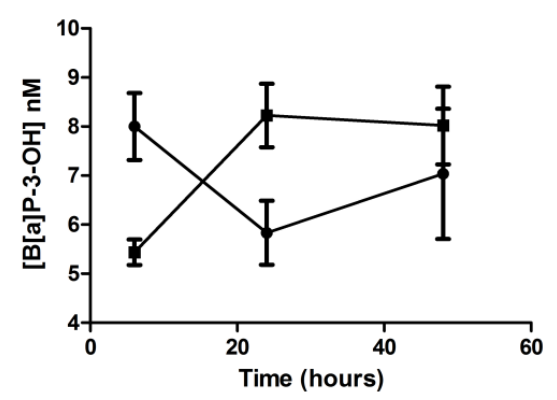

B

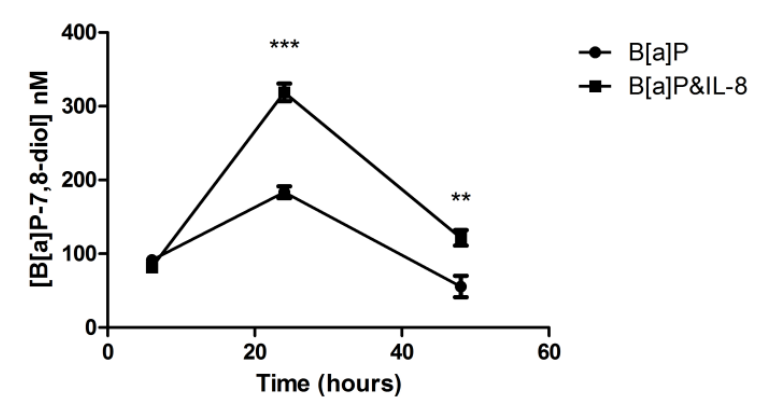

D

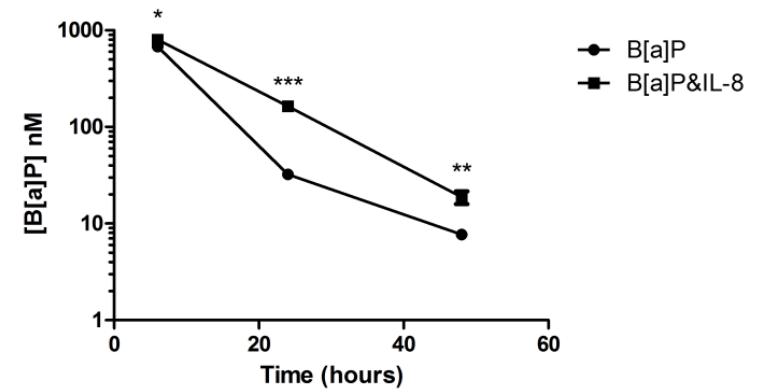

Figure 3. HPLC fluorescence analysis of $\mathrm{B}[\mathrm{a}] \mathrm{P}-9,10$-diol, $\mathrm{B}[\mathrm{a}] \mathrm{P}-7,8-$ diol, $\mathrm{B}[\mathrm{a}] \mathrm{P}-3-\mathrm{OH}$ and $\mathrm{B}[\mathrm{a}] \mathrm{P}$ in culture media of BEAS-2B cells after exposure to $1 \mu \mathrm{M} \mathrm{B}[\mathrm{a}] \mathrm{P}$ or $1 \mu \mathrm{M} \mathrm{B}$ [a]P with $10 \mathrm{ng} / \mathrm{ml} \mathrm{IL}-8$ for 6,24 and 48 hours. All data are given as the means \pm SEM ( $n=6$ per data point). Values significantly different from each other are indicated by asterisks. ${ }^{*} \mathrm{p}<0.05,{ }^{* *} \mathrm{p}<0.01$ and ${ }^{* * *} \mathrm{p}<0.001$. 


\section{Potential mechanism for decreased B[a]P metabolism, but higher levels of phase I metabolites}

\section{IL-8 lowers intracellular NADPH level}

Since NADPH is involved in various ways in B[a]P metabolism especially in CYP activity, intracellular NADPH levels were examined (Fig 4A, 4B and 4C). Compared to vehicle control (DMSO), both B[a]P and IL-8 decreased NADPH levels with 17\% (not statistically significant) after 6 hours incubation. However, the combination of IL-8 and $\mathrm{B}[\mathrm{a}] \mathrm{P}$ treatment significantly decreased the intracellular NADPH levels $(22 \%, p<0.05)$. At $t=24$ h. statistically significant lower levels of NADPH were found in the samples exposed to $\mathrm{B}[\mathrm{a}] \mathrm{P}(20 \%, \mathrm{p}<0.05)$ and samples exposed to $\mathrm{B}[\mathrm{a}] \mathrm{P}$ in combination with $\mathrm{IL}-8(42 \%$, $\mathrm{p}<0.001$ ) when compared to control. Moreover, compared to B[a]P, the NADPH level was $25 \%(\mathrm{p}<0.01)$ lower in the presence of IL-8. At $\mathrm{t}=48 \mathrm{~h}$, a similar trend to 24 hours incubations was observed in all samples, but the overall NADPH levels were lower than at $\mathrm{t}=24 \mathrm{~h}$ (Fig 4B and 4C).

A

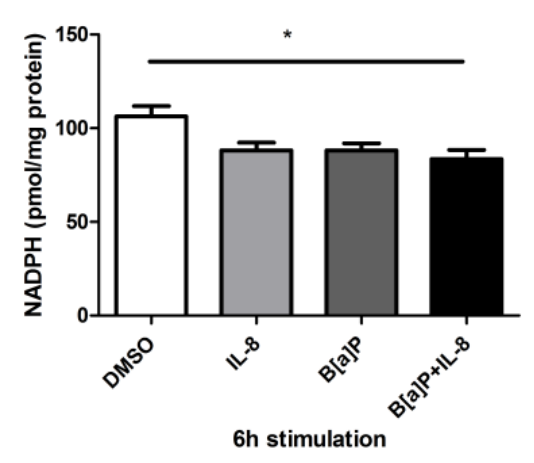

B

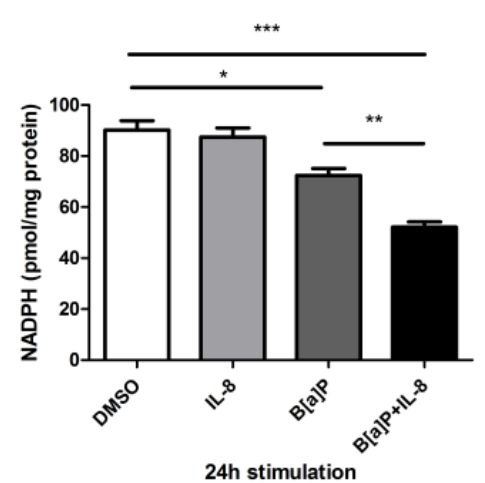

C

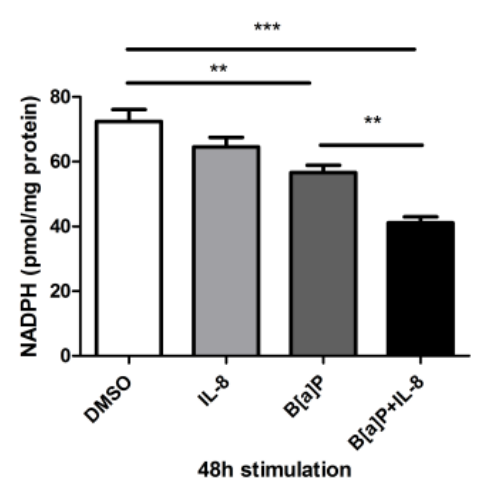

Figure 4. The NADPH level in each treatment (DMSO, IL-8, B [a]P, B $[\mathrm{a}] \mathrm{P}+\mathrm{BSO}$ and $\mathrm{B}[\mathrm{a}] \mathrm{P}+\mathrm{IL}-8)$ after 6 (A), 24 (B) and 48 (C) hours incubations. Data were expressed as pmol/mg protein (means \pm SEM, $n=4$ );

The enhancement of EROD activity by IL-8 is via activation of NOXes but not by reducing the intracellular NADPH level.

As shown in Fig 4A-C, the NADPH level was influenced by both $\mathrm{B}[\mathrm{a}] \mathrm{P}, \mathrm{IL}-8$ or their combination. It is known that IL-8 activates NADPH-oxidases (NOX), leading to the consumption of intracellular NADPH and consequently reduction of NADPH availability for CYP1A1 or CYP1B1 activity. Therefore, the EROD assay was performed (Fig 5A and 5B) with or without addition of NADPH to the reaction mix. As shown in Fig 5A the $\mathrm{B}$ [a]P-induced EROD activity in the presence of extra NADPH was significantly enhanced by IL-8 at 24 and 48 hours. In the absence of extra NADPH (Fig 5B), IL-8 exposure resulted in a similar pattern of EROD activity as in the experiment with extra NADPH; B[a]P-induced EROD activity was significantly increased by addition of IL-8 at 24 $(\mathrm{p}<0.001)$ and $48(\mathrm{p}<0.01)$ hours.

To investigate whether NOXes were involved in the changing of $\mathrm{B}[\mathrm{a}] \mathrm{P}$-induced EROD activity by IL-8 or not, the general NOXes inhibitor DPI was included (Fig 5A and 5B). 1 $\mu \mathrm{M}$ DPI significantly increased $(\mathrm{p}<0.05)$ EROD activity at $\mathrm{t}=6 \mathrm{~h}$. In addition, after 24 hours incubation, both 0.1 and $1 \mu \mathrm{M}$ DPI reduced EROD activity by respectively 27\% $(\mathrm{p}<0.001)$ and $50 \%(\mathrm{p}<0.001)$. At $\mathrm{t}=48 \mathrm{~h}, 0.1$ and $1 \mu \mathrm{M}$ DPI further reduced EROD activity to respectively $21.0 \mathrm{RFU} / \mathrm{min}(\mathrm{p}<0.001)$ and $10.4 \mathrm{RFU} / \mathrm{min}(\mathrm{p}<0.001)$. Taken 
together, these data suggest that NOX activity is indeed involved in regulating CYP1A1/1B1 activity by IL-8, but probably not via reducing intracellular NADPH levels.

A

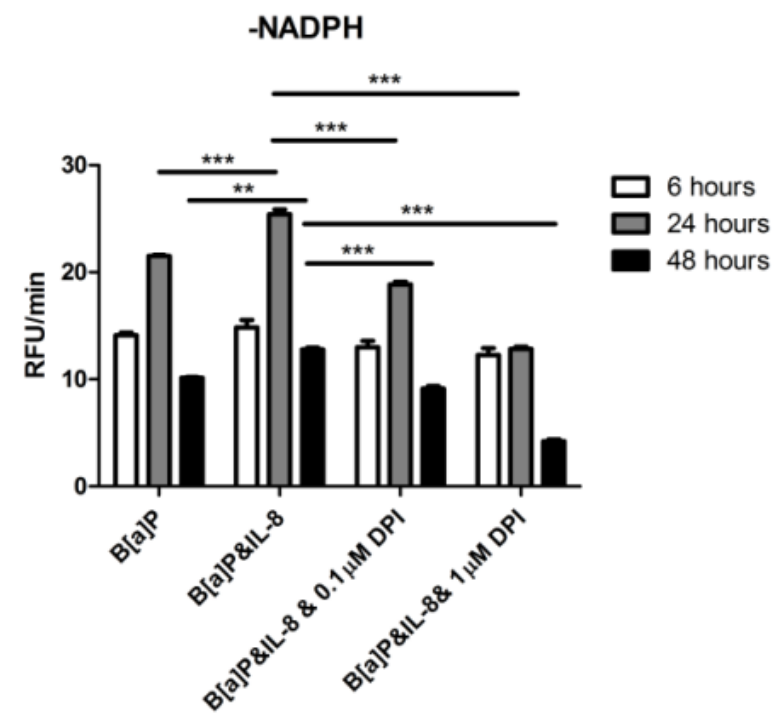

B

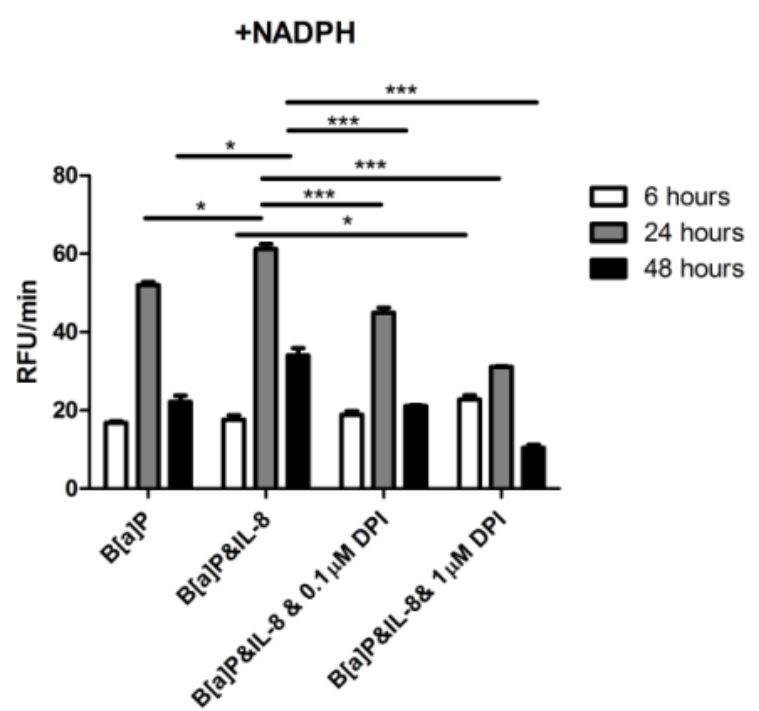

Figure 5. EROD activity in the present (A) or absence (B) of NADPH in BEAS-2B cell treated with $1 \mu \mathrm{M}$ $\mathrm{B}[\mathrm{a}] \mathrm{P}, 1 \mu \mathrm{M}$ B[a]P $+10 \mathrm{ng} / \mathrm{ml}$ IL-8, $1 \mu \mathrm{M}$ B[a]P $+10 \mathrm{ng} / \mathrm{ml}$ IL-8 $+0.1 \mu \mathrm{M}$ DPI or $1 \mu \mathrm{M} \mathrm{B}[\mathrm{a}] \mathrm{P}+10 \mathrm{ng} / \mathrm{ml}$ IL-8 $+1 \mu \mathrm{M}$ DPI for 6, 24 and 48 hours. Data were expressed as RFU/min (means $\pm \mathrm{SEM}, \mathrm{n}=8$ );

\section{IL-8 activates NOXes, leading to consumption of GSH level and delayed B[a]P metabolism}

Since GSH is important for the phase II metabolism of $\mathrm{B}[\mathrm{a}] \mathrm{P}$, it could be anticipated that reduced GSH levels contribute to the delayed $\mathrm{B}[\mathrm{a}] \mathrm{P}$ metabolism observed upon IL-8 activation. Indeed, IL-8 significantly decreased intracellular GSH concentration with about $25 \%(\mathrm{p}<0.01)$ at 24 hours of incubation (Fig 6A and 6B). Treatment with $\mathrm{B}[\mathrm{a}] \mathrm{P}$ only decreased the amount of GSH with $\sim 14 \%$, but this was not statistically significantly different from control (DMSO, $\mathrm{p}=0.078$ ). However, the combination of $\mathrm{B}[\mathrm{a}] \mathrm{P}$ and IL-8 further lowered the GSH level to $49.2 \mathrm{nmol} / \mathrm{mg}$ protein $(47 \%$ decrease, $\mathrm{p}<0.001)$. To investigate whether this decrease in GSH levels would result in the changes in $\mathrm{B}[\mathrm{a}] \mathrm{P}$ metabolism as observed for IL-8, BEAS-2B cells were pre-incubated for 24 hours with $400 \mu \mathrm{M}$ BSO, an inhibitor of gamma-glutamylcysteine synthetase. This BSO pre-incubation lowered the GSH level to $22.6 \mathrm{nmol} / \mathrm{mg}$ protein which is $76 \%$ lower when compared to DMSO. As shown in Fig 6D and 6E, after incubation with IL-8 for 24 hours, the extracellular levels of $\mathrm{B}[\mathrm{a}] \mathrm{P}-7,8$-diol and $\mathrm{B}[\mathrm{a}] \mathrm{P}$ were 1.8 -fold $(\mathrm{p}<0.05)$ and 2.9 -fold $(\mathrm{p}<0.001)$ higher than with $\mathrm{B}[\mathrm{a}] \mathrm{P}$ only, respectively. Similarly, with BSO, the concentrations of $\mathrm{B}[\mathrm{a}] \mathrm{P}-7,8-$ diol and $\mathrm{B}[\mathrm{a}] \mathrm{P}$ were 4-fold and 4.2-fold higher than with $\mathrm{B}[\mathrm{a}] \mathrm{P}$ only. Apparently, reduction of intracellular GSH levels by BSO mimics the changes in $\mathrm{B}[\mathrm{a}] \mathrm{P}$ metabolism as observed after additional IL-8 exposure.

No significant differences were observed with regard to GSSG levels between most treatments (DMSO, IL-8, B[a]P and B[a]P with BSO). However, the combination of $\mathrm{B}[\mathrm{a}] \mathrm{P}$ and IL-8 significantly enhanced GSSG level which was 9-fold $(\mathrm{p}<0.01)$ higher than compared to DMSO which lead to a low GSH/GSSG ratio as shown in Fig 6C. The GSH/GSSG ratio in control samples is approximately 300:1. The GSH/GSSG ratio in cells that were incubated with IL-8, B[a]P and B[a]P combined with BSO decreased to about 110:1, 140:1 and 78:1, respectively. Furthermore, B[a]P combined with IL-8 showed an 
approximately 4-fold lower GSH/GSSG ratio than $\mathrm{B}[\mathrm{a}] \mathrm{P}$ combines with BSO and this indicates that $\mathrm{B}[\mathrm{a}] \mathrm{P}$ in combination with IL-8 increased intracellular oxidative stress.

A

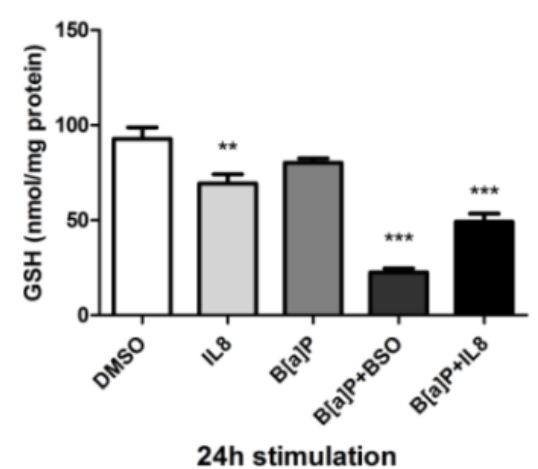

D

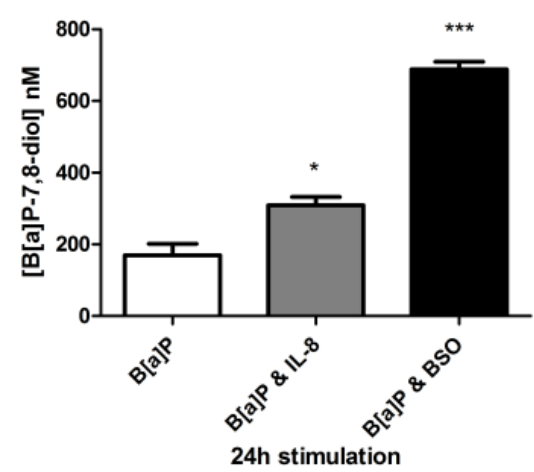

B

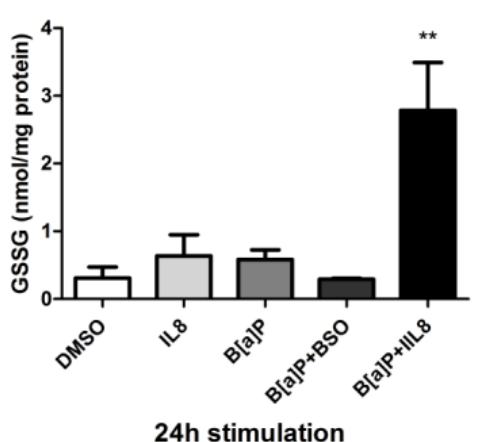

E
C

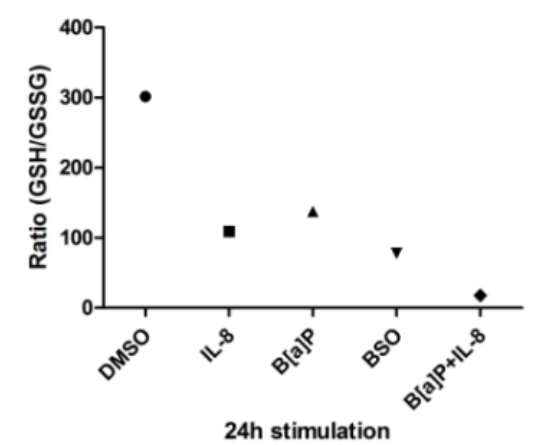

24h stimulation

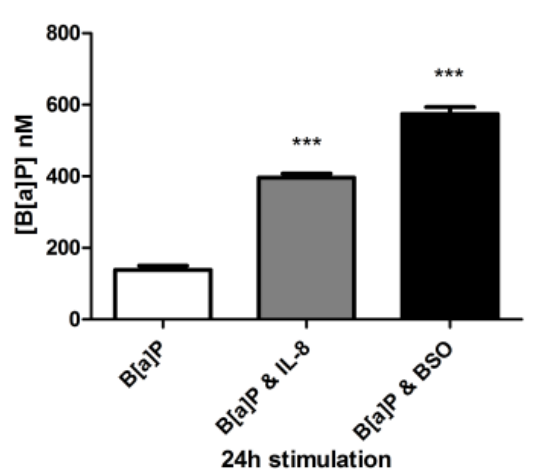

Figure 6. Data were expressed as RFU/min (means \pm SEM, $n=8$ ); The GSH level (A) and GSSG level (B) in BEAS-2B cell after exposure to vehicle control, $10 \mathrm{ng} / \mathrm{ml} \mathrm{IL-8,} 1 \mu \mathrm{M} \mathrm{B}[\mathrm{a}] \mathrm{P}$, preincubated 24 hour with 400 $\mu \mathrm{M} \mathrm{BSO}+1 \mu \mathrm{M} \mathrm{B}[\mathrm{a}] \mathrm{P}$ or $1 \mu \mathrm{M} \mathrm{B}[\mathrm{a}] \mathrm{P}+10 \mathrm{ng} / \mathrm{ml}$ IL-8 for 24 hours. Data were expressed as $\mathrm{nmol} / \mathrm{mg}$ protein (means \pm SEM, $n=4$ ); C, The ratio $\mathrm{GSSH} / \mathrm{GSSG}$ for each treatment; $\mathbf{D}$, The extracellular B[a]P-7,8-diol level in BEAS-2B cell treated with $1 \mu \mathrm{M}$ B[a]P, preincubated 24 hour with $400 \mu \mathrm{M}$ BSO $+1 \mu \mathrm{M}$ B [a] $\mathrm{P}$ or 1 $\mu \mathrm{M} \mathrm{B}[\mathrm{a}] \mathrm{P}+10 \mathrm{ng} / \mathrm{ml}$ IL-8 for 24 hours. E, The extracellular B[a]P level in BEAS-2B cell treated with $1 \mu \mathrm{M}$ $\mathrm{B}[\mathrm{a}] \mathrm{P}$, preincubated 24 hour with $400 \mu \mathrm{M}$ BSO $+1 \mu \mathrm{M} \mathrm{B}[\mathrm{a}] \mathrm{P}$ or $1 \mu \mathrm{M} \mathrm{B}[\mathrm{a}] \mathrm{P}+10 \mathrm{ng} / \mathrm{ml}$ IL-8 for 24 hours. All data are given as the means \pm SEM ( $n=6$ per group). Values significantly different from each other are indicated by asterisks. ${ }^{*} \mathrm{p}<0.05,{ }^{* *} \mathrm{p}<0.01$ and ${ }^{* * *} \mathrm{p}<0.001$.

\section{IL-8 increases NER capacity to remove B[a]P induced DNA adducts.}

To evaluate the ultimate effects of IL-8 on $\mathrm{B}[\mathrm{a}] \mathrm{P}$ metabolism, $\mathrm{B}[\mathrm{a}] \mathrm{P}$ induced DNA adducts were assessed (Fig 7A). Despite the changes in $\mathrm{B}[\mathrm{a}] \mathrm{P}$ metabolism that were induced by additional exposure to IL-8, no significant differences were found in DNA adduct levels. Since the increased levels of $\mathrm{B}[\mathrm{a}] \mathrm{P}-7,8-$ diol would theoretically lead to increased formation of BPDE and thus of DNA adducts, we speculated that cells compensated by increasing their NER capacity (Fig 7C). Indeed, at $t=24 \mathrm{~h}$, the NER capacity was 3 -fold $(p<0.05)$ enhanced by addition of IL-8 when compared to B[a]P exposure alone. 
A

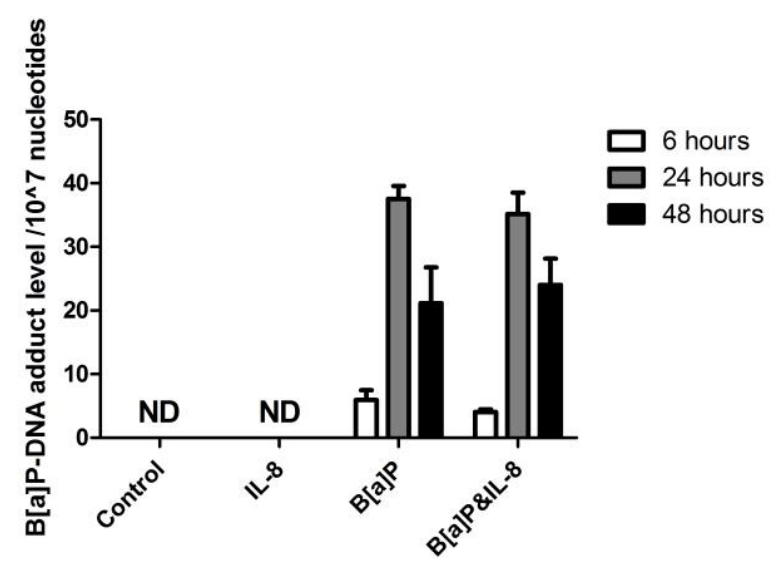

C
B

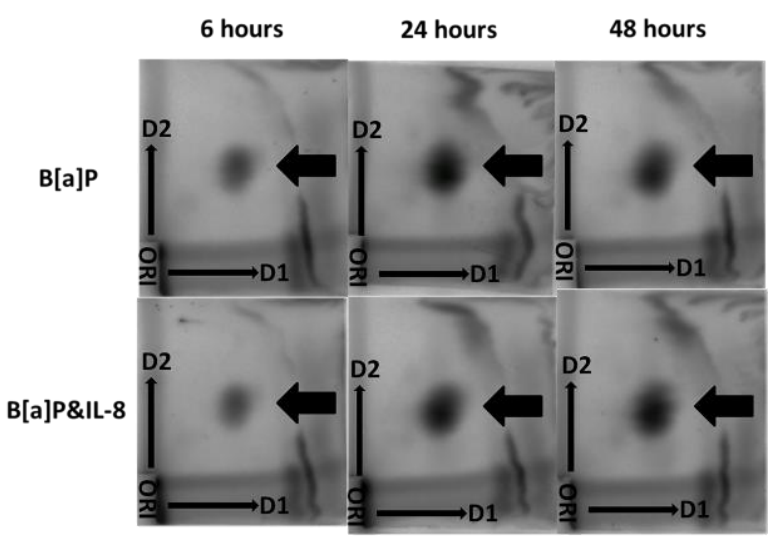

B[a]P\&IL-8

Figure 7. A, B[a]P induced DNA adduct formation. DNA adduct levels were measured by ${ }^{32} \mathrm{P}$-postlabeling in BEAS-2B cell after exposed to B[a]P or $1 \mu \mathrm{M}$ B[a]P with $10 \mathrm{ng} / \mathrm{ml} \mathrm{IL-8} \mathrm{for} 6,24$ and 48 hours. ND, not detected. B, Original Thinlayer chromatography (TLC) results of treatments of B[a]P and B[a]P with IL-8 at different time points. The adduct spot (arrow) that migrated during 2D-TLC to the same position as the major DNA adduct in a BPDE-DNA adduct standard was quantitated in all samples. Before phosphorimaging of the TLC plates the origin located at the bottom left-hand corner was excised. C, Effect of IL-8 on B[a]P induced NER activity in BEAS-2B cell after 24 hour stimulation. D, NER as depicted by the comet assay. Ethidium bromide staining (X 400). All data are given as the means \pm SEM ( $n=6$ per group). Values significantly different from each other are indicated by asterisks. ${ }^{*} \mathrm{p}<0.05, * * \mathrm{p}<0.01$ and $* * * \mathrm{p}<0.001$.

\section{Discussion}

Humans are unavoidably exposed to $\mathrm{B}[\mathrm{a}] \mathrm{P}$, because it is widely present in, for example cigarette smoke, diesel exhaust or environmental particulate matters. $\mathrm{B}[\mathrm{a}] \mathrm{P}$ is the most studied PAH and many studies have shown that it plays an important role in the induction of lung inflammation [50]. However, the simultaneous effect of inflammation on $\mathrm{B}[\mathrm{a}] \mathrm{P}$ metabolism is largely lacking. Therefore, in this study, we focused on how the pro-inflammatory cytokine IL-8 affects $\mathrm{B}[\mathrm{a}] \mathrm{P}$ metabolism as well as $\mathrm{B}[\mathrm{a}] \mathrm{P}$-induced DNA damage and reveal the potential mode of action of IL-8 herein.

Chemical carcinogens may induce inflammation and it has been previously shown that levels of the inflammatory cytokine IL-8 are enhanced upon B[a]P exposure in cells, animals and patients [50-53]. Similarly, we also show in the current study a time-dependent increase of IL-8 concentrations after B[a]P exposure in BEAS-2B cells. In addition, IL-8 binds to its receptors (CXCR1 and CXCR2), and subsequently activates the $\mathrm{NF}-\kappa \mathrm{B}$ pathway which can bind to the endogenous IL-8 promoter to upregulate IL-8 gene 
transcription $[8,54,55]$. Thus, the continuous IL-8 production via this NF- $\kappa B$ pathway generates a positive feedback loop for IL-8 $[56,57]$, providing a possible explanation for our observation that the level of IL-8 remained high and did not decrease in time. Nevertheless, it is currently unknown whether this positive IL-8 feedback loop will affect the detoxification pathways of chemical carcinogens.

The cellular response to chemical mutagenic exposures is the induction of NADPH dependent cytochrome P450s (CYP1A1/CYP1B1) that are able to transform the chemical compounds into hydrophilic compounds. In our experiments, we showed that IL-8 enhanced the expression of CYP1A1 and CYP1B1, leading to higher metabolic activity. As a consequence, higher levels of the metabolite $\mathrm{B}[\mathrm{a}] \mathrm{P}-7,8$ diol were detected but, unexpectedly, also a reduction of the rate of $\mathrm{B}[\mathrm{a}] \mathrm{P}$ metabolism was observed. In order to explain these unexpected contradicting observations, the NOX pathway was investigated, because binding of IL-8 to its receptor will also activate this pathway $[9,58$, 59]. We initially hypothesized that IL-8 mediated activation of NOX would decrease the level of intracellular NADPH, which could limit the CYP1A1/1B1 activity. Additionally, we suggested that lower NADPH levels would change the metabolic profile towards the favorable formation of $\mathrm{B}[\mathrm{a}] \mathrm{P}-7,8$ diol. As a consequence, the rate of $\mathrm{B}[\mathrm{a}] \mathrm{P}$ metabolism would be reduced and the concentration of unmetabolized $\mathrm{B}[\mathrm{a}] \mathrm{P}$ would remain relatively high, whereas $\mathrm{B}[\mathrm{a}] \mathrm{P}-7,8-$ diol could accumulate (Fig 3). It is known that when the concentration of unmetabolized $\mathrm{B}[\mathrm{a}] \mathrm{P}$ and $\mathrm{B}[\mathrm{a}] \mathrm{P}-7,8-$ diol stay high, this will keep triggering the aromatic hydrocarbon receptor (AHR) induced CYP1A1 and CYP1B1 gene expression $[29,60]$. Indeed, B[a]P significantly decreased the NADPH levels, especially in conjunction with IL-8 exposure. This indicated that the NADPH level might be the rate-limiting factor for $\mathrm{B}[\mathrm{a}] \mathrm{P}$ metabolism and that the IL-8 reduced $\mathrm{B}[\mathrm{a}] \mathrm{P}$ metabolism might be due to the lower intracellular NADPH level. To address this hypothesis, an EROD assay was performed in the presence or absence of extra NADPH. Unexpectedly, the results showed that extra NADPH did not counteract the effect of IL-8 on EROD activity. Only, the overall EROD activity expression (RFU/min) was higher by extra NADPH, indicating that the NADPH level might be the limiting factor in the metabolic activity, but not the key factor which caused the higher CYP1A1/1B1 mRNA level and subsequent metabolism of $\mathrm{B}[\mathrm{a}] \mathrm{P}$ to its 7,8-diol.

To further address our hypothesis that NOXes activated by IL-8 can explain the results, pre-incubations with the general NOX inhibitor DPI were performed. Interestingly, the increased EROD activity induced by additional IL-8 after 24 and 48 hours incubation was significantly inhibited upon DPI pretreatment. Moreover, after 6 hours, the EROD activity was significantly enhanced by DPI, These results indicated that IL-8 indeed alters $\mathrm{B}[\mathrm{a}] \mathrm{P}$ induced EROD activity via NOXes, but the downstream mechanism is unlikely to be mediated by NADPH and thus remains unclear.

As some studies have reported that IL-8 greatly enhanced the respiratory burst and generates ROS through the activation of NOXes [9, 61], the production of ROS might be involved in the changes of $\mathrm{B}[\mathrm{a}] \mathrm{P}$ metabolism. One of the most abundant intracellular antioxidant molecules is reduced glutathione (GSH), which removes potential toxic electrophiles [62]. Indeed, the intracellular GSH level was significantly decreased after stimulation with IL-8 for 24 hours. Meanwhile, GSH is a major phase II compound that forms conjugates with BPDE, $\mathrm{B}[\mathrm{a}] \mathrm{P}-7,8$-oxide and other $\mathrm{B}[\mathrm{a}] \mathrm{P}$ metabolites, to protect cells from their toxicity [23]. Incubation of BEAS-2B cells with B[a]P for 24 hours did lower the intracellular GSH level, but not statistically significant $(\mathrm{p}=0.078)$. However, the combination of IL-8 with B[a]P decreased GSH levels with more than $50 \%$ when compared to control. In principle, cells maintain the balance of GSH in its reduced and 
oxidized form (GSSG) with a GSH:GSSG ratio exceeding 100:1 [63]. During oxidative stress (in this particular case induced by exposure to B[a]P or B[a]P with IL-8), GSH is converted into GSSG and the ratio (GSH/GSSG) will decrease [63]. Indeed, we also observed that combined treatment with $\mathrm{B}[\mathrm{a}] \mathrm{P}$ and IL-8 significantly elevated the intracellular GSSG level and reduced the GSH/GSSG ratio to approximately 20:1. However, to maintain the GSH in a reduced state, the GSH redox cycle which is an NADPH-dependent reaction, is triggered. In this redox cycle, GSH is regenerated from GSSG using reduced NADPH, which will be converted into NADP+, [64]. Therefore, we hypothesize that when under low oxidative stress (e.g. IL-8 or B[a]P alone), cells can regenerate GSH via the GSH redox cycle. However, when cells face increased levels of oxidative stress (e.g. combination of $\mathrm{B}[\mathrm{a}] \mathrm{P}$ and IL-8), more GSH is converted into GSSG and the rate of GSSG to GSH conversion may be limited because NADPH is additionally used for B[a]P metabolism. Due to the lower GSH level, the formation of GSH conjugates will be slowed down which leads to accumulation of $\mathrm{B}[\mathrm{a}] \mathrm{P}-7,8-d i o l$. In addition, accumulation of $\mathrm{B}[\mathrm{a}] \mathrm{P}-7,8-$ diol and $\mathrm{B}[\mathrm{a}] \mathrm{P}$ will keep triggering the aryl hydrocarbon receptor (AHR)-mediated $C Y P 1 A 1 / 1 B 1$ gene expression [29]. To further support this hypothesis, experiments with BSO, an inhibitor of GSH synthesis, were included. As expected, we observed that the intracellular GSH decreased and the extracellular $\mathrm{B}[\mathrm{a}] \mathrm{P}$ and $\mathrm{B}[\mathrm{a}] \mathrm{P}-7,8-$ diol concentrations increased after addition of BSO.

$\mathrm{B}[\mathrm{a}] \mathrm{P}$ induced DNA adducts are the net effect of binding of $\mathrm{B}[\mathrm{a}] \mathrm{P}$ related metabolites to DNA and their removal by DNA repair [29]. In principle, higher levels of B[a]P-7,8-diol would result in higher levels of BPDE, and subsequently more DNA adducts. However, we found no significant differences in B[a]P-DNA adduct levels between B[a]P treated samples and samples that were additionally treated with IL-8. We examined whether this could be explained by the induction of DNA repair that counterbalances the increased formation of DNA adducts. Indeed, we observed a 3-fold induction of NER capacity by additional IL-8 exposure after 24 hour of stimulation. This induction of DNA damage repair can be explained by the depletion of intracellular GSH, as Langie et al [65] has previously reported that GSH depletion leads to induction of NER.

In conclusion, this study demonstrated that exposure of BEAS-2B cells to $\mathrm{B}[\mathrm{a}] \mathrm{P}$ combined with IL-8 resulted in upregulation of $\mathrm{B}[\mathrm{a}] \mathrm{P}$-induced $C Y P 1 A 1 / 1 B 1$ gene expression and its activity. Additionally, higher levels of $\mathrm{B}[\mathrm{a}] \mathrm{P}-7,8-$ diol and unmetabolized $\mathrm{B}[\mathrm{a}] \mathrm{P}$ were observed after incubation with additional IL-8. This could be due to IL-8 mediated activation of NOXes which subsequently depletes intracellular GSH, which is also needed to detoxify $\mathrm{B}[\mathrm{a}] \mathrm{P}$ metabolites. It results in higher levels of $\mathrm{B}[\mathrm{a}] \mathrm{P}-7,8-d i o l$ but unexpectedly also in a lower rate of $\mathrm{B}[\mathrm{a}] \mathrm{P}$ metabolism. Higher level of $\mathrm{B}[\mathrm{a}] \mathrm{P}$ and $\mathrm{B}[\mathrm{a}] \mathrm{P}-7,8-$ diol will keep triggering AHR-mediated CYP1A1/1B1 gene expression. It is yet unknown whether an IL-8 induced reduction in NADPH levels is involved in the reduction of $\mathrm{B}[\mathrm{a}] \mathrm{P}$ metabolism. DNA adduct levels were not increased, because the cells compensate by boosting their DNA repair activity (overall hypothesis is depicted in Fig 8). Our results show that the pro-inflammatory cytokine IL-8 can alter not only the $\mathrm{B}[\mathrm{a}] \mathrm{P}$ metabolism but also the formation as well as the removal of $\mathrm{B}[\mathrm{a}] \mathrm{P}$-induced DNA adducts in human lung epithelial cells. This study expands the knowledge on how inflammation-associated cytokines can affect $\mathrm{B}[\mathrm{a}] \mathrm{P}$ induced carcinogenesis. 


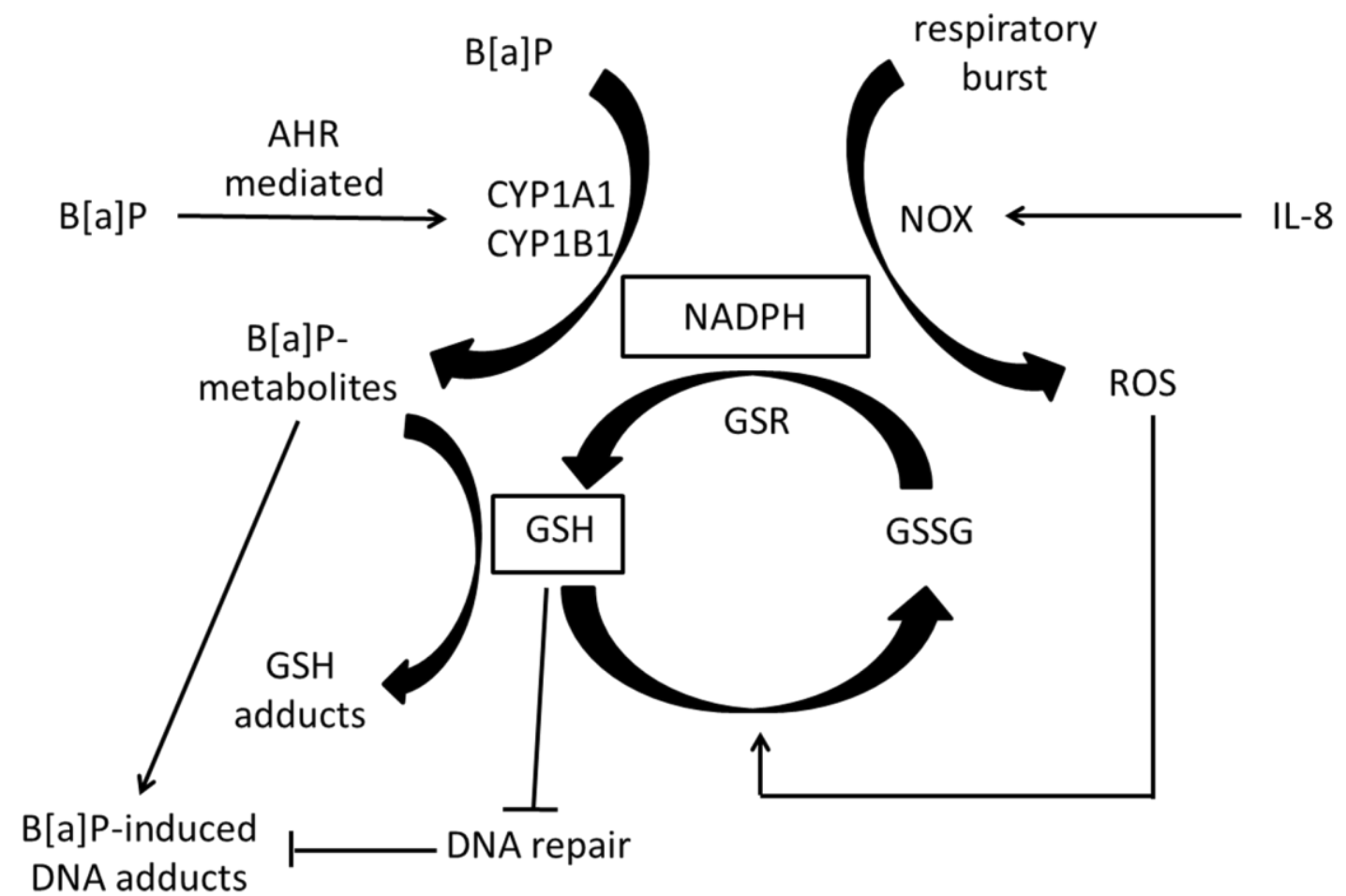

Figure 8. The potential mechanism of NADPH and GSH during incubation of $B[a] P$ and IL-8 in BEAS-2B cells. NADPH is involved in three pathways: First, B[a]P metabolism involves NADPH-dependent CYPs (CYP1A1/CYP1B1) mediated reactions. After B[a]P exposure, CYP1A1/CYP1B1 are significantly upregulated and converting B[a]P into B[a]P metabolites by consuming NADPH. Secondly, NOX dependent ROS production. IL-8 activates the NOX pathway which decreasing the NADPH level. Thirdly, the conversion of GSSG back to GSH needs NADPH. However, in the concurrent exposure to B[a]P and IL-8, GSH is the rate limiting factor compared to NADPH in the B[a]P metabolism. Furthermore, decreased GSH level leads to upregulation of DNA repair capacity (NER) which prevent from forming B[a]P-induced DNA adducts. However, IL-8-induced production of ROS increased the conversion of GSH into GSSG, therefore, resulting in less detoxification of $\mathrm{B}[\mathrm{a}] \mathrm{P}$ metabolism but increasing DNA repair capacity. 


\section{References}

[1] N. Azad, Y. Rojanasakul, V. Vallyathan, Inflammation and lung cancer: roles of reactive oxygen/nitrogen species, Journal of Toxicology and Environmental Health, Part B, 11 (2008) 1-15.

[2] A. Emmendoerffer, M. Hecht, T. Boeker, M. Mueller, U. Heinrich, Role of inflammation in chemical-induced lung cancer, Toxicology letters, 112 (2000) 185-191.

[3] A.M. Knaapen, N. Gungor, R.P. Schins, P.J. Borm, F.J. Van Schooten, Neutrophils and respiratory tract DNA damage and mutagenesis: a review, Mutagenesis, 21 (2006) 225-236.

[4] T.D. Tetley, Inflammatory cells and chronic obstructive pulmonary disease, Current drug targets. Inflammation and allergy, 4 (2005) 607-618.

[5] S. Raviv, K.A. Hawkins, M.M. DeCamp Jr, R. Kalhan, Lung cancer in chronic obstructive pulmonary disease: enhancing surgical options and outcomes, American journal of respiratory and critical care medicine, 183 (2011) 1138-1146.

[6] P.T. King, Inflammation in chronic obstructive pulmonary disease and its role in cardiovascular disease and lung cancer, Clinical and translational medicine, 4 (2015) 1-13.

[7] G. Lee, T.C. Walser, S.M. Dubinett, Chronic inflammation, chronic obstructive pulmonary disease, and lung cancer, Current opinion in pulmonary medicine, 15 (2009) 303-307.

[8] D.J. Waugh, C. Wilson, The interleukin-8 pathway in cancer, Clinical cancer research : an official journal of the American Association for Cancer Research, 14 (2008) 6735-6741.

[9] T. Miyoshi, K. Yamashita, T. Arai, K. Yamamoto, K. Mizugishi, T. Uchiyama, The role of endothelial interleukin-8/NADPH oxidase 1 axis in sepsis, Immunology, 131 (2010) 331-339.

[10] C.L. Elliott, V.C. Allport, J.A. Loudon, G.D. Wu, P.R. Bennett, Nuclear factor-kappa B is essential for up-regulation of interleukin-8 expression in human amnion and cervical epithelial cells, Molecular human reproduction, 7 (2001) 787-790.

[11] A.W. Boots, K. Gerloff, R. Bartholome, D. van Berlo, K. Ledermann, G.R. Haenen, A. Bast, F.J. van Schooten, C. Albrecht, R.P. Schins, Neutrophils augment LPS-mediated pro-inflammatory signaling in human lung epithelial cells, Biochimica et biophysica acta, 1823 (2012) 1151-1162.

[12] H.J. Forman, M. Torres, Reactive oxygen species and cell signaling: respiratory burst in macrophage signaling, American journal of respiratory and critical care medicine, 166 (2002) S4-8.

[13] T.L. Leto, S. Morand, D. Hurt, T. Ueyama, Targeting and regulation of reactive oxygen species generation by Nox family NADPH oxidases, Antioxidants \& redox signaling, 11 (2009) 2607-2619.

[14] J.Y. Djeu, K. Matsushima, J.J. Oppenheim, K. Shiotsuki, D.K. Blanchard, Functional activation of human neutrophils by recombinant monocyte-derived neutrophil chemotactic factor/IL-8, Journal of immunology, 144 (1990) 2205-2210.

[15] S. Bréchard, J.L. Bueb, E.J. Tschirhart, Interleukin-8 primes oxidative burst in neutrophil-like HL-60 through changes in cytosolic calcium, Cell Calcium, 37 (2005) 531-540.

[16] R. Yanagisawa, E. Koike, T.T. Win-Shwe, T. Ichinose, H. Takano, Low-dose benzo[a]pyrene aggravates allergic airway inflammation in mice, J Appl Toxicol, (2016).

[17] V.M. Arlt, A.M. Krais, R.W. Godschalk, Y. Riffo-Vasquez, I. Mrizova, C.A. Roufosse, C. Corbin, Q. Shi, E. Frei, M. Stiborova, F.J. van Schooten, D.H. Phillips, D. Spina, Pulmonary Inflammation Impacts on CYP1A1-Mediated Respiratory Tract DNA Damage Induced by the Carcinogenic Air Pollutant Benzo[a]pyrene, Toxicol Sci, 146 (2015) 213-225.

[18] T.K. Baginski, K. Dabbagh, C. Satjawatcharaphong, D.C. Swinney, Cigarette smoke synergistically enhances respiratory mucin induction by proinflammatory stimuli, American journal of respiratory cell and molecular biology, 35 (2006) 165-174.

[19] T. Chiba, J. Chihara, M. Furue, Role of the Arylhydrocarbon Receptor (AhR) in the Pathology of Asthma and COPD, Journal of allergy, 2012 (2012).

[20] W.M. Baird, L.A. Hooven, B. Mahadevan, Carcinogenic polycyclic aromatic hydrocarbon-DNA adducts and mechanism of action, Environ Mol Mutagen, 45 (2005) 106-114.

[21] L. Umannova, M. Machala, J. Topinka, Z. Novakova, A. Milcova, A. Kozubik, J. Vondracek, Tumor necrosis factor-alpha potentiates genotoxic effects of benzo[a]pyrene in rat liver epithelial cells through upregulation of cytochrome P450 1B1 expression, Mutat Res, 640 (2008) 162-169.

[22] M.A. Trush, J.L. Seed, T.W. Kensler, Oxidant-dependent metabolic activation of polycyclic aromatic hydrocarbons by phorbol ester-stimulated human polymorphonuclear leukocytes: possible link between inflammation and cancer, Proc Natl Acad Sci U S A, 82 (1985) 5194-5198.

[23] S.L. Kabler, A. Seidel, J. Jacob, J. Doehmer, C.S. Morrow, A.J. Townsend, Differential protection by human glutathione S-transferase P1 against cytotoxicity of benzo[a]pyrene, dibenzo[a,l]pyrene, or their dihydrodiol metabolites, in bi-transgenic cell lines that co-express rat versus human cytochrome P4501A1, Chem Biol Interact, 179 (2009) 240-246.

[24] W. Xue, D. Warshawsky, Metabolic activation of polycyclic and heterocyclic aromatic hydrocarbons and DNA damage: a review, Toxicol Appl Pharmacol, 206 (2005) 73-93.

[25] K. Dreij, K. Rhrissorrakrai, K.C. Gunsalus, N.E. Geacintov, D.A. Scicchitano, Benzo[a]pyrene diol epoxide stimulates an inflammatory response in normal human lung fibroblasts through a p53 and JNK mediated pathway, Carcinogenesis, 31 (2010) 1149-1157. 
[26] N. Podechard, V. Lecureur, E. Le Ferrec, I. Guenon, L. Sparfel, D. Gilot, J.R. Gordon, V. Lagente, O. Fardel, Interleukin-8 induction by the environmental contaminant benzo(a)pyrene is aryl hydrocarbon receptor-dependent and leads to lung inflammation, Toxicol Lett, 177 (2008) 130-137.

[27] C.F. Vogel, E. Sciullo, P. Wong, P. Kuzmicky, N. Kado, F. Matsumura, Induction of proinflammatory cytokines and C-reactive protein in human macrophage cell line U937 exposed to air pollution particulates, Environ Health Perspect, 113 (2005) 1536-1541.

[28] I. Shachar, N. Karin, The dual roles of inflammatory cytokines and chemokines in the regulation of autoimmune diseases and their clinical implications, J Leukoc Biol, 93 (2013) 51-61.

[29] Q. Shi, G.R. Haenen, L. Maas, V.M. Arlt, D. Spina, Y.R. Vasquez, E. Moonen, C. Veith, F.J. Van Schooten, R.W. Godschalk, Inflammation-associated extracellular beta-glucuronidase alters cellular responses to the chemical carcinogen benzo[a]pyrene, Arch Toxicol, (2015).

[30] N. Gungor, R.W. Godschalk, D.M. Pachen, F.J. Van Schooten, A.M. Knaapen, Activated neutrophils inhibit nucleotide excision repair in human pulmonary epithelial cells: role of myeloperoxidase, Faseb J, 21 (2007) 2359-2367.

[31] L. Umannova, M. Machala, J. Topinka, J. Schmuczerova, P. Krcmar, J. Neca, K. Sujanova, A. Kozubik, J. Vondracek, Benzo[a]pyrene and tumor necrosis factor-alpha coordinately increase genotoxic damage and the production of proinflammatory mediators in alveolar epithelial type II cells, Toxicol Lett, 206 (2011) 121-129.

[32] P.J. Borm, A.M. Knaapen, R.P. Schins, R.W. Godschalk, F.J. Schooten, Neutrophils amplify the formation of DNA adducts by benzo[a]pyrene in lung target cells, Environmental Health Perspectives, 105 (1997) 1089-1093.

[33] F.J. Van Schooten, A.W. Boots, A.M. Knaapen, R.W. Godschalk, L.M. Maas, P.J. Borm, M. Drent, J.A. Jacobs, Myeloperoxidase (MPO) -463G->A reduces MPO activity and DNA adduct levels in bronchoalveolar lavages of smokers, Cancer Epidemiol Biomarkers Prev, 13 (2004) 828-833.

[34] N. Gungor, A. Haegens, A.M. Knaapen, R.W. Godschalk, R.K. Chiu, E.F. Wouters, F.J. van Schooten, Lung inflammation is associated with reduced pulmonary nucleotide excision repair in vivo, Mutagenesis, 25 (2010) 77-82.

[35] N. Gungor, J.L. Pennings, A.M. Knaapen, R.K. Chiu, M. Peluso, R.W. Godschalk, F.J. Van Schooten, Transcriptional profiling of the acute pulmonary inflammatory response induced by LPS: role of neutrophils, Respir Res, 11 (2010) 24.

[36] N. Gungor, A.M. Knaapen, A. Munnia, M. Peluso, G.R. Haenen, R.K. Chiu, R.W. Godschalk, F.J. van Schooten, Genotoxic effects of neutrophils and hypochlorous acid, Mutagenesis, 25 (2010) 149-154.

[37] N. Gungor, R.W. Godschalk, D.M. Pachen, F.J. Van Schooten, A.M. Knaapen, Activated neutrophils inhibit nucleotide excision repair in human pulmonary epithelial cells: role of myeloperoxidase, FASEB J, 21 (2007) 2359-2367.

[38] R.P. Schins, A.M. Knaapen, C. Weishaupt, A. Winzer, P.J. Borm, Cytotoxic and inflammatory effects of coarse and fine particulate matter in macrophages and epithelial cells, Annals of Occupational Hygiene, 46 (2002) 203-206.

[39] V. Jaquet, J. Marcoux, E. Forest, K.G. Leidal, S. McCormick, Y. Westermaier, R. Perozzo, O. Plastre, L. Fioraso-Cartier, B. Diebold, L. Scapozza, W.M. Nauseef, F. Fieschi, K.H. Krause, K. Bedard, NADPH oxidase (NOX) isoforms are inhibited by celastrol with a dual mode of action, Br J Pharmacol, 164 (2011) 507-520.

[40] C. Riganti, E. Gazzano, M. Polimeni, C. Costamagna, A. Bosia, D. Ghigo, Diphenyleneiodonium inhibits the cell redox metabolism and induces oxidative stress, J Biol Chem, 279 (2004) 47726-47731.

[41] S.J. Gatley, J.L. Martin, Some aspects of the pharmacology of diphenyleneiodonium, a bivalent iodine compound, Xenobiotica, 9 (1979) 539-546.

[42] Q. Shi, L. Maas, C. Veith, F.J. Van Schooten, R.W. Godschalk, Acidic cellular microenvironment modifies carcinogen-induced DNA damage and repair, Arch Toxicol, (2016).

[43] M.M. Sthijns, M.J. Randall, A. Bast, G.R. Haenen, Adaptation to acrolein through upregulating the protection by glutathione in human bronchial epithelial cells: the materialization of the hormesis concept, Biochemical and biophysical research communications, 446 (2014) 1029-1034.

[44] I. Rahman, A. Kode, S.K. Biswas, Assay for quantitative determination of glutathione and glutathione disulfide levels using enzymatic recycling method, Nature protocols, 1 (2006) 3159-3165.

[45] M.D. Burke, R.T. Mayer, Ethoxyresorufin: direct fluorimetric assay of a microsomal 0-dealkylation which is preferentially inducible by 3-methylcholanthrene, Drug metabolism and disposition: the biological fate of chemicals, 2 (1974) 583-588.

[46] K.J. Livak, T.D. Schmittgen, Analysis of relative gene expression data using real-time quantitative PCR and the 2(-Delta Delta C(T)) Method, Methods, 25 (2001) 402-408.

[47] M.V. Reddy, K. Randerath, Nuclease P1-mediated enhancement of sensitivity of 32P-postlabeling test for structurally diverse DNA adducts, Carcinogenesis, 7 (1986) 1543-1551.

[48] R.W. Godschalk, L.M. Maas, N. Van Zandwijk, L.J. van 't Veer, A. Breedijk, P.J. Borm, J. Verhaert, J.C. Kleinjans, F.J. van Schooten, Differences in aromatic-DNA adduct levels between alveolar macrophages and subpopulations of white blood cells from smokers, Carcinogenesis, 19 (1998) 819-825.

[49] S.A. Langie, A.M. Knaapen, K.J. Brauers, D. van Berlo, F.J. van Schooten, R.W. Godschalk, Development and validation of a modified comet assay to phenotypically assess nucleotide excision repair, Mutagenesis, 21 (2006) 153-158.

[50] W. Qamar, A.Q. Khan, R. Khan, A. Lateef, M. Tahir, M.U. Rehman, F. Ali, S. Sultana, Benzo(a)pyrene-induced pulmonary inflammation, edema, surfactant dysfunction, and injuries in rats: alleviation by farnesol, Exp Lung Res, 38 (2012) 19-27.

[51] N. Podechard, V. Lecureur, E. Le Ferrec, I. Guenon, L. Sparfel, D. Gilot, J.R. Gordon, V. Lagente, O. Fardel, Interleukin-8 induction by the environmental contaminant benzo(a)pyrene is aryl hydrocarbon receptor-dependent and leads to lung inflammation, Toxicology letters, 177 (2008) 130-137. 


\section{Chapter 4}

[52] X.H. Pei, Y. Nakanishi, H. Inoue, K. Takayama, F. Bai, N. Hara, Polycyclic aromatic hydrocarbons induce IL-8 expression through nuclear factor kappaB activation in A549 cell line, Cytokine, 19 (2002) 236-241.

[53] R.E. Nocker, D.F. Schoonbrood, E.A. van de Graaf, C.E. Hack, R. Lutter, H.M. Jansen, T.A. Out, Interleukin-8 in airway inflammation in patients with asthma and chronic obstructive pulmonary disease, Int Arch Allergy Immunol, 109 (1996) 183-191.

[54] S.K. Manna, G.T. Ramesh, Interleukin-8 induces nuclear transcription factor-kappaB through a TRAF6-dependent pathway, J Biol Chem, 280 (2005) 7010-7021.

[55] E. Hoffmann, 0. Dittrich-Breiholz, H. Holtmann, M. Kracht, Multiple control of interleukin-8 gene expression, J Leukoc Biol, 72 (2002) 847-855.

[56] H. Korkaya, G.-i. Kim, A. Davis, F. Malik, N.L. Henry, S. Ithimakin, A.A. Quraishi, N. Tawakkol, R. D’Angelo, A. Paulson, S. Chung, T. Luther, H.S. Paholak, S. Liu, K. Hassan, Q. Zen, S.G. Clouthier, M.S. Wicha, Activation of an IL-6 Inflammatory Loop Mediates Trastuzumab Resistance in HER2 Overexpressing Breast Cancers by Expanding the Cancer Stem Cell Population, Molecular cell, 47 (2012) 570-584.

[57] T.A. Libermann, D. Baltimore, Activation of interleukin-6 gene expression through the NF-kappa B transcription factor, Molecular and Cellular Biology, 10 (1990) 2327-2334.

[58] G.Y. Kim, J.W. Lee, H.C. Ryu, J.D. Wei, C.M. Seong, J.H. Kim, Proinflammatory cytokine IL-1beta stimulates IL-8 synthesis in mast cells via a leukotriene B4 receptor 2-linked pathway, contributing to angiogenesis, J Immunol, 184 (2010) 3946-3954.

[59] J.P. Fitzgerald, B. Nayak, K. Shanmugasundaram, W. Friedrichs, S. Sudarshan, A.A. Eid, T. DeNapoli, D.J. Parekh, Y. Gorin, K. Block, Nox4 mediates renal cell carcinoma cell invasion through hypoxia-induced interleukin 6-and 8-production, PloS one, 7 (2012) e30712.

[60] D.W. Nebert, T.P. Dalton, A.B. Okey, F.J. Gonzalez, Role of aryl hydrocarbon receptor-mediated induction of the CYP1 enzymes in environmental toxicity and cancer, J Biol Chem, 279 (2004) 23847-23850.

[61] S. Brechard, J.L. Bueb, E.J. Tschirhart, Interleukin-8 primes oxidative burst in neutrophil-like HL-60 through changes in cytosolic calcium, Cell Calcium, 37 (2005) 531-540.

[62] Z.X. Du, H.Y. Zhang, X. Meng, Y. Guan, H.Q. Wang, Role of oxidative stress and intracellular glutathione in the sensitivity to apoptosis induced by proteasome inhibitor in thyroid cancer cells, BMC Cancer, 9 (2009) 56.

[63] O. Zitka, S. Skalickova, J. Gumulec, M. Masarik, V. Adam, J. Hubalek, L. Trnkova, J. Kruseova, T. Eckschlager, R. Kizek, Redox status expressed as GSH:GSSG ratio as a marker for oxidative stress in paediatric tumour patients, Oncology Letters, 4 (2012) 1247-1253.

[64] T.Y. Aw, Cellular Redox: A Modulator of Intestinal Epithelial Cell Proliferation, Physiology, 18 (2003) 201-204.

[65] S.A. Langie, A.M. Knaapen, J.M. Houben, F.C. van Kempen, J.P. de Hoon, R.W. Gottschalk, R.W. Godschalk, F.J. van Schooten, The role of glutathione in the regulation of nucleotide excision repair during oxidative stress, Toxicol Lett, 168 (2007) 302-309. 


\section{Supplement materials}

A

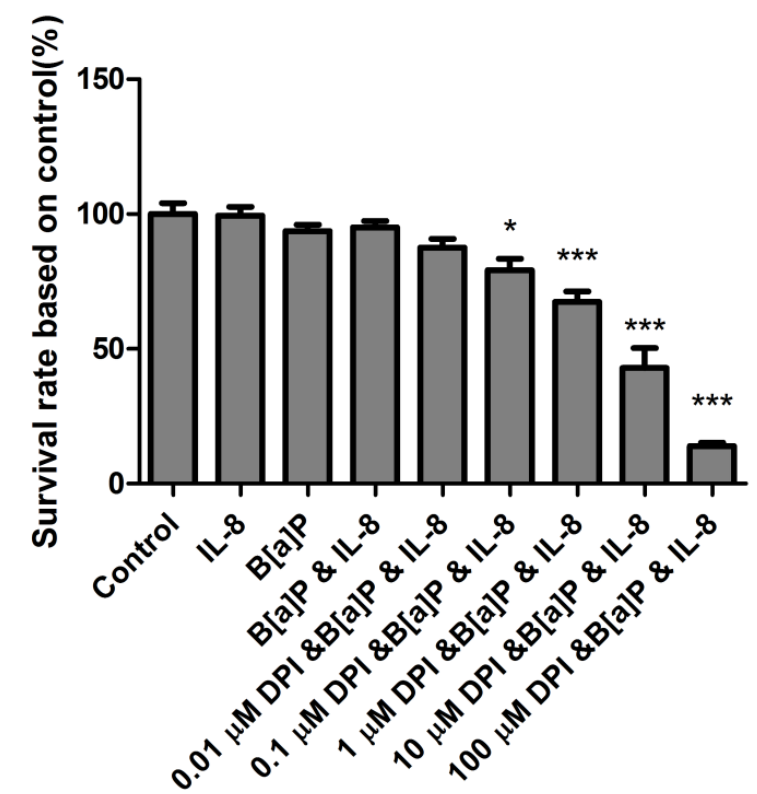

C

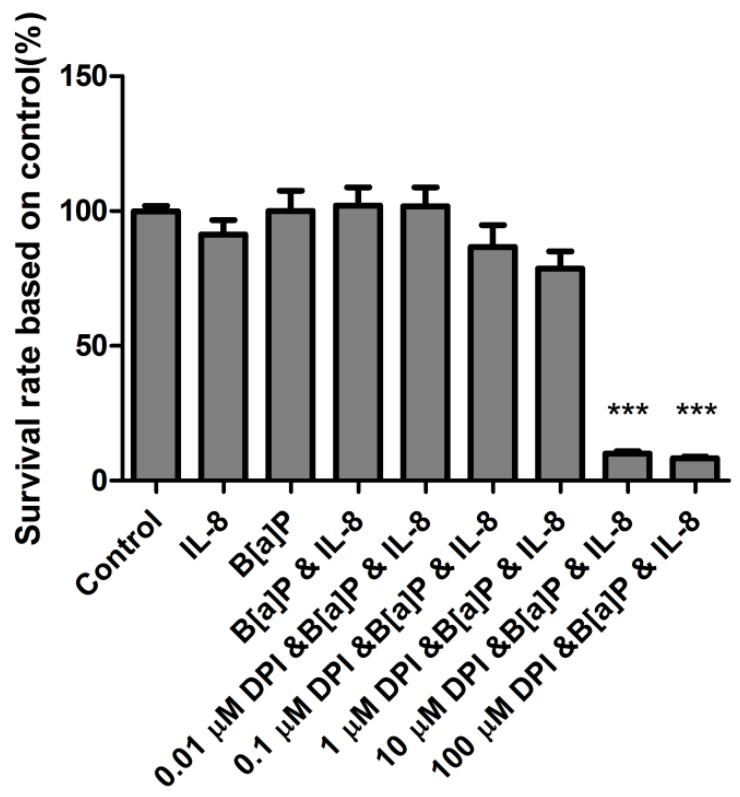

B

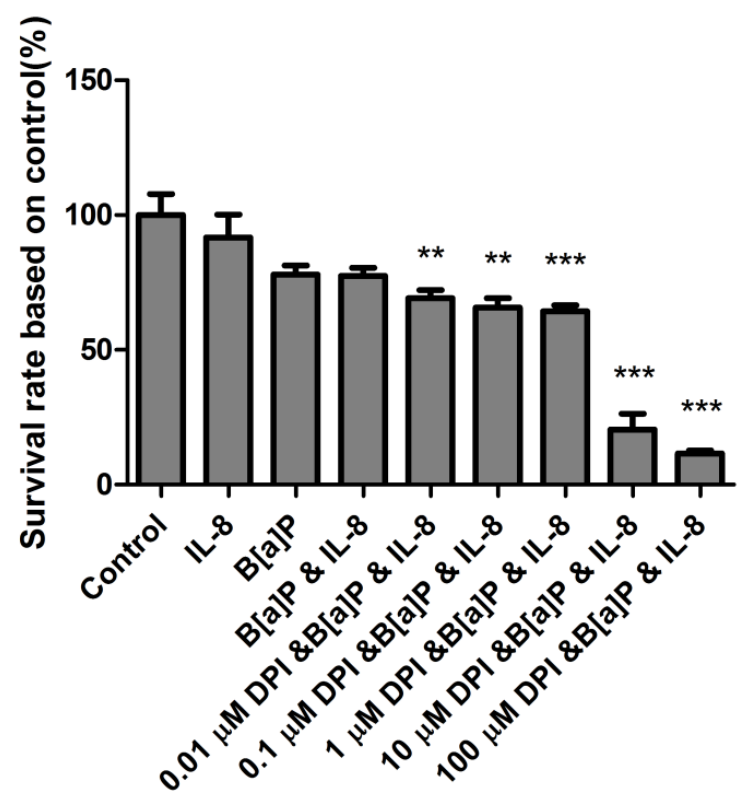

Figure 1. Effect of each treatment on BEAS-2B cell viability/cytotoxicity (MTT). Different treatments including control, IL-8 $(10 \mathrm{ng} / \mathrm{ml}), \mathrm{B}[\mathrm{a}] \mathrm{P}(1 \mu \mathrm{M}), \mathrm{IL}-8$ with B[a]P and various DPI concentrations $(0.01$ to $100 \mu \mathrm{M})$, and incubation times (6, 24 and 48 hours) were used. Data is presented as percentage to control (mean \pm SEM, $n=6$ ). ${ }^{*} \mathrm{p}<0.05,{ }^{* *} \mathrm{p}<0.01$ and ${ }^{* * *} \mathrm{p}<0.001$. 



\section{Chapter 5}

\section{Pulmonary Inflammation Impacts on \\ CYP1A1-Mediated Respiratory Tract DNA \\ Damage Induced by the Carcinogenic Air \\ Pollutant Benzo[a]pyrene}

Arlt VM, Krais AM, Godschalk RW, Riffo-Vasquez Y, Mrizova I, Roufosse CA, Corbin C, Shi

Q, Frei E, Stiborova M, van Schooten FJ, Phillips DH, Spina D.

Toxicol Sci. 2015 Aug;146(2):213-25. doi: 10.1093/toxsci/kfv086. 


\begin{abstract}
Pulmonary inflammation can contribute to the development of lung cancer in humans. We investigated whether pulmonary inflammation alters the genotoxicity of polycyclic aromatic hydrocarbons (PAHs) in the lungs of mice and what mechanisms are involved. To model non-allergic acute inflammation, mice were exposed intranasally to lipopolysaccharide (LPS; $20 \mu \mathrm{g} /$ mouse) and then instilled intratracheally with benzo[a]pyrene (BaP; $0.5 \mathrm{mg} /$ mouse). BaP-DNA adduct levels, measured by 32P-postlabelling analysis, were $\sim 3$-fold higher in the lungs of LPS/BaP-treated mice than in mice treated with BaP alone. Pulmonary Cyp1a1 enzyme activity was decreased in LPS/BaP-treated mice relative to BaP-treated mice suggesting that pulmonary inflammation impacted on BaP-induced Cyp1a1 activity in the lung. Our results showed that Cyp1a1 appears to be important for BaP detoxification in vivo and that the decrease of pulmonary Cyp1a1 activity in LPS/BaP-treated mice results in a decrease of pulmonary $\mathrm{BaP}$ detoxification, thereby enhancing BaP genotoxicity (i.e. DNA adduct formation) in the lung. Because less BaP was detoxified by Cyp1a1 in the lungs of LPS/BaP-treated mice, more BaP circulated via the blood to extra-pulmonary tissues relative to mice treated with $\mathrm{BaP}$ only. Indeed, we observed higher BaP-DNA adduct levels in livers of LPS/BaP-treated mice compared to BaP-treated mice. Our results indicate that pulmonary inflammation could be a critical determinant in the induction of genotoxicity in the lung by PAHs like BaP. Cyp1a1 appears to be involved in both BaP bioactivation and detoxification although the contributions of other enzymes to BaP-DNA adduct formation in lung and liver under inflammatory conditions remains to be explored.
\end{abstract}

Keywords: benzo[a]pyrene, pulmonary inflammation, cytochrome P450, carcinogen metabolism, DNA adducts, bronchoalveolar lavage. 


\section{INTRODUCTION}

Globally, lung cancer is the leading cause of cancer death. Tobacco smoking is the overwhelming cause of lung cancer, although vehicle engine exhaust (e.g. diesel exhaust) and ambient air pollution are also implicated $[1,2]$. Inflammatory diseases of the lung, including fibrosis and chronic obstructive pulmonary disease (COPD), are associated with higher lung cancer risk $[3,4]$. Lung cancer risk in smokers with COPD is increased up to 10-fold in comparison to smokers without COPD [3]. Many inflammatory agents can contribute to the development of diseases like COPD or asthma, including inhaled combustion derived particles such as cigarette smoke, ambient air particulate matter and diesel exhaust particles [5]. Inhalation of such particles can cause a local pulmonary response which is characterised by the influx of neutrophils into the airways [6]. In contrast to their innate protective role in immunity, neutrophils contribute to the pathogenesis of inflammatory lung diseases like COPD and promote tumour development $[6,7]$.

A number of studies have found that occupational exposure to diesel exhaust leads to increased risk of lung cancer [8,9] and the International Agency for Research on Cancer (IARC) has classified diesel engine exhaust as carcinogenic to humans (Group 1) [1]. However, the mechanism of diesel carcinogenesis and precise identity of the carcinogenic components of diesel exhaust are still incompletely understood, as is the magnitude of the carcinogenic risk from environmental exposure. Although exposure to diesel exhaust material induces pulmonary inflammation and exacerbates chronic respiratory inflammatory conditions [5], the contribution of such inflammation to diesel exhaust associated carcinogenic risk potential has not been examined in any great detail. By analogy with the causation of lung cancer by tobacco smoking [10] it was therefore the aim of this study to examine how inflammation in the lung alters the genotoxicity of polycyclic aromatic hydrocarbons (PAHs), which occur in the particulate phase of diesel exhaust, and what specific mechanisms are involved.

PAHs such as benzo[a]pyrene (BaP), also an IARC Group 1 carcinogen [11], exert their carcinogenic effects only after metabolic activation. As shown in Figure $1 \mathrm{BaP}$ is activated by cytochrome P450 (CYP) enzymes, CYP1A1 and CYP1B1 being the most important isoenzymes [12], resulting in highly reactive diol-epoxides capable of forming covalent DNA adducts that can lead to mutations through errors in DNA replication [13]. Inflammatory reactions in vivo involve the production and release of a range of signalling molecules including cytokines and chemokines [7, 14]. In vitro experiments have shown that cytokines like tumour necrosis factor- $\alpha$ (TNF- $\alpha$ ) formed after environmental exposures can alter the expression of metabolic enzymes such as CYPs (e.g. CYP1A1, CYP1B1) involved in BaP bioactivation $[15,16]$. Other in vitro studies have revealed that neutrophil-derived myeloperoxidase (MPO) can activate the BaP metabolite BaP-7,8-dihydrodiol to reactive species (i.e. BaP-7,8-dihydrodiol-9,10-epoxide [BPDE]) that form DNA adducts in lung cells $[17,18]$. In the present study we investigated whether lung inflammation alters the capacity for diesel exhaust carcinogens like BaP to cause DNA damage (e.g. DNA adducts) in vivo and the mechanisms involved. To model non-allergic acute inflammation, mice were exposed to lipopolysaccharide (LPS) and then instilled with BaP. DNA adduct formation was determined by ${ }^{32} \mathrm{P}$-postlabelling analysis. 


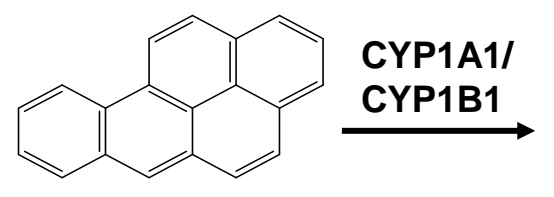

BaP

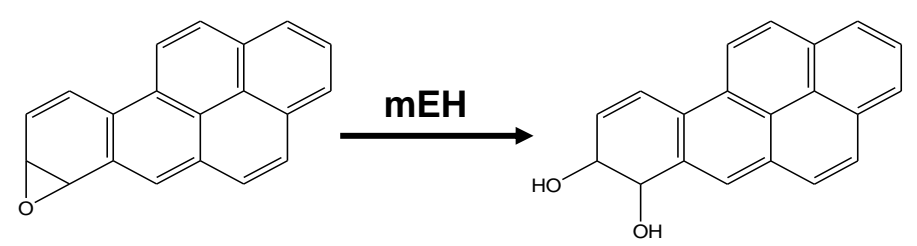

BaP-7,8-epoxide

BaP-7,8-dihydrodiol
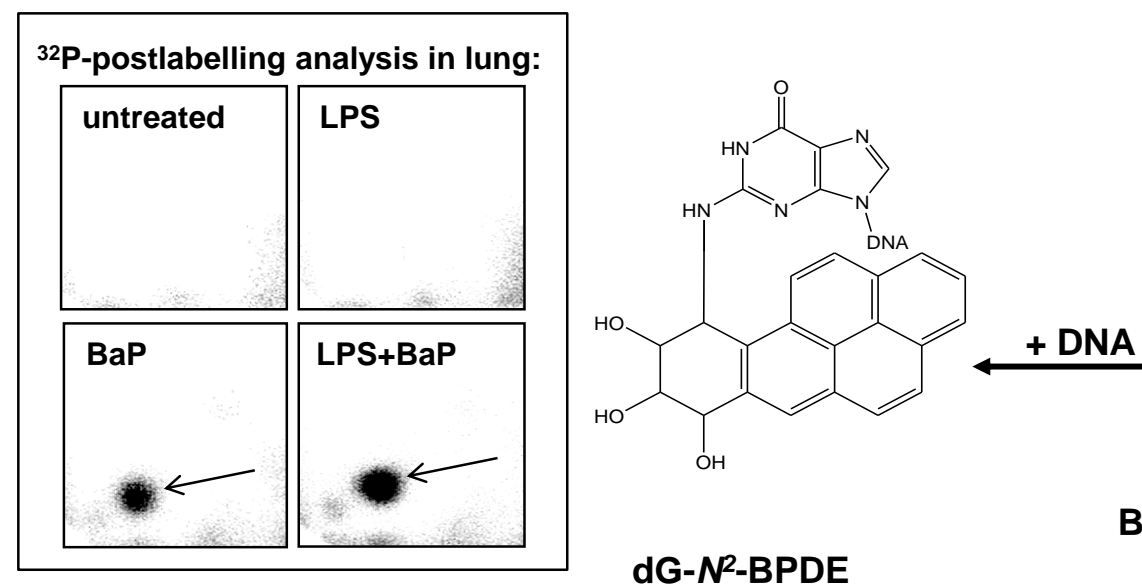

dG- $N^{2}-B P D E$

Figure 1. Main metabolic pathway in the bioactivation and DNA adduct formation of BaP in lung. See text for details. CYP, cytochrome P450; $\mathrm{mEH}$, microsomal epoxide hydrolase; MPO, myleoperoxidase.Inserts: Autoradiographic profiles of DNA adducts formed in lungs of mice; the origin, at the bottom left-hand corner, was cut off before exposure. Autoradiographic profiles in the lungs are representative of those observed in the livers. The arrow shows 10-(deoxyguanosin-N2-yl)-7,8,9-trihydroxy-7,8,9,10-tetrahydro-BaP (dG-N2-BPDE).

\section{MATERIALS AND METHODS}

Carcinogen. Benzo[a]pyrene (BaP; purity $\geq 96 \%$ ) was obtained from Sigma Aldrich.

Animal treatment. C57B16 mice (male; 8-10 weeks old, 20-25 g) were obtained from Charles River Laboratories. All animal experiments were carried out at King's College London under license according to protocols approved by the Home Office under 'The Animals (Scientific Procedures) Act (1986)' after approval by the institutional ethics committee. Animals were kept under controlled pathogen-free conditions and allowed food and water ad libitum. In total, four groups of mice ( $n=4$ per experiment; repeated in triplicate; $n=12$ in total) were used as follows (see Fig. 2): Group I: mice were instilled nasally with saline and 24 hours later instilled intratracheally with vehicle, tricaprylin $(25 \mu \mathrm{L} /$ mouse). Group II: to induce acute pulmonary inflammation mice received an intranasal dose of $20 \mu \mathrm{g}$ lipopolysaccharide (LPS; Escherichia coli, serotype 055:B5; $1 \mathrm{mg} / \mathrm{mL}$; Sigma), and 24 hours later they received tricaprylin ( $25 \mu \mathrm{L} / \mathrm{mouse}$ ) by intratracheal instillation. Group III: mice were instilled nasally with saline and 24 hours later instilled intratracheally with $\mathrm{BaP}(0.5 \mathrm{mg} \mathrm{BaP}$ dissolved in $25 \mu \mathrm{L}$ tricaprylin). Group IV: mice received an intranasal administration of $20 \mu \mathrm{g}$ LPS followed 24 hours later with $\mathrm{BaP}(0.5 \mathrm{mg} \mathrm{BaP} /$ mouse $)$ by intratracheal instillation. In order to have sufficient material available for histopathology and several biological assays, experiments were performed in triplicate on separate occasions $(3 \times n=4 /$ group). All instillations were performed under anaesthesia with isoflurane (Sigma) following injection with ketamine/zylazine ( $1 \mathrm{mg} / 0.166 \mathrm{mg}$ per mouse, respectively; Sigma). Mice were killed 3 days after exposure after anaesthesia with $2 \mathrm{~g} / \mathrm{kg}$ body weight urethane (Sigma) by intraperitoneal administration and a cannula was inserted into the exposed trachea. For the collection of inflammatory cells by bronchoalveolar lavage (BAL) three 
0.5-mL aliquots of sterile saline were injected into the lungs. Lung and liver tissue were also collected, snap-frozen in liquid nitrogen and stored at $-80^{\circ} \mathrm{C}$ until analysis. For histopathology lung sections were fixed for 48 hours in PBS containing 4\% paraformaldehyde.

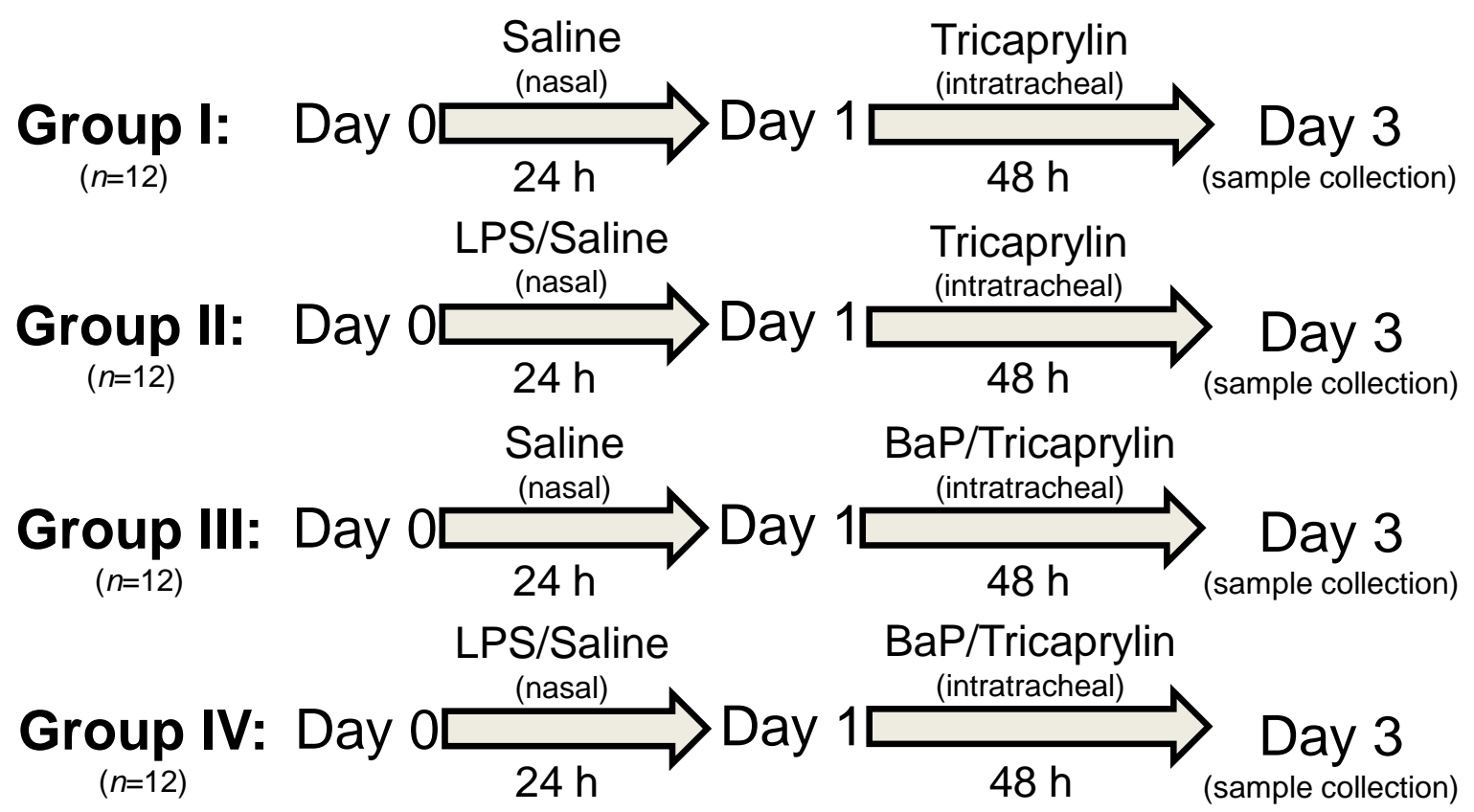

Figure 2. Study design and animal treatment. See Materials \& Methods for additional information.

Assessment of the pulmonary inflammation by histopathology and BAL analysis. Fixed lung sections were embedded in paraffin and 7-micron sections were cut and stained with haematoxylin-eosin (H\&E) [19]. Slides were randomized and analysed at $10 \times$ magnification for the number of fields with inflammation, expressed as $\%$ of the total number of fields of lung tissue on the section. At $40 \times$ magnification, inflammation was qualified as either predominantly neutrophilic or predominantly monocytic.

From the collected BAL fluid, a $50-\mu \mathrm{L}$ aliquot was added to $50 \mu \mathrm{L}$ of haemolysis (Turk) solution. The total number of cells in the BAL fluid was counted with an improved Neubauer haemocytometer. For differential cell counts, cytospin preparations were prepared from aliquots of BAL fluid $(100 \mu \mathrm{L})$, centrifuged at $250 \mathrm{~g}$ for 1 min using a Shandon Cytospin 2 (Shandon Southern Instruments, Sewickley, PA, USA) at room temperature and stained with Diffquick. Two hundred cells were counted to determine the proportion of neutrophils, eosinophils and monocytes using standard morphological criteria [20].

Detection of DNA adducts. DNA from tissue was isolated by a standard phenol-chloroform extraction method. DNA adduct analysis was performed by the nuclease $\mathrm{P} 1$ enrichment version of the ${ }^{32} \mathrm{P}$-postlabelling method as described previously $[21,22]$ with minor modifications. DNA samples $(4 \mu \mathrm{g})$ were digested with micrococcal nuclease (288 mU; Sigma) and calf spleen phosphodiesterase (1.2 mU; MP Biomedical), and then enriched and labelled as reported. Resolution of ${ }^{32} \mathrm{P}-\mathrm{labelled}$ adducts was performed by polyethyleneimine-cellulose (PEI) thin-layer chromatography (TLC) [23]. After chromatography TLC plates were scanned using a Packard Instant Imager (Dowers Grove, IL, USA). DNA adduct levels (RAL, relative adduct labelling) were calculated from adduct counts per minute $(\mathrm{cpm})$, the specific activity of $\left[\gamma^{-32} \mathrm{P}\right] \mathrm{ATP}$ and the amount of 
DNA (pmol) used. Results were expressed as DNA adducts $/ 10^{8}$ normal nucleotides (nt). An external BPDE-modified DNA standard was used to identify BaP-DNA adducts.

Preparation of pulmonary and hepatic microsomal and cytosolic samples. Pooled pulmonary and hepatic microsomal and cytosolic fractions $(n=4)$ were isolated as described $[23,24]$. Briefly, tissue samples were pulverized by grinding snap-frozen pooled lung or liver specimens in a Teflon container frozen in liquid nitrogen with a steel ball using a dismembrator (2600 UPM for 30 seconds; Braun Melsungen AG, Germany). The frozen tissue powder was then homogenized by hand in $0.067 \mathrm{M}$ potassium phosphate buffer ( $\mathrm{pH}$ 7.4) with $0.5 \%$ potassium chloride in a Potter-Elvehjem glass-Teflon homogenizer. The buffer volume (in $\mu \mathrm{L}$ ) used was three times the weight (in mg) of the organ. Nuclei and debris were removed by centrifugation at $18,000 \mathrm{~g}$ for 30 minutes at $4^{\circ} \mathrm{C}$. From the supernatant, microsomal pellets were obtained at $100,000 \mathrm{~g}$ after 1 hour. Supernatant (cytosolic fraction) was gently levered off the sediment into $200-\mu \mathrm{L}$ aliquots and stored at $-80^{\circ} \mathrm{C}$ until further analysis. The sediment (microsomal fraction) was resuspended in phosphate buffer (lung in approximately the same volume (in $\mu \mathrm{L}$ ) as their weight (in mg), liver in twice their weight) and small aliquots $(100 \mu \mathrm{L})$ were stored at $-80^{\circ} \mathrm{C}$ until further analysis. Protein concentrations in cytosolic and microsomal fractions were measured using the bicinchoninic acid (BCA) protein assay with bovine serum albumin as a standard.

Expression of pulmonary and hepatic Cyp1 protein. Immunoquantitation of Cyp1a1 and Cyp1b1 in microsomal fractions was carried out by sodium dodecyl sulphate (SDS)-10\% polyacrylamide gel electrophoresis of samples containing $30 \mu \mathrm{g}$ microsomal proteins. After migration, proteins were transferred onto polyvinylidenedifluoride membranes. Mouse Cyp1a1 protein was probed with goat-anti rat CYP1A1 polyclonal antibodies (1:2500, Antibodies-online $\mathrm{GmbH}$, Aachen, Germany) as reported elsewhere [25]. The goat-anti rat CYP1A1 antibodies recognize this enzyme in mouse pulmonary and hepatic microsomes as one protein band. Rat recombinant CYP1A1 (in Supersomes $^{\mathrm{TM}}$, Gentest Corp., Woburn, MA, USA) was used as positive controls to identify the band of Cyp1a1 in murine microsomes. Mouse Cyp1b1 protein was probed with rabbit-anti human CYP1B1 polyclonal antibodies (G-25) (1:200, Santa Cruz Biotechnology, Dallas, Texas, USA). The goat-anti rabbit CYP1B1 antibodies recognise this enzyme as one protein band. Human recombinant CYP1B1 (in Supersomes ${ }^{\mathrm{TM}}$ ) was used as positive control. The antigen-antibody complex was visualized with an alkaline phosphatase-conjugated rabbit anti-chicken IgG antibody and 5-bromo-4-chloro-3-indolylphosphate/nitrobluetetrazolium as chromogenic substrate [26]. Glyceraldehyde phosphate dehydrogenase was used as loading control and detected by its antibody (1:750, Millipore; MA, USA). Band intensity was quantified using the GeneTools software.

Measurement of pulmonary and hepatic Cyp1a enzyme activity. Microsomal Cyp1a enzyme activity (measured as relative fluorescence unit [RFU]/minute) was determined by following the conversion of 7-ethoxyresorufin into resorufin (EROD assay) using fluorescent measurement on a Synergy HT Plate Reader (Bio-TEK Instruments, USA; 530 $\mathrm{nm}$ excitation, $580 \mathrm{~nm}$ emission) [27]. Cyp1a enzyme activity (measured as RFU/ minute) was also measured with 3-cyano-7-ethoxycoumarin (CEC) as substrate [24]. Briefly, in a 96-well plate the incubation mixture $(200 \mu \mathrm{L})$ contained $67 \mathrm{mM}$ potassium phosphate buffer ( $\mathrm{pH}$ 7.4), $9 \mathrm{mM}$ glucose-6-phosphate, $0.9 \mathrm{U}$ glucose-6-phosphate dehydrogenase, $4.5 \mathrm{mM}$ magnesium chloride, $0.9 \mathrm{mM}$ NADP, $5 \mu \mathrm{M}$ CEC (dissolved in 106 
DMSO) and $50 \mu \mathrm{g}$ of microsomal fraction. The reaction was initiated by the addition of CEC and the formation of 3-cyano-7-hydroxycoumarin was measured every 2 minutes for 30 minutes ( $409 \mathrm{~nm}$ excitation, $460 \mathrm{~nm}$ emission).

Measurement of pulmonary and hepatic Nqo1 enzyme activity. Nqo1 enzyme activity in cytosolic samples was measured with menadione (2-methyl-1,4-naphthoquinone) as substrate essentially as described previously [27]. The standard assay system in a 24-well plate contained in $1 \mathrm{~mL}$ (final concentration) $25 \mathrm{mM}$ Tris- $\mathrm{HCl}$ (pH 7.5), $0.12 \%$ bovine serum albumin, $200 \mu \mathrm{M}$ NADH, $10 \mu \mathrm{M}$ menadione (dissolved in methanol), $77 \mu \mathrm{M}$ cytochrome $c$ and $50 \mu \mathrm{g}$ of cytosolic fraction. The reaction was initiated by the addition of the cytosolic fraction. Enzyme activity (measured as RFU/min) was determined by following the conversion of cytochrome $c$ at $550 \mathrm{~nm}$ on a Synergy HT Plate Reader.

Expression of Cyp1b1 gene expression in the lung. Gene expression analysis was essentially performed as described [28]. Briefly, RNA was isolated from lung samples using the GenElute Mammalian Total RNA Mini Prep Kit (Sigma, UK) according to the manufacturer's instruction. Reserve transcription was performed using random primers and SuperScript ${ }^{\circledR}$ III Reserve Transcriptase (Life Technologies, UK) RNA expression was analysed by quantitative real-time polymerase chain reaction (qRT-PCR) using TaqMan ${ }^{\circledR}$ Universal PCR Master Mix (Life Technologies) and TaqMan ${ }^{\circledR}$ gene expression primers according to the manufacturer's protocol with a 7500HT Fast Real Time PCR System (Applied Biosystems, UK). Probe (Life Technologies, UK) Cyp1b1-Mm00487229_m1 was used and expression levels were normalised to housekeeping gene Gapdh (4352341E). Relative gene expression was calculated using the comparative threshold cycle $\left(C_{T}\right)$ method [29].

Measurement of nucleotide excision repair (NER) capacity. The ability of NER-related enzymes present in isolated tissue extracts to detect and incise substrate DNA containing BPDE-DNA adducts was measured using a modified comet assay [30]. Tissue protein extracts were prepared as described previously [31], and protein concentrations were optimised for analysis of lung and liver samples $(0.2 \mathrm{mg} / \mathrm{mL})$. The ex vivo repair incubation and electrophoresis were performed according to the published protocol [30]. Dried slides stained with ethidium bromide $(10 \mu \mathrm{g} / \mathrm{mL})$ were viewed with a Zeiss Axioskop fluorescence microscope. Comets were scored using the Comet III system (Perceptive Instruments, UK). Fifty nucleoids were assessed per slide and each sample was analysed in duplicate. All samples were measured blindly. Tail intensity (\% tail DNA) was used to calculate repair capacity of the tissue extracts [30].

Statistical analysis. Statistical analyses were performed with Prism GraphPad Software and $P<0.05$ was considered significant.

\section{RESULTS}

\section{Pulmonary histopathology}

Pulmonary inflammation three days after exposure to LPS was assessed by H\&E staining (Fig. 3). The semi-quantitative assessment is summarised in Table 1. The bronchi and vessels in all groups appeared unaffected. In all four groups, there were foci of alveolar inflammation (pneumonia), but the size of the foci and the composition of inflammatory cells were different. Controls (Group I) showed few inflammatory foci (5-14\% of fields), which were small in size and composed predominantly of neutrophils. LPS-treated 
animals (Group II) showed an increase in inflammatory foci (26-92\% of fields) as loose collections mainly of macrophages extending over a larger area. $\mathrm{BaP}$ and LPS+BaP treated animals (Groups III and IV) showed an intermediate number of inflammatory foci (4-32\% and $4-41 \%$ respectively), roughly of the same composition and size as seen in the LPS-treated animals (Group II).

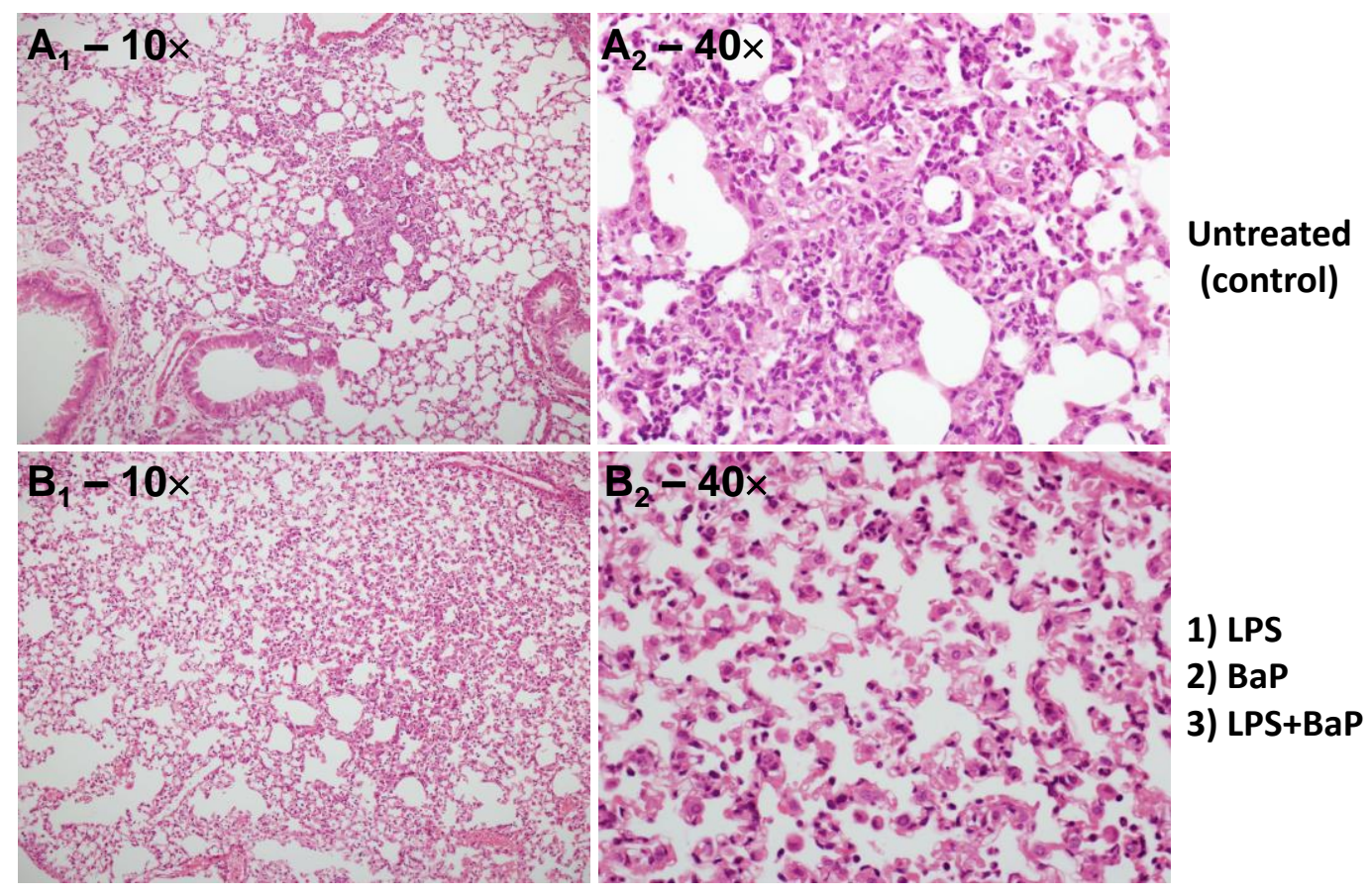

Figure 3. Histological analysis of pulmonary inflammation. Representative photomicrographs of lung tissue section stained with H\&E: (A) control mice: small sense foci of predominantly neutrophils; (B) LPS-, BaP- or LPS+BaP-treated lung: large loose foci of predominantly monocytes. Original magnification x10, left panel; $x 40$, right panel. Semi-quantitative assessment of pulmonary inflammation is summarised in Table 1.

Table 1: Semi-quantitative assessment of pulmonary inflammation from H\&E staining of lung sections

\begin{tabular}{|c|c|c|c|}
\hline $\begin{array}{l}\text { Treatment group } \\
(n=4 \text { per group) }\end{array}$ & $\begin{array}{c}\% \text { of fields with } \\
\text { inflammation (median) }\end{array}$ & $\begin{array}{l}\text { Size of inflammatory } \\
\text { foci } \\
\end{array}$ & $\begin{array}{l}\text { Predominant cell } \\
\text { type }\end{array}$ \\
\hline Controls (Group I) & $5-14(6.5)$ & Small dense & Neutrophils \\
\hline LPS (Group II) & $26-92(79)$ & Large loose & Monocytes \\
\hline BaP (Group III) & $4-32(12.5)$ & Large loose & Monocytes \\
\hline LPS+BaP (Group IV) & $4-41(18.5)$ & Large loose & Monocytes \\
\hline
\end{tabular}

\section{Inflammatory response in BAL}

Using morphological criteria the number of monocytes, eosinophils and neutrophils were counted in BAL fluid (Fig. 4). LPS treatment (Group II) caused significant increases in neutrophils (Fig. 4B) and mononuclear leukocytes (Fig. 4C) recruitment to the lung relative to control mice (Group I). No such effect was seen for eosinophils (Fig. 4D). The recruitment of neutrophils, used as a measure of pulmonary inflammation, in mice treated with LPS and LPS/BaP was high (Fig. 4B). In LPS-treated mice (Group II) the number of neutrophils was $\sim 22$-fold higher than in control mice (Group I) and BaP-treated mice (Group III), however, additional treatment with BaP (Group IV) had no additional effect on neutrophil recruitment. More specifically, 2-way ANOVA showed a 108 
statistically significant effect of LPS-induced inflammation on neutrophil recruitment $[\mathrm{F}(1,41)=31.11, P<0.0001]$ but was not affected by BaP treatment. There was no significant interaction effect.
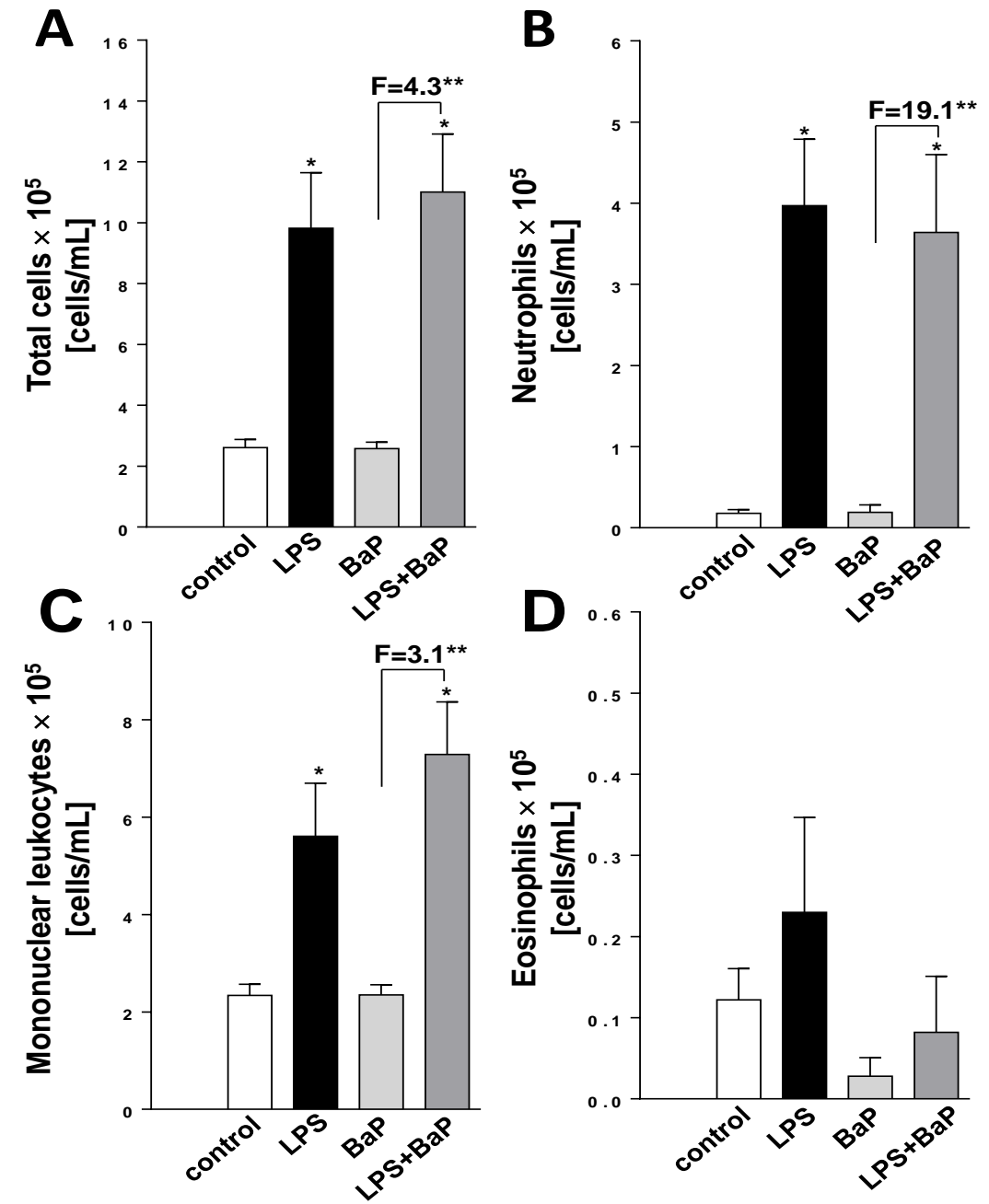

Figure 4. Effect of $\mathrm{BaP}$ treatment on pulmonary inflammation assessing bronchoalveolar lavage fluid. Total (A), neutrophil (B), mononuclear leukocytes (C) and eosinophil (D) cells were quantified by haemocytometry from mice treated with LPS, BaP, LPS+BaP or vehicle only (control). All values are given as the means \pm SEM $(n=12$ per group). In the figure $F=$ fold difference in cell number in LPS/BaP group compared with cell number in $\mathrm{BaP}$ group. Statistical analysis was performed by two-way ANOVA followed by Tukey's multiple comparisons test ${ }^{*} \mathrm{P}<0.05$, versus control [untreated] mice; ${ }^{* * P}<0.05$, different $\mathrm{BaP}$ only treated mice).

\section{DNA adduct formation in lung and liver}

The DNA adduct pattern observed by TLC ${ }^{32} \mathrm{P}$-postlabelling in BaP-treated mice (Groups III and IV) consisted of a single adduct spot, in both lung and liver. Although the ${ }^{32} \mathrm{P}$-postlabelling method does not provide any structural information of the BaP-derived DNA adduct formed, using mass spectrometry the adduct formed in vivo was previously identified [23] as 10-(deoxyguanosin- $N^{2}$-yl)-7,8,9-trihydroxy-7,8,9,10-tetrahydro-BaP (dG- $N^{2}$-BPDE) (Fig. 1; inserts). DNA adducts were not detected either in control (Group I) or in LPS-treated animals (Group II). BaP-DNA adduct levels ranged from 10-30 adducts per $10^{8}$ nucleotides (Fig. 5). Adduct levels were significantly higher in both lung ( 2.5-fold) and liver ( 23.5 -fold) of LPS/BaP-treated mice (Group IV) than in mice treated with BaP alone (Group III). 

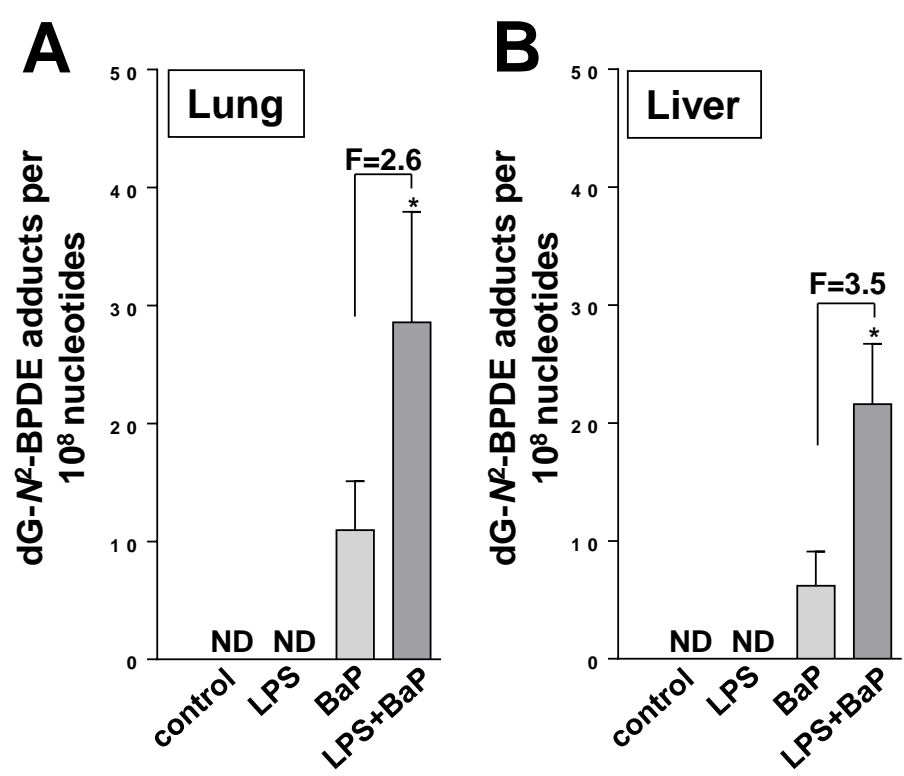
Figure 5. BaP-DNA adduct formation. DNA adduct levels (RAL, relative adduct labelling) were measured by 32P-postlabelling in lung (A) and liver (B) of mice treated with LPS, BaP, LPS+BaP or vehicle only (control). All values are given as the means $\pm \mathrm{SD}(\mathrm{n}=4$ per group). $\mathrm{ND}$, not detected. In the figure $\mathrm{F}=$ fold difference in DNA binding in LPS/BaP group compared with DNA binding in $\mathrm{BaP}$ group. Statistical analysis was performed by unpaired two-tailed t-test $(* \mathrm{P}<0.05$, versus BaP only treated mice).

\section{Expression of BaP-metabolising enzymes in lung and liver}

Cyp1a1 protein levels measured by Western blotting showed a $\sim 5$-fold induction in the lungs after BaP treatment (Group III) (Fig. 6A). Similarly pulmonary Cyp1a1 protein levels increased $\sim 5$-fold in LPS/BaP-treated mice (Group IV) relative to mice treated with LPS alone (Group II). Even though intensities of the Cyp1a1 protein bands in control (untreated) and LPS-treated mice were weak, a clear increase in Cyp1a1 protein levels was detectable in BaP- and LPS/BaP-treated mice. In accordance with these findings treatment of mice with BaP led to a strong increase in EROD (Fig. 7A) and CEC activity (Fig. 7B) in pulmonary microsomes. Interestingly, pulmonary Cyp1a enzyme activity was significantly lower $(\sim 2$-fold) in LPS/BaP-treated mice (Group IV) than in mice treated with BaP alone (Group III).
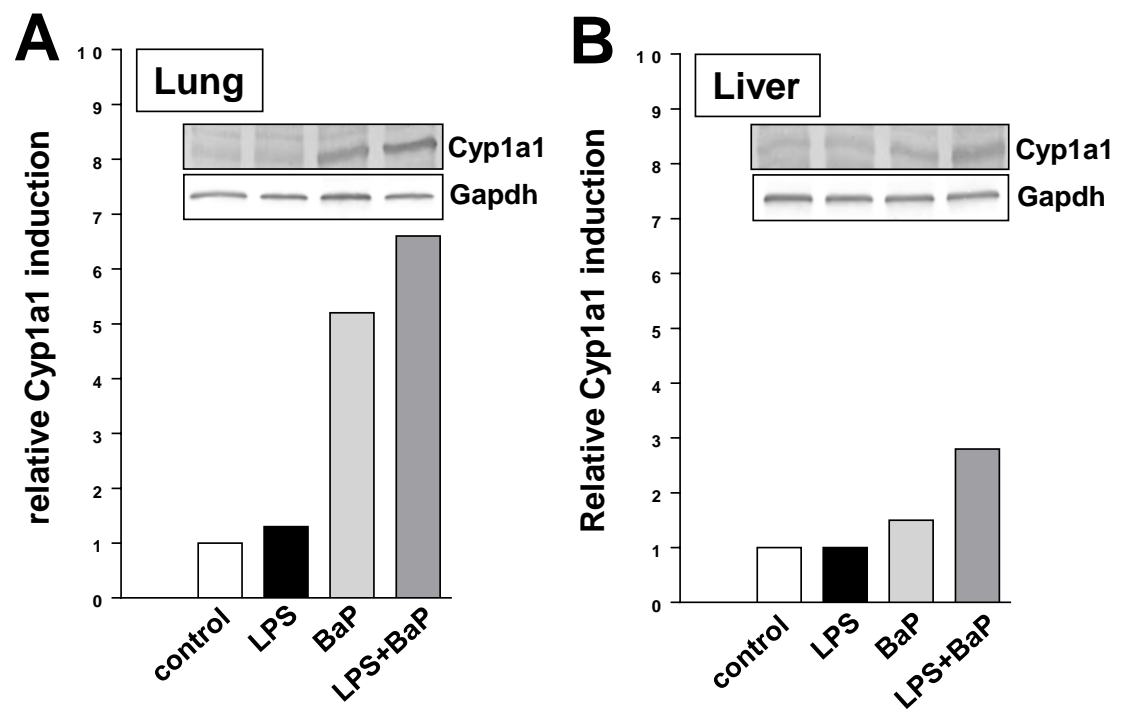

Figure 6. Western blot analysis of Cyp1a1 protein expression in lung (A) and liver (B) of mice treated with LPS, $\mathrm{BaP}, \mathrm{LPS}+\mathrm{BaP}$ or vehicle only (control). Representative images of the Western blotting are shown; duplicate analysis was performed on separate occasions. Gapdh protein expression was used as loading control.

Using Western blotting we found only a slight increase ( 1.5 fold $)$ in Cyp1a1 protein levels in the liver after BaP treatment (Group III) (Fig. 6B). Hepatic Cyp1a1 protein levels increased further in the LPS/BaP-treated mice (Group IV) relative to mice treated with 110 
BaP only (Group III). Similarly, hepatic EROD (Fig. 7C) and CEC activity (Fig. 7D) was up to $\sim 2$-fold higher in LPS/BaP-treated mice (Group IV) compared to mice treated with BaP only (Group III). In addition, LPS exposure alone let to a detectable Cyp1a1 activity in the liver with both substrates (Group II).

As BaP derivates can also be partly metabolised by NQ01, we also determined the activity of Nqo1 in mice exposed to BaP. Nqo1 activity was detected in both lung and liver cytosolic samples of all groups (Fig. 8). Nqo1 enzyme activity was higher after LPS (Group II), BaP (Group III) and LPS/BaP exposure (Group IV) relative to controls (Group I), in both lung (Fig. 8A) and liver (Fig. 8B). Interestingly, pulmonary Nqo1 enzyme activity was significantly lower in LPS/BaP-treated mice (Group IV) than mice treated with BaP alone (Group III), although the magnitude of the effect was modest (1.2-fold) (Fig. 8A). No difference in Nqo1 enzyme activity between the BaP (Group III) and LPS/BaP group (Group IV) was observed in the liver (Fig. 8B).

As previous studies have indicated that CYP1B1 may play a role in the metabolic activation of $\mathrm{BaP}$ within inflamed tissue $[15,16,32]$, expression of Cyp1b1 mRNA in the lung was determined by qRT-PCR. However, as shown in Figure 9A no difference in Cyp1b1 expression was observed between treatment groups. These results were in line with Cyp1b1 protein expression determined in pulmonary microsomes (Fig. 9B). Only very faint Cyp1b1 protein bands were detectable by Western blotting in all treatment groups (Groups I-IV) which could not be accurately quantified.
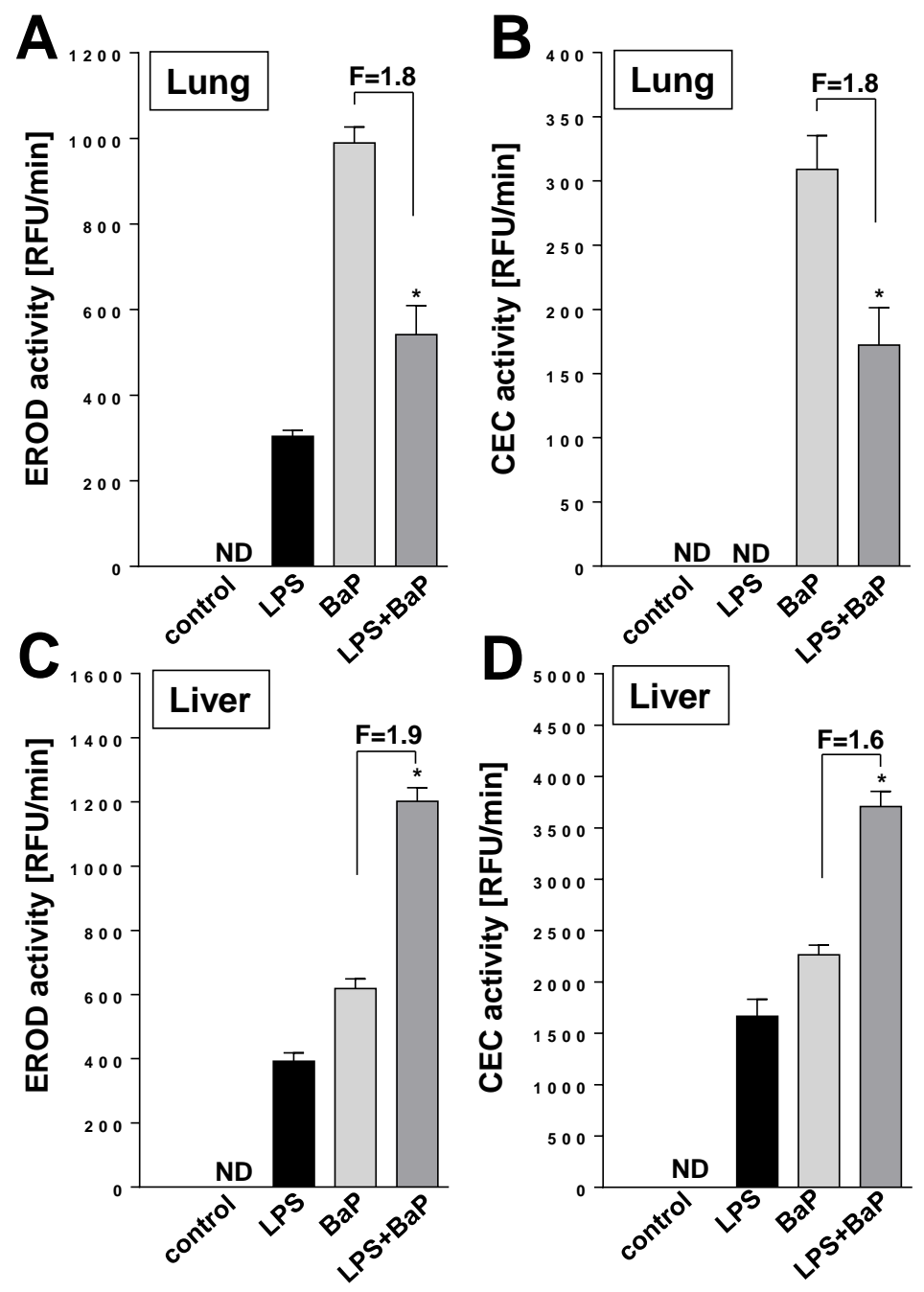

Figure 7. Effect of BaP treatment on Cyp1a enzyme activity. Cyp1a1 enzyme activity as measured by EROD $(\mathrm{A}+\mathrm{C})$ or CEC activity (B+D) in microsomal fractions isolated from lung $(A+B)$ or liver $(C+D)$ tissues of mice treated with LPS, $\mathrm{BaP}, \mathrm{LPS}+\mathrm{BaP}$ or vehicle only (control). All values are given as the means \pm SD of three separate determinations. RFU, relative fluorescence unit. ND, not detected. In the figure $\mathrm{F}=$ fold difference in enzyme activity in LPS/BaP group compared with enzyme activity in BaP group. Statistical analysis was performed by unpaired two-tailed t-test $\left({ }^{*} \mathrm{P}<0.05\right.$, versus $\mathrm{BaP}$ only treated mice). 

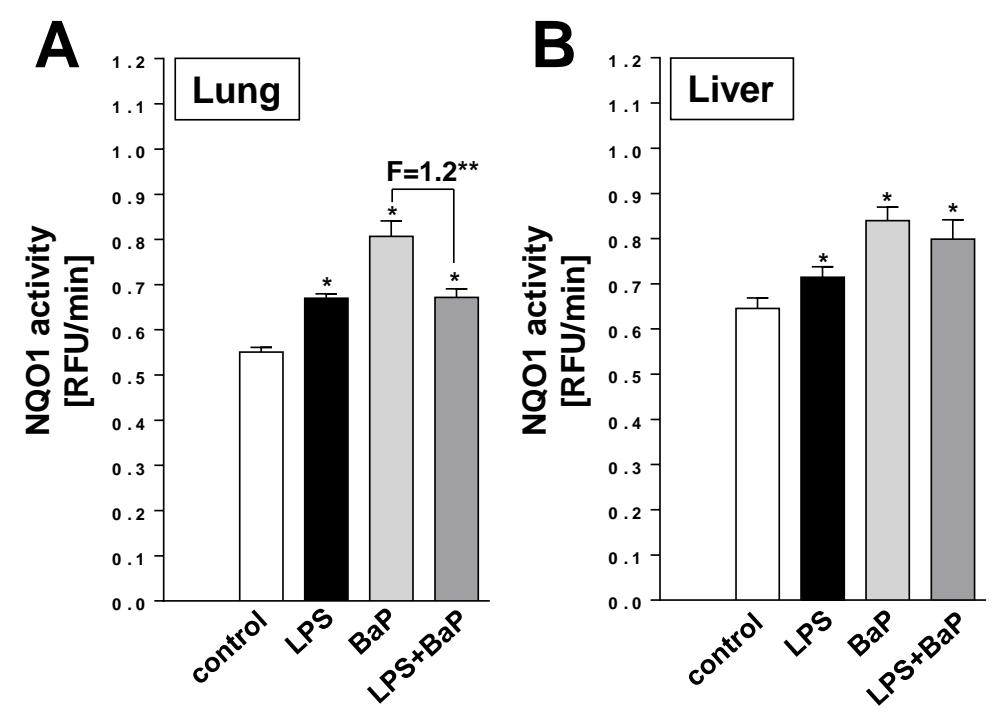

Figure 8. Effect of BaP treatment on Nqo1 enzyme activity. Nqo1 enzyme activity was measured in cytosolic fractions isolated from lung (A) or liver (B) tissues of mice treated with LPS, BaP, LPS+BaP or vehicle only (control). All values are given as the means \pm SD of three separate determinations. RFU, relative fluorescence unit. In the figure $\mathrm{F}=$ fold difference in enzyme activity in LPS/BaP group compared with enzyme activity in BaP group. Statistical analysis was performed by two-way ANOVA followed by Tukey's multiple comparisons test $\left({ }^{*} \mathrm{P}<0.05\right.$ versus control [untreated] mice; ${ }^{* *} \mathrm{P}<0.05$, versus BaP only treated mice).

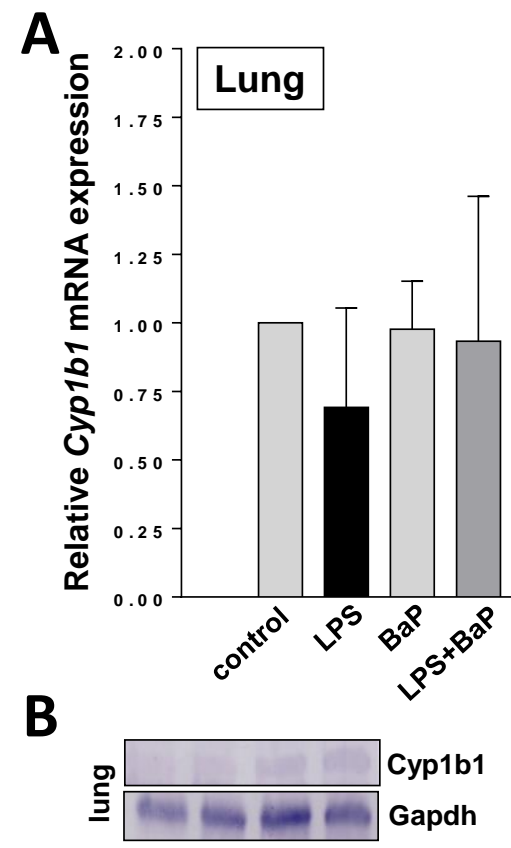

Figure 9. Expression of Cyp1b1 in the lung of mice treated with LPS, BaP, LPS+BaP or vehicle only (control). (A) Gene expression of Cyp1b1 assessed by RT-PCR. All values are given as the means \pm SD ( $n=4$ per group). For statistical analysis the relative mRNA expression data was log2 transformed and analysed using a single sample t-test with Bonferroni correction against the population control mean of 0 ; no significant differences were observed. (B) Cyp1b1 protein expression determined by Western blot analysis. Representative images are shown; duplicate analysis was performed on separate occasions. Gapdh protein expression was used as loading control.

\section{DNA repair capacity in lung and liver}

We assessed whether pulmonary inflammation had an influence on NER activity. We found that in the lung the repair capacity was higher ( $\sim$-fold) in LPS-treated mice (Group II) than in controls (Group I) (Fig. 10A). More specifically, 2-way ANOVA of the log-transformed data indicated that pulmonary repair capacity was significantly increased following LPS-induced inflammation $[\mathrm{F}(1,8)=10.9, P=0.0131]$ (Group II) but was not further affected by BaP treatment (Groups III and IV). There was no significant interaction effect. 
BaP treatment alone (Group III) had no effect on NER activity. Pulmonary repair capacities in the LPS (Group II) and LPS/BaP (Group IV) groups were similar to each other but not significantly different in the LPS/BaP group (Group IV) relative to controls (Group I) due to large inter-individual variability (Fig. 10A). In the liver no significant changes in NER capacity were observed between groups (Fig. 10B).
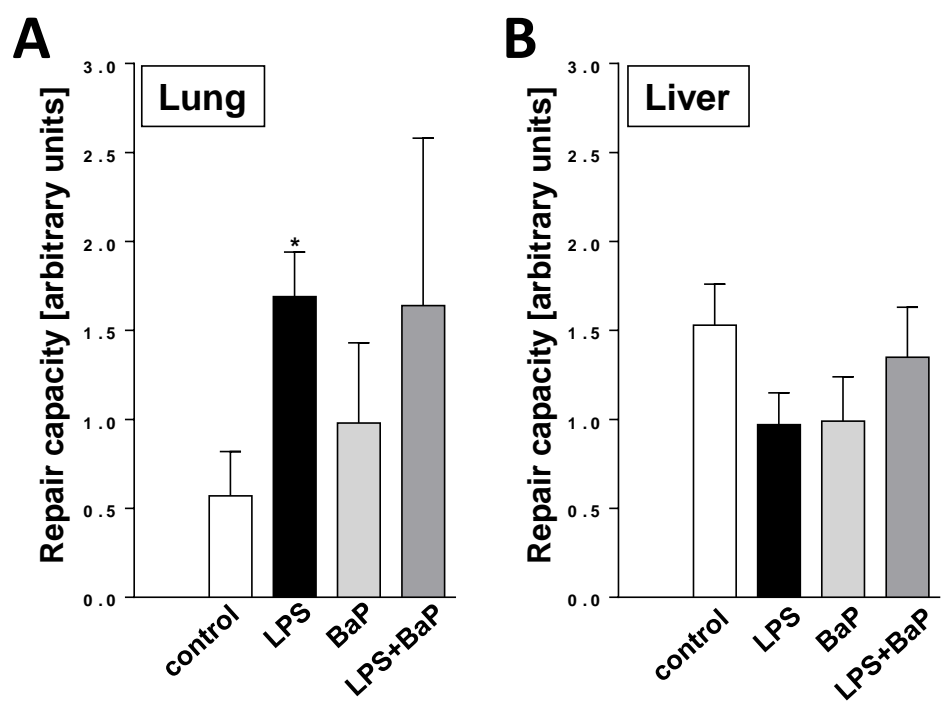

Figure 10. NER repair capacity was measured in tissue extracts isolated from lung (A) or liver (B) tissues of mice treated with LPS, BaP, LPS+BaP or vehicle only (control). All values are given as the means \pm SD (n $=3$ per group). For statistical analysis the relative repair capacity data was log-transformed and analysed by two-way ANOVA followed by Sidak's multiple comparisons test $\left({ }^{*} \mathrm{P}<0.05\right.$, versus control [untreated] mice).

\section{DISCUSSION}

In the present study we have shown that pulmonary inflammation modulates the bioactivation of BaP and the concomitant respiratory tract DNA damage induced by it. To induce pulmonary inflammation we treated mice with LPS which is an established model to study non-allergic inflammation [31, 33, 34]. The BaP dose used in this study ( $0.5 \mathrm{mg} /$ mouse) has been shown to induce mutagenicity in the lung of gpt delta mice after a single intratracheal instillation [35]. We found that BaP-induced DNA adduct formation in the lung was $\sim 3$-fold higher in LPS/BaP-treated mice compared to mice treated with BaP alone. Considering that inhaled combustion derived particles such as cigarette smoke, ambient air particulate matter and diesel exhaust particles contribute to pulmonary inflammation in humans [5] our results demonstrate that pulmonary inflammation could be a critical determinant in the induction of genotoxicity in the lung by particle-bound PAHs like BaP.

Pulmonary inflammation induced by LPS initiates the synthesis of pro-inflammatory cytokines [36, 37]. It has been shown that LPS-induced expression of cytokines like TNF- $\alpha$ and interleukin (IL)-1 $\beta$ in the liver is associated with altered CYP gene expression and CYP enzymes activities during inflammation [38]. In particular, it has been observed that Cyp1a1 gene expression is suppressed by LPS and TNF- $\alpha$ in mouse liver and that activation of the nuclear factor $-\kappa \mathrm{B}(\mathrm{NF}-\kappa \mathrm{B})$ plays an important role in Cyp1a1 suppression [39, 40]. LPS-mediated decrease of hepatic Cyp1a1 was enhanced and accelerated in mice that lack the aryl hydrocarbon receptor (AhR) (i.e. AhR (-/-) mice) compared to $A h R(+/+)$ mice [41]. Others have shown that enhanced expression of AhR in the thymus of LPS-treated mice was accompanied by increased Cyp1a1 expression 
which could be repressed by inhibition of NF- $\mathrm{BB}$ [42]. Further, induction of Cyp1a1 by LPS in the thymus depended on functional AhR as shown in $A h R(-/-)$ mice [42]. Together these data show that there is a cross-talk between AhR and inflammatory response that can be critical for the expression of CYP1A1 [43]. However, the observed responses are complex and tissue-specific, but it is noteworthy that PAHs like BaP can induce Cyp1a1 transcription through binding to AhR [44, 45].

In the present study we found a clear induction of Cyp1a1 protein in the lungs after BaP treatment both alone and in combination with LPS. In contrast no change of pulmonary Cyp1a1 protein was observed after LPS treatment alone. Interestingly pulmonary Cyp1a1 enzyme activity was lower in LPS/BaP-treated mice than in mice treated with $\mathrm{BaP}$ alone suggesting that pulmonary inflammation impacted on BaP-induced Cyp1a1 enzyme activity in the lung. Because BaP-DNA adduct levels in the lung were increased in LPS/BaP-treated mice compared to BaP-treated mice this observation may appear puzzling at first. However, previous studies [23, 46, 47] have revealed a paradox, whereby CYP enzymes (particularly CYP1A1) appear to be more important for detoxification of $\mathrm{BaP}$ in vivo, despite being involved in its metabolic activation in vitro. Therefore, the decrease in pulmonary Cyp1a1 enzyme activity in LPS/BaP-treated mice relative to BaP-treated mice, as measured in pulmonary microsomes, led to a decrease in $\mathrm{BaP}$ detoxification, thereby enhancing BaP genotoxicity (i.e. DNA adduct formation) in the lung. It remains to be investigated how pulmonary inflammation really impacts on Cyp1a1 enzyme activity but not Cyp1a1 protein expression (see below). Some other studies have suggested that CYP1B1 could play a role in the bioactivation of BaP within inflamed tissue as CYP1B1 can be up-regulated by proinflammatory cytokines (i.e. TNF- $\alpha$ ) in BaP-treated cells in vitro and thus may redirect $\mathrm{BaP}$ metabolism to form higher amounts of BPDE and to potentiate DNA adduct formation [15, 16, 32]. However, Cyp1b1 gene expression and Cyp1b1 protein analysis in the lung provided no evidence for an impact of pulmonary inflammation on Cyp1b1-mediated BaP bioactivation in vivo. One mediator that may be involved in the suppression of pulmonary Cyp1a1 enzyme activity after LPS challenge could be the formation of reactive oxygen species (ROS) [48]. In this context it is noteworthy that CYP1A1 can produce ROS during its catalytic cycle [48]. It has been shown not only that LPS results in increased ROS production but also that ROS suppresses CYP1A1 expression in cultured human cells in vitro [49]. Therefore, it has been proposed that ROS such as hydrogen peroxide are involved in haemoprotein inactivation followed by haem loss $[50,51]$. Similarly, BaP $o$-quinones formed during BaP metabolism have been shown to generate ROS [52]. Other potential mechanisms might involve the modification of certain amino acids at or near the active centre of the CYP1A1 enzyme by hydrogen peroxide [51]. Importantly, inactivated Cyp1a1 protein will retain the epitope for its recognition when assayed by Western blot analysis [53] but Cyp1a1 enzyme activity will be lost. Therefore, despite the induction of pulmonary Cyp1a1 protein, as measured by Western blotting in the LPS/BaP-treated mice, we propose that ROS formation leads to an inhibition of Cyp1a1 enzyme activity under the present experimental conditions.

If $\mathrm{BaP}$ is detoxified more slowly by Cyp1a1 in the lungs of LPS/BaP-treated mice, it would be predicted that more BaP circulates via the blood to extra-pulmonary tissues in these mice relative to mice treated with $\mathrm{BaP}$ alone. Indeed we observed higher BaP-DNA adduct levels in the livers of LPS/BaP-treated mice compared with BaP-treated mice. Further, it would be predicted that if in LPS/BaP-treated mice more BaP is transported from the lung via the blood to the liver than in BaP-treated mice, induction of Cyp1a1 protein and Cyp1a1 enzyme activity should be higher in the livers of LPS/BaP-treated 114 
mice relative to mice treated with BaP alone. Indeed, we found Cyp1a1 protein induction as well as an increase in Cyp1a1 enzyme activity in the livers of LPS/BaP-treated mice compared with BaP-treated mice, as measured in hepatic microsomes. Thus it would appear that a higher circulation of BaP to the liver results in higher DNA adduct levels, overriding the tendency of increased Cyp1a1 enzyme activity to result in a greater capacity to detoxify BaP. Our results suggest a dual role of Cyp1a1 in both bioactivation and detoxification of BaP in vivo. Similarly a dual role of CYP1A1 has been shown in the metabolism of the plant carcinogen aristolochic acid I (AAI) where CYP1A1 is able to catalyse the reductive activation of AAI to $N$-hydroxyaristolactam I and the oxidative detoxification to 8-hydroxyaristolochic acid [54,55]. These results in the liver also indicate that the presence of acute inflammation in one organ (i.e. lung) can influence the bioavailability of PAHs like BaP in other organs (i.e. liver) suggesting a systemic effect. LPS-induced pulmonary inflammation also impacted on the expression of other xenobiotic-metabolising enzymes such as Nqo1 which may be important as BaP derivatives can be metabolised by NQ01 [56-58]. We found that Nqo1 enzyme activity was increased in the lung, after LPS and BaP treatment both alone and in combination. This may be critical for the bioactivation of diesel exhaust particle-bound nitro-PAHs as NQ01 has been shown to be a key enzyme in the metabolic activation of nitro-PAHs [59, 60]. Interestingly, pulmonary Nqo1 enzyme activity was decreased in LPS/BaP-treated mice relative to BaP-treated mice suggesting that the bioactivation of nitro-PAHs would be suppressed in these animals.

NER is considered to be the main DNA repair pathway for bulky DNA adducts [61]. Using a modified comet assay we showed that tissue-specific NER capacity did not contribute to the higher BaP-DNA adduct levels observed in LPS/BaP-treated mice than in BaP-treated mice in either lung or liver. LPS treatment led to a significant increase ( 4-fold) in NER capacity in the lung. In contrast, Gungor and coworkers [31] found that LPS exposure reduced NER capacity in lung tissue homogenate by $\sim 50 \%$. Although the LPS dose used was the same in both studies the discrepancy between the two studies might be attributable to the different LPS administration regimes (intratracheal instillation versus intranasal administration) but otherwise it remains unexplained at present.

In summary we found that pulmonary inflammation can impact on enzymes (e.g. CYPs) involved the activation and detoxification of PAHs. Our findings suggest that inflammatory signals and carcinogenic PAHs like BaP may interact and that LPS-induced pulmonary inflammation inhibits Cyp1a1 enzyme activity, which leads to increased DNA damage through the enhanced formation of covalent BaP-DNA adducts in the lungs in vivo. Thus pulmonary inflammation could be a critical contributor to the induction of genotoxicity by particle-bound PAHs in the lung. 


\section{References}

[1] IARC, Diesel and Gasoline Engine Exhausts and Some Nitroarenes, IARC Monographs on the Evaluation of Carcinogenic Risks to Humans2013.

[2] D. Loomis, Y. Grosse, B. Lauby-Secretan, F. El Ghissassi, V. Bouvard, L. Benbrahim-Tallaa, N. Guha, R. Baan, H. Mattock, K. Straif, The carcinogenicity of outdoor air pollution, Lancet Oncol, 14 (2013) 1262-1263.

[3] J.S. Brody, A. Spira, State of the art. Chronic obstructive pulmonary disease, inflammation, and lung cancer, Proc Am Thorac Soc, 3 (2006) 535-537.

[4] D. Schottenfeld, J. Beebe-Dimmer, Chronic inflammation: a common and important factor in the pathogenesis of neoplasia, CA Cancer J Clin, 56 (2006) 69-83.

[5] F.J. Kelly, J.C. Fussell, Air pollution and airway disease, Clin Exp Allergy, 41 (2011) 1059-1071.

[6] A.M. Knaapen, N. Gungor, R.P. Schins, P.J. Borm, F.J. Van Schooten, Neutrophils and respiratory tract D NA damage and mutagenesis: a review, Mutagenesis, 21 (2006) 225-236.

[7] S.I. Grivennikov, F.R. Greten, M. Karin, Immunity, inflammation, and cancer, Cell, 140 (2010) 883-899.

[8] M.D. Attfield, P.L. Schleiff, J.H. Lubin, A. Blair, P.A. Stewart, R. Vermeulen, J.B. Coble, D.T. Silverman, The Diesel Exhaust in Miners study: a cohort mortality study with emphasis on lung cancer, J Natl Cancer Inst, 104 (2012) 869-883.

[9] D.T. Silverman, C.M. Samanic, J.H. Lubin, A.E. Blair, P.A. Stewart, R. Vermeulen, J.B. Coble, N. Rothman, P.L. Schleiff, W.D. Travis, R.G. Ziegler, S. Wacholder, M.D. Attfield, The Diesel Exhaust in Miners study: a nested case-control study of lung cancer and diesel exhaust, J Natl Cancer Inst, 104 (2012) 855-868.

[10] T. Walser, X. Cui, J. Yanagawa, J.M. Lee, E. Heinrich, G. Lee, S. Sharma, S.M. Dubinett, Smoking and lung cancer: the role of inflammation, Proc Am Thorac Soc, 5 (2008) 811-815.

[11] Some non-heterocyclic polycyclic aromatic hydrocarbons and some related exposures, IARC Monogr Eval Carcinog Risks Hum, 92 (2010) 1-853.

[12] W.M. Baird, L.A. Hooven, B. Mahadevan, Carcinogenic polycyclic aromatic hydrocarbon-DNA adducts and mechanism of action, Environ Mol Mutagen, 45 (2005) 106-114.

[13] D.H. Phillips, Macromolecular Adducts as Biomarkers of Human Exposure to Polycyclic Aromatic Hydrocarbons, The Carcinogenic Effects of Polycyclic Aromatic Hydrocarbons, PUBLISHED BY IMPERIAL COLLEGE PRESS AND DISTRIBUTED BY WORLD SCIENTIFIC PUBLISHING CO.2012, pp. 137-169.

[14] P.E. Schwarze, A.I. Totlandsdal, M. Lag, M. Refsnes, J.A. Holme, J. Ovrevik, Inflammation-related effects of diesel engine exhaust particles: studies on lung cells in vitro, Biomed Res Int, 2013 (2013) 685142.

[15] L. Smerdova, J. Smerdova, M. Kabatkova, J. Kohoutek, D. Blazek, M. Machala, J. Vondracek, Upregulation of CYP1B1 expression by inflammatory cytokines is mediated by the p38 MAP kinase signal transduction pathway, Carcinogenesis, 35 (2014) 2534-2543.

[16] L. Umannova, M. Machala, J. Topinka, Z. Novakova, A. Milcova, A. Kozubik, J. Vondracek, Tumor necrosis factor-alpha potentiates genotoxic effects of benzo[a]pyrene in rat liver epithelial cells through upregulation of cytochrome P450 1B1 expression, Mutat Res, 640 (2008) 162-169.

[17] P.J. Borm, A.M. Knaapen, R.P. Schins, R.W. Godschalk, F.J. Schooten, Neutrophils amplify the formation of DNA adducts by benzo[a]pyrene in lung target cells, Environ Health Perspect, 105 Suppl 5 (1997) 1089-1093.

[18] J.M. Petruska, D.R. Mosebrook, G.J. Jakab, M.A. Trush, Myeloperoxidase-enhanced formation of (+-)-trans-7,8-dihydroxy-7,8-dihydrobenzo[a]pyrene-DNA adducts in lung tissue in vitro: a role of pulmonary inflammation in the bioactivation of a procarcinogen, Carcinogenesis, 13 (1992) 1075-1081.

[19] V.M. Arlt, J. Zuo, K. Trenz, C.A. Roufosse, G.M. Lord, J.L. Nortier, H.H. Schmeiser, M. Hollstein, D.H. Phillips, Gene expression changes induced by the human carcinogen aristolochic acid I in renal and hepatic tissue of mice, Int J Cancer, 128 (2011) 21-32.

[20] T. Holand, Y. Riffo-Vasquez, D. Spina, B. O'Connor, F. Woisin, C. Sand, M. Marber, K.B. Bacon, C. Rohlff, C.P. Page, A role for mitogen kinase kinase 3 in pulmonary inflammation validated from a proteomic approach, Pulm Pharmacol Ther, 27 (2014) 156-163.

[21] D.H. Phillips, V.M. Arlt, The 32P-postlabeling assay for DNA adducts, Nat Protoc, 2 (2007) 2772-2781.

[22] D.H. Phillips, V.M. Arlt, 32P-Postlabeling Analysis of DNA Adducts, in: P. Keohavong, S.G. Grant (Eds.) Molecular Toxicology Protocols, Humana Press, Totowa, NJ, 2014, pp. 127-138.

[23] V.M. Arlt, M. Stiborova, C.J. Henderson, M. Thiemann, E. Frei, D. Aimova, R. Singh, G. Gamboa da Costa, O.J. Schmitz, P.B. Farmer, C.R. Wolf, D.H. Phillips, Metabolic activation of benzo[a]pyrene in vitro by hepatic cytochrome P450 contrasts with detoxification in vivo: experiments with hepatic cytochrome P450 reductase null mice, Carcinogenesis, 29 (2008) 656-665.

[24] F.L. Martin, Patel, II, O. Sozeri, P.B. Singh, N. Ragavan, C.M. Nicholson, E. Frei, W. Meinl, H. Glatt, D.H. Phillips, V.M. Arlt, Constitutive expression of bioactivating enzymes in normal human prostate suggests a capability to activate pro-carcinogens to DNA-damaging metabolites, Prostate, 70 (2010) 1586-1599.

[25] M. Stiborova, F. Barta, K. Levova, P. Hodek, E. Frei, V.M. Arlt, H.H. Schmeiser, The influence of ochratoxin A on DNA adduct formation by the carcinogen aristolochic acid in rats, Arch Toxicol, 89 (2015) 2141-2158.

[26] M. Stiborova, H. Dracinska, J. Hajkova, P. Kaderabkova, E. Frei, H.H. Schmeiser, P. Soucek, D.H. Phillips, V.M. Arlt, The environmental pollutant and carcinogen 3-nitrobenzanthrone and its human metabolite 3-aminobenzanthrone are potent inducers of rat hepatic cytochromes P450 1A1 and -1A2 and NAD(P)H:quinone oxidoreductase, Drug Metab Dispos, 34 (2006) 1398-1405. 
[27] J. Mizerovska, H. Dracinska, E. Frei, H.H. Schmeiser, V.M. Arlt, M. Stiborova, Induction of biotransformation enzymes by the carcinogenic air-pollutant 3-nitrobenzanthrone in liver, kidney and lung, after intra-tracheal instillation in rats, Mutat Res, 720 (2011) 34-41.

[28] A.M. Krais, K.R. Muhlbauer, J.E. Kucab, H. Chinbuah, M.G. Cornelius, Q.X. Wei, M. Hollstein, D.H. Phillips, V.M. Arlt, H.H. Schmeiser, Comparison of the metabolic activation of environmental carcinogens in mouse embryonic stem cells and mouse embryonic fibroblasts, Toxicol In Vitro, 29 (2015) 34-43.

[29] J.E. Kucab, D.H. Phillips, V.M. Arlt, Metabolic activation of diesel exhaust carcinogens in primary and immortalized human TP53 knock-in (Hupki) mouse embryo fibroblasts, Environ Mol Mutagen, 53 (2012) 207-217.

[30] S.A. Langie, A.M. Knaapen, K.J. Brauers, D. van Berlo, F.J. van Schooten, R.W. Godschalk, Development and validation of a modified comet assay to phenotypically assess nucleotide excision repair, Mutagenesis, 21 (2006) 153-158.

[31] N. Gungor, A. Haegens, A.M. Knaapen, R.W. Godschalk, R.K. Chiu, E.F. Wouters, F.J. van Schooten, Lung inflammation is associated with reduced pulmonary nucleotide excision repair in vivo, Mutagenesis, 25 (2010) 77-82.

[32] L. Smerdova, J. Neca, J. Svobodova, J. Topinka, J. Schmuczerova, A. Kozubik, M. Machala, J. Vondracek, Inflammatory mediators accelerate metabolism of benzo[a]pyrene in rat alveolar type II cells: the role of enhanced cytochrome P450 1B1 expression, Toxicology, 314 (2013) 30-38.

[33] D. Medan, L. Wang, X. Yang, S. Dokka, V. Castranova, Y. Rojanasakul, Induction of neutrophil apoptosis and secondary necrosis during endotoxin-induced pulmonary inflammation in mice, J Cell Physiol, 191 (2002) 320-326.

[34] N. Moriya, H. Kataoka, H. Fujino, J. Nishikawa, F. Kugawa, Effect of lipopolysaccharide on the xenobiotic-induced expression and activity of hepatic cytochrome P450 in mice, Biol Pharm Bull, 35 (2012) 473-480.

[35] A.H. Hashimoto, K. Amanuma, K. Hiyoshi, H. Takano, K. Masumura, T. Nohmi, Y. Aoki, In vivo mutagenesis induced by benzo[a]pyrene instilled into the lung of gpt delta transgenic mice, Environmental and molecular mutagenesis, 45 (2005) 365-373.

[36] N. Gungor, J.L. Pennings, A.M. Knaapen, R.K. Chiu, M. Peluso, R.W. Godschalk, F.J. Van Schooten, Transcriptional profiling of the acute pulmonary inflammatory response induced by LPS: role of neutrophils, Respir Res, 11 (2010) 24. [37] T. Holand, Y. Riffo-Vasquez, D. Spina, B. O'Connor, F. Woisin, C. Sand, M. Marber, K.B. Bacon, C. Rohlff, C.P. Page, A role for mitogen kinase kinase 3 in pulmonary inflammation validated from a proteomic approach, Pulmonary pharmacology \& therapeutics, 27 (2014) 156-163.

[38] G.W. Warren, S.M. Poloyac, D.S. Gary, M.P. Mattson, R.A. Blouin, Hepatic cytochrome P-450 expression in tumor necrosis factor-alpha receptor (p55/p75) knockout mice after endotoxin administration, J Pharmacol Exp Ther, 288 (1999) 945-950.

[39] S. Ke, A.B. Rabson, J.F. Germino, M.A. Gallo, Y. Tian, Mechanism of suppression of cytochrome P-450 1A1 expression by tumor necrosis factor-alpha and lipopolysaccharide, J Biol Chem, 276 (2001) 39638-39644.

[40] B.N. Zordoky, A.O. El-Kadi, Role of NF-kappaB in the regulation of cytochrome P450 enzymes, Curr Drug Metab, 10 (2009) 164-178.

[41] D. Wu, W. Li, P. Lok, F. Matsumura, C.F. Vogel, AhR deficiency impairs expression of LPS-induced inflammatory genes in mice, Biochem Biophys Res Commun, 410 (2011) 358-363.

[42] C.F. Vogel, E.M. Khan, P.S. Leung, M.E. Gershwin, W.L. Chang, D. Wu, T. Haarmann-Stemmann, A. Hoffmann, M.S. Denison, Cross-talk between aryl hydrocarbon receptor and the inflammatory response: a role for nuclear factor-kappaB, J Biol Chem, 289 (2014) 1866-1875.

[43] J. Vondracek, L. Umannova, M. Machala, Interactions of the aryl hydrocarbon receptor with inflammatory mediators: beyond CYP1A regulation, Curr Drug Metab, 12 (2011) 89-103.

[44] Y. Shimizu, Y. Nakatsuru, M. Ichinose, Y. Takahashi, H. Kume, J. Mimura, Y. Fujii-Kuriyama, T. Ishikawa, Benzo[a]pyrene carcinogenicity is lost in mice lacking the aryl hydrocarbon receptor, Proc Natl Acad Sci U S A, 97 (2000) 779-782.

[45] T. Wang, H.M. Gavin, V.M. Arlt, B.P. Lawrence, S.E. Fenton, D. Medina, B.A. Vorderstrasse, Aryl hydrocarbon receptor activation during pregnancy, and in adult nulliparous mice, delays the subsequent development of DMBA-induced mammary tumors, International journal of cancer, 128 (2011) 1509-1523.

[46] V.M. Arlt, M.C. Poirier, S.E. Sykes, K. John, M. Moserova, M. Stiborova, C.R. Wolf, C.J. Henderson, D.H. Phillips, Exposure to benzo[a]pyrene of Hepatic Cytochrome P450 Reductase Null (HRN) and P450 Reductase Conditional Null (RCN) mice: Detection of benzo[a]pyrene diol epoxide-DNA adducts by immunohistochemistry and 32P-postlabelling, Toxicol Lett, 213 (2012) 160-166.

[47] D.W. Nebert, Z. Shi, M. Galvez-Peralta, S. Uno, N. Dragin, Oral benzo[a]pyrene: understanding pharmacokinetics, detoxication, and consequences--Cyp1 knockout mouse lines as a paradigm, Mol Pharmacol, 84 (2013) 304-313.

[48] Y. Morel, R. Barouki, Repression of gene expression by oxidative stress, Biochem J, 342 Pt 3 (1999) 481-496.

[49] Y. Morel, R. Barouki, Down-regulation of cytochrome P450 $1 \mathrm{~A} 1$ gene promoter by oxidative stress. Critical contribution of nuclear factor 1, J Biol Chem, 273 (1998) 26969-26976.

[50] Karuzina, II, A.I. Archakov, Hydrogen peroxide-mediated inactivation of microsomal cytochrome P450 during monooxygenase reactions, Free Radic Biol Med, 17 (1994) 557-567.

[51] Karuzina, II, A.I. Archakov, The oxidative inactivation of cytochrome P450 in monooxygenase reactions, Free Radic Biol Med, 16 (1994) 73-97.

[52] J.H. Park, D. Mangal, A.J. Frey, R.G. Harvey, I.A. Blair, T.M. Penning, Aryl hydrocarbon receptor facilitates DNA strand breaks and 8-oxo-2'-deoxyguanosine formation by the aldo-keto reductase product benzo[a]pyrene-7,8-dione, J Biol Chem, 284 (2009) 29725-29734. 


\section{Chapter 5}

[53] A.O. El-Kadi, A.M. Bleau, I. Dumont, H. Maurice, P. du Souich, Role of reactive oxygen intermediates in the decrease of hepatic cytochrome P450 activity by serum of humans and rabbits with an acute inflammatory reaction, Drug metabolism and disposition: the biological fate of chemicals, 28 (2000) 1112-1120.

[54] M. Stiborova, K. Levova, F. Barta, Z. Shi, E. Frei, H.H. Schmeiser, D.W. Nebert, D.H. Phillips, V.M. Arlt, Bioactivation versus detoxication of the urothelial carcinogen aristolochic acid I by human cytochrome P450 1A1 and 1A2, Toxicol Sci, 125 (2012) 345-358.

[55] M. Stiborova, F. Barta, K. Levova, P. Hodek, E. Frei, V.M. Arlt, H.H. Schmeiser, The influence of ochratoxin A on DNA adduct formation by the carcinogen aristolochic acid in rats, Archives of toxicology, 89 (2015) 2141-2158.

[56] P. Joseph, A.K. Jaiswal, NAD(P)H:quinone oxidoreductase1 (DT diaphorase) specifically prevents the formation of benzo[a]pyrene quinone-DNA adducts generated by cytochrome P4501A1 and P450 reductase, Proc Natl Acad Sci U S A, 91 (1994) 8413-8417.

[57] P. Joseph, A.K. Jaiswal, NAD(P)H:quinone oxidoreductase 1 reduces the mutagenicity of DNA caused by NADPH:P450 reductase-activated metabolites of benzo(a)pyrene quinones, Br J Cancer, 77 (1998) 709-719.

[58] J. Shen, R.J. Barrios, A.K. Jaiswal, Inactivation of the quinone oxidoreductases NQO1 and NQO2 strongly elevates the incidence and multiplicity of chemically induced skin tumors, Cancer Res, 70 (2010) 1006-1014.

[59] V. Purohit, A.K. Basu, Mutagenicity of nitroaromatic compounds, Chem Res Toxicol, 13 (2000) 673-692.

[60] M. Stiborova, V. Martinek, M. Svobodova, J. Sistkova, Z. Dvorak, J. Ulrichova, V. Simanek, E. Frei, H.H. Schmeiser, D.H. Phillips, V.M. Arlt, Mechanisms of the different DNA adduct forming potentials of the urban air pollutants 2-nitrobenzanthrone and carcinogenic 3-nitrobenzanthrone, Chem Res Toxicol, 23 (2010) 1192-1201.

[61] E.C. Friedberg, How nucleotide excision repair protects against cancer, Nat Rev Cancer, 1 (2001) 22-33. 




\section{Chapter 6}

\section{Altered gene expression profiles in the lungs of benzo[a]pyrene-exposed mice in the presence of lipopolysaccharide-induced pulmonary inflammation}

Shi Q, Fijten RR, Spina D, Riffo Vasquez Y, Arlt VM, Godschalk RW, Van Schooten FJ Toxicol Appl Pharmacol. 2017 Oct 5;336:8-19. doi: 10.1016/j.taap.2017.09.023. 


\begin{abstract}
Patients with inflammatory lung diseases are often additionally exposed to polycyclic aromatic hydrocarbons like $\mathrm{B}[\mathrm{a}] \mathrm{P}$ and $\mathrm{B}[\mathrm{a}] \mathrm{P}$-induced alterations in gene expression in these patients may contribute to the development of lung cancer. Mice were intra-nasally treated with lipopolysaccharide (LPS, $20 \mu \mathrm{g} / \mathrm{mouse}$ ) to induce pulmonary inflammation and subsequently exposed to $\mathrm{B}[\mathrm{a}] \mathrm{P}(0.5 \mathrm{mg} / \mathrm{mouse})$ by intratracheal instillation. Gene expression changes were analyzed in mouse lungs by RNA microarrays. Analysis of genes that are known to be involved in the cellular response to $\mathrm{B}[\mathrm{a}] \mathrm{P}$ indicated that LPS significantly inhibited gene expression of various enzymes linked to $\mathrm{B}[\mathrm{a}] \mathrm{P}$ metabolism, which was confirmed by phenotypic analyses of enzyme activity. Ultimately, these changes resulted in higher levels of B[a]P-DNA adducts in the lungs of mice exposed to $\mathrm{B}[\mathrm{a}] \mathrm{P}$ with prior LPS treatment compared to the lungs of mice exposed to $\mathrm{B}[\mathrm{a}] \mathrm{P}$ alone. Using principle component analysis (PCA), we found that of all the genes that were significantly altered in their expression, those that were able to separate the different exposure conditions were predominantly related to immune-response. Moreover, an overall analysis of differentially expressed genes indicated that cell-cell adhesion and cell-cell communication was inhibited in lungs of mice that received both $\mathrm{B}[\mathrm{a}] \mathrm{P}$ and LPS. Our results indicate that pulmonary inflammation increased the genotoxicity of $\mathrm{B}[\mathrm{a}] \mathrm{P}$ via inhibition of both phase I and II metabolism. Therefore, inflammation could be a critical contributor to $\mathrm{B}[\mathrm{a}] \mathrm{P}$-induced carcinogenesis in humans.
\end{abstract}

Keywords: RNA microarray, Lipopolysaccharide (LPS), Benzo[a]pyrene (B[a]P), Mouse lung 


\section{Introduction}

During inflammation, a variety of inflammatory cells is recruited to the site of inflammation including macrophages, neutrophils and lymphocytes, which contribute to the establishment of an inflammatory micro-environment [1]. Within this micro-environment, a variety of inflammatory mediators or enzymes have been found, including reactive oxygen species (ROS), myeloperoxidase (MPO), $\beta$-glucuronidase, tumor necrosis factor (TNF- $\alpha$ ) and interleukin (IL)-6, [2-6] that are suggested to additionally affect aryl hydrocarbon receptor (AhR) signaling. AhR signaling is important for the cellular response to many environmental carcinogens, such as polycyclic aromatic hydrocarbons (PAHs) like benzo[a]pyrene $\mathrm{B}[\mathrm{a}] \mathrm{P}$. Indeed, individuals that are exposed to $\mathrm{B}[\mathrm{a}] \mathrm{P}$ in combination with pulmonary inflammation have an increased risk for developing lung cancer, for instance patients with chronic obstructive pulmonary disease (COPD) or emphysema [7, 8].

Most patients with chronic lung inflammatory disease are also exposed to environmental genotoxicants, such as cigarette smoke, diesel exhaust or ambient air particulate matter (PM) of various sources that can carry chemical carcinogens [9]. For example, over 70\% of cigarette smokers show inflammatory responses in the lung and especially those people have an increased risk of developing lung cancer [10]. One major group of compounds in cigarette smoke are PAHs, with $\mathrm{B}[\mathrm{a}] \mathrm{P}$ as one of the best studied $\mathrm{PAH}$ that is classified as human carcinogen (Group1) by the International Agency for Research on Cancer (IARC) $[11,12]$. B[a]P crosses the cell membrane and forms a complex with AhR. After binding, the complex translocates into the nucleus where it interacts with the aryl hydrocarbon receptor nuclear translocator (ARNT) and stimulates B[a]P metabolism by inducing the gene expression of cytochrome P450 1A1 (CYP1A1) and 1B1 (CYP1B1) [13, 14]. $\mathrm{B}[\mathrm{a}] \mathrm{P}$ exerts its mutagenic and carcinogenic properties only after metabolic activation, in which CYPs and epoxide hydrolase are involved; $\mathrm{B}[\mathrm{a}] \mathrm{P}$ is converted into the ultimate carcinogenic derivative B[a]P-7,8-dihydrodiol-9,10-epoxide (BPDE), which can covalently bind to DNA and form pre-mutagenic adducts, preferentially at guanine residues (i.e. 10-(deoxyguanosin- $N^{2}$-yl)-7,8,9-trihydroxy-7,8,9,10-tetrahydro-B[a]P $\left[\mathrm{dG}-N^{2}\right.$-BPDE]) $[3,15,16]$. However, the majority of reactive $\mathrm{B}[\mathrm{a}] \mathrm{P}$ intermediates is detoxified by phase II enzymes, which convert these intermediates into water soluble metabolites. Enzymes that are involved in this detoxification include

glutathione-S-transferases (GSTs), UDP-glucuronosyltransferases (UGTs) and sulfotransferases (SULTs) $[17,18]$. In case a reactive intermediate reaches the DNA and forms an adduct, B[a]P-induced DNA damage induces cell cycle arrest by activation of the tumor suppressor protein $\mathrm{p} 53$ to provide enough time for removal of the adducts by DNA repair enzymes. Regarding the bulky DNA lesions that are induced by $\mathrm{B}[\mathrm{a}] \mathrm{P}$, nucleotide excision repair (NER) is the most important DNA repair pathway $[19,20]$. Several studies have shown that $\mathrm{B}[\mathrm{a}] \mathrm{P}$ is capable of inducing an inflammatory response but vice versa inflammatory mediators can also enhance $\mathrm{B}[\mathrm{a}] \mathrm{P}$-induced genotoxicity [21, 22]. For instance, after exposing rats intratracheally to $\mathrm{B}[\mathrm{a}] \mathrm{P}$ for 2 days, lung inflammation, edema, and epithelial damage was observed [23], but additionally, exposure to $\mathrm{B}[\mathrm{a}] \mathrm{P}$ with concomitant activation of inflammatory-related pathways, largely increased $\mathrm{B}[\mathrm{a}] \mathrm{P}$ genotoxicity via various pathways. These pathways included signaling that was initiated by nuclear factor- $\kappa \mathrm{B}$ (NF- $\kappa \mathrm{B})$, TNF- $\alpha, \beta$-glucuronidase, hypoxia-inducible factor (HIF)-1, IL-6 and IL-8 [3, 14, 24-27]. However, although studies have revealed that many inflammation-related mediators promote $\mathrm{B}[\mathrm{a}] \mathrm{P}$ 
genotoxicity, an overall view on how inflammation promotes $\mathrm{B}$ [a]P-induced DNA damage is still missing.

In previous studies [3, 28] we used an animal model of inflammation (i.e. lipopolysaccharides (LPS)-treated mice) and showed that higher B[a]P-DNA adduct levels were observed in the lungs of LPS-treated mice that were additionally exposed to $\mathrm{B}[\mathrm{a}] \mathrm{P}$ relative to the lungs of mice exposed to $\mathrm{B}[\mathrm{a}] \mathrm{P}$ alone $[3,28]$. In the current study, an RNA microarray analysis was performed (mouse whole genome arrays) on lung to get an overview of how inflammation can promote B[a]P-induced genotoxicity.

\section{Materials and Methods}

\subsection{Chemicals}

Benzo[a]pyrene (B[a]P; CAS no. 50-32-8; purity >96\%) was purchased from Sigma-Aldrich (St Louis, MO). All other chemicals were of analytical purity or better.

\subsection{Animal treatment}

All animal experiments were approved by the Institutional Ethics Committee and conducted in accordance with the protocols approved by the Home Office under "The Animals (Scientific Procedures) Act (1986)" at King's College London [28]. C57B1/6 mice (male; approximately 8-10 weeks old, 20-25 g) were obtained from Charles River Laboratories and kept under controlled pathogen-free conditions and allowed food and water ad libitum. Mice were divided into four groups as follows: Group I: control group $(n=3)$, mice were nasally instilled with saline at day 0 and after 24 hours, mice were intratracheally instilled with tricaprylin ( $25 \mu \mathrm{l} /$ mouse); Group II: LPS group $(n=4)$, mice were nasally instilled with $20 \mu \mathrm{g}$ LPS (Escherichia coli, serotype 055:B5; $1 \mathrm{mg} / \mathrm{ml}$; dissolved in saline) at day 0 and after 24 hours, mice were intratracheally instilled with tricaprylin (25 $\mu \mathrm{l} /$ mouse); Group III: B[a]P group ( $\mathrm{n}=4)$, mice were nasally instilled with saline at day 0 and after 24 hours, mice were intratracheally instilled with B[a]P $0.5 \mathrm{mg}$ in $25 \mu \mathrm{l}$ tricaprylin/mouse); and Group IV: LPS\&B[a]P group $(\mathrm{n}=4)$, mice were nasally instilled with $20 \mu \mathrm{g}$ LPS at day 0 and after 24 hours, mice were intratracheally instilled with $\mathrm{B}[\mathrm{a}] \mathrm{P}$ ( $0.5 \mathrm{mg} /$ mouse). All instillations were performed under anesthesia with isoflurane followed by injection of ketamine/zylazine $(1 \mathrm{mg} / 0.166 \mathrm{mg}$ per mouse). Mice were sacrificed at day 3 by intraperitoneal administration of anesthesia $(2 \mathrm{~g} / \mathrm{kg}$ body weight urethane). Lung tissue was collected and snap-frozen in liquid nitrogen. Samples were stored at $-80^{\circ} \mathrm{C}$ until analysis. The selection of the $20 \mu \mathrm{g}$ LPS/mouse is based on our previous study [29] and the use of the $0.5 \mathrm{mg} \mathrm{B}[\mathrm{a}] \mathrm{P} /$ mouse is based on a study published by Dr. Hashimoto who investigated the in vivo mutagenicity of $\mathrm{B}[\mathrm{a}] \mathrm{P}$ in gpt delta mice [30].

\subsection{RNA isolation, purification and quality assessment}

Total RNA was extracted from frozen lung tissue according to the manufacturer's instructions, using TRIzol reagent (Invitrogen, Breda, the Netherlands) and purified on columns using Qiagen RNeasy Micro Kit (Qiagen, Venlo, the Netherlands). RNA concentration and purity were assessed spectrometrically using a Nano Drop ND-1000 spectrophotometer (Isogen, IJsselstein, The Netherlands). RNA quality was assessed on an Agilent 2100 bioanalyzer (Agilent Technologies, Amsterdam, the Netherlands). Microarray hybridization experiments were only performed on RNA samples with a RNA Integrity Number $(\mathrm{RIN})>8.0$. 


\subsection{Microarray processing}

Total RNA (100 ng) was labelled by a Whole Transcript Sense Target Assay and hybridized to mouse whole-genome Affymetrix Gene 1.1 ST arrays targeting 21,115 unique genes (Affymetrix, Santa Clara, CA). Hybridization, washing, and scanning of all Affymetrix Genechips was performed according to standard Affymetrix protocols. Scans of the Affymetrix arrays were processed using the Affymetrix GeneTitan Instrument.

Quality control was performed on raw data by assessing the signal distribution by using scatter plot, MA-plot and a normal probability plot. Positive (landmark) and negative (blank) spots were used in the quality control and not used in further analyses. Normalized data were visualized by Principal Component Analysis (PCA) for additional quality assessment. The gene expression data have been deposited in NCBI's Gene Expression Omnibus (http://www.ncbi.nlm.nih.gov/geo/) and are accessible through GEO Series accession number GSE102016.

\subsection{Analysis of microarray data}

Microarray analysis was performed using the MADMAX pipeline for statistical analysis of microarray data [31]. Briefly, microarrays were normalized with the robust multichip average method and probes were annotated according to Dai et al. [32, 33]. Individual genes were defined as changed when comparison of the normalized signal intensities showed a $\mathrm{p} \leq 0.05$ in a 2 -tailed paired intensity-based moderated t-statistics (IBMT) and a fold change of $>1.2$ or $<-1.2$ [34].

A first dedicated analysis focused on genes that were selected on basis of their known involvement in $\mathrm{B}[\mathrm{a}] \mathrm{P}$ metabolism (phase I and phase II enzymes), DNA repair and transport of $\mathrm{B}[\mathrm{a}] \mathrm{P}$ metabolites over the cell membrane (phase III). Meanwhile, comparison between the gene expression changes and phenotypic assays, which were published in previous work [28], were made, such as Cyp1a (i.e. 7-ethoxy-resorufin-0-deethylase [EROD] and 3-cyano-7-ethoxycoumarin [CEC] assay), $\mathrm{NAD}(\mathrm{P}) \mathrm{H}$ :quinone oxidoreductase (Nqo1) and $\beta$-glucuronidase enzyme activity assays, NER capacity assay, and 32P-postlabelling for BPDE-DNA adducts. A second approach used PCA on all differentially expressed genes (DEGs) to identify the key variables to distinguish the four different treatments (i.e. control, LPS, B[a]P and LPS\&B[a]P) [35]. These genes were subsequently analysed for Gene Ontology (GO, http://www.geneontology.org/) and Kyoto Encyclopedia of Genes and Genomes (KEGG, http://www.genome.jp/kegg/pathway.html) pathway enrichment analysis by using the Database for Annotation, Visualization and Integrated Discovery (DAVID; version 6.8, http://david.abcc.ncifcrf.gov/summary.jsp) online software [36]. The G0 function provides ontologies to attributes of gene function in three domains, including biological process (BP), molecular function (MF) and cellular component (CC) [37]. The KEGG pathway analysis is a software which establish pathway maps that contain current knowledge on biological networks [38]. Finally, an overall analysis was performed on the identified DEGs using DAVID.

\subsection{Principal Component Analysis (PCA) analysis}

Principal Components Analysis (PCA) was applied to separate each treatment based on the gene expression and visualize the distribution of the data. Before PCA analysis, a pool of genes (4731 genes) was pre-selected in each treatment versus control on basis of the statistical significance $(p<0.05)$ and fold change $(>\mid 1.2)$. The data for these 
significant genes was visualized by PCA. Further reduction of the important genes was done by calculating the norm of the PCA loadings to assign a distance measure for each gene. A cut-off of 0.02 was used to select the genes with the highest norm value as they have the largest influence on the PCA distribution of the samples. Calculations were performed in the Matlab ${ }^{\text {TM }}$ software package (The MathWorks, Inc., Natick, MA).

\section{Results}

\subsection{Number of genes changed after each exposure}

When compared with control, a total of 3797, 2208 and 3407 genes were significantly ( $\mathrm{p} \leq 0.05$, fold change $>|1.2|$ ) differentially expressed in LPS-exposed, B[a]P-exposed and LPS- combined with B[a]P-exposed mouse lungs, respectively (Fig 1). Among the 2208 genes altered by $\mathrm{B}[\mathrm{a}] \mathrm{P}$ treatment, 1132 genes were up-regulated and 1076 genes were down-regulated. Of the 2208 genes that were differentially expressed after $\mathrm{B}[\mathrm{a}] \mathrm{P}$ exposure, 585 were also differentially expressed after LPS exposure, but not necessarily in the same direction. The combined exposure to B[a]P and LPS showed overlap with exposure to $\mathrm{B}[\mathrm{a}] \mathrm{P}$ only for 592 genes, but again not necessarily in the same direction. Finally, 318 genes were differentially expressed by all three treatments when compared to controls.

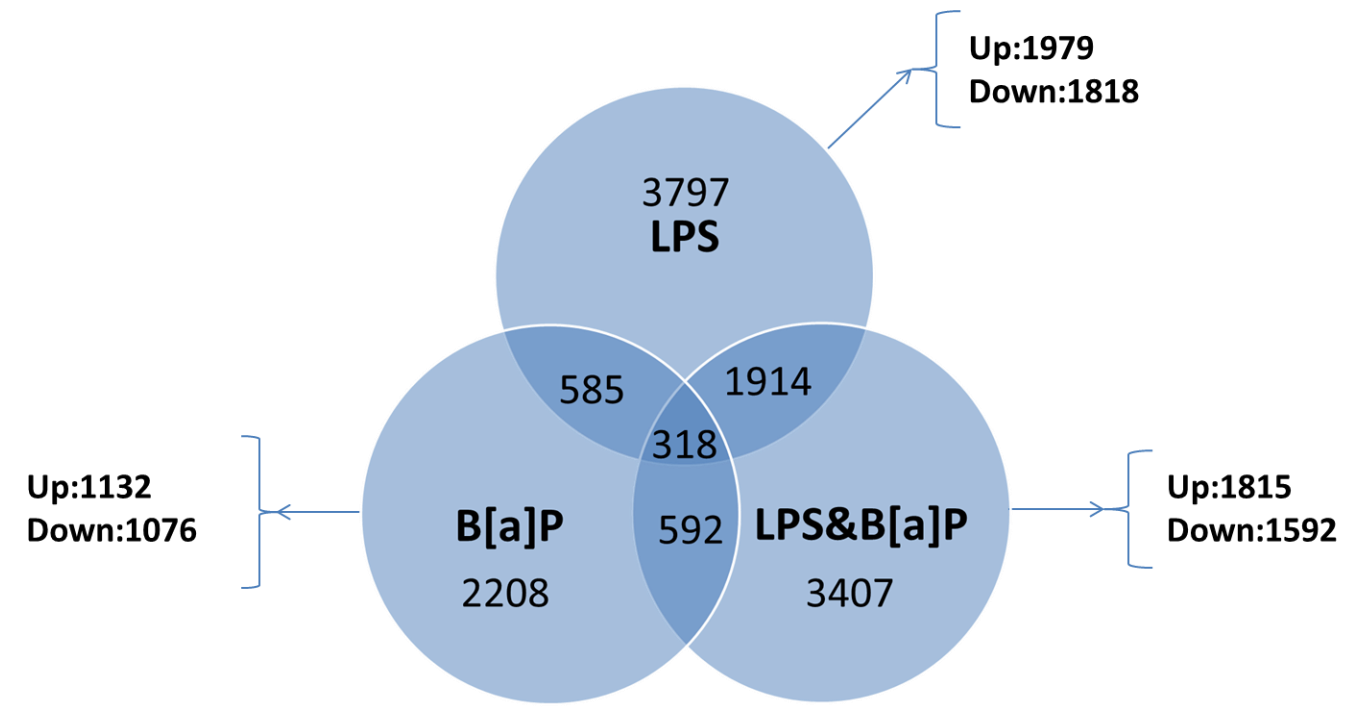

Figure 1. Venn diagram, where each circle shows the number of genes significantly expressed after different treatments (i.e. LPS, B[a]P and LPS with B[a]P) versus control.

\subsection{Dedicated analysis of gene expression profiles involved in $\mathrm{B}[\mathrm{a}] \mathrm{P}$ metabolism and DNA damage response}

To gain further insight into the effect of LPS on B[a]P-induced carcinogenesis, a list of 57 genes were derived from published literature that indicated that these genes are involved in $\mathrm{B}[\mathrm{a}] \mathrm{P}$ metabolism, the cellular response to $\mathrm{B}[\mathrm{a}] \mathrm{P}$ and DNA repair. We divided the gene expression profiles into four categories, phase I metabolism, phase II metabolism, DNA damage response (DDR) and phase III reactions. In this analysis, we focused on the expression of LPS combined with B[a]P versus expression by B[a]P only to establish how LPS exposure can affect the $\mathrm{B}[\mathrm{a}] \mathrm{P}$-induced gene expression changes. As shown in Table 1, 15 out of 17 genes belonging to phase I, phase II and DDR were significantly inhibited by additional exposure to LPS compared to B[a]P alone, including Cyp1a1, Ephx1, Nqo2, Comt, Cat, Gss, Sult1a1, Gstp1, Gstm1, Gstt1, Gpx3, Sod3, and Ddb1. 126 
Only Xpa and Nox1 were up-regulated by additional exposure to LPS, when compared to $\mathrm{B}[\mathrm{a}] \mathrm{P}$ exposure only.

Table 1: Summary of 57 genes that related to B[a]P metabolism and B[a]P-induced DNA damage

\begin{tabular}{|c|c|c|c|c|c|c|}
\hline Category & $\begin{array}{l}\text { Entrez } \\
\text { ID }\end{array}$ & $\begin{array}{l}\text { gene } \\
\text { name }\end{array}$ & Gene description & $\begin{array}{l}\text { LPS\&B[a]P } \\
\text { versus } \mathrm{B}[\mathrm{a}] \mathrm{P} \\
\text { (Log2 } \\
\text { based) Fold } \\
\text { change }\end{array}$ & $\begin{array}{l}\text { t-test } \\
\text { p-value }\end{array}$ & References \\
\hline Phase I & 13076 & Cyp1a1 & $\begin{array}{l}\text { cytochrome P450, family } 1 \text {, } \\
\text { subfamily a, polypeptide } 1\end{array}$ & $-4,44$ & 0,02872 & {$[28,62,63]$} \\
\hline Phase I & 13078 & Cyp1b1 & $\begin{array}{l}\text { cytochrome P450, family } 1 \text {, } \\
\text { subfamily b, polypeptide } 1\end{array}$ & 1,01 & 0,96422 & [62-65] \\
\hline Phase I & 13077 & Сур1а2 & $\begin{array}{l}\text { cytochrome P450, family } 1 \text {, } \\
\text { subfamily a, polypeptide } 2\end{array}$ & 1,04 & 0,79911 & $\begin{array}{l}{[62,63,} \\
65-67]\end{array}$ \\
\hline Phase I & 13112 & Сур3a11 & $\begin{array}{l}\text { cytochrome P450, family } 3 \text {, } \\
\text { subfamily a, polypeptide } 11\end{array}$ & $-1,09$ & 0,61748 & {$[63,65,68]$} \\
\hline Phase I & 13095 & Сур2c29 & $\begin{array}{l}\text { cytochrome P450, family } 2 \text {, } \\
\text { subfamily c, polypeptide } 29\end{array}$ & 1,13 & 0,26600 & {$[63,65,66]$} \\
\hline Phase I & 13095 & Сур2c38 & $\begin{array}{l}\text { cytochrome P450, family } 2 \text {, } \\
\text { subfamily c, polypeptide } 38\end{array}$ & 1,18 & 0,05241 & {$[63,65,66]$} \\
\hline Phase I & 17523 & Mpo & myeloperoxidase & 1,14 & 0,14159 & [69] \\
\hline Phase I & 13849 & Ephx1 & epoxide hydrolase 1 , microsomal & $-1,74$ & 0,00119 & {$[62,70]$} \\
\hline Phase I & 11863 & Arnt & $\begin{array}{l}\text { aryl hydrocarbon receptor nuclear } \\
\text { translocator }\end{array}$ & $-1,11$ & 0,04787 & [71] \\
\hline Phase I & 58810 & Akr1a1 & $\begin{array}{l}\text { aldo-keto reductase family } 1, \\
\text { member } \mathrm{A} 1 \text { (aldehyde reductase) }\end{array}$ & 1,11 & 0,36576 & {$[72]$} \\
\hline Phase I & 70861 & Akr1cl & $\begin{array}{l}\text { aldo-keto reductase family } 1 \text {, } \\
\text { member C-like }\end{array}$ & 1,02 & 0,74712 & {$[72]$} \\
\hline Phase I & 12408 & Cbr1 & carbonyl reductase 1 & $-1,42$ & 0,00165 & [73] \\
\hline Phase I & 18984 & Por & P450 (cytochrome) oxidoreductase & $-1,49$ & 0,00082 & [74] \\
\hline Phase I & 237038 & Nox1 & NADPH oxidase 1 & 1,39 & 0,02639 & [75] \\
\hline Phase I & 224480 & Nox3 & NADPH oxidase 3 & $-1,04$ & 0,68945 & [75] \\
\hline Phase I & 50490 & Nox4 & NADPH oxidase 4 & 1,03 & 0,87572 & {$[75]$} \\
\hline Phase I & 18104 & Nqo1 & $\mathrm{NAD}(\mathrm{P}) \mathrm{H}$ dehydrogenase, quinone 1 & $-1,40$ & 0,08864 & {$[76,77]$} \\
\hline Phase I & 18105 & $\mathrm{Nqo} 2$ & $\mathrm{NAD}(\mathrm{P}) \mathrm{H}$ dehydrogenase, quinone 2 & $-1,14$ & 0,02715 & {$[76,78]$} \\
\hline Phase I & 12846 & Comt & catechol-0-methyltransferase & $-1,31$ & 0,01349 & [79] \\
\hline Phase II & 394436 & Ugt1a1 & $\begin{array}{l}\text { UDP glucuronosyltransferase } 1 \\
\text { family, polypeptide A1 }\end{array}$ & 1,44 & 0,12914 & {$[80,81]$} \\
\hline Phase II & 394435 & Ugt1a6b & $\begin{array}{l}\text { UDP glucuronosyltransferase } 1 \\
\text { family, polypeptide A6B }\end{array}$ & 1,22 & 0,42449 & {$[81,82]$} \\
\hline Phase II & 394434 & Ugt1a9 & $\begin{array}{l}\text { UDP glucuronosyltransferase } 1 \\
\text { family, polypeptide A9 }\end{array}$ & 1,11 & 0,75507 & {$[81,82]$} \\
\hline Phase II & 394430 & Ugt1a10 & $\begin{array}{l}\text { UDP glycosyltransferase } 1 \text { family, } \\
\text { polypeptide A10 }\end{array}$ & 1,06 & 0,63962 & {$[81,82]$} \\
\hline Phase II & 110006 & Gusb & glucuronidase, beta & 1.37 & 0,07471 & [3] \\
\hline Phase II & 20887 & Sult1a1 & $\begin{array}{l}\text { sulfotransferase family } 1 \mathrm{~A}, \\
\text { phenol-preferring, member } 1\end{array}$ & $-1,50$ & 0,03487 & [83] \\
\hline Phase II & 20860 & Sult1e1 & $\begin{array}{l}\text { sulfotransferase family } 1 \mathrm{E} \text {, member } \\
1\end{array}$ & $-1,22$ & 0,23284 & {$[83]$} \\
\hline Phase II & 14854 & Gss & glutathione synthetase & $-1,27$ & 0,01461 & [84] \\
\hline Phase II & 14870 & Gstp1 & glutathione S-transferase, pi 1 & $-1,65$ & 0,00053 & {$[85,86]$} \\
\hline Phase II & 14862 & Gstm1 & glutathione S-transferase, mu 1 & $-1,99$ & 0,00049 & {$[87,88]$} \\
\hline Phase II & 14871 & Gstt1 & glutathione S-transferase, theta 1 & $-1,42$ & 0,03348 & [89] \\
\hline Phase II & 14782 & Gsr & glutathione reductase & 1,19 & 0,14067 & {$[90]$} \\
\hline Phase II & 14775 & Gpx1 & glutathione peroxidase 1 & 1,12 & 0,33496 & {$[90]$} \\
\hline Phase II & 14776 & Gpx2 & glutathione peroxidase 2 & $-1,22$ & 0,13192 & [90] \\
\hline Phase II & 14778 & Gpx3 & glutathione peroxidase 3 & $-1,31$ & 0,00163 & [90] \\
\hline Phase II & 625249 & $\mathrm{Gpx} 4$ & glutathione peroxidase 4 & 1,01 & 0,95164 & [90] \\
\hline Phase II & 14780 & Gpx5 & glutathione peroxidase 5 & 1,04 & 0,57018 & [90] \\
\hline Phase II & 75512 & Gpx6 & glutathione peroxidase 6 & $-1,03$ & 0,82376 & [90] \\
\hline
\end{tabular}




\begin{tabular}{|c|c|c|c|c|c|c|}
\hline Phase II & 67305 & Gpx7 & glutathione peroxidase 7 & $-1,18$ & 0,24477 & [90] \\
\hline Phase II & 69590 & Gpx8 & glutathione peroxidase 8 (putative) & $-1,01$ & 0,91315 & [90] \\
\hline Phase II & 20655 & Sod1 & superoxide dismutase 1 , soluble & $-1,02$ & 0,81073 & [91] \\
\hline Phase II & 20656 & Sod2 & $\begin{array}{l}\text { superoxide dismutase } 2 \text {, } \\
\text { mitochondrial }\end{array}$ & 1,16 & 0,49365 & [91] \\
\hline Phase II & 20657 & Sod3 & $\begin{array}{l}\text { superoxide dismutase } 3 \text {, } \\
\text { extracellular }\end{array}$ & $-1,97$ & 0,00001 & [91] \\
\hline Phase II & 12359 & Cat & catalase & $-1,62$ & 0,00054 & [61] \\
\hline DDR & 13870 & Ercc1 & $\begin{array}{l}\text { excision repair cross-complementing } \\
\text { rodent repair deficiency, } \\
\text { complementation group } 1\end{array}$ & $-1,14$ & 0,15908 & [4] \\
\hline DDR & 22590 & Xpa & $\begin{array}{l}\text { xeroderma pigmentosum, } \\
\text { complementation group A }\end{array}$ & 1,27 & 0,01806 & [4] \\
\hline DDR & 22591 & $\mathrm{Xpc}$ & $\begin{array}{l}\text { xeroderma pigmentosum, } \\
\text { complementation group C }\end{array}$ & $-1,03$ & 0,79776 & [4] \\
\hline DDR & 50505 & $\operatorname{Ercc} 4$ & $\begin{array}{l}\text { excision repair cross-complementing } \\
\text { rodent repair deficiency, } \\
\text { complementation group } 4\end{array}$ & $-1,02$ & 0,84055 & {$[4]$} \\
\hline DDR & 22592 & Ercc5 & $\begin{array}{l}\text { excision repair cross-complementing } \\
\text { rodent repair deficiency, } \\
\text { complementation group } 5\end{array}$ & $-1,04$ & 0,60135 & {$[4]$} \\
\hline DDR & 13871 & $\operatorname{Ercc} 2$ & $\begin{array}{l}\text { excision repair cross-complementing } \\
\text { rodent repair deficiency, } \\
\text { complementation group } 2\end{array}$ & $-1,10$ & 0,31138 & [92] \\
\hline DDR & 71991 & Ercc8 & $\begin{array}{l}\text { excision repaiross-complementing } \\
\text { rodent repair deficiency, } \\
\text { complementation group } 8\end{array}$ & 1,01 & 0,94476 & [93] \\
\hline DDR & 319955 & Ercc6 & $\begin{array}{l}\text { excision repair cross-complementing } \\
\text { rodent repair deficiency, } \\
\text { complementation group } 6\end{array}$ & 1,07 & 0,51230 & [93] \\
\hline DDR & 13194 & $\begin{array}{l}\text { Ddb1 } \\
\text { (Xpe) }\end{array}$ & $\begin{array}{l}\text { damage specific DNA binding } \\
\text { protein } 1\end{array}$ & $-1,31$ & 0,00168 & [94] \\
\hline DDR & 107986 & Ddb2 & $\begin{array}{l}\text { damage specific DNA binding } \\
\text { protein } 2\end{array}$ & 1,11 & 0,25741 & [95] \\
\hline DDR & 19359 & $\begin{array}{l}\text { Rad23b } \\
\text { (Xpg) }\end{array}$ & RAD23b homolog (S. cerevisiae) & $-1,09$ & 0,20104 & [96] \\
\hline DDR & 22059 & Trp53 & transformation related protein 53 & $-1,19$ & 0,22330 & [97] \\
\hline DDR & 16653 & Kras & $\begin{array}{l}\text { v-Ki-ras2 Kirsten rat sarcoma viral } \\
\text { oncogene homolog }\end{array}$ & 1,09 & 0,28840 & [97] \\
\hline Phase III & 26357 & Abcg2 & $\begin{array}{l}\text { ATP-binding cassette, sub-family G } \\
\text { (WHITE), member } 2\end{array}$ & $-1,03$ & 0,75372 & [98] \\
\hline Phase III & 12780 & Abcc2 & $\begin{array}{l}\text { ATP-binding cassette, sub-family C } \\
\text { (CFTR/MRP), member } 2\end{array}$ & 1,02 & 0,75995 & [98] \\
\hline
\end{tabular}

Red $=$ up-regulated $>1.2$ and $\mathrm{p}<0.05$

Green=down-regulated $<-1.2$ and $\mathrm{p}<0.05$

\subsection{Confirmation of DEGs by phenotypic assays}

The expression of several key enzymes in $\mathrm{B}[\mathrm{a}] \mathrm{P}$ metabolism and the response to $\mathrm{B}[\mathrm{a}] \mathrm{P}$ appeared to be differentially expressed after additional exposure to LPS. In order to validate these results, the gene expression data were compared with several phenotypic assays, including the measurement of Cyp1a activity (EROD and CEC assay), Nqo1 activity, $\beta$-glucuronidase activity, and NER capacity (Fig 2). Also B[a]P-DNA adduct levels were assessed as net result of $\mathrm{B}[\mathrm{a}] \mathrm{P}$ exposure, metabolism and DNA repair.

Gene expression of Cyp1a1 correlated with Cyp1a enzymes activity as determined by both EROD and CEC assays (Fig 2A and B).

Although gene expression of Nqo1 was not significantly ( $\mathrm{p}=0.089)$ inhibited by LPS, Nqo1 enzyme activity was slightly lower $(1.2$-fold; $p<0.05)$ in LPS\&B[a]P when compared to $\mathrm{B}[\mathrm{a}] \mathrm{P}$ exposure only. Interestingly, Nqo2 mRNA expression was 128 
significantly down-regulated in the $\mathrm{B}[\mathrm{a}] \mathrm{P} \& \mathrm{LPS}$ group when compared to $\mathrm{B}[\mathrm{a}] \mathrm{P}$ exposure only, which may in part be reflected in this phenotypic assay (Fig 2C).

$\beta$-glucuronidase is produced and released by inflammatory cells after LPS exposure. Indeed, the $\beta$-glucuronidase activity was 1.5 -fold higher in lungs of animals that were exposed to LPS\&B[a]P, and similarly, the gene expression of Gusb was also 1.4-fold higher in LPS\&B[a]P-exposed lungs compared to lungs exposed to B[a]P only (Fig 2D).

Finally, NER capacity was assessed by a modified comet assay, and the expression of Xpa demonstrated the best correlation with this phenotypic endpoint (Fig 2E). Xpa showed a 1.3-fold higher gene expression in LPS\&B[a]P-exposed animals than after $\mathrm{B}[\mathrm{a}] \mathrm{P}$ exposure only. All other DNA repair enzymes did not have statistically significant changes in their expression; except for $D d b 1$, which showed a 1.3-fold lower expression in the LPS\&B[a]P group compared to the $\mathrm{B}[\mathrm{a}] \mathrm{P}$ group. $D d b 1$ was initially implicated in the process of NER, but later it was found that $D d b 1$ primarily functions as a core component of E3 ubiquitin ligase complexes that regulate numerous essential processes in the cell, including DNA repair, DNA replication and chromatin remodeling [39].

Of course mRNA expression does not always reflect phenotypic effects due to posttranslational modifications, but still most phenotypic assays in this study reflect the mRNA expression of their underlying genes. The relationship with DNA repair is more complicated, because of the involvement of many proteins in the NER process and NER is mostly post-translationally regulated. DNA repair activity was (non-significantly) up-regulated in the LPS\&B[a]P group, which may be a direct response to increased levels of DNA damage. Indeed, B[a]P-DNA adduct levels after LPS\&B[a]P exposure were 2.6-fold $(\mathrm{p}<0.05)$ higher than after B[a]P exposure only (Fig 2F). 

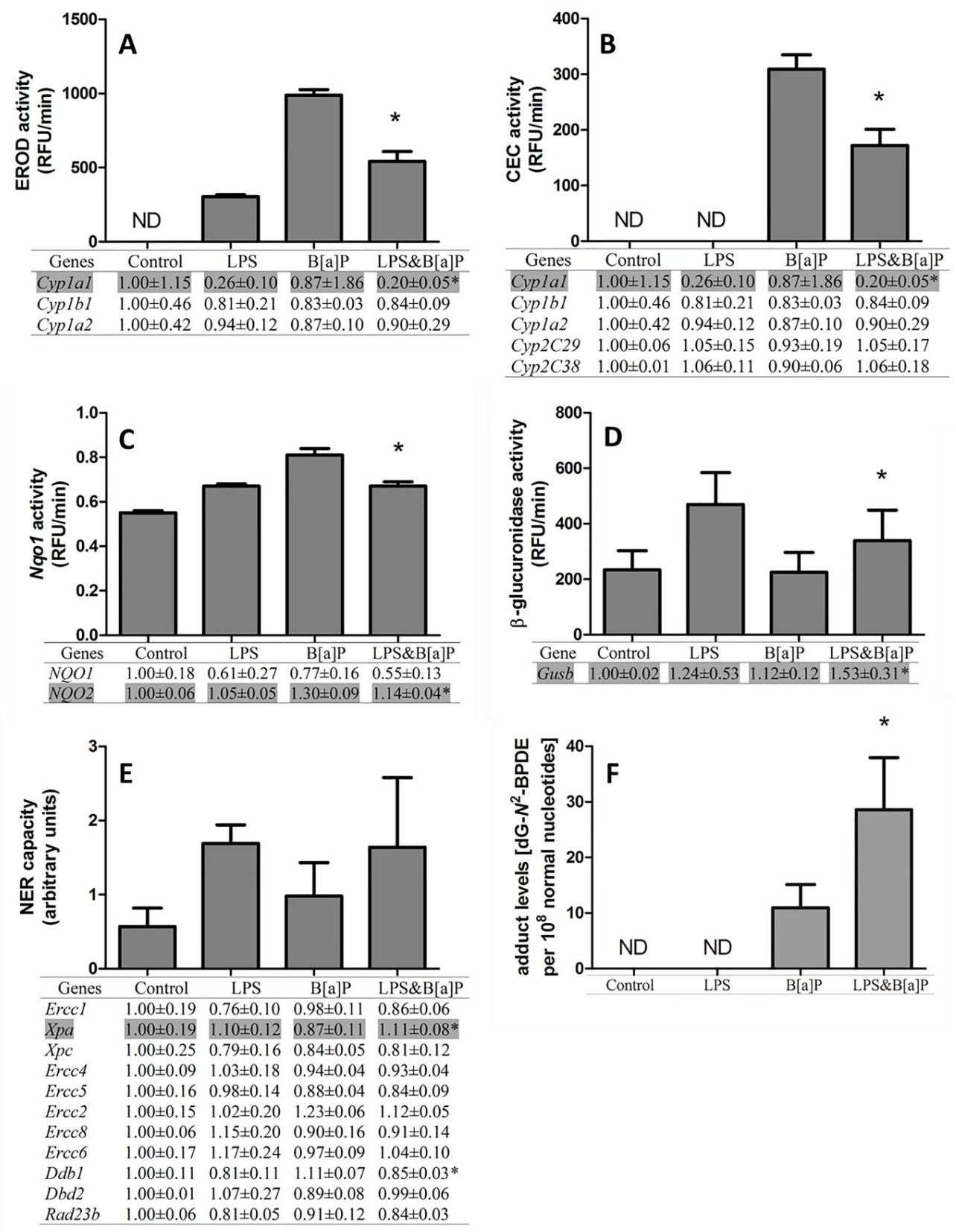

Figure 2. In vitro assay phenotypic data were partly derived from previously published work [28] [3]. (A) and (B) are EROD and CEC assay that mainly measure the Cyp1a enzyme activity in microsomal fractions isolated from lung tissues of mice treated with vehicle (control), LPS, B[a]P and LPS\&B[a]P, respectively. (C) Nqo1 enzyme activity in cytosolic fractions from lung tissues. (D) $\beta$-glucuronidase activity in cytosolic fractions from lung tissues. (E) NER repair capacity in tissue extracts isolated from lung tissues. (E) B[a]P-DNA adduct formation (i.e. dG- $N^{2}$-BPDE) measured by ${ }^{32} \mathrm{P}$-postlabeling in lung of mice treated with vehicle (control), LPS, B[a]P and LPS\&B[a]P. The potentially relevant gene expression data for each phenotype were listed below each figure. Each gene in different treatments was corrected by setting control values as 1 . For each phenotypic assay, the best correlating gene was marked in grey color. All values are given as the means \pm SD $(n=4)$. ND, not detected. RFU, relative fluorescence unit. Statistical analysis in the phenotypic assays was performed by 2-way ANOVA followed by Tukey's multiple comparisons test, and the gene expression data were analyzed by a 2-tailed paired intensity-based moderated t-statistics (IBMT) $\left({ }^{*} \mathrm{p}<0.05\right.$ compared to mice treated with $\mathrm{B}[\mathrm{a}] \mathrm{P}$ only).

\subsection{PCA and KEGG pathway analysis}

In order to investigate the interrelationship among all four groups of treatment, PCA was applied on all DEGs to identify those genes that could distinguish between the various 
treatments (Fig 3). Of all the DEGs, 398 genes were identified that could differentiate between control, LPS, B[a]P and LPS\&B[a]P group. To get further insights into the pathways in which these 398 genes are involved, KEGG pathway analysis was performed. As shown in Table 2, identified pathways related to the immune response and response to infections dominated the list of significantly altered pathways. Since the expression of these genes could also distinguish between control and $\mathrm{B}[\mathrm{a}] \mathrm{P}$-exposed lung samples this indicates that $\mathrm{B}[\mathrm{a}] \mathrm{P}$ exposure alone can already affect inflammation and vice versa.

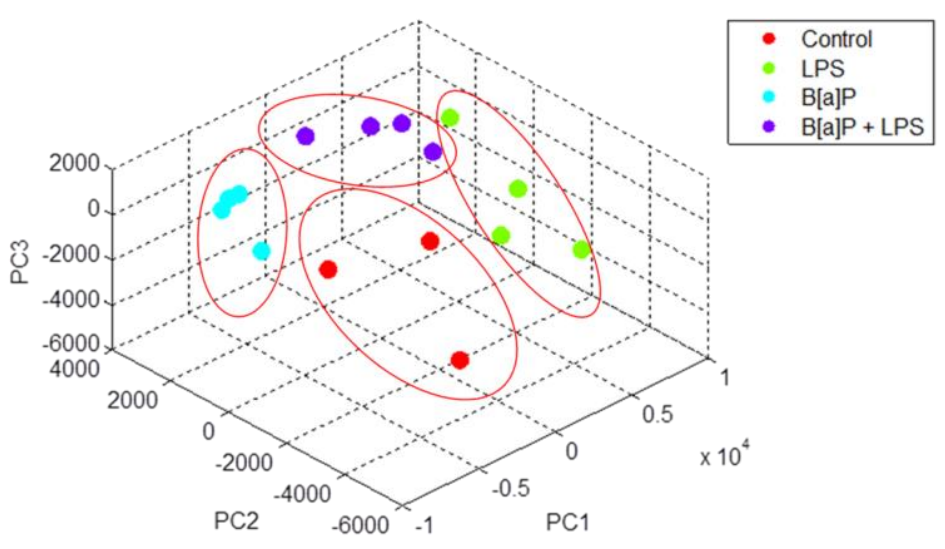

Figure 3. PCA analysis results of gene expressions that optimally differentiate between control, LPS, B[a]P and LPS\&B[a]P treatment.

Table 2: KEGG pathway analysis of genes derived from PCA analysis

\begin{tabular}{|c|c|c|c|}
\hline Term & Count & $\%$ & Benjamini \\
\hline Phagosome & 23 & 5.8 & $4.40 \mathrm{E}-08$ \\
\hline Herpes simplex infection & 22 & 5.5 & $3.80 \mathrm{E}-06$ \\
\hline Cell adhesion molecules (CAMs) & 21 & 5.3 & $3.20 \mathrm{E}-07$ \\
\hline Tuberculosis & 20 & 5 & 4.70E-06 \\
\hline Regulation of actin cytoskeleton & 20 & 5 & $6.30 \mathrm{E}-05$ \\
\hline Endocytosis & 17 & 4.3 & $2.00 \mathrm{E}-02$ \\
\hline Leishmaniasis & 16 & 4 & $1.10 \mathrm{E}-08$ \\
\hline Leukocyte transendothelial migration & 16 & 4 & $1.50 \mathrm{E}-05$ \\
\hline Influenza A & 16 & 4 & $6.00 \mathrm{E}-04$ \\
\hline Focal adhesion & 15 & 3.8 & $9.10 \mathrm{E}-03$ \\
\hline Staphylococcus aureus infection & 14 & 3.5 & $2.80 \mathrm{E}-08$ \\
\hline Measles & 14 & 3.5 & 7.60E-04 \\
\hline Antigen processing and presentation & 13 & 3.3 & $3.10 \mathrm{E}-05$ \\
\hline Osteoclast differentiation & 13 & 3.3 & $1.30 \mathrm{E}-03$ \\
\hline Viral myocarditis & 11 & 2.8 & $6.20 \mathrm{E}-04$ \\
\hline Chagas disease (American trypanosomiasis) & 11 & 2.8 & $3.50 \mathrm{E}-03$ \\
\hline Hepatitis C & 11 & 2.8 & $2.20 \mathrm{E}-02$ \\
\hline Ribosome & 11 & 2.8 & $3.20 \mathrm{E}-02$ \\
\hline Graft-versus-host disease & 10 & 2.5 & $1.40 \mathrm{E}-04$ \\
\hline Type I diabetes mellitus & 10 & 2.5 & $5.50 \mathrm{E}-04$ \\
\hline Adherens junction & 10 & 2.5 & $1.30 \mathrm{E}-03$ \\
\hline Rheumatoid arthritis & 10 & 2.5 & $2.90 \mathrm{E}-03$ \\
\hline Toxoplasmosis & 10 & 2.5 & $2.20 \mathrm{E}-02$ \\
\hline Allograft rejection & 9 & 2.3 & $1.30 \mathrm{E}-03$ \\
\hline Autoimmune thyroid disease & 9 & 2.3 & 4.90E-03 \\
\hline Pertussis & 9 & 2.3 & $6.20 \mathrm{E}-03$ \\
\hline Toll-like receptor signaling pathway & 9 & 2.3 & $3.20 \mathrm{E}-02$ \\
\hline Arrhythmogenic right ventricular cardiomyopathy (ARVC) & 8 & 2 & $2.10 \mathrm{E}-02$ \\
\hline Complement and coagulation cascades & 8 & 2 & $2.70 \mathrm{E}-02$ \\
\hline Prion diseases & 7 & 1.8 & $1.80 \mathrm{E}-03$ \\
\hline Inflammatory bowel disease (IBD) & 7 & 1.8 & $3.00 \mathrm{E}-02$ \\
\hline Biosynthesis of unsaturated fatty acids & 5 & 1.3 & $3.20 \mathrm{E}-02$ \\
\hline
\end{tabular}




\subsection{Overall analysis of impact of LPS and B[a]P exposure: Identification of DEGs}

Finally, to investigate the effect of LPS on B[a]P-induced genotoxicity, an unsupervised analysis was performed. DEGs had to have a $\mathrm{p} \leq 0.05$ in a 2 -tailed paired intensity-based moderated t-statistics (IBMT) and a cut-off of fold change of $>|1.2|$. We filtered data and identified DEGs by using the following criteria: 1) Genes are significantly differentially expressed in $\mathrm{B}[\mathrm{a}] \mathrm{P}$-exposed versus control animals; and 2) Genes are additionally significantly differentially expressed in the LPS\&B[a]P group versus $\mathrm{B}[\mathrm{a}] \mathrm{P}$ group. In other words, we focused on genes that are differentially regulated by $\mathrm{B}[\mathrm{a}] \mathrm{P}$ and their expression is subsequently altered by the presence of inflammation. With these selection criteria, the DEGs that were identified will not represent an LPS effect. This resulted in a total of 971 DEGs (Fig 4). 9 genes were down-regulated after B[a]P exposure when compared to controls and further significantly down-regulated by the combined exposure to LPS and B[a]P. Similarly, 13 genes were up-regulated by the B[a]P group and further significantly up-regulated in the LPS\&B[a]P group. In total, these 22 genes showed a synergistic effect of the combined treatment. However, most DEGs ( 949 genes) demonstrated an inhibition in the combined exposure. For example, 619 genes were significantly up-regulated after $\mathrm{B}[\mathrm{a}] \mathrm{P}$ exposure when compared to controls, but these genes were again significantly down-regulated in the LPS\&B[a]P group. Similarly, 330 genes were significantly down-regulated in the $\mathrm{B}[\mathrm{a}] \mathrm{P}$ group compared to control, whereas up-regulated in combination with LPS treatment.

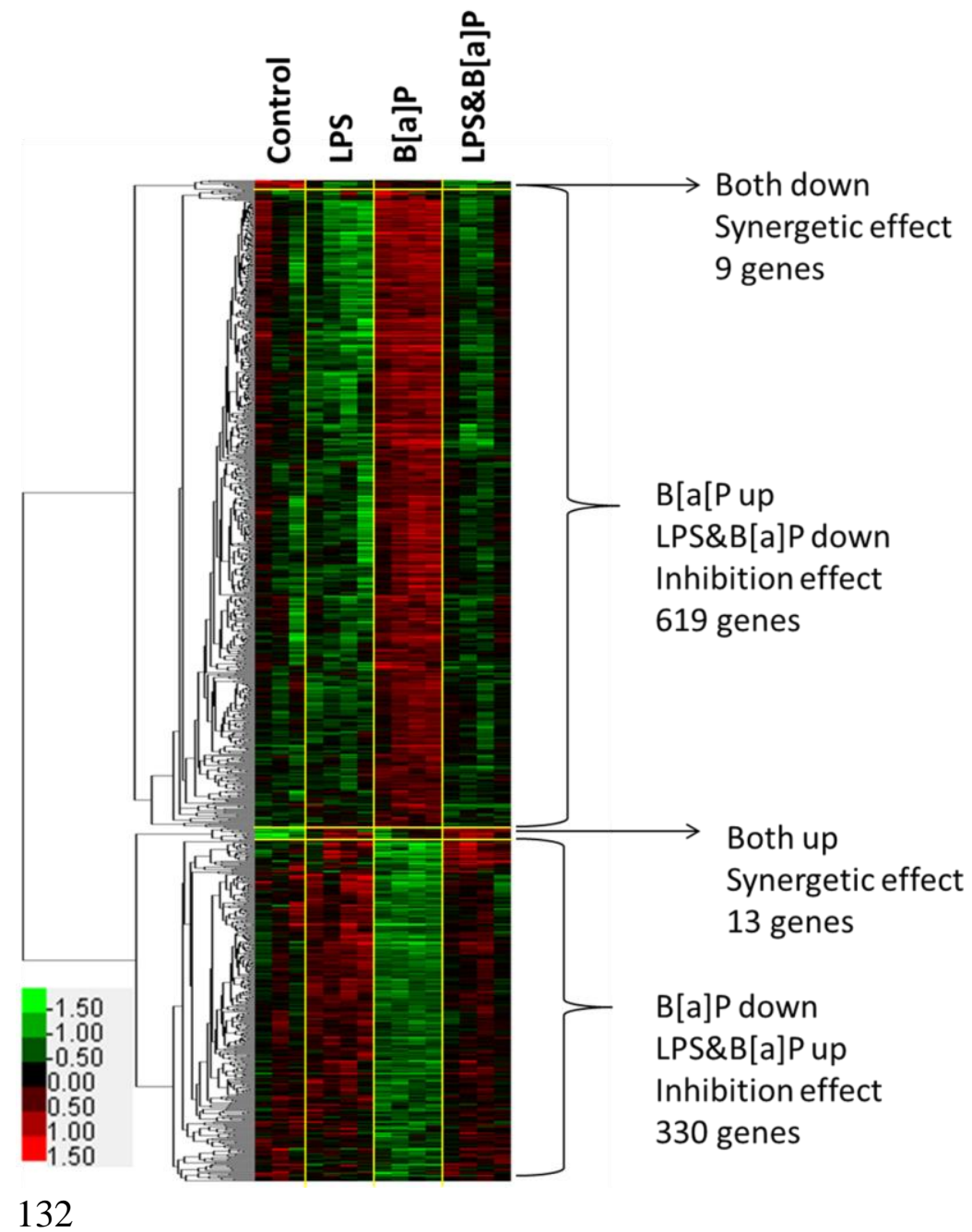

Figure 4. Hierarchical clustering of genes in Control, LPS, B[a]P and LPS \& $\mathrm{B}[\mathrm{a}] \mathrm{P}$ treated samples. In hierarchical clustering, the red color represents up-regulation and the green denotes down-regulation. 


\subsection{Functional and pathway enrichment analysis}

Due to the limited number of genes that were identified in the 'synergistic effect' gene set (22 genes), further analysis focused on the 'inhibitory effect' gene set (949 genes). We assigned the 619 genes that were up-regulated by $\mathrm{B}[\mathrm{a}] \mathrm{P}$ but their increased expression was subsequently inhibited by LPS as group 1, and the other 330 genes as group 2. The list of 949 genes that were identified were analyzed using DAVID to further explore the functions of these DEGs. The top 4 GO terms in each Biological Process (BP), Cellular Component (CC) and Molecular Function (MF) are presented in Fig 5 and Fig 6. The group 1 gene set (619 genes) (Fig 5) was significantly enriched in cell adhesion (35 [number of genes involved], 6\% [the percentage over whole gene set]), protein binding $(173,28 \%)$, cytoplasm $(250,40 \%)$, extracellular exosome $(161,26 \%)$, membrane $(313$, $51 \%$ ), and lipid metabolic process (33,5\%) (for complete analysis see Supplementary Data 1). The results for group 2 (330 genes) (Fig 6) were as follows: translation (17, $5.2 \%)$, poly(A) RNA binding $(43,13.1 \%)$ and nucleus $(103,31.4 \%)$ (for complete analysis see Supplementary Data 2). The same groups were used for pathway analysis by KEGG (Table 3). Group 1 genes were mainly involved in pathways associated with adherence junction, endocytosis, focal adhesion, N-glycan biosynthesis, acute myeloid leukemia, steroid biosynthesis, extracellular matrix (ECM)-receptor interaction, and axon guidance. In addition, pathways related to cancer were also observed for the group 1 gene set. On the other hand, only 'ribosome' $(\mathrm{p}=0.0088)$ was identified in the KEGG pathway analysis for the group 2 gene set. Thus, both analyses (GO terms and KEGG) suggest that cell-cell adhesion and the extracellular matrix is modulated by the combined exposure to $\mathrm{B}[\mathrm{a}] \mathrm{P}$ and LPS when compared to $\mathrm{B}[\mathrm{a}] \mathrm{P}$ exposure only.

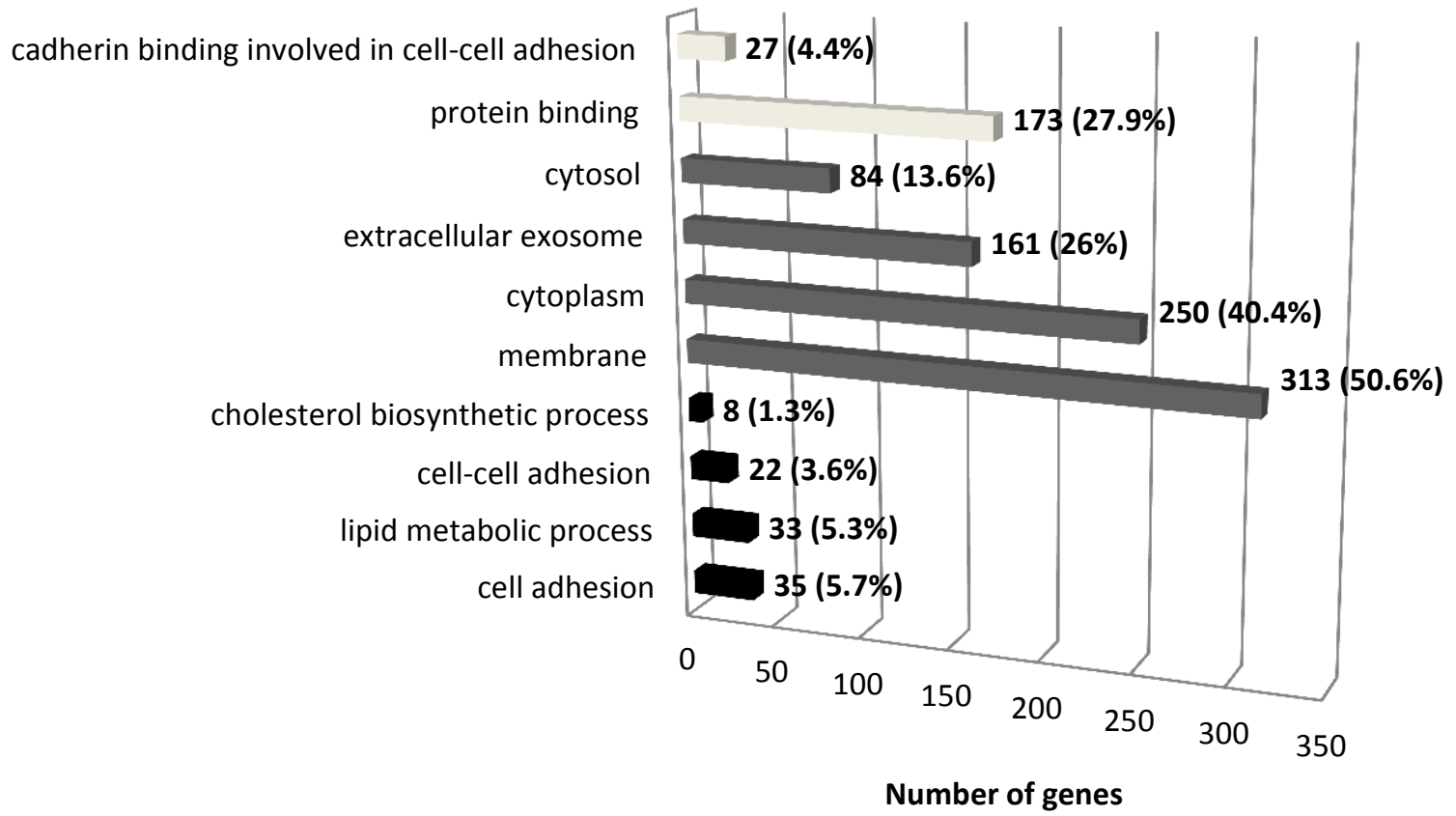

Figure 5. The numbers of genes and the percentage over whole gene set in each enriched GO terms that were identified for group 1 gene set (619 genes). Dark bar represent Biological Process (BP); Grey bar represents cellular component (CC) and light grey bar represents Molecular Function (MF). 


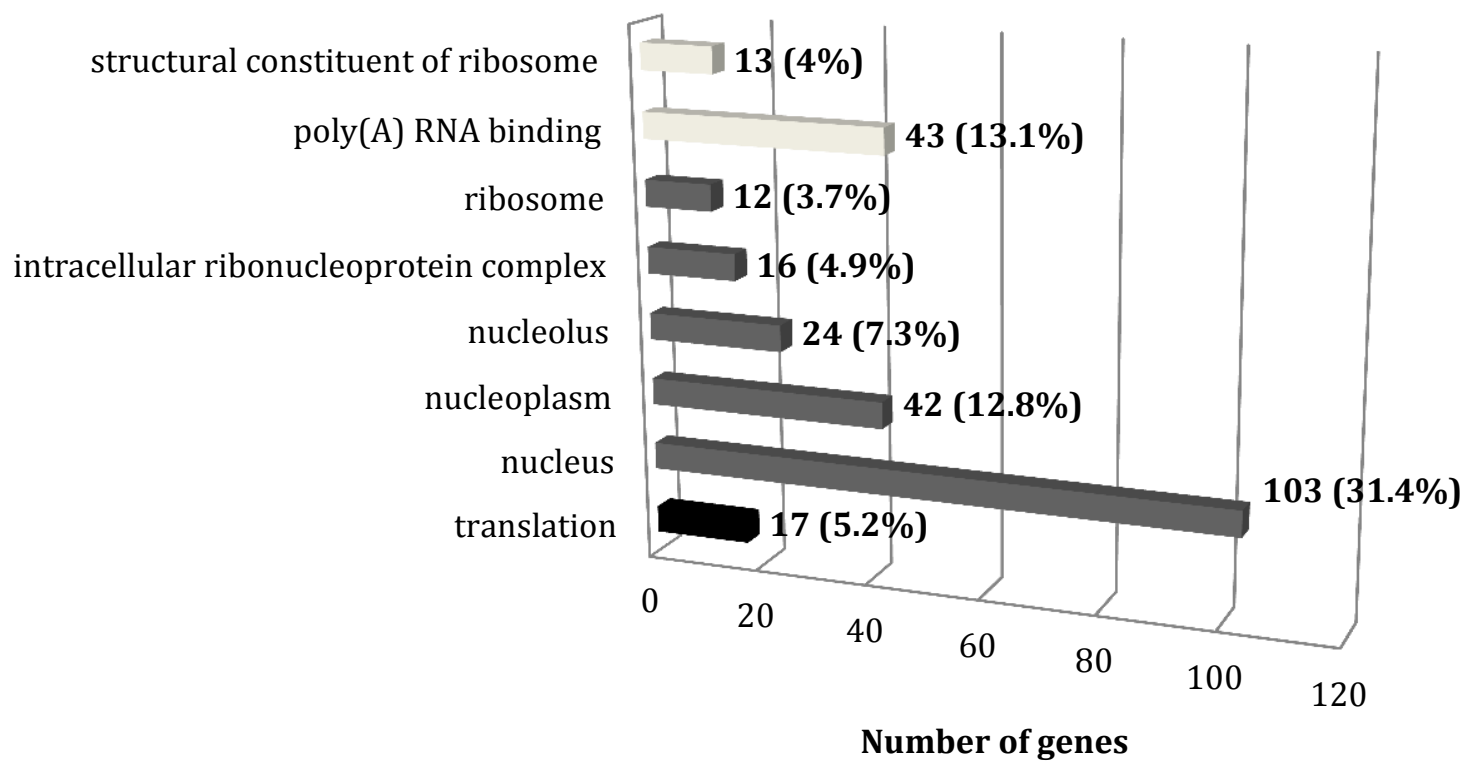

Figure 6. The numbers of genes and the percentage over whole gene set in each enriched GO terms that were identified for group 2 gene set (330 genes). Dark bar represents Biological Process (BP); Grey bar represents Cellular Component (CC)and light grey represents Molecular Function (MF).

Table 3: KEGG pathway enrichment analysis of DEGs

\begin{tabular}{llll}
\hline Term & Count & $\%$ & Benjamini \\
\hline Functional Annotation for 619 genes & & & \\
Pathways in cancer & 26 & 4.2 & $2.40 \mathrm{E}-02$ \\
Endocytosis & 24 & 3.9 & $2.40 \mathrm{E}-03$ \\
Proteoglycans in cancer & 17 & 2.7 & $2.60 \mathrm{E}-02$ \\
Focal adhesion & 16 & 2.6 & $4.70 \mathrm{E}-02$ \\
Axon guidance & 14 & 2.3 & $1.60 \mathrm{E}-02$ \\
Adherens junction & 12 & 1.9 & $3.20 \mathrm{E}-03$ \\
ECM-receptor interaction & 11 & 1.8 & $2.00 \mathrm{E}-02$ \\
N-Glycan biosynthesis & 8 & 1.3 & $2.30 \mathrm{E}-02$ \\
Acute myeloid leukemia & 8 & 1.3 & $4.50 \mathrm{E}-02$ \\
Steroid biosynthesis & 6 & 1 & $1.40 \mathrm{E}-02$ \\
Thyroid cancer & 6 & 1 & $4.40 \mathrm{E}-02$ \\
\hline Functional Annotation for 330 genes & & & \\
Ribosome & 10 & 3 & $8.80 \mathrm{E}-03$ \\
\hline
\end{tabular}

\section{Discussion}

It has been extensively described that $\mathrm{B}[\mathrm{a}] \mathrm{P}$ forms DNA adducts in mouse lung which are involved in lung carcinogenesis [40]. More recently, it has become clear that inflammation can further increase the genotoxicity of $\mathrm{B}$ [a]P [28]. Because inflammatory signaling is complex, and the fact that inflammation can impact on carcinogenesis at multiple levels, there is a lack of complete understanding of how inflammation affects $\mathrm{B}[\mathrm{a}] \mathrm{P}$-induced carcinogenesis and therefore more knowledge is needed to effectively intervene in the process. To get more insight into the processes that are altered by $\mathrm{B}[\mathrm{a}] \mathrm{P}$ exposure during acute pulmonary inflammation, we used microarray technology in a mouse model to identify gene expression patterns that were affected by both stimuli. The resulting gene expression profiles were additionally compared with results of our previous studies $[3,15,27,28]$ which have measured multiple molecular endpoints to 
further increase our biological understanding of the influence of LPS on B[a]P-induced genotoxicity.

It is known that $\mathrm{B}[\mathrm{a}] \mathrm{P}$ by itself is not genotoxic because it does not contain active groups in the molecule, but it's reactive metabolites may contain highly reactive groups that can bind covalently to macromolecules (e.g. protein and DNA). A variety of enzymes are involved in B[a]P metabolism, including enzymes encoded by Cyp1a1, Cyp1b1, Ephx or Arnt [40-42]. Since a lot of information is already available about the metabolic pathways of $\mathrm{B}[\mathrm{a}] \mathrm{P}$, targeted analysis of gene expression profiles was performed, in which we focused on genes that are known to be involved in $\mathrm{B}[\mathrm{a}] \mathrm{P}$ metabolism and $\mathrm{B}[\mathrm{a}] \mathrm{P}$-induced DNA damage response. A total of 57 genes were selected based on studies previously published (Table 1). We directly compared the expression of these genes in the $\mathrm{B}[\mathrm{a}] \mathrm{P}$ and LPS\&B[a]P treatment group and showed that gene expression of several key enzymes in phase I metabolism (e.g. Cyp1a1, Ephx1, Arnt, Cbr1, Por, Nqo2 and Comt) were significantly inhibited by additional exposure to LPS. This may theoretically lead to slower metabolism of $\mathrm{B}[\mathrm{a}] \mathrm{P}$. On the other hand, exposure to $\mathrm{B}[\mathrm{a}] \mathrm{P}$ is reported to cause gene up-regulation of various phase II detoxification enzymes, including GSTs, UGTs and SULTs [43]. In our study gene expression of a majority of these phase II detoxification enzymes was significantly down-regulated by prior exposure to LPS, including Sult1a1, Gstp1, Gstm1, Gstt1 and Gpx3. In contrast our results indicated that UGTs like Ugt1a1 and Ugt1a6 were all up-regulated by prior exposure to LPS although these changes were not statistically significant; UGTs are major detoxification enzymes catalyzing the conjugation of $\mathrm{B}[\mathrm{a}] \mathrm{P}-7,8$-dihydrodiol to glucuronides. $\mathrm{B}[\mathrm{a}] \mathrm{P}$-glucuronides can be cleaved by $\beta$-glucuronidase $(G u s b)$. Interestingly, although Gusb gene expression was not statistic significantly up-regulated $(p=0.075) \beta$-glucuronidase enzyme activity was significantly up-regulated in animals that were treated with both $\mathrm{B}[\mathrm{a}] \mathrm{P}$ and LPS. Therefore, $\beta$-glucuronidase could convert glucuronided $\mathrm{B}[\mathrm{a}] \mathrm{P}$ metabolites back into their active forms [3]. Due to the down-regulation of the phase II enzymes, cells can subsequently not sufficiently detoxify the active metabolites, potentially leading to more DNA adducts. Indeed, higher levels of $\mathrm{B}[\mathrm{a}] \mathrm{P}$-induced adducts were found in inflamed lungs after $\mathrm{B}[\mathrm{a}] \mathrm{P}$ exposure.

In addition, Nox1 was significantly up-regulated in the LPS\&B[a]P group. Nox1 is a biomarker for cellular oxidative stress, indicating that more ROS are produced in LPS\&B[a]P-exposed animals, which may cause additional DNA damage [44]. It was previously reported that ROS may inhibit NER [45]. However, in the present study, out of the 11 selected NER-related genes, only Xpa and Xpe were significantly up-regulated and down-regulated by LPS, respectively. In this case, gene expression changes did not necessarily reflect repair activity, probably because DNA repair activity is mainly regulated at the post-translational level.

To visualize the potential phenotypic effects of gene expression changes, we linked the gene expression profiles with phenotype data which were published by us in our previous studies (Fig 2). The EROD and the CEC assay both mainly measure the activity of CYP1 family enzymes [46, 47]. Using the EROD and CEC assay we observed a significant inhibitory effect in the LPS\&B[a]P-treated animals compared to animals treated with B[a]P only; Cyp1a1 expression changes observed here correlated with the phenotype. In contrast to Cyp1a1 gene expression and enzyme activity, the quantitation of Cyp1a1 and Cyp1b1 proteins by Western blotting showed no difference between $\mathrm{B}[\mathrm{a}] \mathrm{P}$ - and LPS\&B[a]P-exposed mouse lungs (previously published data; Arlt et al., 2015). At this moment it is unknown why gene expression and protein levels of these Cyp1 enzymes do not represent Cyp1 activity. One possible reason is the selection of a 
single time point (48 hours) for both measurements; Cyp1a1 gene expression is an early event whereas protein expression would be considered a later event and enzyme activity may additionally be modulated by posttranslational protein modification. Moreover, CYP activity can also be inhibited by ROS [48-50], which is produced in excess by additional exposure to LPS, which may provide one explanation why protein levels and enzyme activity do not correlate.

In addition, Cyp1a1 is the most induced CYP enzyme after B[a]P exposure in both in vitro and in vivo studies, and it is most relevant for $\mathrm{B}[\mathrm{a}] \mathrm{P}$ metabolism $[16,51,52]$. However, the role of Cyp enzymes in $\mathrm{B}[\mathrm{a}] \mathrm{P}$-induced genotoxicity is still not fully elucidated. While in in vitro studies increased activity of Cyp1a1 is predominantly involved in the activation of $\mathrm{B}[\mathrm{a}] \mathrm{P}$, paradoxically in in vivo studies it seems that Cyp1a1 is more important for $\mathrm{B}[\mathrm{a}] \mathrm{P}$ detoxification $[16,53]$. Since the current study was an in vivo experiment, a decreased expression of Cyp1a1/Cyp1a1 by the presence of inflammation might indicate that less $\mathrm{B}[\mathrm{a}] \mathrm{P}$ is detoxified. Also some for other phenotypic assays, the gene expression pattern did not correspond directly to activity (i.e. NER and NQO1 activity). NER is the major repair mechanism for $\mathrm{B}[\mathrm{a}] \mathrm{P}$ induced DNA damage and the measured repair activity is the net effect of a combination of enzymes during NER process (recognition and incision) (including Xpa, Xpc, Ercc1, Ercc2, and Ercc 4) [54]. NER capacity was higher in the LPS\&B[a]P group than in the B[a]P-exposed animals or controls, but it did not reach statistical significance. Enhanced NER activity seems logical as a reaction to $\mathrm{B}[\mathrm{a}] \mathrm{P}$-induced DNA damage, but due to the LPS-induced oxidative stress both expression of some NER-related genes (Fig 2 E) and activity can be inhibited [55]. Since the level of DNA damage is determined by the formation of DNA adducts and their removal, the higher levels of DNA damage that were observed in the LPS\&B[a]P group cannot be related to changes in DNA repair activity alone.

NQ01 can protect cells against oxidative stress that is induced by redox cycling of B[a]P-quinones [56]. The B[a]P-induced activity of Nqo1 was significantly inhibited by LPS. However, in the current study we found that Nqo2 gene expression displayed a better correlation than Nqo1 gene expression with the phenotypic measure of Nqo1 enzyme activity. It is possible that the phenotypic assay is not specific for Nqo1 alone, but may additionally reflect Nqo2 enzyme activity. Interestingly, higher gene expression of Nox1 and lower gene expressions of Nqo1 and Nqo2 might lead to higher levels of oxidative stress in LPS\&B[a]P animals than animals treated with $\mathrm{B}[\mathrm{a}] \mathrm{P}$ or even LPS alone, further driving the inflammatory response. Indeed, PCA analysis indicated that 398 genes could differentiate animals among all treatment groups (control, LPS, B[a]P and LPS\&B[a]P), and most of these genes are known to be involved in immune response and inflammation (Table 2). Interestingly, both $\mathrm{B}[\mathrm{a}] \mathrm{P}$ and BPDE have been reported to induce inflammation and immune responses in both in vitro and in vivo studies $[23,57]$. These data suggest that genes involved in inflammation may be key determinants in $\mathrm{B}[\mathrm{a}] \mathrm{P}$-induced genotoxicity.

To further analyze the data in an unsupervised approach we identified DEGs on the basis of 2 criteria: 1 . They were altered in expression by B[a]P exposure and 2 . The additional exposure to LPS modified their gene expression. This resulted in genes that mainly displayed an inhibitory effect (i.e. gene expression initially changed by $\mathrm{B}[\mathrm{a}] \mathrm{P}$ but again altered towards controls in the presence of inflammation), and we subsequently performed GO and KEGG enrichment analysis on gene set group 1 (619 genes, initially up-regulated by $\mathrm{B}[\mathrm{a}] \mathrm{P}$ ) and 2 (330 genes, initially down-regulated by $\mathrm{B}[\mathrm{a}] \mathrm{P}$ ) via the online tool DAVID. Among the GO terms identified for the Group 1, the majority of genes were involved in cellular components: membrane (313 genes), cytoplasm (250 genes) 
and extracellular exosome (161 genes). These cellular components are essential for maintaining cellular intactness and interaction between cells [58, 59]. Many of these genes were related to cell adhesion. Cell adhesion plays a significant role in inhibiting the processes in multistage carcinogenesis, cancer cell local invasion and metastasis [60]. However, our data indicate that inflammation (induced by LPS treatment) inactivated cell adhesion, which may further stimulate lung cancer development that was initially induced by $\mathrm{B}[\mathrm{a}] \mathrm{P}$. For the group 2 gene set (initially down-regulated by $\mathrm{B}[\mathrm{a}] \mathrm{P}$ ), genes related to 'RNA translation' processes were identified. This was unexpected because it is known that $\mathrm{B}[\mathrm{a}] \mathrm{P}$ can enhance its own bio-activation by inducing gene expression (e.g. Cyp1a1, Cyp1b1 and $M p o$ ) via binding to xenobiotic-response elements in the nuclear DNA [61]. This should lead to increased RNA production and subsequent translation. It is possible that part of the phenotypic inhibition is due to a slower translation of mRNA into functional proteins. However, it should be noted that we measured RNA expression at 48 hours after $\mathrm{B}[\mathrm{a}] \mathrm{P}$ exposure, and at that time point the largest part of $\mathrm{B}[\mathrm{a}] \mathrm{P}$ may already be metabolized and removed. LPS inhibited the metabolism of $\mathrm{B}[\mathrm{a}] \mathrm{P}$ and therefore we might detect a delayed effect of $\mathrm{B}[\mathrm{a}] \mathrm{P}$ in the lung in the presence of LPS. Another possibility could be that LPS inhibited the down-regulation of genes involved in RNA translation.

The KEGG pathway enrichment analysis showed similar results as the analysis of GO terms. For example, pathways involved in endocytosis and adherens junction were identified for the group 1 gene set and pathways involved in ribosome function was found for the group 2 gene set. Besides that, several pathways related to cancer were observed for group 1 genes. Specifically, genes related to cytokine-cytokine receptor interaction, Wnt signaling pathway and mitogen-activated protein kinase (MAPK) signaling pathway were found. Moreover, the endpoint of these pathways all point to cell proliferation and differentiation. This might provide additional evidence for the delayed effect of $\mathrm{B}[\mathrm{a}] \mathrm{P}$ due to prior LPS exposure; after exposure to $\mathrm{B}[\mathrm{a}] \mathrm{P}$ for 48 hours, cells are recovering from the $\mathrm{B}[\mathrm{a}] \mathrm{P}$-induced damage by modulating cell cycle, $\mathrm{DNA}$ repair, and cell proliferation and differentiation [51]. But, in the presence of LPS, all of these normal cellular responses after $\mathrm{B}[\mathrm{a}] \mathrm{P}$ exposure are inhibited and may happen at or later than 48 hours after the exposure to $\mathrm{B}[\mathrm{a}] \mathrm{P}$.

The current study has some limitations that need to be mentioned. Firstly, the RNA microarray was performed on RNA derived from whole mouse lung. Therefore, part of the gene expression changes may be related to the influx of inflammatory cells into the lung. For instance, increased expression and activity of $\beta$-glucuronidase is probably not due to increased expression of this gene in lung epithelial cells, but may be due to the fact that activated inflammatory cells expressing this gene are present in higher amounts in the lung after LPS exposure. Nevertheless, the gene expression changes observed in the current study still give an indication for the general underlying mechanism(s) and help to understand why the presence of inflammation in the lung leads to higher levels of DNA damage. Secondly, the effect of LPS treatment was not directly included in in the selection of DEGs. Therefore, some of the DEGs that were selected based on our criteria may be related to an LPS effect only. Indeed, we showed that over $50 \%$ of the DEGs in the LPS and LPS\&B[a]P group overlap (Fig 1). However, since it was not the focus of our study to investigate a pure LPS effect on gene expression, these data is not shown but all gene expression data has been deposited.

Last but not least, the animals were sacrificed at one single time point after exposure. Indeed, 48 hours may be too late for assessing very early $\mathrm{B}[\mathrm{a}] \mathrm{P}$ metabolic events, but in our previous studies in which we exposed rodents to $\mathrm{B}[\mathrm{a}] \mathrm{P}$, highest DNA adduct levels 
were always found at approximately 2 days after the exposure [28]. Therefore, to investigate cellular effects at the highest level of DNA damage, 48 hours was chosen as exposure time point. Studying earlier ( $<48$ hours) cellular effect of B[a]P was beyond the scope of the present study.

\section{Conclusion}

Many previous microarray studies have investigated the effect of $\mathrm{B}[\mathrm{a}] \mathrm{P}$ exposure in vitro and in vivo, and we confirmed these results by showing that $\mathrm{B}[\mathrm{a}] \mathrm{P}$ can disrupt cholesterol (steroid) metabolism, DNA repair and cell cycle at 48 hours after exposure. The additional treatment to LPS is less well studied, but may mimic real life situations much better, because many types of environmental exposures (e.g. cigarette smoke, vehicle exhaust, ambient air particulate matter) not only result in the exposure to PAHs but are also capable of inducing inflammation. Combined exposure of mice to LPS and $\mathrm{B}[\mathrm{a}] \mathrm{P}$ resulted in a complex gene expression response which pointed towards delayed metabolism of $\mathrm{B}[\mathrm{a}] \mathrm{P}$. Although the expression of genes that code for enzymes that are known to activate $\mathrm{B}[\mathrm{a}] \mathrm{P}$ were inhibited by inflammation, genes of enzymes in phase II detoxification reactions were also down-regulated by LPS (Fig 7). Consequently, exposure to LPS seems to slow down $\mathrm{B}[\mathrm{a}] \mathrm{P}$ metabolism and this leads to a prolonged exposure of lung cells to $\mathrm{B}[\mathrm{a}] \mathrm{P}$. As a consequence higher $\mathrm{B}[\mathrm{a}] \mathrm{P}-\mathrm{DNA}$ adduct levels were observed in mouse lung after 48 hours of exposure. Additionally, our analysis indicated that cell-cell communication is disturbed, which is important for the process of lung carcinogenesis. Overall, our data support the idea that the combined exposure to PAHs and inflammation will lead to an increased risk for developing lung cancer. 


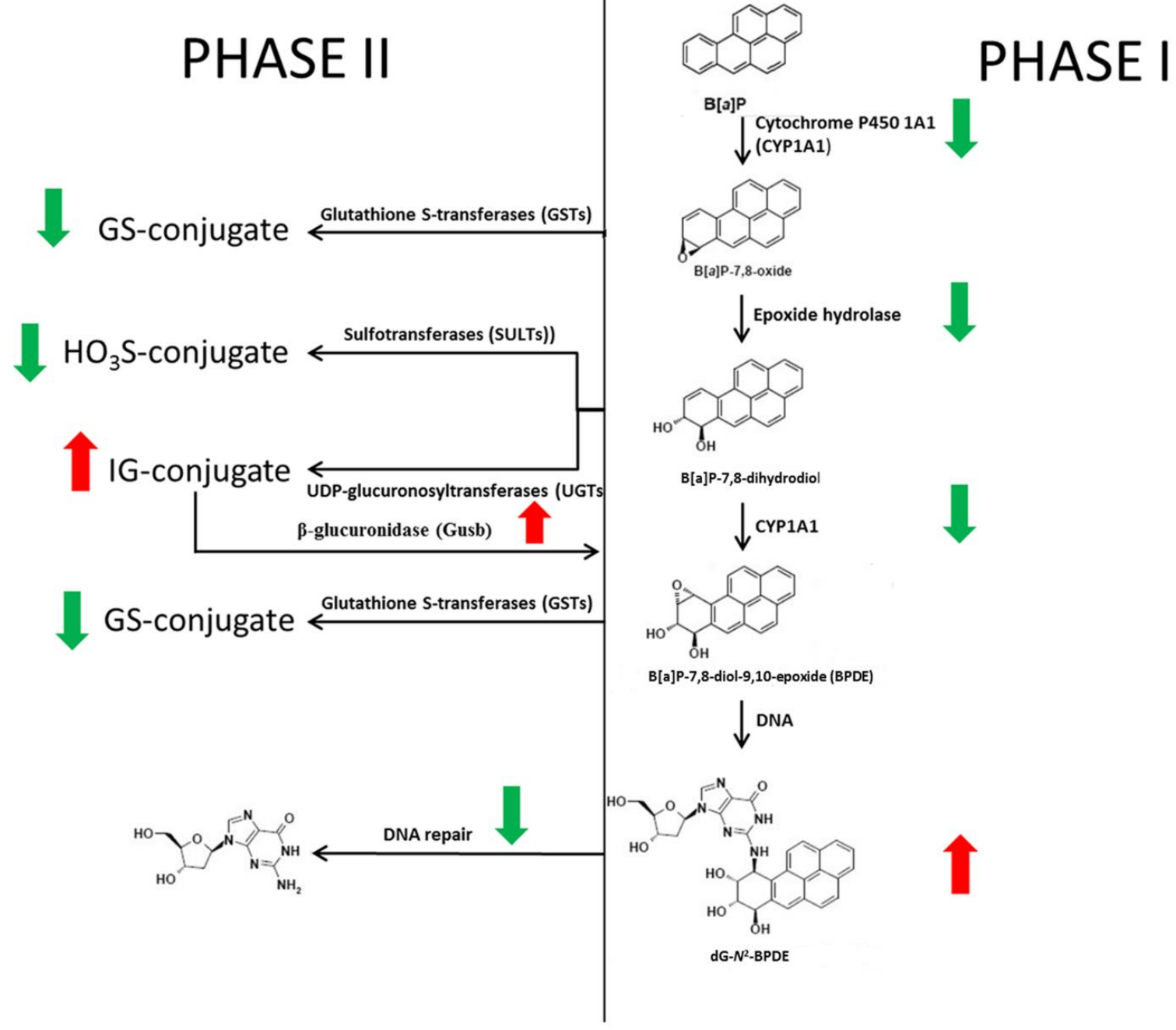

Figure 7. Proposed alternation of B[a]P metabolism pathway after initial LPS-induced inflammation. This pathway is based on our transcriptome analysis together with previous phenotypic analyses, suggesting that LPS inhibits Cyp1a1, epoxide hydrolase, GSTs, SULTs. Although UGTs are up-regulated by LPS, $\beta$-glucuronidase, which could convert UGTs conjugated $\mathrm{B}[\mathrm{a}] \mathrm{P}$ metabolites into their free form, is also up-regulated. Finally, LPS enhanced the B[a]P-induced DNA damage by forming BPDE-DNA adducts. 


\section{References}

[1] P.T. King, Inflammation in chronic obstructive pulmonary disease and its role in cardiovascular disease and lung cancer, Clinical and translational medicine, 4 (2015) 68.

[2] M. Mittal, M.R. Siddiqui, K. Tran, S.P. Reddy, A.B. Malik, Reactive Oxygen Species in Inflammation and Tissue Injury, Antioxidants \& Redox Signaling, 20 (2014) 1126-1167.

[3] Q. Shi, G.R. Haenen, L. Maas, V.M. Arlt, D. Spina, Y.R. Vasquez, E. Moonen, C. Veith, F.J. Van Schooten, R.W. Godschalk, Inflammation-associated extracellular beta-glucuronidase alters cellular responses to the chemical carcinogen benzo[a]pyrene, Arch Toxicol, 90 (2016) 2261-2273.

[4] N. Gungor, R.W. Godschalk, D.M. Pachen, F.J. Van Schooten, A.M. Knaapen, Activated neutrophils inhibit nucleotide excision repair in human pulmonary epithelial cells: role of myeloperoxidase, FASEB journal : official publication of the Federation of American Societies for Experimental Biology, 21 (2007) 2359-2367.

[5] H. Zelová, J. Hošek, TNF- $\alpha$ signalling and inflammation: interactions between old acquaintances, Inflammation Research, 62 (2013) 641-651.

[6] C. Gabay, Interleukin-6 and chronic inflammation, Arthritis Research \& Therapy, 8 (2006) S3-S3.

[7] M. Gomes, A.L. Teixeira, A. Coelho, A. Araujo, R. Medeiros, The role of inflammation in lung cancer, Adv Exp Med Biol, 816 (2014) 1-23.

[8] P.T. King, Inflammation in chronic obstructive pulmonary disease and its role in cardiovascular disease and lung cancer, Clin Transl Med, 4 (2015) 68.

[9] G. Grunig, L.M. Marsh, N. Esmaeil, K. Jackson, T. Gordon, J. Reibman, G. Kwapiszewska, S.-H. Park, Perspective: ambient air pollution: inflammatory response and effects on the lung's vasculature, Pulmonary Circulation, 4 (2014) 25-35.

[10] T. Walser, X. Cui, J. Yanagawa, J.M. Lee, E. Heinrich, G. Lee, S. Sharma, S.M. Dubinett, Smoking and lung cancer: the role of inflammation, Proc Am Thorac Soc, 5 (2008) 811-815.

[11] H.I. Abdel-Shafy, M.S.M. Mansour, A review on polycyclic aromatic hydrocarbons: Source, environmental impact, effect on human health and remediation, Egyptian Journal of Petroleum, 25 (2016) 107-123.

[12] B. Ewa, M.S. Danuta, Polycyclic aromatic hydrocarbons and PAH-related DNA adducts, J Appl Genet, (2016).

[13] M.A. Schults, K. Sanen, R.W. Godschalk, J. Theys, F.J. van Schooten, R.K. Chiu, Hypoxia diminishes the detoxification of the environmental mutagen benzo[a]pyrene, Mutagenesis, 29 (2014) 481-487.

[14] L. Umannova, M. Machala, J. Topinka, Z. Novakova, A. Milcova, A. Kozubik, J. Vondracek, Tumor necrosis factor-alpha potentiates genotoxic effects of benzo[a]pyrene in rat liver epithelial cells through upregulation of cytochrome P450 1B1 expression, Mutat Res, 640 (2008) 162-169.

[15] Q. Shi, L. Maas, C. Veith, F.J. Van Schooten, R.W. Godschalk, Acidic cellular microenvironment modifies carcinogen-induced DNA damage and repair, Arch Toxicol, (2016).

[16] V.M. Arlt, M. Stiborova, C.J. Henderson, M. Thiemann, E. Frei, D. Aimova, R. Singh, G. Gamboa da Costa, O.J. Schmitz, P.B. Farmer, C.R. Wolf, D.H. Phillips, Metabolic activation of benzo[a]pyrene in vitro by hepatic cytochrome P450 contrasts with detoxification in vivo: experiments with hepatic cytochrome P450 reductase null mice, Carcinogenesis, 29 (2008) 656-665.

[17] X. Ren, L. Pan, L. Wang, Metabolic enzyme activities, metabolism-related genes expression and bioaccumulation in juvenile white shrimp Litopenaeus vannamei exposed to benzo[a]pyrene, Ecotoxicol Environ Saf, 104 (2014) 79-86.

[18] Z. Zheng, J.L. Fang, P. Lazarus, Glucuronidation: an important mechanism for detoxification of benzo[a]pyrene metabolites in aerodigestive tract tissues, Drug Metab Dispos, 30 (2002) 397-403.

[19] N. Verhofstad, J.L.A. Pennings, C.T. van Oostrom, J. van Benthem, F.J. van Schooten, H. van Steeg, R.W.L. Godschalk, Benzo(a)pyrene induces similar gene expression changes in testis of DNA repair proficient and deficient mice, BMC Genomics, 11 (2010) 333-333.

[20] J.E. Kucab, H. van Steeg, M. Luijten, H.H. Schmeiser, P.A. White, D.H. Phillips, V.M. Arlt, TP53 mutations induced by BPDE in Xpa-WT and Xpa-Null human TP53 knock-in (Hupki) mouse embryo fibroblasts, Mutat Res, 773 (2015) 48-62.

[21] S. Uno, M. Makishima, Benzo [a] pyrene toxicity and inflammatory disease, Current Rheumatology Reviews, 5 (2009) 266-271.

[22] L. Smerdova, J. Neca, J. Svobodova, J. Topinka, J. Schmuczerova, A. Kozubik, M. Machala, J. Vondracek, Inflammatory mediators accelerate metabolism of benzo[a]pyrene in rat alveolar type II cells: the role of enhanced cytochrome P450 1B1 expression, Toxicology, 314 (2013) 30-38.

[23] W. Qamar, A.Q. Khan, R. Khan, A. Lateef, M. Tahir, M.U. Rehman, F. Ali, S. Sultana, Benzo(a)pyrene-induced pulmonary inflammation, edema, surfactant dysfunction, and injuries in rats: alleviation by farnesol, Exp Lung Res, 38 (2012) 19-27.

[24] S.A. Patel, N.J. Gooderham, Interleukin-6 promotes dietary carcinogen-induced DNA damage in colorectal cancer cells, Toxicology Research, 4 (2015) 858-866.

[25] M.A. Schults, L. Timmermans, R.W. Godschalk, J. Theys, B.G. Wouters, F.J. van Schooten, R.K. Chiu, Diminished carcinogen detoxification is a novel mechanism for hypoxia-inducible factor 1-mediated genetic instability, J Biol Chem, 285 (2010) 14558-14564.

[26] K. Ji, C. Xing, F. Jiang, X. Wang, H. Guo, J. Nan, L. Qian, P. Yang, J. Lin, M. Li, J. Li, L. Liao, J. Tang, Benzo[a]pyrene induces oxidative stress and endothelial progenitor cell dysfunction via the activation of the NF-kappaB pathway, Int J Mol Med, 31 (2013) 922-930. 
[27] Q. Shi, A.W. Boots, L. Maas, C. Veith, K. van Kuijk, G.R. Haenen, R.W. Godschalk, F.J. Van Schooten, Effect of interleukin (IL)-8 on benzo[a]pyrene metabolism and DNA damage in human lung epithelial cells, Toxicology, 381 (2017) 64-74.

[28] V.M. Arlt, A.M. Krais, R.W. Godschalk, Y. Riffo-Vasquez, I. Mrizova, C.A. Roufosse, C. Corbin, Q. Shi, E. Frei, M. Stiborova, F.J. van Schooten, D.H. Phillips, D. Spina, Pulmonary Inflammation Impacts on CYP1A1-Mediated Respiratory Tract DNA Damage Induced by the Carcinogenic Air Pollutant Benzo[a]pyrene, Toxicol Sci, 146 (2015) 213-225.

[29] N. Gungor, A. Haegens, A.M. Knaapen, R.W. Godschalk, R.K. Chiu, E.F. Wouters, F.J. van Schooten, Lung inflammation is associated with reduced pulmonary nucleotide excision repair in vivo, Mutagenesis, 25 (2010) 77-82.

[30] A.H. Hashimoto, K. Amanuma, K. Hiyoshi, H. Takano, K. Masumura, T. Nohmi, Y. Aoki, In vivo mutagenesis induced by benzo[a]pyrene instilled into the lung of gpt delta transgenic mice, Environ Mol Mutagen, 45 (2005) 365-373.

[31] K. Lin, H. Kools, P.J. de Groot, A.K. Gavai, R.K. Basnet, F. Cheng, J. Wu, X. Wang, A. Lommen, G.J. Hooiveld, G. Bonnema, R.G. Visser, M.R. Muller, J.A. Leunissen, MADMAX - Management and analysis database for multiple $\sim$ omics experiments, J Integr Bioinform, 8 (2011) 160.

[32] B.M. Bolstad, R.A. Irizarry, M. Astrand, T.P. Speed, A comparison of normalization methods for high density oligonucleotide array data based on variance and bias, Bioinformatics, 19 (2003) 185-193.

[33] M. Dai, P. Wang, A.D. Boyd, G. Kostov, B. Athey, E.G. Jones, W.E. Bunney, R.M. Myers, T.P. Speed, H. Akil, S.J. Watson, F. Meng, Evolving gene/transcript definitions significantly alter the interpretation of GeneChip data, Nucleic Acids Res, 33 (2005) e175.

[34] M.A. Sartor, C.R. Tomlinson, S.C. Wesselkamper, S. Sivaganesan, G.D. Leikauf, M. Medvedovic, Intensity-based hierarchical Bayes method improves testing for differentially expressed genes in microarray experiments, BMC Bioinformatics, 7 (2006) 538.

[35] S. Raychaudhuri, J.M. Stuart, R.B. Altman, PRINCIPAL COMPONENTS ANALYSIS TO SUMMARIZE MICROARRAY EXPERIMENTS: APPLICATION TO SPORULATION TIME SERIES, Pacific Symposium on Biocomputing. Pacific Symposium on Biocomputing, (2000) 455-466.

[36] X. Jiao, B.T. Sherman, W. Huang da, R. Stephens, M.W. Baseler, H.C. Lane, R.A. Lempicki, DAVID-WS: a stateful web service to facilitate gene/protein list analysis, Bioinformatics, 28 (2012) 1805-1806.

[37] M.A. Harris, J. Clark, A. Ireland, J. Lomax, M. Ashburner, R. Foulger, K. Eilbeck, S. Lewis, B. Marshall, C. Mungall, J. Richter, G.M. Rubin, J.A. Blake, C. Bult, M. Dolan, H. Drabkin, J.T. Eppig, D.P. Hill, L. Ni, M. Ringwald, R. Balakrishnan, J.M. Cherry, K.R. Christie, M.C. Costanzo, S.S. Dwight, S. Engel, D.G. Fisk, J.E. Hirschman, E.L. Hong, R.S. Nash, A. Sethuraman, C.L. Theesfeld, D. Botstein, K. Dolinski, B. Feierbach, T. Berardini, S. Mundodi, S.Y. Rhee, R. Apweiler, D. Barrell, E. Camon, E. Dimmer, V. Lee, R. Chisholm, P. Gaudet, W. Kibbe, R. Kishore, E.M. Schwarz, P. Sternberg, M. Gwinn, L. Hannick, J. Wortman, M. Berriman, V. Wood, N. de la Cruz, P. Tonellato, P. Jaiswal, T. Seigfried, R. White, C. Gene Ontology, The Gene Ontology (GO) database and informatics resource, Nucleic Acids Res, 32 (2004) D258-261.

[38] J.D. Zhang, S. Wiemann, KEGGgraph: a graph approach to KEGG PATHWAY in R and bioconductor, Bioinformatics, 25 (2009) 1470-1471.

[39] E.S. Fischer, K. Böhm, J.R. Lydeard, H. Yang, M.B. Stadler, S. Cavadini, J. Nagel, F. Serluca, V. Acker, G.M. Lingaraju, R.B. Tichkule, M. Schebesta, W.C. Forrester, M. Schirle, U. Hassiepen, J. Ottl, M. Hild, R.E.J. Beckwith, J.W. Harper, J.L. Jenkins, N.H. Thomä, Structure of the DDB1-CRBN E3 ubiquitin ligase in complex with thalidomide, Nature, 512 (2014) 49-53.

[40] J. Zuo, D.S. Brewer, V.M. Arlt, C.S. Cooper, D.H. Phillips, Benzo pyrene-induced DNA adducts and gene expression profiles in target and non-target organs for carcinogenesis in mice, BMC Genomics, 15 (2014) 880.

[41] S.L. Hockley, V.M. Arlt, D. Brewer, R. Te Poele, P. Workman, I. Giddings, D.H. Phillips, AHR- and DNA-damage-mediated gene expression responses induced by benzo(a)pyrene in human cell lines, Chem Res Toxicol, 20 (2007) 1797-1810.

[42] H. Hamouchene, V.M. Arlt, I. Giddings, D.H. Phillips, Influence of cell cycle on responses of MCF-7 cells to benzo[a]pyrene, BMC Genomics, 12 (2011) 333.

[43] H.V. Gelboin, Benzo [alpha] pyrene metabolism, activation and carcinogenesis: role and regulation of mixed-function oxidases and related enzymes, Physiological reviews, 60 (1980) 1107-1166.

[44] A.M. Knaapen, N. Gungor, R.P. Schins, P.J. Borm, F.J. Van Schooten, Neutrophils and respiratory tract DNA damage and mutagenesis: a review, Mutagenesis, 21 (2006) 225-236.

[45] R. Hakem, DNA-damage repair; the good, the bad, and the ugly, The EMBO journal, 27 (2008) 589-605.

[46] F.L. Martin, Patel, II, O. Sozeri, P.B. Singh, N. Ragavan, C.M. Nicholson, E. Frei, W. Meinl, H. Glatt, D.H. Phillips, V.M. Arlt, Constitutive expression of bioactivating enzymes in normal human prostate suggests a capability to activate pro-carcinogens to DNA-damaging metabolites, Prostate, 70 (2010) 1586-1599.

[47] A.M. Krais, E.N. Speksnijder, J.P. Melis, R. Indra, M. Moserova, R.W. Godschalk, F.J. van Schooten, A. Seidel, K. Kopka, H.H. Schmeiser, M. Stiborova, D.H. Phillips, M. Luijten, V.M. Arlt, The impact of p53 on DNA damage and metabolic activation of the environmental carcinogen benzo[a]pyrene: effects in Trp53(+/+), Trp53(+/-) and Trp53(-/-) mice, Arch Toxicol, 90 (2016) 839-851.

[48] Y. Morel, R. Barouki, Down-regulation of cytochrome P450 1A1 gene promoter by oxidative stress. Critical contribution of nuclear factor 1, J Biol Chem, 273 (1998) 26969-26976.

[49] Karuzina, II, A.I. Archakov, Hydrogen peroxide-mediated inactivation of microsomal cytochrome P450 during monooxygenase reactions, Free radical biology \& medicine, 17 (1994) 557-567.

[50] Karuzina, II, A.I. Archakov, The oxidative inactivation of cytochrome P450 in monooxygenase reactions, Free radical biology \& medicine, 16 (1994) 73-97. 
[51] J.H. van Delft, K. Mathijs, Y.C. Staal, M.H. van Herwijnen, K.J. Brauers, A. Boorsma, J.C. Kleinjans, Time series analysis of benzo[A]pyrene-induced transcriptome changes suggests that a network of transcription factors regulates the effects on functional gene sets, Toxicol Sci, 117 (2010) 381-392.

[52] M. Stiborova, R. Indra, M. Moserova, E. Frei, H.H. Schmeiser, K. Kopka, D.H. Philips, V.M. Arlt, NADH:Cytochrome b5 Reductase and Cytochrome b5 Can Act as Sole Electron Donors to Human Cytochrome P450 1A1-Mediated Oxidation and DNA Adduct Formation by Benzo[a]pyrene, Chem Res Toxicol, 29 (2016) 1325-1334.

[53] V.M. Arlt, M.C. Poirier, S.E. Sykes, K. John, M. Moserova, M. Stiborova, C.R. Wolf, C.J. Henderson, D.H. Phillips, Exposure to benzo[a]pyrene of Hepatic Cytochrome P450 Reductase Null (HRN) and P450 Reductase Conditional Null (RCN) mice: Detection of benzo[a]pyrene diol epoxide-DNA adducts by immunohistochemistry and 32P-postlabelling, Toxicol Lett, 213 (2012) 160-166.

[54] O.D. Schärer, Nucleotide Excision Repair in Eukaryotes, Cold Spring Harbor Perspectives in Biology, 5 (2013) a012609.

[55] S.A. Langie, A.M. Knaapen, J.M. Houben, F.C. van Kempen, J.P. de Hoon, R.W. Gottschalk, R.W. Godschalk, F.J. van Schooten, The role of glutathione in the regulation of nucleotide excision repair during oxidative stress, Toxicol Lett, 168 (2007) 302-309.

[56] J. Shen, R.J. Barrios, A.K. Jaiswal, Inactivation of the quinone oxidoreductases NQO1 and NQO2 strongly elevates the incidence and multiplicity of chemically induced skin tumors, Cancer research, 70 (2010) 1006-1014.

[57] K. Dreij, K. Rhrissorrakrai, K.C. Gunsalus, N.E. Geacintov, D.A. Scicchitano, Benzo[a]pyrene diol epoxide stimulates an inflammatory response in normal human lung fibroblasts through a p53 and JNK mediated pathway, Carcinogenesis, 31 (2010) 1149-1157.

[58] J.R. Edgar, Q\&A: What are exosomes, exactly?, BMC Biology, 14 (2016) 46.

[59] X. Tekpli, M. Rissel, L. Huc, D. Catheline, O. Sergent, V. Rioux, P. Legrand, J.A. Holme, M.T. Dimanche-Boitrel, D. Lagadic-Gossmann, Membrane remodeling, an early event in benzo[a]pyrene-induced apoptosis, Toxicol Appl Pharmacol, 243 (2010) 68-76.

[60] R.M. Bremnes, R. Veve, F.R. Hirsch, W.A. Franklin, The E-cadherin cell-cell adhesion complex and lung cancer invasion, metastasis, and prognosis, Lung Cancer, 36 (2002) 115-124.

[61] M.A. Schults, R.K. Chiu, P.W. Nagle, L.C. Wilms, J.C. Kleinjans, F.J. van Schooten, R.W. Godschalk, Genetic polymorphisms in catalase and CYP1B1 determine DNA adduct formation by benzo(a)pyrene ex vivo, Mutagenesis, 28 (2013) 181-185.

[62] J.H. Kim, K.H. Stansbury, N.J. Walker, M.A. Trush, P.T. Strickland, T.R. Sutter, Metabolism of benzo[a]pyrene and benzo[a]pyrene-7,8-diol by human cytochrome P450 1B1, Carcinogenesis, 19 (1998) 1847-1853.

[63] A. Ghosal, N. Hapangama, Y. Yuan, X. Lu, D. Horne, J.E. Patrick, S. Zbaida, Rapid determination of enzyme activities of recombinant human cytochromes P450, human liver microsomes and hepatocytes, Biopharm Drug Dispos, 24 (2003) 375-384.

[64] B. Moorthy, K.P. Miller, W. Jiang, E.S. Williams, S.R. Kondraganti, K.S. Ramos, Role of cytochrome P4501B1 in benzo[a]pyrene bioactivation to DNA-binding metabolites in mouse vascular smooth muscle cells: evidence from 32P-postlabeling for formation of 3-hydroxybenzo[a]pyrene and benzo[a]pyrene-3,6-quinone as major proximate genotoxic intermediates, The Journal of pharmacology and experimental therapeutics, 305 (2003) 394-401.

[65] M. Martignoni, G.M. Groothuis, R. de Kanter, Species differences between mouse, rat, dog, monkey and human CYP-mediated drug metabolism, inhibition and induction, Expert opinion on drug metabolism \& toxicology, 2 (2006) 875-894.

[66] E. Bauer, Z. Guo, Y.F. Ueng, L.C. Bell, D. Zeldin, F.P. Guengerich, Oxidation of benzo[a]pyrene by recombinant human cytochrome P450 enzymes, Chemical research in toxicology, 8 (1995) 136-142.

[67] Z. Guo, E.M. Gillam, S. Ohmori, R.H. Tukey, F.P. Guengerich, Expression of modified human cytochrome P450 $1 \mathrm{~A} 1$ in Escherichia coli: effects of $5^{\prime}$ substitution, stabilization, purification, spectral characterization, and catalytic properties, Archives of biochemistry and biophysics, 312 (1994) 436-446.

[68] C. Luckert, A. Ehlers, T. Buhrke, A. Seidel, A. Lampen, S. Hessel, Polycyclic aromatic hydrocarbons stimulate human CYP3A4 promoter activity via PXR, Toxicology letters, 222 (2013) 180-188.

[69] A. Trush, R.L. Esterline, W.G. Mallet, D.R. Mosebrook, L.E. Twerdok, Further evidence for the role of myeloperoxidase in the activation of benzo[a]pyrene-7,8-dihydrodiol by polymorphonuclear leukocytes, Advances in experimental medicine and biology, 283 (1991) 399-401.

[70] J.D. Adams, Jr., H. Yagi, W. Levin, D.M. Jerina, Stereo-selectivity and regio-selectivity in the metabolism of 7,8-dihydrobenzo[a]pyrene by cytochrome P450, epoxide hydrolase and hepatic microsomes from 3-methylcholanthrene-treated rats, Chemico-biological interactions, 95 (1995) 57-77.

[71] S. Shi, D.Y. Yoon, K.C. Hodge-Bell, I.G. Bebenek, M.J. Whitekus, R. Zhang, A.J. Cochran, S. Huerta-Yepez, S.H. Yim, F.J. Gonzalez, A.K. Jaiswal, O. Hankinson, The aryl hydrocarbon receptor nuclear translocator (Arnt) is required for tumor initiation by benzo[a]pyrene, Carcinogenesis, 30 (2009) 1957-1961.

[72] A.M. Quinn, T.M. Penning, Comparisons of $( \pm)$-Benzo[a]pyrene-trans-7,8-Dihydrodiol Activation by Human Cytochrome P450 and Aldo-Keto Reductase Enzymes: Effect of Redox State and Expression Levels, Chemical research in toxicology, 21 (2008) 1086-1094.

[73] J.L. Kalabus, Q. Cheng, R.G. Jamil, E.G. Schuetz, J.G. Blanco, Induction of carbonyl reductase 1 (CBR1) expression in human lung tissues and lung cancer cells by the cigarette smoke constituent benzo[a]pyrene, Toxicology letters, 211 (2012) 266-273. 
[74] M. Stiborova, R. Indra, M. Moserova, M. Sulc, P. Hodek, E. Frei, H.H. Schmeiser, V.M. Arlt, NADPH- and NADH-dependent metabolism of and DNA adduct formation by benzo[a]pyrene catalyzed with rat hepatic microsomes and cytochrome P450 1A1, Monatshefte fur chemie, 147 (2016) 847-855.

[75] T. Wada, H. Sunaga, R. Ohkawara, S. Shimba, Aryl hydrocarbon receptor modulates NADPH oxidase activity via direct transcriptional regulation of p40phox expression, Molecular pharmacology, 83 (2013) 1133-1140.

[76] J. Shen, R.J. Barrios, A.K. Jaiswal, Inactivation of the quinone oxidoreductases NQO1 and NQO2 strongly elevates the incidence and multiplicity of chemically induced skin tumors, Cancer research, 70 (2010) 1006-1014.

[77] K. Iskander, A. Gaikwad, M. Paquet, D.J. Long, 2nd, C. Brayton, R. Barrios, A.K. Jaiswal, Lower induction of p53 and decreased apoptosis in NQ01-null mice lead to increased sensitivity to chemical-induced skin carcinogenesis, Cancer research, 65 (2005) 2054-2058.

[78] K. Iskander, M. Paquet, C. Brayton, A.K. Jaiswal, Deficiency of NRH:quinone oxidoreductase 2 increases susceptibility to 7,12-dimethylbenz(a)anthracene and benzo(a)pyrene-induced skin carcinogenesis, Cancer research, 64 (2004) 5925-5928.

[79] L. Zhang, Y. Jin, M. Chen, M. Huang, R.G. Harvey, I.A. Blair, T.M. Penning, Detoxication of structurally diverse polycyclic aromatic hydrocarbon (PAH) o-quinones by human recombinant catechol-0-methyltransferase (COMT) via 0-methylation of PAH catechols, The Journal of biological chemistry, 286 (2011) 25644-25654

[80] H. Cai, N. Nguyen, V. Peterkin, Y.-S. Yang, K. Hotz, D. Beaton La Placa, S. Chen, R.H. Tukey, J.C. Stevens, A Humanized UGT1 Mouse Model Expressing the UGT1A1*28 Allele for Assessing Drug Clearance by UGT1A1-Dependent Glucuronidation, Drug Metabolism and Disposition, 38 (2010) 879-886.

[81] Z. Zheng, J.L. Fang, P. Lazarus, Glucuronidation: an important mechanism for detoxification of benzo[a]pyrene metabolites in aerodigestive tract tissues, Drug metabolism and disposition: the biological fate of chemicals, 30 (2002) 397-403.

[82] D.B. Buckley, C.D. Klaassen, Tissue- and gender-specific mRNA expression of UDP-glucuronosyltransferases (UGTs) in mice, Drug metabolism and disposition: the biological fate of chemicals, 35 (2007) 121-127.

[83] L. Zhang, M. Huang, I.A. Blair, T.M. Penning, Detoxication of benzo[a]pyrene-7,8-dione by sulfotransferases (SULTs) in human lung cells, The Journal of biological chemistry, 287 (2012) 29909-29920.

[84] Z.Z. Shi, J. Osei-Frimpong, G. Kala, S.V. Kala, R.J. Barrios, G.M. Habib, D.J. Lukin, C.M. Danney, M.M. Matzuk, M.W. Lieberman, Glutathione synthesis is essential for mouse development but not for cell growth in culture, Proc Natl Acad Sci U S A, 97 (2000) 5101-5106.

[85] H. Raza, Y.C. Awasthi, M.T. Zaim, R.L. Eckert, H. Mukhtar, Glutathione S-transferases in human and rodent skin: multiple forms and species-specific expression, The Journal of investigative dermatology, 96 (1991) 463-467.

[86] L. Romert, L. Dock, D. Jenssen, B. Jernstrom, Effects of glutathione transferase activity on benzo[a]pyrene 7,8-dihydrodiol metabolism and mutagenesis studied in a mammalian cell co-cultivation assay, Carcinogenesis, 10 (1989) 1701-1707.

[87] K. Alexandrov, I. Cascorbi, M. Rojas, G. Bouvier, E. Kriek, H. Bartsch, CYP1A1 and GSTM1 genotypes affect benzo[a]pyrene DNA adducts in smokers' lung: comparison with aromatic/hydrophobic adduct formation, Carcinogenesis, 23 (2002) 1969-1977.

[88] M. Lodovici, C. Luceri, F. Guglielmi, C. Bacci, V. Akpan, M.L. Fonnesu, V. Boddi, P. Dolara, Benzo(a)pyrene diolepoxide (BPDE)-DNA adduct levels in leukocytes of smokers in relation to polymorphism of CYP1A1, GSTM1, GSTP1, GSTT1, and mEH, Cancer epidemiology, biomarkers \& prevention : a publication of the American Association for Cancer Research, cosponsored by the American Society of Preventive Oncology, 13 (2004) 1342-1348.

[89] M. Rojas, I. Cascorbi, K. Alexandrov, E. Kriek, G. Auburtin, L. Mayer, A. Kopp-Schneider, I. Roots, H. Bartsch, Modulation of benzo[a]pyrene diolepoxide-DNA adduct levels in human white blood cells by CYP1A1, GSTM1 and GSTT1 polymorphism, Carcinogenesis, 21 (2000) 35-41.

[90] C.R. Saunders, S.K. Das, A. Ramesh, D.C. Shockley, S. Mukherjee, Benzo(a)pyrene-induced acute neurotoxicity in the F-344 rat: role of oxidative stress, Journal of applied toxicology : JAT, 26 (2006) 427-438.

[91] M. Monari, O. Cattani, G.P. Serrazanetti, A. Selli, G. Pagliuca, E. Zironi, S.C. O'Hara, D.R. Livingstone, Effect of exposure to benzo[a]pyrene on SODs, CYP1A1/1A2- and CYP2E1 immunopositive proteins in the blood clam Scapharca inaequivalvis, Marine environmental research, 63 (2007) 200-218.

[92] S. Kunze, C. Dalke, H. Fuchs, M. Klaften, U. Rossler, S. Hornhardt, M. Gomolka, O. Puk, S. Sabrautzki, U. Kulka, M. Hrabe de Angelis, J. Graw, New mutation in the mouse Xpd/Ercc2 gene leads to recessive cataracts, PLoS One, 10 (2015) e0125304.

[93] J.P.M. Melis, H. van Steeg, M. Luijten, Oxidative DNA Damage and Nucleotide Excision Repair, Antioxid Redox Signal, 18 (2013) 2409-2419.

[94] M. Christmann, B. Kaina, Transcriptional regulation of human DNA repair genes following genotoxic stress: trigger mechanisms, inducible responses and genotoxic adaptation, Nucleic Acids Research, 41 (2013) 8403-8420.

[95] S. Shen, J. Lee, M. Weinfeld, X.C. Le, Attenuation of DNA damage-induced p53 expression by arsenic: a possible mechanism for arsenic co-carcinogenesis, Mol Carcinog, 47 (2008) 508-518.

[96] L.V. Starostenko, E.A. Maltseva, N.A. Lebedeva, P.E. Pestryakov, O.I. Lavrik, N.I. Rechkunova, Interaction of Nucleotide Excision Repair Protein XPC-RAD23B with DNA Containing Benzo[a]pyrene-Derived Adduct and Apurinic/Apyrimidinic Site within a Cluster, Biochemistry (Mosc), 81 (2016) 233-241.

[97] D.L. Gibbons, L.A. Byers, J.M. Kurie, Smoking, p53 Mutation, and Lung Cancer, Molecular cancer research : MCR, 12 (2014) 3-13. 


\section{Chapter 6}

[98] J. Kranz, S. Hessel, J. Aretz, A. Seidel, E. Petzinger, J. Geyer, A. Lampen, The role of the efflux carriers Abcg2 and Abcc2 for the hepatobiliary elimination of benzo[a]pyrene and its metabolites in mice, Chemico-biological interactions, 224 (2014) 36-41. 


\section{Supplement Data}

Supplemental table 1

\begin{tabular}{|c|c|c|c|c|c|}
\hline \multicolumn{6}{|c|}{ Gene Ontology for 619 genes, GOTERM_DIRECT_BP_CC_MF } \\
\hline Category & Term & Count & $\%$ & P-Value & Benjamini \\
\hline GOTERM_BP_DIRECT & cell adhesion & 35 & 5,7 & $7,00 \mathrm{E}-06$ & $8,80 \mathrm{E}-03$ \\
\hline GOTERM_BP_DIRECT & lipid metabolic process & 33 & 5,3 & $1,40 \mathrm{E}-05$ & $1,20 \mathrm{E}-02$ \\
\hline GOTERM_BP_DIRECT & cell-cell adhesion & 22 & 3,6 & $3,70 \mathrm{E}-07$ & $9,30 \mathrm{E}-04$ \\
\hline GOTERM_BP_DIRECT & cholesterol biosynthetic process & 8 & 1,3 & $4,20 \mathrm{E}-05$ & $2,60 \mathrm{E}-02$ \\
\hline GOTERM_CC_DIRECT & membrane & 313 & 50,6 & $6,50 \mathrm{E}-19$ & $1,40 \mathrm{E}-16$ \\
\hline GOTERM_CC_DIRECT & cytoplasm & 250 & 40,4 & $6,10 \mathrm{E}-06$ & $2,90 \mathrm{E}-04$ \\
\hline GOTERM_CC_DIRECT & extracellular exosome & 161 & 26 & $4,20 \mathrm{E}-19$ & $1,80 \mathrm{E}-16$ \\
\hline GOTERM_CC_DIRECT & cytosol & 84 & 13,6 & $3,40 \mathrm{E}-05$ & $1,30 \mathrm{E}-03$ \\
\hline GOTERM_CC_DIRECT & endoplasmic reticulum & 79 & 12,8 & $6,00 \mathrm{E}-09$ & $5,20 \mathrm{E}-07$ \\
\hline GOTERM_CC_DIRECT & Golgi apparatus & 76 & 12,3 & $6,80 \mathrm{E}-10$ & $7,30 \mathrm{E}-08$ \\
\hline GOTERM_CC_DIRECT & cytoskeleton & 57 & 9,2 & $9,80 \mathrm{E}-05$ & $2,30 \mathrm{E}-03$ \\
\hline GOTERM_CC_DIRECT & focal adhesion & 45 & 7,3 & $4,10 \mathrm{E}-14$ & $5,80 \mathrm{E}-12$ \\
\hline GOTERM_CC_DIRECT & endoplasmic reticulum membrane & 42 & 6,8 & $4,90 \mathrm{E}-05$ & $1,50 \mathrm{E}-03$ \\
\hline GOTERM_CC_DIRECT & perinuclear region of cytoplasm & 41 & 6,6 & $5,80 \mathrm{E}-05$ & $1,70 \mathrm{E}-03$ \\
\hline GOTERM_CC_DIRECT & cell junction & 40 & 6,5 & $2,60 \mathrm{E}-04$ & $5,10 \mathrm{E}-03$ \\
\hline GOTERM_CC_DIRECT & cytoplasmic vesicle & 38 & 6,1 & $1,30 \mathrm{E}-04$ & $2,90 \mathrm{E}-03$ \\
\hline GOTERM_CC_DIRECT & $\begin{array}{l}\text { intracellular membrane-bounded } \\
\text { organelle }\end{array}$ & 38 & 6,1 & $2,10 \mathrm{E}-03$ & $3,30 \mathrm{E}-02$ \\
\hline GOTERM_CC_DIRECT & endosome & 35 & 5,7 & $4,60 \mathrm{E}-05$ & $1,50 \mathrm{E}-03$ \\
\hline GOTERM_CC_DIRECT & cell-cell adherens junction & 29 & 4,7 & $3,30 \mathrm{E}-07$ & $2,00 \mathrm{E}-05$ \\
\hline GOTERM_CC_DIRECT & Golgi membrane & 29 & 4,7 & $3,50 \mathrm{E}-05$ & $1,20 \mathrm{E}-03$ \\
\hline GOTERM_CC_DIRECT & extracellular matrix & 28 & 4,5 & $2,60 \mathrm{E}-07$ & $1,90 \mathrm{E}-05$ \\
\hline GOTERM_CC_DIRECT & proteinaceous extracellular matrix & 25 & 4 & $3,10 \mathrm{E}-05$ & $1,30 \mathrm{E}-03$ \\
\hline GOTERM_CC_DIRECT & cell-cell junction & 22 & 3,6 & $7,00 \mathrm{E}-07$ & $3,80 \mathrm{E}-05$ \\
\hline GOTERM_CC_DIRECT & apical plasma membrane & 22 & 3,6 & $9,30 \mathrm{E}-04$ & $1,60 \mathrm{E}-02$ \\
\hline GOTERM_CC_DIRECT & membrane raft & 18 & 2,9 & $2,40 \mathrm{E}-03$ & $3,50 \mathrm{E}-02$ \\
\hline GOTERM_CC_DIRECT & early endosome & 17 & 2,7 & $1,30 \mathrm{E}-03$ & $2,20 \mathrm{E}-02$ \\
\hline GOTERM_CC_DIRECT & actin cytoskeleton & 15 & 2,4 & $3,00 \mathrm{E}-03$ & $4,20 \mathrm{E}-02$ \\
\hline GOTERM_CC_DIRECT & brush border & 11 & 1,8 & $9,60 \mathrm{E}-05$ & $2,40 \mathrm{E}-03$ \\
\hline GOTERM_CC_DIRECT & caveola & 11 & 1,8 & $2,40 \mathrm{E}-04$ & $5,00 \mathrm{E}-03$ \\
\hline GOTERM_CC_DIRECT & basement membrane & 11 & 1,8 & $6,50 \mathrm{E}-04$ & $1,20 \mathrm{E}-02$ \\
\hline GOTERM_CC_DIRECT & ruffle & 10 & 1,6 & 2,20E-03 & $3,30 \mathrm{E}-02$ \\
\hline GOTERM_CC_DIRECT & extracellular vesicle & 9 & 1,5 & $9,30 \mathrm{E}-05$ & $2,50 \mathrm{E}-03$ \\
\hline GOTERM_CC_DIRECT & adherens junction & 9 & 1,5 & $2,20 \mathrm{E}-04$ & $4,60 \mathrm{E}-03$ \\
\hline GOTERM_CC_DIRECT & stress fiber & 9 & 1,5 & $8,40 \mathrm{E}-04$ & $1,50 \mathrm{E}-02$ \\
\hline GOTERM_MF_DIRECT & protein binding & 173 & 27,9 & $8,00 \mathrm{E}-07$ & $3,00 \mathrm{E}-04$ \\
\hline GOTERM_MF_DIRECT & $\begin{array}{l}\text { cadherin binding involved in cell-cell } \\
\text { adhesion }\end{array}$ & 27 & 4,4 & $4,00 \mathrm{E}-07$ & $3,00 \mathrm{E}-04$ \\
\hline
\end{tabular}

Supplemental table 2

\begin{tabular}{llrrrr}
\hline \multicolumn{2}{l}{ Gene Ontology for 330 genes, GOTERM_DIRECT_BP_CC_MF } & & & & \\
\hline Category & Term & Count & $\%$ & P-Value & Benjamini \\
\hline GOTERM_BP_DIRECT & translation & 17 & 5,2 & $5,50 \mathrm{E}-05$ & $4,20 \mathrm{E}-02$ \\
\hline GOTERM_CC_DIRECT & nucleus & 103 & 31,4 & $1,90 \mathrm{E}-04$ & $1,40 \mathrm{E}-02$ \\
GOTERM_CC_DIRECT & nucleoplasm & 42 & 12,8 & $5,50 \mathrm{E}-04$ & $2,50 \mathrm{E}-02$ \\
GOTERM_CC_DIRECT & nucleolus & 24 & 7,3 & $3,90 \mathrm{E}-04$ & $2,20 \mathrm{E}-02$ \\
GOTERM_CC_DIRECT & intracellular ribonucleoprotein complex & 16 & 4,9 & $1,30 \mathrm{E}-05$ & $3,10 \mathrm{E}-03$ \\
GOTERM_CC_DIRECT & ribosome & 12 & 3,7 & $2,60 \mathrm{E}-05$ & $3,00 \mathrm{E}-03$ \\
\hline GOTERM_MF_DIRECT & poly(A) RNA binding & 43 & 13,1 & $1,20 \mathrm{E}-09$ & $3,70 \mathrm{E}-07$ \\
GOTERM_MF_DIRECT & structural constituent of ribosome & 13 & 4 & $2,60 \mathrm{E}-04$ & $3,90 \mathrm{E}-02$ \\
\hline
\end{tabular}





\section{Chapter 7}

\section{Inflammation and the chemical carcinogens benzo[a]pyrene: partners in crime}

Shi Q, Godschalk RWL, Van Schooten FJ

Mutat Res Rev Mutat Res. 2017 Oct-Dec;774:12-24. doi:10.1016/j.mrrev.2017.08.003 


\begin{abstract}
Exposure to benzo[a]pyrene $(\mathrm{B}[\mathrm{a}] \mathrm{P})$ is known to play a role in lung carcinogenesis and the underlying processes can be modified by the presence of inflammation. The inflammatory process can for instance enhance the concentration of reactive metabolites that bind to DNA and may also diminish DNA repair. Additionally, during the inflammatory process mediators are released that create a microenvironment which is suitable for further stimulation of cancer development. Various transcriptional pathways are activated by inflammation, including pathways that are mediated via nuclear factor kappa-light-chain-enhancer of activated B cells (NF- $\kappa B$ ), signal transducer and activator of transcription 3 (STAT-3), and hypoxia-inducible factor-1 (HIF-1). Crosstalk between these pathways and the aryl hydrocarbon receptor (AhR) occurs at multiple levels and thereby boosts $\mathrm{B}[\mathrm{a}] \mathrm{P}$ induced carcinogenesis. This review focuses on inflammatory mediators, including cytokines, chemokines and extracellular enzymes that modulate molecular events in $\mathrm{B}[\mathrm{a}] \mathrm{P}$ induced cancers.
\end{abstract}

Key words: Inflammation, Inflammatory mediators, Carcinogens, Benzo[a]pyrene, Cytochrom P450 1A1 


\section{Introduction}

The development of cancer is a multistage process [1] which can be initiated by DNA damaging events for instance after exposure to environmental pollutants, UV-radiation or endogenously formed reactive oxygen species. DNA damage can lead to the accumulation of mutations if not repaired or not repaired in time before DNA replication. Accumulation of unfavorable mutations over time may lead to the transformation of normal cells into tumor cells. An additional risk factor for the development of cancer may be the presence of inflammation, and it has been estimated that up to $20 \%$ of all human malignancies are linked to chronic inflammatory conditions that may be provoked by environmental and lifestyle factors or induced by microbial pathogen infections (Table 1) [2]. After the primary stimulants, the host initiates an inflammatory response which involves the activation and migration of leukocytes (e.g., neutrophils, monocytes and lymphocytes) from the venous system to the sites of damage or infection $[3,4]$. At the site of inflammation, a range of cytokines, chemotactic cytokines (chemokines), enzymes, reactive oxygen species (ROS) and reactive nitrogen species (RNS) are subsequently produced or released [5-7]. Recent studies indicate that all these inflammation related factors can contribute to tumorigenesis by inducing mutations, genomic instability, and epigenetic modifications [8]. Moreover, inflammation results in a hostile microenvironment, where premalignant cells can survive, expand and accumulate additional mutations and epigenetic changes [8].

Now, the development of cancer might not be a process that is solely driven by exposure to chemical carcinogens or inflammatory mediators, but is a process in which both are synergistically involved; in other words, inflammation and chemical carcinogens may be partners in crime. [2]. This review summarizes multiple pathways through which inflammatory mediators may affect chemically induced carcinogenesis, identifies gaps of knowledge and hints on future developments on how these insights may be translated to more effective cancer prevention.

Table 1: Inflammation and related cancers

\begin{tabular}{lll}
\hline Inductor & Inflammation & Cancer \\
\hline Gut pathogens & Inflammatory bowel disease & Colorectal cancer \\
Tobacco smoke & Bronchitis & Bronchial lung caner \\
Helicobacter pylori & Gastritis & Gastric cancer \\
Human papilloma virus & Cervicitis & Cervical cancer \\
Hepatitic B/C virus & Hepatitis & Hepatocellular carcinoma \\
Bacteria, gall bladder stones & Cholecystitis & Gall Bladder cancer \\
Tobacco, genetics, alcohol & Pancreatitis & Pancreatic cancer \\
Epstein-Barr virus & Mononucleosis & Brukitt's lymphoma \\
Ultraviolet light & Sunburn & Melanoma \\
Asbestos fibers & Asbestosis & Mesothelioma \\
Gram-uropathogens & Schistosomiasis (Bilharzia) & Bladder cancer \\
Gastric acid, alcohol, tobacco & Esophagitis & Esophageal adenocarcinoma \\
\hline
\end{tabular}

Table was adapted from Multhoff et al., [4].

\section{Chemical carcinogenesis: benzo[a]pyrene as example.}

It is already known for more than 100 years that exposure to certain chemicals or mixtures of chemicals, including chimney soot, shale oil, vinyl chloride, benzene and cigarette smoke, is associated with the induction of cancer in humans. $[9,10]$. These chemicals act as initiators of a complex series of events, and the earliest stage is that these chemicals are metabolized into reactive derivatives that can damage DNA and subsequently induce mutations [11]. A well-known example is the group of polycyclic 
aromatic hydrocarbons (PAHs), with benzo[a]pyrene (B[a]P) being one of the best studied compounds [12]. PAH are widely spread in the environment due to pollution and natural burning processes, and humans can be exposed via tobacco smoke, diesel exhaust, and wood combustion emissions $[13,14]$. B[a]P is lipophilic and easily crosses the cell membrane. Intracellularly, it forms a complex with the aryl hydrocarbon receptor (AhR), which stimulates its own metabolism by inducing the expression of cytochrome P450 isoforms 1A1 (CYP1A1) and 1B1 (CYP1B1) [15]. The expression of these genes is induced, because the AhR-B[a]P complex translocate into the nucleus where it dimerizes with the aryl hydrocarbon receptor nuclear translocator (ARNT) [16]. This AhR/ARNT complex activates gene expression by binding to highly conserved DNA enhancer sequences, which are also known as xenobiotic response elements (XRE), located in a variety of genes including $C Y P 1 A 1$ and $C Y P 1 B 1[17,18]$. These cytochrome $\mathrm{P} 450$ 's combined with epoxide hydrolase convert $\mathrm{B}[\mathrm{a}] \mathrm{P}$ to its ultimate carcinogen benzo[a]pyrene-7,8-diol-9,10-epoxide (BPDE), that can covalently bind to DNA to form adducts preferentially at guanine residues. It is generally accepted that the formation of such DNA adducts leads to mutations that are relevant for carcinogenesis [19]. For instance Denissenko et al. showed that the specific location of BPDE-DNA adducts in the TP53 tumor suppressor gene, can induce a mutational profile that is typical for the mutations found in lung cancer of cigarette smokers [20]. Of course, cells are able to prevent this damage by $\mathrm{B}[\mathrm{a}] \mathrm{P}$, and the majority of activated $\mathrm{B}[\mathrm{a}] \mathrm{P}$ will be detoxified in phase II reactions, where $\mathrm{B}[\mathrm{a}] \mathrm{P}$ metabolites are further converted into water soluble metabolites by conjugation reactions that include glutathione-S-transferases (GST's), UDP-glucuronosyltransferases (UGTs) and sulfotransferases (SULTs) (Fig 1) [21-23]. Another important mechanism to prevent the accumulation of mutations after exposure to DNA reactive chemicals is the removal/repair of $\mathrm{B}[\mathrm{a}] \mathrm{P}$-induced DNA damage by various DNA repair processes, such as homologous (HR) and non-homologous end joining (NHEJ) in the repair of double-strand breaks (DSBs), mismatch repair (MMR), base excision repair (BER) and nucleotide excision repair (NER) [24-28]. Each repair pathway is a response to specific types of DNA damage. For $\mathrm{B}[\mathrm{a}] \mathrm{P}$ induced DNA damage, NER is the most important type of DNA repair, since NER is responsible for te removal of bulky lesions (for more details on DNA repair mechanisms, please consult relevant reviews [29-32]). Interestingly, a recent study shows that metabolism of $\mathrm{B}[\mathrm{a}] \mathrm{P}$ and mutations in tumor suppressor genes can be closely linked; B[a]P can mutate the TP53 tumor suppressor gene, which not only leads to the escape from critical cell cycle checkpoints and DNA repair, but TP53 mutations also change the metabolism of $\mathrm{B}[\mathrm{a}] \mathrm{P}$ towards the formation of more reactive metabolites [24, 33, 34]. 


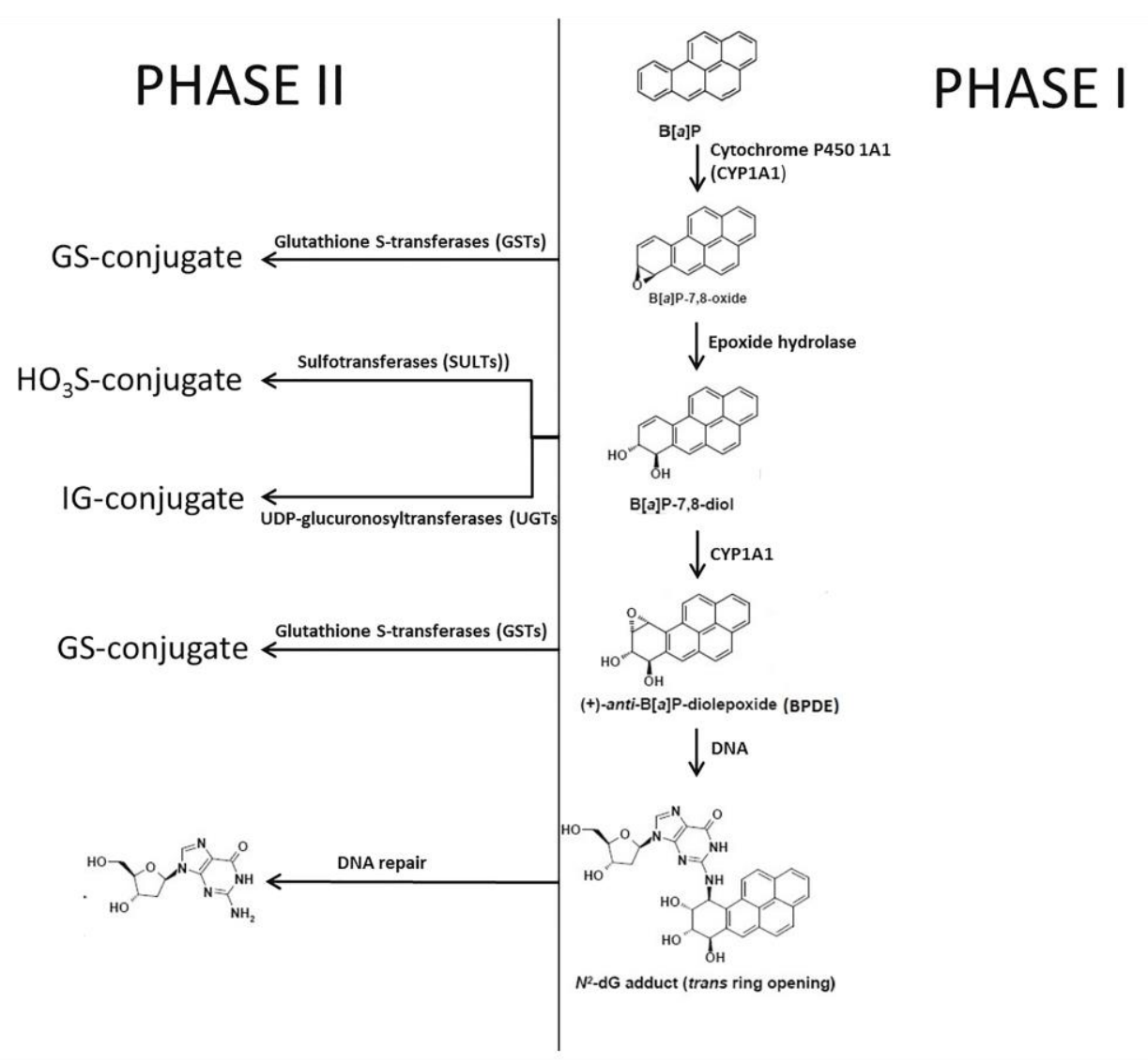

Figure 1. Pathway of B[a]P metabolism (phase I and II) and subsequent formation of DNA damage.

\section{Inflammatory key players and cancer}

Inflammation is a double edged sword: the purpose of the inflammatory response is to fight the intruding pathogens by activating specific immune cells such as macrophages and leukocytes (neutrophils, monocytes and lymphocytes) [8]. Similarly, exposure as for instance to inhalatory particles may lead to an inflammatory response in the lung [35]. After the threat has passed, these immune cells should no longer receive a "stay-alive" signal and immune cells should no longer be attracted to the site of inflammation. However, in case of inadequate pathogen eradication or repeated particle exposures, recurring tissue injury, prolonged inflammatory signaling or failure of anti-inflammatory mechanisms, chronic inflammation can develop, which leads to unintended damage to the host's own cells [36]. Furthermore, numerous studies have provided evidence that chronic inflammation contributes to cancer/tumor development by facilitating unlimited replicative potential, independence of growth factors, resistance to growth inhibition, escape of programmed cell death, enhanced angiogenesis, tumor extravasation and metastasis [37]. The impact of inflammation on tumorigenesis and cancer development can be attributed to the release of inflammatory mediators and related activated pathways (Table 2). Reactive oxygen species (ROS) (e.g. superoxide anion, $\mathrm{H}_{2} \mathrm{O}_{2}$ and hydroxyl radicals) and RNS (e.g. peroxynitrite), which are released by leukocytes (mainly neutrophils), are major players/chemical effectors in inflammation-driven carcinogenesis [38]. Due to their ability to bind to important cellular proteins and lipids, exposure to ROS and RNS has several molecular consequences, including induction of apoptosis, DNA repair, cell cycle arrest and cell senescence [39]. Additionally, ROS and RNS induce DNA damage, including DNA strand 
breaks, DNA base modifications and DNA cross-links, which if not properly repaired lead to an increased mutational load that can activate oncogenes and/or inactivate tumor suppressor genes [24]. For example, mutations in Ras and TP53 leading to activation of the Ras oncogene and loss-of-function of TP53 tumor suppressor gene have been observed in many inflammation-associated cancers $[40,41]$. Next to the ROS and RNS, inflammatory cells produce a variety of soluble factors; cytokines and chemokines including interleukins (ILs), tumor necrosis factor- $\alpha$ (TNF- $\alpha$ ), growth factors and differentiation factors are secreted and they regulate various physiological processes $[24,42]$. These mediators bind to cell-specific cognate receptors (toll-like receptors) and activate downstream transcription pathways, predominately STAT-3 and NF- $\mathrm{\kappa B}$ related pathways [43]. Activation of these pathways stimulates cell proliferation and differentiation, inhibits apoptosis, and stimulates inflammatory angiogenesis by upregulating proangiogenic factors [24]. Moreover, these mediators recruit and activate various leukocyte populations (mainly neutrophils) to the site of inflammation, which creates a microenvironment that promotes an even more pronounced release of inflammatory mediators, thereby, creating a positive amplification loop [36]. In this inflammation driven micro-environment, complex networks of inflammatory signaling pathways are elicited, including HIF-1, STAT-3 and NF- $\kappa$ B signaling [8]. These pathways can also activate/crosstalk with each other, by sharing the same upstream signaling components. One important type of crosstalk is with AhR signaling, because inflammation and exposure to chemical carcinogens should not be regarded as isolated events, but often occur together. For instance, exposure to cigarette smoke induces inflammation in the lung, but also increases exposure to chemicals like B[a]P. Indeed, epidemiological studies provide evidence that patients with chronic obstructive pulmonary disease (COPD) are at increased risk for developing lung cancer [44], which is further elevated when the patient has a smoking history [45]. Similar examples were reported for other organs and exposure to carcinogens, for example alcohol abuse and hepatitis leading to liver cancer [46], the combination of aflatoxin exposures and hepatitis accelerating into liver cancer [47] and ulcerative colitis and foodborne mutagens playing a role in the development of colon cancer $[48,49]$.

Table 2: Key players in inflammation-associated carcinogenesis

\begin{tabular}{|c|c|}
\hline Inflammatory mediators & Role in inflammation-associated carcinogenesis \\
\hline \multirow[t]{4}{*}{ Cytokines } & Promote tumor growth \\
\hline & Induce DNA damage and inhibit DNA repair \\
\hline & Stimulate inflammatory angiogenesis \\
\hline & Stimulate cell proliferation and inhibit apoptosis \\
\hline \multirow[t]{3}{*}{ Chemokines } & Attract inflammatory and immune cells to the site of inflammation \\
\hline & Promote tumor cell migration, invasion and metastasis \\
\hline & Stimulate inflammatory angiogenesis \\
\hline \multirow[t]{3}{*}{ ROS/RNS } & Induce DNA damage and disrupt DNA damage response \\
\hline & Downstream effector of NF- $\kappa B$ and inflammatory cytokine-mediated signaling \\
\hline & Stimulate cell proliferation \\
\hline \multirow[t]{5}{*}{$N F-\kappa B$} & Promote production of ROS and RNS \\
\hline & Promote tumor invasion and metastasis \\
\hline & $\begin{array}{l}\text { Promote expression and production of pro-inflammatory mediators and } \\
\text { amplifies the inflammatory signal transduction }\end{array}$ \\
\hline & Protect transformed cells from apoptosis \\
\hline & Promote chronic inflammation \\
\hline \multirow[t]{2}{*}{ STAT-3 } & Promote cell proliferation, apoptosis resistance and immune tolerance \\
\hline & Activated by pro-inflammatory cytokines \\
\hline \multirow[t]{3}{*}{ HIF-1 } & Promote chronic inflammation \\
\hline & Increase production of pro-inflammatory cytokines \\
\hline & Promote angiogenesis, invasion and metastasis \\
\hline
\end{tabular}




\section{Influence of inflammation on chemical carcinogenesis}

\subsection{Influence of soluble factors released by inflammatory cells on carcinogen metabolism.}

Polymorphonuclear neutrophils (PMNs) are recruited to the site of inflammatory/damage to eliminate invading pathogens during acute inflammation [50]. Neutrophils are short-lived and dismissed/cleared from the circulation in the liver, spleen and bone marrow after acute inflammation $[51,52]$. However, due to continuous attracting stimuli during chronic inflammation, neutrophils may be persistently present in tissues and may contribute to the development of chronic diseases such as COPD, Bechet's disease and inflammatory arthritis [51,53]. Their contribution to the disease etiology is related to the soluble factors they release after being activated at the site of inflammation. These soluble factors include reactive oxygen species (ROS, see section 4.2), the enzymes myeloperoxidase and $\beta$-glucuronidase (see section 4.3 and 4.4 respectively), and various inflammatory mediators (for instance interleukines, see section 4.1.4), which all can affect the way in which the organism deals with chemical carcinogens. Additionally, the release of such soluble factors can also change the micro-environment into an environment in which mutagenesis by environmental mutagens is facilitated. Therefore, we will discuss hypoxia and acidity in more detail in section 5 .

\subsection{Reactive oxygen species (ROS)}

Most tissue/DNA damage caused by activated neutrophils comes from the production of ROS. After the initiation of a respiratory burst, high concentrations of ROS such as NO*, $\mathrm{O}_{2}{ }^{-}, \mathrm{HO} \cdot,{ }^{1} \mathrm{O}_{2}$ and $\mathrm{H}_{2} \mathrm{O}_{2}$, will be generated via NADPH oxidases (NOXs) or nitric oxide synthases in order to neutralize pathogens $[54,55]$. Among these ROS, hydroxyl radicals $\left(\mathrm{HO}^{\circ}\right)$ are considered to be the most DNA reactive radicals which generate a multiplicity of products from all 4 DNA bases [56, 57].

Exposure to $\mathrm{B}[\mathrm{a}] \mathrm{P}$ can also induce oxidative stress and generate ROS via two different pathways; firstly, $\mathrm{B}[\mathrm{a}] \mathrm{P}$ exposure activates the $\mathrm{NF}-\kappa \mathrm{B}$ signaling pathway: after in vitro exposure to endothelial cells to $\mathrm{B}[\mathrm{a}] \mathrm{P}, \mathrm{mRNA}$ expression of the NF- $\kappa \mathrm{B}$ subunits $\mathrm{p} 65$ and p50 was significantly upregulated, leading to increased levels of IL-1 $\beta$, TNF- $\alpha$ and ROS production [58]. In order to maintain the intracellular stress balance, glutathione (GSH) reacts with ROS and serves as the most important ROS scavenger [59]. GSH is present in relatively high concentrations (up to $\mathrm{mM}$ levels) and it can be regenerated from its oxidized form (GSSG) by the NADPH-dependent reductases [59]. However, despite the possibility to regenerate GSH from GSSG, we recently showed that activation of NADPH-oxidases can significantly decrease the concentration of GSH, which shifted the metabolism of $\mathrm{B}[\mathrm{a}] \mathrm{P}$ towards higher concentrations of activated metabolites, including $\mathrm{B}[\mathrm{a}] \mathrm{P}-7,8$ diol, instead of detoxification [60]. Moreover, activation of NOXs can decrease the concentration of NADPH, which is an important co-factor for cytochrome P450. Therefore, the metabolism of B[a]P by cytochrome P450 can be slowed down under inflammatory conditions, suggesting that the CYP-dependent formation of reactive metabolites is inhibited. However, since inactivating phase II reactions by for instance GSH-conjugation are also decreased in their activity, the net effect remains unfavorably towards higher concentrations of DNA-reactive metabolites [60].

Secondly, B[a]P induces ROS production after the formation of $\mathrm{B}[\mathrm{a}] \mathrm{P}$-quinone metabolites. During B[a]P metabolism, B[a]P-dihydrodiol can be further converted into redox active o-quinones by dihydrodiol dehydrogenase and peroxidases [61]. This 
$\mathrm{B}[\mathrm{a}] \mathrm{P}$-quinone has the capacity of undergoing one-electron redox cycling with its semiquinone radicals, which causes the formation of ROS and subsequent lipid peroxidation [62]. In response to the formation of these quinones, various cellular defense system are triggered, including NAD(P)H quinone oxidoreductase (NQO1), which changes the quinone into a less toxic form. Moreover, GSH can detoxify the $\mathrm{B}[\mathrm{a}] \mathrm{P}$-quinone by covalently binding to it $[63,64]$. Despite the possibilities to inactivate these quinones, it was reported that generation of excess ROS during $\mathrm{B}[\mathrm{a}] \mathrm{P}$ metabolism increased lipid peroxidation and decreased the antioxidant defense system, subsequently forcing $\mathrm{B}[\mathrm{a}] \mathrm{P}$ metabolism towards toxification, such as more reactive metabolites and DNA adduct formation [61].

\subsection{Myeloperoxidase (MPO)}

MPO is an enzyme found in human neutrophils [65] and the presence of neutrophils in inflamed tissue increased formation of highly DNA reactive and mutagenic compounds after exposure to a variety of environmental chemical carcinogens via the promotion of metabolic activation of these chemicals [66]. Currently, ample evidence suggests that MPO is involved in the metabolic activation of chemical carcinogens (Table 3). The idea that MPO can act as a metabolic enzyme for carcinogens originates from experiments by Kensler et al. [67] and Trush et al. [68] in the 1980's. They demonstrated that after co-incubation of activated polymorphonuclear leukocytes (PMNs) with pro-carcinogens (for instance B[a]P-7,8-dihydrodiol), the concentration of the ultimate carcinogenic form of the carcinogen was increased and covalently bound to DNA. In contrast to PMNs, stimulated alveolar macrophages (AMs) which lack MPO activity, failed to elicit such an effect. In addition, incubation of stimulated PMNs with the MPO inhibitor sodium azide showed significant inhibition of the metabolic activation of carcinogens [68]. The role of MPO was further demonstrated by Mallet et al. [69] and Petruska et al. [70], who showed that the pre-carcinogen $\mathrm{B}[\mathrm{a}] \mathrm{P}-7,8$-diol may serve as a substrate for MPO which enhanced the formation of BPDE. In addition, the stereo-chemical analysis of tetraol products showed a similar reaction which generated primarily anti-diolepoxides from $\mathrm{B}$ [a]P-7,8-diol with an anti/syn ratio greater than 5 [69]. Consequently, co-incubated activated neutrophils with $\mathrm{B}[\mathrm{a}] \mathrm{P}$ enhance BPDE-DNA adduct formation, which was later confirmed by Borm et al. [71]. Moreover, the role of MPO in the activation of chemical carcinogens was further supported by work of London et al. [72], Rojas et al. [73] and Van Schooten et al. [74]. In 1997, London et al. described that a single base substitution ( $G$ to $A$ ) in the promoter region of the MPO gene reduces its transcription and among the smokers who inherit two copies of the A-allele (A/A) a markedly decreased risk for lung cancer was found [72]. In the study by Rojas et al., it was convincingly demonstrated that MPO had a significant role in B[a]P activation in human skin tissue; BPDE-DNA adducts levels in skin of atopic dermatitis patients treated with coal tar was strongly affected by the MPO -463 $\mathrm{G} \rightarrow \mathrm{A}$ polymorphism [73]. Moreover, the syn/anti ratio of BPDE-DNA adducts that was reported by Rojas et al. further supports the involvement of the peroxidase. This finding was subsequently further confirmed by Van Schooten, who performed a study in bronchial alveolar lavage (BAL) fluid and cells from 106 smoking Caucasian lung patients. Subjects with the MPO -463AA genotype exhibited lower MPO activity/neutrophil than MPO -463AG and MPO -463GG patients. Furthermore, the DNA adducts level in MPO -463AA individuals were significantly lower than in MPO -463AG and MPO -463GG subjects. Overall, these related studies define the role of MPO in human pulmonary carcinogenesis by increasing metabolism of environmental mutagens. 
Additionally it was originally described by Güngör et al. [75] that the MPO product $\mathrm{HOCl}$ could also inhibit DNA repair. However, a recent study by Shi et al. [76] suggested that this may be related to a decrease of local $\mathrm{pH}$ (see section 5.1).

Table 3: Examples of MPO mediated activation of environmental chemicals into genotoxic metabolites

\begin{tabular}{|c|c|c|c|}
\hline Carcinogens compound & $\begin{array}{l}\text { Mutagenic/carcinogenic } \\
\text { product or effect }\end{array}$ & Possible mechanism & References \\
\hline $\mathrm{N}$-arylhydroxamic acids & 2-nitroso-fluorene (2-NOF) & MPO peroxidation & {$[77]$} \\
\hline Aromatic amine (ABZ) & ABZ-DNA adduct & MPO peroxidation & [78] \\
\hline Aromatic amine (ABZ) & 3'-Nitro-ABZ & $\begin{array}{l}\text { Catalyzed by MPO in } \\
\text { presence of nitrite }\end{array}$ & [79] \\
\hline \multirow[t]{2}{*}{ 2-Aminofluorene (2-AF) } & 2-AF-DNA adduct & MPO catalyzed & {$[80]$} \\
\hline & Mutagenesis (Ames test) & MPO catalyzed & [81] \\
\hline $\begin{array}{l}\text { Heterocyclic } \\
\text { (MeIQx) }\end{array}$ & N-nitroso-compounds & $\begin{array}{l}\text { MPO catalyzed } \\
\text { nitrosation }\end{array}$ & {$[82]$} \\
\hline Heterocyclic amines (IQ) & IQ-DNA adduct & MPO catalyzed & {$[83]$} \\
\hline Aromatic Amine (3-ABA) & 3-ABA-DNA adduct & MPO catalyzed & [84] \\
\hline PAH (B[a]P) & B[a]P-DNA adduct & $\begin{array}{l}\text { MPO-dependent } \\
\text { bioactivation }\end{array}$ & {$[85,86]$} \\
\hline
\end{tabular}

\section{4 $\beta$-Glucuronidase}

$\beta$-glucuronidase is an enzyme released by neutrophils during inflammation [87]. There is little knowledge about the role of $\beta$-glucuronidase and how it could directly activate chemical mutagens, however, there seems to be a link between $\beta$-glucuronidase and detoxification reactions of toxic compounds. Glucuronidation is an important detoxification mechanism for many chemical carcinogens including $\mathrm{B}[\mathrm{a}] \mathrm{P}[23,88]$. Glucuronidation is performed by UDP-glucuronosyltransferases (UGTs) which are classified as phase II enzymes and are members of a supergene family of endoplasmic reticulum-bound enzymes $[85,86]$. Thirty-one UGT genes have been identified in human [86]. Without UGTs, several environmental carcinogens may further oxidate to their toxic reactive intermediates that can react with cellular macromolecules, thereby leading to toxicity [89]. Indeed, Hu and Wells (1992) showed with experiments in rats that had a genetic deficiency in bilirubin conjugating UGTs, that the glucuronidation of $\mathrm{B}[\mathrm{a}] \mathrm{P}$ metabolites was decreased, the level of $\mathrm{B}[\mathrm{a}] \mathrm{P}$ that covalently bound to hepatic DNA and microsomal proteins was increased, and that the $\mathrm{B}[\mathrm{a}] \mathrm{P}$ induced embryo toxicity was enhanced [90]. $\beta$-glucuronidase can deconjugate glucuronidated phase II metabolites and make them reactive again [91]. This has been further demonstrated by Shimoi K and Nakayama T, who showed higher levels of $\beta$-glucuronidase activity and free unconjugated metabolites in four kinds of LPS-treated human cells (neutrophils, human umbilical vein endothelial cells, IMR-90, and Caco-2 cells) and in LPS-treated rats, and they suggested that $\beta$-glucuronidase may hydrolyze glucuronide-conjugates to free aglycones at the site of inflammation [87]. Such a reactivation mechanism may also hold true for glucuronidated chemicals such as B[a]P metabolites (e.g. B[a]P-7,8-diol), thereby leading to higher concentration of BPDE and increased level of DNA adducts at the site of inflammation [92]. Interestingly, we previously showed an additional signaling role of $\beta$-glucuronidase in in vitro experiments, indicating that $\beta$-glucuronidase initially blocks CYP1A1 expression, which delayed the metabolism of B[a]P. The intracellular signaling of extracellular $\beta$-glucuronidase may be mediated by binding to the IGF2 receptor, because co-incubation of lung cells with the IGF2R inhibitor mannose-6-phosphate completely abolished the effect of $\beta$-glucuronidase on CYP1A1 
expression. Interestingly, at later time points, $\beta$-glucuronidase significantly enhanced CYP1A1 expression, probably because $\beta$-glucuronidase de-glucuronidated $\mathrm{B}[\mathrm{a}] \mathrm{P}$ metabolites, which continued to trigger the aryl hydrocarbon receptor (Ah receptor) and induced expression of CYP1A1. Consequently, significantly higher concentrations of $\mathrm{B}[\mathrm{a}] \mathrm{P}$ metabolites and DNA adducts were found in $\beta$-glucuronidase-treated cells. Overall, these data show that $\beta$-glucuronidase alters the cellular response to chemical carcinogens, including $\mathrm{B}[\mathrm{a}] \mathrm{P}$, and ultimately enhanced DNA adduct levels. [92]. It should be noted that $\beta$-glucuronidase has a $\mathrm{pH}$-optimum of $<6$, which is actually reached at sites of inflammation (see section 5.1).

\subsection{Impact of released interleukins on carcinogen metabolism}

Various interleukins are secreted during inflammation and they play a crucial role in both pro-inflammatory (e.g. IL-1, IL-6, IL-8) and anti-inflammatory (e.g. IL-1, IL-10, IL-13) processes [3]. Due to limited knowledge about how each of these ILs can affect metabolism of carcinogens, we only focus on ILs which have been shown to potentially affect the genotoxicity of $\mathrm{B}[\mathrm{a}] \mathrm{P}$.

IL-1 has been identified in several human tumors and it has the ability of promoting tumor growth and metastasis [93]. IL-1 has two isoforms, IL-1 $\alpha$ and IL-1 $\beta$, but they mediate different functions. IL-1 $\alpha$ is expressed by malignant cells and it induces an anti-tumor immune response, stimulates cell differentiation and cell growth. Low concentrations of IL-1 $\beta$ could down-regulate inflammation and immune responses, thereby preventing the immune system to recognize tumor cells, whereas high concentrations of IL-1 $\beta$ promote inflammation-associated tissue damage and tumor invasiveness $[3,94]$. Both IL- $1 \alpha$ and IL-1 $\beta$ bind to the IL- 1 receptor type I (IL-1RI) which leads to the production of various inflammatory mediators (e.g. IL-1, TNF- $\alpha$, IL-6, IL-8 etc.) that additionally promote AhR signaling [95-98]. Therefore, IL-1 could increase $\mathrm{B}[\mathrm{a}] \mathrm{P}$ metabolism and it's genotoxicity [99], but it has also been reported that IL-1 $\beta$ inhibits CYP1A1 enzyme activity (EROD) in human hepatocytes [100]. Therefore, the role of IL-1 in changing the metabolism of chemical carcinogens is not yet fully understood and needs further investigation.

IL-6 is another NF- $\kappa$ B regulated pro-inflammatory mediator, which showed the capacity of promoting tumor growth and was found in numerous types of tumors [101, 102]. Although IL-6 plays an important role in terminating inflammation [103], it can bind to the soluble form of the IL-6R (sIL6R) and induce IL-6-trans-signaling, which serves as the major pro-inflammatory pathway that leads to anti-apoptotic gene expression [104, 105]. What is more, IL-6 has been reported to inhibit the function of wild-type p53 protein in a murine myeloid leukaemic cell line [106], whereas proper p53 function is important to regulate the cellular defense mechanisms against chemically induced DNA damage (also see section 7 on bypassing p53). Finally, a recent study reported that IL-6 promotes $\mathrm{B}[\mathrm{a}] \mathrm{P}$ induced DNA damage in a dose-dependent manner in a colorectal cancer cell line, which was mediated by increasing CYP1B1 expression, but not by changing TP53 expression [107].

IL-8 serves as an important chemokine that binds to $G$ protein-coupled receptors (CXCR1 and CXCR2), which subsequently chemoattracts neutrophils to the site of infection, promotes angiogenic responses and increases proliferation and survival of cancer cells [108]. Similar to IL-6, many inflammation-associated pathway, which may potentially enhance genotoxicity of $\mathrm{B}[\mathrm{a}] \mathrm{P}$ can be activated after IL-8 binds to its corresponding receptors, including stimulation of HIF-1, NF- $\kappa$ B, AP-1, STAT-3 and 
$\beta$-Catenin related pathways [108]. Recently, our group showed that IL-8 changed the $\mathrm{B}[\mathrm{a}] \mathrm{P}$ metabolism via significantly decreasing intracellular GSH levels with subsequent increased concentrations of the pro-carcinogen $\mathrm{B}[\mathrm{a}] \mathrm{P}-7,8$-diol [60]. However, the $\mathrm{B}[\mathrm{a}] \mathrm{P}$ induced DNA adduct levels were not enhanced by IL-8, because the decreased GSH level is compensated for by increased NER activity. Increased DNA repair activity as response to decreasing GSH levels was also described by Langie et al. after exposure of human lung epithelial cells to hydrogen peroxide in combination with the inhibitor of GSH synthesis, BSO [109]. On the other hand, exposure to ROS alone inhibited DNA repair very strongly. Obviously, GSH plays a central role in regulating the cellular response to carcinogens, because depletion of GSH may result in decreased conjugation of chemical carcinogens by glutathione transferases in phase II reactions, but it may also result in increased DNA repair activities. The regeneration of GSH from GSSG is a NADPH dependent reaction of glutathione reductase. Combined exposure to IL-8 and $\mathrm{B}[\mathrm{a}] \mathrm{P}$ significantly reduced NADPH levels in lung epithelial cells, which could thus interfere with NADPH dependent reactions in the metabolism of chemical carcinogens [60].

\subsection{Influence of other inflammatory mediators}

Tumor Necrosis Factor- $\alpha$ (TNF- $\alpha$ ). TNF- $\alpha$ is regarded to be a key pro-inflammatory cytokine in controlling inflammatory cell populations as well as mediating many other aspects of the inflammatory process $[2,110]$. Many cells can generate TNF- $\alpha$, including T and B lymphocytes, natural killer (NK) cells, neutrophils, mast cells, endothelial cells, smooth and cardiac muscle cells, fibroblasts and osteoclasts, but the main source of TNF- $\alpha$ are activated macrophages and tumor cells $[111,112]$. TNF binds to the membrane-bound homotrimeric receptor TNF- $\alpha$ receptor I and II (TNFRI and TNFRII) which initiates an inflammatory cascade [4]. TNF- $\alpha$ is undetectable in healthy individuals, but increased serum and tissue levels of TNF- $\alpha$ can be found in acute and chronic inflammatory conditions, including trauma, sepsis, infection and rheumatoid arthritis [110, 113]. In addition, TNF- $\alpha$ plays a critical role in both anti-cancer and pro-cancer actions [114]: high concentration of TNF- $\alpha$ leads to removal of damaged tissue, tissue recovery and tissue remodeling [114], whereas, low concentrations of TNF- $\alpha$ might induce inflammation, may lead to DNA damage, inhibits DNA repair and can promote tumor growth [115-117].

$A$ recent study described that TNF- $\alpha$ enhanced the genotoxicity of $\mathrm{B}[\mathrm{a}] \mathrm{P}$ in rat liver epithelial WB-F344 cells and rat lung epithelial RLE-6TN cells through upregulation of CYP1B1 $[118,119]$. Additionally, TNF- $\alpha$ can alter B[a]P metabolism by reducing the expression of aldo-keto reductase 1C14, which could compete with CYP1B1 for $\mathrm{B}[\mathrm{a}] \mathrm{P}-7,8-$ diol and divert it's metabolism from the formation of ultimate carcinogen BPDE [119]. Moreover, TNF- $\alpha$ significantly enhanced p53 phosphorylation, suggesting that it triggered a cellular response to genotoxic stress $[118,120]$. Furthermore, $\mathrm{B}[\mathrm{a}] \mathrm{P}$ and TNF- $\alpha$ acted synergistically and strongly induced inflammatory responses that are known to enhance the genotoxic effect of chemical carcinogens, including the expression of inducible NO synthase (NOS), COX-2, prostaglandin E2, IL6 and p38 kinase [121].

Transforming growth factor- $\beta$ (TGF- $\beta$ ). TGF- $\beta$ is known as a pleiotropic cytokine that is very potent in regulating inflammatory activity [122]. After TGF- $\beta$ binds to TGF- $\beta$ receptor I or II, the activated receptor complex leads to nuclear translocation of Smad molecules which induces transcription of target genes [123]. TGF- $\beta$ is regarded as pro-inflammatory, because it stimulates migration of monocytes, lymphocytes, neutrophils and fibroblasts [124]. In addition, TGF- $\beta$ can promote inflammation and 
augment autoimmune conditions by differentiating naïve $\mathrm{CD} 4^{+} \mathrm{T}$ cells into $\mathrm{T}$ helper 17 (Th17) cells in the presence of IL-6 [125]. Still, TGF- $\beta$ may also play an important role in the anti-inflammatory response; for example, after treating HUVEC cells with TGF- $\beta 1$, a time and dose-dependent inhibition of IL-8 and E-selectin was observed [126]. Moreover, the best reflection of the anti-inflammatory function of TGF- $\beta 1$ can be observed in TGF- $\beta 1$ deficient mice, which die in utero due to widespread inflammation $[127,128]$. Although TGF- $\beta$ is well known as a regulator of tumor initiation, progression and metastasis [129], its link with metabolism of chemical carcinogens is hardly investigated. One study reported that TGF- $\beta 1$ showed $100 \%$ inhibition of $\mathrm{B}[\mathrm{a}] \mathrm{P}$-induced $C Y P 1 A 1$ mRNA expression and EROD activity in human hepatocytes [130]. This observation is actually in line with previous findings, in which inflammatory mediators slow down metabolism of $\mathrm{B}[\mathrm{a}] \mathrm{P}$ by both phase I, but also phase II reactions. The net result may be that less active metabolites are initially formed, but because these are also less effectively removed by phase II reactions, reactive metabolites may accumulate at the site of inflammation (see Fig 2). Although these effects may be compensated for by increased DNA repair, it seems that the inflammatory micro-environment is more in favor of inhibiting repair activity (see next section).

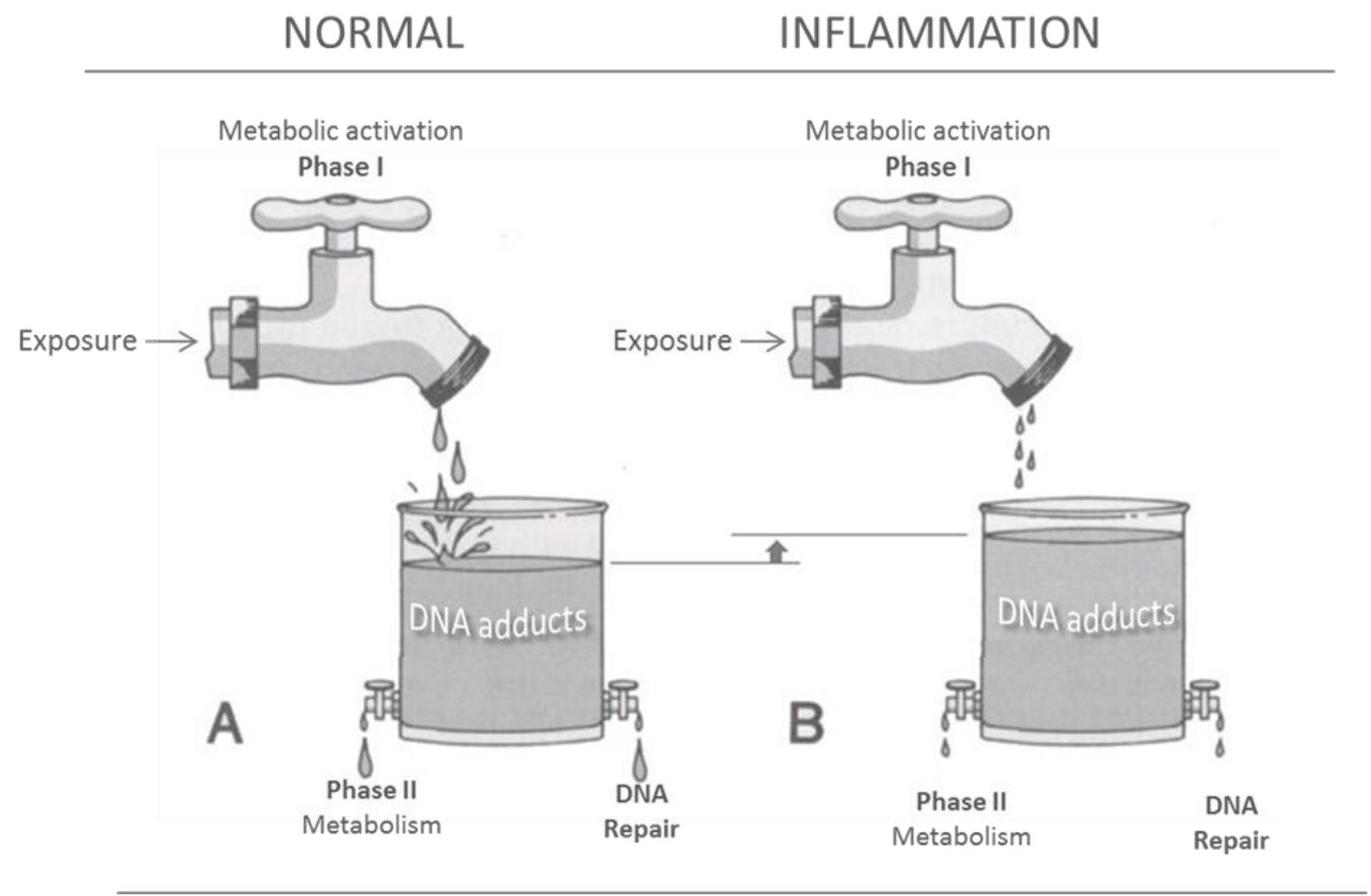

Figure 2. Schematic illustration of the tentative model for the combined role of $\mathrm{B}[\mathrm{a}] \mathrm{P}$ and inflammation in carcinogenesis. A. After exposure to $\mathrm{B}[\mathrm{a}] \mathrm{P}$ in absence of inflammation, $\mathrm{B}[\mathrm{a}] \mathrm{P}$ is metabolically activated through phase I metabolism. Part of these phase I activated B[a]P metabolites are subsequently detoxified via phase II metabolism and DNA damage is removed by DNA repair.; B. However, when exposure to $\mathrm{B}[\mathrm{a}] \mathrm{P}$ coincides with inflammatory conditions, inflammatory mediators can inhibit not only phase I and II metabolism of B[a]P but also the repair of DNA adducts. As a consequence, B[a]P derived reactive metabolites are formed less effectively, but they are also removed at a lower extent by phase II reactions. The DNA adducts that are formed are also less well removed; the net effect is higher levels of $\mathrm{B}[\mathrm{a}] \mathrm{P}$-induced DNA damage if exposure to $\mathrm{B}[\mathrm{a}] \mathrm{P}$ coincides with inflammation. 


\section{Altered micro-environment}

\subsection{Acidic pH microenvironment}

A acidic/low $\mathrm{pH}$ can be found in both the chronic inflammatory as well as tumor microenvironment [131]. Under normal physiological conditions, the local pH of blood and tissue is strictly controlled around $\mathrm{pH} 7.4$, whereas a local $\mathrm{pH}$ range from 7.0 to 5.5 or even lower has been observed in inflamed tissues [132-134]. As an example, the pH of exhaled breath condensate of COPD patients is decreased and related to disease severity [135], and abnormal intestinal luminal $\mathrm{pH}$ was observed in inflammatory bowel disease (IBD) patients [136]. In general, $\mathrm{Na}^{+}-\mathrm{HCO}_{3}-$ co-transporters and $\mathrm{Cl}^{-} / \mathrm{HCO}_{3}^{-}$exchangers contribute to the uptake of $\mathrm{H}^{+}$, where the $\mathrm{Na}^{+} / \mathrm{H}^{+}$exchanger (NHE), $\mathrm{H}^{+}$-lactate co-transporters, monocarboxylate transporters (MCTs) and the $\mathrm{H}^{+}$-ATPase $\left(\mathrm{H}^{+}\right.$pump) are responsible for the secretion of $\mathrm{H}^{+}[131,137,138]$. However, the acidic condition in tumor tissue is due to the "Warburg effect" which produces acidic metabolites (e.g. lactic acid from anaerobic glycolysis in hypoxia) or generation of $\mathrm{H}^{+}$by carbonic anhydrase (CA) via catalyzing hydration of $\mathrm{CO}_{2}$ through the pentose phosphate pathway $[131,139]$. The acidic microenvironment created by inflammation is mainly caused by damage of surrounding tissues and the production of acidic compounds during inflammatory responses, including hypochloric acid $(\mathrm{HOCl})[65,140]$.

$\mathrm{pH}$ regulates various cellular activities and has been extensively studied over the last 20 years, but how pH affects xenobiotic metabolism is not well understood. Some studies suggested that an acidic $\mathrm{pH}$ influenced the immune function of cells and it might change the pattern of $\mathrm{B}[\mathrm{a}] \mathrm{P}$ metabolism $[131,141]$. Indeed, some biomarkers of the inflammatory response (e.g. TNF- $\alpha$, COX-2, iNOS and IL-8) were upregulated via NF- $\kappa$ B under acidic conditions [142-144], and these inflammation-associated mediators can increase the genotoxicity of $\mathrm{B}[\mathrm{a}] \mathrm{P}$ via various pathways which were mentioned previously (see section 4). What is more, some acidic compounds that are generated during inflammation such as $\mathrm{HOCl}$, can promote the genotoxicity of $\mathrm{B}[\mathrm{a}] \mathrm{P}$ by inhibiting DNA nucleotide excision repair (NER) capacity [75]. Although it was originally thought that HOCl, that is produced by MPO, could specifically inhibit NER, but later we showed that the decreased DNA repair activity is a more general response to decreased $\mathrm{pH}[75$, 76]. Indeed, inducing pulmonary inflammation in MPO knock out animals or in animals that were neutrophil depleted (the major MPO producing cell type), did not abolish the inhibitory effect of inflammation on DNA repair [145]. This could be related to the fact that $\mathrm{pH}$ also decreases at sites of inflammation even in the absence of MPO/ HOCl. It should be noted that an acidic $\mathrm{pH}$ can lead to a marked increase in cytotoxicity [146], but once cells survive and adapt to these conditions, it can lead to a more aggressive behavior of cells, very similar to the process of tumorigenesis, including the continuous induction of inflammation, increased drug resistance and the cells can form their own cellular microenvironment $[131,147]$. If this is the case, the cells that actually survived under acidic conditions would be more affected by exposures to carcinogens. Although $\mathrm{B}[\mathrm{a}] \mathrm{P}$ is again less well metabolized under different acidic conditions, a low pH resulted in higher concentrations of the pro-carcinogen $\mathrm{B}[\mathrm{a}] \mathrm{P}-7,8-$ diol, decreased DNA repair and increased formation of $\mathrm{B}[\mathrm{a}] \mathrm{P}-\mathrm{DNA}$ adducts and $\gamma \mathrm{H} 2 \mathrm{AX}$ foci, when compared to normal conditions ( $\mathrm{pH}$ 7.8) [76]. 


\subsection{Local hypoxia induced by inflammation}

It is not yet clear whether hypoxia causes inflammation or inflammation induces hypoxia, however, it is generally accepted that hypoxia and inflammation have been associated with a large number of inflammatory diseases and inflamed tissues are often severely hypoxic [148, 149]. For example, significant increased serum levels of inflammation markers (e.g. interleukin-6, interleukin 1 receptor antagonist and C-reactive protein) were observed in healthy volunteers who spent 3 nights above $3400 \mathrm{~m}$ altitude [150]. When hypoxia occurs, the hypoxia-inducible transcription factor (HIF1) is activated in order to adapt to the new conditions. HIF1 is inactivated when oxygen is abundant [151], because HIF-1 is continuously synthesized and degraded under normoxic conditions, whereas hypoxia prohibits the degradation of the HIF- $1 \alpha$ by the ubiquitin proteasome system. This lack of degradation triggers the nuclear localization of HIF-1 $\alpha$ [152]. Interestingly, when inflammation is initiated, HIF can be activated before tissues become hypoxic. For example, the HIF-1 $\alpha$ transcription level is increased after exposure to LPS [153].

HIF activation is an important hallmark for hypoxia and it crosstalks with many other pathways, such as Nuclear Factor-kappa B (NF-kB) and Aryl hydrocarbon Receptor (AhR) signaling [148, 152]. Since $A h R$ is the receptor for a large amount of environmental pollutants, including dioxins (e.g. 2,3,7,8-tetrachlorodibenzo-p-dioxin, TCDD) and PAH [154], hypoxic responses may interfere with the metabolism of these compounds. Interestingly, HIF-1 consists of two subunits (HIF- $1 \alpha$ and HIF-1 $\beta$ ) and HIF- $1 \beta$ is identical to ARNT $[155,156]$. Thus, there is a possibility that $\mathrm{B}[\mathrm{a}] \mathrm{P}$ metabolism is affected by hypoxic condition, because the binding of AhR to ARNT may compete with the binding of HIF-1 $\beta$ to HIF-1 $\beta /$ ARNT.

However, there is still debate about the crosstalk between HIF and AhR. Nie et al., (2001) reported that desferrioxamine (Dfx) and $\mathrm{CoCl}_{2}$, both are hypoxia inducers, significantly reduced AhR mediated CYP1A1 activity (Dfx decreased CYP1A1 activity by $67 \%$ in Hepa1 cells and reduced CYP1A1 activity to background level in B-1 cells) [152]. This inhibitory effect was also observed in A549 cells in which CYP1A1 mRNA expression level was inhibited after combined exposure to $\mathrm{B}[\mathrm{a}] \mathrm{P}$ and $\mathrm{CoCl}_{2}$. No differences were observed in DNA adduct formation, but exposure to $\mathrm{B}[\mathrm{a}] \mathrm{P}$ and $\mathrm{CoCl}_{2}$, increased the B[a]P induced mutation HPRT frequency approximately 3 times [154]. In that study, there was no direct measurement of DNA repair activity, but single cell gel electrophoresis experiments indicated that there was a decrease in the formation of transient DNA strand breaks in the combined incubation with $\mathrm{B}[\mathrm{a}] \mathrm{P}$ and $\mathrm{CoCl}_{2}$ compared to $\mathrm{B}[\mathrm{a}] \mathrm{P}$ alone. These data confirmed the findings that hypoxia reduced NER [157].

In order to further confirm these results, Schults et al., exposed A549 cells to B[a]P under different oxygen concentrations (20\% and $0.2 \%$ ) [158]. They found opposite results when compared to cells exposed to hypoxia inducers (e.g. Dfx and $\mathrm{CoCl}_{2}$ ). Under hypoxia condition ( $0.2 \%$ oxygen), mRNA expression of CYP1A1 and CYP1B1 were significantly enhanced compared to the normoxic condition (20\% oxygen). In addition, the level of of $\mathrm{B}[\mathrm{a}] \mathrm{P}$ metabolites (e.g. B[a]P-7,8-diol) and unmetabolised $\mathrm{B}[\mathrm{a}] \mathrm{P}$ were 3.7-fold and 9-fold higher in hypoxic conditions than under normoxic condition. Furthermore, under hypoxic condition, the amount of DNA adducts formed was about 1.6 times higher than under normoxic conditions. It can be speculated that exposure of cells to hypoxia inducers increased HIF-1 level, but it does not cause real hypoxia inside the cell $\left(\mathrm{O}_{2}\right.$ is still available). Therefore, the later experiment may give a more realistic view on how cells metabolize $\mathrm{B}[\mathrm{a}] \mathrm{P}$ under low oxygen conditions. In a nutshell, hypoxia 
prolongs exposure to $\mathrm{B}[\mathrm{a}] \mathrm{P}$ by altering kinetics of metabolism, consequently leading to higher DNA damage to cells. HIF induction may additionally inhibit DNA repair.

Taken together, inflammatory conditions seem to slow down various mechanisms that are related to the metabolism of chemical carcinogens and the repair of their DNA binding products. The net effect is more DNA damage that may lead to an environment that favors accumulation of mutations (Fig 2).

\section{Cross-talk between inflammatory signaling pathways with AhR}

\subsection{Cross talk between $N F-\kappa B$ and aryl hydrocarbon receptor}

The NF- $\kappa$ B pathway is considered to be a prototypical inflammatory signaling pathway and $\mathrm{NF}-\kappa \mathrm{B}$ is suggested to play a key role in pro-inflammatory processes [159]. As a host protective mechanism, NF- $\kappa \mathrm{B}$ is triggered to produce cytokines and chemokines which attract and activate various innate and adaptive immune cells at the site of injury or pathogen invasion [160]. Moreover, in order to increase the self-defense of cells at the site of inflammation, NF- $\kappa \mathrm{B}$ induces expression of anti-apoptotic factors, scavengers of ROS, growth factors and angiogenic factors, which subsequently restore local tissue integrity [161]. However, continuously activation of NF- $\kappa \mathrm{B}$ mostly contributes to genomic and epigenetic instability which are likely to be responsible for the pro-carcinogenic effects of chronic inflammation [43], especially if these cells are additionally exposed to chemical carcinogens.

Among the transcription factors affected by $\mathrm{B}[\mathrm{a}] \mathrm{P}$ exposure, NF- $\mathrm{KB}$ regulated pathways showed the best correlation with $\mathrm{B}$ [a]P induced DNA adduct levels [162]. In vitro and in vivo studies have demonstrated that LPS induced the expression of AhR which was NF- $\kappa B$-dependent because inhibition of the NF- $\kappa B$ pathway also suppressed AhR-dependent genes (e.g. CYP1A1) [98]. However, one study pointed out that unligated AhR repressed NF- $\kappa B$ activation and only ligated AhR could induce the inflammatory response [163]. Next to the fact that $\mathrm{B}[\mathrm{a}] \mathrm{P}$ exposure can elicit the $\mathrm{NF}-\kappa \mathrm{B}$ signaling pathway, NF- $\kappa B$ itself can have strong cross talk with AhR signaling, which is important for subsequent $\mathrm{B}[\mathrm{a}] \mathrm{P}$ metabolism $[164,165]$ and $\mathrm{B}[\mathrm{a}] \mathrm{P}$ induced tumorigenesis [58]. The majority of studies showed that activation of both NF- $\mathrm{BB}$ and AhR directly regulates a large amount of genes after $\mathrm{B}[\mathrm{a}] \mathrm{P}$ exposure in a variety of cell types and these genes contributed to elevated $\mathrm{B}[\mathrm{a}] \mathrm{P}$ genotoxicity $[119,166,167]$.

\subsection{STAT-3 regulates AhR}

Activation of STAT-3 is found in various types of cancer (e.g. breast, ovarian, prostate, brain, leukemia, lymphoma and multiple myeloma) and also in inflammation [4, 145, 168, 169]. STAT-3 induces the expression of inflammation-associated mediators (e.g. cytokines, chemokines, pro-angiogenic factors and growth factors) and these released mediators bind to their corresponding receptors which activate STAT-3 mediated pathways $[4,68]$. In this case, a positive amplification loop is formed which will continuously activate STAT-3. This activation will not only promote cancer-related inflammation, but it also suppress anti-inflammatory immune responses [4, 67]. In addition, STAT- 3 contributes to the persistent activation of NF- $\kappa B$ by inhibiting IKK and promoting transcription of RelA-encoded target genes (e.g. IL-6) [4]. Beside these pro-inflammatory effects of STAT-3, it has also shown the capacity to regulate AhR and its downstream targets [170-172]. For example, gene expression of AhR was significantly inhibited after silencing STAT-3, and loss of AhR-induced genes was 
observed in STAT-3 $\%$ mice $[69,70]$. Hence, although there is no direct evidence indicating the correlation between $\mathrm{B}[\mathrm{a}] \mathrm{P}$ metabolism and STAT-3, it is reasonable to hypothesize that STAT-3 signal pathway might influence B[a]P metabolism via AhR.

\section{Bypassing p53}

The p53 protein is regarded to be the "guardian of the genome" and the "cellular gatekeeper" and thus plays a key role in tumor suppression $[173,174]$. In response to DNA damage, oncogene activation, acidic $\mathrm{pH}$ or hypoxia, the p53 protein transmits a variety of stress-inducing signals resulting in an anti-proliferative cellular responses, apoptosis, cell-cycle arrest, irreversible arrest (senescence) or modulation of autophagy [175-178]. In general, p53 is activated through several basic steps. First, stabilization of p53 is performed via the amino-terminal phosphorylation of p53 that prevent the interaction with Mdm2, which is a negative regulator that mediates a ubiquitin-mediated degradation of p53 [175]. Following p53 stabilization, p53 binds to DNA in a sequence-specific manner $[179,180]$. After stabilization and binding to specific sequences, p53 activates or suppresses its target genes [178, 181, 182]. The TP53 gene is one of the most commonly mutated genes in various types of human cancers and the binding region of TP53 is a "hot spot" for the majority of tumor-associated mutation in TP53 [183]. Therefore, maintaining proper p53 function is of importance for the integrity of the genome after exposure to chemical carcinogens $[174,183]$.

On the other hand, a large amount of experimental evidence indicates a mutual negative regulation between chronic inflammation (mainly NF- $\kappa B$ ) and p53 [43, 184, 185]. In response to stress conditions (i.e. DNA damage, inflammatory cytokines and chemokines), both inactivate forms of NF- $\kappa \mathrm{B}$ and p53 are released from their inhibitors, translocate into the nucleus, bind to their specific DNA binding-sites and initiate the transcription of numerous responsive genes [43]. Interestingly, both NF- $\kappa B$ and p53 induce the expression of genes whose proteins are antagonists of each other's action [185]. For example, activation of p53 result in cell cycle arrest, senescence or apoptosis, but activation of NF- $\mathrm{BB}$ upregulates transcription of positive growth regulators and various anti-apoptotic factors [186]. What is more, due to the limited amount of the transcriptional coactivator proteins (i.e. p300 or related CREB binding protein), both $\mathrm{NF}-\kappa \mathrm{B}$ and $\mathrm{p} 53$ compete and suppress each other $[187,188]$. In addition, NF- $\kappa \mathrm{B}$ develops several ways to maximize its activity, which can make NFkB the 'ultimate winner' of this competition with p53. For example, NF- $\kappa \mathrm{B}$ induces the expression of pro-inflammatory cytokines (e.g. IL-6 and MIF) which can inhibit p53 transcriptional activity or NF-kB upregulates the levels of the Mdm2 which is the major p53 inhibitor [106, 189-191]. Hence, continuous activation of NF- $\kappa \mathrm{B}$ during chronic inflammation creates conditions equivalent to genetic TP53 deficiency, which leads to the increased frequency of genomic rearrangements, genomic instability and eliminates the growth arrest response or apoptotic response induced by DNA damaging genotoxic insults [183, 192-195].

Additionally, B[a]P exposure activates p53 proteins, because p53 plays important roles in the defense against B[a]P-induced DNA damage [196]. Substantial in vitro and in vivo studies have documented the correlation between p53 protein and $\mathrm{B}[\mathrm{a}] \mathrm{P}$-induced DNA adducts [24, 197, 198]. As it is known that reactive $\mathrm{B}[\mathrm{a}] \mathrm{P}$ metabolites (BPDE) can covalently bind to DNA and this induces TP53 mRNA expression, cell cycle arrest and DNA repair [183, 196, 199].

However, for a long period of time, p53 was thought to only contribute to this cellular reaction to DNA damage, but recent studies show that p53 can also affect the 
metabolism of B[a]P. Treatment of TrP53(+/+), TrP53(+/-) and TrP53(-/-) mice with $\mathrm{B}[\mathrm{a}] \mathrm{P}$, not only resulted in significantly higher DNA adduct levels in liver and kidney of TrP53(-/-) mice than of TrP53(+/+) mice, but it also affected the profile of $\mathrm{B}[\mathrm{a}] \mathrm{P}$ metabolites. Bypassing the need for metabolic activation by treating mice with the ultimate genotoxin B[a]P-7,8-dihydrodiol-9,10-epoxide (BPDE) resulted in similar adduct levels in all studied organs and cells, confirming that the influence of p53 is via the biotransformation of the parent compound and not only as a response after DNA damage. Higher B[a]P-related DNA adduct levels in livers of TrP53(-/-) mice correlated with higher CYP1A protein levels and increased CYP1A enzyme activity, further demonstrating that p53 is also involved in the metabolism of $\mathrm{B}[\mathrm{a}] \mathrm{P}$ in vivo. Since inflammation may lead to a situation that mimics p53 deficiency, these data are of relevance for the further understanding of the link between inflammation and carcinogen metabolism.

\section{Discussions and Conclusions}

\subsection{Complexity of the interaction between inflammation and chemical carcinogenesis}

Differentiating friend from foe after a combined exposure to chemical challenges and simultaneous release of cytokines/chemokines/enzymes during inflammation is not an easy task. Triggering inflammation is the natural response of the human body to defend itself against invaders of various types, including for instance bacteria and viruses, but also particles and chemicals can induce inflammation [200]. Still, many studies indicate that inflammation contributes to a vast number of diseases, including highly prevalent chronic disease (e.g. atherosclerosis, COPD, IBD and Crohn's disease and cancer) [2, 200] and these subjects are unavoidably exposed to environmental or dietary chemicals. Therefore, over the decades, researchers have begun to investigate the mechanisms that underlying inflammation and its consequences in different kinds of inflammatory related diseases, but the large amount of molecular profiles after different inflammatory stimuli is complex and the addition of their interaction with chemical carcinogens is adding another level of complexity. Thus, researchers started to investigate the role of every inflammatory mediator (e.g. cytokine, chemokine and enzyme) individually and subsequently try to put the pieces together and tried to distinguish harmful from harmless. Figure 3 illustrates the complexity of interactions between inflammation and chemical carcinogenesis). New developments, including advanced microscopy, different specific transgenic or knock-out cell models or mouse/rat animal models, and various high throughput analyses may lead to a deeper understanding of how inflammation works and how it interferes or collaborates with carcinogen-induced diseases.

\subsection{Different results between in vitro and in vivo studies}

From a toxicological point of view, animal models seem the most appropriate model for testing medicines or drugs. However, many in vitro results cannot be reproduced in vivo and vice versa, which is also the case for the role of CYP1A1 in $\mathrm{B}[\mathrm{a}] \mathrm{P}$ metabolism; although in vitro studies clearly indicate that cytochrome $\mathrm{P} 450$ can activate $\mathrm{B}[\mathrm{a}] \mathrm{P}$, in vivo studies suggest that CYP's are more involved in the detoxification of B[a]P [201]. Additionally, the mechanism of p53 mediated alterations of CYP1A1 gene expression and activity seem different in the in vitro and in vivo situation [24]. Inflammatory conditions changed the in vitro effects of $\mathrm{B}[\mathrm{a}] \mathrm{P}$ exposure in such a way, that it mimics in vivo studies; for instance, in vitro inhibition of CYP1A1 activity by hypoxia or lowered $\mathrm{pH}$, led to 
higher DNA adduct levels, which was also seen in CYP-knockout models in vivo. Therefore, including inflammatory mediators in genotoxicity studies may improve in vitro investigations of chemical carcinogens. Especially, since we know that exposure of many chemical carcinogens may already elicit an inflammatory response, without additional exposure to known inflammatory triggers like LPS.

\subsection{Conclusions and Perspective}

Inflammation can link to every aspect of cancer development and progression that is induced by chemical carcinogens (e.g. B[a]P) [4]. In the past two decades, several inflammation-associated mediators have been identified as being implicated in carcinogen-induced carcinogenesis, such as pro-inflammatory cytokines, invasion-promoting factors, inflammatory enzymes as well as chemokines. Among them, IL-1, TNF- $\alpha$, IL-6, IL-8, MPO and $\beta$-glucuronidase act as crucial mediators of inflammation and $\mathrm{B}[\mathrm{a}] \mathrm{P}$ driven carcinogenesis. In Fig 3, we summarize known underlying interactions between inflammation-associated mediators and $\mathrm{B}[\mathrm{a}] \mathrm{P}$ metabolism as discussed in this review. Chronic inflammation can contribute to a cancer-prone microenvironment [145], which also affects the way cells handle chemical carcinogens, such as $\mathrm{B}[\mathrm{a}] \mathrm{P}$. Unfortunately, there are still many contradicting results between different cell lines and between in vitro and in vivo experiments, which has become another hurdle on the way of understanding inflammation and B[a]P induced carcinogenesis. Moreover, Figure 3 is probably far from complete. In conclusion, since inflammation and chemically induced cancers seem to be linked to each other very tightly, a combination of anti-inflammatory approaches and reducing exposure to genotoxic chemicals may lead to a reduction of cancer incidences in people with chronic inflammatory diseases such as COPD. Molecular approaches and animal models for inflammation-derived cancers will be necessary and helpful to further elucidate this intriguing puzzle. We believe that the carcinogen is like the match that lights the fire, and inflammation is the fuel that feeds the flame (or vice versa). 


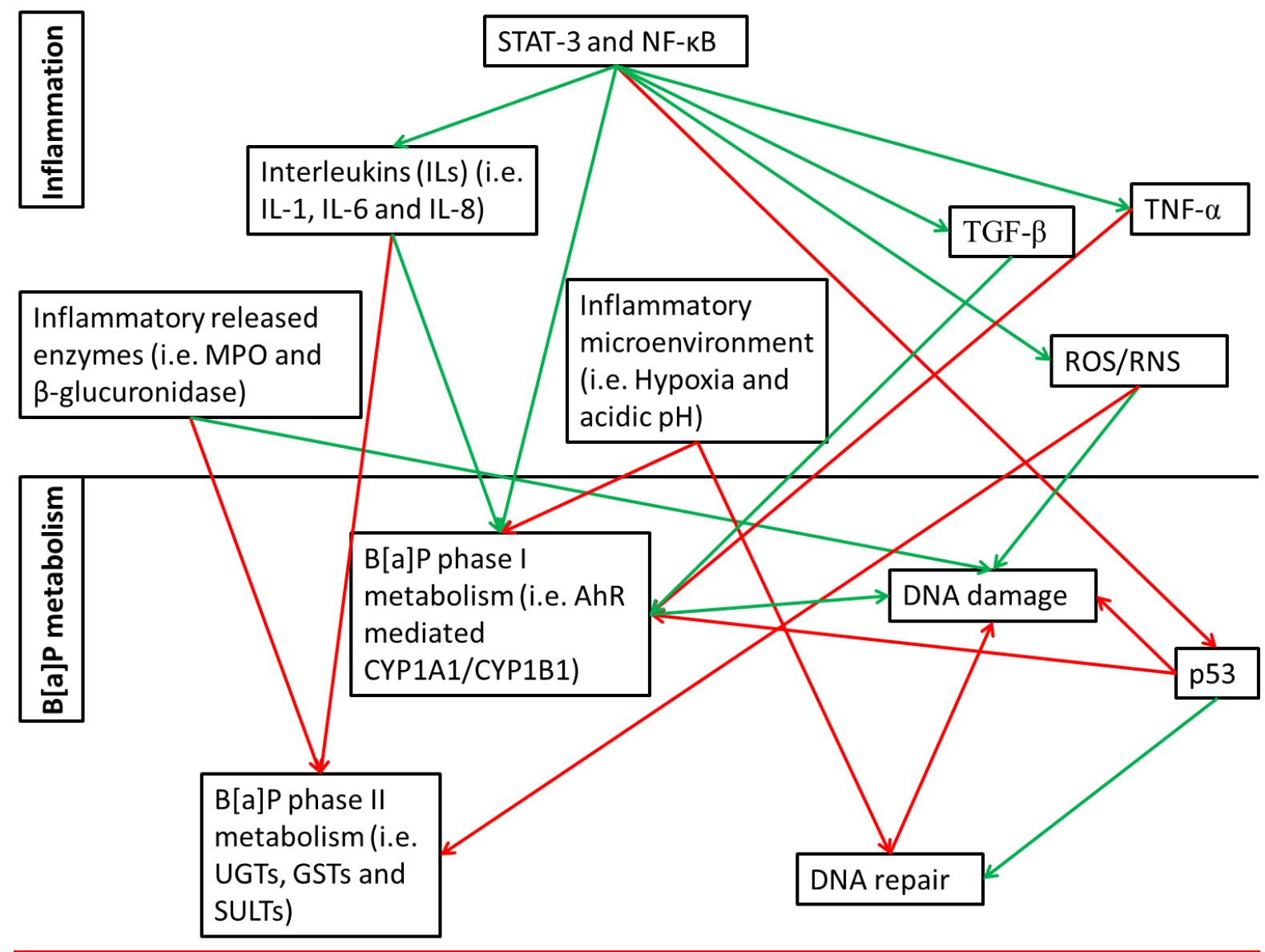

Figure 3. Simplified overview of the complex interaction network of inflammatory mediators in $\mathrm{B}[\mathrm{a}] \mathrm{P}$-induced DNA damage and cancer development. Among the inflammatory factors, STAT-3 and NF- $\kappa \mathrm{B}$ activate all kinds of inflammatory mediators and their down-stream effects, which influence different stages of $\mathrm{B}[\mathrm{a}] \mathrm{P}$ metabolism. Green arrow indicates promotion and red arrow indicates inhibition.

\section{Glossary}

Abbreviations

AhR

$\mathrm{B}[\mathrm{a}] \mathrm{P}$

Aryl hydrocarbon receptor

BPDE

Benzo[a]pyrene

CYP1A1/1B1

Benzo[a]pyrene-7,8-diol-9,10-epoxide

GSH

Cytochrome P450 1A1/1B1

HIF-1

Glutathione

ILS

hypoxia-inducible factor- 1

LPS

Interleukins

MPO

Lipopolysaccharide

NER

Myeloperoxidase

NF- $\kappa B$

PMNs

ROS

STAT-3

TGF- $\beta$

Nucleotide excision repair

nuclear factor kappa-light-chain-enhancer of activated B cells

polymorphonuclear neutrophils

TNF- $\alpha$

Reactive oxygen species

signal transducer and activator of transcription 3

Transforming growth factor- $\beta$

Tumor necrosis factor- $\alpha$ 


\section{References:}

[1] E. Farber, The multistep nature of cancer development, Cancer research, 44 (1984) 4217-4223.

[2] S. Perwez Hussain, C.C. Harris, Inflammation and cancer: an ancient link with novel potentials, International journal of cancer, 121 (2007) 2373-2380.

[3] L.M. Coussens, Z. Werb, Inflammation and cancer, Nature, 420 (2002) 860-867.

[4] G. Multhoff, M. Molls, J. Radons, Chronic inflammation in cancer development, Front Immunol, 2 (2011) 98.

[5] F. Balkwill, A. Mantovani, Inflammation and cancer: back to Virchow?, The lancet, 357 (2001) 539-545.

[6] D. Rossi, A. Zlotnik, The biology of chemokines and their receptors, Annual review of immunology, 18 (2000) 217-242.

[7] B. Homey, A. Müller, A. Zlotnik, Chemokines: agents for the immunotherapy of cancer?, Nature Reviews Immunology, 2 (2002) 175-184.

[8] S.I. Grivennikov, F.R. Greten, M. Karin, Immunity, inflammation, and cancer, Cell, 140 (2010) 883-899.

[9] M.C. Poirier, Chemical-induced DNA damage and human cancer risk, Nature reviews. Cancer, 4 (2004) 630-637.

[10] M.C. Poirier, Chemical-induced DNA damage and human cancer risk, Discov Med, 14 (2012) 283-288.

[11] G. Cooper, The Cell: A Molecular Approach. 2nd edition, Sinauer Associates2000.

[12] P. Boyle, B. Levin, World cancer report 2008, IARC Press, International Agency for Research on Cancer2008.

[13] N.R. Khalili, P.A. Scheff, T.M. Holsen, PAH source fingerprints for coke ovens, diesel and, gasoline engines, highway tunnels, and wood combustion emissions, Atmospheric environment, 29 (1995) 533-542.

[14] P. Tancell, M. Rhead, C. Trier, M. Bell, D. Fussey, The sources of benzo [a] pyrene in diesel exhaust emissions, Science of the total environment, 162 (1995) 179-186.

[15] J.R. Petrulis, G.H. Perdew, The role of chaperone proteins in the aryl hydrocarbon receptor core complex, Chem Biol Interact, 141 (2002) 25-40.

[16] H. Reyes, S. Reisz-Porszasz, O. Hankinson, Identification of the Ah receptor nuclear translocator protein (Arnt) as a component of the DNA binding form of the Ah receptor, Science, 256 (1992) 1193-1195.

[17] A. Fujisawa-Sehara, K. Sogawa, C. Nishi, Y. Fujii-Kuriyama, Regulatory DNA elements localized remotely upstream from the drug-metabolizing cytochrome P-450c gene, Nucleic acids research, 14 (1986) 1465-1477.

[18] F.J. Gonzalez, D.W. Nebert, Autoregulation plus upstream positive and negative control regions associated with transcriptional activation of the mouse P1(450) gene, Nucleic acids research, 13 (1985) 7269-7288.

[19] J.E. Kucab, H. van Steeg, M. Luijten, H.H. Schmeiser, P.A. White, D.H. Phillips, V.M. Arlt, TP53 mutations induced by BPDE in Xpa-WT and Xpa-Null human TP53 knock-in (Hupki) mouse embryo fibroblasts, Mutat Res, 773 (2015) 48-62.

[20] M.F. Denissenko, A. Pao, M. Tang, G.P. Pfeifer, Preferential formation of benzo[a]pyrene adducts at lung cancer mutational hotspots in P53, Science, 274 (1996) 430-432.

[21] X. Ren, L. Pan, L. Wang, Metabolic enzyme activities, metabolism-related genes expression and bioaccumulation in juvenile white shrimp Litopenaeus vannamei exposed to benzo[a]pyrene, Ecotoxicol Environ Saf, 104 (2014) 79-86.

[22] A. Strobel, P. Burkhardt-Holm, P. Schmid, H. Segner, Benzo(a)pyrene Metabolism and EROD and GST Biotransformation Activity in the Liver of Red- and White-Blooded Antarctic Fish, Environ Sci Technol, 49 (2015) 8022-8032.

[23] Z. Zheng, J.L. Fang, P. Lazarus, Glucuronidation: an important mechanism for detoxification of benzo[a]pyrene metabolites in aerodigestive tract tissues, Drug Metab Dispos, 30 (2002) 397-403.

[24] A.M. Krais, E.N. Speksnijder, J.P. Melis, R. Indra, M. Moserova, R.W. Godschalk, F.J. van Schooten, A. Seidel, K. Kopka, H.H. Schmeiser, M. Stiborova, D.H. Phillips, M. Luijten, V.M. Arlt, The impact of p53 on DNA damage and metabolic activation of the environmental carcinogen benzo[a]pyrene: effects in Trp53(+/+), Trp53(+/-) and Trp53(-/-) mice, Arch Toxicol, 90 (2016) 839-851.

[25] E.W. Tung, N.A. Philbrook, C.L. Belanger, S. Ansari, L.M. Winn, Benzo[a]pyrene increases DNA double strand break repair in vitro and in vivo: a possible mechanism for benzo[a]pyrene-induced toxicity, Mutat Res Genet Toxicol Environ Mutagen, 760 (2014) 64-69.

[26] N. Verhofstad, J.L.A. Pennings, C.T. van Oostrom, J. van Benthem, F.J. van Schooten, H. van Steeg, R.W.L. Godschalk, Benzo(a)pyrene induces similar gene expression changes in testis of DNA repair proficient and deficient mice, BMC Genomics, 11 (2010) 333-333.

[27] E. Braithwaite, X. Wu, Z. Wang, Repair of DNA lesions induced by polycyclic aromatic hydrocarbons in human cell-free extracts: involvement of two excision repair mechanisms in vitro, Carcinogenesis, 19 (1998) 1239-1246.

[28] S. Zienolddiny, D. Ryberg, D.H. Svendsrud, E. Eilertsen, V. Skaug, A. Hewer, D.H. Phillips, H. te Riele, A. Haugen, Msh2 deficiency increases susceptibility to benzo[a]pyrene-induced lymphomagenesis, International journal of cancer, 118 (2006) 2899-2902.

[29] T.S. Dexheimer, DNA Repair Pathways and Mechanisms, in: L.A. Mathews, S.M. Cabarcas, E.M. Hurt (Eds.) DNA Repair of Cancer Stem Cells, Springer Netherlands, Dordrecht, 2013, pp. 19-32.

[30] J.P.M. Melis, H. van Steeg, M. Luijten, Oxidative DNA Damage and Nucleotide Excision Repair, Antioxid Redox Signal, 18 (2013) 2409-2419.

[31] C.R. Boland, M.G. Luciani, C. Gasche, A. Goel, Infection, inflammation, and gastrointestinal cancer, Gut, 54 (2005) 1321-1331.

[32] J.A. Marteijn, H. Lans, W. Vermeulen, J.H.J. Hoeijmakers, Understanding nucleotide excision repair and its roles in cancer and ageing, Nat Rev Mol Cell Biol, 15 (2014) 465-481. 
[33] R. Nahta, F. Al-Mulla, R. Al-Temaimi, A. Amedei, R. Andrade-Vieira, S. Bay, D. G. Brown, G.M. Calaf, R.C. Castellino, K.A. Cohen-Solal, A. Colacci, N. Cruickshanks, P. Dent, R. Di Fiore, S. Forte, G.S. Goldberg, R.A. Hamid, H. Krishnan, D.W. Laird, A. Lasfar, P.A. Marignani, L. Memeo, C. Mondello, C.C. Naus, R. Ponce-Cusi, J. Raju, D. Roy, R. Roy, E. P. Ryan, H.K. Salem, A.I. Scovassi, N. Singh, M. Vaccari, R. Vento, J. Vondráček, M. Wade, J. Woodrick, W.H. Bisson, Mechanisms of environmental chemicals that enable the cancer hallmark of evasion of growth suppression, Carcinogenesis, 36 (2015) S2-S18.

[34] M. Pliskova, J. Vondracek, B. Vojtesek, A. Kozubik, M. Machala, Deregulation of cell proliferation by polycyclic aromatic hydrocarbons in human breast carcinoma MCF-7 cells reflects both genotoxic and nongenotoxic events, Toxicol Sci, 83 (2005) 246-256.

[35] G. Oberdörster, Pulmonary effects of inhaled ultrafine particles, International archives of occupational and environmental health, 74 (2000) 1-8.

[36] G. Multhoff, M. Molls, J. Radons, Chronic inflammation in cancer development, Front Immunol, 2 (2011) 98.

[37] D. Hanahan, R.A. Weinberg, The hallmarks of cancer, Cell, 100 (2000) 57-70.

[38] J.K. Kundu, Y.J. Surh, Inflammation: gearing the journey to cancer, Mutat Res, 659 (2008) 15-30.

[39] H. Bartsch, J. Nair, Oxidative stress and lipid peroxidation-derived DNA-lesions in inflammation driven carcinogenesis, Cancer detection and prevention, 28 (2004) 385-391.

[40] K. Rajalingam, R. Schreck, U.R. Rapp, S. Albert, Ras oncogenes and their downstream targets, Biochim Biophys Acta, 1773 (2007) 1177-1195.

[41] S. Strano, S. Dell'Orso, S. Di Agostino, G. Fontemaggi, A. Sacchi, G. Blandino, Mutant p53: an oncogenic transcription factor, Oncogene, 26 (0000) 2212-2219.

[42] H. Lu, W. Ouyang, C. Huang, Inflammation, a key event in cancer development, Mol Cancer Res, 4 (2006) 221-233.

[43] A. Yoshimura, Signal transduction of inflammatory cytokines and tumor development, Cancer Sci, 97 (2006) 439-447.

[44] A.M. Houghton, Mechanistic links between COPD and lung cancer, Nature reviews. Cancer, 13 (2013) 233-245.

[45] E.A. Engels, Inflammation in the development of lung cancer: epidemiological evidence, Expert Rev Anticancer Ther, 8 (2008) 605-615.

[46] S. Larsson, A. Wolk, Overweight, obesity and risk of liver cancer: a meta-analysis of cohort studies, Br J Cancer, 97 (2007) 1005-1008.

[47] C.P. Wild, R. Montesano, A model of interaction: aflatoxins and hepatitis viruses in liver cancer aetiology and prevention, Cancer Lett, 286 (2009) 22-28.

[48] K. Kobayashi, H. Tomita, M. Shimizu, T. Tanaka, N. Suzui, T. Miyazaki, A. Hara, p53 Expression as a Diagnostic Biomarker in Ulcerative Colitis-Associated Cancer, Int J Mol Sci, 18 (2017).

[49] V. Ho, V. Brunetti, S. Peacock, T.E. Massey, R.W.L. Godschalk, F.J. van Schooten, J.E. Ashbury, S.J. Vanner, W.D. King, Exposure to meat-derived carcinogens and bulky DNA adduct levels in normal-appearing colon mucosa, Mutation Research/Genetic Toxicology and Environmental Mutagenesis, 821 (2017) 5-12.

[50] M. Phillipson, P. Kubes, The neutrophil in vascular inflammation, Nat Med, 17 (2011) 1381-1390.

[51] H.L. Wright, R.J. Moots, R.C. Bucknall, S.W. Edwards, Neutrophil function in inflammation and inflammatory diseases, Rheumatology (Oxford), 49 (2010) 1618-1631.

[52] J. Shi, G.E. Gilbert, Y. Kokubo, T. Ohashi, Role of the liver in regulating numbers of circulating neutrophils, Blood, 98 (2001) 1226-1230.

[53] M.R. Galdiero, E. Bonavita, I. Barajon, C. Garlanda, A. Mantovani, S. Jaillon, Tumor associated macrophages and neutrophils in cancer, Immunobiology, 218 (2013) 1402-1410.

[54] A.W. Boots, K. Gerloff, R. Bartholome, D. van Berlo, K. Ledermann, G.R. Haenen, A. Bast, F.J. van Schooten, C. Albrecht, R.P. Schins, Neutrophils augment LPS-mediated pro-inflammatory signaling in human lung epithelial cells, Biochim Biophys Acta, 1823 (2012) 1151-1162.

[55] J.B. Weinberg, M.A. Misukonis, P.J. Shami, S.N. Mason, D.L. Sauls, W.A. Dittman, E.R. Wood, G.K. Smith, B. McDonald, K.E. Bachus, et al., Human mononuclear phagocyte inducible nitric oxide synthase (iNOS): analysis of iNOS mRNA, iNOS protein, biopterin, and nitric oxide production by blood monocytes and peritoneal macrophages, Blood, 86 (1995) 1184-1195.

[56] R.V. Lloyd, P.M. Hanna, R.P. Mason, The origin of the hydroxyl radical oxygen in the Fenton reaction, Free radical biology \& medicine, 22 (1997) 885-888.

[57] W.A. Pryor, Why is the hydroxyl radical the only radical that commonly adds to DNA? Hypothesis: it has a rare combination of high electrophilicity, high thermochemical reactivity, and a mode of production that can occur near DNA, Free radical biology \& medicine, 4 (1988) 219-223.

[58] K. Ji, C. Xing, F. Jiang, X. Wang, H. Guo, J. Nan, L. Qian, P. Yang, J. Lin, M. Li, J. Li, L. Liao, J. Tang, Benzo[a]pyrene induces oxidative stress and endothelial progenitor cell dysfunction via the activation of the NF-kappaB pathway, Int J Mol Med, 31 (2013) 922-930.

[59] K. Das, A. Roychoudhury, Reactive oxygen species (ROS) and response of antioxidants as ROS-scavengers during environmental stress in plants, Frontiers in Environmental Science, 2 (2014).

[60] Q. Shi, A.W. Boots, L. Maas, C. Veith, K. van Kuijk, G.R. Haenen, R.W. Godschalk, F.J. Van Schooten, Effect of interleukin (IL)-8 on benzo[a]pyrene metabolism and DNA damage in human lung epithelial cells, Toxicology, 381 (2017) 64-74.

[61] M. Patri, A. Padmini, P.P. Babu, Polycyclic aromatic hydrocarbons in air and their neurotoxic potency in association with oxidative stress: a brief perspective, Annals of Neurosciences, 16 (2010) 22-30. 
[62] T.M. Penning, M.E. Burczynski, C.F. Hung, K.D. McCoull, N.T. Palackal, L.S. Tsuruda, Dihydrodiol dehydrogenases and polycyclic aromatic hydrocarbon activation: generation of reactive and redox active o-quinones, Chem Res Toxicol, 12 (1999) 1-18.

[63] P. Joseph, A.K. Jaiswal, NAD(P)H:quinone oxidoreductase 1 reduces the mutagenicity of DNA caused by NADPH:P450 reductase-activated metabolites of benzo(a)pyrene quinones, Br J Cancer, 77 (1998) 709-719.

[64] D. Armstrong, Free radicals in diagnostic medicine: A systems approach to laboratory technology, clinical correlations, and antioxidant therapy, Springer Science \& Business Media2012.

[65] N. Gungor, A.M. Knaapen, A. Munnia, M. Peluso, G.R. Haenen, R.K. Chiu, R.W. Godschalk, F.J. van Schooten, Genotoxic effects of neutrophils and hypochlorous acid, Mutagenesis, 25 (2010) 149-154.

[66] A.M. Knaapen, N. Gungor, R.P. Schins, P.J. Borm, F.J. Van Schooten, Neutrophils and respiratory tract DNA damage and mutagenesis: a review, Mutagenesis, 21 (2006) 225-236.

[67] T.W. Kensler, P.A. Egner, K.G. Moore, B.G. Taffe, L.E. Twerdok, M.A. Trush, Role of inflammatory cells in the metabolic activation of polycyclic aromatic hydrocarbons in mouse skin, Toxicol Appl Pharmacol, 90 (1987) 337-346.

[68] M.A. Trush, J.L. Seed, T.W. Kensler, Oxidant-dependent metabolic activation of polycyclic aromatic hydrocarbons by phorbol ester-stimulated human polymorphonuclear leukocytes: possible link between inflammation and cancer, Proc Natl Acad Sci U S A, 82 (1985) 5194-5198.

[69] W.G. Mallet, D.R. Mosebrook, M.A. Trush, Activation of (+-)-trans-7,8-dihydroxy-7,8-dihydrobenzo[a]pyrene to diolepoxides by human polymorphonuclear leukocytes or myeloperoxidase, Carcinogenesis, 12 (1991) 521-524.

[70] J.M. Petruska, D.R. Mosebrook, G.J. Jakab, M.A. Trush, Myeloperoxidase-enhanced formation of (+-)-trans-7,8-dihydroxy-7,8-dihydrobenzo[a]pyrene-DNA adducts in lung tissue in vitro: a role of pulmonary inflammation in the bioactivation of a procarcinogen, Carcinogenesis, 13 (1992) 1075-1081.

[71] P.J. Borm, A.M. Knaapen, R.P. Schins, R.W. Godschalk, F.J. Schooten, Neutrophils amplify the formation of DNA adducts by benzo[a]pyrene in lung target cells, Environmental health perspectives, 105 Suppl 5 (1997) 1089-1093.

[72] S.J. London, T.A. Lehman, J.A. Taylor, Myeloperoxidase genetic polymorphism and lung cancer risk, Cancer research, 57 (1997) 5001-5003.

[73] M. Rojas, R. Godschalk, K. Alexandrov, I. Cascorbi, E. Kriek, J. Ostertag, F.J. Van Schooten, H. Bartsch, Myeloperoxidase--463A variant reduces benzo[a]pyrene diol epoxide DNA adducts in skin of coal tar treated patients, Carcinogenesis, 22 (2001) 1015-1018.

[74] F.J. Van Schooten, A.W. Boots, A.M. Knaapen, R.W. Godschalk, L.M. Maas, P.J. Borm, M. Drent, J.A. Jacobs, Myeloperoxidase (MPO) -463G->A reduces MPO activity and DNA adduct levels in bronchoalveolar lavages of smokers, Cancer Epidemiol Biomarkers Prev, 13 (2004) 828-833.

[75] N. Gungor, R.W. Godschalk, D.M. Pachen, F.J. Van Schooten, A.M. Knaapen, Activated neutrophils inhibit nucleotide excision repair in human pulmonary epithelial cells: role of myeloperoxidase, FASEB journal : official publication of the Federation of American Societies for Experimental Biology, 21 (2007) 2359-2367.

[76] Q. Shi, L. Maas, C. Veith, F.J. Van Schooten, R.W. Godschalk, Acidic cellular microenvironment modifies carcinogen-induced DNA damage and repair, Archives of toxicology, (2016) 1-17.

[77] D. Malejka-Giganti, C.L. Ritter, Peroxidative metabolism of carcinogenic N-arylhydroxamic acids: implications for tumorigenesis, Environmental health perspectives, 102 Suppl 6 (1994) 75-81.

[78] V.M. Lakshmi, F.F. Hsu, B.B. Davis, T.V. Zenser, N-Acetylbenzidine-DNA adduct formation by phorbol 12-myristate-stimulated human polymorphonuclear neutrophils, Chem Res Toxicol, 13 (2000) 785-792.

[79] V.M. Lakshmi, F.F. Hsu, B.B. Davis, T.V. Zenser, Reactive nitrogen oxygen species metabolize N-acetylbenzidine, Chem Res Toxicol, 14 (2001) 312-318.

[80] J.H. Shen, M. Wegenke, T. Wolff, Capability of human blood cells to form the DNA adduct, C8-(N2-aminofluorenyl)-deoxyguanosine-3'-5'-diphosphate from 2-aminofluorene, Carcinogenesis, 11 (1990) 1441-1444.

[81] V.J. Isola, T.C. Hartman, S.J. Trumble, M.C. Ruzek, J.M. Gentile, Metabolism of 2-aminofluorene by human polymorphonuclear leukocytes: more evidence for the association between inflammation and cancer, Environmental health perspectives, 101 Suppl 3 (1993) 27-31.

[82] V.M. Lakshmi, F.F. Hsu, T.V. Zenser, Nitric oxide-mediated nitrosation of 2-amino-3,8-dimethylimidazo[4,5-f]quinoxaline potentiated by hemin and myeloperoxidase, Chem Res Toxicol, 18 (2005) 1038-1047.

[83] J.A. Williams, E.M. Stone, B.C. Millar, B.A. Gusterson, P.L. Grover, D.H. Phillips, Determination of the enzymes responsible for activation of the heterocyclic amine 2-amino-3-methylimidazo[4,5-f]quinoline in the human breast, Pharmacogenetics, 8 (1998) 519-528.

[84] V.M. Arlt, C.J. Henderson, C.R. Wolf, H.H. Schmeiser, D.H. Phillips, M. Stiborova, Bioactivation of 3-aminobenzanthrone, a human metabolite of the environmental pollutant 3-nitrobenzanthrone: evidence for DNA adduct formation mediated by cytochrome P450 enzymes and peroxidases, Cancer Lett, 234 (2006) 220-231.

[85] T. Iyanagi, Molecular Mechanism of Phase I and Phase II Drug-Metabolizing Enzymes: Implications for Detoxification, International Review of Cytology, Academic Press2007, pp. 35-112.

[86] S. Ohno, S. Nakajin, Determination of mRNA expression of human UDP-glucuronosyltransferases and application for localization in various human tissues by real-time reverse transcriptase-polymerase chain reaction, Drug Metab Dispos, 37 (2009) 32-40.

[87] K. Shimoi, T. Nakayama, Glucuronidase deconjugation in inflammation, Methods Enzymol, 400 (2005) 263-272.

[88] P. van den Hurk, M.O. James, Sulfation and glucuronidation of benzo[a]pyrene-7,8-dihydrodiol in intestinal mucosa of channel catfish (Ictalurus punctatus), Marine Environmental Research, 50 (2000) 11-15. 
[89] Z. Hu, P.G. Wells, Modulation of benzo[a]pyrene bioactivation by glucuronidation in lymphocytes and hepatic microsomes from rats with a hereditary deficiency in bilirubin UDP-glucuronosyltransferase, Toxicol Appl Pharmacol, 127 (1994) 306-313.

[90] Z. Hu, P.G. Wells, In vitro and in vivo biotransformation and covalent binding of benzo(a)pyrene in Gunn and RHA rats with a genetic deficiency in bilirubin uridine diphosphate-glucuronosyltransferase, J Pharmacol Exp Ther, 263 (1992) 334-342.

[91] R. Bartholome, G. Haenen, C.H. Hollman, A. Bast, P.C. Dagnelie, D. Roos, J. Keijer, P.A. Kroon, P.W. Needs, I.C. Arts, Deconjugation kinetics of glucuronidated phase II flavonoid metabolites by beta-glucuronidase from neutrophils, Drug Metab Pharmacokinet, 25 (2010) 379-387.

[92] Q. Shi, G.R. Haenen, L. Maas, V.M. Arlt, D. Spina, Y.R. Vasquez, E. Moonen, C. Veith, F.J. Van Schooten, R.W. Godschalk, Inflammation-associated extracellular beta-glucuronidase alters cellular responses to the chemical carcinogen benzo[a]pyrene, Arch Toxicol, (2015).

[93] A.M. Lewis, S. Varghese, H. Xu, H.R. Alexander, Interleukin-1 and cancer progression: the emerging role of interleukin-1 receptor antagonist as a novel therapeutic agent in cancer treatment, Journal of Translational Medicine, 4 (2006) 48-48.

[94] R.N. Apte, Y. Krelin, X. Song, S. Dotan, E. Recih, M. Elkabets, Y. Carmi, T. Dvorkin, R.M. White, L. Gayvoronsky, S. Segal, E. Voronov, Effects of micro-environment- and malignant cell-derived interleukin-1 in carcinogenesis, tumour invasiveness and tumour-host interactions, Eur J Cancer, 42 (2006) 751-759.

[95] N.J. Gay, M. Gangloff, L.A. O'Neill, What the Myddosome structure tells us about the initiation of innate immunity, Trends Immunol, 32 (2011) 104-109.

[96] W.S. Cho, C. Chae, Expression of inflammatory cytokines (TNF-alpha, IL-1, IL-6 and IL-8) in colon of pigs naturally infected with Salmonella typhimurium and S. choleraesuis, J Vet Med A Physiol Pathol Clin Med, 50 (2003) 484-487.

[97] B. Hoesel, J.A. Schmid, The complexity of NF- $\kappa$ B signaling in inflammation and cancer, Molecular cancer, 12 (2013) 86-86.

[98] C.F. Vogel, E.M. Khan, P.S. Leung, M.E. Gershwin, W.L. Chang, D. Wu, T. Haarmann-Stemmann, A. Hoffmann, M.S. Denison, Cross-talk between aryl hydrocarbon receptor and the inflammatory response: a role for nuclear factor-kappaB, J Biol Chem, 289 (2014) 1866-1875.

[99] Y. Tian, S. Ke, M.S. Denison, A.B. Rabson, M.A. Gallo, Ah receptor and NF-kappaB interactions, a potential mechanism for dioxin toxicity, J Biol Chem, 274 (1999) 510-515.

[100] Z. Abdel-Razzak, L. Corcos, A. Fautrel, J.P. Campion, A. Guillouzo, Transforming growth factor-beta 1 down-regulates basal and polycyclic aromatic hydrocarbon-induced cytochromes P-450 1A1 and 1A2 in adult human hepatocytes in primary culture, Molecular pharmacology, 46 (1994) 1100-1110.

[101] S. Rose-John, H. Schooltink, Cytokines Are a Therapeutic Target for the Prevention of Inflammation-Induced Cancers, in: H.-J. Senn, U. Kapp (Eds.) Cancer Prevention, Springer Berlin Heidelberg, Berlin, Heidelberg, 2007, pp. 57-66.

[102] M.R. Schneider, A. Hoeflich, J.R. Fischer, E. Wolf, B. Sordat, H. Lahm, Interleukin-6 stimulates clonogenic growth of primary and metastatic human colon carcinoma cells, Cancer Lett, 151 (2000) 31-38.

[103] B.I. Hudson, A.M. Carter, E. Harja, A.Z. Kalea, M. Arriero, H. Yang, P.J. Grant, A.M. Schmidt, Identification, classification, and expression of RAGE gene splice variants, FASEB journal : official publication of the Federation of American Societies for Experimental Biology, 22 (2008) 1572-1580.

[104] C. Becker, M.C. Fantini, C. Schramm, H.A. Lehr, S. Wirtz, A. Nikolaev, J. Burg, S. Strand, R. Kiesslich, S. Huber, H. Ito, N. Nishimoto, K. Yoshizaki, T. Kishimoto, P.R. Galle, M. Blessing, S. Rose-John, M.F. Neurath, TGF-beta suppresses tumor progression in colon cancer by inhibition of IL-6 trans-signaling, Immunity, 21 (2004) 491-501.

[105] S. Rose-John, J. Scheller, G. Elson, S.A. Jones, Interleukin-6 biology is coordinated by membrane-bound and soluble receptors: role in inflammation and cancer, J Leukoc Biol, 80 (2006) 227-236.

[106] E. Yonish-Rouach, D. Resnitzky, J. Lotem, L. Sachs, A. Kimchi, M. Oren, Wild-type p53 induces apoptosis of myeloid leukaemic cells that is inhibited by interleukin-6, Nature, 352 (1991) 345-347.

[107] S.A.A. Patel, N.J. Gooderham, Interleukin-6 promotes dietary carcinogen-induced DNA damage in colorectal cancer cells, Toxicology Research, 4 (2015) 858-866.

[108] D.J. Waugh, C. Wilson, The interleukin-8 pathway in cancer, Clin Cancer Res, 14 (2008) 6735-6741.

[109] S.A. Langie, A.M. Knaapen, J.M. Houben, F.C. van Kempen, J.P. de Hoon, R.W. Gottschalk, R.W. Godschalk, F.J. van Schooten, The role of glutathione in the regulation of nucleotide excision repair during oxidative stress, Toxicol Lett, 168 (2007) 302-309.

[110] C. Popa, M.G. Netea, P.L. van Riel, J.W. van der Meer, A.F. Stalenhoef, The role of TNF-alpha in chronic inflammatory conditions, intermediary metabolism, and cardiovascular risk, J Lipid Res, 48 (2007) 751-762.

[111] J.R. Bradley, TNF-mediated inflammatory disease, J Pathol, 214 (2008) 149-160.

[112] Y. Tian, A. Kijlstra, J. Renes, M. Wabitsch, C.A.B. Webers, T.T.J.M. Berendschot, Lutein Leads to a Decrease of Factor D Secretion by Cultured Mature Human Adipocytes, Journal of Ophthalmology, 2015 (2015) 7.

[113] T. Robak, A. Gladalska, H. Stepien, The tumour necrosis factor family of receptors/ligands in the serum of patients with rheumatoid arthritis, Eur Cytokine Netw, 9 (1998) 145-154.

[114] F. Balkwill, Tumor necrosis factor or tumor promoting factor?, Cytokine Growth Factor Rev, 13 (2002) 135-141.

[115] M. Jaiswal, N.F. LaRusso, L.J. Burgart, G.J. Gores, Inflammatory cytokines induce DNA damage and inhibit DNA repair in cholangiocarcinoma cells by a nitric oxide-dependent mechanism, Cancer research, 60 (2000) 184-190.

[116] M. Philip, D.A. Rowley, H. Schreiber, Inflammation as a tumor promoter in cancer induction, Seminars in cancer biology, 14 (2004) 433-439. 
[117] S. Wu, C.M. Boyer, R.S. Whitaker, A. Berchuck, J.R. Wiener, J.B. Weinberg, R.C. Bast, Jr., Tumor necrosis factor alpha as an autocrine and paracrine growth factor for ovarian cancer: monokine induction of tumor cell proliferation and tumor necrosis factor alpha expression, Cancer research, 53 (1993) 1939-1944.

[118] L. Umannova, M. Machala, J. Topinka, Z. Novakova, A. Milcova, A. Kozubik, J. Vondracek, Tumor necrosis factor-alpha potentiates genotoxic effects of benzo[a]pyrene in rat liver epithelial cells through upregulation of cytochrome P450 1B1 expression, Mutat Res, 640 (2008) 162-169.

[119] L. Smerdova, J. Neca, J. Svobodova, J. Topinka, J. Schmuczerova, A. Kozubik, M. Machala, J. Vondracek, Inflammatory mediators accelerate metabolism of benzo[a]pyrene in rat alveolar type II cells: the role of enhanced cytochrome P450 1B1 expression, Toxicology, 314 (2013) 30-38.

[120] S.Y. Shieh, M. Ikeda, Y. Taya, C. Prives, DNA damage-induced phosphorylation of p53 alleviates inhibition by MDM2, Cell, 91 (1997) 325-334.

[121] L. Umannova, M. Machala, J. Topinka, J. Schmuczerova, P. Krcmar, J. Neca, K. Sujanova, A. Kozubik, J. Vondracek, Benzo[a]pyrene and tumor necrosis factor-alpha coordinately increase genotoxic damage and the production of proinflammatory mediators in alveolar epithelial type II cells, Toxicol Lett, 206 (2011) 121-129.

[122] M.O. Li, R.A. Flavell, Contextual regulation of inflammation: a duet by transforming growth factor-beta and interleukin-10, Immunity, 28 (2008) 468-476.

[123] S. Sanjabi, L.A. Zenewicz, M. Kamanaka, R.A. Flavell, Anti- and Pro-inflammatory Roles of TGF- $\beta$, IL-10, and IL-22 In Immunity and Autoimmunity, Current opinion in pharmacology, 9 (2009) 447-453.

[124] G. Han, F. Li, T.P. Singh, P. Wolf, X.-J. Wang, The Pro-inflammatory Role of TGF $\beta 1$ : A Paradox?, International Journal of Biological Sciences, 8 (2012) 228-235.

[125] T. Korn, E. Bettelli, M. Oukka, V.K. Kuchroo, IL-17 and Th17 Cells, Annual review of immunology, 27 (2009) 485-517.

[126] W.B. Smith, L. Noack, Y. Khew-Goodall, S. Isenmann, M.A. Vadas, J.R. Gamble, Transforming growth factor-beta 1 inhibits the production of IL-8 and the transmigration of neutrophils through activated end othelium, J Immunol, 157 (1996) 360-368.

[127] E. Lutgens, M. Gijbels, M. Smook, P. Heeringa, P. Gotwals, V.E. Koteliansky, M.J. Daemen, Transforming growth factor-beta mediates balance between inflammation and fibrosis during plaque progression, Arterioscler Thromb Vasc Biol, 22 (2002) 975-982.

[128] M.M. Shull, I. Ormsby, A.B. Kier, S. Pawlowski, R.J. Diebold, M. Yin, R. Allen, C. Sidman, G. Proetzel, D. Calvin, et al., Targeted disruption of the mouse transforming growth factor-beta 1 gene results in multifocal inflammatory disease, Nature, 359 (1992) 693-699.

[129] B. Bierie, H.L. Moses, Transforming growth factor beta (TGF- $\beta$ ) and inflammation in cancer, Cytokine Growth Factor Rev, 21 (2010) 49-59.

[130] Z. Abdel-Razzak, L. Corcos, A. Fautrel, J.P. Campion, A. Guillouzo, Transforming growth factor-beta 1 down-regulates basal and polycyclic aromatic hydrocarbon-induced cytochromes P-450 1A1 and 1A2 in adult human hepatocytes in primary culture, Mol Pharmacol, 46 (1994) 1100-1110.

[131] Y. Kato, S. Ozawa, C. Miyamoto, Y. Maehata, A. Suzuki, T. Maeda, Y. Baba, Acidic extracellular microenvironment and cancer, Cancer Cell International, 13 (2013) 89-89.

[132] P. Vaupel, F. Kallinowski, P. Okunieff, Blood flow, oxygen and nutrient supply, and metabolic microenvironment of human tumors: a review, Cancer research, 49 (1989) 6449-6465.

[133] R.A. Gatenby, R.J. Gillies, Why do cancers have high aerobic glycolysis?, Nature reviews. Cancer, 4 (2004) 891-899.

[134] C.R. Justus, L. Dong, L.V. Yang, Acidic Tumor Microenvironment and pH-Sensing G protein-Coupled Receptors, Frontiers in Physiology, 4 (2013).

[135] A.I. Papaioannou, S. Loukides, M. Minas, K. Kontogianni, P. Bakakos, K.I. Gourgoulianis, M. Alchanatis, S. Papiris, K. Kostikas, Exhaled breath condensate pH as a biomarker of COPD severity in ex-smokers, Respir Res, 12 (2011) 67.

[136] S.G. Nugent, D. Kumar, D.S. Rampton, D.F. Evans, Intestinal luminal pH in inflammatory bowel disease: possible determinants and implications for therapy with aminosalicylates and other drugs, Gut, 48 (2001) 571-577.

[137] M. Chesler, C. Nicholson, Regulation of intracellular pH in vertebrate central neurons, Brain Res, 325 (1985) 313-316.

[138] T. Nishisho, K. Hata, M. Nakanishi, Y. Morita, G.H. Sun-Wada, Y. Wada, N. Yasui, T. Yoneda, The a3 isoform vacuolar type $\mathrm{H}(+)$-ATPase promotes distant metastasis in the mouse B16 melanoma cells, Mol Cancer Res, 9 (2011) 845-855.

[139] G. Helmlinger, A. Sckell, M. Dellian, N.S. Forbes, R.K. Jain, Acid production in glycolysis-impaired tumors provides new insights into tumor metabolism, Clin Cancer Res, 8 (2002) 1284-1291.

[140] W.F. Ganong, Physiology: A study guide, California: Lange Medical Publications, 19851985.

[141] A. Lardner, The effects of extracellular pH on immune function, J Leukoc Biol, 69 (2001) 522-530.

[142] T.K. Hunt, R.S. Aslam, S. Beckert, S. Wagner, Q.P. Ghani, M.Z. Hussain, S. Roy, C.K. Sen, Aerobically derived lactate stimulates revascularization and tissue repair via redox mechanisms, Antioxid Redox Signal, 9 (2007) 1115-1124.

[143] F. Vegran, R. Boidot, C. Michiels, P. Sonveaux, O. Feron, Lactate influx through the endothelial cell monocarboxylate transporter MCT1 supports an NF-kappaB/IL-8 pathway that drives tumor angiogenesis, Cancer research, 71 (2011) 2550-2560.

[144] A. Riemann, A. Ihling, J. Thomas, B. Schneider, O. Thews, M. Gekle, Acidic environment activates inflammatory programs in fibroblasts via a cAMP-MAPK pathway, Biochim Biophys Acta, 1853 (2015) 299-307. 
[145] N. Gungor, A. Haegens, A.M. Knaapen, R.W. Godschalk, R.K. Chiu, E.F. Wouters, F.J. van Schooten, Lung inflammation is associated with reduced pulmonary nucleotide excision repair in vivo, Mutagenesis, 25 (2010) 77-82.

[146] J.R. Geffner, A.S. Trevani, F. Minnucci, M.S. Palermo, N. Maugeri, M.A. Isturiz, Extracellular acidic pH modulates oxygen-dependent cytotoxic responses mediated by polymorphonuclear leucocytes and monocytes, Clinical and Experimental Immunology, 91 (1993) 164-169.

[147] A.S. Trevani, G. Andonegui, M. Giordano, D.H. Lopez, R. Gamberale, F. Minucci, J.R. Geffner, Extracellular acidification induces human neutrophil activation, J Immunol, 162 (1999) 4849-4857.

[148] L. D'Ignazio, D. Bandarra, S. Rocha, NF-kappaB and HIF crosstalk in Immune Responses, Febs J, (2015).

[149] H.K. Eltzschig, P. Carmeliet, Hypoxia and inflammation, N Engl J Med, 364 (2011) 656-665.

[150] G. Hartmann, M. Tschop, R. Fischer, C. Bidlingmaier, R. Riepl, K. Tschop, H. Hautmann, S. Endres, M. Toepfer, High altitude increases circulating interleukin-6, interleukin-1 receptor antagonist and C-reactive protein, Cytokine, 12 (2000) 246-252.

[151] W.G. Kaelin, Jr., P.J. Ratcliffe, Oxygen sensing by metazoans: the central role of the HIF hydroxylase pathway, Mol Cell, 30 (2008) 393-402.

[152] M. Nie, A.L. Blankenship, J.P. Giesy, Interactions between aryl hydrocarbon receptor (AhR) and hypoxia signaling pathways, Environ Toxicol Pharmacol, 10 (2001) 17-27.

[153] C.C. Blouin, E.L. Page, G.M. Soucy, D.E. Richard, Hypoxic gene activation by lipopolysaccharide in macrophages: implication of hypoxia-inducible factor 1alpha, Blood, 103 (2004) 1124-1130.

[154] M.A. Schults, L. Timmermans, R.W. Godschalk, J. Theys, B.G. Wouters, F.J. van Schooten, R.K. Chiu, Diminished carcinogen detoxification is a novel mechanism for hypoxia-inducible factor 1-mediated genetic instability, J Biol Chem, 285 (2010) 14558-14564.

[155] G.L. Wang, B.H. Jiang, E.A. Rue, G.L. Semenza, Hypoxia-inducible factor 1 is a basic-helix-loop-helix-PAS heterodimer regulated by cellular 02 tension, Proc Natl Acad Sci U S A, 92 (1995) 5510-5514.

[156] G.L. Wang, G.L. Semenza, Purification and characterization of hypoxia-inducible factor 1, J Biol Chem, 270 (1995) 1230-1237.

[157] J. Yuan, L. Narayanan, S. Rockwell, P.M. Glazer, Diminished DNA repair and elevated mutagenesis in mammalian cells exposed to hypoxia and low pH, Cancer research, 60 (2000) 4372-4376.

[158] M.A. Schults, K. Sanen, R.W. Godschalk, J. Theys, F.J. van Schooten, R.K. Chiu, Hypoxia diminishes the detoxification of the environmental mutagen benzo[a]pyrene, Mutagenesis, 29 (2014) 481-487.

[159] T. Lawrence, The nuclear factor NF-kappaB pathway in inflammation, Cold Spring Harbor perspectives in biology, 1 (2009) a001651.

[160] A.V. Gudkov, K.V. Gurova, E.A. Komarova, Inflammation and p53: A Tale of Two Stresses, Genes \& Cancer, 2 (2011) 503-516.

[161] M. Karin, NF-kappaB as a critical link between inflammation and cancer, Cold Spring Harbor perspectives in biology, 1 (2009) a000141.

[162] J.H. van Delft, K. Mathijs, Y.C. Staal, M.H. van Herwijnen, K.J. Brauers, A. Boorsma, J.C. Kleinjans, Time series analysis of benzo[A]pyrene-induced transcriptome changes suggests that a network of transcription factors regulates the effects on functional gene sets, Toxicol Sci, 117 (2010) 381-392.

[163] J. Ovrevik, M. Lag, V. Lecureur, D. Gilot, D. Lagadic-Gossmann, M. Refsnes, P.E. Schwarze, T. Skuland, R. Becher, J.A. Holme, AhR and Arnt differentially regulate NF-kappaB signaling and chemokine responses in human bronchial epithelial cells, Cell Commun Signal, 12 (2014) 48.

[164] J.J. Tsay, K.M. Tchou-Wong, A.K. Greenberg, H. Pass, W.N. Rom, Aryl hydrocarbon receptor and lung cancer, Anticancer Res, 33 (2013) 1247-1256.

[165] I.A. Murray, A.D. Patterson, G.H. Perdew, Aryl hydrocarbon receptor ligands in cancer: friend and foe, Nature reviews. Cancer, 14 (2014) 801-814.

[166] C.F.A. Vogel, W. Li, E. Sciullo, J. Newman, B. Hammock, J.R. Reader, J. Tuscano, F. Matsumura, Pathogenesis of Aryl Hydrocarbon Receptor-Mediated Development of Lymphoma Is Associated with Increased Cyclooxygenase-2 Expression, The American Journal of Pathology, 171 (2007) 1538-1548.

[167] S.C. Degner, A.J. Papoutsis, O. Selmin, D.F. Romagnolo, Targeting of aryl hydrocarbon receptor-mediated activation of cyclooxygenase-2 expression by the indole-3-carbinol metabolite 3,3'-diindolylmethane in breast cancer cells, J Nutr, 139 (2009) 26-32.

[168] H. Yu, D. Pardoll, R. Jove, STATs in cancer inflammation and immunity: a leading role for STAT3, Nature reviews. Cancer, 9 (2009) 798-809.

[169] H. Yu, M. Kortylewski, D. Pardoll, Crosstalk between cancer and immune cells: role of STAT3 in the tumour microenvironment, Nature reviews. Immunology, 7 (2007) 41-51.

[170] M.C. Simeone-Penney, STAT3: A Novel Regulator of Airway Inflammation and Remodeling in Asthma, ProQuest2008.

[171] N. Stobbe-Maicherski, S. Wolff, C. Wolff, J. Abel, U. Sydlik, K. Frauenstein, T. Haarmann-Stemmann, The interleukin-6-type cytokine oncostatin $M$ induces aryl hydrocarbon receptor expression in a STAT3-dependent manner in human HepG2 hepatoma cells, The FEBS journal, 280 (2013) 6681-6690.

[172] F.J. Quintana, D.H. Sherr, Aryl hydrocarbon receptor control of adaptive immunity, Pharmacological reviews, 65 (2013) 1148-1161.

[173] D.P. Lane, Cancer. p53, guardian of the genome, Nature, 358 (1992) 15-16.

[174] A.J. Levine, p53, the cellular gatekeeper for growth and division, Cell, 88 (1997) 323-331. 
[175] J.T. Zilfou, S.W. Lowe, Tumor Suppressive Functions of p53, Cold Spring Harbor perspectives in biology, 1 (2009) a001883.

[176] D.R. Green, G. Kroemer, Cytoplasmic functions of the tumour suppressor p53, Nature, 458 (2009) 1127-1130.

[177] T. Riley, E. Sontag, P. Chen, A. Levine, Transcriptional control of human p53-regulated genes, Nat Rev Mol Cell Biol, 9 (2008) 402-412.

[178] K.S. Yee, K.H. Vousden, Complicating the complexity of p53, Carcinogenesis, 26 (2005) 1317-1322.

[179] W.S. el-Deiry, S.E. Kern, J.A. Pietenpol, K.W. Kinzler, B. Vogelstein, Definition of a consensus binding site for p53, Nat Genet, 1 (1992) 45-49.

[180] P. Hainaut, M. Hollstein, p53 and human cancer: the first ten thousand mutations, Adv Cancer Res, 77 (2000) 81-137.

[181] M.E. Murphy, The thousand doors that lead to death: p53-dependent repression and apoptosis, Cancer Biol Ther, 2 (2003) 381-382.

[182] N.G. Iyer, H. Ozdag, C. Caldas, p300/CBP and cancer, Oncogene, 23 (2004) 4225-4231.

[183] X.H. Pei, Y. Nakanishi, K. Takayama, F. Bai, N. Hara, Benzo[a]pyrene activates the human p53 gene through induction of nuclear factor kappaB activity, J Biol Chem, 274 (1999) 35240-35246.

[184] J.M. Lowe, D. Menendez, M.B. Fessler, A new inflammatory role for p53 in human macrophages, Cell cycle, 13 (2014) 2983-2984.

[185] S. Pal, A. Bhattacharjee, A. Ali, N.C. Mandal, S.C. Mandal, M. Pal, Chronic inflammation and cancer: potential chemoprevention through nuclear factor kappa B and p53 mutual antagonism, J Inflamm (Lond), 11 (2014) 23.

[186] Z. Feng, W. Hu, G. Rajagopal, A.J. Levine, The tumor suppressor p53: cancer and aging, Cell cycle, 7 (2008) 842-847.

[187] A. Ikeda, X. Sun, Y. Li, Y. Zhang, R. Eckner, T.S. Doi, T. Takahashi, Y. Obata, K. Yoshioka, K. Yamamoto, p300/CBP-dependent and -independent transcriptional interference between NF-kappaB RelA and p53, Biochem Biophys Res Commun, 272 (2000) 375-379.

[188] G.A. Webster, N.D. Perkins, Transcriptional cross talk between NF-kappaB and p53, Mol Cell Biol, 19 (1999) 3485-3495.

[189] J.D. Hudson, M.A. Shoaibi, R. Maestro, A. Carnero, G.J. Hannon, D.H. Beach, A proinflammatory cytokine inhibits p53 tumor suppressor activity, J Exp Med, 190 (1999) 1375-1382.

[190] L.J. Egan, L. Eckmann, F.R. Greten, S. Chae, Z.W. Li, G.M. Myhre, S. Robine, M. Karin, M.F. Kagnoff, IkappaB-kinasebeta-dependent NF-kappaB activation provides radioprotection to the intestinal epithelium, Proc Natl Acad Sci U S A, 101 (2004) 2452-2457.

[191] V. Tergaonkar, M. Pando, O. Vafa, G. Wahl, I. Verma, p53 stabilization is decreased upon NFkappaB activation: a role for NFkappaB in acquisition of resistance to chemotherapy, Cancer Cell, 1 (2002) 493-503.

[192] M.B. Kastan, Q. Zhan, W.S. el-Deiry, F. Carrier, T. Jacks, W.V. Walsh, B.S. Plunkett, B. Vogelstein, A.J. Fornace, Jr., A mammalian cell cycle checkpoint pathway utilizing p53 and GADD45 is defective in ataxia-telangiectasia, Cell, 71 (1992) 587-597.

[193] L.R. Livingstone, A. White, J. Sprouse, E. Livanos, T. Jacks, T.D. Tlsty, Altered cell cycle arrest and gene amplification potential accompany loss of wild-type p53, Cell, 70 (1992) 923-935.

[194] Y. Yin, M.A. Tainsky, F.Z. Bischoff, L.C. Strong, G.M. Wahl, Wild-type p53 restores cell cycle control and inhibits gene amplification in cells with mutant p53 alleles, Cell, 70 (1992) 937-948.

[195] M.B. Kastan, S.J. Kuerbitz, Control of G1 arrest after DNA damage, Environmental health perspectives, 101 (1993) 55-58.

[196] S.Y. Park, S.M. Lee, S.K. Ye, S.H. Yoon, M.H. Chung, J. Choi, Benzo[a]pyrene-induced DNA damage and p53 modulation in human hepatoma HepG2 cells for the identification of potential biomarkers for PAH monitoring and risk assessment, Toxicol Lett, 167 (2006) 27-33.

[197] M. Ramet, K. Castren, K. Jarvinen, K. Pekkala, T. Turpeenniemi-Hujanen, Y. Soini, P. Paakko, K. Vahakangas, p53 protein expression is correlated with benzo[a]pyrene-DNA adducts in carcinoma cell lines, Carcinogenesis, 16 (1995) 2117-2124.

[198] R.W. Godschalk, J.U. Ostertag, A.M. Zandsteeg, B. Van Agen, H.A. Neuman, H. Van Straaten, F.J. Van Schooten, Impact of GSTM1 on aromatic-DNA adducts and p53 accumulation in human skin and lymphocytes, Pharmacogenetics, 11 (2001) 537-543.

[199] M.F. Denissenko, A. Pao, M.-s. Tang, G.P. Pfeifer, Preferential Formation of Benzo[a]pyrene Adducts at Lung Cancer Mutational Hotspots in P53, Science, 274 (1996) 430-432.

[200] K. Gammon, Inflammation: A complex problem, Nature, 502 (2013) S86-S87.

[201] V.M. Arlt, M. Stiborova, C.J. Henderson, M. Thiemann, E. Frei, D. Aimova, R. Singh, G. Gamboa da Costa, O.J. Schmitz, P.B. Farmer, C.R. Wolf, D.H. Phillips, Metabolic activation of benzo[a]pyrene in vitro by hepatic cytochrome P450 contrasts with detoxification in vivo: experiments with hepatic cytochrome P450 reductase null mice, Carcinogenesis, 29 (2008) 656-665. 


Chapter 8

Summary and general discussion 
On basis of epidemiological observations it is widely accepted that combined presence of inflammation together with exposure to chemical carcinogens leads to a more than additional increasing risk of cancer. However, the molecular and cellular mechanisms mediating this relationship remain unresolved. Therefore, the main objective of the present thesis was to investigate the underlying mechanisms of how inflammatory factors can alter the metabolism of chemical carcinogens and subsequent formation of DNA damage. The well known environmental mutagen benzo[a]pyrene was used as a model compound in the studies described in this thesis.

\section{Chapter 2: Inflammation-associated extracellular $\beta$-glucuronidase alters cellular responses to the chemical carcinogen benzo[a]pyrene}

The aim of this study was to show the effect of $\beta$-glucuronidase on $\mathrm{B}[\mathrm{a}] \mathrm{P}$ induced genotoxicity in in vitro cultured cells and to identify possible underlying mechanisms.

\subsection{Main findings}

$\beta$-glucuronidase is an enzyme released by neutrophils during inflammation. Our original hypothesis proposed that $\beta$-glucuronidase could re-activate detoxified $\mathrm{B}[\mathrm{a}] \mathrm{P}$ metabolites via hydrolysis of glucuronide conjugates. Hence, the presence of $\beta$-glucuronidase will increase the level of $\mathrm{B}[\mathrm{a}] \mathrm{P}$ metabolites and may ultimately result in higher $\mathrm{B}[\mathrm{a}] \mathrm{P}-\mathrm{DNA}$ adduct formation. However, after co-incubation of liver and lung cells with $\beta$-glucuronidase and $\mathrm{B}[\mathrm{a}] \mathrm{P}$, we initially observed a significantly lower level of the pre-carcinogenic metabolite $\mathrm{B}[\mathrm{a}] \mathrm{P}-7,8-$ dihydrodiol, as well as CYP1A1 expression in comparison with $\mathrm{B}[\mathrm{a}] \mathrm{P}$ only. In contrast, at a later time point $(\mathrm{t}=24 \mathrm{~h})$, the presence of $\beta$-glucuronidase indeed significantly enhanced $\mathrm{B}[\mathrm{a}] \mathrm{P}-7,8$-dihydrodiol levels, CYP1A1 expression, and $\mathrm{B}[\mathrm{a}] \mathrm{P}-\mathrm{DNA}$ adduct levels. Interestingly, the concentration of unmetabolized $\mathrm{B}[\mathrm{a}] \mathrm{P}$ remained higher for a longer period of time by addition of $\beta$-glucuronidase to the $\mathrm{B}[\mathrm{a}] \mathrm{P}$ treatment.

\subsection{Discussion}

Based on these observations, we proposed and verified several possible modes of action. Firstly, there is a possibility that $\beta$-glucuronidase prevents $\mathrm{B}[\mathrm{a}] \mathrm{P}$ from entering cells because it could bind with the parent compound, because $\beta$-glucuronidase is a large protein which contains multiple binding sites for various different substrates [1]. Hence, when $\beta$-glucuronidase is released at the site of inflammation, $\mathrm{B}[\mathrm{a}] \mathrm{P}$ might bind to $\beta$-glucuronidase and consequently results in a slower rate of $\mathrm{B}[\mathrm{a}] \mathrm{P}$ entering into cells. Indeed, a high concentrations of $\mathrm{B}[\mathrm{a}] \mathrm{P}$ was able to reduce $\beta$-glucuronidase activity by approximately $20 \%$ (indicating an interaction between both). This $20 \%$ should however be considered as a minor effect and it is unlikely to be the cause of the significant inhibition of CYP1A1 expression and delayed $\mathrm{B}[\mathrm{a}] \mathrm{P}$ metabolism, because in the cell incubations $\mathrm{B}[\mathrm{a}] \mathrm{P}$ was added in $\sim 10$ fold excess when compared to the amount of $\beta$-glucuronidase. Secondly, it was investigated whether $\beta$-glucuronidase activity is needed for the inhibition of CYP1A1 expression at 6 hours. Therefore, we added the $\beta$-glucuronidase inhibitor D-saccharic acid 1,4-lactone monohydrate to the incubations with $\mathrm{B}[\mathrm{a}] \mathrm{P}$ and $\beta$-glucuronidase. However, the inhibition of $\beta$-glucuronidase activity did not change the down regulation of CYP1A1 expression by $\beta$-glucuronidase. Since the inhibitory effect on $C Y P 1 A 1$ expression was activity independent, it was studied whether blocking the cellular binding site of $\beta$-glucuronidase (i.e., insulin-like growth factor 2 receptor (IGF2R)) by mannose-6-phosphate could explain the down regulation of 176 
CYP1A1 expression. High concentrations of mannose-6-phosphate competitively inhibit $\beta$-glucuronidase binding to IGF2R. This time, the $\beta$-glucuronidase induced inhibition of $\beta$-glucuronidase was abolished. Therefore, we suggested a connection between IGF2R as receptor of extracellular $\beta$-glucuronidase and intracellular AhR-signalling after $\mathrm{B}[\mathrm{a}] \mathrm{P}$ exposure. It should be mentioned that this connection between IGF2R and AhR signaling could be mediated by transforming growth factor $\beta$ (TGF- $\beta$ ), because binding of ligands to IGF2R activates TGF- $\beta$, which suppresses AhR-mediated gene expression including the expression of CYP1A1 [2, 3]. Unfortunately, assessment of TGF- $\beta$ activity was not included in current work and needs further investigation and confirmation in the future. One more remark that needs to be made is that all experiments in Chapter 2 were conducted at $\mathrm{pH} 5.5$, because $\beta$-glucuronidase activity has a $\mathrm{pH}$ optimum at $\mathrm{pH}<6$. Therefore, the effect of lowered pH was further investigated as described in Chapter 3.

\subsection{Implications}

It is known that $\mathrm{B}[\mathrm{a}] \mathrm{P}$ metabolites can be detoxified via UDP-glucuronosyltransferase (UGT) and $\beta$-glucuronidase at sites of inflammation could cleave the conjugated $\mathrm{B}[\mathrm{a}] \mathrm{P}$ metabolites by which reactive metabolites are re-activated. We confirm in chapter 2 , for the first time, that $\beta$-glucuronidase indeed hydrolysis glucuronidated $\mathrm{B}[\mathrm{a}] \mathrm{P}$ metabolites. In addition, the current study also indicated another pathway in which $\beta$-glucuronidase enhanced $\mathrm{B}[\mathrm{a}] \mathrm{P}$ induced DNA damage by interacting with the IGF2R. Whether $\beta$-glucuronidase or IGFR2 can serve as possible targets for preventing the increased cancer risk in subjects with inflammatory diseases needs further investigation. Moreover, these findings might also be applicable to other chemicals which are known to be conjugated via UGT.

\section{Chapter 3: Acidic cellular microenvironment modifies carcinogen-induced DNA damage and repair.}

An acidic microenvironment is very common at the site of inflammation. The reason for this acidic microenvironment is primarily the secretion of lactate from anaerobic glycolysis and some other acidic metabolites released during inflammatory reactions (e.g. HOCl). Since the majority of studies on the genotoxicity of $\mathrm{B}[\mathrm{a}] \mathrm{P}$ have been performed under neutral conditions (i.e. $\mathrm{pH}$ 7.4-7.8), it was investigated how $\mathrm{B}[\mathrm{a}] \mathrm{P}$ is metabolized under acidic conditions. The role of acidity in biotransformation processes is currently poorly understood.

\subsection{Main findings}

In Chapter 3, we co-incubated A549 and BEAS-2B cells with B[a]P in media with different extracellular $\mathrm{pH}$ conditions (i.e. $\mathrm{pH}_{\mathrm{e}} 7.8,7,6.5,6$ and 5.5). We observed a $\mathrm{pH}$ dependent decrease of CYP1A1 and CYP1B1 gene expression, EROD activity, $\mathrm{B}[\mathrm{a}] \mathrm{P}-7,8-$ dihydrodiol levels, nucleotide excision repair (NER) capacity, B[a]P-DNA adduct levels and other types of DNA damage $(\gamma$-H2AX foci) at $t=6 \mathrm{~h}$ after the initiation of exposure. At later time points up to 48 hours, when the $\mathrm{pH}$ recovers to near neutral levels, the trend was reversed and a $\mathrm{pH}$ dependent increase was observed, except for NER capacity. In addition, the changes in intracellular $\mathrm{pH}\left(\mathrm{pH}_{\mathrm{i}}\right)$ and extracellular $\mathrm{pH}\left(\mathrm{pH}_{\mathrm{e}}\right)$ were examined, and a time dependent increased $\mathrm{pH}$ (restoration towards neutral conditions ( $\mathrm{pH}$ 7.4-7.8)) was found. We concluded that acidic $\mathrm{pH}$ inhibits CYP1A1 gene expression and enzyme activity, leading to lower $\mathrm{B}[\mathrm{a}] \mathrm{P}$ metabolism. However, when the $\mathrm{pH}_{\mathrm{e}}$ and $\mathrm{pH}_{\mathrm{i}}$ restored, CYP1A1 expression and enzyme activity also recovered. 
Consequently, more $\mathrm{B}[\mathrm{a}] \mathrm{P}-7,8$-dihydrodiol and $\mathrm{B}[\mathrm{a}] \mathrm{P}$ induced DNA adducts were seen in the acidic $\mathrm{pH}$ samples. Although cells try to compensate by increasing repair activity (after the pH is restored), it could not prevent DNA adduct accumulation.

\subsection{Discussion}

We could explain the altered cellular response to genotoxins by acidic $\mathrm{pH}$ by assuming that at low pH enzyme activity is inhibited. However, some enzymes may actually have a higher activity at slightly decreased $\mathrm{pH}$, dependent on their $\mathrm{pH}$ optimum. Moreover, there are many other factors that can be affected by acidic $\mathrm{pH}$, which may contribute to lowered $\mathrm{B}[\mathrm{a}] \mathrm{P}$ metabolism which need to be verified in the future. For example, lowering intracellular $\mathrm{pH}$ can activate certain inflammation related pathways and its downstream targets, including activator protein 1 (AP-1), MAPK/ERK, nuclear factor kappa-light-chain-enhancer of activated B cells (NF- $\mathrm{kB}$ ) pathways, as well as tumor necrosis factor $\alpha(\mathrm{TNF}-\alpha)$, extracellular signal-regulated kinases (ERK1/2), isoforms of nitric oxide synthase (iNOS), and p38 [4-6]. In addition, the acidic pH microenvironment causes hypoxia like reactions, oxidative stress and ROS formation. All these phenomena added up makes the interpretation of the results observed from our current study more complicated to explain from a mechanistic point of view [4, 6-8].

\subsection{Implications}

The majority of studies that investigate the genotoxic effects of $\mathrm{B}[\mathrm{a}] \mathrm{P}$ in vitro, were performed under near to neutral conditions (i.e. $\mathrm{pH}$ 7.4-7.8). However, during inflammation, the $\mathrm{pH}$ at the site of inflammation may vary from 7.2 to 5.5 , and this acidic microenvironment might alter the metabolic pattern of chemicals. Therefore, in this chapter, we demonstrated how $\mathrm{B}[\mathrm{a}] \mathrm{P}$ is metabolized under lowered $\mathrm{pH}$ conditions, and how $\mathrm{pH}$ influences $\mathrm{B}[\mathrm{a}] \mathrm{P}$ induced genotoxicity in more detail. This including changes in the intra- and extra-cellular $\mathrm{pH}$, gene expression and enzyme activity of CYP1A1 which is critical for metabolizing $\mathrm{B}[\mathrm{a}] \mathrm{P}$, and $\mathrm{B}[\mathrm{a}] \mathrm{P}$ induced DNA damage and repair. These findings might give further clues to explain some previous findings of inflammation induced cellular effects. For example, we previously observed an inhibition of DNA repair by hypochlorous acid $(\mathrm{HOCl})$, which is generated during inflammation, and we now propose that the observed inhibitory effect on DNA repair can also be caused by acidic $\mathrm{pH}$. It is unclear at this moment whether restoring the lowered $\mathrm{pH}$ to more neutral conditions would be a good intervention to prevent genotoxic effects in subjects with inflammatory diseases, because a low $\mathrm{pH}$ is also required for an adequate immune response against potential 'invaders'. In addition, this chapter also included a summary table that describes the relationship between each measured parameter (e.g. gene expression, CYP1A1 enzyme activity, DNA damage, DNA repair etc.), which might provide the starting parameters that are needed for in silico computer modelling.

\section{Chapter 4: Effect of interleukin (IL)-8 on benzo[a]pyrene metabolism and DNA damage in human lung epithelial cells.}

Interleukin-8 (IL-8) is an essential chemoattractant cytokine found in a variety of tissues and blood which attracts and activates neutrophils in inflammatory regions [9]. However, there is currently little knowledge on how IL-8 can affect B[a]P induced genotoxicity. Therefore, in Chapter 4, we investigated the effect of IL-8 on B[a]P metabolism in BEAS-2B cells and describe a possible underlying mechanism. 


\subsection{Main findings}

After culturing BEAS-2B cells with IL-8 and B[a]P for 6 hours, there is no difference between the two treatments regarding genotoxic endpoints. But at $t=24 \mathrm{~h}$, we observed a significantly increased level of $C Y P 1 A 1, C Y P 1 B 1$ gene expression, EROD activity and

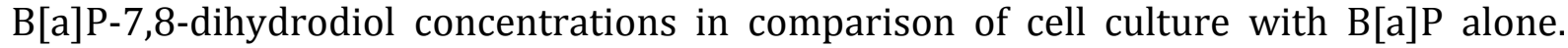
Moreover, the unmetabolized $\mathrm{B}[\mathrm{a}] \mathrm{P}$ concentration remains higher in IL-8 samples at all timepoints than in samples that were not treated with IL-8. Overall, there is no difference in $\mathrm{B}[\mathrm{a}] \mathrm{P}-\mathrm{DNA}$ adducts level between the samples of different treatment conditions.

\subsection{Discussion}

In theory, IL-8 could both activate as well as inhibit certain pathways that are important for $\mathrm{B}[\mathrm{a}] \mathrm{P}$ metabolism. For instance, IL-8 is known to induce a respiratory burst and it increases oxidative stress because it activates nicotinamide adenine dinucleotide phosphate (NADPH) oxidases (Noxes) [10]. Because IL-8 could activate various Noxes, we hypothesized that stimulation by IL-8 reduced the intracellular NADPH level which inhibits CYP1A1 activity since CYP1A1 is a NADPH dependent enzyme. Consequently, less $\mathrm{B}[\mathrm{a}] \mathrm{P}-7,8$-dihydrodiol is produced and less $\mathrm{B}[\mathrm{a}] \mathrm{P}$ is metabolized. This delayed $\mathrm{B}[\mathrm{a}] \mathrm{P}$ metabolism, which is similar to the effect seen after $\beta$-glucuronidase and acidic $\mathrm{pH}$, will continue to trigger $C Y P 1 A 1 / C Y P 1 B 1$ gene expression, therefore resulting in a higher CYP1A1, CYP1B1 gene expression, EROD activity, B[a]P-7,8-dihydrodiol concentration and $\mathrm{B}[\mathrm{a}] \mathrm{P}$ induced DNA adducts at later timepoints (i.e. $\mathrm{t}=24$ and $48 \mathrm{~h}$ ). In order to confirm this, we measured the intracellular NADPH level and performed EROD assays with and without addition of NADPH. Indeed, IL-8 lowered the intracellular NADPH level. Although EROD enzyme activity was higher after addition of extra NADPH to the reaction mix, it appeared not to be the rate limiting factor for the effect of IL-8 on $\mathrm{B}[\mathrm{a}] \mathrm{P}$ metabolism. After that, we blocked Nox activity by adding the general Nox inhibitor (DPI), because IL8 is known to activate these type of enzymes. Interestingly, the IL-8 effect was abolished which indicated that the downstream effects of IL8 on B[a]P metabolism is mediated via Noxes. Therefore, we further investigate the effects of Noxes after IL-8 exposure. It has been reported that IL-8 can enhanced oxidative stress via generating ROS, which could subsequently deplete intracellular GSH level, and GSH is important for phase II detoxification of reactive $\mathrm{B}[\mathrm{a}] \mathrm{P}$ metabolites. Indeed, we observed a significant decreased level of GSH after IL-8 treatment or with IL-8 combined with $\mathrm{B}[\mathrm{a}] \mathrm{P}$. Moreover, the GSSG level significantly increased only in the combination treatment (IL-8 and $\mathrm{B}[\mathrm{a}] \mathrm{P}$ ). All these observations provide evidence that GSH plays a central role in the IL-8 induced delayed $\mathrm{B}[\mathrm{a}] \mathrm{P}$ metabolism. Hence, BSO, which is a glutathione synthesis inhibitor, was used to validate our hypothesis. Indeed, after depletion of GSH by BSO, B[a]P metabolism is similarly delayed as observed after exposure to IL-8. As a result, higher concentrations of unmetabolized $\mathrm{B}[\mathrm{a}] \mathrm{P}$ and

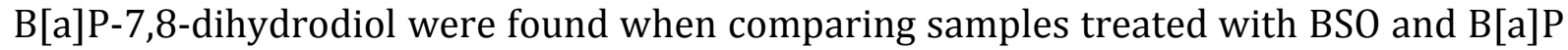
with samples only treated with $\mathrm{B}[\mathrm{a}] \mathrm{P}$. Despite the higher concentrations of pre-mutagenic $\mathrm{B}[\mathrm{a}] \mathrm{P}$ metabolites, no increased levels of $\mathrm{B}[\mathrm{a}] \mathrm{P}$ related $\mathrm{DNA}$ adducts were observed. In order to answer this discrepancy, we examined NER capacity, which is the main mechanism for repairing $\mathrm{B}[\mathrm{a}] \mathrm{P}$ induced DNA damage. A previous study indeed showed that the depletion of GSH could enhance NER capacity [11]. As we hypothesized, IL-8 showed a 3-fold induction of NER activity after 24 hours stimulation. 


\subsection{Implications}

IL-8 is another important inflammatory mediator that can increase the genotoxicity of chemicals. In this study, we demonstrated that IL-8 acts on B[a]P metabolism, which could further clarify the role of IL-8 in the combined effect of inflammation and $\mathrm{B}[\mathrm{a}] \mathrm{P}$ on cancer risk, but is also illustrative for the complexity of this relationship, because IL8 acted not only on B[a]P metabolism but also the cellular defense against oxidative stress, and DNA repair. Still, depletion of GSH seemed to play a central role, and therefore, it may be beneficial to restore GSH pool in people with chronic inflammatory diseases. This could be achieved by N-acetylcysteine (NAC), a GSH precursor. Although NAC is not considered successful in the treatment of COPD, patient may still benefit on the long run by preventing malignant diseases.

\section{Chapter 5: Pulmonary Inflammation Impacts on CYP1A1-Mediated Respiratory Tract DNA Damage Induced by the Carcinogenic Air Pollutant Benzo[a]pyrene.}

In order to further confirm and compare the observations in previous in vitro studies, an in vivo mouse model was used and investigated in Chapter 5.

\subsection{Main findings}

After exposing mice intra-nasally to LPS and subsequently to intra-tracheally instilled $\mathrm{B}[\mathrm{a}] \mathrm{P}$, several phenotypic endpoints were examined in lung tissue and bronchoalveolar lavage fluid (BAL fluid), including histopathology of pulmonary inflammation, enzyme activities (e.g. Cyp1a, Nqo1, and $\beta$-glucuronidase), repair capacity, and the formation of DNA adducts. After the inflammatory trigger, larger amounts of inflammatory cells (mainly monocytes) were found in mouse lung, even in combination with $\mathrm{B}[\mathrm{a}] \mathrm{P}$ (LPS\&B[a]P), when compared to control. $\beta$-glucuronidase activity was also increased in $\mathrm{BAL}$, indicative for the presence and activation of inflammatory cells. However, a lower level of Cyp1a and Nqo1 enzyme activity was observed in the LPS\&B[a]P exposed mice than in mice treated with $\mathrm{B}[\mathrm{a}] \mathrm{P}$ alone. Although there is a lower level of Cyp1a enzyme activity in the LPS\&B[a]P group, the $\mathrm{B}[\mathrm{a}] \mathrm{P}$ induced DNA adduct levels were significantly higher by the simultaneous exposure to $\mathrm{B}[\mathrm{a}] \mathrm{P}$ and inflammation. There were no differences in CYP1B1 activity and NER capacity. Thus, it was concluded that the decrease of CYP1A1 activity in the lungs of LPS\&B[a]P treated mice results in a decrease of $\mathrm{B}[\mathrm{a}] \mathrm{P}$ detoxification, consequently leading to an increasing in $\mathrm{B}[\mathrm{a}] \mathrm{P}-\mathrm{DNA}$ adduct formation in the lung.

\subsection{Discussions}

Interestingly, the inhibition of Cyp1a1 was also observed in our previous in vitro studies ( $\beta$-glucuronidase or IL8 exposure and acidic microenvironment). The difference between in vivo and in vitro studies regarding the role of CYP1A1 activity and subsequent genotoxicity of $\mathrm{B}[\mathrm{a}] \mathrm{P}$ is still a matter of debate. In vitro, it was considered that CYP1A1 activity was indispensable for genotoxicity of $\mathrm{B}[\mathrm{a}] \mathrm{P}$, whereas in vivo studies seemed to point to the opposite; CYP1A1 is indispensable for the detoxification of $\mathrm{B}[\mathrm{a}] \mathrm{P}$ $[12,13]$. Therefore, it seems that mimicking inflammatory conditions in vitro, can reproduce the in vivo findings with more accuracy. More work should be done to understand the role of CYP1A1 on B[a]P induced genotoxicity and how inflammatory markers can affect that relationship. For a better understanding of the effect of LPS on 
$\mathrm{B}[\mathrm{a}] \mathrm{P}$ induced genotoxicity in mouse lungs, we applied microarray technology (next chapter), to find further leads for underlying mechanisms.

\subsection{Implications}

This study gave evidence that air pollution is health threatening in multiple ways; by inducing inflammation, and also by increasing the genotoxicity of chemicals that are simultaneously inhaled. It confirmed our in vitro experiments, and therefore it can be stated that for optimal prevention, both sides of the coin need to be addressed. Not only exposure should be limited but also inflammation (due to presence of disease or induced by the exposure) should be avoided as much as possible. In regulatory toxicology, the presence of inflammation is not at all taken into account. We show here, however, that the genotoxic potential of compounds might be higher in the presence of inflammation/inflammatory mediators. Therefore, a better view of reality may be obtained by choosing other test conditions such as combination of inflammation and chemical carcinogens.

\section{Chapter 6: Altered gene expression profiles in the lungs of benzo[a]pyrene-exposed mice in the presence of lipopolysaccharide-induced pulmonary inflammation}

To gain more insight into the mechanism of how LPS influences B[a]P induced genotoxicity in the lungs of mice, RNA microarray technology was applied in Chapter 6.

\subsection{Main findings}

By performing a dedicated analysis of genes that are known to be involved in the cellular response to $\mathrm{B}[\mathrm{a}] \mathrm{P}$, we confirmed the phenotypic observations as described in the previous Chapter 5. For instance, a down-regulation of Cyp1a1 $(\mathrm{p}<0.05)$ and Nqo1 $(\mathrm{p}=0.088)$, an up-regulation of Gusb ( $\beta$-glucuronidase, $\mathrm{p}=0.075)$, and no significant differences in Cyp1b1 were shown in comparing lungs of mice exposed to LPS\&B[a]P with lungs of mice that were exposed to $\mathrm{B}[\mathrm{a}] \mathrm{P}$ alone. Besides that, many other genes related to phase I and II metabolism of B[a]P were significantly inhibited after exposure to LPS, including Ephx1, Arnt, Cbr1, Por, Nqo2 and Comt, as well as Sult1a1, Gstp1, Gstm1, Gstt1 and Gpx3. Despite the fact that we did not observe a difference in NER capacity, a few NER related genes were significantly up- (i.e. Xpa) and down-regulated (i.e. Ddb1). Moreover, we applied a principal component analysis (PCA) analysis in order to identify the interrelationship among each exposure (i.e. Control, B[a]P, LPS and LPS\&B[a]P) and genes that were able to separate the different exposure conditions were predominantly related to immune-response. This immune-response dependent separation of all exposure conditions is a further confirmation that $\mathrm{B}[\mathrm{a}] \mathrm{P}$ alone can already induce an inflammatory responses, and is also an indication that inflammation may play an underestimated role in $\mathrm{B}[\mathrm{a}] \mathrm{P}$ induced genotoxicity and possibly carcinogenicity. Finally, we also performed a global analysis based on the differentially expressed genes (DEGs) and a high percentage of the genes that were differentially regulated by $\mathrm{B}[\mathrm{a}] \mathrm{P}$, were inhibited by LPS. For example, cell-cell adhesion, cell-cell communication, RNA translation and ribosome related processes were altered in such a way. This may indicate that pathways/cellular events to recover from the $\mathrm{B}[\mathrm{a}] \mathrm{P}$ exposure may be postponed by additional induction of inflammation by LPS. 


\subsection{Discussions}

We confirmed in vivo our hypothesis that LPS, by counteracting some of the $\mathrm{B}[\mathrm{a}] \mathrm{P}$ transcriptomic changes, is actually prolonging the time window of $\mathrm{B}[\mathrm{a}] \mathrm{P}$ action and actually increased its overall genotoxic potential. However, there are some limitations of the study, which need to be addressed. For instance, CYP1a1 gene expression and CYP1a1 protein activity is usually induced by $\mathrm{B}[\mathrm{a}] \mathrm{P}$, but this was not found in the current study. This might be due to the selection of a single time point (48 hours) for both measurements; Cyp1a1 gene expression is an early event, whereas protein expressions can be considered as a later event but enzyme activity additionally relies on posttranslational protein modifications. For instance, CYP activity can be inhibited by ROS, which is produced in excess by additional exposure to LPS, which may provide one explanation for the discrepancy between protein levels and enzyme activity, which do not correlate. 48 hours may thus be too late for assessing very early $\mathrm{B}[\mathrm{a}] \mathrm{P}$ metabolic events, but in our previous studies in which we exposed rodents to $\mathrm{B}[\mathrm{a}] \mathrm{P}$, highest DNA adduct levels were always found at approximately 2 days after the exposure (Chapter 5). Therefore, to investigate cellular effects at the highest level of DNA damage, 48 hours was chosen as the exposure time point.

\subsection{Implications}

This study is the continuation of the study in Chapter 5 and aimed at obtaining more insight in additional underlying mechanisms for further research. The general concept that the presence of inflammation can inhibit the initial metabolism of B[a]P by phase I and II metabolism was confirmed at the level of gene transcription. New leads for future research could aim on cell-cell communication and cell adhesion. All data that were obtained in this study are shared and publicly available online for other researchers, who could benefit from our findings in explaining their in vivo findings with other genotoxic chemicals.

\section{Concluding remarks and future perspective}

The present thesis focused on the effect of inflammation on $\mathrm{B}[\mathrm{a}] \mathrm{P}$ metabolism and $\mathrm{B}$ [a]P-DNA adduct formation in vitro and in vivo. Currently, there is accumulating evidences that chronic inflammation contributes to the genotoxicity and carcinogenicity of chemical carcinogens, ultimately leading to cancer. However, due to the complex underlying network, there are only few studies that have investigated how inflammation contributes to the chemically induced carcinogenesis. Moreover, contradicting results between in vitro and in vivo studies even made this big puzzle more difficult to solve. In order to fill this knowledge gap, we systematically performed several in vitro and in vivo studies. So far, the results from our studies support the hypothesis that inflammation delays the metabolism of $\mathrm{B}[\mathrm{a}] \mathrm{P}$ and this leads to a prolonged exposure of cells to the parent compound $\mathrm{B}[\mathrm{a}] \mathrm{P}$. Consequently, higher $\mathrm{B}[\mathrm{a}] \mathrm{P}-\mathrm{DNA}$ adduct levels are formed which theoretically increase the risk for developing cancer. However, the more we study inflammation, the more we know its complexity, with many cytokines and pathways that are triggered and their crosstalk with each other and with other cellular processes. In addition, in the current thesis, only three inflammatory factors were studied in more detail for their effect on $\mathrm{B}[\mathrm{a}] \mathrm{P}$, and there are other inflammatory factors that remain to be investigated. On top of that, most of the studies that investigated the link between inflammation and chemical carcinogens were conducted based on a single variable, 
including TNF- $\alpha$, IL-6, IL-1 $\beta$, hypoxia, oxidative stress and MPO, whereas the mixture of inflammatory mediators and the resulting microenvironment should be taken into account as a whole. Therefore, further research is needed.

An important observation in the current thesis is that in vitro studies should be performed in a time-dependent manner. Many in vitro studies on $\mathrm{B}$ [a]P were conducted at a single time point (most of the time 24 hours incubations), this might result in drawing misleading conclusions. For example, some inflammatory factors could inhibit CYPs at early time points, which leads to an induction of CYPs at later time points, because unmetabolized $\mathrm{B}[\mathrm{a}] \mathrm{P}$ keeps triggering the AhR-receptor.

In conclusion, the results presented in this thesis demonstrate the impact of various inflammatory factors on the genotoxicity of $\mathrm{B}[\mathrm{a}] \mathrm{P}$. We provide mechanistic information on how inflammatory factors can make humans more susceptible to carcinogen exposure. It may also open doors for new preventive measures to lower cancer incidences in patients with chronic inflammatory diseases; a combination of anti-inflammatory approaches and reducing exposure to genotoxic chemicals is required. Furthermore, the application of state-of-the-art techniques in molecular approaches and animal models of inflammation-derived cancers could further help to elucidate this intriguing puzzle. 


\section{References}

[1] K. Sasaki, F. Taura, Y. Shoyama, S. Morimoto, Molecular characterization of a novel beta-glucuronidase from Scutellaria baicalensis georgi, J Biol Chem, 275 (2000) 27466-27472.

[2] A. Starsichova, E. Hruba, E. Slabakova, Z. Pernicova, J. Prochazkova, K. Pencikova, V. Seda, M. Kabatkova, J. Vondracek, A. Kozubik, M. Machala, K. Soucek, TGF-beta1 signaling plays a dominant role in the crosstalk between TGF-beta1 and the aryl hydrocarbon receptor ligand in prostate epithelial cells, Cell Signal, 24 (2012) 1665-1676.

[3] A. Gemma, Y. Hosoya, K. Uematsu, M. Seike, F. Kurimoto, A. Yoshimura, M. Shibuya, S. Kudoh, Mutation analysis of the gene encoding the human mannose 6-phosphate/insulin-like growth factor 2 receptor (M6P/IGF2R) in human cell lines resistant to growth inhibition by transforming growth factor beta(1) (TGF-beta(1)), Lung Cancer, 30 (2000) 91-98.

[4] Y. Kato, S. Ozawa, C. Miyamoto, Y. Maehata, A. Suzuki, T. Maeda, Y. Baba, Acidic extracellular microenvironment and cancer, Cancer Cell Int, 13 (2013) 89.

[5] A. Bellocq, S. Suberville, C. Philippe, F. Bertrand, J. Perez, B. Fouqueray, G. Cherqui, L. Baud, Low environmental pH is responsible for the induction of nitric-oxide synthase in macrophages. Evidence for involvement of nuclear factor-kappaB activation, J Biol Chem, 273 (1998) 5086-5092.

[6] A. Riemann, B. Schneider, A. Ihling, M. Nowak, C. Sauvant, O. Thews, M. Gekle, Acidic environment leads to ROS-induced MAPK signaling in cancer cells, PLoS One, 6 (2011) e22445.

[7] J. Chiche, M.C. Brahimi-Horn, J. Pouyssegur, Tumour hypoxia induces a metabolic shift causing acidosis: a common feature in cancer, J Cell Mol Med, 14 (2010) 771-794.

[8] L.M. Maurer, E. Yohannes, S.S. Bondurant, M. Radmacher, J.L. Slonczewski, pH regulates genes for flagellar motility, catabolism, and oxidative stress in Escherichia coli K-12, J Bacteriol, 187 (2005) 304-319.

[9] M. Bickel, The role of interleukin-8 in inflammation and mechanisms of regulation, J Periodontol, 64 (1993) 456-460.

[10] Q. Shi, A.W. Boots, L. Maas, C. Veith, K. van Kuijk, G.R. Haenen, R.W. Godschalk, F.J. Van Schooten, Effect of interleukin (IL)-8 on benzo[a]pyrene metabolism and DNA damage in human lung epithelial cells, Toxicology, 381 (2017) 64-74.

[11] S.A. Langie, A.M. Knaapen, J.M. Houben, F.C. van Kempen, J.P. de Hoon, R.W. Gottschalk, R.W. Godschalk, F.J. van Schooten, The role of glutathione in the regulation of nucleotide excision repair during oxidative stress, Toxicol Lett, 168 (2007) 302-309.

[12] V.M. Arlt, M. Stiborova, C.J. Henderson, M. Thiemann, E. Frei, D. Aimova, R. Singh, G. Gamboa da Costa, O.J. Schmitz, P.B. Farmer, C.R. Wolf, D.H. Phillips, Metabolic activation of benzo[a]pyrene in vitro by hepatic cytochrome P450 contrasts with detoxification in vivo: experiments with hepatic cytochrome P450 reductase null mice, Carcinogenesis, 29 (2008) 656-665.

[13] D.W. Nebert, Z. Shi, M. Galvez-Peralta, S. Uno, N. Dragin, Oral benzo[a]pyrene: understanding pharmacokinetics, detoxication, and consequences--Cyp1 knockout mouse lines as a paradigm, Molecular pharmacology, 84 (2013) 304-313. 


Hoofdstuk 8

Samenvatting en algemene discussie 
Op basis van epidemiologische waarnemingen wordt het over het algemeen vanuit gegaan dat de aanwezigheid van ontsteking, in combinatie met de blootstelling aan carcinogene stoffen, leidt tot een toegenomen risico op kanker. Het hoofddoel van dit proefschrift was daarom om de onderliggende mechanismen van hoe ontstekingsfactoren het metabolisme van carcinogene stoffen en de daaropvolgende vorming van DNA schade kunnen veranderen. De bekende mutagene stof benzo[a]pyreen is gebruikt als modelverbinding in de studies die beschreven staan in dit proefschrift.

\section{Hoofdstuk 2: Ontstekings-geassocieerde extracellulair $\beta$-glucuronidase verandert cellulaire reacties op de carcinogene stof benzo[a]pyreen}

Het doel van deze studie was om het effect van $\beta$-glucuronidase op B[a]P geinduceerde genotoxiciteit in in vitro gekweekte cellen aan te tonen en mogelijke onderliggende mechanismen te identificeren.

\subsection{Voornaamste bevindingen}

$\beta$-glucuronidase is een enzym dat wordt vrijgelaten door neutrofielen gedurende ontsteking. Onze oorspronkelijke hypothese stelde dat $\beta$-glucuronidase gedetoxificeerde $\mathrm{B}[\mathrm{a}] \mathrm{P}$ metabolieten opnieuw zou kunnen activeren door de hydrolyse van glucuronide conjugaten. Daarom zal de aanwezigheid van $\beta$-glucuronidase het niveau van de $\mathrm{B}[\mathrm{a}] \mathrm{P}$ metabolieten verhogen en kan dit uiteindelijk resulteren in een toegenomen vorming van $\mathrm{B}[\mathrm{a}] \mathrm{P}$-DNA adducten. Echter, na co-incubatie van $\beta$-glucuronidase en $\mathrm{B}[\mathrm{a}] \mathrm{P}$ in leveren longcellen bleek er een significant lager niveau van de pre-carcinogene metaboliet

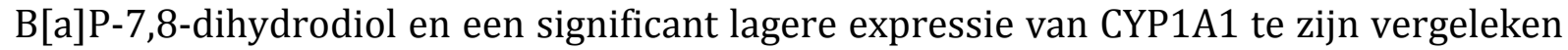
met de cellen blootgesteld aan alleen $\mathrm{B}[\mathrm{a}] \mathrm{P}$. In tegenstelling, de aanwezigheid van $\beta$-glucuronidase verhoogde inderdaad de $\mathrm{B}[\mathrm{a}] \mathrm{P}-7,8$-dihydrodiol niveaus, de CYP1A1 expressie en de $\mathrm{B}[\mathrm{a}] \mathrm{P}-\mathrm{DNA}$ adduct levels op een later tijdstip $(\mathrm{t}=24 \mathrm{uur})$. Interessant genoeg bleef de concentratie van ongemetaboliseerd $\mathrm{B}[\mathrm{a}] \mathrm{P}$ hoger gedurende een langere periode door de toevoeging van $\beta$-glucuronidase aan de $\mathrm{B}[\mathrm{a}] \mathrm{P}$ behandeling.

\subsection{Discussie}

Op basis van deze bevindingen hebben we verschillende mogelijke werkwijzen voorgesteld en gecontroleerd. Ten eerste bestaat er de mogelijkheid dat $\beta$-glucuronidase voorkomt dat $\mathrm{B}[\mathrm{a}] \mathrm{P}$ de cellen in komt doordat het kan binden aan $\mathrm{B}[\mathrm{a}] \mathrm{P}$, aangezien $\beta$-glucuronidase een groot eiwit is dat meerdere bindingsplaatsen bevat voor veschillende substraten [1]. Wanneer $\beta$-glucuronidase op de plaats van de ontsteking vrijkomt, zou $\mathrm{B}[\mathrm{a}] \mathrm{P}$ dus kunnen binden aan $\beta$-glucuronidase wat derhalve resulteert in een langzamere snelheid van $\mathrm{B}[\mathrm{a}] \mathrm{P}$ opname in de cellen. Inderdaad, een hoge concentratie van $\mathrm{B}[\mathrm{a}] \mathrm{P}$ was in staat om de activiteit van $\beta$-glucuronidase te verminderen met ongeveer $20 \%$ (wat indiceert dat er een interactie is tussen beide). Deze $20 \%$ dient echter als een klein effect beschouwd te worden en het is onwaarschijnlijk dat dit de oorzaak is van de significante remming van CYP1A1 expressie en vertraagd $\mathrm{B}[\mathrm{a}] \mathrm{P}$ metabolisme, aangezien in de cel incubaties $\mathrm{B}[\mathrm{a}] \mathrm{P}$ werd toegevoegd in 10 -voudige overmaat vergeleken met de hoeveelheid van $\beta$-glucuronidase. Ten tweede werd er onderzocht of $\beta$-glucuronidase activiteit nodig is voor de remming van de expressie van CYP1A na 6 uur. Daarom hebben we de $\beta$-glucuronidase remmer D-saccharinezuur1,4-lactonemonohydraat toegevoegd aan de incubaties met B[a]P en glucuronidase. De remming van $\beta$-glucuronidase activiteit had echter geen effect op de 188 
downregulatie van CYP1A1 expressie door $\beta$-glucuronidase. Aangezien het remmend effect op de expressie van CYP1A1 onafhankelijk was van de activiteit, werd er onderzocht of het blokkeren van de cellulaire bindingsplaats van $\beta$-glucuronidase (dat wil zeggen de insulin-like growth factor 2 receptor (IGF2R)) door mannose-6-fosfaat de downregulatie van CYP1A1 expressie zou kunnen verklaren. Hoge concentraties van mannose-6-fosfaat remt de binding van $\beta$-glucuronidase aan de IGF2R op een competitieve manier. Deze keer werd de $\beta$-glucuronidase geinduceerde remming van $\beta$-glucuronidase opgeheven. Daarom suggereerden we dat er een verband is tussen IGF2R als receptor van $\beta$-glucuronidase en intracellulaire AhR-signalering na $\mathrm{B}[\mathrm{a}] \mathrm{P}$ blootstelling. Er dient te worden opgemerkt dat dit verband tussen IGR2R en AhR signalering kan worden gemedieerd door het omzetten van groeifactor $\beta$ (TGF-ß), omdat binding van liganden aan IGF2R TGF- $\beta$ activeert, die AhR-gemedieerde genexpressie, zoals de expressie van CYP1A1, onderdrukt $[2,3]$. De TGF- $\beta$ activiteit is helaas niet onderzocht in deze studie en dit zal dus in de toekomst verder onderzocht en bevestigd moeten worden. Een opmerking die gemaakt moet worden is dat alle experimenten in hoofdstuk 2 bij een $\mathrm{pH}$ van 5.5 werden uitgevoerd, omdat $\beta$-glucuronidase activiteit een $\mathrm{pH}$-optimum bij $\mathrm{pH}<6$ heeft. Daarom werd het effect van een lagere $\mathrm{pH}$ verder onderzocht zoals beschreven in hoofdstuk 3.

\subsection{Implicaties}

Het is bekend dat $\mathrm{B}[\mathrm{a}] \mathrm{P}$ metabolieten kunnen worden ontgift door UDP-glucuronosyltransferase (UGT) en dat op plekken van ontsteking $\beta$-glucuronidase de geconjugeerde $\mathrm{B}[\mathrm{a}] \mathrm{P}$ metabolieten kan spitsen waardoor de reactieve metabolieten worden geactiveerd. In hoofdstuk $\boldsymbol{2}$ bevestigen wij voor de eerste keer dat $\beta$-glucuronidase inderdaad glucuronideerde $\mathrm{B}[\mathrm{a}] \mathrm{P}$ metabolieten hydrolyseert. Daarnaast duiden de resultaten uit deze studie erop dat er nog een andere weg is, waarin $\beta$-glucuronidase $\mathrm{B}[\mathrm{a}] \mathrm{P}$ geinduceerde DNA schade verhoogde door de interactie met IGF2R. Of $\beta$-glucuronidase en IGFR2 als mogelijke doelen kunnen dienen om het verhoogde risico op kanker bij patiënten met ontstekingsziekten te voorkomen, moet nog verder worden onderzocht. Bovendien kunnen deze bevindingen ook van toepassing zijn op andere chemicaliën die door UGT geconjugeerd worden.

\section{Hoofdstuk 3: Zure cellulaire micro-omgeving verandert carcinogeen-geïnduceerde DNA schade en reparatie.}

Een zure micro-omgeving is heel gewoon op de plaats van een ontsteking. De reden voor deze zure micro-omgeving is voornamelijk de afscheiding van lactaat uit anaerobe glycolyse en enkele andere zure metabolieten die vrijkomen tijdens ontstekingsreacties (bijvoorbeeld $\mathrm{HOCl}$ ). Aangezien de meeste studies naar de genotoxiciteit van $\mathrm{B}[\mathrm{a}] \mathrm{P}$ onder neutrale condities zijn uitgevoerd (d.w.z. pH 7,4-7,8), werd in dit hoofdstuk onderzocht hoe $\mathrm{B}[\mathrm{a}] \mathrm{P}$ wordt gemetaboliseerd onder zure omstandigheden. De rol van zuurheid bij biotransformatieprocessen is momenteel nog niet goed begrepen.

\subsection{Voornaamste bevindingen}

In hoofdstuk 3 hebben we A549- en BEAS-2B-cellen geincubeerd met B[a]P in media met verschillende extracellulaire $\mathrm{pH}$-omstandigheden (dat wil zeggen $\mathrm{pH}_{\mathrm{e}}$ van 7.8, 7, 6.5, 6 en 5.5). We hebben een $\mathrm{pH}$-afhankelijke afname van CYP1A1- en CYP1B1-genexpressie, EROD-activiteit, B[a]P-7,8-dihydrodiol niveaus, nucleotide excisie reparatie (NER) capaciteit, B[a]P-DNA-adductniveaus en andere typen DNA schade ( $\gamma$-H2AX foci) 
waargenomen op $t=6$ uur na de aanvang van de blootstelling. Op latere tijdstippen tot 48 uur na begin van de blootstelling, wanneer de $\mathrm{pH}$ is teruggekomen naar bijna neutrale niveaus, werd de trend omgedraaid en werd een $\mathrm{pH}$-afhankelijke toename waargenomen, behalve in de NER-capaciteit. Daarnaast werden de veranderingen in intracellulaire $\mathrm{pH}(\mathrm{pHi})$ en extracellulaire $\mathrm{pH}(\mathrm{pHe})$ onderzocht en werd er een tijdsafhankelijke verhoging van de $\mathrm{pH}$ gevonden (herstel naar neutrale condities $(\mathrm{pH}$ 7,4-7,8)). Geconcludeerd kan worden dat een zure $\mathrm{pH}$ de CYP1A1-genexpressie en enzymactiviteit remt, wat leidt tot een verminderd $\mathrm{B}[\mathrm{a}] \mathrm{P}$ metabolisme. Echter, wanneer de $\mathrm{pHe}$ en $\mathrm{pHi}$ herstelden naar normale waardes, werden ook CYP1A1 expressie en enzymactiviteit hersteld. Bijgevolg werden meer $\mathrm{B}[\mathrm{a}] \mathrm{P}-7,8-d i h y d r o d i o l-~ e n ~ B[a] P$ geïnduceerde DNA-adducten gezien in de zure pH-monsters. Hoewel cellen dit proberen te compenseren door de reparatieactiviteit te verhogen (nadat de $\mathrm{pH}$ is hersteld), kan het DNA-adduct accumulatie echter niet voorkomen.

\subsection{Discussie}

De veranderde cellulaire respons op genotoxines door een zure $\mathrm{pH}$ kan verklaard worden door aan te nemen dat bij een lage $\mathrm{pH}$ de enzymactiviteit geremd wordt. Sommige enzymen kunnen echter daadwerkelijk een hogere activiteit hebben bij een licht verminderde $\mathrm{pH}$, afhankelijk van hun $\mathrm{pH}$-optimum. Bovendien zijn er vele andere factoren die beïnvloed kunnen worden door een zure $\mathrm{pH}$, welke kunnen bijdragen aan een verlaagd $\mathrm{B}[\mathrm{a}] \mathrm{P}$ metabolisme en welke in de toekomst moet worden geverifieerd. Het verlagen van de intracellulaire $\mathrm{pH}$ kan bijvoorbeeld bepaalde ontstekingsgerelateerde pathways en zijn downstream doelen activeren, met inbegrip van activator eiwit 1 (AP-1), MAPK / ERK, nucleaire factor kappa-light-chain-enhancer van geactiveerde B-cellen (NF-KB), alsook tumor necrosefactor $\alpha$ (TNF-a), extracellulaire signaal-gereguleerde kinasen (ERK1 / 2), isoformen van stikstofoxide-synthase (iNOS) en p38 [4-6]. Daarnaast veroorzaakt de zure pH-micro-omgeving hypoxie-achtige reacties, oxidatieve stress en ROS-vorming. Al deze verschijnselen opgeteld maken de interpretatie van de resultaten die in onze huidige studie worden waargenomen, ingewikkelder om vanuit mechanistisch oogpunt te kunnen verklaren [4, 6-8].

\subsection{Implicaties}

De meeste studies die de genotoxische effecten van $\mathrm{B}[\mathrm{a}] \mathrm{P}$ in vitro onderzoeken, werden onder (bijna) neutrale omstandigheden uitgevoerd (d.w.z. pH 7,4-7,8). Bij ontsteking kan de $\mathrm{pH}$ op de ontstekingsplaats echter variëren van 7,2 tot 5,5 en deze zure micro-omgeving kan het metabolische patroon van chemicaliën veranderen. Daarom hebben we in dit hoofdstuk aangetoond hoe $\mathrm{B}[\mathrm{a}] \mathrm{P}$ wordt gemetaboliseerd onder verlaagde $\mathrm{pH}$-omstandigheden en hoe de $\mathrm{pH}$ de geïnduceerde genotoxiciteit van $\mathrm{B}[\mathrm{a}] \mathrm{P}$ beïnvloedt. Dit omvat veranderingen in de intra- en extracellulaire $\mathrm{pH}$, genexpressie en enzymactiviteit van CYP1A1, die belangrijk zijn voor het metaboliseren van B[a]P en het repareren van $\mathrm{B}[\mathrm{a}] \mathrm{P}$ geïnduceerde DNA-schade. Deze bevindingen kunnen verdere aanwijzingen geven om enkele eerdere bevindingen van ontstekings-geïnduceerde cellulaire effecten te verklaren. Bijvoorbeeld, we hebben eerder een remming van DNA-reparatie door hypochloorzuur $(\mathrm{HOCl})$ waargenomen wat tijdens ontsteking wordt gegenereerd. We stellen nu voor dat het waargenomen remmende effect op DNA-reparatie ook kan worden veroorzaakt door een zure $\mathrm{pH}$. Het is op dit moment onduidelijk of het herstellen van de verlaagde $\mathrm{pH}$ naar meer neutrale omstandigheden een goede interventie zou zijn om genotoxische effecten bij personen met 
ontstekingsziekten te voorkomen, omdat een lage $\mathrm{pH}$ ook nodig is voor een adequate immuunrespons tegen potentiële indringers. Daarnaast bevat dit hoofdstuk ook een samenvattende tabel waarin de relatie tussen elke gemeten parameter wordt omschreven (bijv. Genexpressie, CYP1A1-enzymactiviteit, DNA-schade, DNA-reparatie, enz.), welke de startparameters die nodig zijn voor in silico modellen kunnen voorzien.

\section{Hoofdstuk 4: Effect van interleukine (IL) -8 op benzo[a]pyreen metabolisme en DNA schade in humane longepitheelcellen.}

Interleukine-8 (IL-8) is een essentiële chemoattractant cytokine, welke gevonden wordt in een verscheidenheid aan weefsels en bloed en neutrofielen aantrekt en activeert in ontstekingsgebieden [9]. Er is echter momenteel weinig kennis over hoe IL-8 $\mathrm{B}$ [a]P-geïnduceerde genotoxiciteit kan beïnvloeden. Daarom hebben we in hoofdstuk 4 het effect van IL-8 op B[a]P metabolisme in BEAS-2B cellen onderzocht en beschrijven we een mogelijk onderliggende mechanisme.

\subsection{Voornaamste bevindingen}

$\mathrm{Na}$ het kweken van BEAS-2B cellen met IL-8 en B[a]P gedurende 6 uur, was er geen verschil gevonden tussen de twee behandelingen met betrekking tot genotoxische eindpunten. Echter, op $\mathrm{t}=24$ uur hebben we een significant verhoogd niveau van CYP1A1, CYP1B1 genexpressie, EROD-activiteit en B[a]P-7,8-dihydrodiol concentraties waargenomen in vergelijking met cellen blootgesteld aan alleen $\mathrm{B}[\mathrm{a}] \mathrm{P}$. Bovendien blijft de ongemetaboliseerde $\mathrm{B}[\mathrm{a}] \mathrm{P}$-concentratie bij alle tijdspunten hoger in IL-8 monsters dan in monsters die niet met IL-8 werden behandeld. Over het algemeen is er geen verschil in $\mathrm{B}[\mathrm{a}] \mathrm{P}-\mathrm{DNA}$-adducten tussen de monsters van verschillende behandelingsomstandigheden.

\subsection{Discussie}

In theorie zou IL-8 bepaalde pathways die belangrijk zijn voor B [a] P metabolisme zowel kunnen activeren als remmen. Het is bijvoorbeeld bekend dat IL-8 een ademhalingsuitbarsting kan veroorzaken en oxidatieve stress kan verhogen doordat het nicotinamide adenine dinucleotidefosfaat (NADPH) oxidasen (Noxes) activeert [10]. Aangezien IL-8 verschillende Noxes zou kunnen activeren, veronderstelden we dat stimulatie door IL-8 het intracellulaire NADPH-niveau verminderde, wat CYP1A1-activiteit remt, aangezien CYP1A1 een NADPH-afhankelijk enzym is. Bijgevolg wordt er minder $\mathrm{B}[\mathrm{a}] \mathrm{P}-7,8$-dihydrodiol geproduceerd en wordt er minder $\mathrm{B}[\mathrm{a}] \mathrm{P}$ gemetaboliseerd.

Dit vertraagde $\mathrm{B}[\mathrm{a}] \mathrm{P}$ metabolisme, welke vergelijkbaar is met het effect dat wordt gezien na blootstelling aan $\beta$-glucuronidase en een zure $\mathrm{pH}$, zal CYP1A1 / CYP1B1 genexpressie blijven veroorzaken, wat resulteert in een hogere CYP1A1, CYP1B1 genexpressie, EROD-activiteit, $\mathrm{B}[\mathrm{a}] \mathrm{P}-7,8$-dihydrodiolconcentratie en $\mathrm{B}[\mathrm{a}] \mathrm{P}$ geïnduceerde DNA-adducten op latere tijdspunten (d.w.z. $\mathrm{t}=24$ en 48 uur). Om dit te bevestigen, hebben we het intracellulaire NADPH-niveau gemeten en EROD-analyses uitgevoerd met en zonder toevoeging van NADPH. Inderdaad, IL-8 verlaagde het intracellulaire NADPH niveau. Hoewel EROD-enzymactiviteit hoger was na toevoeging van extra NADPH aan het reactiemengsel, bleek het niet de snelheid beperkende factor voor het effect van IL-8 op B[a]P metabolisme. Daarna hebben we de Nox activiteit geblokkeerd door de algemene Nox-remmer (DPI) toe te voegen, aangezien IL-8 bekend staat om dit soort enzymen te activeren. Interessant is dat het IL-8 effect teniet werd gedaan, wat aangeeft 
dat de downstream effecten van IL-8 op B[a]P metabolisme wordt gemedieerd door de Noxen. Daarom hebben we de effecten van de Noxen na blootstelling aan IL-8 verder onderzocht. Er is gerapporteerd dat IL-8 oxidatieve stress kan verhogen door de vorming van ROS, waardoor het intracellulaire GSH nivean vervolgens kan worden afgebroken. GSH is belangrijk voor de fase II ontgifting van reactieve B[a]P metabolieten. Inderdaad, we vonden een significant verminderd niveau van GSH na behandeling met IL-8 alleen of gecombineerd met B[a]P. Bovendien is het GSSG niveau alleen significant verhoogd in de combinatiebehandeling (IL-8 en $\mathrm{B}[\mathrm{a}] \mathrm{P}$ ). Al deze waarnemingen geven aan dat GSH een centrale rol speelt in de IL-8 geïnduceerde vertraagde $\mathrm{B}[\mathrm{a}] \mathrm{P}$ metabolisme. Daarom is BSO, een glutathione synthese remmer, gebruikt om onze hypothese te valideren. Na de uitputting van GSH door BSO, werd het B[a]P metabolisme inderdaad op dezelfde wijze vertraagd als waargenomen na blootstelling aan IL-8. Als gevolg daarvan werden hogere concentraties niet-gemetaboliseerd $\mathrm{B}[\mathrm{a}] \mathrm{P}$ en $\mathrm{B}$ [a]P-7,8-dihydrodiol gevonden bij het vergelijken van monsters behandeld met BSO en $\mathrm{B}[\mathrm{a}] \mathrm{P}$ en monsters behandeld met alleen $\mathrm{B}[\mathrm{a}] \mathrm{P}$. Ondanks de hogere concentraties van pre-mutagene $\mathrm{B}[\mathrm{a}] \mathrm{P}$ metabolieten werden geen verhoogde niveaus van $\mathrm{B}[\mathrm{a}] \mathrm{P}$ gerelateerde DNA adducten waargenomen. Om deze discrepantie te beantwoorden, hebben we NER-capaciteit onderzocht, welke het belangrijkste mechanisme is voor het repareren van $\mathrm{B}[\mathrm{a}] \mathrm{P}$ geïnduceerde DNA schade. Uit een eerdere studie bleek inderdaad dat de uitputting van GSH de NER-capaciteit zou kunnen verbeteren [11]. Zoals we vermoedden, bleek IL-8 een 3-voudige inductie van NER activiteit na 24 uur te bewerkstelligen.

\subsection{Implicaties}

IL-8 is een andere belangrijke ontstekingsmediator die de genotoxiciteit van chemicalien kan verhogen. In deze studie hebben we aangetoond dat IL-8 effecten heeft op het $\mathrm{B}[\mathrm{a}] \mathrm{P}$ metabolisme, wat de rol van IL-8 in het gecombineerde effect van ontsteking en $\mathrm{B}$ [a]P op het kankerrisico verder kan verduidelijken, maar ook illustratief is voor de complexiteit van deze relatie, aangezien IL-8 niet alleen effect had op het B[a]P metabolisme, maar ook op de cellulaire verdediging tegen oxidatieve stress en DNA reparatie. Toch leek de uitputting van GSH een centrale rol te spelen, en daarom kan het voordelig zijn om de GSH-pool te herstellen bij mensen met chronische ontstekingsziekten. Dit kan worden bereikt door N-acetylcysteïne (NAC), een GSH precursor. Hoewel NAC niet succesvol wordt beschouwd bij de behandeling van COPD, kan de patient nog steeds op de lange termijn profiteren door slechtaardige ziekten te voorkomen.

\section{Hoofdstuk 5: Pulmonale inflammatie beinvloedt de CYP1A1-gemedieerde luchtweg DNA schade veroorzaakt door de kankerverwekkende luchtvervuiler Benzo[a]pyreen.}

Om de waarnemingen van de eerdere in vitro studies te bevestigen en te vergelijken werd een in vivo muismodel gebruikt en onderzocht in hoofdstuk 5.

\subsection{Voornaamste bevindingen}

Nadat muizen intra-nasaal warden blootgesteld aan LPS en vervolgens aan intratracheistische ingebracht $\mathrm{B}[\mathrm{a}] \mathrm{P}$, werden verschillende fenotypische eindpunten onderzocht in longweefsel- en brochnoalveolaire lavagevloeistof (BAL-vloeistof), waaronder histopathologie van longontsteking, enzymactiviteiten (bijv. CYP1a, Nqo1 en $\beta$-glucuronidase), reparatiecapaciteit en de vorming van DNA adducten. $\mathrm{Na}$ de 192 
ontstekingstrigger werden grotere hoeveelheden ontstekingscellen (hoofdzakelijk monocyten) gevonden in de longen van de muis, zelfs in de combinatie met B[a]P \{LPS \& $\mathrm{B}[\mathrm{a}] \mathrm{P})$ in vergelijking met controle. $\beta$-glucuronidase activiteit werd ook verhoogd in $\mathrm{BAL}$, wat indicatief is voor de aanwezigheid en activatie van ontstekingscellen. Een lagere enzymactiviteit van CYP1a en Nqo1 werd echter waargenomen in de LPS \& $\mathrm{B}[\mathrm{a}] \mathrm{P}$-blootgestelde muizen vergeleken met muizen die werden behandeld met $\mathrm{B}[\mathrm{a}] \mathrm{P}$ alleen. Hoewel er een lager enzymactiviteit van Cyp1a in de LPS \& B[a]P-groep was, waren de $\mathrm{B}[\mathrm{a}] \mathrm{P}$ geinduceerde DNA adductniveas significant hoger door de gelijktijdige blootstelling aan B[a]P en ontsteking. Er waren geen verschillen in CYP1B1 activiteit en NER capaciteit. Zo werd geconcludeerd dat de afname van CYP1A1 activiteit in de longen van LPS \& B[a]P behandelde muizen resulteert in een afname van $\mathrm{B}[\mathrm{a}] \mathrm{P}$ detoxificatie, waardoor er een toename in $\mathrm{B}[\mathrm{a}] \mathrm{P}-\mathrm{DNA}$ adductvorming in de long is.

\subsection{Discussie}

Interessant genoeg is ook de inhibitie van Cyp1a1 waargenomen in onze eerder in vitro studies ( $\beta$-glucuronidase of IL-8 blootstelling en zure omgeving). Het verschil tussen de in vivo en in vitro studies met betrekking tot de rol van CYP1A1-activiteit en de daaroplvolgende genotoxiciteit van $\mathrm{B}[\mathrm{a}] \mathrm{P}$ is nog steeds een kwestie van debat. In vitro werd geconcludeerd dat de activiteit van CYP1A1 onmisbaar was voor de genotoxiciteit van $\mathrm{B}[\mathrm{a}] \mathrm{P}$, terwijl in vivo studies het tegendeel lieten zien; CYP1A1 is onmisbaar voor de ontgifting van $\mathrm{B}[\mathrm{a}] \mathrm{P}[12,13]$. Het lijkt er daarom op dat door het nabootsen van ontstekingsomstandigheden in vitro, de in vivo bevindingen met meer nauwkeurigheid kan worden gereproduceerd. Meer onderzoek moet worden gedaan om de rol van CYP1A1 op B[a]P geïnduceerde genotoxiciteit beter te begrijpen en hoe ontstekingsmarker die relatie kunnen beïnvloeden. Voor een beter inzicht in het effect van LPS op B[a]P geinduceerde genotoxiciteit in de longen van de muis hebben we microarray technologie (volgend hoofdstuk) toegepast om verdere aanknopingspunten voor onderliggende mechanismen te vinden.

\subsection{Implicaties}

Deze studie gaf aanwijzingen dat luchtverontreiniging de gezondheid bedreigt op meerdere manieren: door ontsteking te veroorzaken, en ook door het verhogen van de genotoxiciteit van chemicaliën die tegelijkertijd worden ingeademd. Het heeft onze in vitro experimenten bevestigd, en daarom kan worden gesteld dat voor een optimale preventie, beide zijden van de munt moeten worden aangepakt. Niet alleen dient de blootstelling beperkt te worden, maar ook ontsteking (door aanwezigheid van ziekte of door blootstelling veroorzaakt) moet zoveel mogelijk gemeden worden. Bij de regulatoire toxicologie wordt er geen rekening gehouden met de aanwezigheid van ontsteking. Wij tonen hier echter aan dat het genotoxische potentieel van verbindingen hoger kan zijn in de aanwezigheid van ontsteking/ ontstekingsmediatoren. Daarom kan er een betere kijk op de realiteit worden verkregen door andere testomstandigheden te kiezen, zoals combinatie van ontsteking en chemische carcinogene stoffen. 


\section{Hoofdstuk 6: Veranderde gen expressie profielen in de longen van benzo[a]pyreen-blootgestelde muizen in de aanwezigheid van lipopolysaccharide geïnduceerde pulmonale ontsteking.}

Om meer inzicht te krijgen in het mechanisme van hoe LPS invloed heeft op B[a]P geinduceerde genotoxiciteit in de longen van muizen, werd RNA microarray technologie toegepast in hoofdstuk 6.

\subsection{Voornaamste bevindingen}

Door een toegewijde analyse uit te voeren van genen die bekend zijn bij de cellulaire respons op $\mathrm{B}[\mathrm{a}] \mathrm{P}$, hebben we de fenotypische waarnemingen bevestigd zoals beschreven in hoofdstuk 5. Zo werden er bijvoorbeeld een downregulatie van Cyp1A1 $(\mathrm{p}<0,05)$ en Nqo1 ( $p=0,088)$, een upregulatie van Gusb ( $\beta$-glucuronidase, $p=0.075)$ en geen significante verschillen in Cyp1B1 aangetoond bij het vergelijken van longen van muizen blootgesteld aan LPS \& B[a]P met longen van muizen blootgesteld aan $\mathrm{B}[\mathrm{a}] \mathrm{P}$ alleen. Daarnaast werden veel andere genen, gerelateerd aan fase I en II metabolisme van $\mathrm{B}[\mathrm{a}] \mathrm{P}$, aanzienlijk geremd na blootstelling aan LPS, waaronder Ephx1, Arnt, Cbr1, Por, Nqo2 en Comt, evenals Sult1a1, GSTp1, Gstm1, Gstt1 en Gpx3. Ondanks het feit dat we geen verschil in NER-capaciteit hebben waargenomen, hadden een paar NER-gerelateerde genen een aanzienlijk hogere expressie (d.w.z. Xpa) en een lagere expressie (d.w.z. Ddb1). Daarnaast hebben we een principal component analyse (PCA) toegepast om de onderlinge relatie tussen elke blootstelling (d.w.z. controle, B[a]P, LPS en LPS \& B[a]P) te bepalen en genen die de verschillende blootstellingsomstandigheden konden scheiden, waren voornamelijk gerelateerd aan immuunrespons. Deze immuunresponsafhankelijke scheiding van alle blootstellingsomstandigheden is een verdere bevestiging dat $\mathrm{B}[\mathrm{a}] \mathrm{P}$ alleen al een ontstekingsreactie kan veroorzaken en ook een aanwijzing da ontsteking een onderschatte rol kan spelen in $\mathrm{B}[\mathrm{a}] \mathrm{P}$ geïnduceerde genotoxiciteit en eventueel carcinogeniteit. Tenslotte hebben we ook een globale analyse uitgevoerd op basis van de differentieel uitgedrukte genen (DEG's) en een groot percentage van de genen die door $\mathrm{B}[\mathrm{a}] \mathrm{P}$ differentieel gereguleerd werden, werden door LPS geremd. Bijvoorbeeld, cel-cel adhesie, cel-cel communicatie, RNA-translatie en ribosoom gerelateerde processen werden zodanig veranderd. Dit kan aangeven dat pathways/cellulaire gebeurtenissen, die betrokken zijn bij het herstel van $\mathrm{B}[\mathrm{a}] \mathrm{P}$ blootstelling, kunnen worden uitgesteld door extra inductie van ontsteking door LPS.

\subsection{Discussie}

Wij hebben in vivo onze hypothese bevestigd dat LPS, door sommige transcriptomische veranderingen van $\mathrm{B}[\mathrm{a}] \mathrm{P}$ genen tegen te gaan, het tijdsverloop van $\mathrm{B}[\mathrm{a}] \mathrm{P}$ werking daadwerkelijk verlengt en zijn algemene genotoxische potentieel daadwerkelijk verhoogt. Er zijn echter enkele beperkingen van de studie, die moeten worden aangehaald. Bijvoorbeeld, CYP1A1-genexpressie en CYP1A1-eiwitactiviteit worden gewoonlijk geïnduceerd door B[a]P. Dit werd echter niet gevonden in de huidige studie. Dit kan het gevolg zijn van de keuze van een enkel tijdpunt (48 uur) voor beide metingen; CYP1A1-genexpressie is een vroege gebeurtenis, terwijl eiwitexpressies als een latere gebeurtenis kunnen worden beschouwd. Enzymactiviteit berust echter ook op posttranslationele-eiwitmodificaties. CYP-activiteit kan bijvoorbeeld worden geremd door ROS, wat in overmaat wordt geproduceerd door extra blootstelling aan LPS. Dit kan een verklaring geven voor de discrepantie tussen eiwitgehalten en enzymactiviteit, die 
niet correleren. 48 uur kan dus te laat zijn voor het beoordelen van zeer vroege metabole activiteiten van B[a]P. Echter, in onze eerdere studies waarin we knaagdieren aan $\mathrm{B}[\mathrm{a}] \mathrm{P}$ hebben blootgesteld, werden de hoogste DNA-adductniveaus altijd gevonden op ongeveer 2 dagen na de blootstelling (hoofdstuk 5). Om de cellulaire effecten op het hoogste niveau van DNA schade te onderzoeken, werd daarom 48 uur gekozen als belichtingspunt.

\subsection{Implicaties}

Deze studie is de voortzetting van de studie in hoofdstuk 5 en gericht op het verkrijgen van meer inzicht in aanvullende onderliggende mechanismen voor verder onderzoek. Het algemene concept dat de aanwezigheid van ontsteking het initiele metabolisme van $\mathrm{B}[\mathrm{a}] \mathrm{P}$ door fase I en II metabolisme kan remmen werd bevestigd op het niveau van gentranscriptie. Nieuwe aanknopingspunten voor toekomstig onderzoek kunnen gericht zijn op celcommunicatie en celadhesie. Alle gegevens die in deze studie zijn verkregen, worden gedeeld en online beschikbaar gesteld voor andere onderzoekers, die kunnen profiteren van onze bevindingen om hun in vivo bevindingen te verklaren met andere genotoxische chemicaliën.

\section{Concluderende opmerkingen en toekomstperspectief}

Het huidige proefschrift richtte zich op het effect van ontsteking op B[a]P metabolisme en $\mathrm{B}[\mathrm{a}] \mathrm{P}-\mathrm{DNA}$ adductvorming in vitro en in vivo. Momenteel is het verzamelen van bewijzen dat chronische ontsteking bijdraagt aan de genotoxiciteit en carcinogeniteit van chemische carcinogene stoffen, die uiteindelijk tot kanker leiden. Echter, door het complexe onderliggende netwerk, zijn er maar weinig studies die hebben onderzocht hoe ontsteking bijdraagt aan de chemisch geïnduceerde carcinogenese. Bovendien hebben tegenstrijdige resultaten tussen in vitro en in vivo studies het oplossen van deze grote puzzel zelfs moeilijker gemaakt. Om dit gat in de kennis te vullen, hebben we in vitro en in vivo studies systematisch uitgevoerd. Tot nu toe ondersteunen de resultaten van onze studies de hypothese dat ontsteking de stofwisseling van $\mathrm{B}[\mathrm{a}] \mathrm{P}$ vertraagd en dit leidt tot langdurige blootstelling van cellen aan de verbinding $\mathrm{B}[\mathrm{a}] \mathrm{P}$. Bijgevolg worden hogere $\mathrm{B}[\mathrm{a}] \mathrm{P}-\mathrm{DNA}$-adductniveaus gevormd die theoretisch het risico op kankerontwikkeling verhogen. Hoe meer we echter ontsteking bestuderen, hoe meer we zijn complexiteit kennen, met veel cytokines en pathways die worden geactiveerd en hun crosstalk met elkaar en met andere cellulaire processen. Daarnaast werden in het huidige proefschrift slechts drie ontstekingsfactoren gedetailleerd bestudeerd voor hun effect op $\mathrm{B}[\mathrm{a}] \mathrm{P}$, en er zijn andere ontstekingsfactoren die nog onderzocht moeten worden. Daarnaast werden de meeste studies die het verband tussen ontsteking en chemische carcinogenen onderzochten, uitgevoerd gebaseerd op een enkele variabele, waaronder TNF- $\alpha$, IL-6, IL-1 $\beta$, hypoxie, oxidatieve stress en MPO, terwijl met het mengsel van ontstekingsmediatoren en de daaruit voortvloeiende micro-omgeving in hun geheel rekening mee gehouden moet worden.

Een belangrijke observatie in het huidige proefschrift is dat in vitro studies op tijdsafhankelijke wijze moeten worden uitgevoerd. Veel in vitro studies naar $\mathrm{B}[\mathrm{a}] \mathrm{P}$ werden uitgevoerd op één enkel tijdstip (meestal 24 uurs incubaties), wat kan resulteren in het trekken van misleidende conclusies. Sommige ontstekingsfactoren kunnen bijvoorbeeld CYP's op vroege tijdspunten belemmeren, wat leidt tot een inductie van CYP's op latere tijdspunten, omdat ongemetaboliseerd $\mathrm{B}[\mathrm{a}] \mathrm{P}$ de Ahr receptor activeert. 
Concluderend, de resultaten die in dit proefschrift gepresenteerd worden, tonen de impact van verschillende ontstekingsfactoren op de genotoxiciteit van $\mathrm{B}[\mathrm{a}] \mathrm{P}$. Wij geven mechanistische informatie over hoe ontstekingsfactoren mensen meer vatbaar kunnen maken voor blootstelling aan kankerverwekkende stoffen. Het kan ook deuren openen voor nieuwe preventieve maatregelen om kankergevallen bij patiënten met chronische ontstekingsziekten te verminderen; een combinatie van anti-inflammatoire benaderingen en vermindering van blootstelling aan genotoxische chemicalien is vereist hiervoor. Bovendien kan de toepassing van state-of-the-art technieken in moleculaire benaderingen en diermodellen van ontsteking gerelateerde kanker verder helpen om deze intrigerende puzzel te verhelderen. 


\section{Referenties}

[1] K. Sasaki, F. Taura, Y. Shoyama, S. Morimoto, Molecular characterization of a novel beta-glucuronidase from Scutellaria baicalensis georgi, J Biol Chem, 275 (2000) 27466-27472.

[2] A. Starsichova, E. Hruba, E. Slabakova, Z. Pernicova, J. Prochazkova, K. Pencikova, V. Seda, M. Kabatkova, J. Vondracek, A. Kozubik, M. Machala, K. Soucek, TGF-beta1 signaling plays a dominant role in the crosstalk between TGF-beta1 and the aryl hydrocarbon receptor ligand in prostate epithelial cells, Cell Signal, 24 (2012) 1665-1676.

[3] A. Gemma, Y. Hosoya, K. Uematsu, M. Seike, F. Kurimoto, A. Yoshimura, M. Shibuya, S. Kudoh, Mutation analysis of the gene encoding the human mannose 6-phosphate/insulin-like growth factor 2 receptor (M6P/IGF2R) in human cell lines resistant to growth inhibition by transforming growth factor beta(1) (TGF-beta(1)), Lung Cancer, 30 (2000) 91-98.

[4] Y. Kato, S. Ozawa, C. Miyamoto, Y. Maehata, A. Suzuki, T. Maeda, Y. Baba, Acidic extracellular microenvironment and cancer, Cancer Cell Int, 13 (2013) 89.

[5] A. Bellocq, S. Suberville, C. Philippe, F. Bertrand, J. Perez, B. Fouqueray, G. Cherqui, L. Baud, Low environmental pH is responsible for the induction of nitric-oxide synthase in macrophages. Evidence for involvement of nuclear factor-kappaB activation, J Biol Chem, 273 (1998) 5086-5092.

[6] A. Riemann, B. Schneider, A. Ihling, M. Nowak, C. Sauvant, O. Thews, M. Gekle, Acidic environment leads to ROS-induced MAPK signaling in cancer cells, PLoS One, 6 (2011) e22445.

[7] J. Chiche, M.C. Brahimi-Horn, J. Pouyssegur, Tumour hypoxia induces a metabolic shift causing acidosis: a common feature in cancer, J Cell Mol Med, 14 (2010) 771-794.

[8] L.M. Maurer, E. Yohannes, S.S. Bondurant, M. Radmacher, J.L. Slonczewski, pH regulates genes for flagellar motility, catabolism, and oxidative stress in Escherichia coli K-12, J Bacteriol, 187 (2005) 304-319.

[9] M. Bickel, The role of interleukin-8 in inflammation and mechanisms of regulation, J Periodontol, 64 (1993) 456-460.

[10] Q. Shi, A.W. Boots, L. Maas, C. Veith, K. van Kuijk, G.R. Haenen, R.W. Godschalk, F.J. Van Schooten, Effect of interleukin (IL)-8 on benzo[a]pyrene metabolism and DNA damage in human lung epithelial cells, Toxicology, 381 (2017) 64-74.

[11] S.A. Langie, A.M. Knaapen, J.M. Houben, F.C. van Kempen, J.P. de Hoon, R.W. Gottschalk, R.W. Godschalk, F.J. van Schooten, The role of glutathione in the regulation of nucleotide excision repair during oxidative stress, Toxicol Lett, 168 (2007) 302-309.

[12] V.M. Arlt, M. Stiborova, C.J. Henderson, M. Thiemann, E. Frei, D. Aimova, R. Singh, G. Gamboa da Costa, O.J. Schmitz, P.B. Farmer, C.R. Wolf, D.H. Phillips, Metabolic activation of benzo[a]pyrene in vitro by hepatic cytochrome P450 contrasts with detoxification in vivo: experiments with hepatic cytochrome P450 reductase null mice, Carcinogenesis, 29 (2008) 656-665.

[13] D.W. Nebert, Z. Shi, M. Galvez-Peralta, S. Uno, N. Dragin, Oral benzo[a]pyrene: understanding pharmacokinetics, detoxication, and consequences--Cyp1 knockout mouse lines as a paradigm, Molecular pharmacology, 84 (2013) 304-313. 



\section{Appendix I}

\section{Valorization Addendum}




\section{Valorization addendum}

According to the graduation regulations of Maastricht University dated on $19^{\text {th }}$ June 2014, an additional chapter, the Valorization Addendum, is needed for the dissertation of the Ph.D candidate. The definition of valorization is "the process of creating value from knowledge, by making knowledge suitable and/or available for social (and/or economic) use and by making knowledge suitable for translation into competitive products, services, processes and new commercial activities" (Maastricht promotie reglement, 2013). Therefore, in the next section, answers to the following four questions are outlined: 1) What is the social (and/or economic) relevance of our research results (i.e. in addition to the scientific relevance)?; 2) To whom, in addition to the academic community, are the research results of interest and why?; 3) Into which concrete products, services, processes, activities or other activities could our results be translated and shaped?; and to what degree can the results be called innovative?; 4) What will be the value of our research for future valorization?

\subsection{Social Relevance}

The current thesis reports on fundamental research, to further clarify the relationship between inflammation, exposure to genotoxic chemicals and their combined contribution to subsequent cancer risk. More specifically, the focus of this thesis is how inflammation can influence carcinogenesis by the chemical carcinogen benzo[a]pyrene $(\mathrm{B}[\mathrm{a}] \mathrm{P}) . \mathrm{B}[\mathrm{a}] \mathrm{P}$ is chosen as an example, because it is a widely studied genotoxic agent. However, with the development of human society, more than 10,000 chemicals have been produced each year, and some of them were identified and grouped as genotoxic and/ or chemical carcinogen [1]. Therefore, exposure to genotoxic compounds seems inevitable for the general population. A chemical carcinogen is a compound that can directly or indirectly react with DNA, which could eventually cause genome mutations. It is generally accepted that more mutations will result in a higher risk of developing cancer. Dermal contact, intake or inhalation of such chemical carcinogens can lead to the formation of various cancers at different sites of the body, including lung, liver, breast, colon, stomach, skin, bladder, prostate and nose. Although it is not allowed to produce and use chemical carcinogens in consumer products, still they are generated naturally and presented in ambient environment, food, water and soil. One group of carcinogens is the polycyclic aromatic hydrocarbons (PAHs), which is a group of aromatic compounds found in natural sources and produced due to incomplete combustion of organic matter [2]. $\mathrm{B}[\mathrm{a}] \mathrm{P}$ is one of the best studied PAH and is considered to be classic example of PAHs that is widely present in human daily life, including cigarette smoke, diesel exhaust and barbecued meat products. Due to the fact that exposure is inevitable for humans, the human body developed a system to guard against all sorts of harmful exposures. For example, the body can detoxify harmful compounds via metabolism, which convert toxic compound into less toxic ones that can be excreted out of the body. Even though there is damage to DNA, cells can often repair DNA damage or undergo apoptosis dependent on the exposure dose. However, unsuccessful detoxification or unrepaired DNA damage will lead to changes in gene expression and mutations in certain genes that can drive carcinogenesis. Until now, it is estimated that chemical carcinogens are responsible for approximately $41 \%$ of the worldwide cancer incidence and $42 \%$ of cancer death $[3,4]$. With a deeper and more profound understanding of carcinogen induced cancer development, scientists found out that there are many risk factors that contribute to the susceptibility of part of the population to carcinogens. Known risk factors are age, 200 
genetics, and lifestyle. Currently, another risk factor namely "inflammation" has attracted attention and it was suggested to play an important role in chemically induced carcinogenesis. Inflammation is a powerful physiological response to defend the human body against intruders, such as pathogens, chemicals, or irritants, as well as to help damaged tissue healing by removing cell debris and rebuilding tissue [5]. However, once the inflammation persists, chronic inflammation will be developed, and chronic inflammation is responsible for $20 \%$ of related cancers [5]. Moreover, recent epidemiological studies have found that, the combination of inflammation and chemical carcinogen exposure increased the risk of cancer even further; for example, COPD patients are at risk of developing lung cancer and the risk is further increased in patients who are smoking.

Thus, we have now realized that exposure to carcinogens induces carcinogenesis, inflammation induces carcinogenesis, and the combination of carcinogen exposure and inflammation even further increases the health risks. According to the NIH national cancer institute database, inflammation and carcinogeninduced diseases account for around 166.1 deaths per 100,000 persons each year [6]. Although exposure to environmental chemicals is often unavoidable, inflammation is a condition against which there are many potential medical remedies. However, the mechanism of how inflammation contributes to the development of chemically induced cancer remains unclear. More knowledge about this mechanism could thus help people with chronic inflammatory diseases to prevent the development of cancer as a secondary disease. This may be of particular importance when treatment of chronic inflammatory diseases increases the life span of subjects, which also increases the chance of getting cancer. The studies described in this thesis can give important leads for further research on the prevention of cancer, which still is an enormous societal burden.

\subsection{Target groups}

There are multiple potential target groups besides the academic community, which might benefit from current research, which includes pharmaceutical companies, patient communities and regulators of governments.

First of all, our research results might provide pharmaceutical companies with preliminary data or/and ideas for their current or future product development, targeted at subjects with chronic inflammatory diseases. Secondly, patient communities could obtain important information about the cause of secondary diseases as a result of their chronic condition. A better understanding about the sources of additional health dangers that come with their medical status, may lead to behavioral changes to prevent concomitant disease, in this particular case cancer in patients with inflammatory conditions. Last, but probably the most important target group is regulators at the government. The government plays a significant role in guarding the society via promulgating regulation and law, and negotiating with industries. Specific attention can be given to setting guidelines to protect the most vulnerable populations, including diseased subjects.

\subsection{Products and Innovation}

For the academic community, six published scientific articles from this thesis are available online. Besides that, the results were presented at (inter)national conferences via oral presentation and poster presentations. Our studies provide leads for the effective prevention of cancer in subjects with chronic inflammatory diseases. We now 
realize that every individual is different and the exposure conditions may vary for each person as well. For example, a patient may develop lung cancer due to a long-term smoking history, whereas other patients with the same type of lung cancer developed the cancer because he/ she lived in a highly polluted area with accompanying lung inflammation. Therefore, "personalized medicine" is also at place for prevention in order to further increase its effectivity. This thesis focused on several conditions that occur in subjects that are exposed to chemical carcinogens, while the lung is inflamed. Since this field has not yet been thoroughly investigated, lots remain unknown. In chapter 2, 3 and 4 , we demonstrated the mechanism of how $\beta$-glucuronidase, acidic microenvironment, and IL-8 influence $\mathrm{B}[\mathrm{a}] \mathrm{P}$ metabolism and modulates the formation of DNA damage. Although inflammation is of course much more complex then these 3 factors, this simplified approach provided leads for interventions to decrease risks of cancer as secondary disease: it could be of importance to inhibit the activity and release of enzymes like $\beta$-glucuronidase or MPO, or to restore local $\mathrm{pH}$ to prevent increased cancer risks. Moreover, we also showed that inflammation significantly inhibited phase II detoxification processes and DNA repair. These findings offer new targets for drug development and research.

The metabolism of $\mathrm{B}[\mathrm{a}] \mathrm{P}$ in vitro is markedly different from in vivo. For instance, cytochrome $\mathrm{P} 4501 \mathrm{~A} 1$ is an activator of $\mathrm{B}[\mathrm{a}] \mathrm{P}$ in vitro, whereas in vivo studies with CYP1A1 knockout animals indicate that CYP1A1 is an important detoxifying enzyme. The reasons for the discrepancies between in vitro and in vivo $\mathrm{B}[\mathrm{a}] \mathrm{P}$ genotoxicity remain largely unclear. However, we showed that after introducing inflammatory parameters in in vitro settings, that the metabolism of $\mathrm{B}[\mathrm{a}] \mathrm{P}$ mimicked the in vivo situation much better. Regulatory testing of chemicals relies for a large part on in vitro experiments, which are obviously not carried out under conditions that mimic the in vivo situation best. For instance, oxygen concentrations are often much higher than the levels that can be reached in vivo. Therefore, our studies give leads to further optimize the in vitro testing of chemical safety.

\subsection{Future value}

The current thesis can be considered as an initial search for the underlying mechanisms of the increased cancer risk in subjects with chronic inflammatory diseases. Therefore, the results of this thesis should predominantly be considered as lead-finding studies for effective intervention/ prevention in subjects with inflammatory diseases. It is important to increase the awareness of physicians and researchers for these additional risks of inflammatory diseases and that early action is needed for patients, to prevent cancer development as secondary disease. The effectiveness of combinations of treatment should therefore be investigated. The future formulation of research proposals on basis of our findings may lead to important new applications or insights for both industry and society. Although the performance of clinical trials and subsequent use of new drugs for treatment is a long process, contacts with industry may already be initiated at an early stage. 


\section{References}

[1] I.A.f.R.o. Cancer, IARC monographs on the evaluation of carcinogenic risk of chemicals to man, IARC monographs on the evaluation of carcinogenic risk of chemicals to man., 1 (1972).

[2] K. Ravindra, R. Sokhi, R. Van Grieken, Atmospheric polycyclic aromatic hydrocarbons: Source attribution, emission factors and regulation, Atmospheric Environment, 42 (2008) 2895-2921.

[3] V. Gorbunova, A. Seluanov, Z. Mao, C. Hine, Changes in DNA repair during aging, Nucleic Acids Research, 35 (2007) 7466-7474.

[4] C. Bernstein, A.R. Prasad, V. Nfonsam, H. Bernstein, DNA Damage, DNA Repair and Cancer, in: C. Chen (Ed.) New Research Directions in DNA Repair, InTech, Rijeka, 2013, pp. Ch. 16.

[5] L.M. Coussens, Z. Werb, Inflammation and cancer, Nature, 420 (2002) 860-867.

[6] U.C.S.W. Group, United States cancer statistics: 1999-2006 incidence and mortality web-based report, Atlanta: US Department of Health and Human Services, Centers for Disease Control and Prevention and National Cancer Institute, (2010). 

Appendix II

Acknowledgements 


\section{Acknowledgements}

I would like to express my gratitude to all the people who have ever supported and helped me to accomplish this achievement. First of all, my gratitude goes to my co-promoter and supervisor Roger. You were an extremely excellent supervisor and played a super important role during my PhD life. Not only your strikingly handsome appearance, but also your guidance, critical comments and enthusiasm for science encouraged me to carry on further. Besides these, I also appreciate your friendliness and humor, which made my start not so tough. More importantly, you always allowed me to just drop by to your office for a short discussion and you were always there for me although you were busy with tons of different tasks. I learned a lot from you on how to do research, but also on how to solve problems and see things from a broader point of view. Your support was not only about scientific topics, but also about personal things. I really appreciate the trust and encouragement that you had in me, and your patience to guide me in my PhD career.

My gratitude also goes to my promoter Frederik-Jan. You are very friendly and kind. I still remember the first time I had the job interview with you, and you led the whole talk and made the atmosphere very comfortable for me. I'm very grateful that you offered me the opportunity to work with you and your group right after our interview. Besides your personality and charm, your great success in science also influenced me a lot, especially in my publications. Your constructive comments and ability to capture critical problems in no time often saved me from heading toward nowhere. You are also incredibly efficient and no matter where you were, you always replied to my emails. This was very much appreciated, especially during the last stretch of my PhD project. I am also grateful that you manage such a nice and lively atmosphere at the department with such wonderful colleagues around.

Many special thanks to Aalt, Agnes and Guido for their valuable contributions to my project. Aalt, you are a very kind and easy going professor. I've learned so much from every talk we had, and you always encouraged me and taught philosophy of science in a mysterious way. In addition, thank you for being my European Registered Toxicologist trainer. I'd like to express my appreciation to Agnes and Guido for your constructive feedback to my work towards this thesis.

I would like to thank all my colleagues in the department, where I have spent wonderful four years as a PhD student. First of all, a big thanks goes to my paranymphs, Misha and Carmen. Thank you for being my paranymphs, helping me in preparing and arranging everything for my big day, and standing and supporting me during my defense. You guys are the best paranymphs ever. Misha, you are my best friend. It's fantastic to have met you. We've been friends for God-knows-how-long (actually four years, but I feel like we've been friends for ages), and you are always there for me. I still remember every inside joke we have ever created and all the fun activities we have done (such as the NVT meetings). Thank you for always being my best supporter. Even if we live a thousand lives, I will always pick you as my beloved best friend. I'd wish you and yours all the best. Carmen, as my best female friend in the department, you are an amazing German girl with lots of intelligence and ambition. When we talked about something, the way how you saw and answered my questions always surprised and inspired me. You are a pretty nice person, always optimistic for everything. Thank you for respecting my values and opinions, even if you disagreed. It's fun being with you. Hope you will never change. I'd wish you all the best and good luck with finishing your thesis. Marie-Claire, you are my goddess in the department. Thank you so much for what you've done for me. You've 206 
played such an important role in my $\mathrm{PhD}$ life. Without your care and thoughtful arrangements, I could not finish my $\mathrm{PhD}$ in time, especially those administrative things that I had no clues what to do with otherwise. Not only for me, but you take care of everyone in the department and make sure everything goes smoothly. Rianne, you are the most talent girl I've ever met. You are really good at presenting and selling your opinion. I had lots of fun when I talked to you and I've learned a lot from you, especially in how to deal with the kid. Timme and Charlotte, thank you for all the fun and amazing talks we had and the accompany during my stay in the department. It's really nice to have you here and you made that I did not feel bored after a whole day of experiments. I also want to thank you guys for keep inviting me to join the lunch during the last two or three years although I only joined for few times. Mireille, another talent girl, in fact we did not have many conversations during the past four years. But once you talk, you always could surprise me or make me laugh for a whole day. Sven, my dear roommate, it's my honor to be your roommate. You are such a talented guy, good at lots of things. I wish you all the best and luck with your PhD. Philippe, you are the one we don't need to talk to every single day, weeks, but when you do, it's as if you'd never stopped talking. I will memorize all the great talk we had. My buddy Lou, thanks a lot for your dedicated work, as well as cozy conversations, sharing lots of personal interest and jokes. Roger B, thank you for all the efforts and contributions that you've made for the department, I've really enjoyed every activity you've arranged during your time in the department. Kristien, you are the nicest person I've known. I will always remember your kindness. Matt, thank you for all the jokes and laugh. Evelyn, thank you for all the conversations we had. I really like to talk to you and I hope our conversation never reaches the end of the horizon. Thank you all the other colleagues who I have worked with: Agnieszka S, Jan, Antje, Volker, Gertjan, Sebastien, Alex, Geja, Gesiele, Ming, Caroline, Ben, Harry, Matthijs, Josephina, Paul, Agnieszka B, Danielle, Marie-Jose, Edwin, Lily, Peter, Jacques and Khrystyna. I would also like to thank all my former MSC and BSC students for their hard work and contributions to my project.

I also would like to thank my dear friends who supported me and went through tough times together. My Chinese friends that I met in the Netherlands, Xiang, Chenxi, Qu, Han, Sha, Qi, Yifan, Yuehan, Jing, Wanjun, Hanshu, Xiaoxue, Xinyi, Houyu, Sicong, Chengkun, Juan, Shan, Wei, Li, Jia, Mengying, Lu, Shiyang, Yue, Si, Hequn, Xiao, Yimin and Kun. My Dutch course friend Ron, our Dutch may not have improved as much as we had hoped for but still our conversations in English brightened my life up. My friends from MSc study in Wageningen, especially Ignacio, Marcia and Myrto.

Most importantly, I would like to thank my family. Thanks to my parents for their endless support and encouragement. Without the inspiration, drive, and support that you have given me, I might not be the person I am today. Thanks to my beloved wife, Yuan, you are not just my partner, you are my lover, you are not just my companion, you are my inspiration, you are not just my wife, you are my life. I still remember the first time I met you. You are the best thing that happened to me. You are the best thing that is still happening to me and you are going to be the best thing to happen to me, ever. Thank you. If there was a number higher than zillion, bazillion or gazillion, I would thank you that many number of times for everything you have done for me. I love you.

Dec 2017

Quan Shi 

Appendix III

\section{Curriculum Vitae}





\section{Curriculum Vitae}

Quan Shi was born on November 11th, 1988 in Anhui, China. He grew up in Shenzhen city until he finished his secondary education. In July 2011, he received his Bachelor degree (BSc) in biotechnology at the Beijing Normal University (Zhuhai, China) and the Technology Park Malaysia College (Kuala Lumpur, Malaysia). Following his BSc in 2011, he came to Wageningen University in the Netherlands and started with his master study (MSc) in Food Safety. During his master study, he performed his MSc thesis at the Division of Toxicology, Wageningen University, and conducted his internship at RIKILT Wageningen University and Research Centre (Wageningen, the Netherlands). In November 2013, he started his PhD project presented in this thesis under the supervision of Prof. dr. F. J. van Schooten and Dr. R. W. L. Godschalk at the department of Toxicology, Maastricht University. During his PhD study, he followed a number of postgraduate education courses in Toxicology which is required for registration as a European Toxicologist. 



\section{Appendix IV}

\section{List of Publications}





\section{List of Publications}

Shi, Q., G. R. Haenen, L. Maas, V. M. Arlt, D. Spina, Y. R. Vasquez, E. Moonen, C. Veith, F. J. Van Schooten \& R. W. Godschalk (2016) Inflammation-associated extracellular beta-glucuronidase alters cellular responses to the chemical carcinogen benzo[a]pyrene. Archives of toxicology, 90, 2261-73.

Shi, Q., L. Maas, C. Veith, F. J. Van Schooten \& R. W. Godschalk (2017) Acidic cellular microenvironment modifies carcinogen-induced DNA damage and repair. Archives of toxicology, 91, 2425-2441.

Shi, Q., A. W. Boots, L. Maas, C. Veith, K. van Kuijk, G. R. Haenen, R. W. Godschalk \& F. J. Van Schooten (2017) Effect of interleukin (IL)-8 on benzo[a]pyrene metabolism and DNA damage in human lung epithelial cells. Toxicology, 381, 64-74.

Shi, Q., R. W. L. Godschalk \& F. J. van Schooten (2017) Inflammation and the chemical carcinogen benzo[a]pyrene: Partners in crime. Mutation Research/Reviews in Mutation Research, 774, 12-24.

Shi, Q., R. R. Fijten, D. Spina, Y. Riffo Vasquez, V. M. Arlt, R. W. Godschalk \& F. J. Van Schooten (2017) Altered gene expression profiles in the lungs of benzo[a]pyrene-exposed mice in the presence of lipopolysaccharide-induced pulmonary inflammation. Toxicology and applied pharmacology, 336, 8-19.

Arlt, V. M., A. M. Krais, R. W. Godschalk, Y. Riffo-Vasquez, I. Mrizova, C. A. Roufosse, C. Corbin, Q. Shi, E. Frei, M. Stiborova, F. J. van Schooten, D. H. Phillips \& D. Spina (2015) Pulmonary Inflammation Impacts on CYP1A1-Mediated Respiratory Tract DNA Damage Induced by the Carcinogenic Air Pollutant Benzo[a]pyrene. Toxicological sciences : an official journal of the Society of Toxicology, 146, 213-25.

Fijten, R., A. Smolinska, Q. Shi, D. Pachen, J. Dallinga, A. Boots \& F. J. van Schooten (2017) Exposure to genotoxic compounds alters in vitro cellular VOC excretion. Journal of breath research. 